Historic, Archive Document

Do not assume content reflects current scientific knowledge, policies, or practices. 


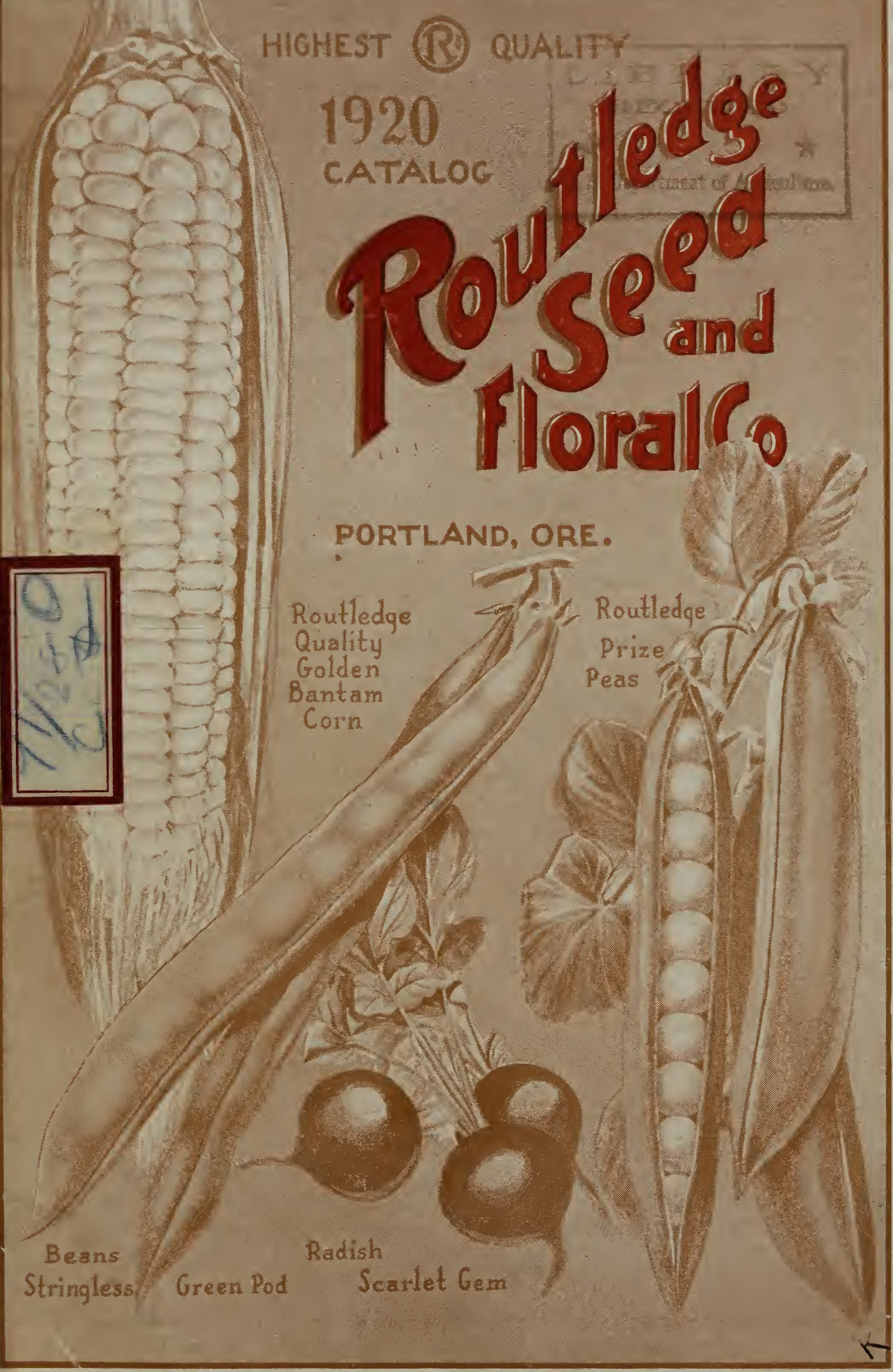




\section{What WE Do and What YOU Should Do FORWARDING CHARGES BY PARCEL POST, EXPRESS OR FREIGHT By Mail or Parcel Post}

OTHER STATES.-Customers ordering from other states must add postage (see rate table, page 2), if wanted by mail, otherwise shipment will be made by express or freight, transportation charges collect.

The following rules apply to the states west of the Rocky Mountains, i. e., OREGON, WASHIINGTON, CALIFORNIA, IDAHO and MONTANA:

On Cash Orders we will at prices printed in this catalog send by prepaid parcel post all seeds in packets, ounces, or single pounds.

Small Plants (not potted), Bulbs, Roots and 1-year-old Roses are prepaid unless otherwise stated.

SEEDS IN BULK. - When you order Seeds in quantity above $1 \mathrm{lb}$., add postage. (See parcel post rates, page 2.)

TOOLS, SUPPLIES, FOODS, REMEDIES, ETC.-On this class of goods we have marked the parcel post weight, including packing (PP. Wgt.), so that you can add postage to catalog prices if you want them by parcel post.

HARDY FLOWERING SHRUBS, SMALL FRUIT, BERRY and ORNAMENTAL SHRUBS and PLANTS, CLIMBING VINES and 2-YEAR.OLD ROSE BUSHES can be sent by parcel post if necessary, but be sure you. send extra money for packing and postage. Postage and packing charges will be specified on the ditferent pages unless the prices are postpaid.

NOT MAILABLE.-Plants in pots, large branching shrubs, Evergreens of ali kinds, that must be balled in earth, Fruit and Shade Trees, over 1 year old and taller than 3 feet cannot be sent by Parcel Post. Neither can Insecticides that are poisonous, flower pots, jardinieres, bird cages, or liquids in larger than 1: pint cans.

\section{By Freight or Express}

We DO NOT at catalog prices pay freight or express charges on any stock we offer, unless so stated; therefore, take note of the following paragraph:

LARGE ORDERS.-Any gardener, institution or individual wishing seeds, plants, trees or supplies in large quantities is requested to mail a list of what is wanted, stating grade, size or amount, and we will promptly return it with our very lowest prices. A letter of inquiry may save you dollars if you want to buy in QUANTITY.
STOCKS.

PREPAY STATIONS.-When you send in orders to go by fieight or express be sure you send extra money to pay the transportation charges if your station is a prepay point, which is always the case where there is no regular agent. If you send more than enough, we will refund it as soon as we get the prepay bill. If not enough, we will write for the balance and expect you to remit promptly.

ORDER EARLY.-We aim to execute all orders as soon as received, but during the rush season in April and May delays are unavoidable, which, however, can be partly overcome by our patrons anticipating their wants and ordering and taking delivery of their requirements early.

CASH WITH ORDER.-Please send money with the order sufficient to cover the whole bill. We decline sending goods "Collect on Delivery," unless remittance be made on account to guarantee acceptance.

CORRESPONDENCE.-We try to give prompt attention to all proper letters of inquiry, etc., but ask, as a favor, that all questions be stated clearly and briefly, and not on order sheets.

SEASONABLE STOCKS.-Many customers order plants and bulbs out of seasonthat is, before we get stocks in or perhaps too late in the spring. Rather than delay the balance of your order, we will send what is seasonable at once and defer the balance until proper planting season unless otherwise instructed.

REPORTS-GOOD OR BAD.-Will you help us to attain greater success by writing and telling us how our Seeds and Supplies reach you, how they grow and how you like them? We will certainly appreciate it. Your criticisms, if you have any, as well as your praises, are desired.

MISTAKES.-These will happen occasion. ally, in spite of all care. Write us at once, with copy of original order, if possible, and mistakes will be promptly rectified.

NOTE.-We use every precaution in procuring fresh, pure and reliable seeds, etc., but we, in common with other responsible seed houses, sell our goods subject to the following disclaimer, it being that adopted by the American Seed Trade Association, i. e.: We give no warranty, express or implied, as to description, quality, productiveness or any other matter of any seeds, bulbs, nursery stock, roots or plants sent out and will not be in any way responsible for the crop. If the purchaser does not accept the goods on these terms they are to be returned at once. ROUTLEDGE SEED \& FLORAL CO 


\section{Order Sheet 1920145147 2nd St. PORTzANID ORE.}

\section{Zone}

In filling this order we will use the greatest care to have it true to name, and will replace uny that may prove untrue. But no sale by us carries a warranty of quality, express or implied, and for any error we shall not be liable for more than the purchase price. Every purchase from us is made on these terms. ROUTLEDGE SEED \& FLORAL CO.

DO NOT USE

NAME

THESE SPACES

POST OFFICE

R. F. D. NO.

No.

STATION

$$
\text { (If different from P. O.) }
$$

COUNTY

DATE

FORWAIRD BY State if wanted by Mail, Fxpress, Freight or Steamer. (Read Note on bottom of this page.)
S'TATE

AMOUNT ENCLOSED, \$

O. K. by

Card Made

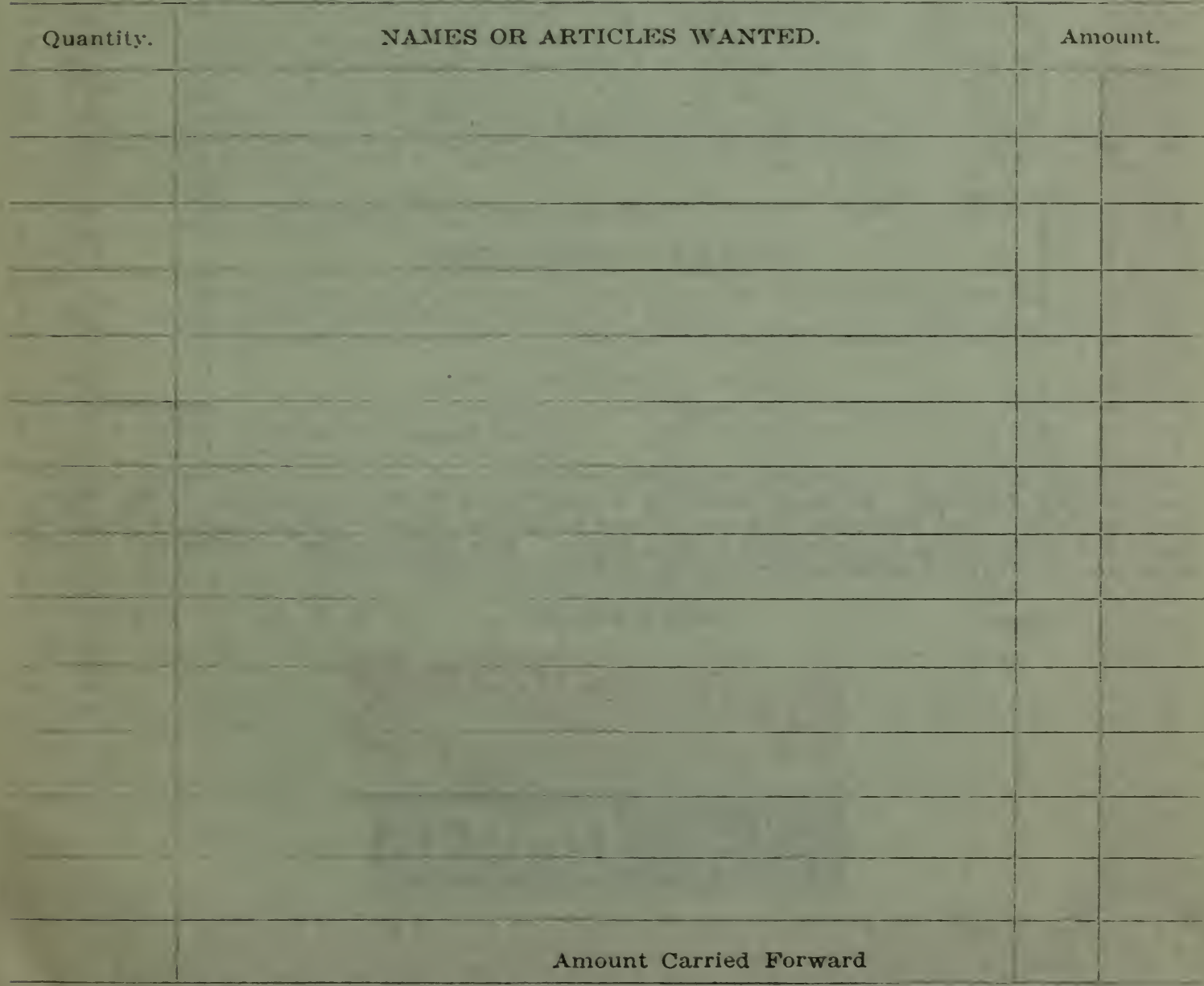

NOTE.-Before you send this order read carefully what we have to say about parcel post and transportation charges on inside front cover and on page 1. 


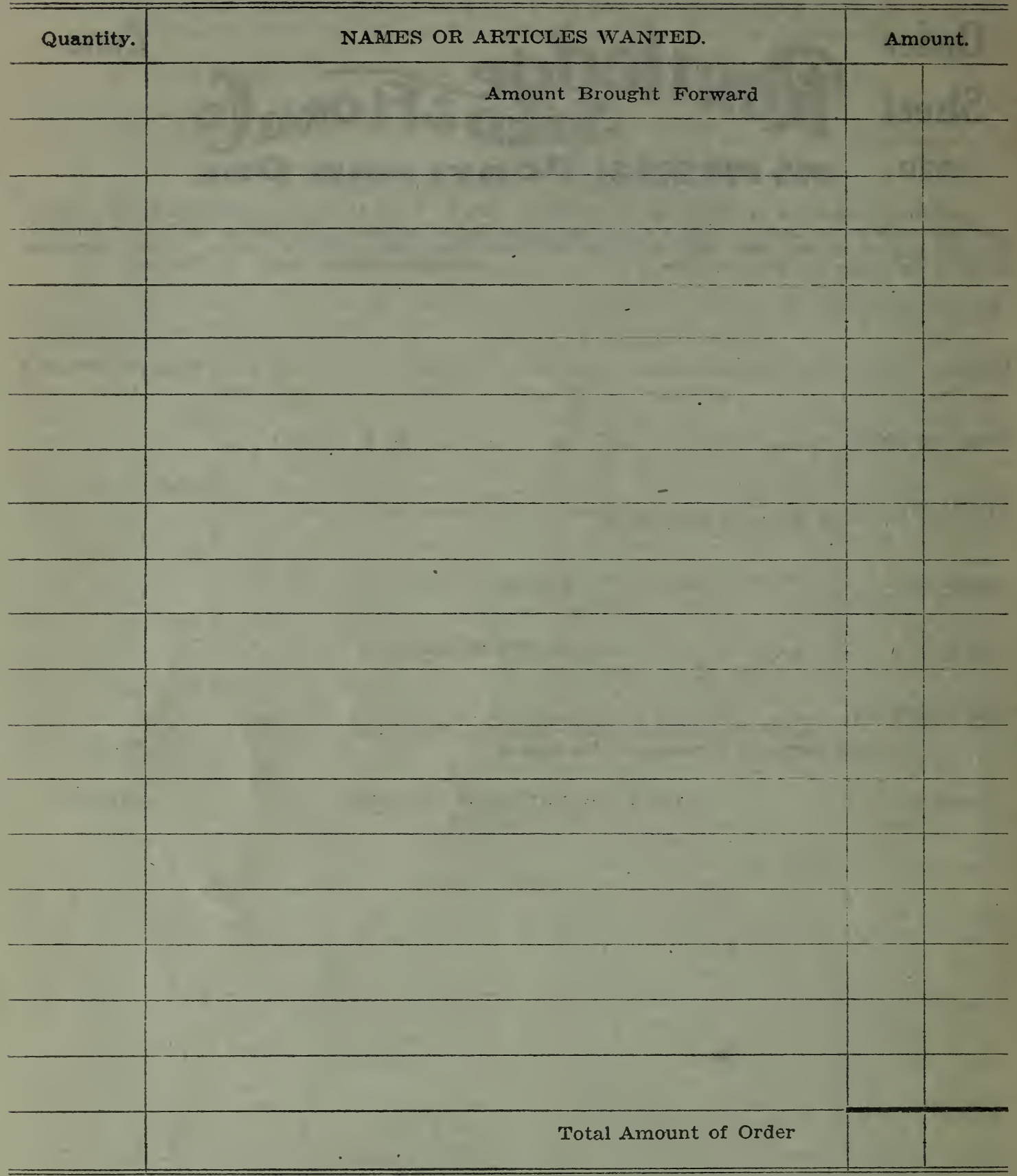

SPECIAL NOTICE. - We shall esteem it a great favor if you will give us in the spaces below the names and addresses of some of your neighbors or any acquaintances in the West whom you think would be interested in this catalog. For your kindness, we will put in your order free of charge a premium plant, bulb, or seeds-our selection.

\begin{tabular}{|c|c|c|c|}
\hline NAME & POST OFFICE & R. F. D. & STATE \\
\hline & & & \\
\hline & & & \\
\hline & & & \\
\hline & & & \\
\hline & & & \\
\hline
\end{tabular}

NOTE.-Before you send this order read carefully what we have to say about parcel post and transportation charges on inside front cover and on page 1. 


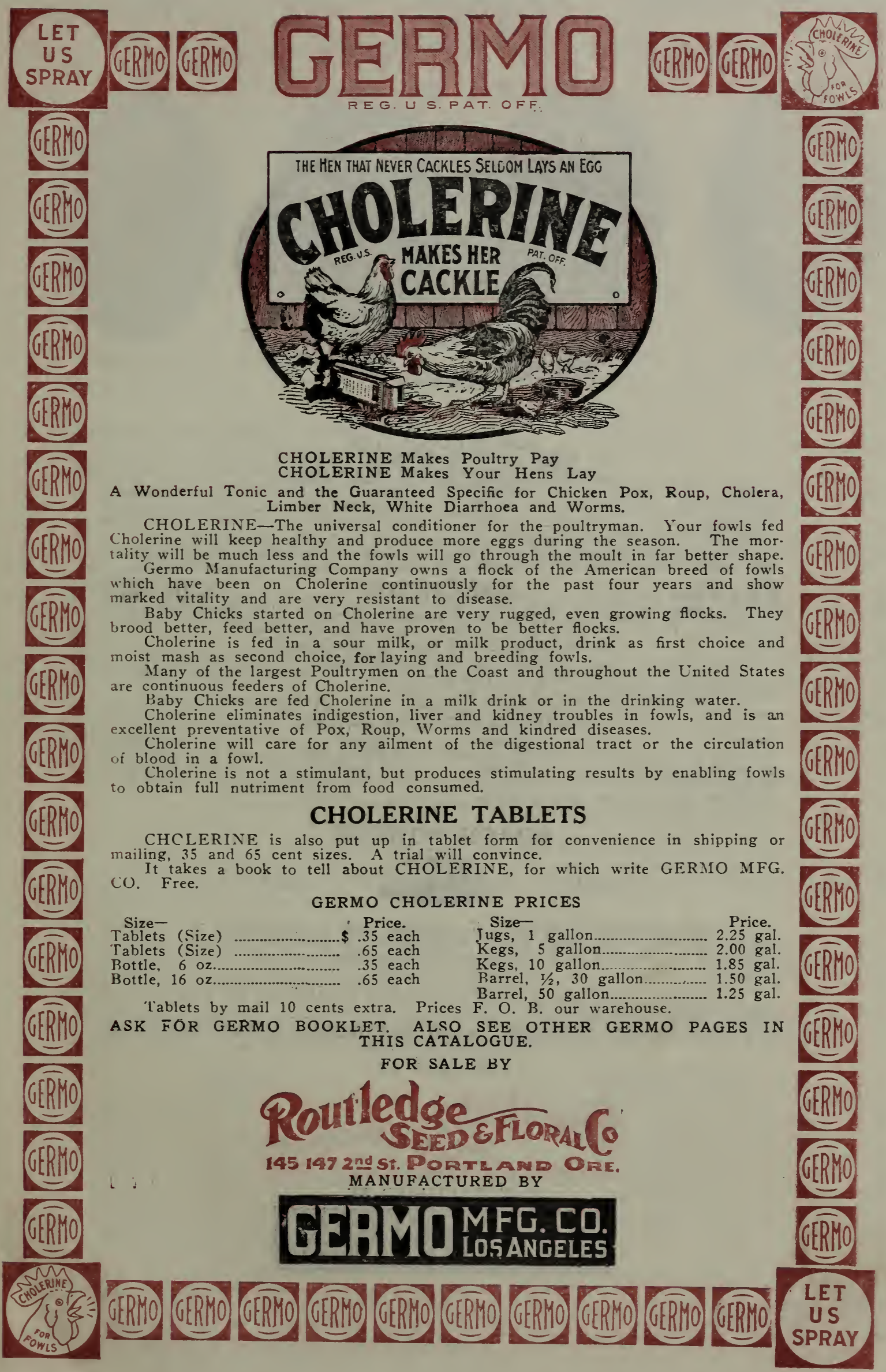




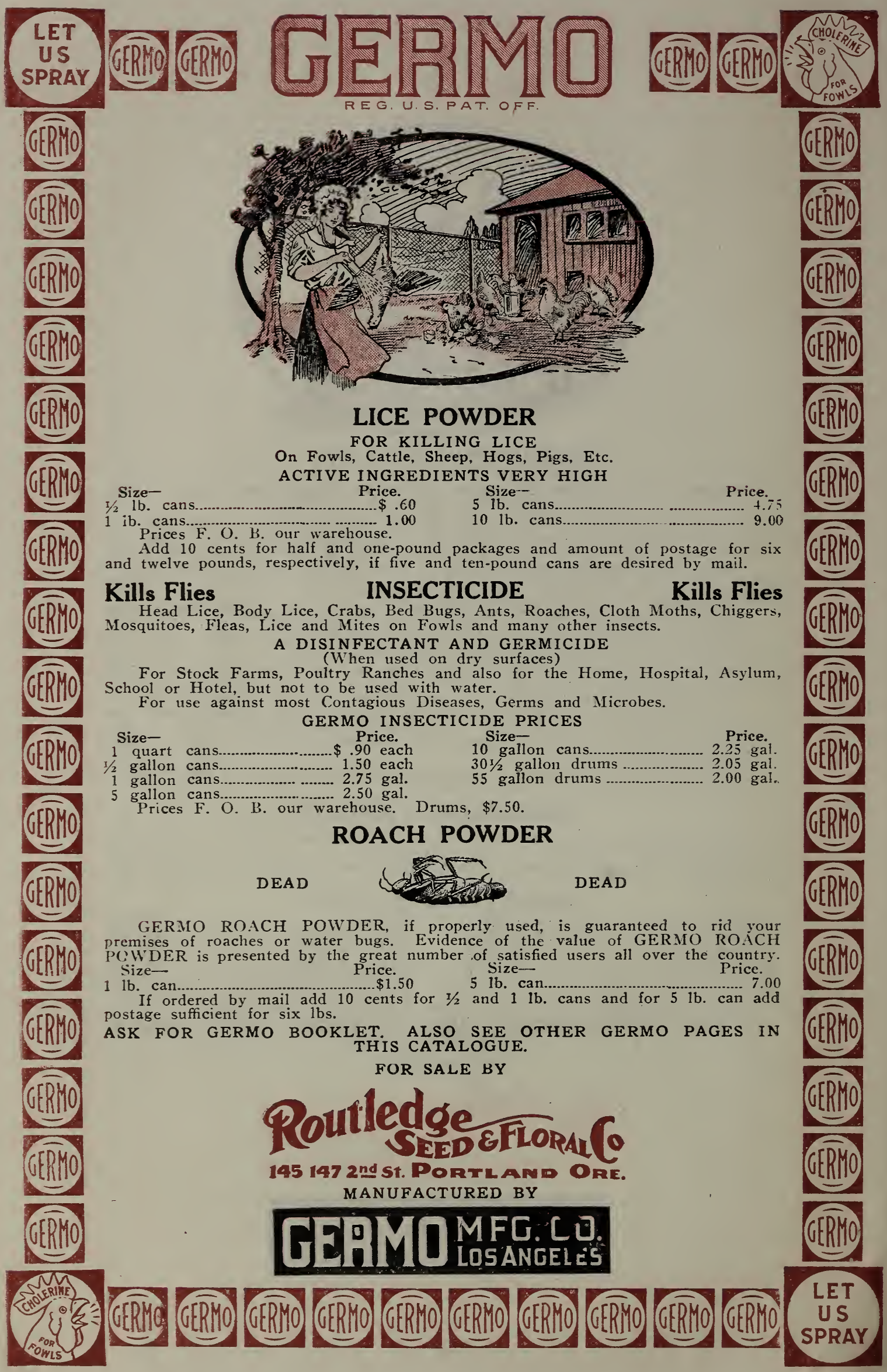




\section{Learn to know them by their given names to save confusion}

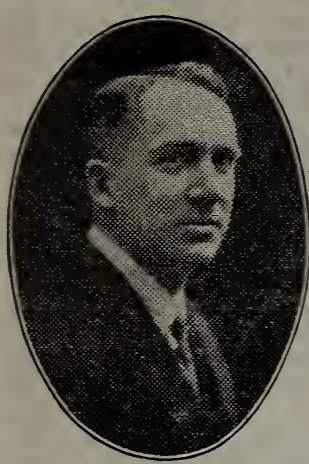

RALPH R.

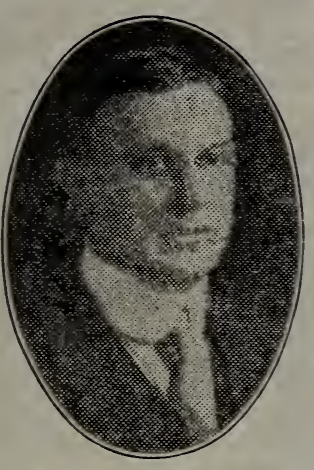

J. IRA

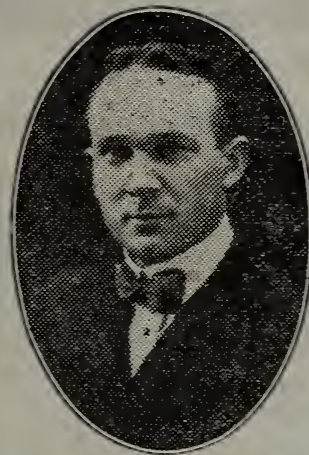

C. H.- "DUKE',

Mgr. Salesroom

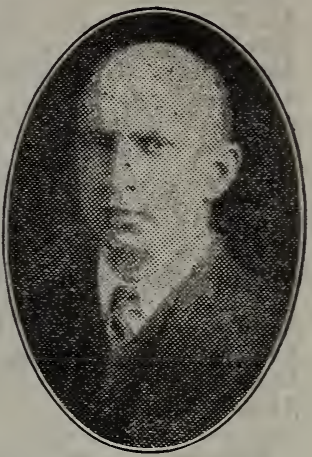

GEORGE L.

Mgr. Pet Stock Dept.

Portland, Ore., Jan. 1st, 1920.

\section{Greetings to Our Customers and Friends}

On this New Year's day we extend to all the "season's greetings." May your fondest wishes come true and may you prosper and be successful.

Since last season we have doubled the size of our office, salesroom and mail order department. We also have a new warehouse on the East Side. All these improvements will enable us to continue to give our rapidly increasing customers quick and satisfactory service.

With the present high cost of living it will pay everyone, who has the room, to raise all the vegetables, fruit and poultry possible. Aside from the savings, profits and healthful exercise derived, the fact that you know your products are fresh and wholesome will be a great satisfaction.

America must help feed and supply the starving nations of Europe, so let us all keep busy and put in another year of extensive work. Raise all the fruit, vegetables, grain and meat possible.

Some seeds and supplies are higher this year; others lower. We have used great care in the selection of the stocks offered and assure you of the same "high quality" and efficient service as heretofore.

"Our Motto": Quality First, then prices as low as we can make them.

We thank you sincerely for past orders and hope that we will have the pleasure of serving you again this year.

\section{Routledge Seed \& Floral Co.}

OFFICE AND SALESROOM, 145-147 Second St., between Morrison and Alder. WAREHOUSE, Corner Union Avenue and Oregon Street.

\section{U. S. PARCEL POST RATES AND REGULATIONS}

BY PARCEL POST.-We do not have agents or traveling salesmen, but do a direct mail order business withour customers. This enables us to give you direct and personal attention, quick service and lower prices.

\section{Size and Weight of Parcel Post Packages}

Packages cannot be sent that measure over 84 inches in length and girth combined. The weight limit for the local, first, second and third zones is 70 pounds. The weight limit for the third to eighth zones is $50 \mathrm{lbs}$., except as follows:

ALASKA, MEXICO, CUBA, HAWAII, PANAMA and the PHILIPPINES take the 8th zone rate with a WEIGHT LIMIT OF 20 LBS. We do not pay postage in 7 th and 8 th zones.

CANADA takes the EIGHTH zone rate with a WEIGHT LIMIT OF 4 LBS. 6 OZS.

\section{Zones}

\section{Postage Rates}

First and second zone..... 50 to 150 miles, first $1 \mathrm{~b}$. 5c; each additional lb.,or fraction $1 \mathrm{c}$ Third zone ........... 150 to 300 miles, first lb. $6 \mathrm{c}$; each additional lb. or fraction $2 \mathrm{c}$ Fourth zone $\ldots \ldots \ldots \ldots \ldots \ldots 300$ to 600 miles, first lb. $7 \mathrm{c}$; each additional lb. or fraction $4 \mathrm{c}$ Fifth zone ...........6. 600 to 1000 miles, first lb. 8c; each additional lb. or fraction $6 \mathrm{c}$ Sixth zone ............1000 to 1400 miles, first lb. 9c; each additional lb. or fraction $8 \mathrm{c}$ Seventh zone ...........1400 to 1800 miles, first lb. 11c; each additional lb. or fraction 10c Eighth zone ................. ovll over 1800 miles, first lb. 12c; each additional lb. or fraction $12 \mathrm{c}$ War Postage Tax.-Add the war tax of 1c extra for each 25c or fraction thereof. Don't forget.

When you order from Portland, look for the zone that corresponds to the number of miles you are away, add up total weight of your order, consult the table above and add postage.

ALL MISCELLANEOUS MERCHANDISE offered in this catalog THAT CAN BE SENT BY PARCEL POST is malked P. P. and the PACKED WEIGHT is given so that extra money for POSTAGE can be remitted according to the table above, OTHERWISE we will send by freight or express. Read copy Inside front cover. 
A

Achilla ......P 80

Acroclinum ..... 50

Aconitum $\ldots \ldots \dot{\mathrm{P}} 80$

Acuba ..........104

Ageratum $\ldots 50$ P 79

Agrostemma .....5 50

Alfalfa $\ldots \ldots \ldots 48$

Alfalfa Meal........145

Almond $\quad \ldots \ldots \ldots \ldots$.

Aloysia $\ldots \ldots \ldots \ldots+100$

Alyssum...50, $\mathbf{P} 79,80$

Amaranthus $\ldots \ldots .6 \%$

Ampelopsis $\cdots \cdots$....106

Anchusa $\quad \ldots . .$. P 80

Anemone $\quad \ldots \ldots$ P 80

Anise Annual Bedding

Plants....76 to 80

Antirrhinum.52. P 79

Apples $\ldots \ldots \ldots 109$

Aquariums
Aquilegia.

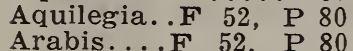

Arborvitae .....104

Araucaria .........104

Armeria $\quad \cdots \cdots \cdots$ P 80

Artichoke.....4, R 43

Asparagus...F 52 ,

S 4 \& P 74, R 117 Aspidistra ....P 75

Asters ..51, P 79, 80

Azalia ......100, 104

\section{B}

Baby Breath (see Gypsophila) $59, \dot{\mathrm{P}}$

Baloon Vine $\ldots . .$. P 53

Balm .......... 37

Balsam $\ldots \ldots \ldots \ldots$ P2

Bamboo stakes...118

Barley $\ldots \ldots \ldots \ldots .44$

Bachelor Button

(See Centaurea)

Beans ...........

Beet . 4-5-6-7-8, F 67

Beef scraps .......145

Begonias ........778

Belgian Hares, etc. 156

Bellflower (see

Campanula)

Berberis...F 54, $\dot{\mathrm{P}} 81$

Bellis ...F $\ddot{52}, \ddot{\mathbf{P}} 80$

Bigonia (see Trum-

pet Vine) …107

Birch ...........105

Birds, Seeds, Foods

\& Supplies ....

Blackberries

Bleeding Heart

(see Dicentra) .. 82

Bone Meal .....4 40

Bone Mills ..138,-139

Books... 130, 152-156

Boston Ivy (see

Ampelopsis Veit-

chii) ........106

Borage ........ 37

Boxwood $\quad . . \ldots \ldots 104$

Broccoli ....11, P 37

Brussels Sprouts
Brooders...132 to 135 D

Browallia $\ldots \ldots .53$

Buckwheat $\ldots \ldots$.

Buttermilk Foods.145

\section{C}

Cages, etc. .153 to 155

Cabbage..12, 13, P 37

Calla Lily $\ldots \ldots . .6 \%$

Calla Lily ....... 990

Caliceolaria $\ldots . .53$

Camelia ..........104

Campanula...54, P 81

Canary Seed …1151

Canary Birds....150

Candy Tuft .....

......F $5 \dot{4}, \dot{\mathbf{P}} 79$

Canna ....F 53, B 89

Cantebury Bells

Caponizing 54, P 81

Carco ............125

Carraway ............. 37

Carrot .........14, 15

Cardinal Climber.. 54

Castor Oil Bean 7,

see Ricinus F.. 67

Catnip Balls, Mice.158

Catnip Seed ....3.37

Catalpa $\quad \ldots \ldots \ldots 105$

Cat Foods, etc......158

Cauliflower. 16, P 37

Cavies ..........155

Cedar .........104

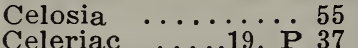

Celeriac $\quad \ldots \ldots 19, \mathbf{P} 37$

Centaurea $\ldots \ldots \ldots 55$

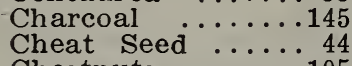

Chinese Wool $\ldots .105$

Chinese Wool .... 55

Cherries .........109

Chervil ........16

Chick Boxes .....137

Chick Feed.145 to 149

Chick Greasers...138

Chickory .......16

Chives $\ldots \ldots \ldots \ldots 37$

Chrysanthemum

$\begin{array}{cccc}0 . \ldots F & 56, \quad P \quad 77,81 \\ \text { Cineraria } & \ldots \ldots & 56\end{array}$

Clarkia .........556

Clematis ...106-107

Clovers $\ldots \ldots \ldots \ldots .48$

Clover Meal .....
Cobea Scandens.

Collards .F 56, P 79

Coleus ....

Columbine (see

Aquilegia F 52, P 80

Conkey's Foods...145

Conkey's Stock and Poultry Reme-

dies .........149

Coreopsis ...56, P 80

Coriander ........ 37

Corn Salad ....... 16

Corn (Sweet) ....18

Corn (Field) …

Cotoneasters …100

Cow Peas .......44

Cress .......... 16

Cultivators $\ldots 120-121$

Currants.F 100, P 112

Cuttle Bone .....151

Cypress Tree ...104

Dad's Lanterns...122

D F $57, \ddot{B} \ddot{9} 1, \ddot{9}$

Daisies...F 57, P 84

Daisy (see Bellis)

$\ldots \ldots$ P $80-84$, F 57

Daphne .........104

Dandelion Puller.118

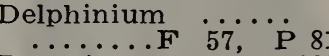

Deutzia ….....100

Dewberries .....113

Dianthus ........ 81

Dicentra $\ldots \ldots$ R 82

Dimorphoteca $\ldots 57$

Dill ............... 37

Dog Foods, etc.157-159

Dogwood ....100-105

Dolichos …....

$\begin{array}{lll}\text { Doronicum } & \ldots \text { P } & 81 \\ \text { Dracaena } & \ldots . . P & 79\end{array}$

Dusty Miller (see

Centaurea) …54

\section{E}

Echinocystis .... 58

Egg Plant ........19

Egg Boxes...136, 137

Egg Testers ....142

Egg Preserver ...136

Elm …........

Emmer (Speltz)...4 47

Eschschoitzia …

Euonymous ,.....100

Extension Rods...129

Evaporator .....122

\section{$\mathbf{F}$}

Fennel

Feeders ..........34

Ferns, etc......74, 75

Fertilizer ..38, 39, 40

Field Seeds...42 to 48

Filberts .......112

Field Peas .....44

Fish, Fish Food,

Globes, etc. ...160

Flower Pots, etc..119

Flowering Cur-

rant, Cherry and

Crab ........100

Fountains $\ldots \ldots \ldots 140$

Myosotis) $\mathrm{F} 63, \mathrm{P} 82$

Forysthia $\ldots \ldots \ldots 100$

Four o'Clock (see

Marvel of Peru)

italis) ...58, P 81

Fruit Dryer $\ldots .122$

Fruit Ladders ...123

Fruit Picking

Bags .........123

Fruit Trees, etc..

Fuchsias ........ P 78

\section{G}

Gaillardia .. 58, P 82

Garden Hose, etc

arden Stakes.......129

...118 Kirk System ....440

Tools..118-121 Knives, etc. ....119

Garlic .........19 Kohl-Rabi ..... 19

Genista .........101 Kochia .......61

Cypress Vine ...F 57 Geranium ...P 76, 79 Kudzu Vine...61-106

Geum $\ldots \ldots \ldots$ P 82

Gloxinia $\quad \ldots \ldots 888$, 89

lobe Amaranth

(see Gomphrena) 59

Gio....... 59

Rudbeckia) ,....

Gold Fish, etc. P 160

Gomphrena $\ldots \ldots 59$

Gooseberries $\ldots \ldots 112$

Gopher Traps ....119

Wafting Wax...125

Grapes $\ldots \ldots \ldots 114$

Grinding Mills 138-139

Grass Seeds....42-43

Grit ...............145

Gynerium..F $59, \quad \dot{\mathbf{P}}^{83}$

Gypsophila F 59, P 82

Hanging Baskets.P 79

awthorn $\ldots . \ldots 101$

Helianthus.59, 60, P 82

Hemp

Hemerocallis ...P 82

Heuchera $\ldots .$. P $^{37}$

orehound $\ldots \ldots .37$

Holly $\ldots \ldots \ldots \ldots 104$

Honeysuckle $\ldots .107$

Hop Roots ......117

Horseradish …

Humulus $\ldots \ldots \ldots 61$

Hyacinth Bean (see

Dolichos) ..... 58

.......101

Hygrometers $\quad \ldots .142$
Hypericum

Hyslop $\ldots \ldots \ldots .37$

Iberis..P 82, (see

Candytuft) F 54, P 79

Incubator $\quad \ldots \ldots \ldots 131$

cticides $\quad \ldots 123-125$

\section{$\boldsymbol{J}$}

Japanese Hop (see

Jardiniers .........6118

Jasmine .......106

Juniper .......104

Kaffir Corn ....4 47

Kale, Garden.19, P 37

Kale Stock...44, P 37

Killing Knives....140 


\section{INDEX TO CONTENTS - Continued}

\section{Page}

Note.-B-Bulbs. P-Plants. R-Roots. F-Flowers.
L

Land Plaster..... 40 Labels .............118

Laburnum .......101

Lantana .........990

Lamps, etc. ........141

Larkspur ...61, P 81

Laurel ….......104

Laurustinus $\ldots 37, \ldots 104$

Lathyrus …....66 61

Lawn Grass .....4 49

Lawn Rollers..... 40

Leg Bands ......143

Lentils Lily (see 47

Lemon Lily (see
Hemerocallis)..P

Lemon Verbena

(see Aloysia)... 50

Leek ............ 19

Lice Powder and

Liquids ........149

Lilac $\ldots \ldots \ldots \ldots$........

Lilies $\ldots \ldots \ldots \ldots$.... 85

Limestone $\ldots \ldots \ldots 40$

Lime $\ldots \ldots \ldots \ldots \ldots 105$

Lily of the valley 85

Loganberries ....113

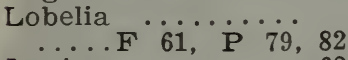

Lupinus $\ldots \ldots \ldots 62$

Lychnis $\ldots \ldots \ldots$ P 82

M

Magnolia .......104

Mahonia ….....104

Majoram .........37

Marigold ...62, P 79

Marvel of Peru...62

Maples .....102, 105

Mesembryantheum 62

Migonette .....6.62

Millet $\ldots \ldots \ldots 47,151$

Mimulus $\ldots \ldots \ldots, 62$

Ninle Traps ......
Moon Flower (see

Moon Flower (see

Morning Glory....66 63

Moss $\because \ldots \ldots \ldots \ldots$........

Mountain Ash....105

Mrulford's Cultures 41

Muskmelon $\ldots . .24$

Muskplant (see

Mimulus) (.....66 62

Mushroom spawn. 23

Mustard ........23

Myosotis …6. 63 , P 82

Myrtle (see Vinca)

.......... 79

$\mathbf{N}$

Nasturtium

84

Nigelia .......66 63 Puppies, Foods,

Nitro-germ .......41 etc. $\ldots \ldots \ldots 157,159$

Nozzles, etc. .....129 Pumpkin .........31

Nox-i-cide .......149 Pyrethrum. $\mathbb{F} 67$, P 83

0

Oat Sprouters

(Write; we have

some).

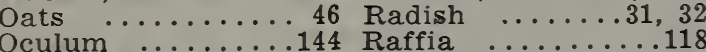

Oregon Grape (see Rape ........47, 151

MIahonia) ….104 Raspberries .....114

Onion Sets …2.23 Rat Cure, Poison.125

Onion ........22-23 Reference Tables

Okra ...........23 .Inside Back Cover

Retinospora ......105

Rhododendrons ...105

Rhubarb.S 32, R 117

Ricinu

Rock Cress (see

Arabis) F 52, P 80

Paeony $\ldots \ldots \ldots 87$

Palms, etc. ....... 75

Pampas Grass, $P$ $82 ;$ (also see Gy-

nerium) $\cdots 6 \%$ P 79

Parsley …......2 29

Parrots, Cages,

Foods, etc...150-156

Parsnip ......... 30

Peaches .........111

Pears $\quad \ldots \ldots \ldots .110$

Peas $\ldots \ldots \ldots 25-26-27$

Peanuts Bianks...157

Pedigree Blanks..157
Pentstemon $\ldots . . .64$

Pepper .....30, P 37

Persimmons …1112

Pe-Tsai $\because \ldots \ldots 13$

Phenomenal Ber-

ries .........113

Phenola .........125

Philadelphus ....102

Phlox ...55, $\stackrel{\text { P } 79,83}{ }$

Pigeon Food ....146

Pine $\ldots \ldots \ldots \ldots 104$

Pink P 81 (see Dianthus) $\ldots .57, \mathrm{P} 81$

Planet Junior....122

Plant Stakes .....118

Plums .........111

Poppy..F 66,67 P 82

Poplar $\ldots \ldots \ldots 105$

Potatoes $\quad \ldots \ldots 28,29$

Potato Planters.

(Write; we have some.)

Pots, Pot Labels.118

Poultry Remedies, .........130 to 149

Powder Guns....128

Privet ............105

Primrose... $\mathrm{F}$ 78, P 83

Nectarines .......111

Nemesia $\ldots . .663$

Nest Eggs $\ldots \ldots \ldots 144$

Nests, wire.......143

Nitrate of Soda.. 40

Nicotiana Soda.. 40 pound

Com-

St. John's Worth
(see Hypericum)

124 Stramberries. iij, 82

Roses …...94 to 99

Rosemary ........ 37

Rubber Plant .....75

Rudabeckia $\dddot{F} \dddot{6} \ddot{8}, \ddot{P} 83$

Rye …..... 47

$\mathbf{s}$

Saxifragas ....P 84

Sage …......... 37

Salpiglossis $\ldots \ldots \ldots \ldots$

Salsify $\cdots \cdots \cdots$ P $^{33}$

Savory …....... 37

Scabiosa $\ldots .72$, P 84
Schizanthus

Schizanthus .... F 68

Shade Trees .....105

Shamrock $\ldots \ldots 72$

Shasta Daisy 57, P 84

Sheep and Hog 149

Dip .........149

Snapdragon (see

Antirrhinum) . . 52

Snowball ........103

Spratt's Foods

etc. ......158, 159

Spray Pumps.126-128

Sprays $\ldots 124,125,149$

Speedtwell $(\mathrm{see}) \mathrm{Ve}-$

ronica) ....... 84

Spinach ........ 33

Sprinklers .......129

Spruce $\cdots \ldots \ldots .105$

Squirrel Poison...125

Stocks ....F 68, P 79

Stock Foods, Rem-

edies, etc. .....14

St. John's Worth

82
116
42

Uunflower .......S 32

Also Helianthus

$\ldots \ldots \ldots \ldots$...... 59,60 .

Sugar cane ..... 47

Sumack :.........103

Sweet Clover..... 48

Sweet Peas $\because \cdots 71,72$

Sweet Potato

Plants ........37

Sweet Sultan (see

Centaurea) ....5 54

Sweet William... 68

Swiss Chard (see

Symphoricarpus $\ldots 103$

\section{$T$}

Tamerix ........103

Thermometers ...142

Thumbergia .... 72

Thyme $\ldots \ldots \ldots 37$

Tobacco $\ldots \ldots 3 \ddot{3}^{3}{ }^{35}$

Tromato $\ldots .35$, P 37

Tree Tinglefoot...123

Trumpet Vine...107

Tritoma...F 72, P 84

Tube Roses..... B 90

Tulip Trees.......105

Turnip $\ldots \ldots \ldots .36$

\section{$\nabla$}

Valeriana .......72 72

Vegetable Plants and Roots...37, 117 Verbena...F 73, P 79 Vetches …... 47 Veronica '.......P 84 Vinca $\ldots . . P$ P 79,84

Virburnum $\ldots 103$

Virginia Creeper

(see Ampelopsis) 106

\section{W}

Wallflower F 73, P 84

Walnuts .......106

Water-Glass ......136

Watermelon .....24

Weeders ........119

Weed Killer .......123

Weigelia ........103

Wheat ........48

Whitewash (see

Phenola) ….125

Wild Cucumber

(see Echinocystis) 58 Wild Flower Gar

den ..........73

rvillow Trees.......

Wire Baskets, etc.118

Wistaria ........107

Wong Box ........ 13

Wonder Fertilizer. 38

Wormwood …...3 37

Y-Z

Yucca $\quad \ldots \ldots \ldots .105$

Zinnia $\quad \ldots .73, \mathrm{P}^{79}$

OUR FALL CATALOG READY ABOUT SEPTEMBER 1ST

Our fall catalog of Flowering Bulbs, Hardy Plants and Shrubs, Rose Bushes, Fruit, Shade and Ornamental Trees, Shrubs and Vines is issued about September 1st each season. If you would like a copy, make your request at any time and we will put your name on the mailing list for catalog in season. 


\section{ARTICHOKE}

LARGE GREEN GLOBE.-The well-known French vegetable; the undeveloped flower heads, when properly prepared, make a most deli-

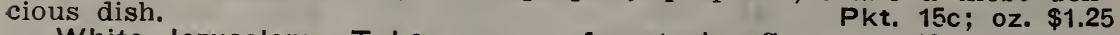

White Jerusalem.-Tubers grown for stock. See page 43.

\section{ASPARAGUS}

COLUMBIAN MAMMOTH WHITE.-Gives immense yield of large. clear: white shoots; very tender and of excellent flavor.

Pkt. 5c: oz. 15c; 4 oz. 35c; lb. $\$ 1.00$

PALMETTO.-Early, prolific; large, this:k, dark-green shoots. Popular commercial variety. Pkt. $5 \mathrm{c} ;$ oz. $15 \mathrm{c} ; 4$ oz. $35 \mathrm{c}$; ib. $\$ 1.00$

CONOVER'S COLOSSAL.-A good, standard large sort of approved quality. Shoots bright green, very tender.

Pkt. $5 \mathrm{c} ;$ oz. $15 \mathrm{c} ; 4$ oz. $35 \mathrm{c}$; lb. $\$ 1.00$

ASPARAGUS ROOTS

You can save two or three years' time by buying Asparagus Roots.

For prices, see Vegetable Roots, page 117.

\section{GARDEN BEANS}

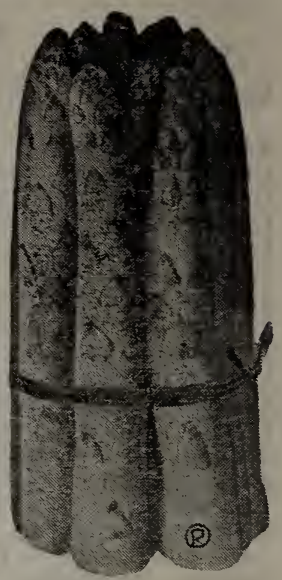

Asparagus Tips

\section{DWARF OR BUSH--GREEN PODDED KINDS}

Packet and single pound prices only are prepaid. Add postage to 10 lb. prices if wanted by mail. (10)

\section{STRINGLESS GREEN-POD}

The Most Popular and Best Liked Green Snap Bean

This famous bean is unequaled a: a first-early; also for main crop. It combines unusual hardiness extreme earliness, and wonderful productiveness with handsome appearance and finest quality of pods. Extia early plantings may be made to produce the earliest crop, and even with later plantings this bean is the quickest to produce pods.

By repeated plantings pods may be had in constant succession from spring until cut off by heavy frosts in the fall. Combined with the extra hardiness and early maturity, the pods are the finest in quality, of a rich green, very iound and almost straight, long. solidly meaty and plump,-deeply saddie-backed, caused by the rounded swell of the fleshy sides. The pods are tender. brittle, and of finest flavor, always entirely stringless even when fully matured.

Large pkt. $15 \mathrm{c}$; Ib. $35 \mathrm{c}$; 10 Ibs. $\$ 3.00$

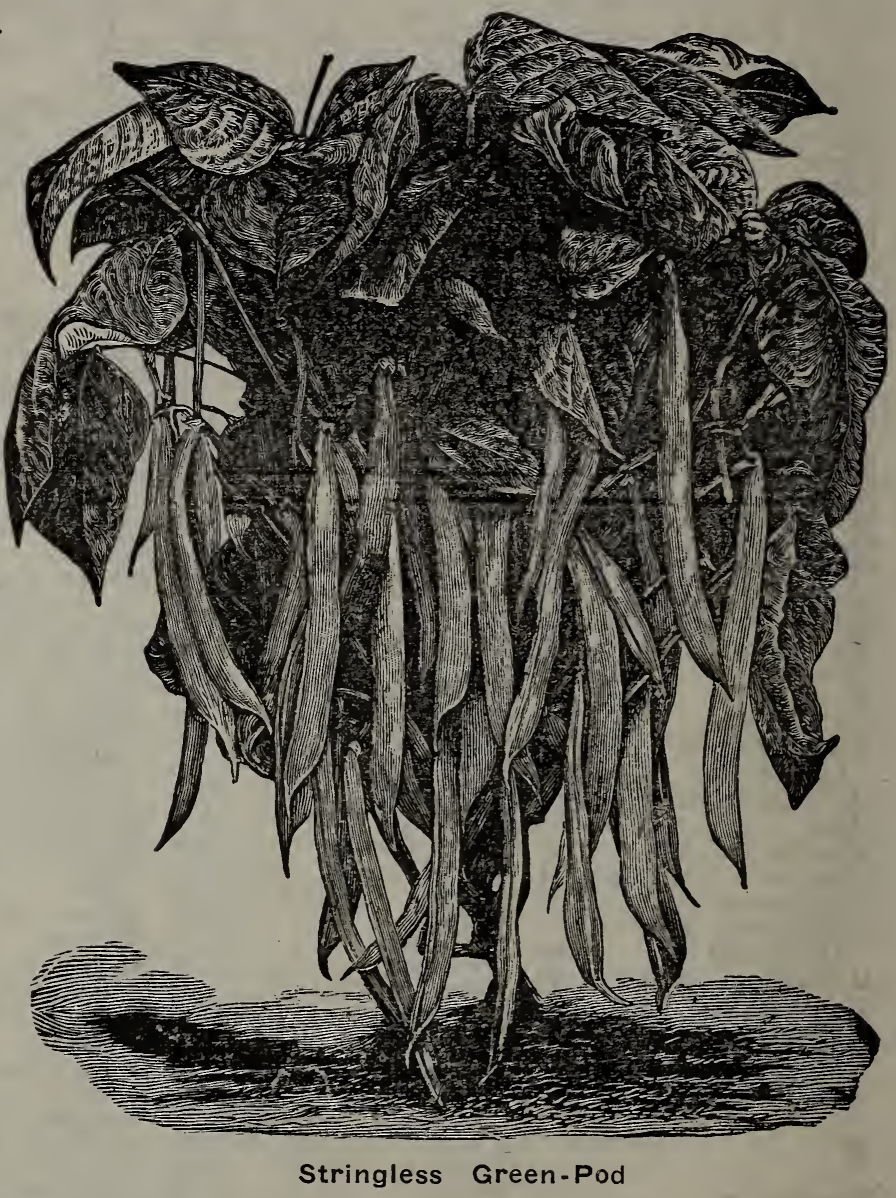

DWARF HORTICUITURAL

One of the best dwarf sorts for green shell beans for the home garden and market and can be used early as a garden podded snap bean. The plants are very productive. compact and upright, with large leaves. The mature pods are about five to five and one-half inches in length, broad and thick, curved, with splashes of bright red on a yellowish ground. They become fit for use as green shelled beans early and in this condition the beans are very larg€, easily shelled and are about equal to the Lima in quality. Seed large, ovel. plump, pale buff splashed with deep red. Excellent for canning.

Extra Early Refugee

Large pkt. 15c; Ib. $35 c ; 10$ Ibs. $\$ 2.75$

Very hardy and extremely productive. Pods round and straight, tender and of excellent quality. Excellent as a snap bean and always in demand as a pickling and canning variety.

Large pkt. 15c; lb. 35c; $10 \mathrm{lb}=\$ 3.00$

Market and Truck Gardeners should write us for special prices and state quality and kinds wanted. We'll save you money and you will get "Highest Quality" Seeds. 


\section{INOCULATE THIS \\ SEED WITH \\ MULFORD CULTURE}

\section{DWARF OR BUSH-YELI,OW PODDED}

\section{PROLIFIC BLACK WAX}

The earliest wax variety. Pods a rich, creamy yellow, round, fleshy, tender, stringless and remain in fit condition for some time. Enormously productive and of fine quality, and one of the most reliable sorts for general use.

Large pkt. 15c; Ib. $40 \mathrm{c} ; 10$ Ibs. $\$ 3.25$

\section{IMPROVED GOLDEN WAX}

Medium early, heavy cropper, vine vigorous. May be sown early or late with the assurance of a good crop. Pods are golden yellow, fleshy and solid, brittle, waxy texture and have an exceptionally rich buttery flavor. Excellent for home or market garden.

Large pkt. $15 \mathrm{c} ;$ Ib. $40 \mathrm{c}$; 10 lbs. $\$ 3.50$

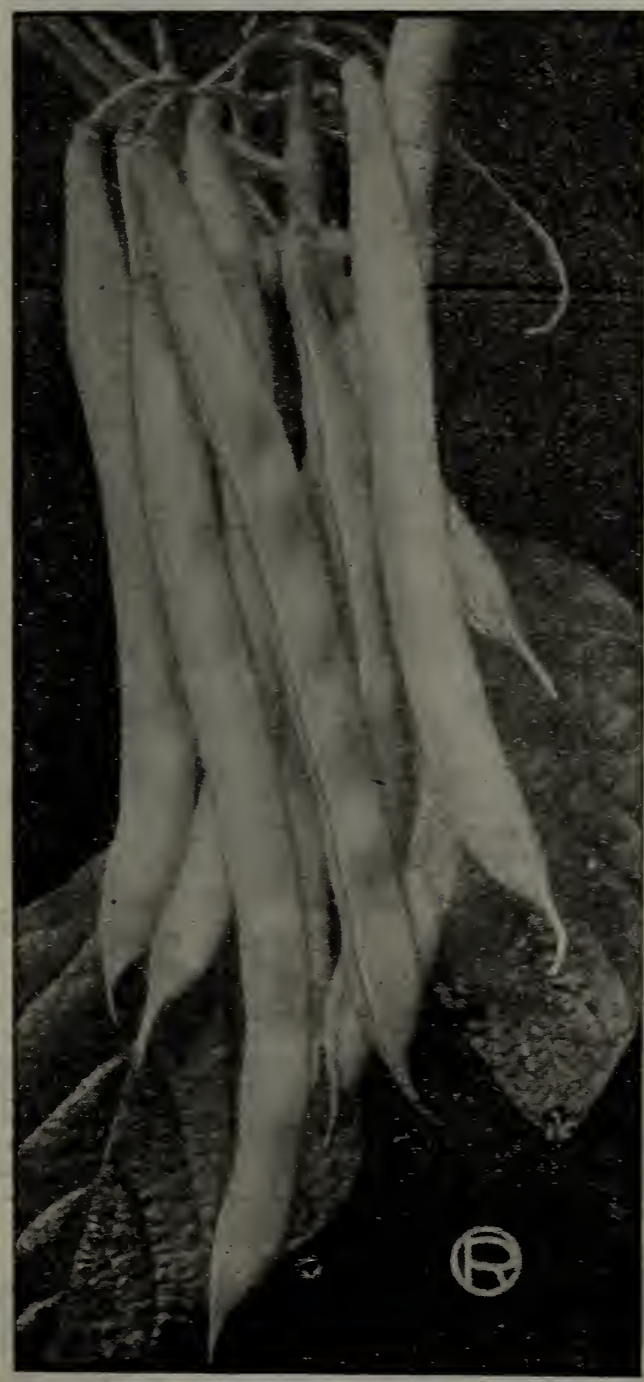

Davis Wax

\section{INOCULATE THIS SEED WITH MULFORD CULTURE}

Packet and single pound prices are pre. paid. Add postage to 10 lbs. prices if wanted by mail.

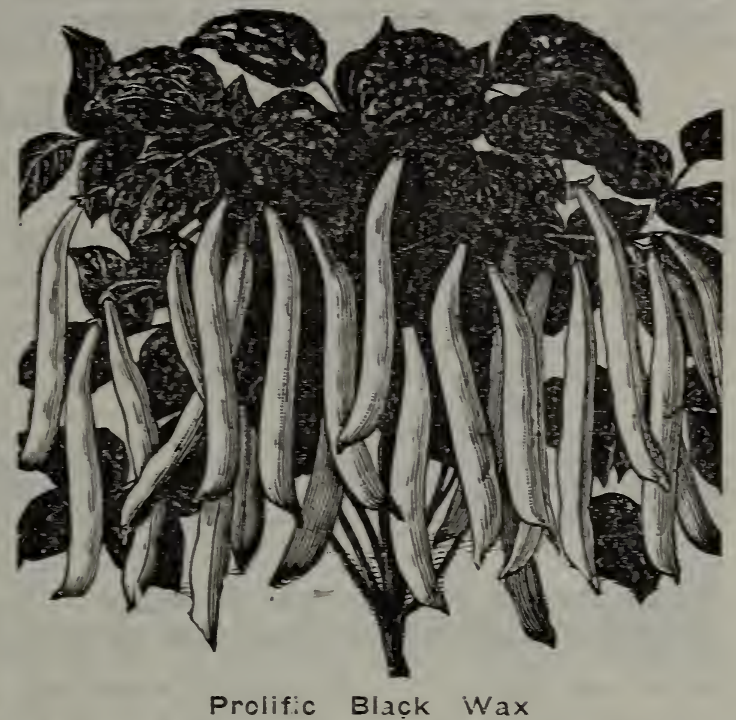

Skagway, Alaska, March 21, 1919. Routledge Seed \& Floral Co.

Gentlemen: A small order for seeds and bulbs I sent your firm on February 10 came on time. The seeds were all planted and are now all up and I can compliment you on the high quality of seeds you sent. Yours truly.

\section{O. WALKER.}

DAVIS KIDNEY WAX (See Cut)

The most hardy and productive wax bean The pods are long, white, straight, crisp and tender. The vine is rustless and very vizorous, bearing the pods ir clusters. For canning this is unexcelled on account of purity of the pod and bean. It is a remarkably good variety for shipping; seed white, and on this account it is desirable for a shelled bean in winter.

Large pkt. $15 \mathrm{c}$; Ib. $35 \mathrm{c} ; 10$ lbs. $\$ 3.00$

\section{NEW BRITTLE WAX}

Extremely early and of such superb quality it might almost be called "Best of All." The plants are of vigorous growth, with large foliage, and appear completely loaded with handsome pods, which are nearly stiaight and measure $4 \frac{1 / 2}{2}$ to 6 inches long. They are broad, fleshy, tender, "brittle" and entirely stringless at all stages of growth. The pods are unexcelled as snapshorts. Seed white, showing only a small dark dot at the eye; any surplus allowed to riped will be readily salable as winter shell beans. (Seed crop very short.)

Large pkt. $15 \mathrm{c}$; lb. $40 \mathrm{c}$; 10 lbs. $\$ 3.25$

Wardwell's Kidney Wax

A popular and well-known variet $r$; pods long, golden-yellow, brittle and stringless: seed white, with dark markings about the eye. Market gardeners find this bean one of the most profitable. (Seed crop very short.) Large pkt. 15c; Ib. $40 \mathrm{c} ; 10$ Ibs. $\$ 3.25$

NEW BOOK-GARDEN GUIDE

The best book of its kind we have ever read, of real value. See Books, page 130. 


\section{DWARF BEANS-Continued \\ French Green (Haricots Verts)}

A fairly good string bean when young, but it is a most delicious shelled bean, either green or dry. When a French cook sees this variety, he knows that he can prepare a most delicately flavored dish, attractive to the eye and extremely palatable. The dry bean is medium size, rather flat and light green in color, which is retained after cooking. Very distinct. A vigorous grower and extremely productive. This bean should be harvested before they get too dry and keep from sunlight to retain color. Seed scarce, stock limited.

\section{CLIMBING POLE BEANS}

Packet and Single Pound ONLY are postpaid. Add postage If wanted in 10-lb. lots by mail.

\section{Routledge Perfection "White Seeded" Pole Bean}

Our start of this meritorious new variety was obtained from a few seeds brought over from England. It produces large, quick growing vines which scon cover the poles, bearing a very heavy crop of handsome green pods about iz inchs in length which are very meaty, stringless and of delicious flavor. The vines produce their pods very early and continue to bear immense quartities of snap pods throughout the season. Excellent for canning. The dry beans being white and of good size when allowed to ripen on the vines. make it an excellent soup or bake bean for winter use. Stock limited.

Large pkt. 20c; Ib. 50c

Improved Kentucky: Wonder (Asparagus)

A very popular variety; often sold as asparagus. More extensively planted than any other. Pods green, very long, round and perfectly stringless. Enormously productive and early, remaining in "fit" condition a long time. Unsurpassed for the table, being very tender and of delicious flavor.

Large pkt. 15c; lb. 40c: 10 lbs. $\$ 3.25$

\section{Kentucky Wonder Wax}

The best wax podded pole bean. Very similar to the green podded Kentucky Wonder but the pods are a little broader. They are very fleshy and stringless as snaps and are of excellent quality. The pods are very long, handsome light yellow. Seed medium sized, oval, flattened, very irregular, usuallv somewhat shriveled, dark brown. Its earliness and hardiness commend this as a pole bean well adapted for northern latitudes. $\quad$ Large pkt. 15c; Ib. 45c; 10 lbs. $\$ 3.50$

\section{Harlequin-New}

The finest pole horticultural variety in cultivation and on account of its wonderful productiveness and superior quality takes first rank as a late Shell Bean. The strain we offer is an especially fine one. Pods extra long, 6 to 7 inches. brilliantly colored with crimson carmine and are borne in clusters. Unequaled for tenderness and delicious flavor. either shelled or as snaps. Dry beans a little larger and a trifle longer than the old Horticultural Pole. Large pkt. 20c; Ib. 50c

\section{Lazy Wife}

One of the best of the later green podded pole beans for snap or green shell use. The medium green pods, borne in large clusters, are five to six inches long, broad, thick, fleshy and entirely stringless. When young they have a rich, buttery flavor which is retained until they are nearly ripe. The dry beans are excellent for winter use. The seed is white, medium size, slightly oval or nearly round.

Large pkt. 15c; lb. 45c; 10 lbs. $\$ 3.75$

Large pkt. 20c; Ib. 50c

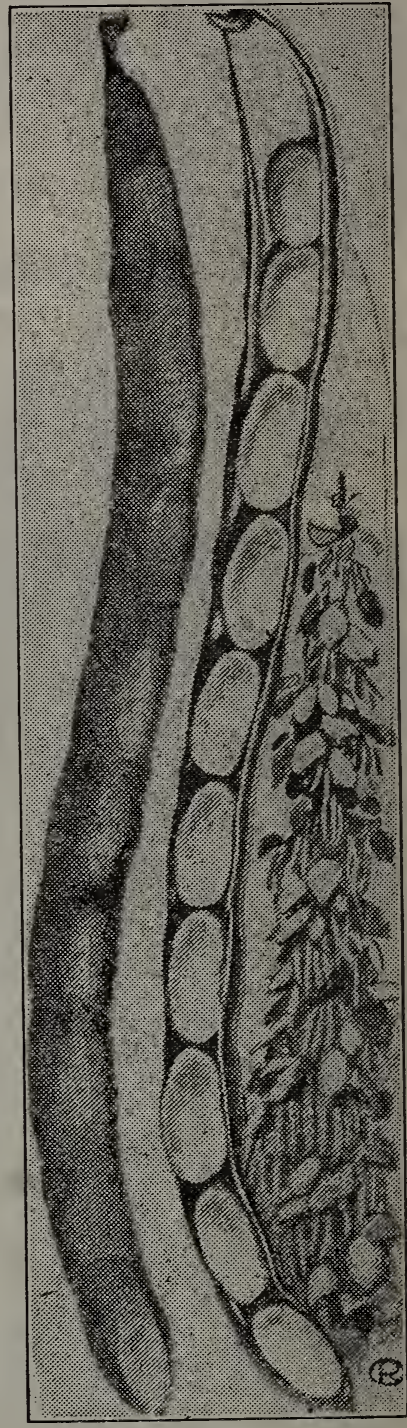

Kentucky Wonder Asparagus,

\section{Horticultural Pole}

Speckled Cranberry or Wren's Egg.-Vines vigorous, quite early. Pods short, broad. green, streaked with bright rer. Beans are rourd, splashed and spotted with red. Of fine quality, either as a green Shelled Bear or dry for winter use.

Large pkt. 15c; lb. 35c; 10 lbs. $\$ 3.00$

\section{Dutch Case Knife}

A moderate climber with long, flat, fleshy vods, which become creamy white as they mature; seed broad, flat -and clear white. Good as a dry bean.

Pkt. 15c; Ib. 35c; 10 lbs. $\$ 2.75$

\section{Scarlet Runner}

Grown extensively for ornamental purposes, as flowers are a most brilliant scarlet and borne profusely; beans are broad and flat, and of fine flavor when cooked, same as Lirra beans. Large pkt. 15c; Ib. 40c

Crabtree, Ore., March 15, 1919. Routledge Seed \& Floral Co.

Dear Sirs: We have been sending for seed from your house for two years with great satisfaction. The Improved Tree Beans is great. Thanking you,

MR. C. L. UNKE.

Although pole beans require a IIttle more care and labor, they are, when properly grown, usually of longer bearing perlod than the dwarf sorts and are much more productive. 


\section{Commercial Dry Table Beans}

Beans will grow successfully on most any kind of soil, but they will do better and yield heavier on soil that is mellow, well drained and warm. Land that will produce good corn or wheat will grow good beans. Sandy river bottom is especially good.

PLANT TRUE PURE SEED.-It certainly pays to secure a clean, true seed stock. Don't plant any common stock, even though it looks all right. You cannot tell by looking at it whether it is early or late, or acclimated.

The stocks we offer are of known varieties, acclimated and hand-picked and grown espe. cially for seed-by far the safest, best and most profitable in the end, even though it costs a little more at planting time.

\section{Brown Swedish}

Dry beans, rather small size, round, oblong, light golden brown with a white eye. As a cooking or baking bean the quality is very superior, having a richness and flavor all its own. Our customers who planted it last spring praise it very highly. They say on account of its excellent qualities, they piefer it for their own table use. It is unusually productive, pods long and straight and always well filled. Bush strong, healthy and vigorous. Crop matures early. Pkt. 15c; Ib. 30c; 10 lbs. $\$ 2.50$ To insure the greatest success

INOCULATE THIS
SEED WITH
MULFORD CULTURE

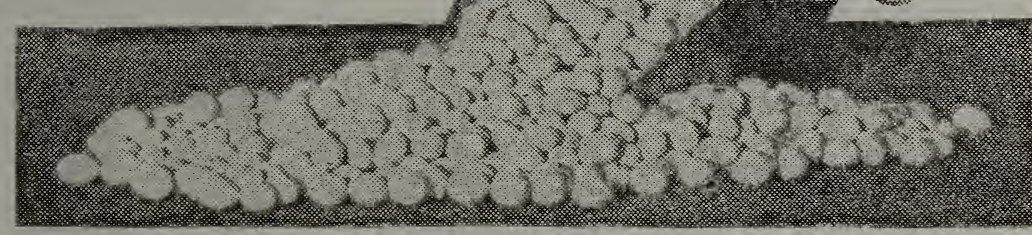

See page 41

Improved Tree Beans

\section{IMPROVED TREE BEAN}

\section{Early, Wonderfully Productive}

Of all the varieties we have tested we believe this is the best and most profitable white field bean for Oregon from the reports we have had from those who have planted it. On account of its snowy whiteness and uniformly small size, it commands the highest price in all markets. The plants grow upright, have less foliage than most varieties and hold the pods well up from the ground, thus keeping the beans from getting dirty and discolored. The pods are very freely produced, are long and well-filled. The dry bean is small, white, plump and almost round. Cooking and eating qualities are unsurpassed... The whole crop will ripen early and evenly and you can get it safely harvested before the rainy season sets in. Our stock of this particular strain is rather limited, so order early.

We will appreciate reports from all who plant it.

Prices: Large pkt. 15c; lb. 35c; 10 lbs. $\$ 2.25 ; 25$ lbs. $\$ 5.00$.

\section{Lady Washington}

A great improvement over the old "Navy," for Western Oregon and Washington growers, as it is much earlier, a trifle larger, and a very heavy yielder, especially adauted to western conditions. The pods all ripen together and early enough to harvest before winter rains. Bean pure white and of excellent quality. Growers report our stock very superior.

Large pkt. 15c; lb. 25c; 10 lbs. $\$ 2.00$

Write for quantity prices.

\section{Broad Windsor}

An English variety; large, broad, flat beans of delicious flavor; used as a shell bean. Good for hog pasture; very hardy and very productive.

Large pkt. 15c; Ib. 25c; 10 lbs. $\$ 2.00$

\section{Boston Yellow Eye}

A bean of merit. 'Try it. Almost every' one who has lived in New Englard knows the Boston Yellow Eye Bean and prefer them to any other Bean for cuoking, as they possess a richness and flavor known to no other variety. As a shell Bean they are delicious, and for cooking in a dry state they have no equal. The dry Bean is almost round, plump and of a beautiful light-brown with a yellow eye. We strongly recommend the planting of the Boston Yellow Eye. Once used, they are always wanted.

Large pkt. $15 \mathrm{c} ;$ Ib. $35 \mathrm{c} ; 10$ lbs. $\$ 3.00$

\section{White Wonder}

Many of our customeis have asked for a green podded white bean that would answer for a "snap bean" as well as a white bean for winter use. White Wonder is the bean to plant for this purpose. The strong points in its favor are its exceptionally fine flavor, remarkable productiveness, extreme hardiness and splendid appearance. It is a string bean, but there are few if any beans that cook more tender. Pods large, round and straight. Seed pure white. of medium size and excellent quality, baked or boiled.

Large pkt. $15 \mathrm{c} ;$ Ib. $35 \mathrm{c}$; 10 lbs. $\$ 2.75$

\section{Red Mexican}

An excellent $d_{\iota} y$ bean for winter use. Used extensively for baking and Spanish dishes. We offer select, hand picked. Oregon grown, acclimated seed.

Large pkt. 15c; Ib. 25c; 10 lbs. $\$ 2.00$

FOR LIMA BEANS SEE PAGE 8.

\section{Castor Bean}

Used for medicinal purposes and by some claimed to keep moles away. Ornamental foliage, $4 \mathrm{ft}$ Large pkt. 15c: ib. $50 \mathrm{c}$ 


\section{BEANS-Continued}

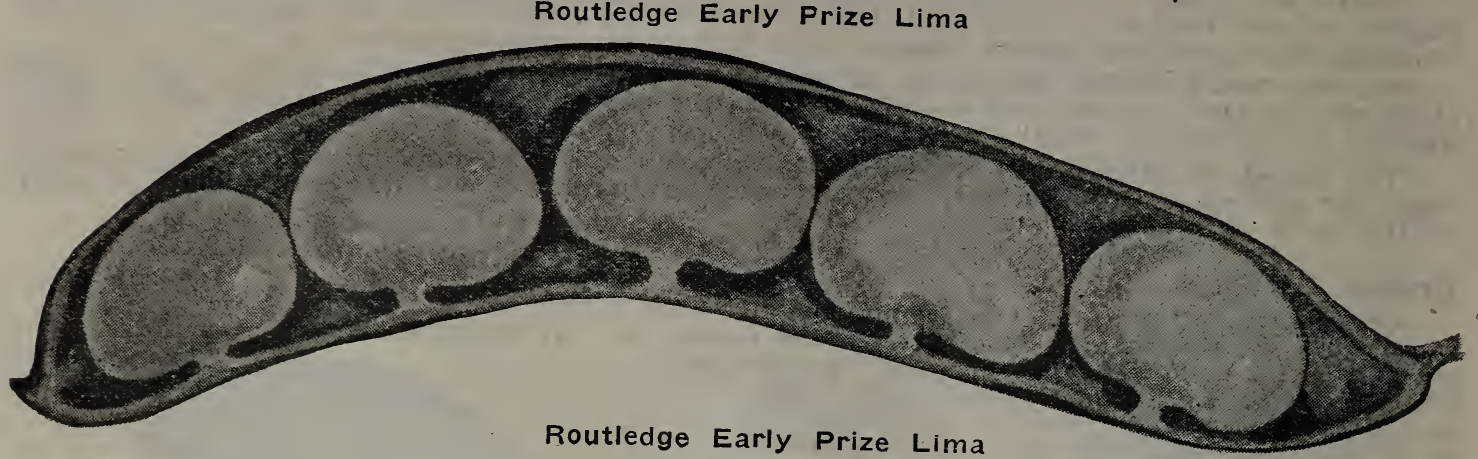

POLE LIMAS

Of all the pole beans, limas are considered to have the greatest economic value. The culture is the same as for other pole beans except that being more tender, the seed is usually planted one to two weeks later.

\section{Routledge Early Prize Lima}

An imported variety procured at the same time as Routledge Perfection "snap" bean. By careful selection we now offer a strain fully two weeks earlier than "Oregon." It will actually mature a full crop of dry beans in the early fall. In earliness, ease of shelling, size, beauty and quality of the dry beans, this variety leads all other early limas for either the home garden or market. The vines are vigorous and remarkably productive. The extra long, large, flat, mode 1 ately curved pods are well filled. The green shell beans are very large, very tender and of finest quality. It has the rich, buttery flavor, always desired but seldom found. Gardeners will make no mistake in testing this new, extra eaıly lima. Large pkt. 20c; Ib.55c

\section{Oregon Pole Lima}

Excellent for the Northwest. Strong, vigorous grower. In July the blooms come in long panicles from the top shoots and the large, broad pods are freely produced until frost. The large, plump, white beans are of delicious quality, green, shelled or dry. They are in "prime condition" when the pods begin to turn yellow. Oregon grown, acclimated seed. Large pkt. 15c; lb. 50c; 10 lbs. $\$ 4.50$

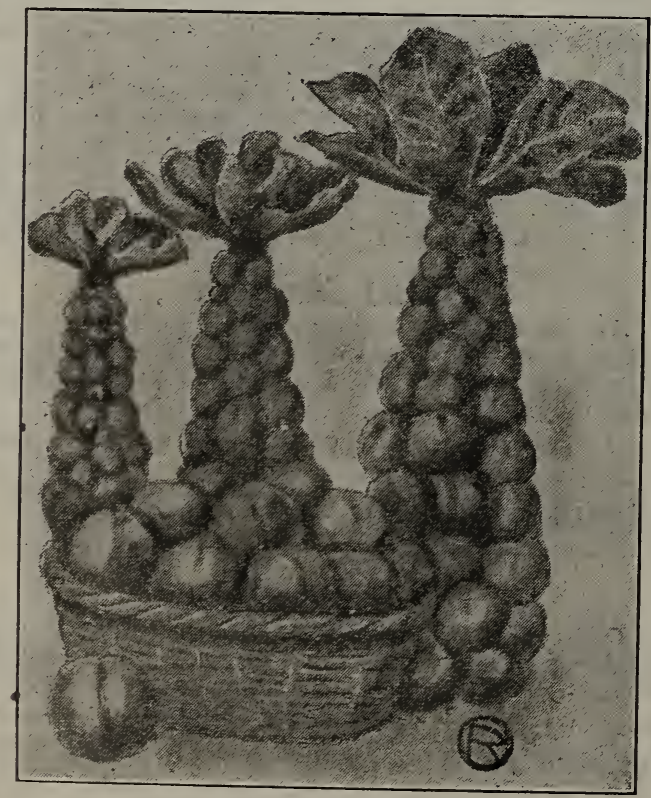

Brussels spruuss

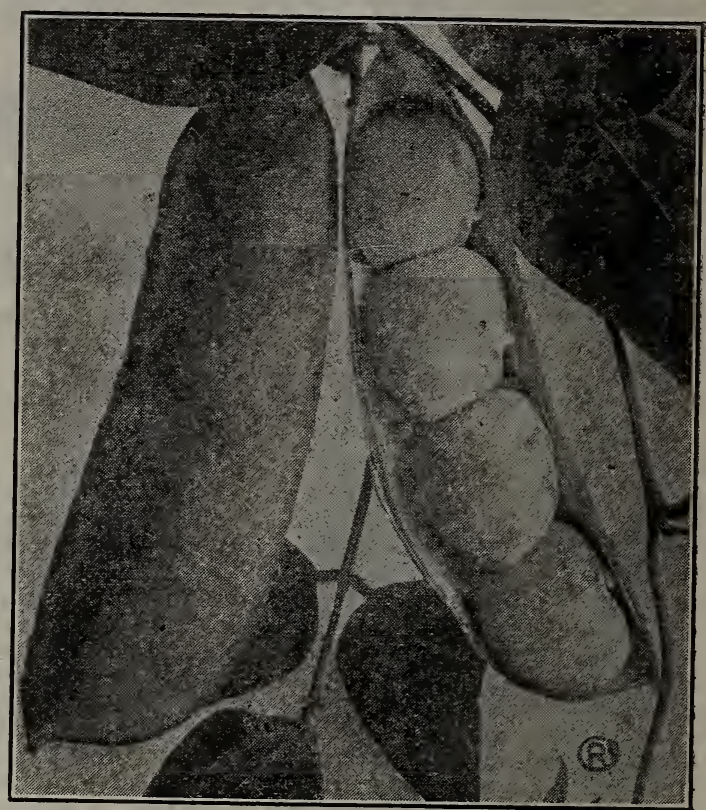

Burpee's Improved Bush Lima

\section{DWARF OR BUSH LIIVA}

BURPEES IMPROVED BUSH LIMA.Best of the Bush Lima type. Very large, broad pods, excellent flavored beans, borne on large vigorous plants. Extremely prolific. Pods contain from four to six very large beans of greenish white color.

Pkt. $15 \mathrm{c}$; Ib. $50 \mathrm{c}$; 10 lbs $\$ 4.25$

\section{BRUSSELS SPROUTS}

The plants, which are very hardy, grow two or three feet high, and produce, from the sides of the stalks, nume sous little sprouts, which resemble very small cabbages one or two inches in diameter. The leaves should be broken down in the fall, to give the little heads more room to grow. They should be treated in all respects like winter cabbage or kale.

PERFECTION OR DALKEITH. - Plants are of dwarf growth and stems are thickly set with large, solid sprouts. This variety is very hardy and even during quite severe weather, the plants maintain their snrouts; in fact, the flavor and quality is much im-. proved by frost. Pkt. 10c; oz. 35c; 4 oz. $\$ 1.00$ 


\section{TABLE BEETS}

\section{Routledge Favorite}

A select strain, very early. Perfectly globe shaped, with a single tap root, and of the richest color of any of the beets. It is a splendid keeper, is not excelled in yielding qualities by any other sort, is exceedingly tender, fine and sweet and is unequaled for table use. Market gardeners will find our Favorite a very profitable variety to grow, as no other sort approaches it in attractiveness or quality.

Pkt. 10c; oz. $20 \mathrm{c} ; 4$ oz. $60 \mathrm{c}$; lb. $\$ 2.00$

\section{Crosby's Egyptian}

Very popular, extremely early beet, as it reaches the desired size quickly. The beets are of good size, rather flat than round, flesh rich vermilion red, very attractive. Pkt. $5 c$; oz. $15 c ; 4$ oz. $45 c$; lb. $\$ 1.25$

\section{Detroit Dark Red}

Excellent variety, nearly globular, dark skin and rich red flesh, maturing early and keeping crisp and tender for a long time. Very popular with market gardeners.

Pkt. 5c; oz. $15 c ; 4$ oz. $45 c$; lb. $\$ 1.25$
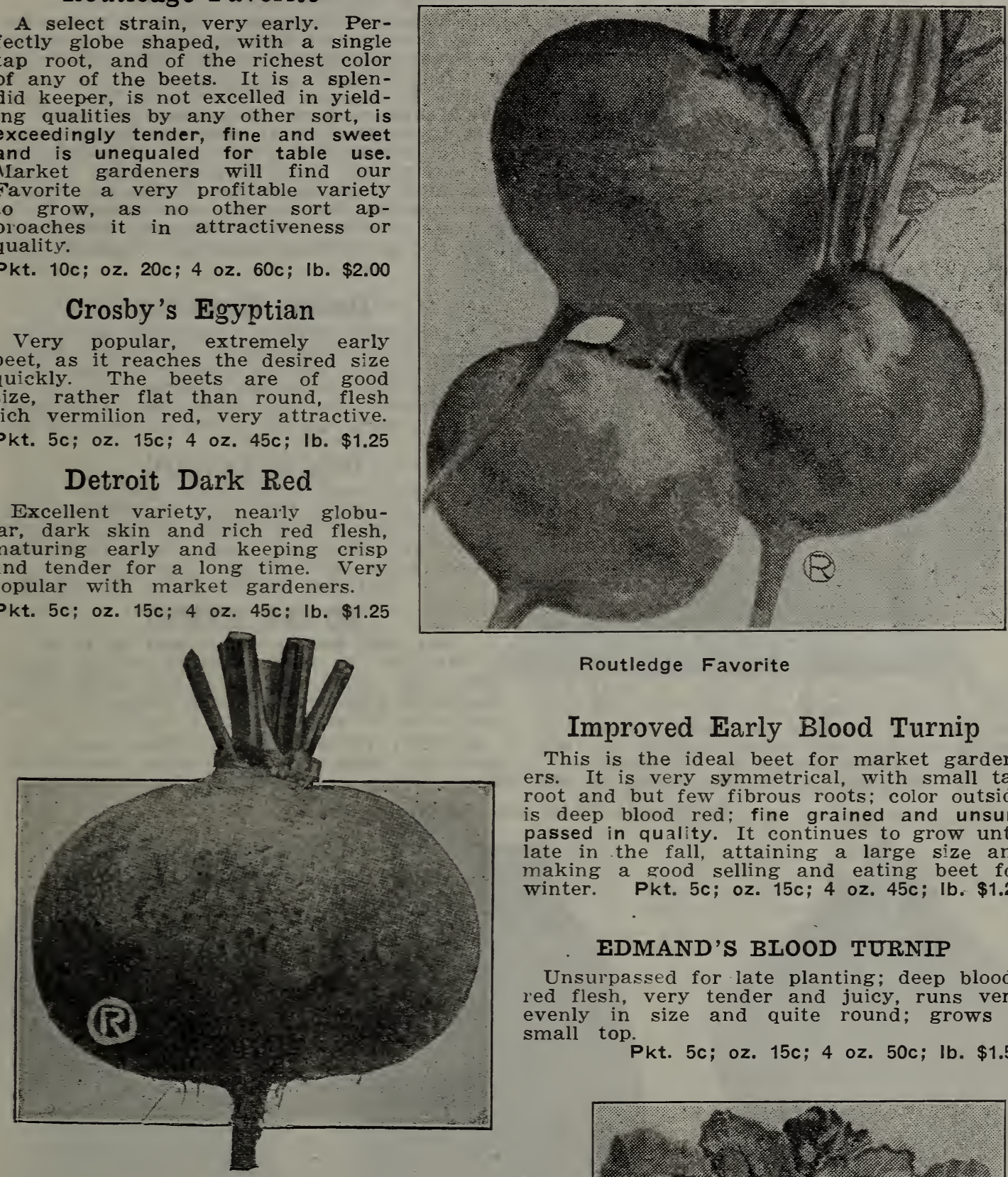

Routledge Favorite

\section{Improved Early Blood Turnip}

This is the ideal beet for market gardeners. It is very symmetrical, with small tap root and but few fibrous roots; color outside is deep blood red; fine grained and unsurpassed in quality. It continues to grow until late in the fall, attaining a large size and making a good selling and eating beet for winter. Pkt. 5c; oz. $15 \mathrm{c} ; 4$ oz. $45 \mathrm{c}$; lb. $\$ 1.25$

\section{EDMAND'S BLOOD TURNIP}

Unsurpassed for late planting; deep bloodred flesh, very tender and juicy, runs very evenly in size and quite round; grows a small top.

Pkt. $5 \mathrm{c}$; oz. $15 \mathrm{c} ; 4$ oz. $50 \mathrm{c}$; lb. $\$ 1.50$

\section{Improved Early Blood Turnip}

\section{Swiss Chard}

\section{Luccullus "Spinach Beet"}

This does not make edible roots like the regular garden beets, but is grown for the broad white leaf-stalks, which are bunched and cooked in the -ame manner as asjaragus. The young leaves may be gathered also and cooked like spinach. Makes a delicious summer vegetable.

Pkt. 10c; oz. 20c; 4 oz. 60c; Ib. $\$ 2.00$

HALF LONG BLOOD.-Becoming more and more popular. Excellent in shape and quality; yields well. Pkt. 5c; oz. 15c; 4 oz. 50c: ib. $\$ 1.50$

LONG BLOOD.-The reot is smonth and handsome, flesh brilliant in color and excellent quailty. Good keeper. Pkt. 5c; oz. 15c: 4 oz. 50c; lb. $\$ 1.50$

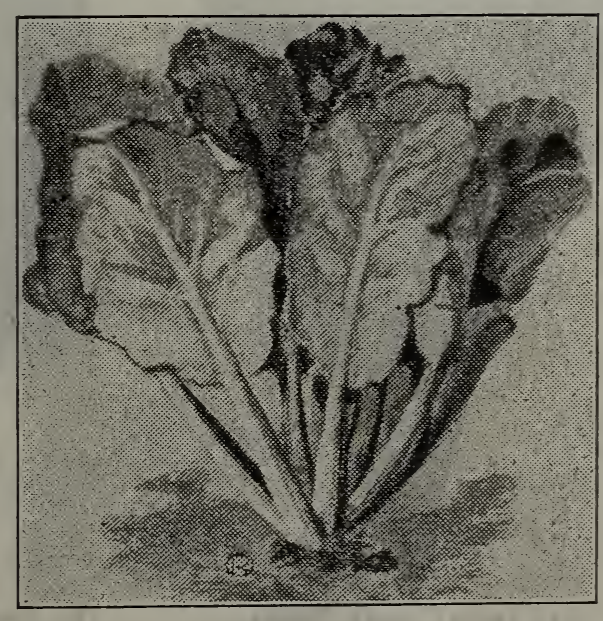

Swiss Chard

OUR GARDEN CULTIVATORS are priced very low and will save you much work in the garden. See pages 120 and 124 . 


\section{Stock Beets or Mangels}

Excellent winter feed for horses, cattle, sheep, hogs and chickens. Farmers and stock raisers of the United States do not appreciate so fully the value of Mangels for feeding cattle, hogs, sheep, ete., as do the farmers of Europe. In France, Great Britain and other European countries, it is the exception rather than the rule where Mangels are not grown on a large scale on every farm. The immense yield which may be secured from an acre, with very little expense either for material or labor, makes the Mangel crop one of the most profitable on the farm. Fifteen to 20 tons of roots an acre is not an unusual yield; some specimens weigh 20 to $30 \mathrm{lbs}$. each. Where properly cultivated, seeded and harvested the cost of growing a bushel should not exceed 10c. When fed in combirsation with grain they are worth almost as much, pound for pound, as the grain. This statement may seem absurd, but experience has proved that Mangels so aid digestion and assimilation by keeping the animals in a healthy condition, that they increase the feeding value of other feeds consumed, beside the nutrients the roots contain. Every farmer ought to put in at least an acre of Mangels this coming season, 5 or 10 acres will be much better.

\section{Giant Yellow Eckendorf}

A new mangel of great merit. The roots are smooth, long and cylindrical in shape, very heavy, weighing up to 15 and 20 pounds each: grow two-thirds above ground. The flesh is firm, crisp and solid, white in color and of high feeding value. (See cut.)

Pkt. 5c; oz. 15c; 4 oz. $35 \mathrm{c}$; lb. $80 \mathrm{c}$

\section{Giant Half Sugar Mangel}

Yields as much per acre as the best Mangels, and twice as much per acre (bulk of roots) as the rich sugar beet. Roots grow very large above the ground. Smooth, creamy white in color and very nutritious. Easily pulled. (See illustration No. 1.)

Pkt. $5 \mathrm{c}$; oz. $15 \mathrm{c} ; 4$ oz. $35 \mathrm{c}$; Ib. $80 \mathrm{c}$

\section{Mammoth Long Red}

Very popular and much used. A large and heavy cropper. Dark red skin, with whitish flesh: grows one-half or more above the ground; roots quite regular; attain a very large size. (Same shape as No. 2.)

Pkt. 5c; oz. 15c; 4 oz. 35c; lb. $80 \mathrm{c}$

\section{Danish Sludstrup}

An improver variety, considered one of the best. Awarded first class certificate. Color, reddish yellow, and of a distinct type. It is very hardy, grows well above ground; is easily pulled and very nutritious. (See cut.) Pkt. $5 \mathrm{c}$; oz. $15 \mathrm{c}$; 4 oz. $35 \mathrm{c}$; Ib. $80 \mathrm{c}$

\section{Golden Tankard}

An enormous yielder of weight per acre, and at the same time very nutritious; flesh deep yellow, of fine shape, growing largely above ground, thus being easily harvested. (Same shape as cut No. 3.)

Pkt. $5 \mathrm{c}$; oz. $15 \mathrm{c} ; 4$ oz. $35 \mathrm{c} ; \mathrm{Ib} .80 \mathrm{c}$

\section{SUGAR BEETS}

Pkt. $10 \mathrm{c}$; oz. $15 \mathrm{c} ; 4$ oz. $45 \mathrm{c}$; lb. $\$ 1.50$

FRENCH WHITE SUGAR. - The sugar beet most generally grown for stock, as it combines with heavy yield, from 10 to 13 per cent of sugar.

KLEIN WANZLEBEN. - The most popular for table and for sugar production.

Tops rather large and slightly waved.

\section{NOTE. - In $10-\mathrm{lb}$. lots, $5 \mathrm{c}$ per Ib. less}

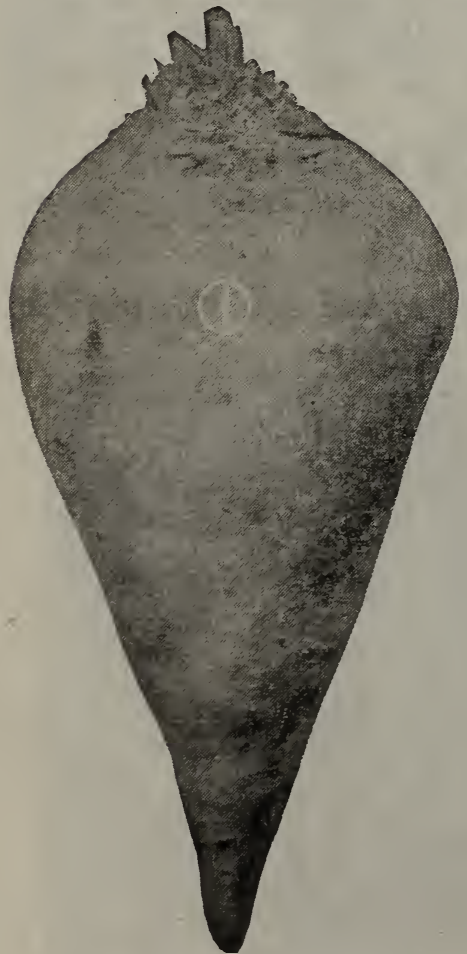

(1) Giant malf Sugar

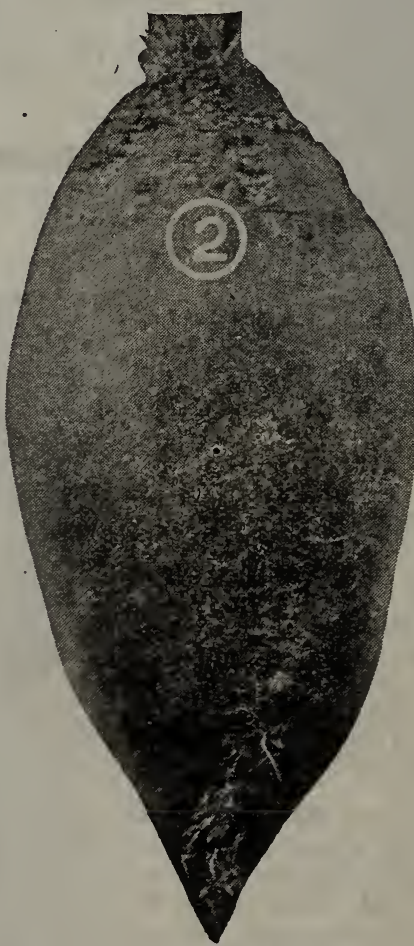

(2) Danish Sludstrup

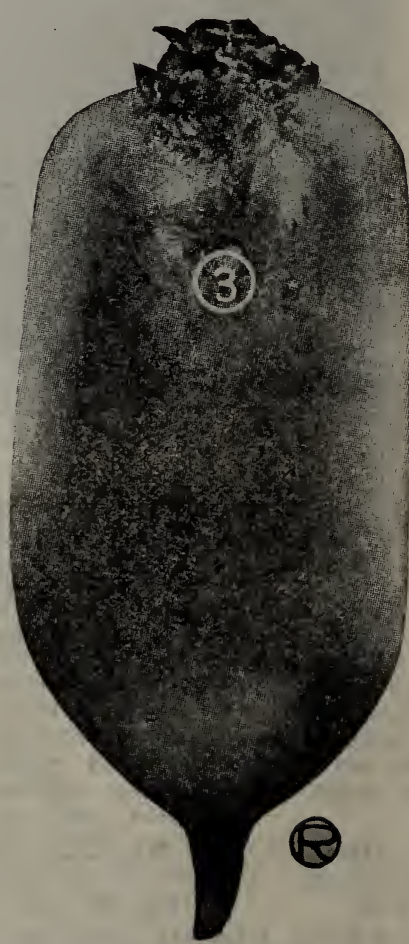

(3) Giant Yellow Eckendorf.

Write for quantity prices. For amount of seed per acre, any kind, see "Seed Table," inside back cover. 


\section{BROCCOLI-Winter Cauliflower}

Forms a head like cauliflower, but is much hardier; stands wet and cold better and gives excellerit results. For fall use sow from March to May; for winter and spring cutting, May to July. Very extensively planted by our local market gardeners for use in the late fall. winter and spring when cauliflower is out of season.

\section{St. Valentine}

Well and favorably known and extensively planted by the large commercial growers. Produces large, solid, white heads. Season March to May. This strain of Oregon grown tested seed has given good satisfaction. $\$ 2.50$.

Pkt. 10c; 1/4 oz. 25c; oz. $75 c ; 4$ oz.

\section{Routledge H. Q. St. Valentine}

In this seed, we are offering our customers a very select, high-grade strain of the well-known St. Valentine. By selecting only the most perfect heads, those showing the most desirable leaf formation for the protection of the developing head and those of large size and perfect compact heads free from small center head leaflets, we have produced this superb strain. The last two years our $H$. Q. St. Valen. tine produced larger, later and far better heads than the best imported English seed, and it was so far superior to seed produced from other sources that there was no comparison. For instance-last February our grower reported that $\mathbf{H}$. $\mathbf{Q}$. stock was cutting 95 per cent of heads that brought him double the price of other ordinary stock.

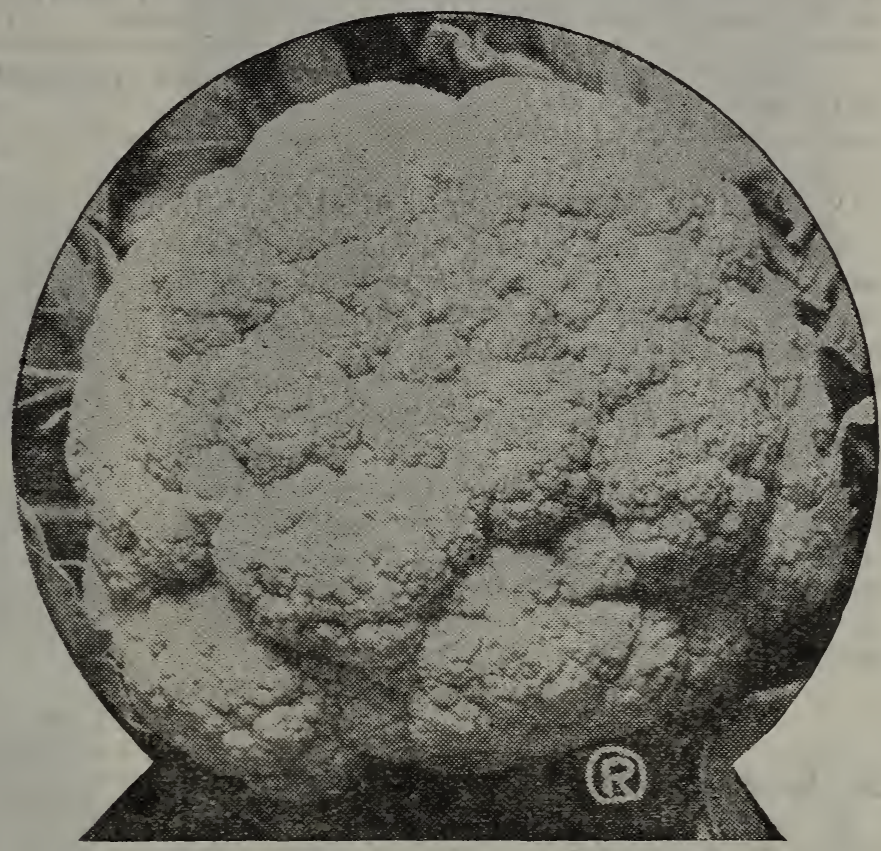

“H. Q." St. Valentine Broccoll

Every ounce of our H. Q. St. Valentine seed we are offerings this year is from just such perfect heads as shown herewith. Our seed of this particular lot is quite limited, so order early. $\quad$ H. Q.: Pkt. $15 \mathrm{c} ; 1 / 4$ oz. $50 \mathrm{c} ;$ oz. $\$ 1.50 ; 4$ oz. $\$ 4.50 ; \mathrm{Ib} . \$ 15.00$

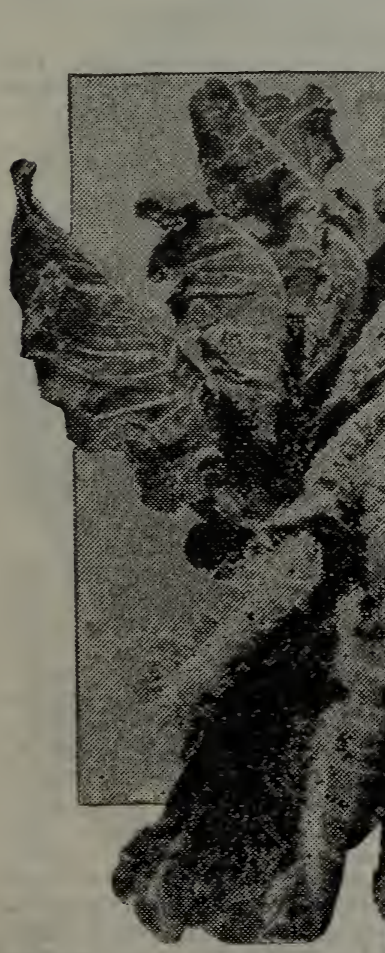

Front leaves urunen down to show formation of growth.

\section{Sutton's Winter Mammoth}

An English variety. Immense white heads, superb in texture and quality, coming into use in midwinter. Vigorous in habit and selfprotecting. (Imported seed.)

Pkt. $10 \mathrm{c} ; 1 / 4$ oz. $35 \mathrm{c}$; oz. $\$ 1.00$

\section{Sutton's Late Queen}

Quite distinct, dwarf and compact in growth, rarely affected by frost, and when planted late pro. duces splendid heads the following spring in May. Has successfupy passed through most severe winters. Heads well protected, large, handsome, excellent quality. (Imported seed.)

Pkt. 10c; $1 / 4$ oz. 35c; oz. $\$ 1.00$

\section{White French}

A valuable early variety, large white heads of good quality. Hardier and of the same season as summer cauliflower.

Pkt. 10c; oz. $\$ 1.00 ; 4$ oz. $\$ 3.00$

Edmonds, Wash., April 18, 1919. Routledge Seed \& Floral Co.

Dear Sirs: Last year I had a paeket of your $H$. $Q$. St. Valentine Brocoli. It is now fit for use and is the best we ever ate. Simply delicious.

Respectfully.

FREE BULLETINS AND PAMPHLETS on general gardening and many special crops, alse spraying, etc., are issued by the Oregon Agricultural College at Corvallis. Ore. These are sent free on request. We advise our customers to secure them. THEY ARE OF GREAT VALUE. 


\section{"Highest Quality"}

Our Cabbage Seeds come from the world's best growers-pure, true strains, of highest quality. One ounce will produce over 3,000 plants. Ore-quarter pound of seed will produce plants sufficient for one acre, therefore, don't practice false economy by buying low-priced, low-quality seed. There is a great amount of inferior, poorly grown, mixed cabbage seed on the market this year. Beware of low prices.

"Carco," an inexpensive and very valuable insecticide for cabbage growers. Read about it on page 125.

\section{Early Jersey Wakefield}

The earliest and hardest heading of first early cabbages. Most gardeners depend upon it for the bulk of their extra early crop. Its exceeding hardiness not only to resist cold but other unfavorable conditions, insures the greatest likelihood of profitable and satisfactory results. Our stock is grown and selected with the greatest care; there is none better, and few as good. Head conical, very compact, solid and of excellent quality. The thick, stout leaves and compact habit makes it the best sort for very early setting. HIGHEST QUALITY SEED.

Pkt. $10 \mathrm{c} ;$ oz. $75 \mathrm{c} ; 4$ oz. $\$ 2.25$; Ib. $\$ 7.50$

\section{R. S. \& F. Co.'s Oregon Wakefield}

A new, most remarkable and valuable strain of Wakefield. It has the same general charactesistics of other Wakefield cabbages, the heads being conical with a rounded or blunt point. It is, however, far superior to other strains, being nearly double the size and of better quality, and at the same time is almost as early. It has few outer leaves, permitting close planting. Pkt. 10c; oz. 60c; 4 oz. $\$ 2.00$; lb. $\$ 7.00$

\section{"CARCO" YOUR CABBAGE}

This new non-poisonous liquid properly used will insure your cabbage plants against the attack of the cabbage grub or maggot that eats the root. Don't fail to use it. See page 125 .

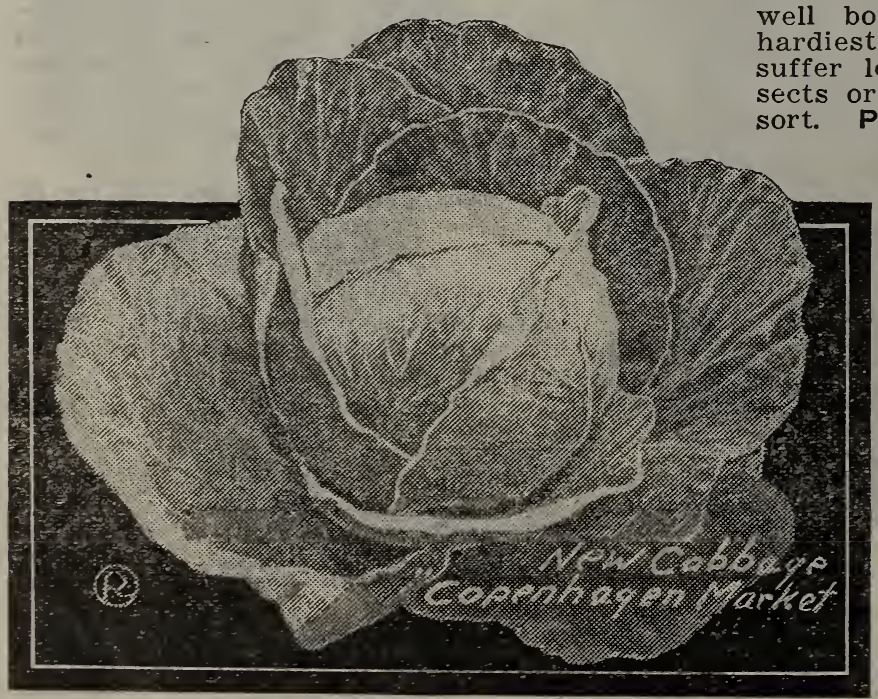

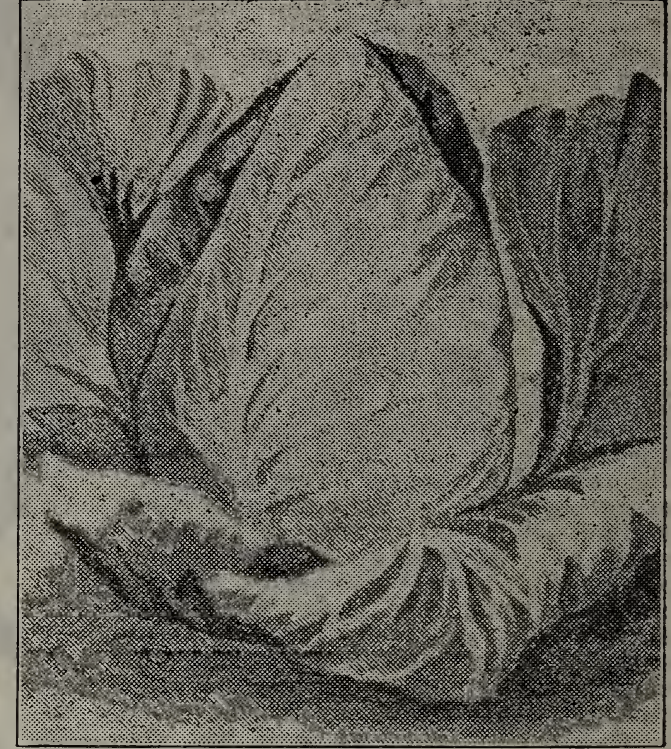

Early Jersey Wakefield

Edgewood, Cal.

Routledge Seed \& Floral Co.,

Dear Sirs: Last year I gave you an order for all my garden seeds. I found them of the highest and best quality. All of the seeds were as you guaranteed them to be.

Enclosed please find order.

$$
\text { Yours very truly, }
$$

FRANK E. ALEXANDER.

\section{EARLY WINNINGSTADT}

One of the best for general use, being very hardy, sweet, fine quallty, and sure to head. Head regular, conical, very haid and keeps well both summer and winter. It is the hardiest, not only as regards frost, but will uffer less from excessive wet, dıought, insects or disease than any other second early
sort. Pkt. $10 \mathrm{c} ;$ oz. $60 \mathrm{c} ; 4$ oz. $\$ 2.00 ; \mathrm{lb} . \$ 6.00$

\section{Copenhagen Market}

The earliest large round-headed cabbage yet introduced. Sure to head and every head perfect. The plant is of vigorous habit but compact, with short stem and few outer leaves which are of rather upright growth. The leaves are medium light green, nearly round, comparatively thick and smooth. The heads are round, very solid and of exceptionally good quality. Its earliness, compact growth, uniformity and size of head, firmness and most excellent quality combine to make Copenhagen Market the most valuable cabbage of recent introduction. We recommend it unreservedly. Worth the additional price.

Pkt. 10c; $1 / 2$ oz, $45 c ;$ oz, $85 c ; 4$ oz $\$ 2.60$ : Ib. \$n.00. 


\section{CABBAGE-Continued-Late Varieties}

\section{Wong Bok-Pe-Tsai}

\section{Or Chinese Cabbage}

Chinese or Celery Cabbage has attained great popularity in the last two years.

We offer the true Pe-Tsai or Chinese Cabbage, which has been known and cultivated in China for many years. While practically unknown in many markets, the Chinese gardeners of the Pacific Coast have successfully cultivated it for years.

Pe-Tsai produces beautiful, ciisp, celerylike heads that blanch easily and that resemble a giant Cos Lettuce. As a salad it rivals the finest lettuce, while cooked like cabbage or spinach it makes a delightful "greens."

Pe-Tsai will not stand heavy frosts, so that heads intended for winter use should be dug and stored in a cool cellar.

Plant seed from June to August thinly in drills or grow like late cabbage and transplant to 1 foot apart in rows. When grown it can be blanched like celery by trying or wrapping up. Pkt. 10c; oz. 50c

\section{Danish Round Head}

An earlier short-stemmed strain of the famous Danish Ball Head.

Large and very solid round head on short stems, having the same keeping quality as the uriginal strain of Danish Ball Head, so widely known. It is 10 days to 2 weeks earlier and produces larger yields. It is especially valuable for high, dry land, produc.ng good sized heads where other strains would be too small. For shipping in the late fall or winter there is no finer cabbage. Our seed of Danish Round Head comes direct from the originator in Denmark and is of the Highest Quality.

Pkt. $10 \mathrm{c} ; 1 / 2$ oz. $50 \mathrm{c} ;$ oz. $85 \mathrm{c} ; 4$ oz. $\$ 2.50 ;$ lb. $\$ 8.50$

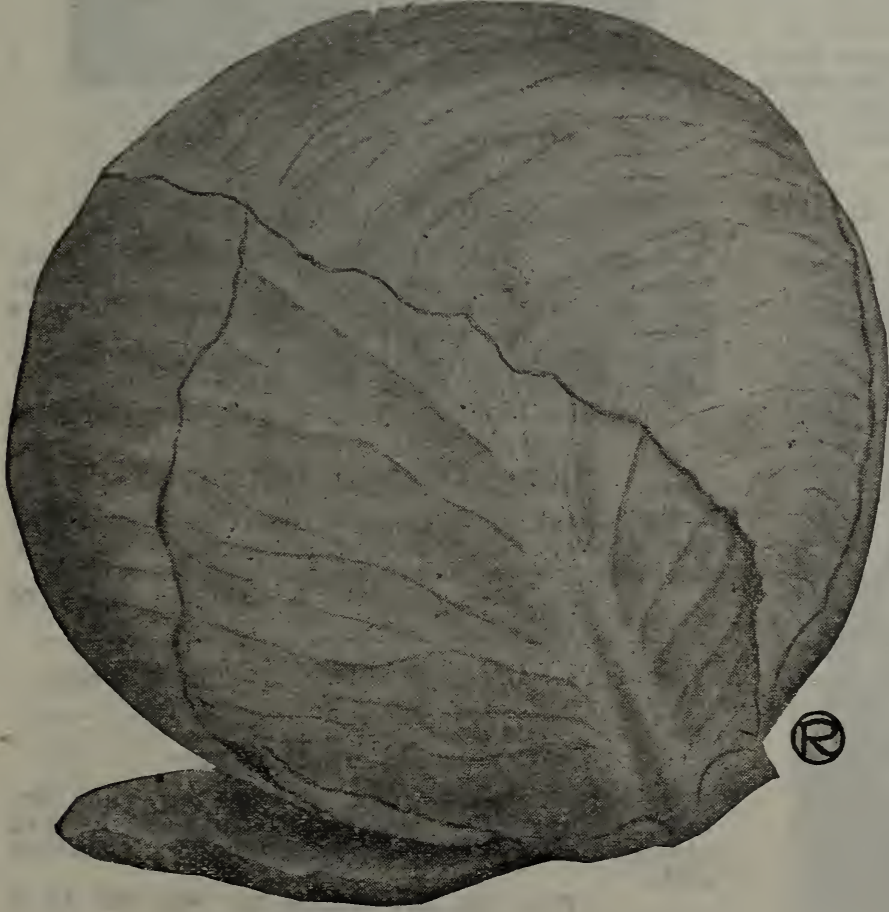

Premium Late Flat Dutch A low growing variety; heads large, bluish green; round, solid, broad and flat on top; an excellent fall and winter variety, and a.good keeper. It is a sure headei. Our stock has been grown from carefully selected heads, and we consider it superior to any other strain of Flat Dutch cabbage on the market.

Pkt. 10c; oz. 60c; 4 oz. $\$ 2.00$; Ib. $\$ 5.50$.

\section{Perfection Drumhead Savoy}

A variety that is much prized by those who are familiar with it. It is very sweet and crisp, and always tender. Heads medium size and compact, with densely and uniformly crimped or savoy leaves.

Pkt. 10c; oz. 60c; 4 uz, $\$ 2.00$; Ib. $\$ 5.50$.

\section{Mammoth Rock Bed}

Best hard-headed, red variety; large heads, globular, and very deep red on top. Very tender and excellent quality; fine for cold salads on account of its attractive color.

Pkt. 10c; oz. 60c; 4 oz. $\$ 2.00$

\section{Danish Ball Head-True, Highest Quality Seed}

Most remarkable late cabbage yet produced, heads hard and solid-fine grained and tender. Entirely distinct. Exceedingly hardy in resisting cold and wet weather. We offer true, pure seed of the very finest medium short stemmed $t$ pe. Famous for its hardheading qualities, which at once recommends it as highly valuable for shipping. The magnificent heads are round in form and keep in excellent condition during winter coming out in the spririg perfectly solid. Pkt. $10 \mathrm{c} ; 1 / 2$ oz. $50 \mathrm{c} ;$ oz. $85 \mathrm{c} ; 4$ oz. $\$ 2.60 ; \mathrm{lb} . \$ 9.00$ 


\section{CARROT}

\section{ROUTLEDGE IMODEL-Coreless}

The finest early table variety grown. Hand. some, meltingly tender and sweet.

This new carrot is our own strain, grown from the French carrot, Nantes. You will be delighted with the melting tenderness and sweet, mild flavor of Routledge Model. It is a half-long cylindrical carrot, blunt pointed, with a small tap root and small top. They run very uniform in shape and grow just the right size for table use. The flesh is of fine texture, entirely devoid of stringyness, coarseness and woody heart; color orange scarlet, very attractive when served.

Pkt. 10c; oz. 25c; 4 oz. 60c; lb. $\$ 2.00$

Aberdeen, Wash., March 20, 1919.

Routledge Bros.

Gentlemen: Having bought my seed from you last year, will say that I had splendid luck with everything.

Was especially pleased with R. R.'s Model Coreless Carrots. They are a revelation in earliness and flavor.

As you will see, am ordering from you again this year.

Yours truly,

MRS. J. S. COLE.

\section{Early Scarlet Horn}

May be planted very early in spring, and is an excellent summer variety. Tops small and roots grow about 3 inches long; reddish-orange and good flavor.

Pkt. 10c; oz. 15c; 4 oz. 40c; Ib. $\$ 1.25$

\section{Chantenay}

The Market Gardener's Favorite. - Tops medium sized, necks small, roots tapering slightly, but uniformly stump-rooted and smooth; color deep orange-red; flesh very crisp and tender; medium early; a heavy cropper.

Pkt. 10c; oz. 20c 4 oz. 40c; lb. $\$ 1.00$

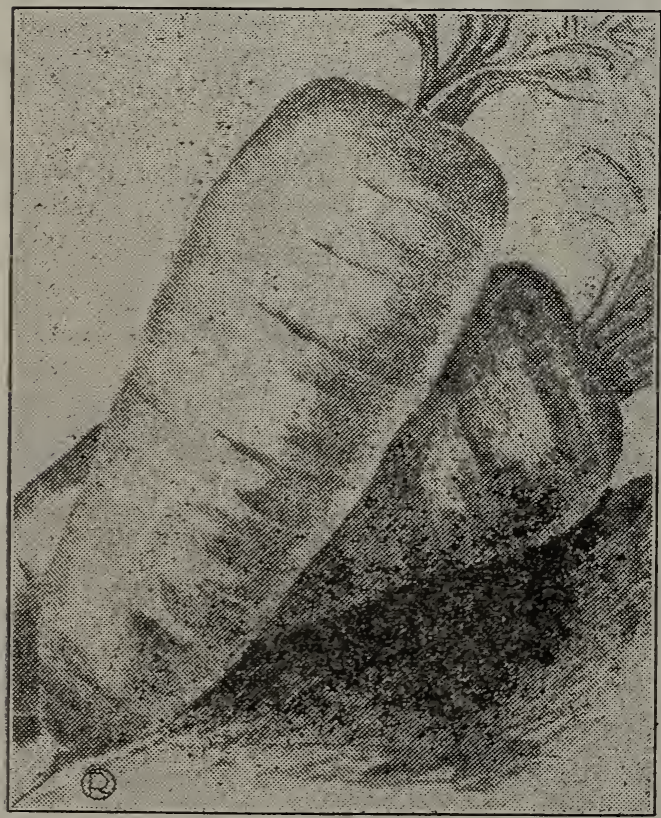

Chantenay

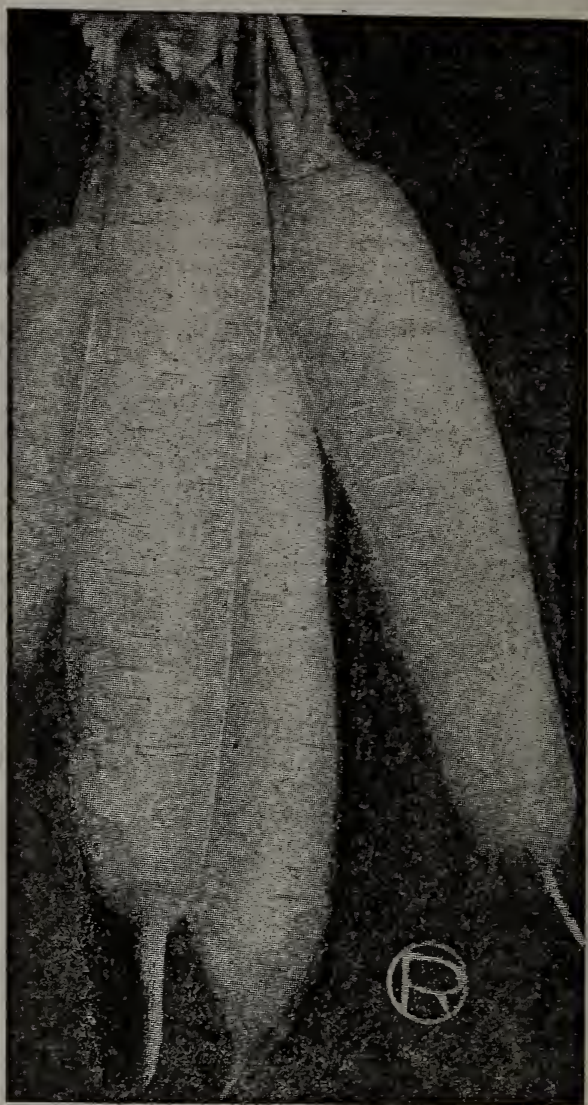

\section{Routledge Model-Coreless}

\section{Danver's Half-Long}

A great favorite; big cropper; the roots are smooth and handsome, medium size, tapering uniformly to a blunt point and of a rich, dark orange; fine for table. On account of its productiveness it is a profitable variety to grow for stock feeding.

Pkt. 5c; Oz. 15c; 4 oz. 45c; Ib. $\$ 1.00$

\section{Long Orange Improved}

The best of the long carrots, especially for stock; color bright orange, with long, tapering roots, requiring a deep soid.

Pkt. 10c; oz. 15c; 4 oz. $50 c$; ib. $\$ 1.00$

\section{ROUTLEDGE MAMMOTH, next page.}

\section{Guerande, or Oxheart}

Bright orange, broad at the top and terminates abruptly in a small tap root. Length about 4 to 5 inches; excellent for shallow soils.

Pkt. $5 c$; oz. $15 c ; 4$ oz. $40 c$; Ib. $\$ 1.10$

\section{Large Whito Belgian}

Extensively grown for stock feeding; roots white; green above ground and growing to a large size; flesh rather coarse. 1 good cropper.

Pkt. 5c; oz. 15c; 4 oz. $40 c ;$ Ib. $\$ 1.00$

DAD'S ELECTRIC LANTERN-A Penetrating, Bright Llght. The best and safest light for the farmer. No matches or danger of fire around the barns. See page 122. 


\section{CARROTS-Continued}

\section{Routledge Mammoth Stock Carrot}

The heaviest cropping carrot grown, yielding more tons to the acre than any other sort. The flesh is yellowish-white, crisp and solid, and very sweet in flavor. It is a vast improvement on the Belgian sorts, which have been favorites in the past, as it is not only much more productive, but vastly easier to handle. The roots are short and very heavy at the shoulder, rendering them easily harvested. Too much can scarcely be said of their size and great productiveness. Every farmer should grow a good supply of carrots for winter feed and Routledge Mammoth is the kind to plant. Yields reported from 20 to 50 tons per acre.

Large pkt. $10 \mathrm{c}$ oz. 20c; 4 oz. 50c; Ib. $\$ 1.50$ 2 Ibs., enough for one acre, $\$ 2.50$.

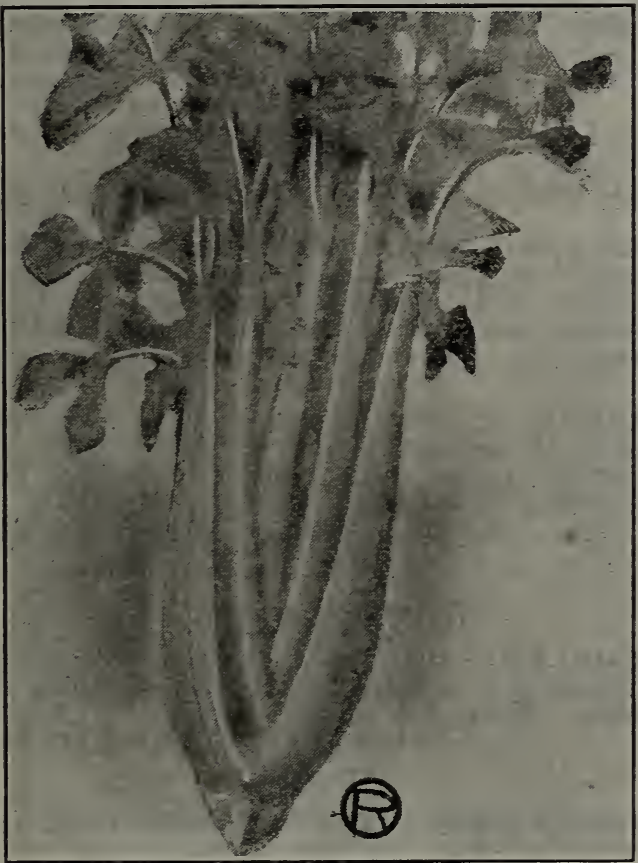

Paris Golden Self-Blanching

Weiser, Idaho, February 7, 1919. Gentlemen: I am boosting the Routledge Bros. in my community. I have always found your seeds satisfactory and expecting a big crop this year.

MRS. L. L. VREDENBURG.

Giant Pascal

Excellent for fall or winter use, and has increased in popularity every year. A large tall grower of the finest nut flavor, being free from any bitter taste. Very broad stalks, blanching very quickly with little banking up; an admirable keeper.

Pkt. 10c; oz. 35c; 4 oz. $\$ 1.00$

\section{Winter Queen}

One of the best winter varieties, and highly recommended. It is tall and forms a large bunch. The leaves are light green. Pkt. $5 \mathrm{c} ;$ oz. $30 \mathrm{c} ; 4$ oz. $75 \mathrm{c}$

\section{CELERIAC}

Turnip Rooted Celery, see page 19.

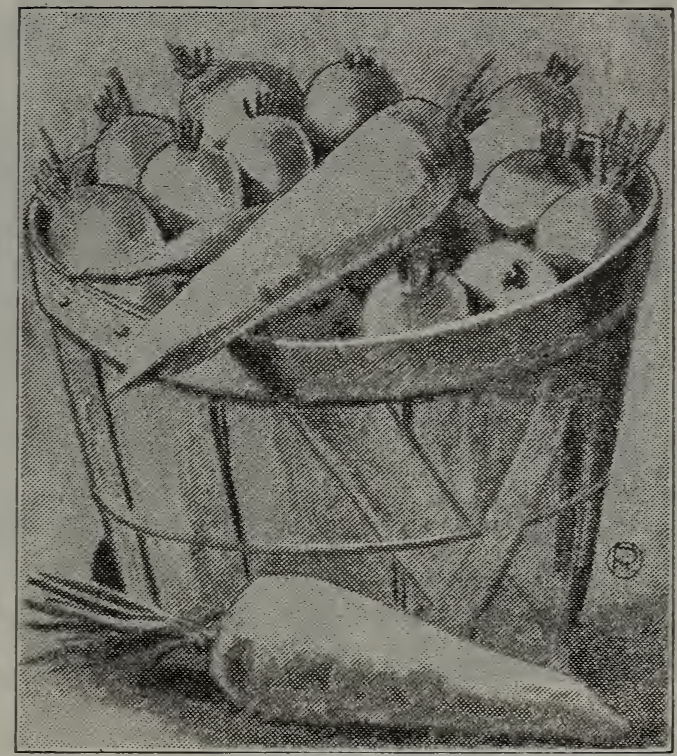

Routledge Mammoth

Highest

Quality

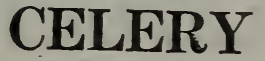

Plants Page 37

R. R.'s White Plume

Our Leading Early White Celery

A handsome, crisp sort, of very easy cultivation. Naturally its stalks and portions of inner leaves and heart are white, so that by closing the stalks, either tieing or by simply drawing the soil up against the plant and pressing it together, the work of blanch. ing is completed witnout the troublesome process of "banking" or "earthing up." It is the earliest celery known, delicious and fine flavored.

Pkt. 10c; oz. 35c; 4 oz. $\$ 1.00$

\section{PARIS, GOLDEN SELF-BLANCHING}

The finest strain of French grown seed. This splendid vatiety is without douit the most popular celery grown. It is a selfblanching sort, for with a little banking or covering, even the outer ribs assume a beautiful golden yellow, while the heart or vine stalks are deliciously tender, brittle and sweet. This variety is being very extensively grown both for market and private use, not only on account of its ease of cultivation, but for its superior quality. It is not quite so early as the White Plume, hut is of heavier and more compact growth, the stalks being thick, crisp and brittle.:

Select quallty: Pkt. 15c; 1/4 oz. 40c; oz. $\$ 1.00 ; 4$ oz. $\$ 3.50$.

\section{Golden Yellow Self-Blanching}

Same variety of celery as above, but is American grown. It is equal to most seeds offered, but not as true, dependable or of such high quality as the French grown stock.

Pkt. $10 \mathrm{c} ;$ oz. $50 \mathrm{c} ; 4$ oz. $\$ 1.50 ;$ Ib. $\$ 5.00$

GARDEN GUIDE Worth Many We think it the any garden. er. We think it the best book we have ever read. See Book list on page 130. 


\section{"Highest Quality" CAULIFLOWER Plants Page 37}

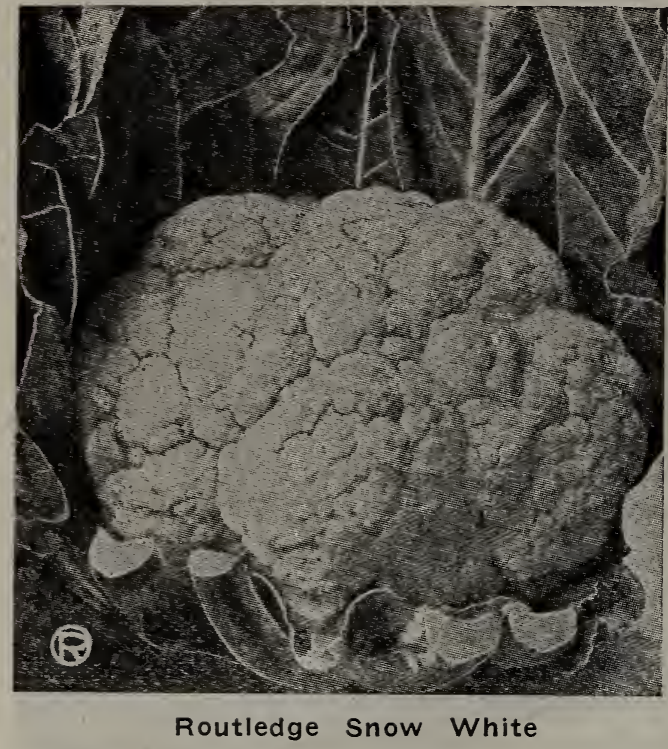

EXTRA EARLY SNOWBALL (EXtra Selected).-This is the choicest selected strain of the popular Erfurt type, and is remarkable for its extreme earliness and reliability in heading. Medium size heads. Plants quite dwarf.

Pkt. 20c; $1 / 4$ oz. $\$ 1.50 ;$ oz. $\$ 4.00$

VEITCH'S AUTUMN GIANT.-A large, late variety, very hardy. The heads are well protected by the foliage, enabling it to resist unfavorable climatic conditions. Pkt. 10c; $1 / 4$ oz. $60 \mathrm{c}$; oz. $\$ 1.50 ; 4$ oz. $\$ 5.00$

\section{ROUTLEDGE “SNOW WHITE”,}

The Finest Cauliflower Grown.

In competition with all other strains, this cauliflower has won the approval of critical gardeners, being early and also the best main crop sort grown. It is suitable not only for early use, but is superior for late planting. The heads are compact, firm and solid, and do not spread as do some of the inferior sorts. No other equals it in purity of color, being clear snow white. It is equally desirable for family use and for the market garden. The heads are large-from 9 to 12 inches in diameter. Very iesisting against unfavorable seasons and dry weather, the foliage giving a splendid protection.

Pkt. $25 \mathrm{c} ; 1 / 4$ oz. $\$ 1.50 ; 1 / 2$ oz. $\$ 2.50 ;$ oz. $\$ 4.50$

\section{Early Snowball}

This variety is much in demand by market gardeners. Its earliness, compact habit, largesized heads and snow-white color recommend it to every grower as a variety of especial merit. We have an extra selected stock of this sort, and recommend it with the greatest confidence.

Pkt. $20 \mathrm{c} ; 1 / 4$ oz. $\$ 1.25 ; 1 / 2$ oz. $\$ 2.25 ;$ oz. $\$ 4.00$

NEW CALIFORNIA WONDER.-A late variety, forming good, large, solid heads during the winter. This variety has given great satisfaction in Oregon and California, wherever tried.

Pkt. 15c; 1/4 oz. 50c; oz. $\$ 1.50 ; 1 / 4$ lb. $\$ 5.00$

ALGIERS.-A very strong growing late variety, with large leaves of a bluish cast. In cool locations and rich soil it produces very large, solid, white heads late in the fall.

Pkt. $15 \mathrm{c} ; 1 / 4$ oz. $75 \mathrm{c} ;$ oz. $\$ 2.25 ; 4$ oz. $\$ 6.00$

\section{CHICORY}

\section{Witloof-Called also "French En- dive" and "Christmas Salad"}

Heretofore large importations have been made, but it is easily grown here. Plant the seed in the spring in drills, 12 inches apart, and thin out to 3 or 4 inches apart in the row. About November pull up the roots, break off the leaves, side shoots if any, and small root end so that the roots are not over 10 inches long. At once, or later as you get time, dig a trench about 18 inches deep and reset these trimmed roots crowns up, placing them about $11 /$ inches apart. Cover with loose, rich soil; the roots should be set in the trench so that the top will be covered about 8 inches. They will soon make thick shoots or top growth (below the surface) which is the edible part. Dig as wanted, cut just below the crown and serve with French or "Mayonnaise" dressing. Witloof is really a delicate and delicious dish.

Pkt. 10c; oz. 60c

LARGE ROOTED OR COFFEE.-Grown quite etxensively for the large thick roots, which are sliced, dried, roasted and ground as a substitute or adulteration for coffee. To secure large smooth roots the soil should be light rich, and deeply worked, and the plants should be thinned out to stand four to six inches apart.

Pkt. $10 \mathrm{c} ;$ oz. $50 \mathrm{c} ; 4$ oz. $\$ 1.50$

\section{CHERVIL}

CURLED.-An aromatic herb, resembling parsley, and used for flavoring in soups and salads. Fine for garnishing.

Pkt. 10c; oz. 30c; 4 oz. $\$ 1.00$

\section{CRESS}

CURLED OR PEPPER GRASS.-Used as a salad and fine for garnishing.

Pkt. 5c; oz. 15c; 4 oz. $40 \mathrm{c}$

TRUE WATER.-This is quite distinct from the former and only thrives when its roots and stems are submerged in water. It is one of the most delicious of small salads.

Pkt. 10c; oz. 60c

\section{COLLARDS}

TRUE GEORGIA. - Used as "greens" mainly in the South and West. As the leaves are pulled off, others grow in their places.

Pkt. 10c; oz. 25c; 4 oz. 60c

\section{CORN SALAD}

Fetticus or Lamb's Lettuce. - This is a hardy winter salad, the small leaves being served like lettuce during the cool fall and early winter months. It does not succeed during warm weather, and the seed should be sown thinly in drills during August, September and October to supplv fresh leaves during the cool fall and winter months. It is quite hardy, and after cold weather sets in can be protected by a thin mulch of soft hay or straw.

Pkt. 10c; oz. 25c; 4 oz. $75 \mathrm{c}$

BUG DEATH kills all leaf-eating insects; excellent for using on cabbage, cauliflower, etc. Can be used either dry or in water. See description, page 126; also dusters and blowers, page 128. 


\section{CUCUMBERS}

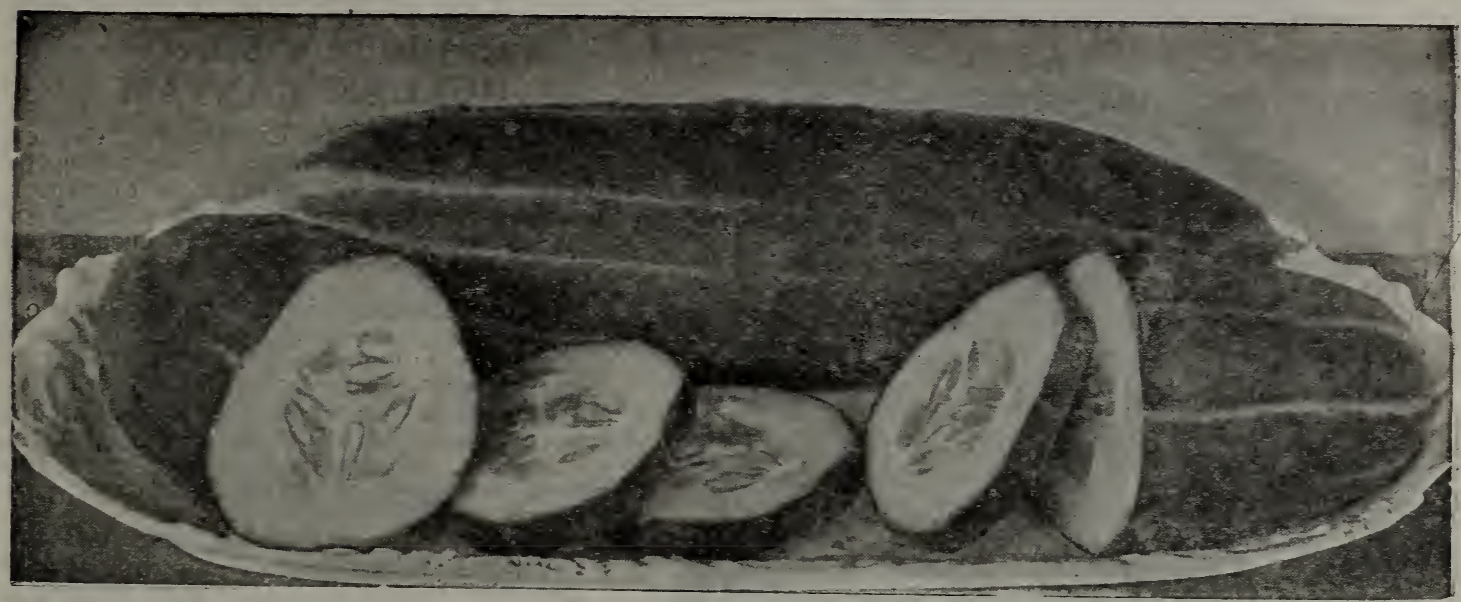

Routledge Highest Quality Cucumber

\section{Routledge Highest Quality}

A quick grower and always commands "fancy prices" on account of its fine form and superb quality.

It is the earliest white spine cucumber, suitable for table, market or shipping purposes, under all conditions of culture, whether under glass or in the open ground. Color a very deep green, which it retains during a long period, while in symmetry of form it is so regular, so uniform, as to create comment wherever seen.

Quality is superb, being exceedingly brit. tle and crisp. The flavor is delicate and entirely devoid of the bitter taste so frequently noticed in other varieties.

Pkt. 10c; oz. 20c; 4 oz. 50c; lb. $\$ 1.50$

\section{Arlington White Spine}

One of the best sorts for table use. Vines vigorous, fruiting early and abundantly. Fruit uniformly straight, light, bright green in color, with a few white spines. Flesh crisp, tender and of excellent quality.

Pkt. $5 \mathrm{c}$; oz. $15 \mathrm{c} ; 4$ oz. $45 \mathrm{c}$; Ib. $\$ 1.25$

\section{Improved Long Green}

The leading large variety. F'uit from 10 to 12 inches long, dark green, crisp and tender. A good variety for slicing, and when ripe they are the best for sweet pickles.

Pkt. 10c; oz. 15c; 4 oz. 50c; Ib. \$1.25

\section{Davis' Perfect}

As now selected, the long, even fruits are of fine form, with an intensely dark rich green skin. The solid white flesh is of superb quality for slicing. So handsome and regular are the fruits, even when grown outside, that they bring an extra price on the market, often being taken for "hot-house grown."

Pkt. $5 c$; oz. $15 c ; 4$ oz. $40 c$; lb. $\$ 1.25$

\section{Gherkin for Pickling}

A very small, oval, prickly variety, quite dsitinct from all others.

Pkt. 10c; oz. 20c; 1/4 lb. 50c

\section{Japanese Climbing}

A vigorous grower, can be trained on a trellis or the garden fence, thereby saving ground space. Fruit from 12 to 16 inches long, dark green and smooth. Flesh pure white, crisp and tender.

Pkt. $5 c$; oz. $15 c ; 4$ oz. 40 c; lb. $\$ 1.25$

\section{Lemon Cucumber}

New. Highly recommended by all who have tried it for slicing and salads. Resembles a lemon both in size, form and color. Has a distinctive and delicious flavor su. perior to and not found in any other cucumber. A variety of real merit-try it.

Pkt. $10 \mathrm{c}$; 0z. $25 \mathrm{c} ; 4$ oz. $75 \mathrm{c}$; Ib. $\$ 2.00$

\section{Boston Pickling}

A distinct variety, very popular for pickles; color bright green, a great producer and of excellent quality. It is for producing medium-sized pickles that this variety is so highly esteemed. If the fruits are gathered as soon as large enough, the vines will continue bearing through a long season

Pkt. $5 c$; oz. $15 c ; 4$ oz. 40 c; lb. $\$ 1.25$

Early Short Green

A very early and productive variety, bright green, rather short, straight and a little smaller at the ends. Crisp and tender. Good for pickling or slicing.

Pkt. $5 \mathrm{c}$; oz. $15 \mathrm{c} ; 4$ oz. $35 \mathrm{c}$; Ib. $\$ 1.00$

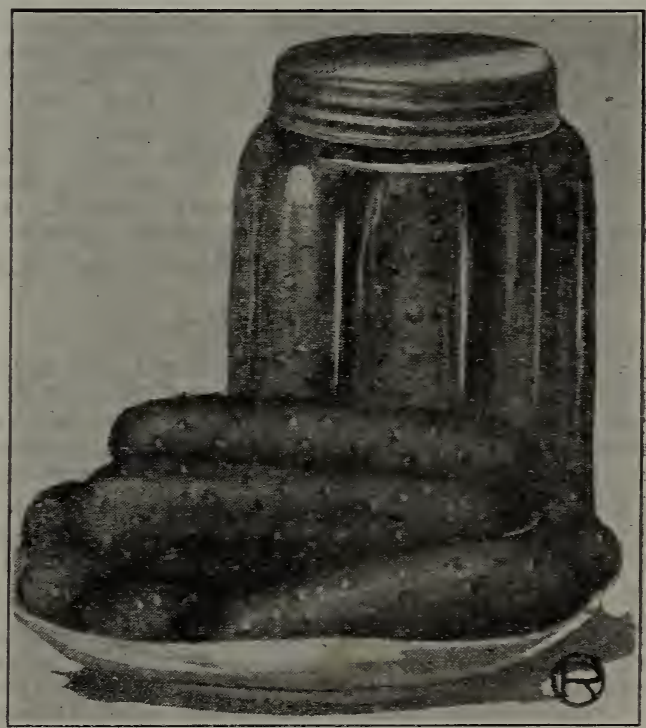

Boston Pickling

USE WONDER.-So many of our customers tell us of the wonderful results, the increased yield and quick growth obtained by using our Gdorless "Wonder" Fertilizer, that we again call YOUR attention to it. Remember you can get it by parcel post. See page 38 . 


\section{Selected Sweet Corn-Northern Grown}

Packet and single pound prices only prepaid. Add postage to $10 \mathrm{lb}$. prices if wanted by mail. Write for quantity price.

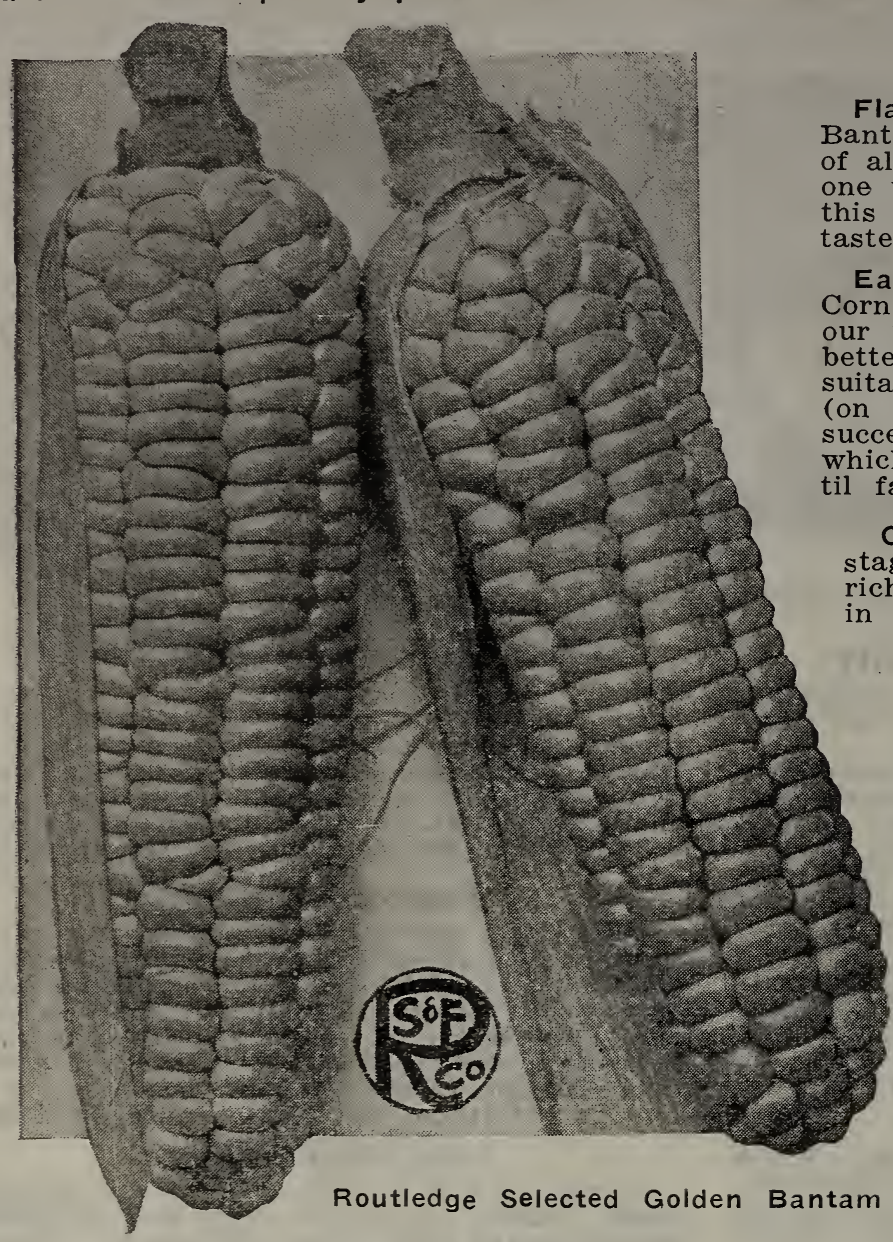

\section{Routledge's Selected GOLDEN BANTAII}

Flavor.-Without exception, Golden Bantam Corn is the richest in flavor all varieties; a sweet corn of which one will never tire. The first trial of this delicious Sweet Corn creates a taste "like more."

Earliness.-Golden Bantam $\mathrm{S}$ w e e $\mathrm{t}$ orn is only exceeded in earliness by our "Superb," but we like the quality better. It matures quickly and is suitable not only for early planting (on account of its hardiness), but a succession of sowings may be made which will give continuous supply until fall.

Color.-When picked at the proper stage of its growth the kernels are a rich, creamy yellow and unsurpassed in quality.

Growth.-Being dwarf in its growth, with stalks small in size, it can be planted quite close, and a large crop may be obtained on a small area. The ears are 8 to 10-rowed, and about 6 inches long - just the right size for the table.

Remember our selected strain is northern grown, better fla. vored and truer than most seed offered. There is no other yellow or golden sweet corn that can compare to our selected Golden Bantam. Try it and be convinced.

Price: Large pkt. 15c; Ib. $40 \mathrm{c}$; 10 lbs. $\$ 3.25$.

\section{Howling Mob}

\section{Routledge Superb}

We do not hesitate to recommend this new sweet corn to our customers. Its earliness, hardiness, size and quality make it of real merit to the western planters. It is extremely early, almost two weeks ahead of Golden Bantam and one week ahead of Portland Market. The large ears are always well filled with 12 to 14 rows of large, plump, white, sweet grains, of handsome appearance and excellent quality. Large pkt. 15c; Ib. 45c; 10 lbs, $\$ 3.50$

\section{Portland Market}

An Oregon introduction, a very early large eared sweet corn and very productive. It's large well-filled ears, together with its plump, sweet grains of purest white, makes it a most profitable home or market variety. Very popular with our market gardeners.

Large pkt. 15c; lb. 40c; 10 lbs. $\$ 3.25$

\section{Early Evergreen}

This fine variety is 10 to 12 days earlier than Stowell's Evergreen and yields large, handsome, 10 to 12-rowed ears. An excellent variety to follow the first early kinds. Near Portland it will make a late or main crop variety.

Large pkt. 15c; Ib. 40c; 10 lbs. $\$ 3.25$
This is one of the newer varieties that has become very popular here for main or late crop. The seed we offer is Oregon grown and acclimated. You must remember that the early corn listed by Eastern seed houses will be late hère.

Howling Mob is a large-eared, vigorous grower, ears large, well protected with husks and having 12 to 16 rows of the sweetest flavored, tender, delicious white corn-good for canning.

Large pkt. $15 \mathrm{c} ; \mathrm{lb} .40 \mathrm{c} ; 10$ lbs. $\$ 3.25$

\section{EVERGREEN FODDER}

This is the best of all the sweet corns to grow for green fodder for stock; much richer than field corn, large cropper but ears will not mature. Stalks sweet and rich.

Lb. $30 \mathrm{c} ; 10 \mathrm{c}$ Ibs. $\$ 2.25$

STOWELL'S EVERGREEN

A good main crop or late sort. Remains longer in green state than any other. Very large ears, with deep grains, and remarkably sweet. Locally it must be planted early to mature. Quite extensively planted by dairymen for feeding green on account of its sweetness.

Large pkt. 15c; lb. 35c; 10 Ibs. $\$ 2.75$

\section{POP CORN}

WHITE RICE.-Most popular and profitable kind; short ears, white, pointed kernels. Large pkt. 15c; Ib. 35c; 10 lbs. $\$ 3.00$ 
DRY FRUIT AND VEGETABLES

By securing a "Home" Evaporator you can, with very little trouble, dry your surplus fruit and garden truck for winter use. It will give you more variety and reduce your grocery bill. See Page 122.

\section{CELERIAC}

Turnip Rooted Celery.-The roots, which are the edible portion, keep well for winter use and are excellent for soups and stews. They are also cooked and sliced as a salad. Sow seed at the same season and give the same treatment as any root crop.

LARGE ERFURT. - An improved form producing large, smooth roots, which are nearly round. Pkt. 10c; oz. 25c; 4 oz. $75 c$

\section{EGGPLANT}

Sliced and fried takes the place of meat. Culture same as for tomatoes.

NEW YORK IMPROVED SPINELESS.Considered the best variety. Oval shaped, deep purple, large size and fine flavor.

Pkt. $10 \mathrm{c} ; 1 / 2$ oz. $45 \mathrm{c} ;$ oz. $75 \mathrm{c}$

\section{ENDIVE}

This plant furnishes an attractive and appetizing salad for the fall and winter months or by repeated sowings a supply may be had nearly all the year round. Useful in flavoring soups, stews, etc. Makes delicious greens if cooked like spinach. Cultivation same as for lettuce. The bleaching of Endive is brought about by drawing the leaves together into a head and tying them and this should be done a month before it is wanted for table use.

BROAD LEAVED BATAVIAN. - Leaves are broad, thick, green, more or less twisted and waved with white mid-ribs. It forms large hearts, which when blanched, form one of the best winter salads. Crisp, tender and fine flavor.

Pkt. $5 \mathrm{c}$; oz. $15 \mathrm{c} ; 4$ oz. $50 \mathrm{c}$; lb. $\$ 1.50$

GREEN CURLED. - The hardiest of all, with beautifully curled dark green leaves, tender and crisp.

Pkt. $5 \mathrm{c}$; oz. $15 \mathrm{c} ; 4$ oz. $50 \mathrm{c}$; Ib. $\$ 1.50$

WHITE CURLED.-Very tender and light green, blanches easily, very ornamental.

Pkt. 10c; oz. 20c; 4 oz. 50c; lb. $\$ 1.50$

\section{GARLIC}

Garlic is a perennial plant with a bulbous root and belongs to the onion family. It has flat leaves and the bulb is composed of several parts or bulblets similar to those of a multiplier onion set. We cannot offer seeds but can supply the bulbs or sets.

Prepare the ground as for onions, separate the sets and plant them in drills eight inches apart and four to six inches apart in the drill, covering two inches deep. Cultivate like onion sets. When the leaves turn yellow, pull up the bulbs and dry in the shade.

Per Ib. $60 \mathrm{c}$. postpaid

Write for quantity price. Requires about 250 lbs. sets per acre.

\section{HORSERADISH ROOTS}

Will form radishes of large size in one season's growth. For prices, see Vegetable Plants and Roots, page 117.

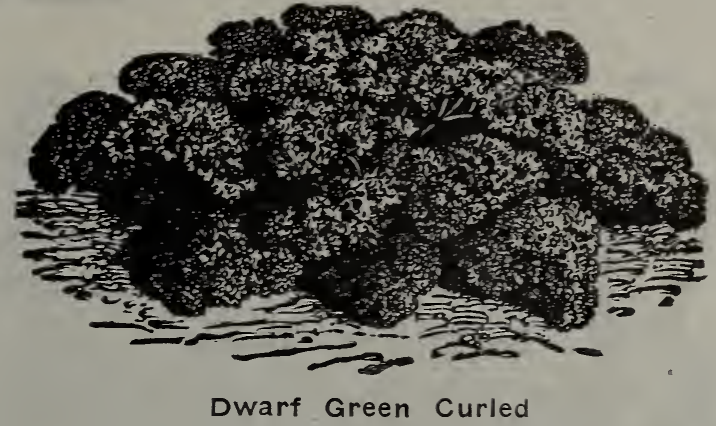

\section{KALE, OR BORECOLE}

This is a popular boiling-green resembling cabbage in flavor. The plant is entirely hardy in well-drained soil and can be grown easily from seed planted during the summer and fall months. With the tall varieties it is customary to pull off the lower leaves and let the plant grow on to furnish a continuous supply. The sweetness and flavor of these greens are improved by frost or light freeze.

\section{Dwarf Green Curled}

Beautifully curled, bright green Ieaves, tender and of fine flavor.

Pkt. $10 \mathrm{c} ;$ oz. $25 \mathrm{c} ; 4$ oz. $75 \mathrm{c} ; \mathrm{lb} . \$ 2.50$

TALL GREEN CURLED.-Grows about 2 feet high; leaves dark green; curled and wrinkled; very hardy.

Pkt. 5c; oz. 25c; 4 oz. 75 c; lb. $\$ 2.25$

\section{Fmerald Isle}

A very handsome variety of medium height. Leaves attractive, closely curled and of fine flavor.

Pkt. 10c; oz. 25c; 4 oz. 75c; lb. $\$ 2.50$

THOUSAND-HEADED. - For stock feeding. Pkt. 5c. See Field Seeds, page 44.

\section{KOHL-RABI}

A delicious vegetable. In growth this is half way between cabbage and turnip; the edible portion is the large bulk which forms on the stem above the soil. By making successive sowings, tender bulbs may be had throughout summer and fall, and are highly esteemed for their mild, delicate, cabbagelike flavor. Slice and boil, discarding the hard lower part of bulb. Sow in drills or raise and transplant like cabbage 6 to 10 inches apart.

EARLY WHITE VIENNA. - Extremely early, medium size, excellent quality.

Pkt. 10c; oz. 30c; 4 oz. 90c

\section{LEEK}

A species of onion which does not form a bulb, but is used for its mild and delicious root, stem or neck. Plant in rows and thin to about four inches. Hardy, and frost improves the flavor. Hill up to whiten.

\section{American Flag}

Mild and sweet; long, large stems; hardy and of the finest quality.

Pkt. 5c; oz. 25c; 4 oz. 90c

CARENTAN.-Very broad, thick stems of good flavor. Very large variety.

Pkt. $10 \mathrm{c}$; oz. $35 \mathrm{c} ; 4$ oz. $\$ 1.00$

On Cucumber and Garden Plants use "Bug Death" for Insects (see page 124), and "WONDER FERTILIZER" (see page 38 ), and you will be more than pleased with results. 


\section{LETTUCE}

\section{Grand Rapids}

Very popular with private gardeners and as a lettuce for greenhouse forcing. It will stand shipping better than most curled sorts. Of quick growth and stands for some days after being fit to cut. The plant is upright, and forms a loose head or cluster of large, bright green leaves, finely crimped and ruffled; rather thin, good flavor, c 1 isp and tender. Pkt. 10c; oz. 20c; 4 oz. 50c; Ib. $\$ 1.50$

\section{Early Prize Head}

A large, clustering, non-heading lettuce, most excellent for the home garden and undoubtedly the most easily glown variety in cultivation. It is too tender, however, to stand shipping or handling on the market. Leaves finely curled and crumpled, bright green tinged with brownish red, very crisp, tender and sweet.

Pkt. 10c; oz. 20c; 4 oz. $45 c$; lb. $\$ 1.40$

\section{Big Boston-Improved}

Plants large, very hardy and vigorous. Leaves broad, comparatively smooth, wavy at edges, thin, very firm and crisp; color bright light green, slightly tinged with reddish brown. Grown extensively in the South for shipment north in the winter. It usually heads up under cold weather conditions better than any other variety.

Pkt. 10c; oz. 20c; 4 oz. 60c; lb. $\$ 1.75$

EARLY WHITE COS-Trianon Cos or Romaine.-Distinct in having long, narrow, spoon-shaped leaves, folding into loose, sugar-loaf-shaped heads which blanch better by having the outer leaves drawn about them and tied. Leaves yellowish white, crisp, tender and of a distinct and pleasing flavor.

Pkt. $5 \mathrm{c}$; oz. 15c; 4 oz. $35 \mathrm{c}$; lb. $\$ 1.25$

SIMPSON'S EARLY CURLED.-A very eXtensively used early loose-leaved, or clustering variety. Leaves light green, slightly frilled, crisp, sweet and tender.

Pkt. $5 c$; oz. $15 c ; 4$ oz. $35 c$; lb. $\$ 1.25$

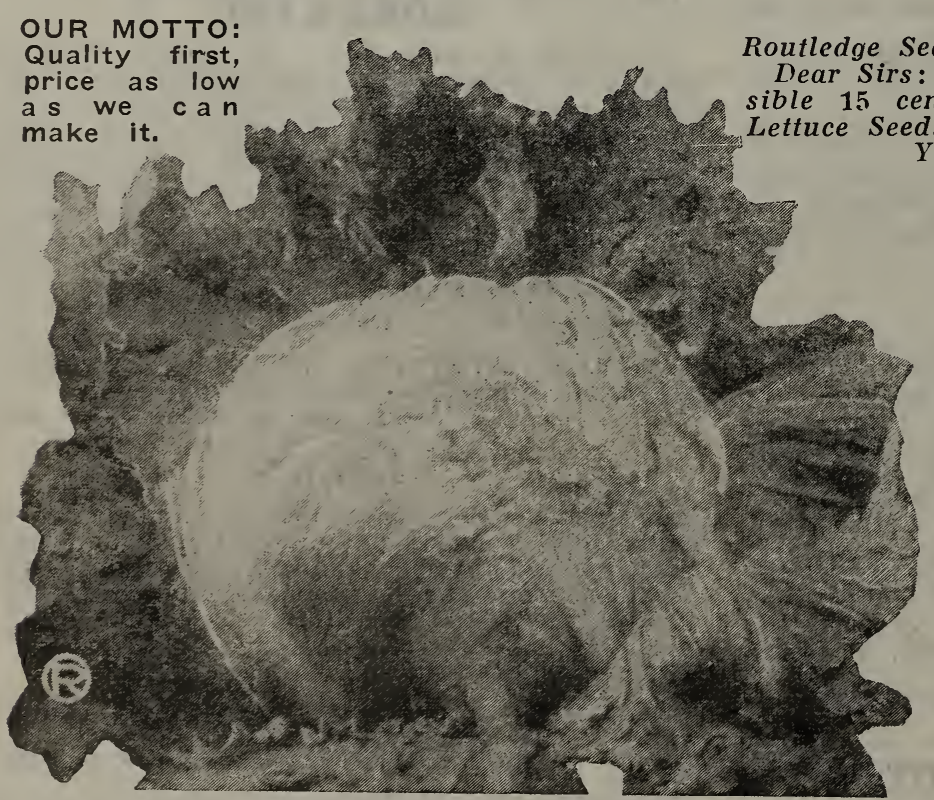

R. R.'s Wonderful

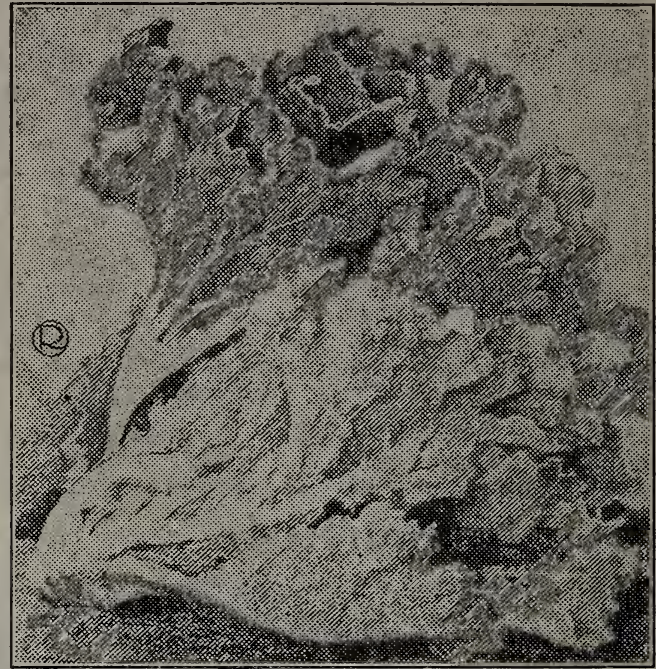

Grand Rapids

\section{Hanson}

Improved Hard Head.ng Stock. -The leading head lettuce. We can recommend this as one of the very best. Heads green outside and white inside; grow to a remarkable size; very solid, and is deliciously sweet, crisp and tender. It withstands the hot sun.

Pkt. 10c; oz. 20c; 4 oz. 60c; lb. $\$ 1.75$

Fort Gragg, Cal.

Routledge Seed \& Floral Co.,

Gentlemen: Your Lettuce is true to the name. They are wonderful.

Our grocery man pays one cent preminm on every head we raise. First we had to convince him, as he specialized in Los Angeles Lettuce before.

\section{Yours truly.} HERMAN A. MATSON.

Chehalis, Wash.

Seed \& Fioral Co. \& Floral Co.,
Kindly send me as soon as posworth of R. R.'s Wonderful ours very respectfully.

CARL CONZELMANN.

\section{R. R.'s Wondreful}

A re-selected, hand-picked strain of the original New York or Wonderful. Our grower has given this stock special attention and it is a wonderful strain. It produces immense heads of closely folding ruffled leaves. The heart blanches beauti. fully and is crisp, tender and delicious. A robust variety, rooting deeply and thus able to - resist hot, dry weather; slow to seed and a sure header. The outer color is of a distinct apple-green. A rapid grower and unsurpass. ed as a home or market let. tuce.

Read reports above.

Pkt. 10c; 1/2 oz. 20c; oz. 35c; 4 oz. $\$ 1.00$; Ib. $\$ 3.00$.

A NEW STRAWBERRY_Read about the wonderful "Marvel," a new variety of sterling merit, most delicious of all. Get a start_you'll be delighted. See Page 115. 


\section{LETTUCE-Continued}

\section{R. R.'s Tender Crisp}

A distinct and extra choice variety for those who like curly, crisp, tender Lettuce of the finest quality.

Grows to a large size, makes most desirable heads of pleasing appearance, and retains its crispness and mild flavor to a greater degree during the hot summer months than any other crisp-head variety. While especially adapted for midsummer, it is most desirable also for spring and fall. The plants are of quick, strong growth; the leaves are of a soft, bright green, growing closely around the heads, which are tightly folded and blanch to a silver white, and crisp and brittle as could be desired.

Pkt. 10c; 1/2 oz. 15c; oz. 20c; 4 oz. $60 \mathrm{c}$; lb. $\$ 2.00$.

New York (Los Angeles)

A large, crisp, curly-leaf, close-heading lettuce of the finest quality. A great favorite in the markets of Los Angeles and San Francisco. Carloads of this variety are shipped by California growers and it brings the highest prices.

Pkt. 10c; oz. 30c; 4 oz. $75 \mathrm{c} ;$ Ib. $\$ 2.50$

\section{Early May King}

The plants are of quick growth, practically all head and extremely handsome. From early spring plantings in the open ground they grow quickly to a diameter of 6 to 7 inches with the broad, light-green outer leaves folding closely about the round solid head. The inner leaves (practically the entire head) are branched to a rich golden yellow and have a specially fine, rich, but. tery flavor.

Pkt. 5c; oz. 15c; 4 oz. $45 c$; lb. $\$ 1.40$

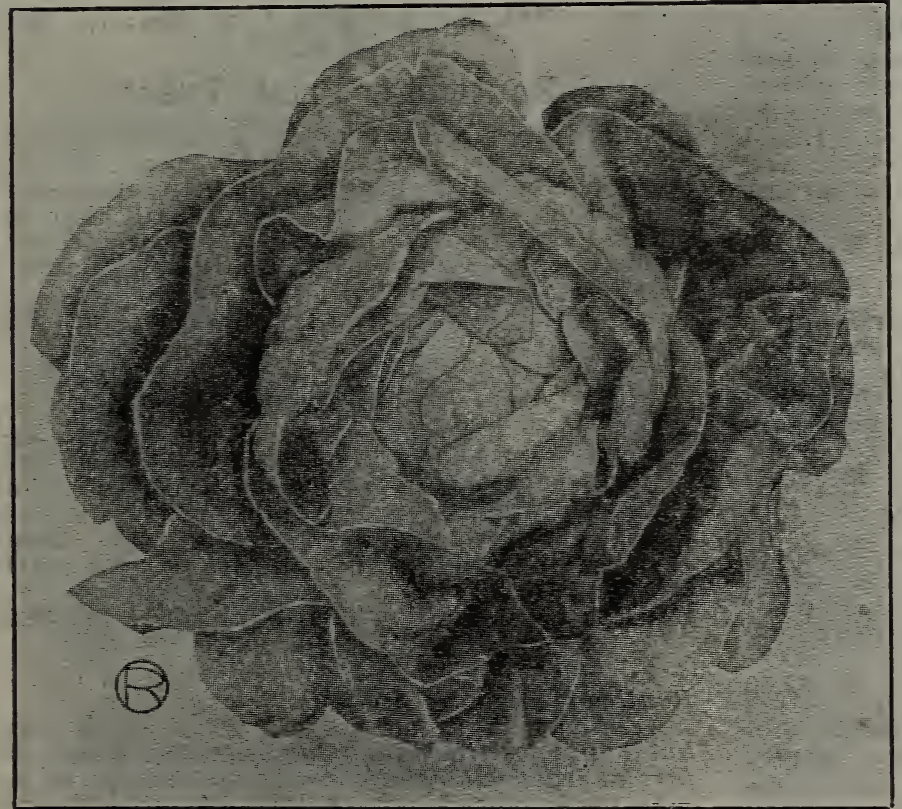

Wayahead-Extra Early

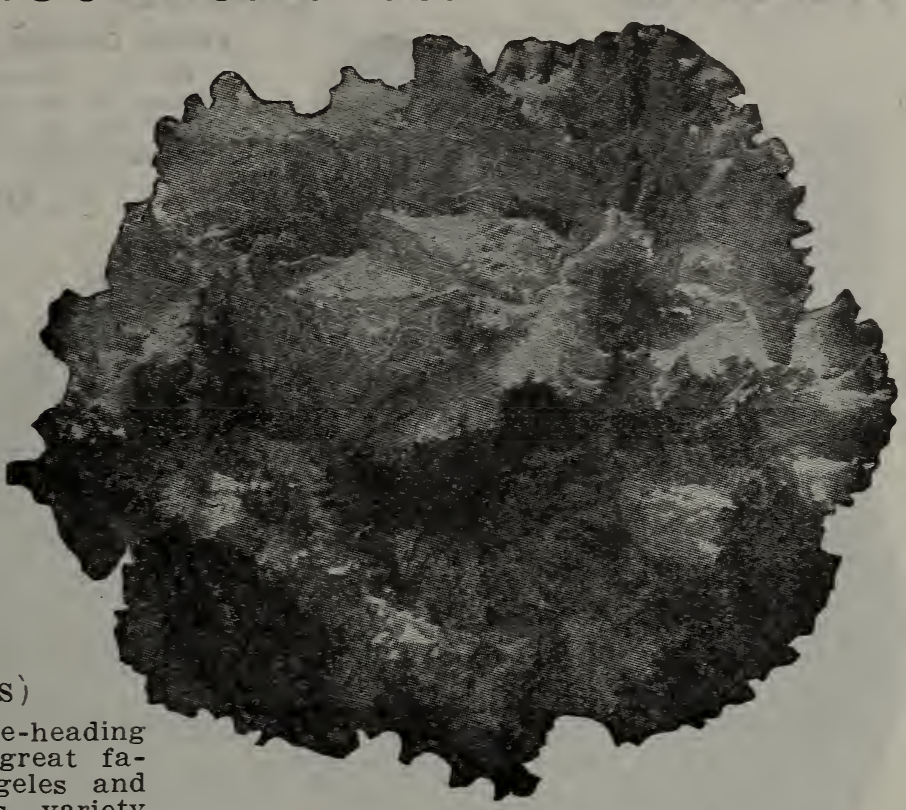

R. R.'s Tender Crisp Lettuce

OUR MOTTO IS

"Highest Quality",

It's quality FIRST, then price as low as possible. The best seeds are the cheapest in the end, even though they cost a little more.

John Day, Ore., February 19, 1919.

Dear Sirs: I am sending an order for seeds and plants. I used your seeds the last two years and they proved to be of fine quality.

Yours truly,

W. A. SMITH.

\section{Way-a-head}

\section{Extra sariy}

A new lettuce showing a remarkable combination of earliness, firm heading character, handsome appearance and fine quality. Both in coldframes early in the spring and in the open ground-in spring, summer and early fall months -it has proved to be not only the earliest and one of the sur. est heading of all early lettuce, but also of the very fin. est quality. It is not only earlier than May King and other fine early varieties, but the tightly folded heads are generally larger in size. The outer leaves are a light green, with the inner head finely blanched to a rich buttery yellow. We urge you to try this new variety (see cut).

Pkt. 10c; $1 / 2$ oz. 15c; oz. 20c; 4 oz. 50c; lb. $\$ 1.75$.

PLANT SMALL FRUITS around your garden. What's nicer than delicious fresh fruit. fresh from your garden? See Fruit Department, pages 108 to 117. 


\title{
True Seeds
}

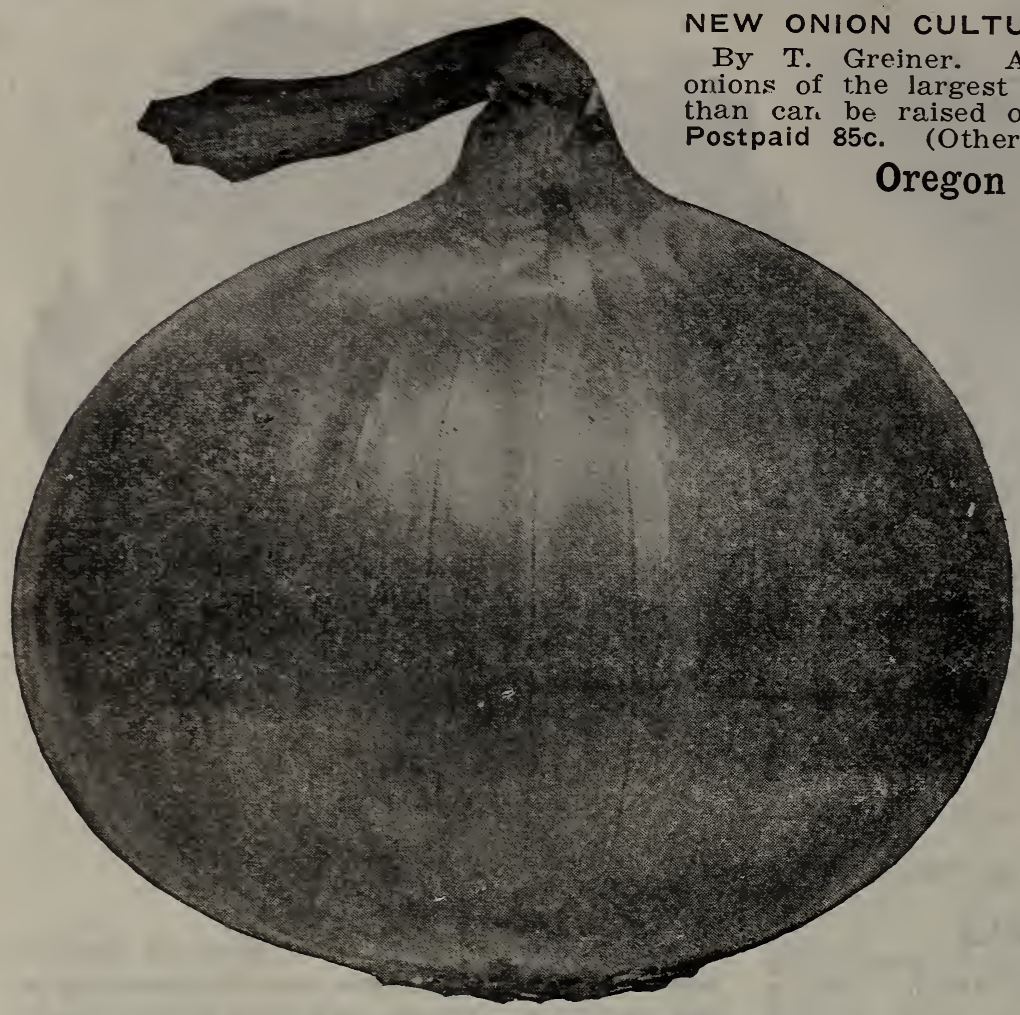

Highest Quality

ONION

NEW ONION CULTURE

By $T$. Greiner. A new methed of growing of largest size and yield on less land cald on the old 140 pages. (Other good books on page 130.)

\begin{abstract}
This is $t h$ e variety planted almost entirely in the Northwest, particularly in Oregon. The largest crops of onions and the best keepers, bringing the highest prices in the Pacific Coast and Middle Western markets, are the Oregon Yellow Danvers. The bulbs are uniformly large, three-quarters globe shape, with small necks. It is the earliest, largest in size, most perfect in shape, the largest cropper and the best keeper, and as a market or table onion cannot be excelled. Our seed is grown specially for us by the best onion seed growers in Oregon. No onion grower can afford to plant anything inferior when such seeds can be obtained at the following prices:
\end{abstract}

Pkt. 10c; oz. 30c; 4 oz. $75 c$; Ib. $\$ 3.00$.

\section{Oregon Yellow Danvers Onion}

Elbe, Wash., March 13, 1919.

Routledge Seed \& Floral Co.

Gentlemen: We have discovered that your seeds bring the exhibition prizes to our school, while we have failed with other seeds and plants.

ELBE SCHOOL, By Pearl E. Engel.

\section{Yellow Globe Danvers}

One of the most extensively used yellow onions. Bulbs of good size, uniformly globeshaped, with small neck, and ripen very evenly. Flesh white, crisp and of mild and excellent flavor. An enormous yielder and a fine keeper. We offer a select strain, unsurpassed.

Pkt. 10c; oz. 25c; 4 oz. $75 c ;$ lb. $\$ 2.50$

\section{Australian Brown}

Its remarkable keeping qualities and handsome appearance makes it very desirable. Resembles the Yellow Danvers in general appearance, but has a clear, amber-brown skin. It matures early, ripens uniformly and is a good, long keeper.

Pkt. 5c; oz. 20c; 4 oz. $60 \mathrm{c} ;$ Ib. $\$ 2.00$

Southport White Globe

An enoımous yielder and superb keeper; perfect globe-shaped, very large, clear white skin and considered one of the handsomest varieties grown. Planted extensively by market gardeners for green onions.

Pkt. 10c; oz. 30c; 4 oz. $\$ 1.00$; Ib. $\$ 3.50$

\section{White Portugal or Silverskin}

The finest flavored of all the whiteskinned onions. Quite early, half-globe shaped, a fine cropper; very firm and an excellent keeper. Planted thickly in broad drills makes fine pickling onions. (Short crop.)

Pkt. 10c; oz. 35c; 4 oz. $\$ 1.00$; lb. $\$ 3.25$

\section{Iarge Red Wethersfield}

The Standard variety of the red onions. Of large size, half globe, a heavy yielder, and one of the best for keeping. Skin a deep purplish red, smooth and glossy; will do better on fair upland soil than most varieties; flesh white, rather strong.

Pkt. 5c; oz. 25c; 4 oz. $60 \mathrm{c} ;$ Ib. $\$ 2.00$

\section{Routledge Prize Taker}

This onion has become a great favorite on account of its large size and great solidity. It is perfectly globe-shaped, with straw-colored skin; the necks are very small and the onions always ripen up hard. 'An excellent keeper, exceedingly fine, mild flavor and a very popular variety. (See cut.)

Pkt. 10c; oz. 25c; 4 oz. $75 \mathrm{c}$; lb. $\$ 2.25$

\section{Extra Early Red Flat}

The first Red Onion to ripen. A mediumsized, flat variety; an abundant producer and very uniform in shape and size; fine grained, mild flavored, and comes into use nearly two weeks earlier than the Large Red Wethersfield; very desirable for early market use.

Pkt. 5c; oz. 25c; 4 oz. 75 c; lb. $\$ 2.25$

Wedderburn, Oregon, Feb. 24, 1918. Routledge Seed \& Floral Co.

Gentlemen: I can get all those seeds here, but I am positive that your seeds are better by far; at least I have always found them to be so. In my enclosed order I don't know how much postage to send. I enclose 50 cents; if not enough please answer and I will immediately remit.

M. DOYLE. 


\section{ONION-Continued}

\section{Southport Red Globe}

A large globe-shaped, bright purplish-red variety. Is a late sort and an excellent keeper. A very handsome variety and of fine quality.

Pkt. $15 \mathrm{c} ;$ oz. $30 \mathrm{c} ; 4$ oz. $75 \mathrm{c} ; \mathrm{lb} . \$ 2.50$

\section{White Bartletta-Queen}

An early white variety; prized for home gardens and pickling on account of its small size. White Portugal is a much better keeper. (Very short crop.)

Pkt. $15 \mathrm{c} ;$ oz. $50 \mathrm{c} ; 4$ oz. $\$ 1.50$; lb. $\$ 5.00$

\section{Crystal White Wax}

A large, pure white, flat onion. During the last few years it has become very popular. Extremely early and one of the mildest and sweetest of all. It is very fine for slicing, the color being so clear and pule. We offer the genuine true seed. (Short.)

Pkt. $15 \mathrm{c} ;$ oz. $50 \mathrm{c} ; 4$ oz. $\$ 1.50$; lb. $\$ 5.00$

\section{ONION SETS}

NOTE.-Onion sets subject to market changes; short crop this year.

BOTTOM ONION SETS. - These small onions are grown from seed that have been sown too thick to attain a large size. The small onions (about $1 / 2$-inch in diameter) thus obtained are planted out and are ready in a shoit time to pull as green onions for the table.

Per lb. 35c; not postpaid $30 \mathrm{c}$ or 3 lbs. $75 \mathrm{c}$. Write for quantity prices.

TOP SETS.-Lb. 35c; not postpaid $25 \mathrm{c}$.

SHALLOTS.-Valuable for bunching or for an early crop. Each bulb makes from 3 to 5 green onions.

Per lb. 35c; 4 lbs. \$1.25; prepaid

\section{OKRA}

IMPROVED DWARF GREEN.-Very productive; long, slender green pods. Pkt. 5c; oz. 15c; 4 oz. 30c

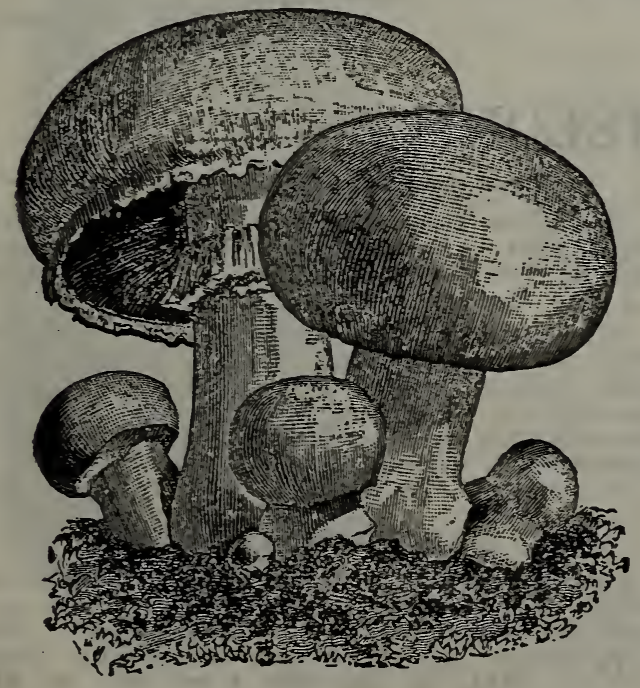

Mushrooms

MUSHROOM CULTURE.-We have a 32 page booklet on Mushroom Culture, nicely illustrated, for $35 \mathrm{c}$, postpaid. Free with an order for 10 bricks.

\section{Highest Quality True Seed}

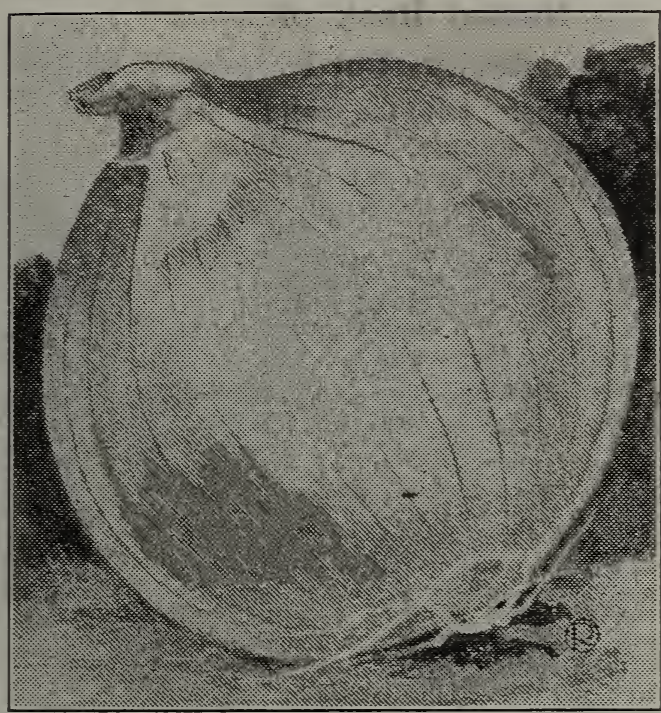

Routledge Prize Taker (see next page).

\section{MUSTARD}

The leaves of mustard make excellent greens of sharp, pungent flavor, and are cooked the same as spinach or beet leaves.

\section{Southern Giant Curled}

Large variety, forming a great mass of beautiful leaves, which are ruffled and finely curled on the edges; hardy, vigorous, highly recommended.

Pkt. $5 c$; oz. $15 c ; 4$ oz. $35 c$; lb. $\$ 1.00$

\section{Ostrich Plume}

Leaves dark green, beautifully curled and plume-like. Very vigorous and productive, stands well. Of distinctive flavor; superior to spinach for greens and excellent for salad.

Pkt. 10c; oz. 20c; 4 oz. 50c; lb. $\$ 1.50$

WHITE ENGLISH.-Light green variety; tender leaves; seed light yellow.

Pkt. $5 \mathrm{c} ;$ oz. $15 \mathrm{c} ; 4$ oz. $40 \mathrm{c}$; lb. $\$ 1.00$

\section{MUSHROOM SPAWN}

LAMBERT'S PURE CULTURE SPAWN.Iushrooms may be grown in any place where conditions of temperature and moisture are favorable. A shed, cellar or cave may be utilized to advantage for this purpose. It is essential that the temperature be maintained. from 53 to 60 degrees $F$. and that the moisture be properly regulated. Lambert's Pure Culture Spawn is far superior to the old-stvle varieties, and much better results can be obtained from its use. The bricks should be broken into pieces about two inches square and planted from 10 inches to a foot apart. Bricks weigh from 18 to 20 ounces. A brick will spawn 10 square feet of bed. With Lambert's Pure Culture Spawn it is impossible to raise poisonous mushrooms.

DIRECT SPAWN.-Latest and best. Mam moth White, Cream White or Bohemian Brown.

Price, per brick, not prepaid, $35 \mathrm{c}$; 10 bricks $\$ 3.00$; add postage at rate of $11 / 2$ lbs. per brick. Write for quantity price. 


\section{MUSKMELON}

\section{Netted Rock or Rocky Ford}

The most popular and best seller among Muskmelons

The fruit is oval and completely covered with a beautiful lace-like netting. Flesh very thick; green, very sweet, luscious, melting and superb flavor. The fruit is wonderfully uniform in shape and quality. The favorite everywhere. $\$ 1.50$.

Pkt. 10c; oz. 20c; 4 oz. 50c; lb.

\section{Burrell's Gem}

Select Strain.-A new, medium-sized oval variety, well ribbed and covered with a fine grayish netting and having reddish orange flesh of fine, spicy flavor, sweet and delicious, distinct flavor. There is a growing demand here for the finegrained, smooth, salmon, redfleshed Muskmelons. $\$ 1.50$.

Pkt. 10c; oz. 20c; 4 oz. 50c; lb.

\section{The Hoodoo}

One of the best of recent introductions. It is early and prolific. The fruit is of medium size, the seed cavity very small, the rind very thin, indeed, and the edible fleshy part thick and meaty. It is of orange or salmon color, the type much preferred now; but its great charm is its flavor, which is par excellence. Test it.

Pkt. $10 \mathrm{c}$; oz. $25 \mathrm{c} ; 4$ oz. $60 \mathrm{c}$; lb. $\$ 2.00$

Osage, or Miller's Cream

Medium to large, flesh thick, deep salmon, of excellent quality, rich and sweet; skin dark green, slightly netted and ribbed. A favorite variety for the later markets.

Pkt. 5c; oz. 15c; 4 oz. 45c; lb. $\$ 1.25$

Montreal Improved Nutmeg

Valued for ths size and delicious flavor. Round in shape, with remarkably thick

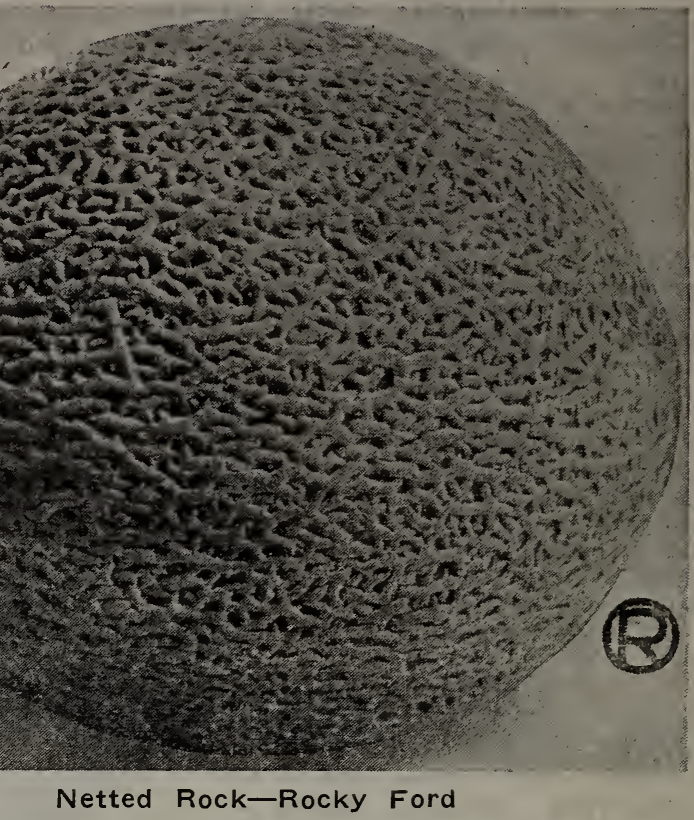

green flesh. One of our handsomest varieties.

Pkt. 5c; oz. 15c; 4 oz. 50c; lb. $\$ 1.50$

Golden Beauty Cassaba

Fall and Winter Muskmelons

Skin wrinkled, flesh thick, excellent flavor and fine aroma. When nearly ripe pick and stow away in a cool, dark place until the rind becomes slightly softened and moist. Melons wil actually keep until February. Pkt. 10c; oz. 20c; 4 oz. 60c; lb. \$1.75

Raymond, Wash., February 14, 1919. Routledge Seed \& Floral Co.

Gentlemen: Your seed has always been the very best, every kind I have bought of you, and I hope that I can always get your seeds.

Yours truly, MRS. SADIE CRAMER.

\section{WATERMELON}

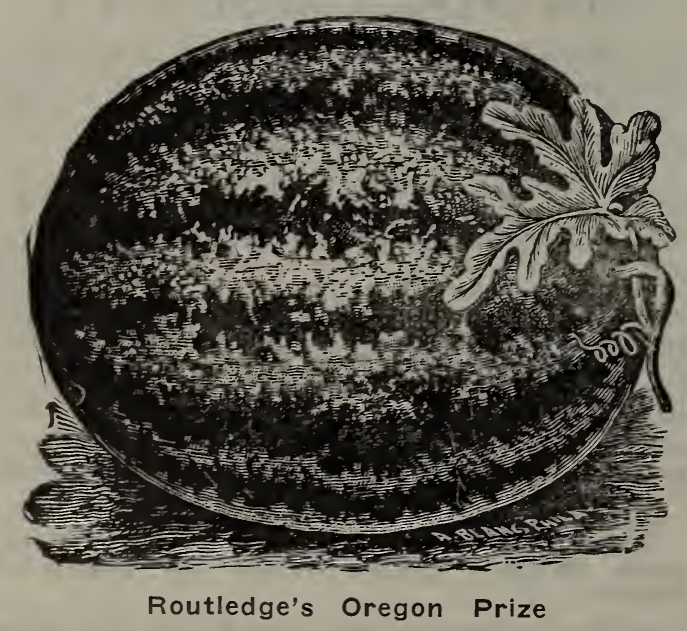

\section{ROUTLEDGE'S OREGON PRIZE}

We offer this new Melon with the assurance that it is not only remarkably early, but as sweet, delicate and melting in flavor as any variety grown.

The flesh is of a deep scarlet; rind thin, and on this account is not a particularly good shipping sort, but is emphatically the variety for home use and sale. It will ripen in altitudes where it has not been thought possible to mature a good watermelon.

Pkt. 10c; oz. 20c; 1/4 Ib. 60c; Ib. $\$ 2.00$

\section{KLECKLEY'S SWEET}

Unsurpassed for home use or near markets. Vine vigorous and productive; fruit of medium size, oval; color dark green; flesh very bright, rich red and exceedingly sweet. Pkt. 5c; oz. 15c; 4 oz. 35c; lb. $\$ 1.10$

Citron, Red Seeded.-Flesh white and solid, used exclusively for pickles and preserves.

Pkt. 10c; oz. 25c; 4 oz. $50 \mathrm{c}$

Seed arid Reference Tables, Amount to Plant, etc., see complete reference tables inside back cover. Always refer to "Index," pages 2 and 3 , for anything wanted. 


\section{"Highest Quality" GARDEN PEAS Hand Picked}

There is a vast difference in "strains" of garden peas. You will find our stock "very superior," healthy, vigorous and true, much better than the average seed sold by wholesale seed dealers and jobbers. Try them if you want "Highest Quality."

Packet and single pound prices only are prepaid. Add postage to 10-lb. prises if wanted by mail. WRITE FOR QUANTITY PRICES, but new crop of new pea seeds is very short.

ALASKA. - An extra early, exceedingly hardy pea. Pods of perfect shape, well filled with smooth peas of unrivaled quality. Height $21 / 2$ feet. Can be planted much earlier than wrinkled peas.

Large pkt. 15c; Ib. 35c; 10 Ibs. $\$ 3.00$

\section{AMERICAN WONDER}

Well known and very popular; extra early, productive and good flavor; grows 10 inches high.

Pkt. 15c; Ib. 40c; 10 Ibs. $\$ 3.50$

\section{Duke's Delight}

A very dwarf, extra early delicious pea of great merit.

Our regular customers are now demanding it in preference to American Wonder, Notts and Gem varieties.

Duke's Delight easily outclasses these old popular kinds in productiveness, size and fullness of pods, color, sweetness and flavor. The sturdy, stocky, healthy vines grow about 12 to 14 inches high. Every grower praises it. Read reports, we receive many like them.

Large pkt. 15c; lb. 45c; 10 lbs. $\$ 4.00$

Ashland, Ore., January 17, 1919.

Routledge Seed \& Floral Co.

Dear Sirs: Please give me prices on Duke's Delight Peas in quantities of 50 pounds. Duke's Delight were the only peas in the neighborhood that did not have aphis on them. They bore heavier than any other variety and my neighbors want me to order for them. Yours respectfully,

T. S. WILEY.

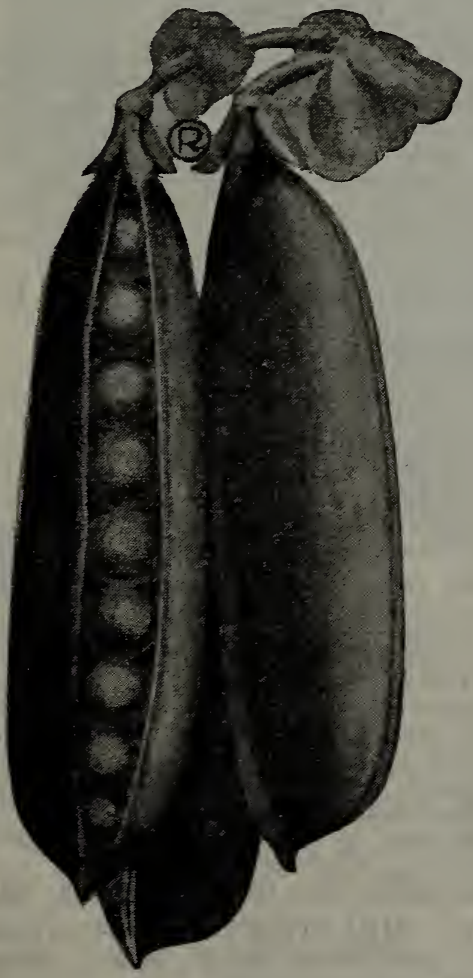

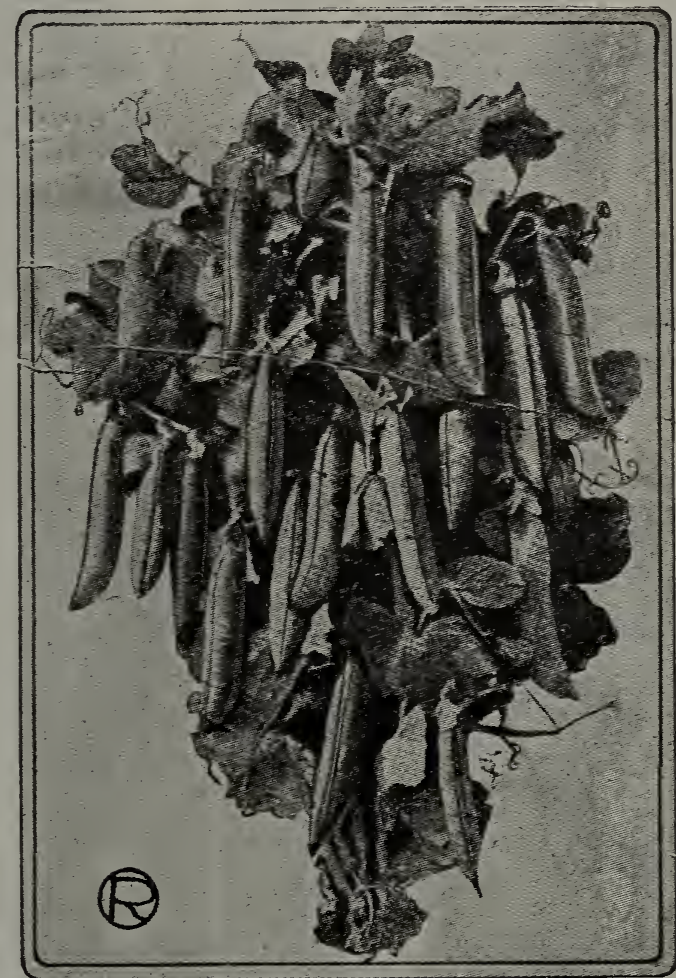

Duke's Delight

SUTTON'S EXCELSIOR

This handsome wrinkled Pea is so hardy that it may safely be planted as early as Alaska. The plants are dwarf, sturdy, very stout, exceedingly productive and the "quality" is all that could be desirea. The pods are large for so dwarf a variety and always weli filled. Improvement over Notts Excelsior.

Large pkt. 15c; lb. 40c; 10 lbs. $\$ 3.25$

\section{RICHARD SEDDON}

The pods are deep green, crowded with from 7 to 9 large peas of very fine color and flavor. An extremely early type, maturing only a week later than the Alaska, when sown at the same time. A splendid all-around early dwarf variety. On account of its immense productivity, evenness of maturity, compact, well filled pods and excellent color and quality, it is especially desirable for canning purposes.

$$
\text { Large pkt. 15c; Ib. 40c; } 10 \text { lbs. } \$ 3.25
$$

\section{New Book-The Garden Guide}

Thoroughly covering Vegetable and Fruit Raising. How to Plan, Plant and Maintain the Home Grounds, the Suburban Garden, the City Plot. How to Care for Roses and other Favorite Flowers, Hardy Plants, Trees, Shrubs, Lawns, Porch Plants and Window Boxes. With Chapters on Pruning, Propagation, Fertilizirs, Insect Pests, Tools, Winter Storage. Canning, Birds, Gat den Furniture and 1001 Practical Pointers.

Heavily illustrated with over 275 teaching plans and diagrams and reproduced photngraphs, all made expressly for this Standard Text Book.

Prices: Paper Covered 85c; Cloth Cover \$1.10, post. paid.

Be sure you read about Mulford's Culture for inoculating pea seed. Increases the yield and improves the soil. (See page 41.) Plant extra early, early and late varietles all at same time for a succession of prime pods. 


\section{Highest Quality Garden Peas-Continued}

Market Gardeners who buy Peas in quantity should write us for prices, stating variety and amount wanted. Single pound prices only are prepaid. See notes top of page 25 .

\section{BURPEE'S BLUH: BANTAM}

Unequaled for extreme earliness, superb quality, and unusual productiveness. The dwarf vigorous vines average 15 inches in height and carry really enormous crops of large, deep bluish-green pods. The handsome pointed pods average 4 inches long and are tightly packed with extra large, deep bluish-green peas of most luscious flavor. Large pkt. $15 \mathrm{c}$; Ib. $45 \mathrm{c}$; 10 Ibs. $\$ 3.75$

\section{ITTTLE MARVEL}

An extremely valuable variety, especially suited to small home gardens, and early market. It matures very early and produces large crops. Vines 15 to 18 inches high. The pods are dark green, good size, produced in pairs and are closely filled with 6 to 7 peas of extra fine flavor.

Large pkt. 15c; Ib. $40 \mathrm{c} ; 10$ lbs. $\$ 3.50$

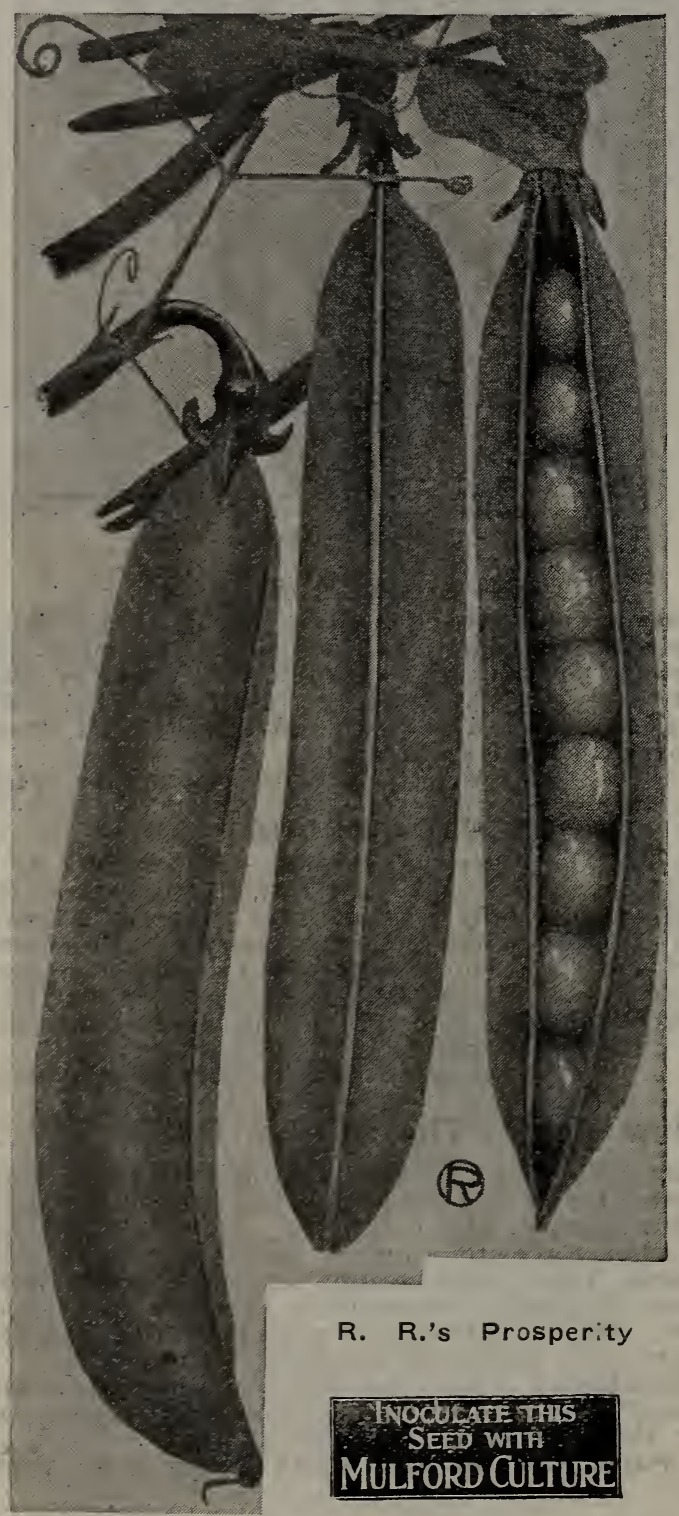

\section{R. R.'s Prosperity}

The Earliest Large Podded, Sweet Garden Pea to date.

It is hardy and can be planted fully as early as Alaska.

This grand, large podded, extremely early, prolific variety, is vigorous and robust; height $31 / 2$ to 4 feet; only a few days later than the earliest smooth sorts.

The pods are very large, and are invariably well filled with from 8 to 10 sweet, luscious, tender wrinkled peas of large size and delicious flavor.

The peas remain tender and sweet for some time after they are large enough to use. Its heavy yield and excellent quality makes it a most profitable market variety. Large pkt. $15 \mathrm{c} ; \mathrm{Ib} .45 \mathrm{c} ; 10$ lbs. $\$ 4.00$

\section{IAXTONIAN}

This is an ideal market and home garden pea, medium dwarf in habit of growth, but with very large pods, averaging five to six inches in length. Laxtonian seldom has any blank spaces in the pods.

Large pkt. $15 \mathrm{c} ;$ Ib. $45 \mathrm{c} ; 10$ lbs. $\$ 4.00$

\section{DWARF TELEPHONE-DAISY}

A splendid mid-season variety, growing only about 18 inches in height; vines very stout and bear a good crop of large, wellfilled, bright green pods. The pods average 5 inches in length, containing 7 to 9 large peas which are tender and sweet. A popular sort.

Large pkt. $15 \mathrm{c} ; \mathrm{lb} .40 \mathrm{c} ; 10$ lbs. $\$ 3.50$

\section{GRADUS}

Extra early. This popular large-podded wrinkled pea of finest quality matures pods only two or three days later than the small-podded round-seeded exrra earlies. Vines four feet high. It proauces uniformly large pods, measuring from four to four and a half inches in length, nearly lound, and well filled with very large, handsome peas of the finest flavor.

Large pkt. $15 \mathrm{c} ; \mathrm{lb} .40 \mathrm{c} ; 10$ lbs. $\$ 3.50$

\section{IMPROVED STRATEGEM}

A very productive semi-dwarf variety with large leaves and large pods. Requires no support. The peas are dark green, wrinkled, and large. It is planted in large quantities by gardeners for market. In quality it is unsurpassed, the peas when cooked being of the most delicious sweetness.

Large pkt. $15 \mathrm{c} ;$ Ib. $40 \mathrm{c} ; 10$ lbs. $\$ 3.00$

\section{EDIBLE PODDED OR SUGAR PEAS}

A great favorite with many. In the EdiblePodded or Sugar Peas the pods are gathered, broken and cooked like string-beans when the peas start to develop in the pod or have reached about half their full size.

DWARF SUGAR.-Grows about 2 feet in height, producing a heavy crop of small flat pods about 3 inches in length.

Large pkt. $15 \mathrm{c}$; Ib. $50 \mathrm{c}$; 10 ibs. $\$ 4.00$

MAMMOTH MELTING SUGAR.-Grows 4 feet tall, producing very large, broad, flattened pods.

Large pkt. 15c; lb. $50 \mathrm{c} ; 10$ lbs. $\$ 4.00$ 
PEAS-CONTINUED-LARGE PODDED, LATE OR MAIN CROP

Packet and single pound prices only postpaid. Prices high. New crop very short.

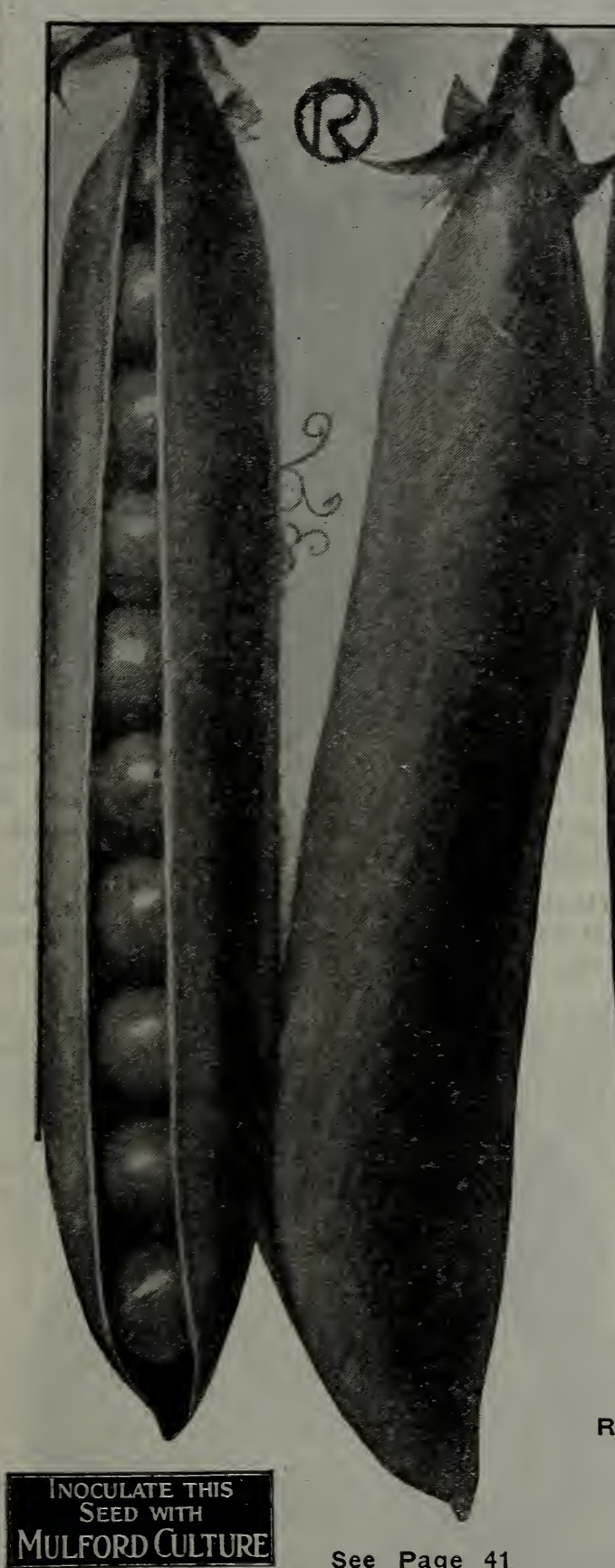

Portland, Ore., September 3, 1919. Routledge Seed \& Floral Co.

Dear Sirs: You wished reports on the Routledge Prize Pea. Our vines grew about five feet high-seven to nine pods to the vine, nine to ten peas to the pod; peas measured 9-16 inch in diameter, almost the size of marbles. A bag of them unshelled weigh half again as much as any other peas we had, and for the first time we had more peas than we could use.

We intend to plant them exclusively next year for late peas. very truly yours,

A. T. WALKER.

\section{TELEPHONE}

One of the most popular and largest peas we have. Vines attain a height of $41 / 2$ feet, bearing profusely the extra long, handsome pods; tender, sweet and superb flavor. We offer a very carefully rogued, select strain of unusual merit. Large pkt. 15c; Ib. 40c; 10 lbs. $\$ 3.75$.

\section{Routledge Prize}

A new, sweet, wrinkled, mammoth podded Pea of extra value.

This re-selected new strain, grown especially for us in New Zealand, will be found true to name. A sturdy, healthy grower. Vines and pods are a deep, rich green. A bushel of Routledge Prize pods will shell out nearly twice as many peas as a bushel of Telephone. The vines are enormously productive, being completely covered with immense long pods, well filled with from 8 to 11 large peas of the richest flavor. This variety grows about 4 feet high and as an abundant cropper is superior to all other sorts.

Nothing in the line of peas excells the Routledge Prize in richness, sweetness and flavor. We are sure our customers will agree with us after testing this new pea. Try them and report results if you will. Large pkt. 15c; lb. 45c; 10 lbs. $\$ 3.75$.

Read these reports:

Gaston, Ore.

Routledge Seed \& Floral Co..

Dear Sirs: Routledge's Prize

Peas sure were fine. never saw Peas beal so and the pods were full of large, fine-flavored peas.

We must have some more of those Peas. Yours truly, W. W. EARE.

Everett, Wash., March 27, 1919. Dear Sirs: Please find enclosed order for some of your good seeds, as I have had some of them before. Especially your Routledge Prize Peas. They are just grand.

Yours truly,

MRS. J. KINGS.

Salem, Ore., July 27, 1919.

Routledge Seed \& Floral Co.

Gentlemen: Our Routledge Prize Peas averaged six feet high. We picked 80 pounds from the 75 feet of rows and let about 8 feet of one row ripen for seed.

Ordinary garden soil, no fertilizer except "C. M." in the rows. Everybody who saw them said they were the finest peas they had even seen.

Yours truly,

W. L. HATCH. 


\section{Routledge Seed \& Floral Co.'s PURE SEED POTATOES}

We offer a few varieties of special merit that we recommend to our friends and customers. We think it is folly to plar, ordinary or common stock. Many gardeners insist on the best vegetable seeds, but plant any old kind of potatoes bought from their groceryman or taken from their supply of "eating stock," without even knowing whether they are early or late. Buy our pedigreed select seed potatoes this year and secure a real crop.
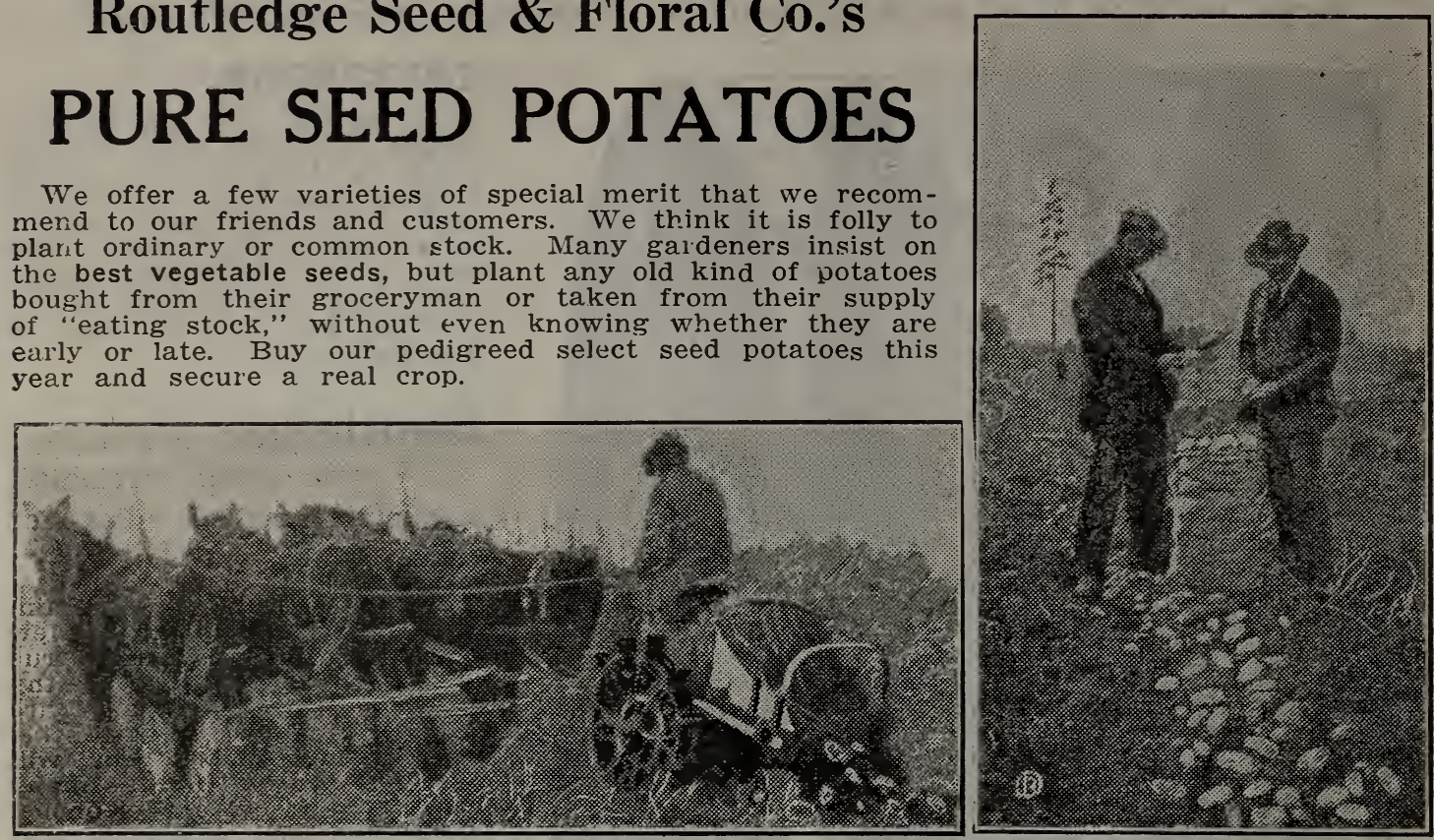

Digging and inspecting a 40-acre field of our "Pride of Multnomah." Illustrition from photographs made by the writer. Considering the season, this field certainly produced a phenomenal yield of 95 per cent select, salable potatoes. This proves that hill-selected. disease-free, improved potatoes are the only profitable kind to plant.

ABOUT PRICES.-Prices are subject to important market changes. Ask for quotations on larger lots. Good, true, healthy stock of the best named Seed Potatoes are never plentiful and are always in demand. Order early and get our own contract-inspected stock.

\section{EXTRA EARLY IRISH COBBLER}

One of the first varieties of potatoes to be ready for market, and therefore always commands a good price. The skin is smooth and white, sometimes finely netted, which is an indication of good quality; eyes are strong and well developed. The flesh is white and of fine flavor and quality, even when used very small. 'Tubers grow to good size very quickly. Excellent keepers. Vines sturdy, stocky and healthy. Always in big demand. Can be planted close.

Price, not prepaid; add postage if wanted by mail; 1 lb. 10c; 5 lbs. 40c; 10 lbs. 75c; 50 lbs. $\$ 3.25$; 100 Ibs. $\$ 6.00$.

\section{"EARLIEST OF ALL"}

Its quick growth and early maturity, combined with its excellent cooking qualities, makes it very valuable. Summer drought does not affect it, for its growth is complete before it can be injured. Plant early to obtain large size. Ready for the table nine weeks from planting, and fully matured in 12 weeks.

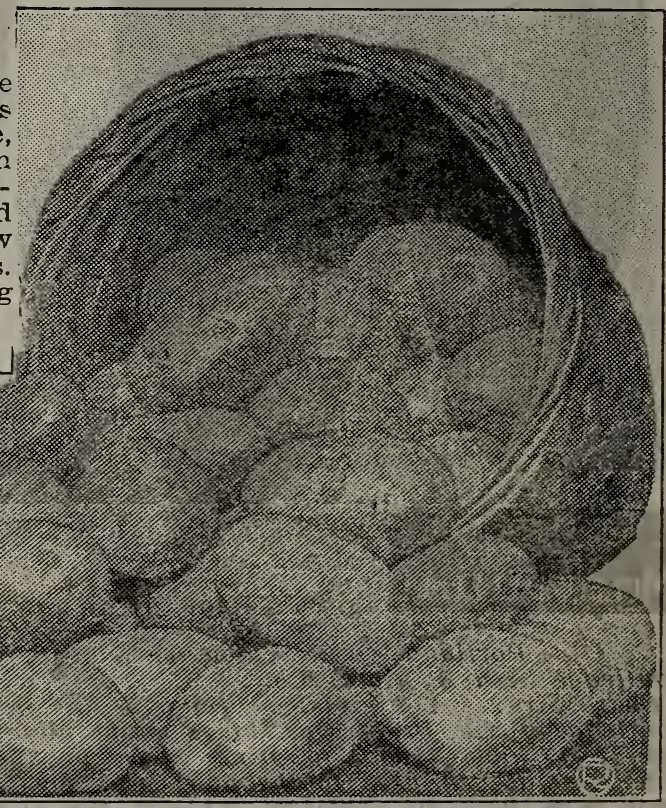

Irish Cobbler, Extra Quality

"Earliest of All" is a healthy, vigorous grower, not subject to blight or disease and does not make a second growth. Keeps as well as any late potato. A handsome, shallow-eyed. round, slightly flattened, white-skinned prtato of the finest table qusility Price, not pre. paid, add postage if wanted by mail: Lb. 10c; 5 lbs. $40 \mathrm{c} ; 10 \mathrm{lbs}$. $75 \mathrm{c} ; 50 \mathrm{lbs}$. $\$ 3.25 ; 100 \mathrm{lbs} . \$ 6.00$.

NOTE.-This form of our catalog went to press Dec. 24, and at that time prices on potatoes were advancing rapidly on account of the loss of thousands of sacks by fieezing. All potato price subject to market: Write when ready to huy. 


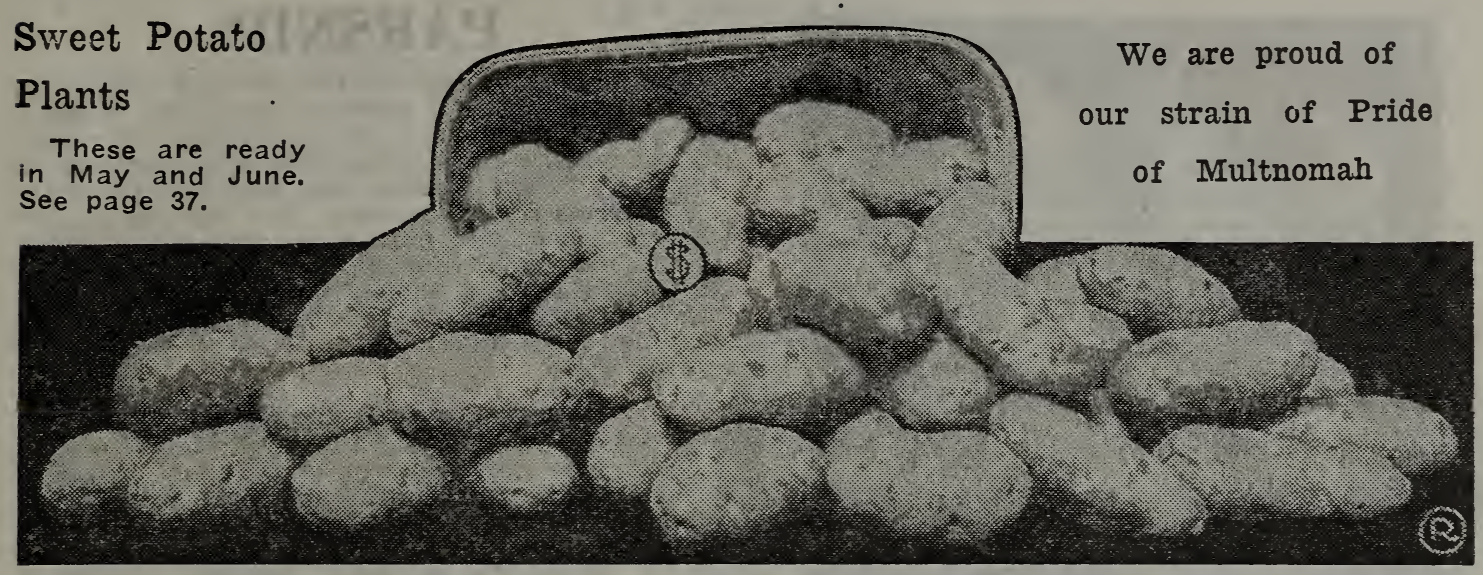

"Pride of Multnomah" raised from our "hill-selected," pedigree stock. Ideal in shape, heavy and solid; free from all disease. The $\$$ size cilcle gives comparative size. Order early and be sure of good stock.

PRICES.-All potato prices are subject to change without notice. Write for prices, stating quantity wanted, when ready to buy.

\section{EARLY ROSE}

A great favorite for many years on all markets and many growers still claim that the true stock has never been excelled in quality and productiveness. Potatoes are long in shape, good size, showing trace of pink at the bud end. They cook mealy and are of fine flavor.

Prices, not prepaid, 5 lbs. $40 \mathrm{c}$; 10 lbs. $65 \mathrm{c}$; 50 lbs. $\$ 2.75$; 100 lbs. $\$ 5.00$; quaritity prices on request.

\section{BRITISH QUEEN}

A new English variety of real merit. Its great productiveness, large size, excellent quality, health and vigor puts it at "the top" as a fancy table and shipping potato. Tubers oblong, slightly flattened, with white, smooth skin, shallow eyes. A profitable main crop variety you should try.

Prices, not postpaid, Ib. 10c; 5 Ibs. 40c; 10 lbs. $65 \mathrm{c}$; 50 lbs. $\$ 2.75 ; 100$ lbs. $\$ 5.00$.

\section{AMIERICAN WONDER}

One of the best all-around white potatoes, very popular for early main crop. A strong grower and a great producer; tubers white, uniform in size, elongated, of excellent quality.

Price, not prepaid: 5 lbs. $40 \mathrm{c}$; 10 los. $65 \mathrm{c}$; 50 lbs. $\$ 2.75$; 100 lbs. $\$ 5.00$; quantity price on request.

\section{PRIDE OF MULTNOMAH}

Our leading main crop variety; has no equal as a profitable commercial variety.

It is one of the heaviest yielding, most even growing main crop variety. The skin is smooth and white, eyes shallow, and cooking qualities unexcelled, being fine grained and of snowy whiteness either boiled or baked. Withstands drought better than most varieties. We offer hand-selected stock from our expert grower. (See illustration.)

The original stock of Multnomah, we thought, had a tendency to grow too long and pointed, and we have hill-selected to get a shorter, thicker, heavier type that ships and handles better, the "Ideal Type" that brings the "fancy prices."

Price, not prepaid, add postage if wanted by parcel post, 5 lbs. $40 \mathrm{c}$; $10 \mathrm{lbs}$. $65 \mathrm{c}$; $50 \mathrm{lbs}$. $\$ 2.75 ; 100$ lbs. $\$ 5.00$. Do you prefer large or medium seed stock?

\section{PRODUCFR}

A large, smooth, oval, whice potato with shallow eyes, of finest table quality; will not "boil to pieces," and baked has no supetior; it is a hardy, vigorous grower that earned its name of "Producer" on account of its enormous and never-failing yield.

Price, not prepaid, add postage if wanted by parcel post, 5 lbs. $10 \mathrm{c}$; 10 lbs. $75 \mathrm{c} ; 50 \mathrm{lbs}$. $\$ 2.75 ; 100$ Ibs. $\$ 5.00$.

\section{BURBANK}

A standard commercial variety, but most stock is "run-out." We offer hand selected stock that will yield much heavier than most.

Prices, not prepaid: 5 lbs. 35c; 10 lbs. $65 \mathrm{c}$; 100 lbs. $\$ 5.00$; quantity price on request.

\section{PARSLEY}

CHAMPION MOSS CURLED.-An English strain, with beautiful n oss-curled foliage; vigorcus grower.

Pkt. 10c; oz. 20c; 4 oz. 45c; lb. $\$ 1.25$

ARLINGTON EXTRA CURLED.-Very choice strain, having the greatest possible curl to the leaves and the darkest green color; a very vigorous grower; will stand heat and drought better than ary other.

Pkt. 10c; oz. 20c; 4 oz. 45c; lb. $\$ 1.25$

PLAIN LEAF.-Single-leaved variety, very fine and excellent flavor. Pkt. $5 \mathrm{c}$; oz. $10 \mathrm{c} ; 4$ oz. $30 \mathrm{c} ; \mathrm{lb} .75 \mathrm{c}$

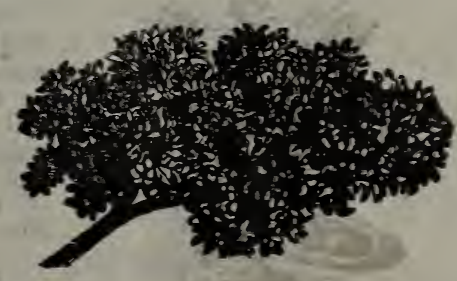

IT PAYS TO USE “WONDER" FERTILIZER.-W. L. Richards reports a crop of 422 lbs. of large, choice potatoes from a 100-foot row where he used "WONDER FERTILIZER," and only 138 lbs. of small "spuds" where "Wonder" WAS NOT USED. Soil and growing con. ditions the same. Note-He brought samples to our store. 


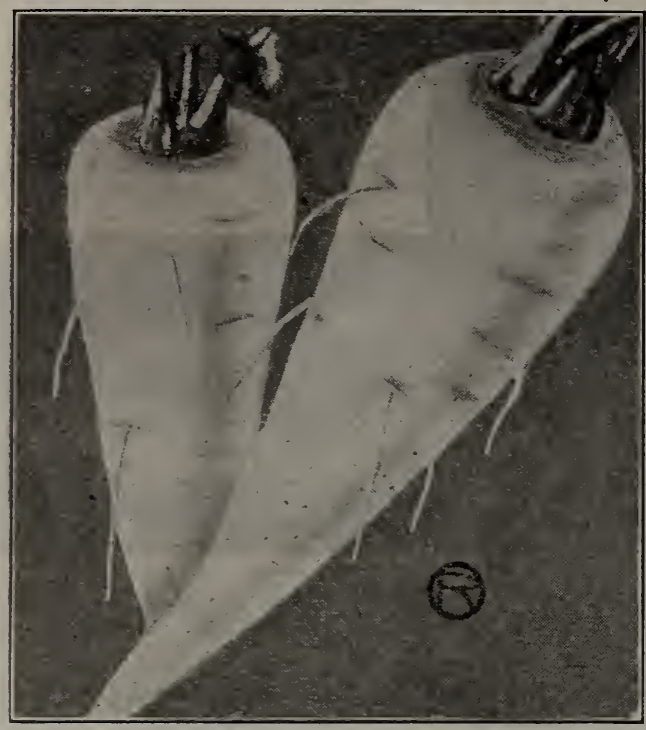

Sweet Marrow Parsnips

\section{PEPPER}

Plant seed early in the spring; culture same as for tomatoes. Plants in season. See Vegetable Plant List, page 37.

\section{CHINESE GIANT}

The largest of all the peppers, very sweet and mild. Brilliant, glossy scarlet when ripe. Excellent for stuffing.

Pkt. 15c; oz. 85c

\section{RUBY KING}

Plants grow 2 feet high and bear a fine crop of handsome, extra large, scarlet fruits. The flesh is thick, sweet, and mild. Especially fine for mangoes. An excellent sort

Pkt. 15c; oz. 75c

\section{PIMENTO-PERFECTION}

This is a sweet Pepper-one which you will enjoy eating in salad, either fresh or canned. Gardeners are planting Pimento largely. Quite large, top shaped, very thick flesh and wonderful mild flavor. Pkt. 10c; oz. 75c

LARGE BELL OR BULL NOSE. - The plants are vigorous, compact and very productive, early and mild, fruit large, bright crimson when ripe. Pkt. 10c; oz. 65c RED CHILI. - A small, pointed, bright red variety. The pods are used in making chili and pepper sauce, and are very pungent and hot; very productive.

Pkt. 10c; oz. 75c

CAYENNE.-Long, red, pointed pods; very strong and used largely for making pepper sauce; popular variety. . . Pkt. 10c; oz. $75 \mathrm{c}$

\section{PARSNIP}

While highly appreciated for the table the great value of the parsnip for stock feeding is but little known. The roots are very rich in saccharine food, adding to the richness of the milk when freshly dug and fed to cows.

Culture. - Sow as early in the spring as the weather will admit in drills 18 inches apart and 1/2-inch deep, in a rich, deep soil; thin out 3 to 6 inches apart in the rows. The quality of the roots is improved by leaving them in the ground over winter for spring use.

\section{SWEET MARROW}

This fine new parsnip of English origin is offered with full confidence that it will become a prime favorite with all who use it. It is very fine grained and exceedingly sweet, while the peculiar "parsnip" flavor is fully preserved. The roots are unusually smooth and attractive in appearance. The best of all parsnips for the private or market gardens.

Pkt. 10c; oz. 20c; 4 oz. 50c; Ib. $\$ 1.50$

\section{HOLLOW CROWN}

The most popular variety; medium length roots, very smooth and of the finest quality. Derives its liame from a depression at top of crown or root; very fine table sort. Pkt. 5c; oz. 15c; 4 oz. 40c; lb. $\$ 1.25$

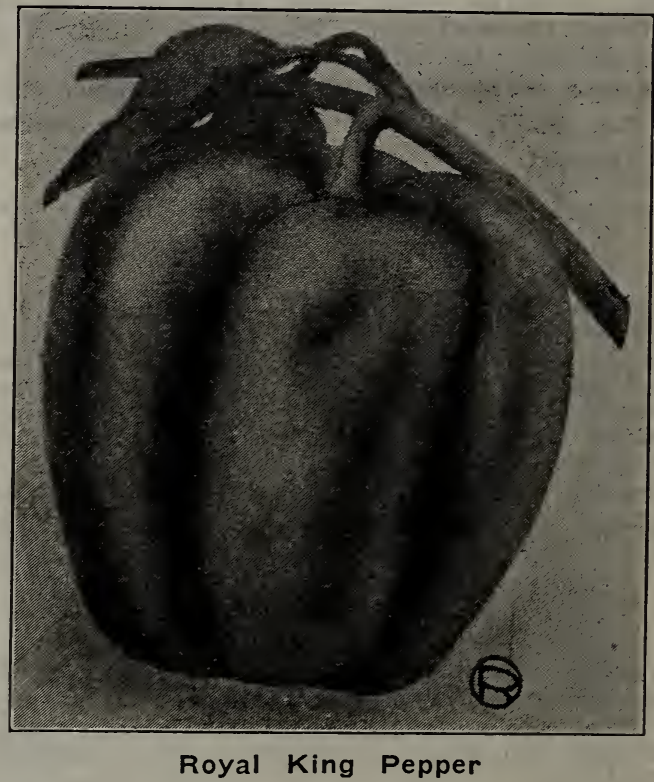

CHERRY RED.-Rich, glossy, scarlet fruit at maturity; small, smooth and round; of dwarf habit.

\section{PEANUTS}

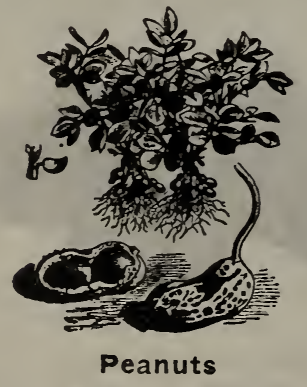

As we have had many calls for peanuts for planting and know that they do fairly well in the Northwest, we offer two good kinds.

Culture.-Remove the shell carefully so as not to break the skin and plant 10 inches apart in rows, cover 2 inches. Warm, sandy, rich loam soil is best. When grown, pull up and dry in the sun.

IVERSON'S IMPROVED.-Early, large, and productive, yielding few imperfect pods and less "pops" than any other sort.

Large pkt. 10c; Ib. 60c

EARLY SPANISH.-Although small, this variety is especially adapted to the north. Yields heavily, pods solid and unusually well filled. Sweeter and more delicious than the larger varieties. Large pkt. 10c; lb. 60c 


\section{PUMPKIN}

DOUBLE THE YIELD AND SIZE OF YOUR PUMPKINS by using a handful of "WONDER" Fertilizer to each hill and be sure you mix it well with top soil. (See page 38.)

\section{Winter Luxury}

An enormously productive variety of medium size and superior keeping qualities. Of rounding shape, about 10 inches in diameter; golden russet color, finely netted, rich deep golden flesh; sweet and tender. By far the best for pies; try it.

Pkt. 10c; oz. 20c; 4 oz. 50c; Ib. $\$ 1.50$ Small Sugar

Fine grained, very sweet and excellent keeper. Skin deep orange yellow. Pkt. 5c; oz. $15 \mathrm{c} ; 4$ oz. 50c; lb. $\$ 1.25$ King of Mammoths

The largest of all; grow this variety to win the prizes at the fair.

Pkt. 10c; oz. 25c; 4 oz. 60c; lb. $\$ 1.75$ Connecticut Field

The best for field culture and excellent for stock.

Pkt. 5c; oz. 15c; 4 oz. 35c; Ib. $\$ 1.00$

Large Sweet Cheese

A popular variety; fruit flattened; skin mottled light green and yellow; flesh yellow, thick and tender; very nutritious and of excellent quality; a most productive variety.

Pkt. $5 \mathrm{c}$; oz. $15 \mathrm{c} ; 4$ oz. $40 \mathrm{c}$; lb. $\$ 1.25$

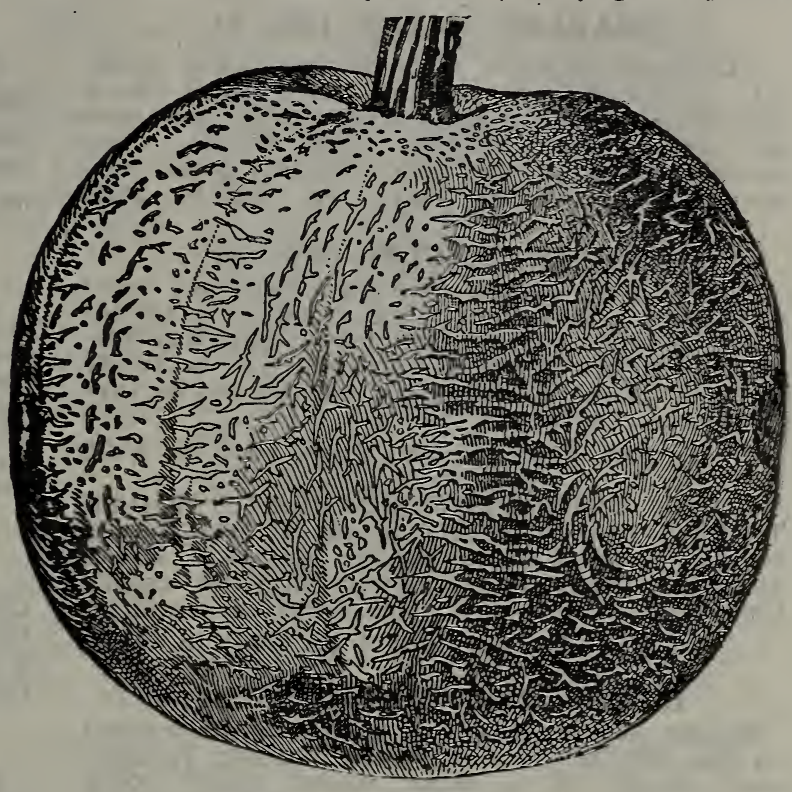

Winter Luxury Pumpkin

"Highest
Quality" RADISH "Hignest

REMEMBER-For a continuous supply of crisp, tender Radishes, sow seed every week, as they remain in "prime" condition only a few days after attaining full size.

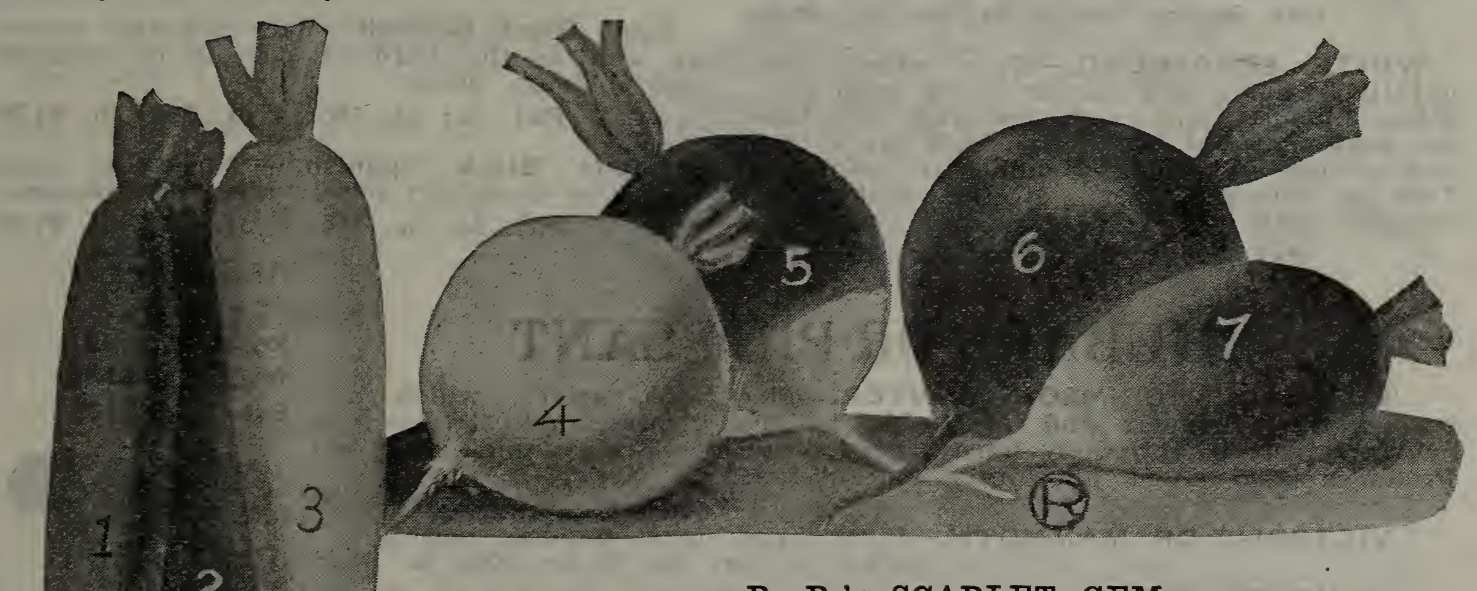

This splendid radish is the very finest early strain of the round, bright red radishes. No other can surpass its table excellence or its beauty. The skin is bright scarlet, flesh pure white. crisp, tender and of delicious quality.

Pkt. 5c; oz. 15c; 4 oz. 40c; Ib. $\$ 1.25$

SCARLET TURNIP, WHITE TIPPED (No. 5)

A beautiful variety, deep scarlet with white tip. Very early, crisp and delicious. It is most attractive in appearancs and cannot fail to give satisfaction; very popular as a market sort

Pkt. 5c; oz. 15c; 4 oz. 40c; lb. $\$ 1.25$

\section{EARLY SCARIET TURNIP}

Small top; of quick growth; mild and crisp. Very popular. Pkt. 5c; oz. 15c; 4 oz. $40 \mathrm{c} ;$ Ib. $\$ 1.10$

FRENCH BREAKFAST (No. 7)

Very popular, crisp, tender and mild; grows about 2 inches long, stump rooted, tipped white.

Pkt. 5c; oz. 15c; 4 oz. 40c: It. $\$ 1.00$ 


\section{RADISH-Continued}

Rake a liberal amount of our kiln-dried pulverized cow manure into your Radish bed if your soil is heavy. See page 38.

\section{SCARLET GIANT (No. 6)}

"Crimson Giant." The largest early scarlet turnip-shaped radish. The flesh is a sparkling white, solid, crisp, juicy and are of the mildest flavor. The bright, deep crimson color of the skin remains quite constant. Pkt. 5c; oz. 15c; 4 oz. 40c; lb. $\$ 1.25$

WHITE ICICLE (No. 3) attractive. It is not only crisp and tender when young, but retains these qualities until the roots attain large size. It is ready nip-shaped sorts.

Dkt. 10c; oz. 20c; 4 oz. 60c; Ib. $\$ 1.75$

LONG BRIGHTEST SCARLET, WHITE TIPPED (No. 1). - The brightest and handsomest long scarlet radish known. Roots mature quickly and continue in good condition until full grown. Of excellent quality.

Pkt. 5c; oz. 10c; 4 oz. 30c; Ib. $\$ 1.00$

EARLY SNOWBALL (No. 4) on the White Box or White Turnip Radish; very early, of a clear white color, solid, juicy, crisp, tender and unsurpassed in flavor. Pkt. 5c; oz. 10c; 4 oz. 30c; lb. $\$ 1.00$

\section{LONG SCARLET (No. 2)}

Grows perfectly straight and smooth, 6 to 7 inches in length. Skin scarlet, very thin; the flesh crisp, brittle and of delightful flavor; the finest long red radish.

Pkt. 5c; oz. 10c; 4 oz. 30c; lb. $\$ 1.00$

WHITE STRASBURG.-Even when comparatively small this variety is in good condition for use, and continues crisp and tender until matured, when the roots are 4 to 5 inches long and about 2 inches in diameter. This is considered one of the best large summer sorts.

Pkt. 5c oz. 15c; 4 oz. 35c; lb. $\$ 1.25$
This superb radish is pure white and most for use almost as quickly as the early tur-

Model White Box. A grand improvement

\section{WINTER RADISHES}

The merits of Winter Radishes are little appreciated. These grow to large size and keep well for winter and spring use. Sow seed in July and August. Early planting is not advisable.

\section{NERIMA—Japanese Long White}

A late fall and winter radish that has recently made its appearance on the Portland market and created much favorable comment. It grows from 12 to 30 inches long and about 2 inches in diameter. Skin white and smooth, flesh firm, crisp, tender and mild. Very popular and in good demand; keeps well all winter.

Pkt. 10c; oz. 25c; 4 oz. 75c; lb. $\$ 2.25$

California Mammoth White-Also called Chinese White Winter or Celestial. A long, thick, stump rooted variety. Pure white. The flesh is tender and crisp, keeping well through the winter.

Pkt. $5 c$; oz. $15 c ; 4$ oz. $40 c$; lb. $\$ 1.50$

SAKURAJIMA. - Japanese variety that grows to an immense size, almost globe shaped. The skin is smooth and white, and the flesh is always mild, crisp and tender.

Pkt. 10c; oz. 15c; 4 oz. 50c; lb. $\$ 1.50$

China Rose.-Bright rose color, flesh firm and piquant, largest at the bottom. One of the best. Pkt. 5c; oz. 15c; 4 oz. 40 c; lb. $\$ 1.50$

Long Black Spanish.-Very popular; latest, as well as the hardiest. Roots of medium size, oblong, black.

Pkt. $5 \mathrm{c}$; oz. $15 \mathrm{c}$; 4 oz. $35 \mathrm{c}$; lb. $\$ 1.25$

Round Black Spanish.-Three or four inches in diameter; flesh white; good keeper. Pkt. 5c; oz. 15c; 4 oz. 35c; lb. $\$ 1.00$

\section{RHUBARB OR PIE PLANT}

BURBANK'S CRIMSON WINTER.-The new variety. which has become very popular and profitable to the grower, has a delicious fruitly flavor, is extremely hardy, very prolific and very quick growing. Produces good stems all winter and spring.

Pkt. 10c; oz. 80c; 4 oz. $\$ 2.50$

VICTORIA, OR MAMMOTH.-Very large; most popular variety.

Pkt. 5c; oz. 15c; 4 oz. 40c; lb. $\$ 1.25$

RHUBARB ROOTS.-From October to June we can alwuys supply one, two, and often larger clumps of Rhubarb Roots. Customers will save much valuable time by ordering roots instead of seed. For prices, etc., seé page 117.

\section{SUNFLOWER}

LARGE RUSSIAN.-This has very large single heads borne at the top of a single unbranched stalk usually, and with much more and larger seed than the common sorts. It is used extensively for feeding poultry. The plant aften grows 10 feet high. Sow seed as soon as ground is fit for planting corn, in rows 3 to 4 feet apart and 10 inches apart in row. Cultivate same as corn. When the seed is ripe and hard, cut oft the heads and pile loosely in an airy, dry place where they will soon cure so as to be threshed out and cleaned. This variety will yield 1000 pounds or more of seed per acre. Some species are planted largely in the flower garden for ornanient. (See Flower Seeds under Helianthus.) Pkt. $5 \mathrm{c} ; 1 \mathrm{oz}$. $10 \mathrm{c} ; 4 \mathrm{oz} .20 \mathrm{c}$; Ib. $50 \mathrm{c}$, postpaid; for larger quantities inquire for prices.

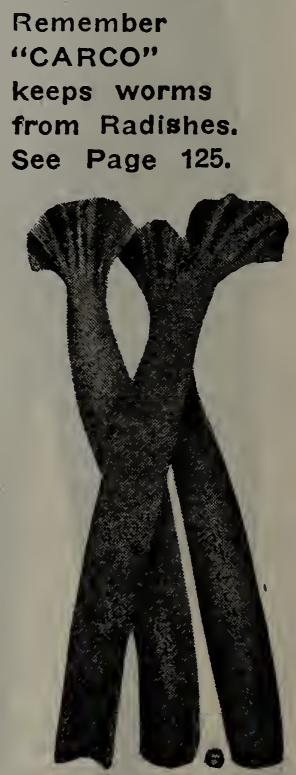

Rhubarb 


\section{SALSIFY OR VEGETABLE OYSTER}

One of the most desirable winter vegetables. The roots when cooked are very palatable and nutritious and are served in a variety of ways. The flavor is similar to oysters. Salsify succeeds best in a light, well enriched soil, which should be stirred to a good depth. Coarse and fresh manure should be avoided, as it will surely cause the roots to grow uneven and illshaped. Sow early and quite deep, giving the general culture recommended for parsnip. The roots are perfectly hardy and may remain out all winter. Frost does not injure the roots; may be stored in a pit or in a very cool cellar.

MAMMOTH SANDWICH ISLAND

This variety is large and strong growing with long, smooth, white, tapering roots, and is less liable to branch than the other sorts. It is invaluable for market gardeners' use. Pkt. 10c; oz. 30c; 4 oz. 90c; lb. $\$ 3.00$.

\section{SPINACH}

Plant in the richest soil you have very early in the spring or not until fall for winter use, as it does not do well in hot weather.

IMPROVED THICK-LEAVED.-A variety which grows very rapidly, forming a cluster of large, very thick, slightly wrinkled leaves of fine color and quality when cooked; best for market gardeners.

Pkt. $10 \mathrm{c} ;$ oz. $15 \mathrm{c} ; 4$ oz. $40 \mathrm{c}$; ib. $\$ 1.25$

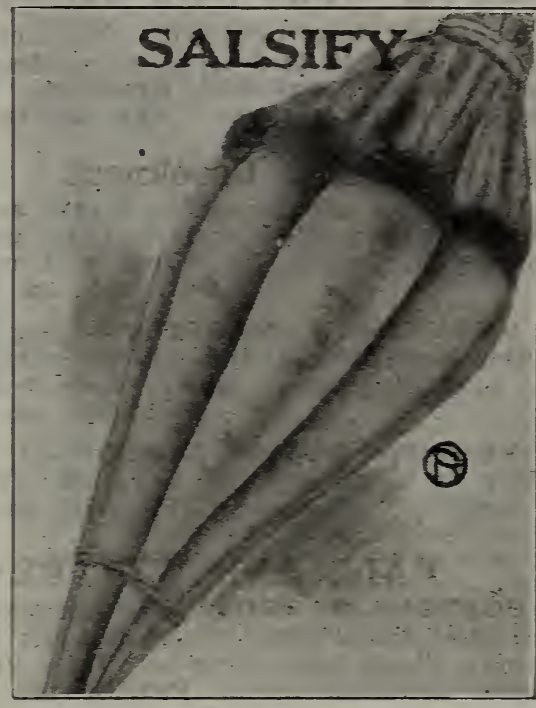

NEW ZEALAND.-Unlike true spinach in type and in that it thrives during hot weather and in any soil rich or poor. The tender shoots are of good quality and may be cut throughcut the summer. The plant becomes quite large and spreading. The leaves are comparatively small, broad and pointed. Germination of the seed can be hastened by soaking in warm water twenty-four hours. Pkt. 10c; oz. 20c; 4 0z. 60c; Ib. \$2.00

LONG STANDING.-An improved variety of excellent quality for general use; slow going to seed. Remains in good condition longer than most. Dark rich green.

Pkt. $10 \mathrm{c} ;$ oz. $15 \mathrm{c} ; 4$ oz. $40 \mathrm{c}$; Ib. $\$ 1.00$

BLOOMSDALE SAVOY LEAVED.-Very early; of upright growth; leaves broad and pointed, dark green, fine quality; grows quickly. Good for all seasons.

Pkt. 10c; 4 oz. 40c; Ib. $\$ 1.00$

PRICKLY WINTER.-Very desirable; very hardy and easily glown; bears large, smooth broad pointed leaves. Color, bright green. A fine winter and spring variety. $\$ 1.00$.

kt. $5 \mathrm{c}$; oz. $15 \mathrm{c} ; 4$ oz. $40 \mathrm{c}$; lb.

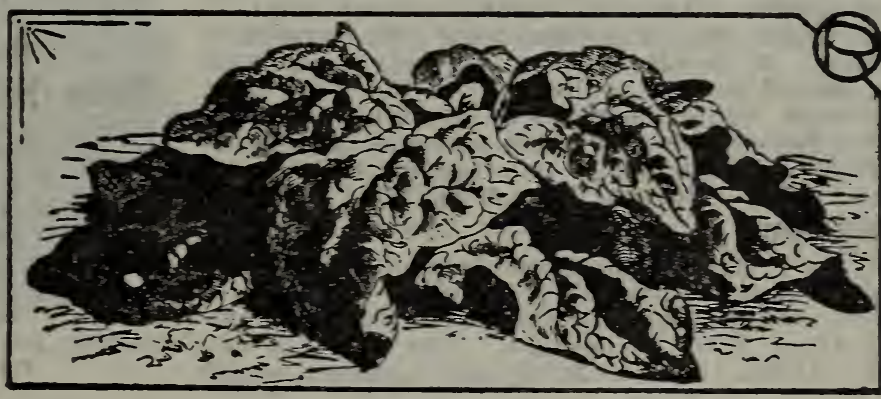

Improved Thick Leaved SQUASH

\section{Delicata Squash}

A perfect all-season squash. A summer and winter crop on one plant. Produces 15 to 20 fruits to a vine that are as deliciously flavored as the winter kinds.

It is ready almost as soon as the early summer sorts. Of excellent flavor, and remains in perfect condition a long time. The fruits are about 9 inches long, and as shown in the cut, slightly ribbed. When ripe, the ground color is deep yellow, irregularly st 1 iped and marbled with dark olive-green.

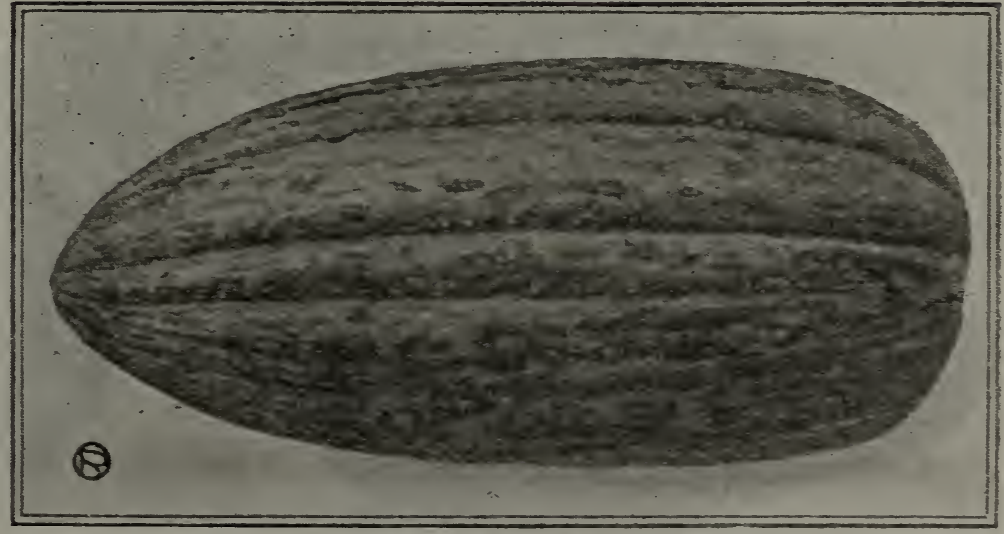

Delicata Squash-Try It

The flesh is thick, of fine texture, and pale-yelolw in color. It is unexcelled for baking - the shape and size make it perfect for this purpose. When boiled it turns out dry, mealy and sweet. Excellent for pies.

Pkt. 10c; oz. 25c; 4 oz. $65 \mathrm{c}$; ib. $\$ 1.75$

Make liquid manure from "C-M" (pg. 38) and give each hill a quart or two occasionally during hot weather. The results will surely surprise you. 


\section{SQUASH-Continued}

\section{Mammoth White Bush Scallop}

The fruit is a beautiful, clear, creamy white; superior in size and beauty, and is quite uniformly warted. The handsomest of the scalloped squashes. The stock we offer is exceptoinally true to type. Pkt. $5 \mathrm{c} ;$ oz. $15 \mathrm{c} ; 4$ oz. $35 \mathrm{c} ; \mathrm{lb}$. $\$ 1.25$

\section{Golden Summer Crookneck}

Early and prolific. The fruits are of the true crookneck type, heavily warted and of light golden color. One of the most popular sorts for home and market.

Pkt. 10c; oz. 15c; 4 oz. $40 \mathrm{c}$; Ib. $\$ 1.25$

VEGETABLE MARROW.-Long White Bush. A very popular sort abroad and can be raised equally well here. Is long and slim, color white, with delicious white flesh.

Pkt. 10c; oz. 15c; 4 oz. $40 \mathrm{c}$; lb. $\$ 1.50$

YELLOW BUSH SCALLOP.-A very eary, flat, scallop variety of large size; color yellow; flesh pale yellow and well flavored.

\section{FALL AND WINTER VARIETIES}

BOSTON MARROW.-A popular variety for canning; large oval fruit; skin bright reddish orange, with light cream netting; flesh rich orange, fine grained and of excellent quality.

Pkt. $5 \mathrm{c}$; oz. $15 \mathrm{c} ; 4$ oz. 35c; lb. $\$ 1.25$

\section{Mammoth Chili}

The largest of all squashes, growing to an enormous size, often weighing over 200 pounds. while its rich, fine flavored flesh insures its value for all purposes. Its size makes it valuable for stock feeding. Pkt. 10c; oz. 20c; 4 oz. 45c; lb. $\$ 1.75$

\section{Golden Hubbard}

The same in size, shape and quality as the well-known Hubbard Squash, except that it is a bright red or golden color and somewhat earlier. It is also a long keeper; considered by expert judges to be one of the very best fall and winter sorts yet introduced. Matures before the frosts; is vigorous and wonderfully productive. In flavor it has no equal. Pkt. 10c; oz. 20c; 4 oz. 50c; lb. $\$ 1.75$

\section{Delicious}

Finer-grined and more delicious than the well-krie, n Hubbard. The color of skin is green or blue-black. Medium size, weighirg from 5 to 10 pounds. The shell is not verv thick. but is hard and strong; small

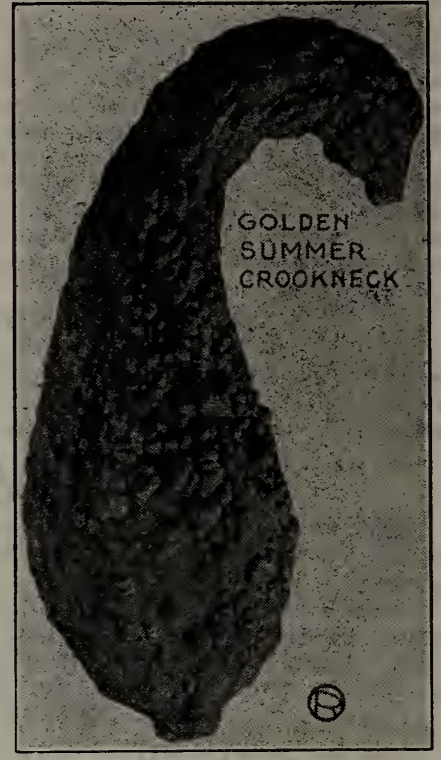

See DAD'S ELECTRIC

I.ANTERN. page 122.

seed cavity; the flesh is very lm.n it bright yellow color, fine-grained anv if splendid quality. For table use. either" " a fall or winter squash, it cannot be ex. celled. Pkt. 10c; oz. 20c; 4 oz. 50c; Ib $\$ 1.50$

\section{True Hubbard}

One of the best of the winter squashes. Vines vigorous and very prodictive. Fruit large, heavy, moderately warted with very hard shell. Skin uniformly dark bronzegreen. Flesh bright irange-yellow, fine grained, thick, dry and richly flavored. Can be kept in good condition until spring. Our seed is carefully selectrod and is much superior to most offered.

Pkt. 10c; oz. 20c; 4 oz. 50c; lb. $\$ 1.75$

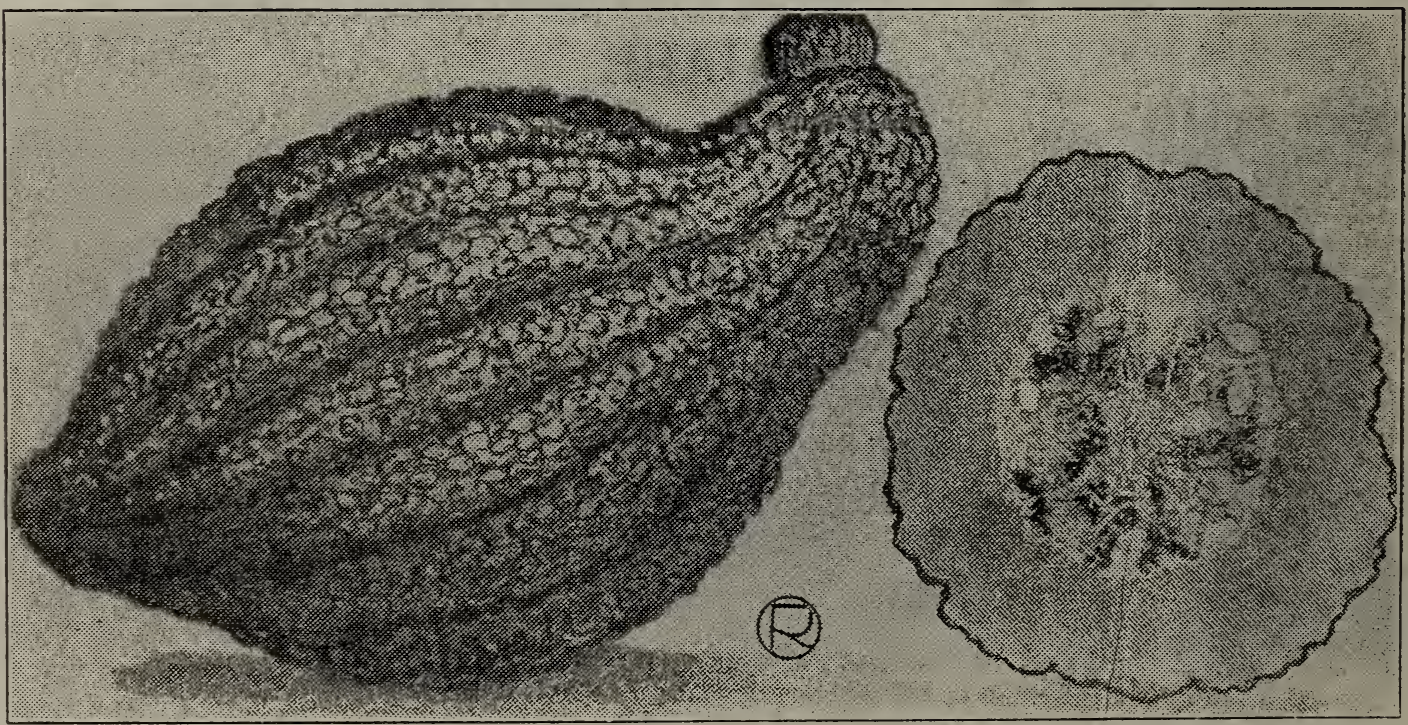

True Hubbard.-Note the thickness of the flesh.

DOUBLE the yield of your squash by using a handful of "WONDER" Fertilizer to each nill. (See page 38.) You know the richer your ground, the larger the yield, and Wonder Lertilizer certainly contains more plant food than any other brand. 


\section{TOMATO}

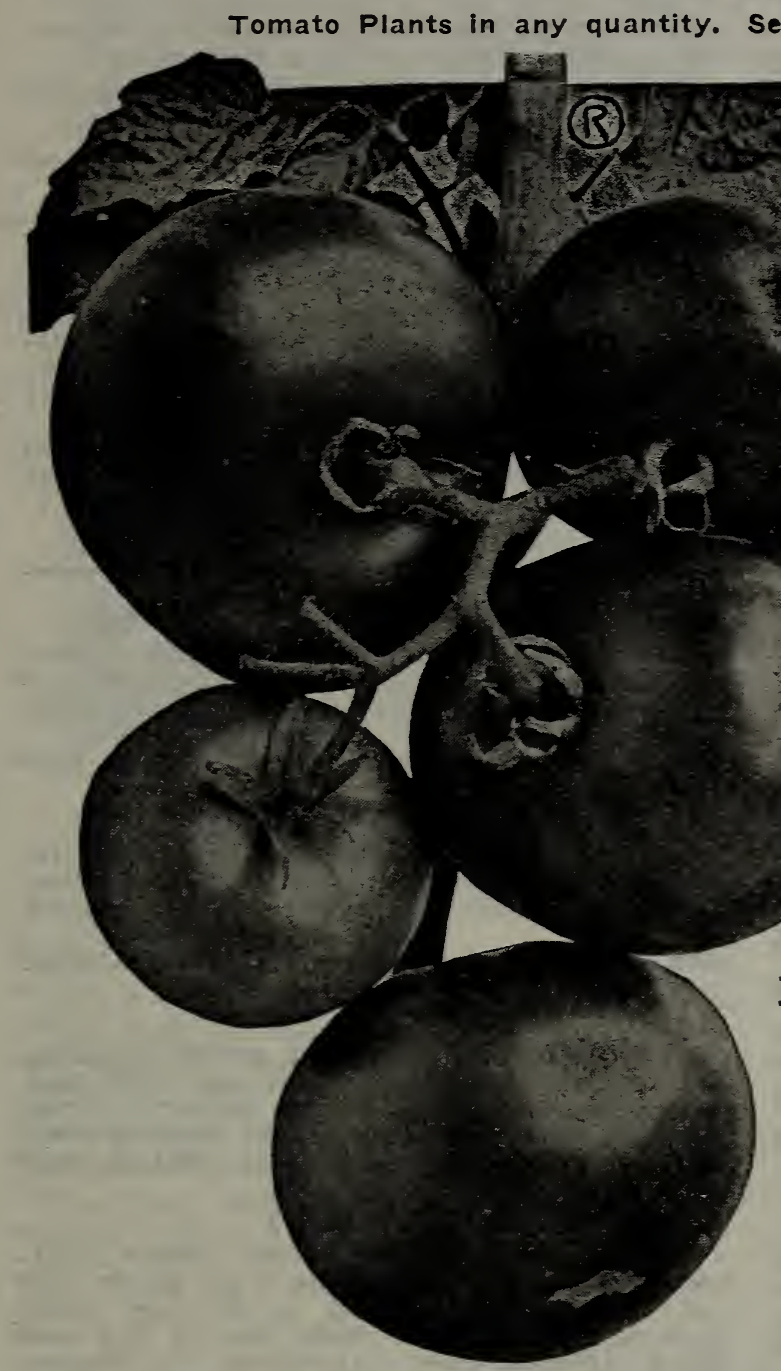

\section{Bonny Best}

Highly prized by many Oregon growers. Tomatoes large, smooth and of a rich scarlet red, the color that sells quickly. Fruit thick with a small core, a profitable tomato for any purpose. Slices exceptionally well. Flesh and flavor excellent. Nearly globe shaped, slightly flattened at stem. Borne in clusters of 5 or 6 fruits all ripening evenly together. Very productive and one of the very earliest.

Pkt. 10c; $1 / 2$ oz. $25 \mathrm{c}$; oz. $45 \mathrm{c} ; 4$ oz. $\$ 1.25$

\section{Husk or Ground Cherry}

Used for preserves and eating from the hand. The seed we offer is that of the true Yellow Ground Cherry, not the purplefruited sort, which is scarcely edible.

Pkt. 10c; oz. $40 \mathrm{c}$

\section{TOBACCO}

Culture practically same as cabbage.

Havana or Connecticut Seed Leaf.-Both good, hardy varieties for general planting here.

\section{Routledge's Early Oregon}

Very hardy and succeeds everywhere. The Early Michigan, Fordhook and Atlantic Prize were good sorts "in their day," but the Early Oregon is superior to these in shapeliness, color, size, smoothness, solidity and flavor, as well as being earlier. Those wishing to have the earliest "GOOD" tomato should raise our Early Oregon. Highly recommended for the home or market gardener. Try it; you will not be disappointed.

I Pkt. 10c; $1 / 2$ oz. 25c; oz. $40 c ; 4$ oz. $\$ 1.25$

\section{Spark's Earliana}

The earliest tall variety, forming ripe fruit much earlier than most early varieties. The fruit is large, smooth, of a bright scarlet color and of fine quality. Very valuable for early market use.

Pkt. 10c; oz. $40 \mathrm{c} ; 4$ oz. $\$ 1.20$

STONE.--Grown very extensively for a main crop by market gardeners; very large, smooth and solid, of a bright red color and a heavy yielder; of excellent quality and not subject to rot. Pkt. $5 \mathrm{c} ;$ oz. $30 \mathrm{c} ; 4 \mathrm{oz} . \$ 1.00$

DWARF CHAMPION.-Eorms a strong, erect, bushy plant 2 feet higs; often sold as Tree Tomato. Fruit smooth, medium sized, solid and of good flavor.

Pkt. 10c; oz. 40C; 4 oz. $\$ 1.20$

YELLOW OR RED PEAR.-Used for preserves and to make "tomato figs." Fruit distinctly pear shaped and of excellent flavor $\quad$ Pkt. 10c; oz. $50 \mathrm{c}$

RED PLUM.-Same prices as above.

RED OR YELLOW CHERRY.-Fruit small. about $5 / 8$-inch in diameter; perfectly round and smooth; fine for pickles and preserves. Pkt. 10c; oz. 50c 
HIGHEST QUALITY

For spring use sow very early in rich, loose ground. They must make a quick growth to be tender and sweet. For fall and winter use sow in July, August or early September.

Beware of low priced turnip seed this year. The country is full of cheap seed grown from small scrub field roots.

\section{Extra Early \\ WHITE' MILAN TURNIP \\ The Very Earliest}

An excellent table turn $ı$, and the earliest of all varieties; adupted for very early spring or fall planting. The tops are small; the bulbs of medium size, flattened, and ivory-white in color. The flesh is finegrained, tender, and of a mild, sweet flavor. It remains in good condition for a long period of time, and does not become pithy or stringy.

Pkt. 10c; oz. 25c; 2 oz. 45c; 4 oz. 75c; Ib. $\$ 2.25$

\section{Orange Jelly, or Golden Ball}

Delicate and sweet, yellow flesh, medium in size, firm, crisp and most excellent flavor; keeps well and is superior as a table variety. Pkt. 10c; oz. 15c; 2 oz. 25c; 4 oz. $45 c$; lb. $\$ 1.50$

\section{Early White Flat Dutch}

A leading white fleshed variety; either for the family, market garden or field crop; it is medium size and produces a large crop; the flesh is firm, but tender, and of a superior rich, buttery flavor; a good keeper.

Pkt. 5c; oz. 15c; 2 oz. 25c; 4 oz. 45c; lb. $\$ 1.25$

\section{Early Snowball}

A superior table variety, meltingly tender, with snow-white flesh. Matures six weeks after sowing; medium size, smooth and perfectly globular.

Pkt. 5c; oz. 20c; 2 oz. 35 c; 4 oz. $40 c$; lb. $\$ 1.25$

\section{White Egg}

Is perfectly smooth, of a pure clear white; a very choice kind for table use; of excellent flavor, sweet and mild; pulls clean from the ground; thin, snow-white skin. Egg shaped. Pkt. $10 \mathrm{c}$; oz. $20 \mathrm{c} ; 2$ oz. $30 \mathrm{c} ; 4$ oz. $40 \mathrm{c} ;$ ib. $\$ 1.50$

\section{Early Purple Top IMilan}

This variety is ready for the table almost as early as white Milan flesh white, firm and delicate.

Pkt. 10c; cz. 20c; 2 oz. 35c; 4 oz. 60c; lb. $\$ 2.00$

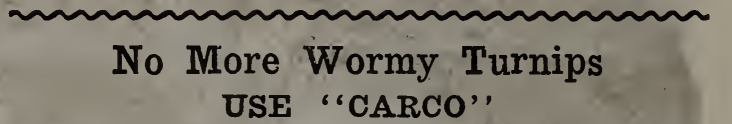

A new and wonderfully successful spray for destroying maggots, grubs and worms whlch infest Turnips, Radishes, Beets, Rutabagas, Cauliflower, Cabbage, Onions, etc., and also recommended for combatting crown borers in Strawberries.

A marked increase in yield of vegetables follows the use of "Carco" spray. See page 125.

\section{USE CARCO}

\section{Early Purple Top (Strap Leaved)}

One of the best and universally grown; flesh firm, but very tender and sweet; of quick growth; attains large size, profitable for stock, keeps well.

Pkt. 5c; oz. 15c; 2 oz. $25 \mathrm{c} ; 4$ oz. $40 \mathrm{c}$; lb. $\$ 1.25$

\section{Purple Top White Globe}

A very heavy cropping, globe-shaped variety, with white skin and flesh, excellent flavor and much in favor with the market gardeners.

Pkt. 10c; oz. 15c; 2 oz. $25 \mathrm{c} ; 4$ oz. $40 \mathrm{c} ;$ Ib. $\$ 1.25$

\section{Yellow Aberdeen}

Round, medium size, light yellow; produces a large crop; is hardy and keeps well; flesh very firm, but tender and sweet; a great favorite with the dairymen for feeding cows. Pkt. $5 \mathrm{c}$; oz. $15 \mathrm{c} ; 2$ oz. $25 \mathrm{c} ; 4^{\circ}$ oz. $45 \mathrm{c} ;$ lb. $\$ 1.25$

\section{Cowhorn (Long White)}

Slightly crooked, pure white, except a little shade of green at the top; grows half out of the ground and is of very rapid growth. Has proved itself one of the best stock turnips ever introduced in Oregon. Pkt. 5c; oz. 15c; 2 oz. 25c; 4 oz. $45 c$; lb. $\$ 1.50$

For valuable and "up-to-date" books on Gardening, Poultry and Pets, see page 130.

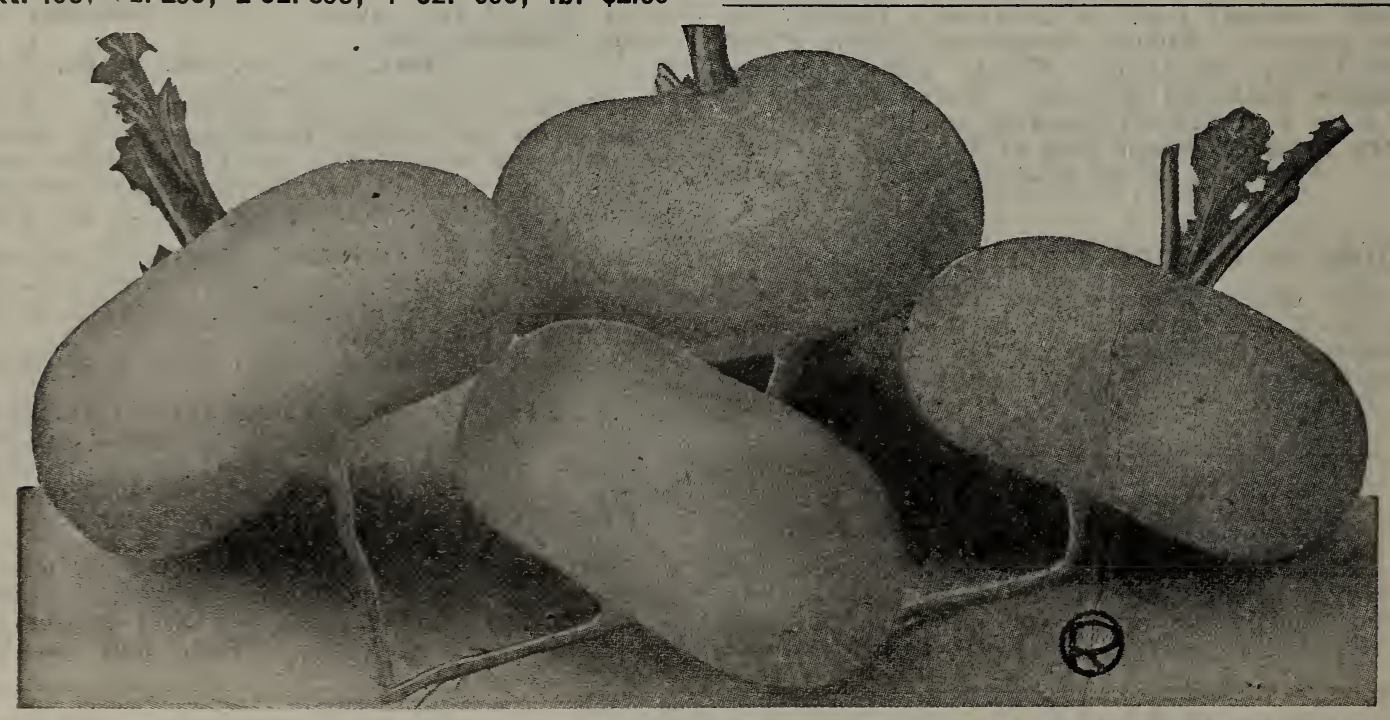




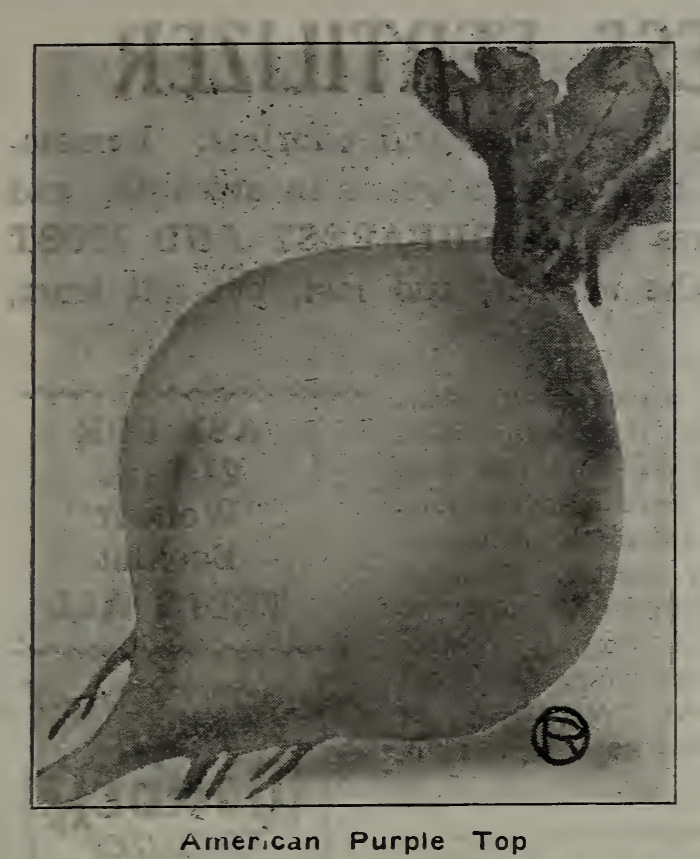

Herbs in general delight in rich, mellow soil. Those marked with a (*) are perennial. All the Flowering Herbs 10c per Packet, unless Otherwise Prlced.

Anise.-Seeds aromatic; used medically.20c *Balm.-For culinary purposes; Pkt. 15c.75c Basil.-Sweet; for flavoring scups......30c Borage.-For flavoring; also bee pasture.25c Caraway.-For flavoring . . . . . . . 30c *Catnip.-Mild nervine ...........40c Coriander.-Used for flavoring........20 c Dill.-Used medicinally and for pickles.25c *Fennel.-Flavor of celery ............35c

\section{RUTABAGA -SWEDES}

For feeding stock in fall and winter there is nothing superior to turnips and rutabagas, as they are much liked by all kinds of stock, and serve to keep them in good con-

\section{Improved American Purple Top}

The leading and most popular variety, being very distinct in type, attaining a wonderfully large size; immense yielder; the flesh is very firm, cream yellow, fine grained, sweet and tender Excellent both for table and stock feeding. Keep all win-

Pkt. $10 \mathrm{c} ;$ oz. $20 \mathrm{c} ; 2$ oz. $35 \mathrm{c} ; 4$ oz. $60 \mathrm{c} ; \mathrm{lb} . \$ 2.00$

\section{White Sweet Russian}

This variety is most excellent either for table or stock; it grows to a very large size; flesh white, solid, of a firm texture, sweet and rich; an excellent keeper.

Pkt. $5 \mathrm{c} ;$ oz. $15 \mathrm{c} ; 2$ oz. $30 \mathrm{c} ; 4$ oz. $60 \mathrm{c} ; \mathrm{Ib}$. $\$ 2.00$

\section{HERB SEEDS}

\author{
Pot, Sweet and Medicinal
} dition.

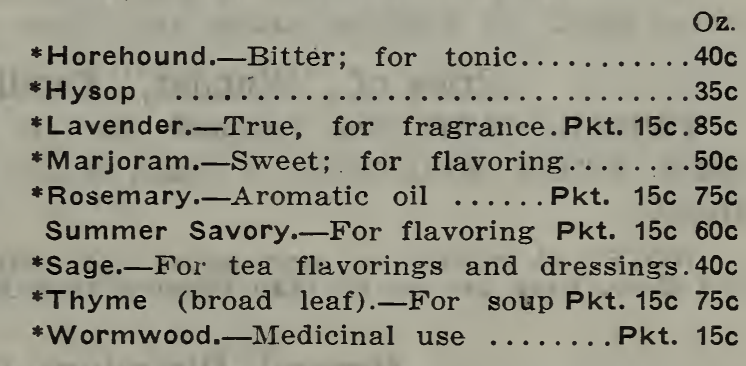

\section{VEGETABLE PLANTS}

We grow large quantities of choice vegetable plants, and can supply all of the varieties listed below, in their proper season, in most any quantity. We can supply all vegetable plants in two grades-plants direct from the seed beds and those that have been transplanted into shallow boxes. Transplanted plants are much stronger and better rooted, and are well worth the price, especially in the early part of the season. We can supply most any of the leading sorts. Tell us your choice of varieties, and we will send it or give good substitute. No PLANTS SENT C. O. D. Write for prices on 5 to 10 thousand lots.

NOTE.-Dozen prices only are postpald. We will send 100 and 1,000 lots by express at your expense, unless you wish to send $35 \mathrm{c}$ extra per hundred to pay packing and postage. Tomatoes $50 \mathrm{c}$ per 100 extra.-Pot-grown tomato plants should have all the dirt left on the roots and are not mailable.

\section{CABBAGE AND GARDEN KALE}

Dozen $100 \quad 1000$

Early kinds, transplanted.\$ $.25 \$ 1.00 \$ 8.00$

Late, not transplanted.... $\quad .75 \quad 7.00$

Stock kale ............ $\quad .75 \quad 6.00$

CAULIFLOWER AND BROCCOLI

Early Snowball, St. Valentine

transplanted ..............30 1.2510 .00

$\begin{array}{lllll}\text { Late -kinds, transplanted.. } & .30 & 1.00 & 8.50\end{array}$

Late, not transplanted.... $\quad .75 \quad 7.50$

CELERY AND CELERIAC T.R.

$\begin{array}{cccccc}\text { Leading } & \text { kinds, } & \text { trans- } & & & \\ \text { planted } & \ldots \ldots \ldots \ldots \ldots \ldots \ldots & .30 & 1.25 & 8.50 \\ \text { Not transplanted } & \ldots \ldots \ldots & & 1.00 & 7.50\end{array}$

PEPPER AND BRUSSEL SPROUTS

Dozen $100 \quad 1000$

Transplanted .........\$.30 $\$ 1.25 \$ 10.00$

SWEET POTATO PLANTS

Sweet Potato Plants..... $.35 \quad 1.25 \quad 9.00$

TOMATOES

Leading kinds, our selec-

tion, transplanted $\ldots \ldots . .35 \quad 1.25 \quad 8.50$

Not transplanted ....... $\quad 1.00 \quad 7.50$

Pot Grown Tomato Plants.-These large plants give the most profitable results. Can not be mailed. Prices: $3-$ in. pots, $15 \mathrm{c}$ each, $\$ 1.50$ doz.; 4 -in. pots, $20 \mathrm{c}$ each, $\$ 2.00$ doz; must go by express, charges collect.

Chives (Schnittlauch)-Per bunch, post-

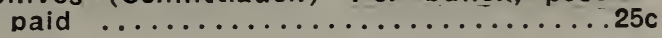




\section{WONDER ODERLESS FERTILIZER}

The best fertilizer for the city gardener; clean and odorless. Remember, it's ALL FERTILIZER; a wonder in action, a giant in strength, and the small amount necessary to use makes it the CHEAPEST AND MOST EFFICIENT High Grade Fertilizer on the market, and last, but not least, IT IS ODORLESS.

In "WONDER" you get the latest scientific discovery in plant food, something which gives results, something that astonishes. This "WONDER" fertilizer is the result of years of study and trials by a fertilizer expert. In "WONDER" we have a meritorious and ODORLESS concentrated fertilizer, put up in small packages, thereby making its distribution a cheap and easy matter. Being a concenträted fertilizer, only a very small amount is required to produce the largest yield. (See general directions below.) There's no use of your paying dray and freight charges on bulky fertilizers containing three-fourths sand, ash or dirt filler. "WONDER" is the pure "DOPE"-clean and easy to apply. We guarantee it tc give results.

The small amount of "WONDER" required reduces the expense of fertilizing to about one-half the cost of manure or the average commercial fertilizers on the market. Rich in potash.

The "WONDER" Fertilizer is sold only in 25-1b. white, clean canvas bags, 2-lb. odorless cartons and 125-lb. sacks.

\section{Price of "Wonder" Fertilizer}

TWO-LB. CANS, Not Postpaid, 40c (P. P. Wgt. 21/2 lbs.) 25-LB. DRILL BAG, \$2.65; 3 Bags, \$7.50; large 125-1b. sack, $\$ 10.00$.

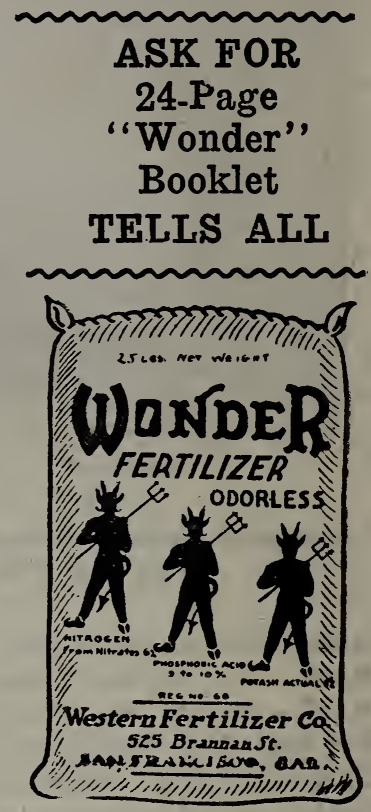

NOTE.-If wanted by parcel-post add postage. "Wonder" is odorless and 2-lb. cans and 25-1b. bags can go by mail cheaper than express or freight in most cases:

\section{General Directions for Using Wonder}

Remember, a 25-1b. bag of "WONDER"' is equal, in plant food, to $100 \mathrm{lbs}$. of most any other commercial fertilizer on the market.

For Ferns and House Plants: One-half teaspoonful to a 6-in. pot, dug into the top soil; 1 teaspoonful, heaping, when repotting, mix well through the soil.

For Vegetables: A teaspoonful to a Cabbage, Tomato, Cucumber, Pumpkin or Melon Vine. Sprinkle over the top soil before planting Radish, Lettuce, Peas, etc., or hoe in after they are up. For Flowers outside: A very little to each plant, or cultivate into the top soil before or after planting. Use $1 \mathrm{lb}$. to 10 foot square.

For the Lawn: One 25-1b. bag of “WONDER" will go over a space of your lawn $50 \times 50$ or 2500 square feet, and is sufficient for same, applied once yearly. In dry weather always water after applying. Double the amount when making new lawns.

For Fruit, Roses, Etc.: A heaping tablespoonful for a small Fruit, Berry, or Rose Bush, a cupful for a 3 or 4-year tree; 1 to 3 lbs. to a full bearing Fruit Tree, large Flowering Shrub or Vine.

CAUTION! Always mix the fertilizer into the top soil as much as possible, and water or sprinkle after applying it, especially on grass or tender foilage or growth.

Ask for "WONDER" 20-PAGE BOOKLET that gives plain facts and fill information and directions for all purposes. FREE.

NOTE.-Three sacks "C M." (see opposite page) and one sack of "Wonder" mixed together will make a very rich combination fertilizer that will prove highly satisfactory for all uses-as it will be very rich in plant food and supply the necessary humus for heavy soils.

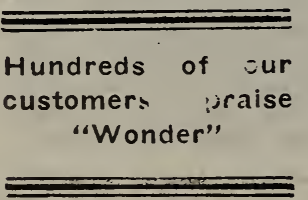

IT PAYS TO USE “WONDER."

W. L. Richards, 58 E. 78th St., S., city, reports a crop of 422 lbs. of these potatoes from a $100-$ foot row" WHERE HE USED "WONDER FERTILIZER" and only 138 like the smaller "spud" where "Wonder" WAS NOT. USED. Soil and growing conditions the same. $\overline{\text { You try it and be }}$ convinced. You r report, please 


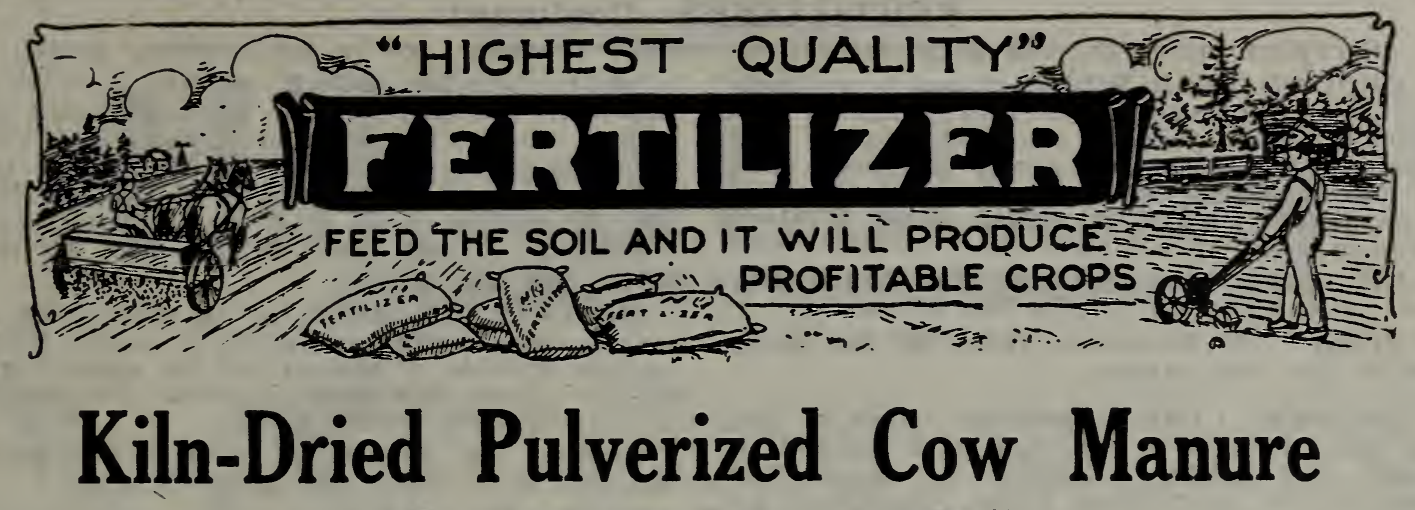

\section{For Short, We Call It “C. M."}

Supplies the "Humus" lacking in chemical fertilizers and the analysis shows it to be quite rich in nitrogen, potash and phosphoric acid. It will not burn or harm the most tender seeds or plants.

This product is made of green cow manure by putting it through a dry-kiln with heat enough to evaporate the water and kill all weed seed without burning the compost or destroying the fertilizing elements. It is then ground finely and sacked.

Hundreds of our Gardeners and Farmers have discovered its great value, and are buying large quantities.

EIGHT TO ONE.-You can get a good idea of the value of this concentrated product when we state that it takes 8 to 10 tons, in the green or natural state, to make 1 ton ready to sack. We are offering, in a most convenient dry state, a fertilizer and compost that heretofore you have bought by the wagon load, in a most dirty, foul and disagreeable form.

SUPPLIES THE HUMUS.-This new product supplies all the humus and fertilizing value of the old form, without the disagree. able odor, coarse straw, chatf and weed seeds. In fact you get everything in an ideal form except the live weed seed and moisture. You do not want the weeds and can easily apply water when needed. There is no use of paying dray, freight or handling / charges for dirty, foul, water-soaked manure when this product can be had.

CHEAPER AND MORE CONVENIENT.The old form cow manure costs about $\$ 3.50$ a load delivered and about $\$ 3.00$ or more to get it placed and spaded under. Three sacks of our Dry-Kiln C. M., which is practically odorless and can be spread around by anyone at leisure, will cost less and give better results.

\section{Uses and Directions for "C. M."}

\section{FOR ROSE BEDS AND BORDERS FRUIT AND BERRY BUSHES GRAIN FIELDS AND MEADOWS}

Apply "C. M." broadcast at the rate of 3 sacks per city lot; for large fields, 15 to 20 sacks per acre. It will pay to use a ton per acre.

\section{FOR SEED BEDS}

As a top dressing over seed beds, where small flower or vegetable seeds are to be started, nothing else could be better, as it is full of "humus" (like leaf-mold) which keeps the top soil loose and open. Rake "C. M." into the top soil or after seeding, sprinkle "C. M." over the surface.

\section{FOR VEGETABLES AND FLOWERS}

Use "C. M." on any soil that needs loosening up and enriching. To raise choice vegetables and large beautiful flowers, the soil must be rich, well worked and loamy.

\section{FOR I.AWNS}

"C. MI." is just what has been wanted for years by amateur and professional lawnmakers. Heretofore on account of heavy soils that would bake and crack, the best cow manure obtainable was used to open up and keep the soil loose. It was not the plant food needed, as that could easily be applied in the form of Chemical Fertilizer but it was the "riumus" in the stable manure that was wanted, but NOW with this Dry-Kiln, weed free, "C. M.." the lawnmaker's troubles are greatly reduced.

HOW TO USE.-After the lawn has been graded, raked, seeded and rolled, spread " $\mathrm{C}$. II." broadcast over the seed. covering it well. If it is dry weather, sprinkle, but sprinkle lightly so as not to wash it off. It absorbs water slowly, but after it is once wet it becomes part of the surface soil and will nemain.

ANOTHER WAY.-Providing you will use "C. M." in a liberal amount, it would be better raked into the surface soil, then seed, rake lightlv and roll.

\section{PRICES OF DRY-KILN “C. M." AT OUR STORE}

Large Sks., \$2.00; 3 Sks., $\$ 5.50 ; 5$ Sks., $\$ 9.00 ; 10$ Sks., \$17.50; 20 Sks., $\$ 32.50$; small lots-2 Lbs., 15c; 5 Lbs., 25c; 10 Lbs., $40 \mathrm{c} ; 30$ Lbs., $\$ 1.00$.

With our new fertilizer Dry-Kiln "C. M." to supply humus, and "Wonder," the strongest and richest odorless chemical fertilizer and "Ground Lime," the great soil conditioner, we have a combination that will supply every need. (See pages $3 \delta$ and 40.)

The day of strong smelling, udorous fertilizers is over, we believe, at least for the city and suburban gardener.

For Llquid Manure-Empty half a sack of "C. M." into a 50 gal. barrel and fill with water. Use this liquid straight or diluted form, for watering. The increased vigor and growth of plants will almost immediately be noticed. 


\section{FERTILIZERS-Continued}

Fertilizer prices on this page subject to market changes. Write for quantity price.

GROUND LIME ROCK.-Lime is an indirect soil improver and a very valuable conditioner, and releases the plant foods. Its application on heavy or clay soil will open it up, make it lighter and more workable. Few people realize its value. Most Western Oregon soils need lime.

Use $1 / 2$ to 1 ton per acre. For heavy clay soil in the garden double the amount.

Prices: 100 lb. sacks, $\$ 1.25 ; 500$ lbs. $\$ 5.50$; write for ton prices.

GARDEN LIME (Fertilizer Lime).-This is put through a process that makes it finer and lighter. Quicker in action and well worth the higher price. Excellent for moss in lawns and general garden work.

Prices: 5 lbs. 25c; 10 lbs. 40c; 50 lbs. $\$ 1.00 ; 100$ Ibs. $\$ 1.75 ; 500$ lbs. $\$ 7.50$; write for ton price.

LAND PLASTER.-Used largely on grass and clover crops. Highest grade.

Prices: 10 lbs. 25c; 50 lbs. 75c; 100 lbs. $\$ 1.25 ; 500$ lbs. $\$ 5.00$. Low ton price, write.
HIGH GRADE BONE MEAL. - This is finely ground and of best quality. Used for Lawns, Roses, Shrubs and Trees. Not very quick in action and should be applied in the fall or very early spring. Use 1000 to 2000 lbs. per acre.

Prices: 5 ibs. $30 \mathrm{c}$; 10 lbs. $50 \mathrm{c} ; 50$ lbs. $\$ 2.00 ; 100$ lbs. $\$ 3.50$.

NITRATE OF SODA.-It is very quick in action, and hastens maturity of crops. Being quickly soluble, it should not be applied until the plants are above ground. Be careful or it will burn tender foliage.

Prices: Lb. 15c; 5 lbs. 50c; 25 lbs. $\$ 2.00$; 100 lbs. \$6.75; write for quantity price.

SHEEP GUANO.-One of the best natural manures, dried and ground. Concentrated, soluble; quick in action, and free from weed seed. Splendid for vegetables; fine for roses and flowers. Excellent for lawns, small fruits, berries, etc., but we really prefer "C. M." See page 39 .

Prices: 100 lbs \$2.25; 500 lbs. \$10.00; write for ton or carload prices.

\section{Kirk System of Fertilizing and Spraying}

A simple, practical, easy way of spraying or fertilizing. The water as it passes through the feeder, slowly dissolves the cartridge contained therein and is applied upon whatever you wish it.

KIRKE FEEDER.-Consists of cylindrical nickel-plated metal cartridge holder, which is made to connect to any standard size hose coupling, and in which is placed a KIRKE Fertilizer, Insecticide or Fungicide cartridge. Put the feeder or castridge holder on the end of the hose. then-screw on a regular hose nozzle and turn the water on.

\section{Dunham Water-Weight Lawn Rollers}

This roller has a water-tight steel drum which can be filled with water to make it heavy. and emptied when storing away.

The roller is fitted with steel roller bearings and is an easy-running, long-wearing machine,

\begin{tabular}{|c|c|c|c|c|c|}
\hline Drum & Number & & \multicolumn{2}{|c|}{ Filled } & Portland \\
\hline Sizes & Sections & Empty & Water & Sand & Prices \\
\hline WB3 $\ldots .14 \times 20$ in. & 1 & 65 & 200 & 300 & $\$ 14.50$ \\
\hline WB5 ...18x24 in. & 1 & 80 & 300 & 500 & 18.50 \\
\hline W B7 . . 24x 24 in. & 1 & 125 & 500 & 800 & 23.50 \\
\hline WB11...18x24 in. & 2 & 115 & 330 & 500 & 25.00 \\
\hline WB13...24x32 in. & 2 & 170 & 650 & 1000 & 33.0 \\
\hline WB15...24x24 in. & 2 & 145 & 500 & 800 & 29.2 \\
\hline
\end{tabular}

During Winter Months freezing and thawing and heavy rains loosen the soil and heave the turf away from the subsoil, leaving millions of sensitive "feeder roots" exposed to the air. In the spring when the grass should start growing these roots soon dry out and die.

In summer, too, sun and wind tend to dry out, bake and crack the surface soil around the roots and this is equally harmful to the lawn. A good roller will compress the soil around the roots, and press the turf back against the moist sub-soil so roots can absorb the water and plant food.

Rolling occasionally throughout the summer (especially after heavy rains) keeps the surface even and prevents the soil drying out. It discourages the work of worms, ants, moles and gives a smooth, even lawn for the mower to run over.

It is absolutely impossible to keep a lawn, large or small, in perfect condition without rolling, no matter how many other things may be done in taking care of it.

FREE- "THE PROPER CARE OF LAWNS."-This gives you full information about these Lawn Rollers and valuable information on the subject of lawns and how to keep them.

LAWN MOWERS AND GARDEN TOOLS.-In addition to the miscellaneous tools listed on pages 118 to 130, we carry in stock Lawn Mowers, Cycles, Rakes, etc. If you can not call, write for what you want. 


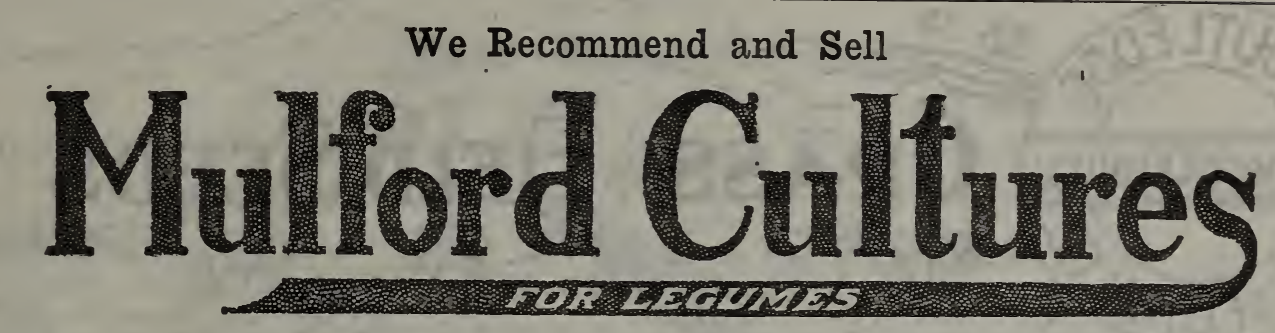

To supply or increase the nitro-gathering bacteria in the soil

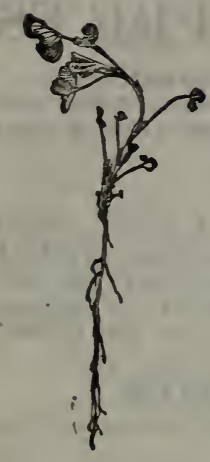

Not Inoculated

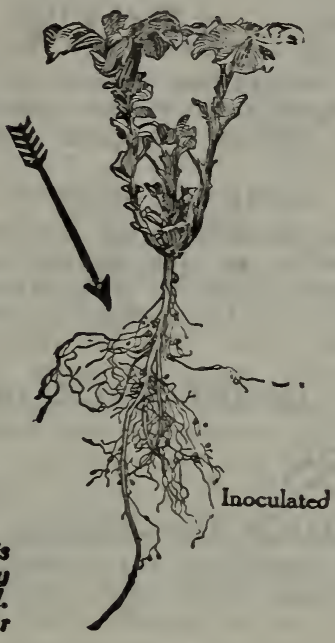

These alfalfa plants were sown same day in the same soil Illustrations tell their own story.

Mulford's experts claim an "ALL-CROP" culture is not prac. tical.
Always inoculate seed (or soil) with the MULFORD NITRO-GERM CULTURE before planting Garden or Field Beans and Peas, Sweet Peas, Alfalfa, Clovers, Vetch and other field or garden legumes.

It means great increased crop and improved soil.

The MULFORD CULTURES contain nitrogen-fixing bacteria, which form nodules on the roots of field and garden legumes that act by collecting nitrogen from the air and converting it into nitrates-food for soil and plants. It puts more into the soil than the growing crops need and it won't leach out; enriches the soil for succeeding crops of all kinds. Government tests have proved this scientific method of immense value to farmers and truckers.

Failure to produce satisfactory crops of Clover, Alfalfa, Vetch, Peas, Beans and other legumes, is more often attributable to lack of the necessary bacteria in the soil than merely to poor soil.

When these germs are present in sufficient numbers, small nodules form on the roots of leguminous plants, as shown in accompanying cut, and the nodules store up the nitrogen which is drawn from the air by the plant.

Without these germs a good crop is impossible. Therefore always inoculate the seeds mentioned at planting time with the MULFORD CULTURES, which contain active nitrogen-fixing bacteria. The bacteria in this product have all been proved by actual test to be active and vigorous. It is easily and quickly used by mixing with water and applying to the seed or soil; the directions which accompany each package are so complete and explicit that anyone can use it.

MULFORD CULTURES are "DIFFERENT" and should not be confused with other brands. The count is different (bacterial counts show fully twice as many bacteria as in the old-form cultures). The bottle is different (being sealed-an Important feature which prevents all possibility of contamination from the outside air).

\section{Increase Your Crops-Improve Your Soil}

Legumes offer the best-known means of maintaining soil fertility and rejuvenating over-cropped and worn-out fields. They add both humus and nitrogen to your soil and thus increase your yield of non-legume crops.

The U. S. Department of Agriculture and many State Agricultural Experiment Stations recommend inoculation of lesumes with nitrogen-fixing bacterial to induce a prompt "catch" and increase your yield.

MULFORD CULTURES are scientifically prepared and tested by experts, in the biological laboratories of H. K. Mulford Co., Philadelphia. with the same degree of care as Mulford Antitoxins, Serums, Vaccines, etc., which are standard all over the world.

CAUTION-Be sure to specify the particular legume on which you desire to use the MULFORD CULTURES, OTHERWISE WE WILL NOT KNOW HOW TO FILL YOUR ORDER.' We have it for Alfalfa, Red Clover, White Clover, Sweet Clover, Alsike Clover, Field Peas, Vetch, Garden Peas, Garden Beans and Sweet Peas.

The Mulford experts do not believe in an "All-Crop" culture.

PRICES_Quarter acre size, 50c; 1 acre size, $\$ 1.50 ;-5$ acre size, $\$ 5.00$, postpaid.

GARDEN SIZE ONLY for Sweet Peas, Garden Peas, Garden Beans, 25c; postpaid 30c

Why büy expensive commercial nitrates when you can grow legume "crops and, thus Increase your yleld and at the same tlme increase the nitrates and enrich

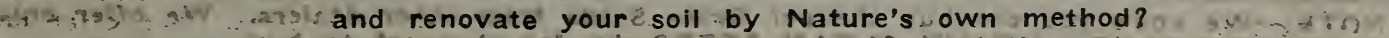




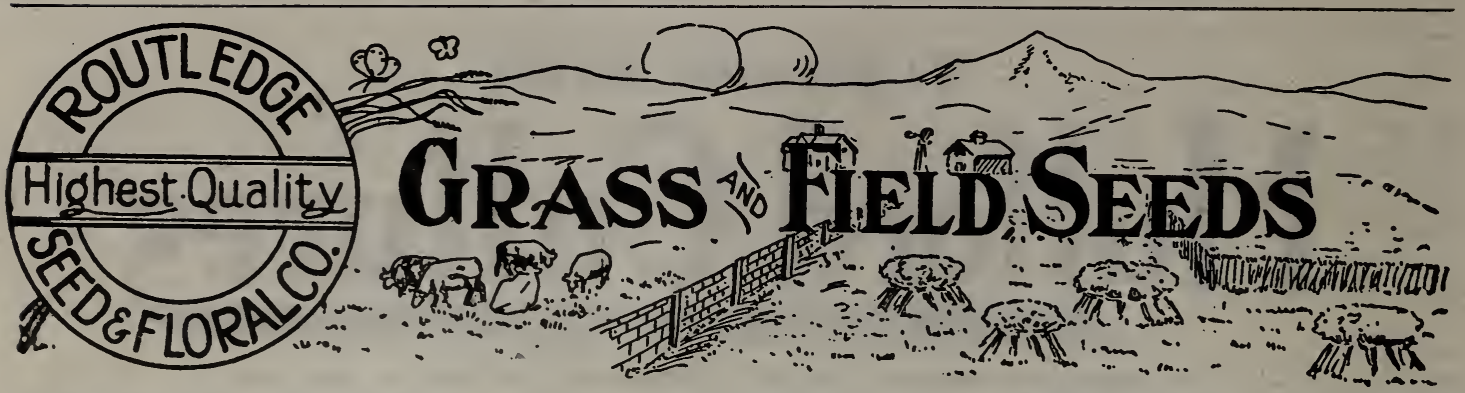

\section{ABOUT PRICES read the following ABOUT PRICES}

Only one grade priced, the best, choice, clean seed. Write for prices in quantity.

Single pound prices on Grass and Clover Seeds are prepaid. Prices per ten, fifty and one hundred pounds are not prepaid and are subject to market changes. Reference tables inside back cover.

\section{YOU WILL ALWAYS GET YOUR MONEY'S WORTH}

Prices on Grass and Field Seeds change occasionally, therefore we cannot print prices good for any length of time. When ready to buy, write us for special prices, stating quantity wanted, or order what you want at catalog prices, and we guarantee that we will give you full value for the money sent, whether the price at the time you order be higher or lower. In other words, we will always ship seed to cover the full amount of money sent to us.

FOR AMOUNT TO SOW PER ACRE, SEE INSIDE BACK COVER

\section{SUDAN GRASS}

\section{A New Forage and Hay Crop-A Valuable One-Season Crop}

This grass was introduced in the States by the Department of Agriculture and has proved a great success, especially for dry-land conditions, and from many reports and observations and samples of the grass shown it appears to do equally well in all parts of the Willamette Valley.

Sudan Grass is strictly an annual and dies each year like Millet and must be seeded again each sping. This makes it fit admirabli into any system of rotation, and while it does not benefit the soil like legumes, it does afford a change in crop and this is a good thing for the soil. Sudan Grass is tall, reaching a height of from seven to nine feet. The plant stools wonderfully and produces under favorable conditions as many as 100 stems from a single root.

It belongs to the sorghum family, but is more slender and grassy in manner of growth, earlier and hardier, and matures in 10 to 12 weeks. Yields a good crop of first-class hay. - 11 stock relish it green or cured and thrive on it. The quality is said to be equal to timothy or alfalfa. Yields of from two to four tons per acre are common, and under irrigation they run as high as eight to ten tons per acre.

Seeding. Do not plant until the soil has become warm in the spring or any time during the summer as a catch crop. Sudan Grass can be sown in rows 12 to 36 inches apart, drilled in with a grain drill or sown broadcast. In the semi-arid sections it is much more profitable to seed it in rows and cultivate, and even in the humid regions a small amount of cultivation appears to give added vigor to the plants. Seeded in drills 36 inches apart, 5 pounds per acre; drilis 18 inches apart, 10 pounds; broadcast and harrowed in, 20 to 25 pounds per acre.

Harvesting. Sudan grass is easy to cut with a mower and cures readily. When cut for hay it is best to cut just after full bloom, so that it will have as much time as possible for a second growth. After cutting it renews its growth promptly when moisture conditions are favorable. The grass stools abundantly after first cutting and the second and third cuttings are very fine stemmed.

Every farmer looking for a new forage or hay crop should try at least an acre or two. Beware of cheap, inferior seed.

Prices, Select, Tested Seed: $10 \mathrm{lbs}$. \$2.50; per Ib. 35c postpaid. Write for quantity price.

KENTUCKY BLUE (Poa Pratensis)

One of the best grasses for permanent pasture furnishing a constant supply of the most nutritious feed during the greater part of the year.

For Lawns.-Blue Grass is used very extensively for lawns and is found in all lawn grass mixtures.

Fancy, 10 lbs. $\$ 3.00$ per lb. postpald $40 \mathrm{c}$.

Our H. Q. (highest quality) Extra Fancy seed is unexcelled for weight and purity. Few dealers handle this high grade recleaned seed on account of its cost. This seed, straight or mixed with Fancy White Clover, is excellent for lawns.

H. Q. extra fancy, 10 lbs. \$3.75; per Ib. postpald $50 \mathrm{c}$.
ENGLISH RYE GRASS (Lolium Perenne)

A strong-growing, hardy perennial grass, noted for its nutritive qualities. It is equally valuable for both grazing and hay. It grows very rapidly and makes a good showing in a few weeks.

For Lawns this is used and recommended by many gardeners. Unless sown thickly, it grows too coarse. For large grounds and parks it is very successful. Often mixed with White Clover

10 Ibs. \$2.00; 100 lbs. \$19.00; per lb. post. paid $30 \mathrm{c}$.

\section{MESQUTTE (Holcus Lanatus)}

It is usually sown on virgin soil, without cultivation, after the ground has been burned over.

Fancy Hulled Seed, 10 lbs. $32.25 ; 100$ ibs. $\$ 21.00$; per lb. postpaid $35 \mathrm{c}$. 


\section{GRASS SEEDS-Continued}

For amounts of seed to sow per acre, see inside back cover

ORCHARD (Dactylis Glomerata)

Of the greatest value in permanent pasture mixtuies; thrives best in moist, shady places, but will withstand drought exceedingly well. Will do well under trees, or shady paces. Valued for hay crop, as it is very nutritious if cut early.

10 Ibs. $\$ 3.75 ; 100$ lbs. $\$ 34.00$; per Ib. postpaid $45 c$.

\section{RED TOP (Agrostis Vulgaria)}

of great value for mixing with hay or permanent pasture grasses; will succeed in rearly any soil, but thrives best in a rich, moist soil; makes a fine bottom growth, rendering it invaluable to be sown with timothy, orchard or alsike clover.

Choice Seed, not hulled, 10 Ibs. $\$ 1.80 ; 100$ Ibs. $\$ 16.00$; per lb. postpaid 25c.

Fancy Hulled Seed, $10 \mathrm{lbs}$. $\$ 2.50 ; 100$ lbs. $\$ 23.00$; per lb. postpaid $30 \mathrm{c}$.

\section{ITATIAN RYE (Iolium Italicum)}

A quick-growing grass, attaining a height of $21 / 2$ to 4 feet; very desirable for meadows or permanent pastures; thrives best on soils that are slightly moist, and will even stand considerable overflow; grows easily arid bears an abundance of foliage that makes the best and sweetest hay imaginable.

10 Jbs. \$2.25; 100 lbs. \$19.00; per lb. postpald $35 \mathrm{c}$.

\section{RHODE ISIAND BENT (Agrostis Canina)}

Forms a very fine turf even on light soils; desirable for lawns. as it forms a very close sward. Write for prices.

\section{IIMOIHY (Phelum Pratense)}

As a hay crop, timothy is unsurpassed by any other grass. 'Thrives on ordinary soil, but succeeds best in a moist loam. Best to cut it when in blossom or soon after flowering. Beneficial to sow timothy with red top and sed clover, as they produce more of a bottom growth.

10 lbs. $\$ 2.10$; 100 lbs. $\$ 17.50$; per lb. postpaid $30 \mathrm{c}$.

MEADOW FESCUE (English Blue Grass)

Perennial; grows three to four feet high. Roots deep, thus resisting drouth. It succeeds on any ordinary soil; yields a heavy crop of superior hay, one of the best grasses for pastures, being valuable to mix with other kinds. Sown alone, use 40 pounds per acre.

10 lbs. $\$ 3.50 ; 100$ lbs. $\$ 33.50$; per lb. post. paid $45 \mathrm{c}$.

\section{BROMUS INERMIS (Brome Grass)}

On account of its strong perennial character, and its unusual drought-resisting powers, is the best grass we have for the gemiarid regions of the Northwest. It grows luxuriantly, is freely eaten in either the dry or green state by cattle, and yields enormously, making the best of hay for horses or cattle.

10 lbs. $\$ 3.50$; 100 lbs. $\$ 33.00$; per lb. postpaid $45 \mathrm{c}$.

\section{CRESTED DOG'S TAIT (Cynosurus Cristatus)}

A perennial grass, forming a smooth and lasting turf, excellent in mixtures for lawns, putting-greens, and pastures. It thrives best on rich, moist land, but can accommodate itself to almost any soil, and, as tho roots penetrate deeply into the ground, it can stand severe drought.

10 Ibs. \$4.25; per Ib. postpald 55c.

\section{FIELD AND FARM SEEDS}

Single pound prices are prepaid. Ten, fifty and one hundred pound prices are NOT prepaid and subject to market changes. Seed to cover amount remitted always sent unless otherwise ordered, or write for prices when ready to buy. See notes, page 42.

\section{White Jerusalem Artichokes}

Planted and cultivated for the tuber, the same as potatoes. Of great value for feeding stock. They are the best and cheapest hog feed known. They are remarkable for great productiveness, over 25 tons have been raised on 1 acre. Easier to grow than potatoes. They need not be dug. If hogg are turned in on them they can easily root the tubers out. One acre will keep from twenty to thirty hogs in fine condition for several months Said to be a preventive of cholera and other hog diseases. Excellent for fattening if fed with a grain or mash ration. Plant $400 \mathrm{lbs}$. per acre early in the spring.

By freight or express, $10 \mathrm{lbs}$. $50 \mathrm{c} ; 50 \mathrm{lbs}$. $\$ 2.00 ; 100$ lbs. $\$ 2.50$. Per lb., prepald, 20c; 4 lbs. 60c. Write for quantity price.

\section{CONDENSED BUTTERMILK The Great Hog Food}

You need it if you have hogs or poultry. See Index for page giving full information.

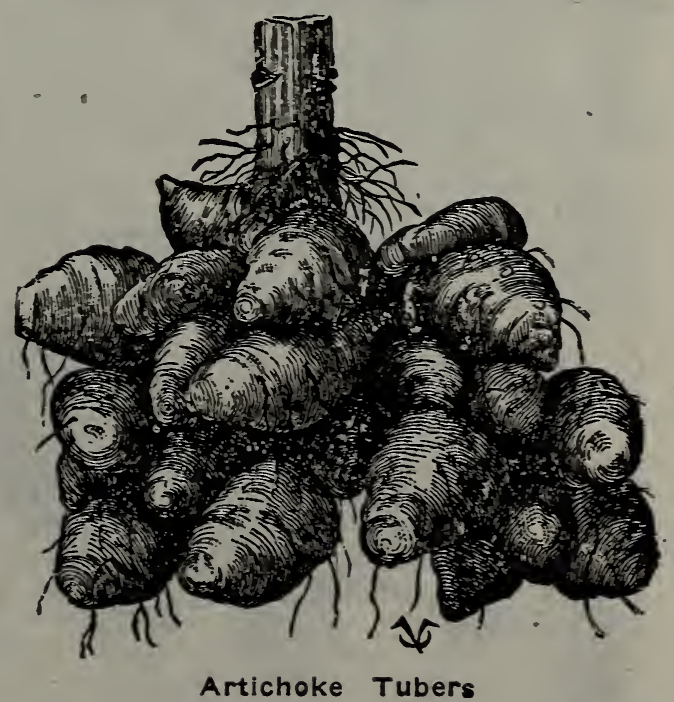

You Need One DAD's NEW ELECTRIC IIGHT is something that will bo of You Need One real service to our city, suburban and country customers. It's an all-around light, lantern or flashlight, in fact, it's "THE IIGHT OF ALI IIGHTS", -makes "NIGHT TIME A BRIGHT TIME." ' It takes the place of ALI' open flame, gas or oil explosive lights for ATI PEOPIE and ALL PURPOsES. It is always ready.

Seo index for page. 


\section{Barley}

BEARDLESS BARLEY.-The straw is abcut the height of the common barley, but better, and will stand up on any land; with good season, land has produced 80 bushels per acre. Very hardy, can be sown very early or as late as July 1 on moist land. This, as its name implies, is almost entirely beaıdless. We handle only the purest strains obtainable. As easy to grow and handle as oats. It is becoming more popular each season.

10 lbs. $75 c$; 100 lbs. $\$ 6.00$; per Ib. postpaid $20 \mathrm{c}$.

WHITE HULLESS Or BALD BARLEY.An excellent beardless barley for stock feeding. Grain plump, heavy, and when threshed is hulless like wheat; a heavy cropper. When grown and cut for hay it produces a magnificent crop, which is very rich and almost equal to a grain feed. Much relished by horses and stock of all kinds. An excellent hog feed. Culture same as common barley. 10 Ibs. 75 c; 100 lbs. $\$ 6.50$; per Ib. postpaid $25 \mathrm{c}$.

WISCONSIN PEDIGREE BARLEY.-This six rowed barley was introduced by the Wisconsin Agricultural Experiment Station, the originators of the well known Oderb. ucker Barley, to which they claim that this is much superior.

The heads are exceedingly long and are uniformly well filled; the straw is strong; the grain is large, plump and heavy; a heavy yielder.

Prices: 10 lbs: $75 \mathrm{c} ; 100$ lbs. $\$ 6.00$; per lb. postpaid 20c; 3 for $50 \mathrm{c}$ postpaid.

HANNCHEN BARLEY.-Earliest and best of the 2-rowed barleys. A sure and hedvy cropper. Grain plump, thin hull and beards $d_{1}$ op or break off readily. For spring planting but will do well seeded in fall where winters are mild.

Prices: 10 lbs. $75 \mathrm{c}$; 100 lbs. $\$ 5.50$; per lb. 20c, 3 for 50c postpaid.

COMMON BARLEY.-We always aim to have a nice, clean stock of good Seed Barley on hand at all times.

10 lbs. 70c; 100 lbs. $\$ 5.50$; per lb., post. paid, 20c. Write for quantity prices.

\section{Cow Peas}

Are really small beals of vigorous vining habit and heavy foliage of great nutritious

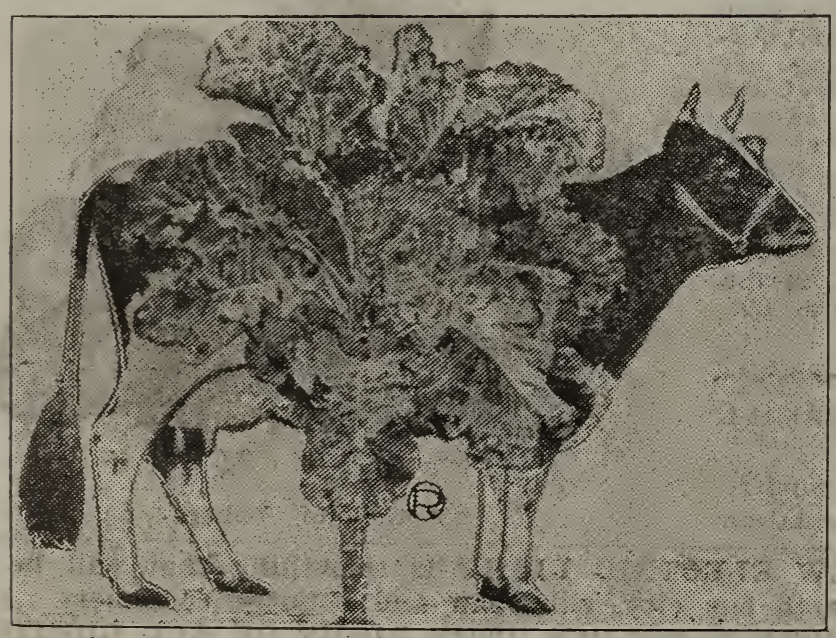

This cut is from photo, and gives you a good idea of the size and plant when well grown. value. Make excellent green feed cut and fed or pastured. They are great nitrogen gatherers and one of the best fertilizers when turned under. Sow 100 lbs, per acre.

10 lbs. $\$ 1.25 ; 100$ lbs. $\$ 10.00 ; 1$ lb. $25 \mathrm{c} ; 3$ lbs. $50 \mathrm{c}$.

\section{Buckwheat}

SILVER HULL.-A very good and popular variety; grain is of a light gray color; has a thin husk; matures early, and yields heavily; a good milling variety.

10 lbs. $\$ 1.25$; 100 lbs. $\$ 8.50$; per lb. post. paid 25c.

JAPANESE.-Good yielder, ripens early; excellent for bees to work on as it remains in bloom longer.

10 lbs. $\$ 1.25$; 100 lbs. $\$ 9.00$; per lb. post. paid $25 c$.

\section{Cheat Seed}

Cheat seed yields a good crop of hay, especially on low or moist soil, and will stand considerable overflow without harm. Sow in the fall or early spring, the same as oats and about 100 pounds per ucre.

10 bs. $60 \mathrm{c} ; 100$ lbs. $\$ 4.50$; per lb. post. paid $20 \mathrm{c}$.

\section{Field Peas}

Field Peas are a very piofitable crop and are grown here very extensively. They can be grown alone or with oats. When planted with oats and cut green they make a large amount of very rich feed; also very valuable for enriching the soil if plowed under. The dry peas make excellent hog feed and are quite fattening. Sow, if alone, 2 bushels to an acre; if with oats, $80 \mathrm{lbs}$ peas and 2 bushels oats.

WHITE CANADIAN.-The leading and most popular kind; seed creamy white; a heavy cropper. Yields, 30 to 50 bushels per acre.

10 lbs. $\$ 1.25$; 100 lbs. $\$ 8.50$; per lb. post paid $25 \mathrm{c}$.

BLUE PRUSSIAN.-Valuable variety, seed green. Used extensively as a dry soup pea 10 ibs. $\$ 2.00$; per lb. postpaid $25 \mathrm{c}$.

SWISS.-A flat or 3 cornered variety of excellent quality for soup. Insects do not trouble this variety.

Per Ib., postpaid, 35c. Seed scarce.

\section{Thousand-Headed Kale}

Commonly Called coW KALE

Recommended by agricultural col. leges, granges and dairymen as one of the most valuable green forage plants for the Pacific Coast.

It grows rapidly and produces a mass of large, thick, curly $g_{1}$ een leaves, rich and succulent, which are eagerly eaten by stock and poultry. If planted early will produce valuable green feed during the dry summer months. Makes the most rapid growth if sown in the early spring. but locally it is extensively plantea in summer and fall for winter feea. Will stand light freezing. Stalks can be cut off, or the larger lower leaves broken off, leaving the tops to grow. Under good cultivation plants will grow from 5 to 6 feet high. Sow 2 to 3 lbs. per acre, thinly in drills 2 to 4 feet apart and thin out. For late planting (July and August) it is better to have st nng nlants from earlier seeding and set out same as cabbage, 2 teer apart, in rows. Thin out later if plants attain extra large size.

Pkt. $5 \mathrm{c} ;$ oz, 15c; 4 oz. 25c: Ib. $75 \mathrm{c}$ postpaid. 


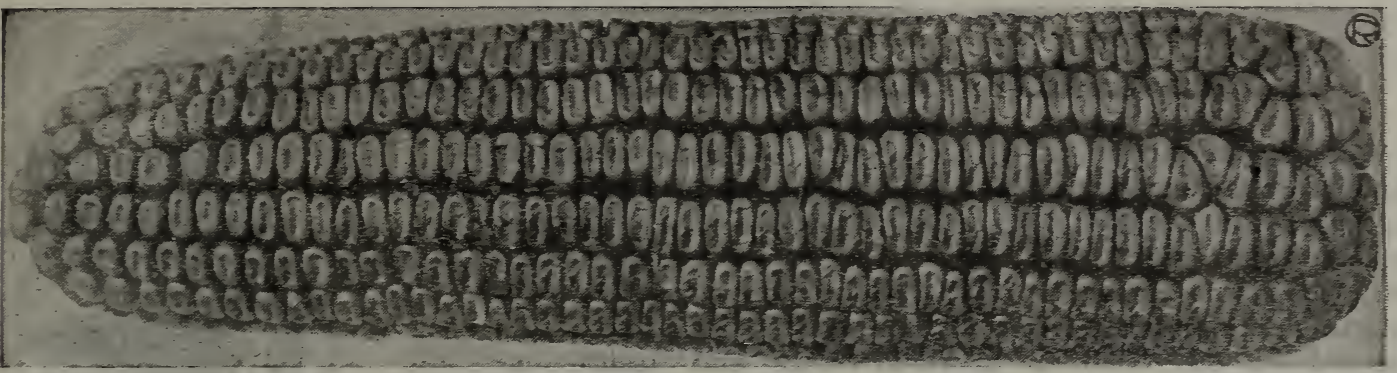

Routledge Pride of the West

\section{Field Corn for Oregon}

If you want to raise some good Field Corn, plant our Western grown Seed Corn. The strains, we are offering you are acclimated and especially adapted to our short, cooi summers. Éastern and Southern grown field corr seed is all right for green fodder, but of little value on this Coast, if you want to raise matured, dry ears.

\section{Routledge Pride of the West}

Oregon grown; acclimated. A grand success in Oregon. We have been raising this variety for years, and by selecting the earliest ripening and best select ears, now have a strain that is a revelation to many peuple who have thought Oregon and Washington could not raise profitable field corn.

Routledge Pride of the West Field Corn is an early maturing variety, producing stalks from 6 to 8 and often 10 feet high, and large ears, 8 and 9 inches long. Cobs covered with 14 to 16 rows of deep, yellow kernels. It is a heavy yielder. Our strain has been greatly improved in the last few years. Plant some of this corn this season; you will be pleased with results, we are sure.

We claim this is the earliest and heaviest yielding strain of Yellow Dent corn grown in Oregon. Try it and be convinced.

Large pkt. 10c; lb. 25c, postpaid. Not postpaid, 10 lbs. $\$ 1.50 ; 100$ tbs. $\$ 12.50$.

\section{Routledge Seed \& Floral Co.,}

Gentlemen: Your Pride of the West corn is the best field corn I ever planted. F. L. CHRISTIE, Bancroft, Ore.

\section{Longfellow Extra Early}

\section{Unsurpassed for Early Mature Ears and}

$$
\text { Production }
$$

This valuable corn is a flint variety, Oregon grown and thoroughly acclimated. Has been grown near Portland for the past six years with great success.

We believe this is hardier, earlier, and will grow under more adverse conditions than most any other kind. We recommend Longfellow to all growers who have not had success with the Yellow Dent varieties and for sections with a short season and cool nights.

LONGFELLOW FLINT.-The ears are 8 rowed, from 10 to 15 inches long and $11 / 2$ to $13 / 4$ inches in diameter. The cob is .very small, kernels large, broad, glossy, deep yellow and very rich in food value. Stalks 5 to 7 feet high. Fifty lbs. of corn on the ears will shell $40 \mathrm{lbs}$. of corn, leaving only $10 \mathrm{lbs}$. of cob, showing that the grain yield is equal, if not greater than the large eared kinds.

Per large pkt. 10c; lb. 25c, postpaid. Not prepaid, 5 lbs. $85 \mathrm{c}$; 10 -lbs. $\$ 1.60 ; 100$ Ibs., $\$ 12.50$.
Routledge Seed \& Floral Co.

Gentlemen Your Pride of the West field corn is the best I ever raised. Planted it in July and it was ready for the silo October 1 uithout a drop of rain. Planted earlier it certainly would mature a big crop of dro ears for Winter feed. Yours truly,

\section{A. J. KRUEGEK}

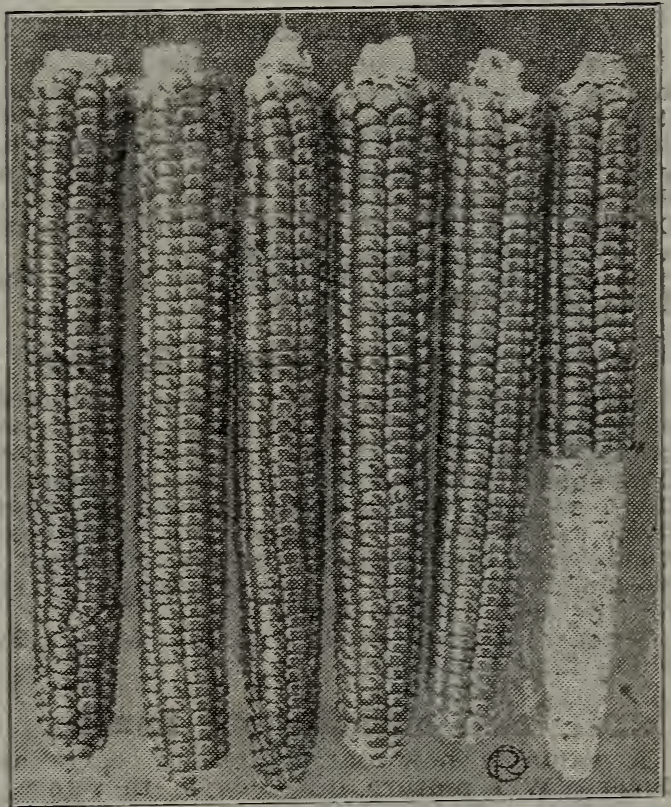

Longfellow Extra Early Flınt

Minnesota No. 13

Well and favorably knowr in many sections of the West. Produces splendid large ears with deep kernels of bright yellow. A strong and vigorous grower with heavy foliage. A good fodder corn.

Oregon Grown. - Large pkt. 10c; lb. 25c, postpaid. Not prepaid, 10 lbs. $\$ 1.40 ; 100$ lbs. $\$ 12.00$.

\section{Evergreen Fodder}

This is the best of all the sweet corns to grow for green fodder for stock; much richer than field corn, large cropper but ears will not mature. Stalks sweet and rich.

Lb. $30 \mathrm{c}$, postpaid; 10 lbs. $\$ 2.00$. 


\section{SEED OATS}

We do not know of a better line of Oats than the famous Shadeland varieties. On the Shadeland Farm they are grown especially for seed purposes. They are reselected each year, sown, grown, harvested and recleaned with the greatest care so as to keep each variety free of mixtures or foreign seeds. Each variety is sacked and marked at the farm to prevent errors and assure our customers of the Originator's improved stock. REMEMBER, no other Seed Store will have the Originator's 1919 crop of Shadeland Oats. These seeds cost more, of course, but they are worth more-much more.

\section{Shadeland Hulless}

"Originator's Stock",

Shadeland Hulless is the heaviest yielding of all hulless Oats-300 lbs. produced nearly 3 tons-one pound in a garden row 100 yards long, produced 100 lbs. This Oat grows and is harvested like any other oat, but it comes from the cleaner minus the hulls and is ready to grind, roll or chop, or can be cooked whole-the quality is un. surpassed. By growing Shadeland Hulless you can produce "Table oats" at a cost of 2 cents per lb., thereby reducIng the "High Cost of Living"; sow 40 to 50 lbs. per acre. Prlces: 10 lbs. $\$ 1.25 ; 100$ lbs. $\$ 10.00$. By mail postpaid: 1 lb. $25 \mathrm{c} ; 3$ lbs. $65 \mathrm{c}$.

\section{Shadeland Climax}

This grand oat belongs to the tree or branching class, and is a vigorous, healthy grower of strong stooling qualities. This is one of the heaviest yielding oats intro. duced to date. It does not produce much straw, but the yield of "thin hulled" plump heavy grain is amazing. For early spring planting, large yield and quick maturity, cllmax is a winner. Can safely be planted in the fall where the winters are mild.

Prices: 25 lbs. $\$ 1.50 ; 100$ lbs. $\$ 4.75$. By mail postpaid, 1 lb. $15 \mathrm{c} ; 4 \mathrm{lbs}$. $50 \mathrm{c}$.

\section{Shadeland Eclipse}

This wonderful "side Oat" was produced from a handpicked selection of the choicest, largest and best yielding grain heads from fields of the well known "Shadeland Challenge," which was, until the introduction of "Eclipse," the best side oat known. Eclipse is enormously produc. tive, early, more vigorous, and produces massive heads filled with large, flump grains of finest milling quality. Shadeland Eclipse has won 3 times, "First Special Prize." for the best milling Oat.

Prices: 25 lbs. $\$ 1.50 ; 100$ lbs. $\$ 4.75$. By mail postpaid, 1 lb. 15c; 4 lbs. 50c.

\section{Shadeland Senator}

A valuable new oat, extremely early and a great producer. Will mature in 90 days, therefore, can be planted quite late. Especially adapted for rich, moist, late ground or overflow bottom lands. It's just the oat for late planting on the bottom lands of the Columbia. Senator is a quick, strong growing variety, has stiff straw, stands up well and produces handsome, large, full heads of extra large, plump grain. Try it.

Prices: 25 lbs. $\$ 1.50 ; 100$ lbs. $\$ 4.75$. By mail postpaid, 1 lb. $15 \mathrm{c} ; 4 \mathrm{lbs}$. $50 \mathrm{c}$.

TO GET TRUE STOCK FOR 1920.-C. D. Nairn, origInator and expert grower of Shadeland Oats, hus given us exclusive sale In Portland of his 1919 crop, therefore if you want the originator's true stock-order direct from us.

PRIZE OATS.-For 20 years Shadeland Oats have never failed to win first prizes at Oregon State and many other County Fairs and Land Products Shows. Increase your crop 25 to 50 per cent by planting pedigreed prize oats.

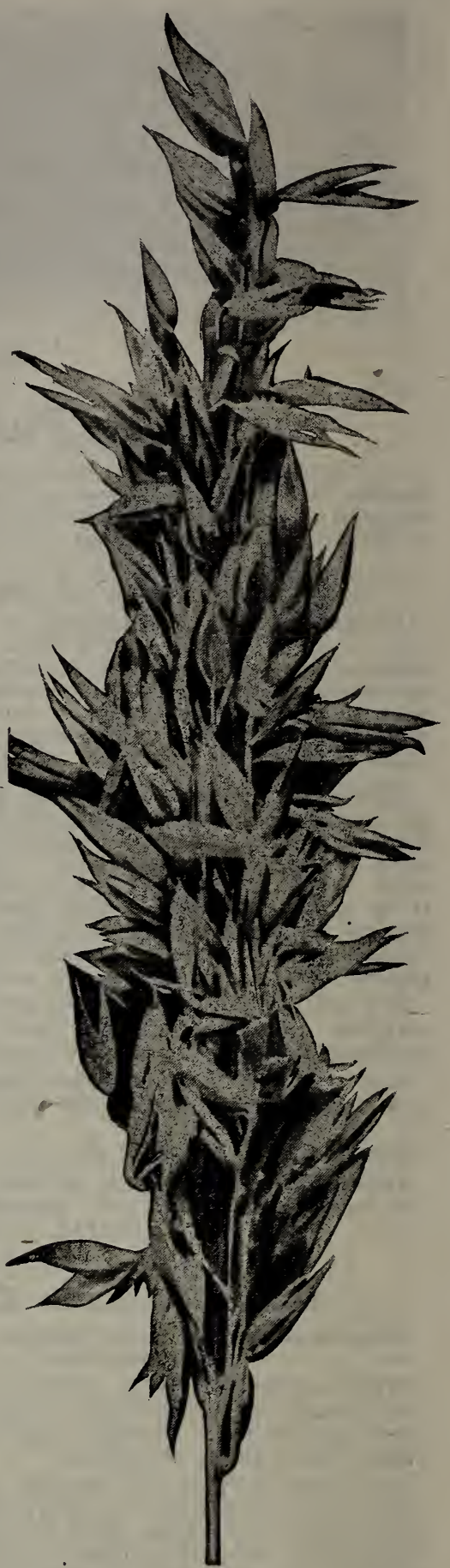

No. 1. White Seed Oats

\section{Grey Winter Oats}

Aside from the Shadeland Seed Stock we can supply other choice seed oats at about market price-order what you want at $\$ 4.50$ per $100 \mathrm{Ibs}$. and you will get "full value," or write first, for quotations, stating amount wanted.

Prices on Oats subject to market changes. See note about prices, pages $42-43$. 


\section{Kaffir Corn}

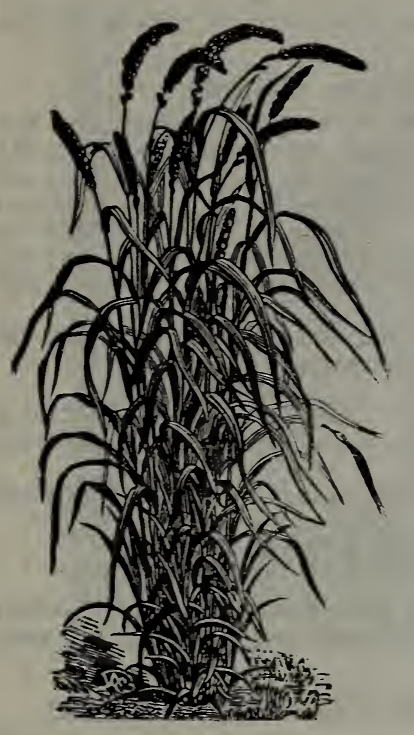

Millet

An excellent fodder plant. Seed small and almost round, valuable poulty and pigeon food. It does best sown thinly in drills three feet apart. 10 lbs. \$1.50; per lb. postpaid 25c

\section{Lentils}

Succeed best in dry, sandy soil. A leguminous annual, the seeds of which are valuable for pigeons and are used largely for soups. The leafy stalks make good forage.

Per Ib. postpaid 50c; 3 lbs. $\$ 1.00$

\section{Millets}

Sow in April, May or June, 20 pounds for seed or 35 pounds for hay per acre. MLust be sown early to mature in Willamette Valley.

EARLY FORTUNE.-This variety seems to do extra well here; try it. Heads large and loose, and seed is amber red and three times as lärge as the Common Golden. Miakes good poultry feed.

10 lbs. \$1.50; 25 Ibs. \$2.75; 100 Ibs., write; per lb. postpaid 25c

LIBERTY (formerly called German).-An improved variety, yielding a larger crop of seed than the Common Millet; it is also taller than the Common Golden, and yields a heavier crop of hay.

10 Ibs. $\$ 1.50 ; 25$ lbs. $\$ 3.00$; 100 lbs., write; per lb. postpaid $25 \mathrm{c}$

HUNGARIAN.-A dwarf millet; superior for hay.

10 Ibs. $\$ 1.75 ; 25$ Ibs. $\$ 3.00 ; 100$ lbs., write; per Ib. postpaid 25c

\section{Profitable Potatoes for Seed-See Pages 28-29}

\section{Rape, Dwarf Essex}

We offer you true, pure seed. One of the best forage plants, on account of the large amount of green feed it will produce at a season of the year when everything else is dried up. It has yielded ten tons of green forage per acre, and has twice the feeding value of green clover. Sheep, swine, cattle and poultry eai it readily. Rape will do wil or, almost any soil. Prepare the ground as for turrips, and sow any time-from May till September; or plas.: : $t$ with grain. Sow, per acre, three pounds, in drills; or it broadcast, five pounds.

10 Ibs. \$1.75; write for quantity prices; per lb., postpaid, $30 \mathrm{c}$.

\section{Seed Rye}

When ready to buy Fall or Spring Rye Seed, write us for quotations on quantity wanted or send in your order and we will give full value.

10 Ibs. 75c; 100 Ibs. \$6.00; per Ib., postpaid, 20c; 3 Ibs. 50c

\section{Speltz-Emmer}

Sow in the spring, the same as wheat, at the rate of two bushels per acre. Cut when the graln is past the middle stage of milk, when it will make splendid grain and lots of rich straw hay. Thresh like wheat, only not so closely. Can be fed whole, rolled like barley, or ground.

10 Ibs. $\$ 1.20$; 100 lbs. $\$ 5.50$; per Ib. postpaid 20c; 3 Ibs. $50 \mathrm{c}$

\section{Sugar Cane or Sorghum}

A valuable crop to grow for fodder or ensilage, as it furnishes an immense tonnage to the acre.

10 lbs. $\$ 1.75$; 100 lbs., write; per Ib. postpaid $30 \mathrm{c}$

\section{Vetches}

OREGON VETCH (Vicia Sativa).-Oregon's greatest forage plant. Often called Fall Vetch. Grown very extensively in Western Oregon and Washington. especially in the Willamette Valley and on the Oregon const. It furnishes an abundance of excellent feed, either green or dried. The seed is generally mixed with wheat, oats or rye having a stiff straw to hold it up. Sown alone 85 pounds or 60 pounds with a bushel of grain per acre. Sow in the fall or early spring.

Prlces: 10 Ibs. \$1.50; 100 Ibs. \$12.00; per Ib. 25c; 3 Ibs. $60 \mathrm{c}$ postpaid.

Note.-Crop very short and seed is scarce and high. Write for prices.

HAIRY SAND OR WINTER (Vicia Villose).-This variety thrives on poor arid, sandy soils. It is sown in the fall or spring, mixed with rye, which serves to support the plants. Sow 20 pounds per acre.

10 Ibs. \$3.50; per lb. postpaid 45c

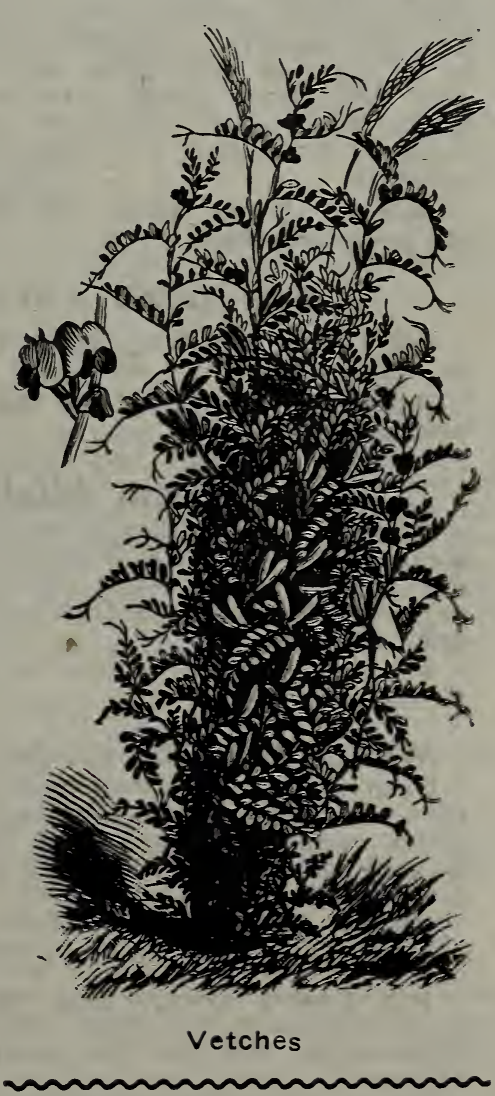

THE WISE ONES

Will use Mulford's Vetch Culture to inoculate their seed before sowing. There is no question about its VAIUE. "Evidence," a new booklet, will prove it. (See page 11.)

Single pound prices are prepaid, but ten, fifty and one hundred pound prices are NOT prepaid and subject to market changes. See notes, page 43. For amount of seed to sow per acre soe table inside back cover. 


\section{SEED WHEAT}

Prices subject to market changes. Will send full value of money sent or quote prices on request for prompt acceptance.

\section{Marquis}

A cross between Fife and Red Calcutta. An early maturing red spring wheat which has been introduced recently from Canada. It may be grown in the place of Bluestem where an early maturing wheat is desirable. It does not shatter easily and stands well. It has a short, plump, very hard kernel. Splen. did milling and baking quality.

Price: Bu. $\$ 3.50$; 100 lbs. $\$ 5.50$; per lb. 20c; 3 for $50 \mathrm{c}$, postpaid.

FORTY FOLD-WINTER.-Forty Fold is referred to as "Gold Coin" in some sections. Is quite early, seed resembling Blue Stem. A favorable winter variety in many localities, :and in good demand for milling.

Prices: Bu. $\$ 3.60$; 100 lbs. $\$ 5.50$; per lb. 20 c, 3 lbs. 50 c, postpaid

\section{ALFALFA AND CLOVER SEEDS}

Single pound prices on Grass Seed are prepaid. Ten, fifty and one hundred pound prices are NOT prepaid and subject to change. See notes, page 42. For amount of seed to sow per acre see table inside back cover.

ALFAIFA, OR IUCERNE CLOVER

Reports prove that Alfalfa will grow in all parts of the West, but requires a deep, loose soil. Will not thrive on heavy clay or where there is hard pan. As soon as cut it immediately commences to grow. Excellent hay or pasture. Alfalfa, once established, is a crop so profitable that every farmer may well take great care to get a stand. Much has been published about its high feeding, fertilizing and wonderful yield possibilities.

Price: 10 lbs. $\$ 5.00 ; 100$ lbs. $\$ 48.00$. Per fb. postpaid $60 \mathrm{c}$.

\section{DRY ILAND ALFALFA}

For high, dry, hot land, where irrigation is impossible.

Price: 10 lbs. $\$ 5.00$; 100 lbs. $\$ 49.00$; per Ib. postpaid $60 \mathrm{c}$.

\section{Grimm Alfalfa}

This is a very hardy variety, claimed by some as the best for Western Oregon, thriving on all soils except undrained meadows and not affected by extreme hot, cold, wet or dry climate.

Prices: $\$ 1.00$ lb. Seed scarce and high. Write.

\section{WHITE CLOVER (Trifolium Repems)}

Used largely in lawns and permanent pasture mixtures. Accommodates itself to a great variety of soils. High grade clean seed is very scarce and high this year; beware of low-priced seed this season.

Choice seed, 10 lbs. \$7.50; per lb. post. paid $85 c$.

For Lawns always buy our Extra Fancy Seed, which is the purest high quality seed obtainable, and the true very dwarf, hardy variety.

Extra Fancy Seed.-Per Ib. postpaid 90c.

\section{CRIMSON CLOVER (Trifolium} Incarnatum)

A thrifty annual. It germinates quickly, grows rapidly and stools abundantly.

in lbe. \$2.50. nar lb. poctpaid $45 \mathrm{c}$
RED CLOVER (Trifolium Pratense)

Hardy, and succeeds well on any good soil. Very short crop, prices high; write. 10 lbs. \$6.25; per Ib. postpaid 70c.

Clover very short crop, prices high; write.

ALSIKE CLOVER (Trifolium Hybridum)

Valued highly for sowing with other grasses. Excellent for hay and pasture; valuable for bees: resists both drought and excessive moisture.

10 lbs. $\$ 5.50$; per lb. postpaid $65 \mathrm{c}$.

SWEET CLOVER (Melilotus)

Sweet clover has come to stay. There is no doubt about it. Ask any farm paper, any state college, the U. S. Department, or better yet, any farmer who has grown it.

Sweet clover is used as either a feed crop or as a fertilizer to plow under to improve the soil and increase the crop to follow. It grows fast and is easy to start.

Grows luxuriantly on good soils but it will also grow and thrive on thin, sandy soil, hardpan, gumbo, rocky upland, clay and alkali land.

Sweet clover lives two years. It makes large, rapid growth the first season and can be cut for hay or pastured the last half of the summer, but does not bloom or bear seed. The second year it blooms, bears seeds and dies. Will make two crops of hay or a crop of hay and one of seed the second year. Can be plowed under either the first or second year, but to get the full value in humus the second season is better on account of the large roots that penetrates the lower layers of soil, thereby loosening it up and adding much humus and more nitrogen.

Sown very early in the spring. It does well sown either alone or with a nurse crop of small grain. Use 15 to 20 pounds of seea per acre.

Sweet clover makes excellent pasture for horses, cattle, sheep, hogs or chickens. A very early and continuous cropper.

Price: Per lb. 45 c postpaid; 10 lbs. $\$ 3.50$; trial pkg. 10c. Write for quantity price.
INOCULATE THIS SEED WITH MULFORD CULTURE
The MULFORD CULTURES contain nitrogen-fixing bacteria, which form nodules on the roots of field and garden legumes that act by collecting nitrogen .from the air and converting it into nitrates-food for soil and plants. Get wise by reading page 41 , 2 . sen ox. 


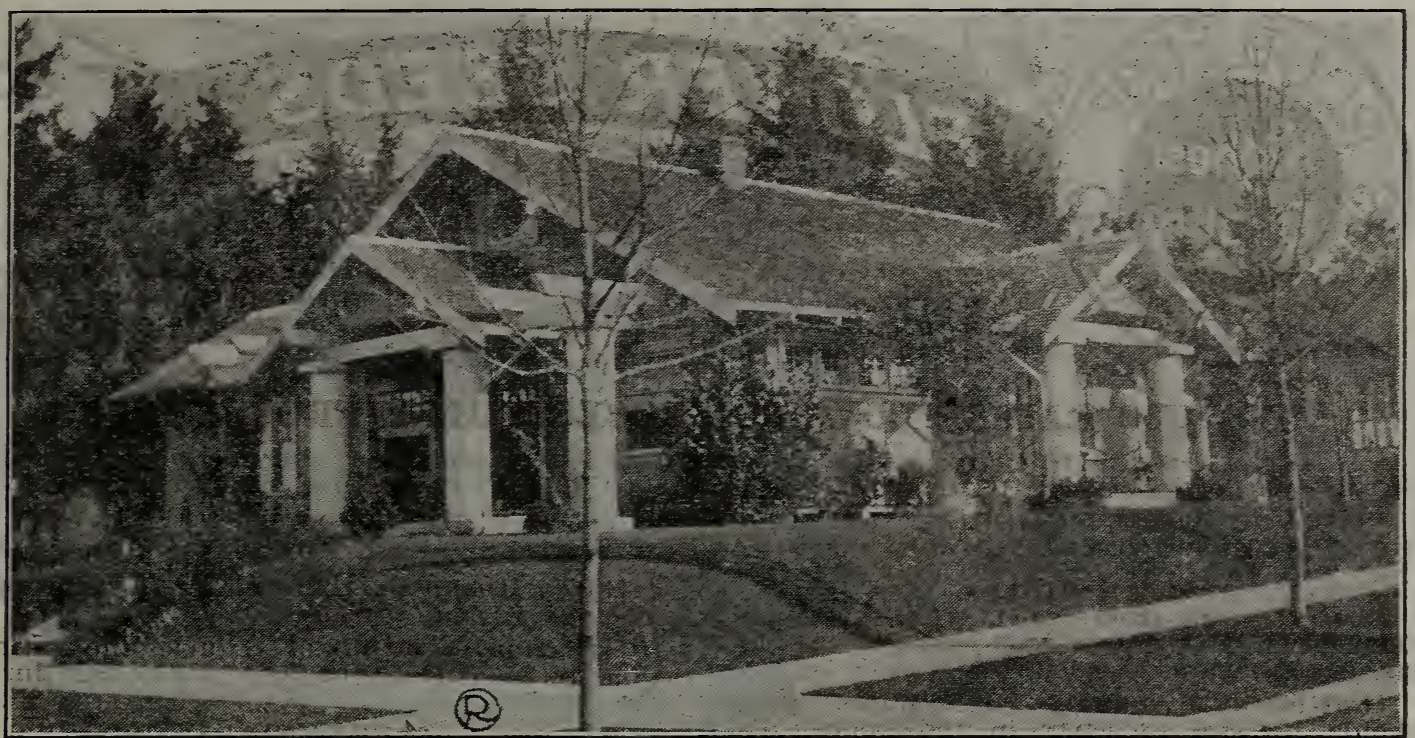

One of our Portland Bungalows with a beautiful lawn, shrubs and vines

Nothing adds a greater air of refinement to a home than a beautiful, well-kept lawn. The time, labor and money spent is a good investment, to say nothing of the pleasure it gives the owner, as well as those who pass by. The planting of a few shrubs, vines and loses should not be forgotten. The pretty home above is "well done," attractive and inviting, and the owner has just cause to be proud of it.

\section{LAWN GRASS SEED}

Though we offer, separately, seed of many of the grasses suitable for the lawn, we consider as very erroneous the somewhat prevalent idea that any single variety of grass seed is preferable or equal to a mixture.

\section{R. R.'S EVERGREEN LAWN GRASS}

To obtain a good Lawn Grass Mixture, it is necessary that the best possible seed of fine grasses be used in the combination, embracing such varieties as are of neat, close growth, extreme hardiness, and adapted to produce a quick, permanent sod. Judicious selection of seed. knowledge of the habits, vigor, quality and hardiness of varieties used in the mixture can only be gained by thorough and practical tests under different climatic and soil conditions. After many years' experience, we offer our pure, clean Evergreen Lawn Grass Seed Mixture, composed of a thoroughly balanced combination of various native and foreign fineleaved, deep-rooting grasses of interweaving habit, that will flourish under varied soil and climatic conditions, and which may be depended upon to produce a beautiful, compact, evergreen sod that will resist tramping and hard usage, and at the same time present that handsome, velvety appearance so much desired.

PRICE, 50c per lb. postpaid; $10 \mathrm{lbs}$. or more, NOT PREPAID, at $45 \mathrm{c}$ per Ib.

Note.-You better spend a few cents or a dollar extra on the seed you buy and have a fine lawn that you'll be proud of. Sow 1 pound seed to 15 feet square for best results.

WHITE CLOVER.-Many gardeners like white clover mixed in lawn seeds and it is excellent, especially if your soil is heavy or poor. White clover grows quickly and acts as a nuise crop and protects the fine leaved grasses. Evergreen Lawn Grass with one-fourth white clover is $60 \mathrm{c}$ per pound, postpaid.

\section{Seeds for Lawns and Special Mixtures}

SEED.-There is as much difference between clean, high-grade grass and clover seeds for lawn making and the common or ordinary grass seeds as there is between high-grade white flour and bran. You would not think of trying to make light, white bread of bran, neither should you expect to make a fine, green, velvety lawn from low grade, light weight, immature and foul grass seeds. Weight, purity and germination is what sets the price of grass and clover seeds. We buy and use the highest grade, pure tested seeds for ou. Evergreen Lawn Grass Mixture. Of course, they cost more, but we know from experience that they give best results and are the only kind of seeds that it pays to use if you want a reautiful lawn. Do not buy low priced Lawn Grass Mixtures and expect good results. NO ONE gives you anything better than you pay for.

SPECIAL MIXTURES.-For all round general conditions, our Evergreen Mixture is unexcelled, but we will prepare special mixtures for shady places, low, wet soils, very dry soils and terraces. Just mention it when ordering.

Do not starve the grass if you want it to look green and velvety; use "Wonder" and "'C-M,', as per directions. See pages 38 and 39. Also read about Lawn Rollers, see index. 


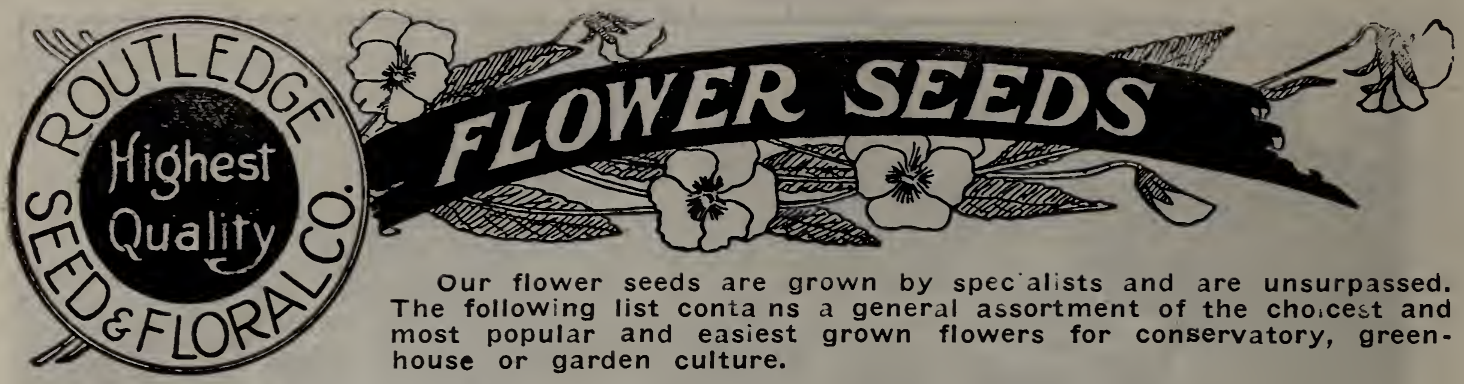

\section{HOW TO RAISE FLOWERS SUCCESSFULLY FROM SEEDS}

The above is the title of a two-page leaflet we have issued for our customers. It tells HOW, WHEN and WHERE to plant. It is free to all. You will find it of great value.

IF YOU WILL MEMORIZE the following definition of the flower classes THEY WILL HELP YOU WONDERFULLY in the selection of seeds and your garden work in general.

These grow from ANALS

Their grow from seed, flower, mature words, the same season.

Half-Hardy Annuals are those which should be started early in the house, conservatory or hotbed, and transplanted to the garden in settled warm weather.

Hardy Annuals are those which can be sown in the open ground in early spring or started inside and transplanted if very early flowers are desired.

\section{BIENNIALS}

These grow from seed, sown from June to August, flower, ripen their seed and die the next year, though some varieties bloom the same season if sown early in gentle heat.
Hardy Biennials will wincer in the open ground without protection.

Half-Hardy Biennials require the protection of a cold-frame or cool-house during the winter.

\section{PERENNIALS}

These grow from / seed, and continue flowering annually for many years after the first season. Some varieties llower the first season if started very early. Sow in the fall for flowers next year.

Handy Perennials can remain in the open ground during winter without protection.

Half-Hardy Perennials require the protection of a cold-frame or cool-housing during winter.

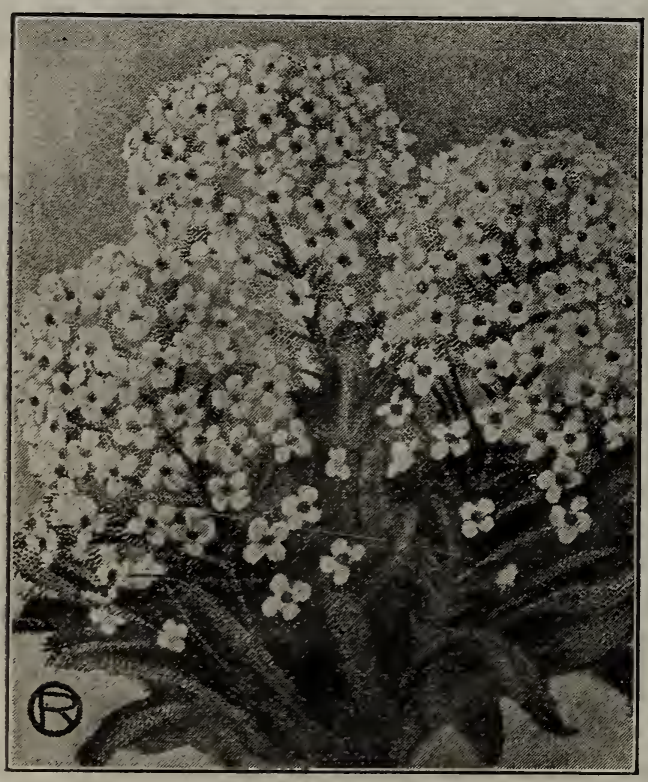

Sweet Alyssum

\section{AGERATUM}

Half-hardy annuals, especially well adapted to edge large beds of geraniums, salvia coleus or cannas; flower continuous through the summer. 15 inches.

MEXICANUM.-Dwarf, blue.

Album.-Pure white Pkt. 10c; 1/4-oz. 25c

Finest Mixed.-All colors. 10c; 1/4-oz. 30c

Pkt. 5c; 1/4-oz. 25c

\section{ACROCLINIUIM}

Hardy annual, with everlasting flowers; good for cutting; flowers double and dry nicely if cut in bud; 1 foot; July to October. Album.-Double white. Pkt. 5c Mixed.-All colors. Pkt. 5c DWARF LITTLE BLUE STAR.-New; one of the handsomest blue-flowered dwarf edging plants; grows 5 inches high, and is just covered with small, bright blue flowers.

Pkt. 15c; 1/8-0z. $\$ 1.00$

\section{AGROSTEMIMA}

\section{(Rose of Heaven)}

COELI-ROSA.-Superb free-flowering, hardy annual, rose-colored flowers; fine for cutting: height $11 / 2$ feet; July to September.

Pkt. 5c; 1/4-0z. 25c

\section{ALOYSIA}

\section{(Lemon Verbena)}

CITRIODORA. - A greenhouse shrub, valuable for the fragrance of the foliage; 2 feet.

\section{ALYSSUIM}

One of the most popular hardy annuals, used especially for edging and also valuable for cutting on account of the fragrance of flowers.

SWEET.-Pure white; 6 inches; June to November.

Pkt. 5c; oz. 50c

LITTLE GEM.-The dwarfest and best for design bedding; plants very compact and bushy, and grow only 3 inches high.

Pkt. 10c; 1/4-0z. 25c

LILAC QUEEN.-Dwarf, compact, lilac flowers.

Pkt. 10c; 1/4-0z. 35c

SAXATILE COMPACTUM (GOLD DUST).Hardy perennial; yellow flowers; April to June; height 9 to 12 inches.

Pkt. 1Cc; 1/4-0z. 25c

Have you a beautiful lawn? If not, see pg. 49 for Seed, pgs. 38 and 39 for Fertilizer 


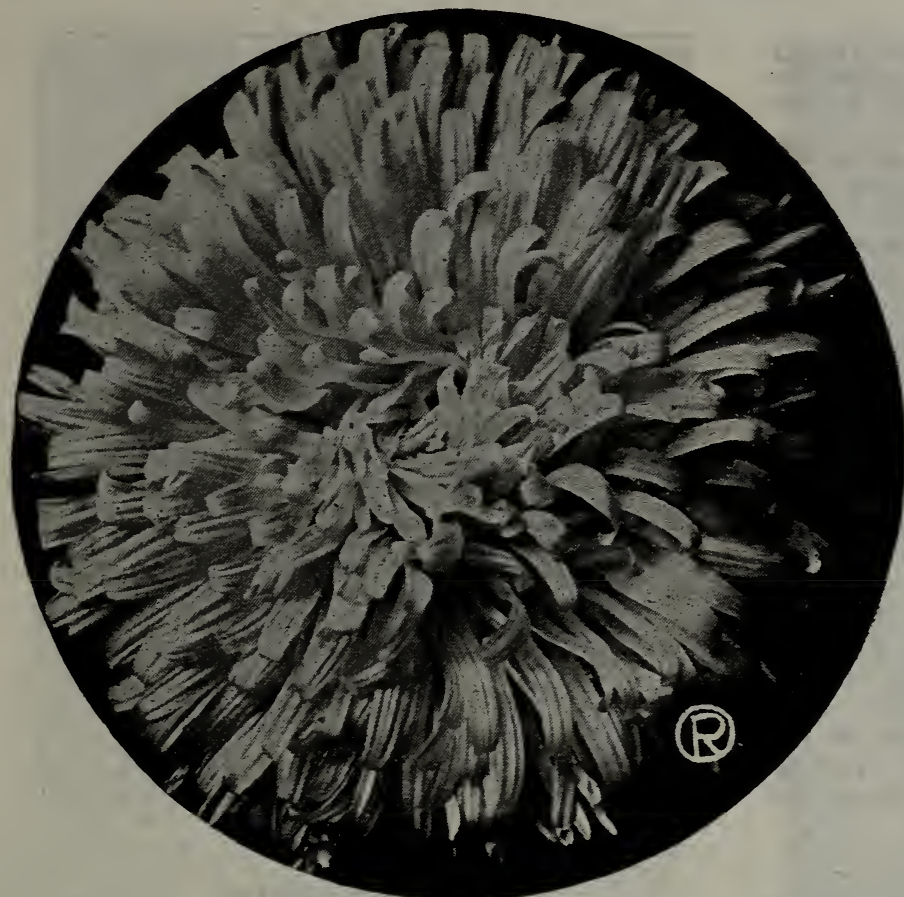

Improved Giant Crego Aster

\section{White Fleece}

One of the largest and most perfect of the early flowering (Comet type), bearing flowers 5 inches and over across, formed into a plumy globe of glistening white; blooms at the same time as Lavender Gem, making a splendid companion. Pkt. 10c; 1/8-0z. 40c

\section{Mikado}

Very similar to the Crego's Giant, but more dwarf in growth and comes into bloom fully two weeks earlier. The plants attain a height of about 18 inches, of branching habit, and the flowers, borne on long, strong stems, are of colossal size, five and six inches across. We offer two colors, viz.:

MIKADO PINK (or Rochester). A charming shade of pink suffused with lavender.

Pkt. 10c; 1/8-0z. 50c

MIKADO WHITE.-Of purest glistening white; a magnificent and aitistic flower.

\section{New Giant Comet}

Pkt. 10c; $1 / 8-0 z$. $50 c$

Considered by many to be the most beautiful of all the Asters (see cut). It is an ideal cuting variety, as each plant bears freely exquisitely iormed large flowers on long stiff stems.

Pure White, Pink, Lavender or Finest Mixed.

Pkt. $15 \mathrm{c} ; 1 / 8-0 z$. 6uc

\section{Lavender Gem}

One of the best; comet type; very early and a charming shade of lavender; excellent in every way. Pkt. 15c; 1/8-0z. 50c

\section{New Crimson Giant}

A late-branching variety of upright growth with extra large, densely double flowers or rich blood-crimson; makes a brilliant bed or border and is splendid for cutting. The form of the flower is nicely shown in plate above.

\section{Asters, Fins Mixed}

Pkt. 15c; 1/8-0z. 60c

A mixture of choice kinds for all season blooms.

\section{ASTERS}

One of the easiest and most satisfactory summer and fall flowers to grow. We take the utmost pains to select seeds from the most perfect flowers only, and wish to assure our patrons that our strains are the superiority of perfection.

\section{Improved Giant Crego}

The most beautiful and desirable aster we have ever seen; very hardy, free-flowering and one of the best for general planting; the plant is a strong, healthy grower, and will produce 12 to 15 icrg istemmed flowers of the most graceful and pleasing style (see cut). With ordinary care you can grow flowers measuring 5 to 6 inches across. Most of the handsome large aster blooms you see in the Portland flower stores are of this kind.

Pure White, Shell Pink, Rose Pink, Purple, Lavender or Mixed. Pkt. $15 \mathrm{c} ; 1 / 8-0 z .50 \mathrm{c}$

SPECIAL.-One packet each of the five colors only $60 \mathrm{c}$.

Routledge Seed \& Floral Co. Plants received. Very much deligthed. MRS. EARL EWING.

See Plant Dept., pages 75 to 94.

Queen of the Market

Most valuable for early cutting; the plants branch freely and produce a great many well-formed flowers nearly a month in advance of the later sorts.

White, Pink, Lavender or Finest Mixed. Pkt. 10c; 1/4-0z. 50c

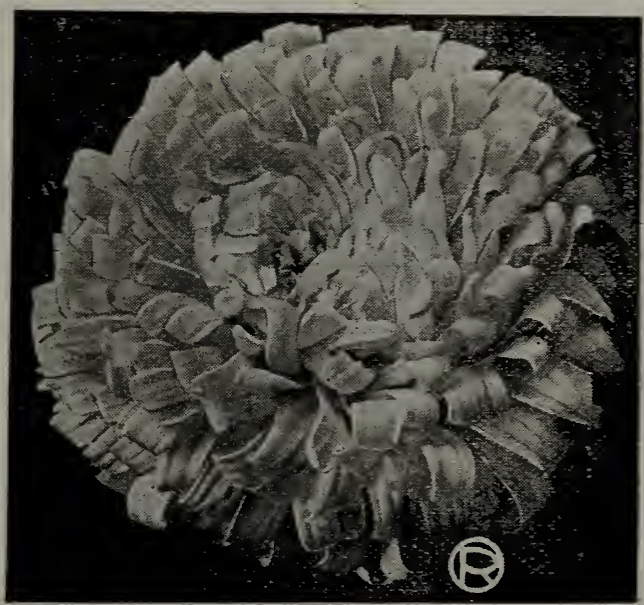

Superb Late Branening

\section{Superb Late Branching}

The most popular late-flowering aster. Flowers are very full, large in size, 3 to 4 inches across and borne on long stiff stems 2 to $2 \frac{1}{2}$ feet high. A very desirable, beautiful and satisfactory variety.

Deep Rose, Dark Blue, Light Blue, Shell Pink, White or Finest Mixed.

Pkt. 10c; 1/4-0z. 60c

ASTER PLANTS and all popular annual bedding plants supplied in season. See pages 75 to 94 . 


\section{AMARANTHUS}

CAUDATUS (Love-Lies-Bleeding). - Hardy annual; ornamental foliage plant; fine for bedding; green foliage with long, drooping crimson racemes; 2 feet.

Pkt. 10c; 1/4-0z. 25c

CRUENTUS (Prince's Feather).-Dark red foliage and feathery flowers; 2 feet.

Pkt. 10c; 1/4-0z. 25c

TRICOLOR (Joseph's Coat).-Ornamental; for foliage only; red, yellow and green.

\section{ANTIRRHINUM}

\section{(Snapdragon)}

Half-hardy perennial and annual; blooms in July if sown early in the house; one of our finest cut flowers; 2 to 3 feet.

Queen Victoria.-New, tall; very large; pure white; superb.

Daphne.-Soft blush pink.

Pkt. 10c.

Golden Queen.-Rich, pure yellow. Pkt. 1Ge

Defiance.-Brilliant scarlet.

Pkt. $10 \mathrm{c}$

Tall Giant, Finest Mixed.-Our seed of this is exceptionaly fine; height, 3 feet.

Pkt. $10 \mathrm{c} ; 1 / 8-0 z .25 \mathrm{c}$

Semi-Dwarf.-Fine for bedding; 18 inches. Finest Mixed. Pkt. 10c; $1 / 8-0 z .25 \mathrm{c}$

\section{AQUILEGIA}

\section{(Columbine)}

Hardy perennials; are most elegant plants and invaluable for cutting or as hardy border flowers; beautiful and graceful; June to September. 2 to 3 feet.

LONG SPURRED.-Superb mixture of all the most desirable shades. Pkt. 15c; 1/8-0z. $75 c$ Single, Finest Mixed. Pkt. 10c; $1 / 4-0 z$. 35c Double, Finest Mixed. Pkt. 10c; $1 / 4-0 z .35 c$

\section{ARABIS}

(Rock Cress)

ALPINA.-Hardy perennial; pure white flowers in close head; excellent for edging, rockwork or dry situations; 6 inches; Apiil to June. Pkt. 10c; 1/4-0z. 50c FOR PERENNIAL PLANTS SEE PAGES 80 TO 84.

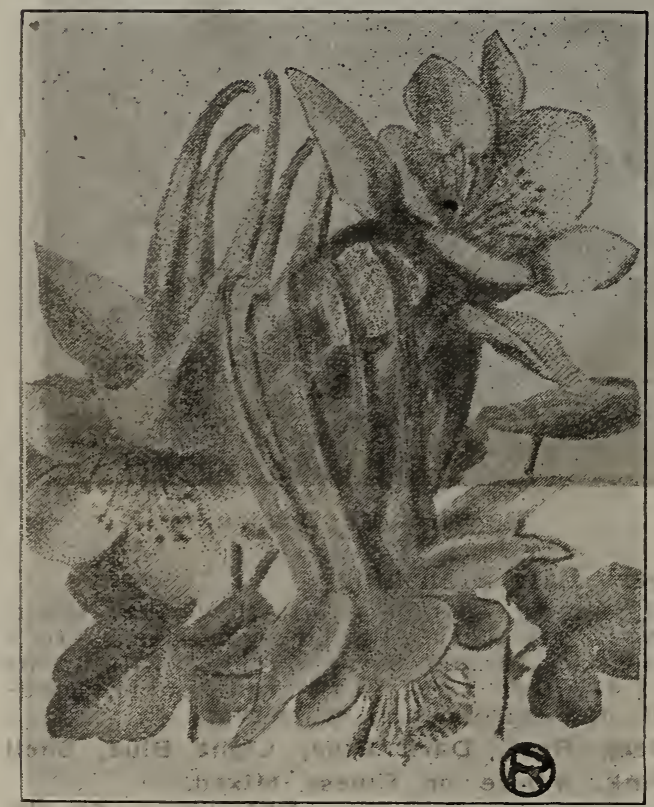

Aquilegia (Columbine)

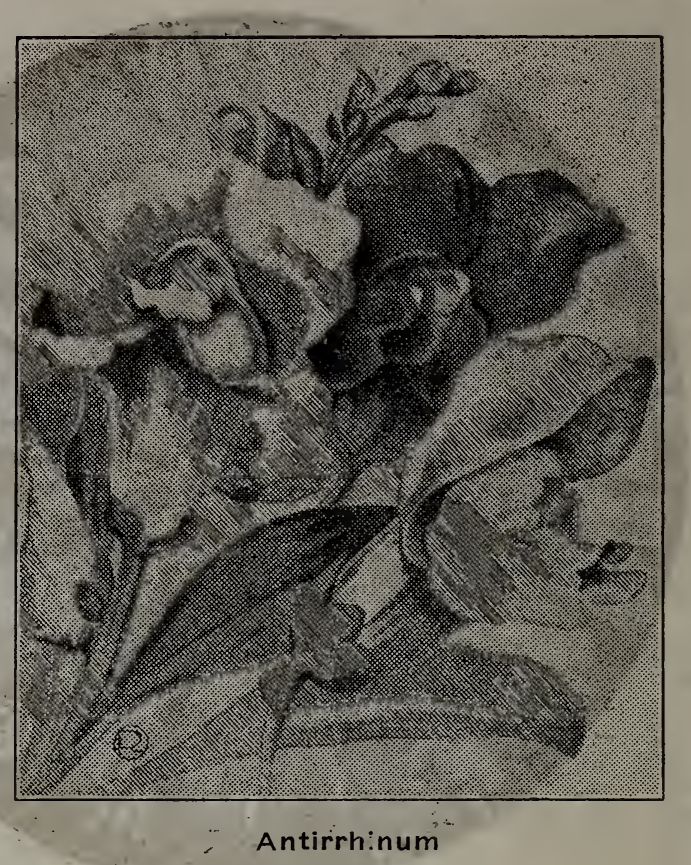

\section{ASPARAGUS}

PLUMOSUS NANUS.-A graceful pot plant for either house or conservatory (see illustration under Fern Plants); very finely cut, delicate lace-like foliage.

Pkt. 25c; 100 seeds $\$ 1.00$ SPRENGERI.-Drooping foliage; adapted for hanging baskets or cutting.

Pkt. 10c; 100 seeds $50 c$ See Gypsophila, page 59 .

\section{BALSAIM}

\section{(Lady Slipper)}

Hardy annual, succeeding best in sunny situations, rich loam and moisture; very showy and of easy culture; $1 \frac{1 / 2}{2}$ feet; July to September.

PRIZE MIXTURE-This strain will produce the most perfectly formed double flowers in the greatest variety of colors.

Pkt. $10 \mathrm{c} ; 1 / 4$ oz. $50 \mathrm{c}$

IMPROVED CAMELIA - FLOWERED FINEST MIXED.-Large, extra double flowers.

\section{BELLIS}

Pkt. $10 c ; 1 / 4-0 z .35 c$

(Double English Daisy)

Popular spring and summer flowering perennial; fine for borders; height 4 inches. Easily raised from seed sown from early sp.ing to September; April to September. Double Mixed. Longfellow.-Double pink flowers. Pkt. 15c Snowball.-Free flowering; pure white. Pkt. 15c

Giant Red or Giant White.-Mammoth in size; very rare. Give them rich ground.

\section{BEAN}

SCARLET RUNNER.-The well-known, rapid glowing annual climber, with bright red flowers, from July to September; height 8 feet. $\quad$ Pkt. 10c; 1/4-oz. 20c See Plant Dept., pages 75 to 79 Kerry, Ore., May 25, 1919.

Routledge Seed \& Floral Co.

Dear Sirs: Received the Geranium plants some time ago. They are all growing fine. Yours truly,

USE. "WONDER."-The best Fertilizer and plant-food-known. A teaspoonful to a plant does wonders. See page 38 . 


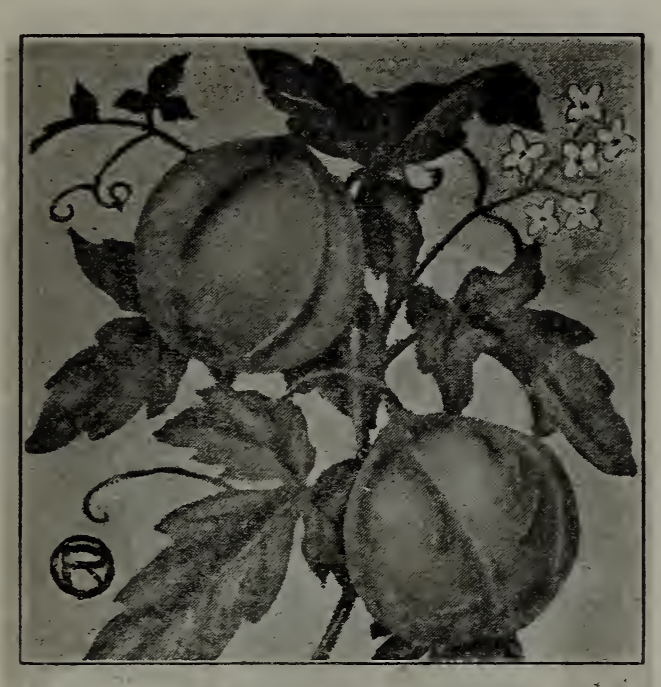

Balloon Vine

\section{BALLOON VINE}

A rapidly growing annual climber; succeeds best in light soil and warm situation; flowers white; seed vessels look like miniature balloons and of great interest to children; 8 to 10 feet (see cut).

Pkt. $10 \mathrm{c} ; 1 / 2-0 z .50 \mathrm{c}$

\section{BROWALLIA}

(Amethyst)

A very profuse blooming, half-hardy annual bedding plant, bearing during summer and autumn handsome winged flowers of different shades of blue; $11 / 2$ feet.

Finest Mixed. P.kt. 10c; 1/4-0z. 50c

\section{CALCEOLARIA}

An ornamental plant, and a universal favorite; produces a mass of beautiful puffed, pocket-like flowers of brilliant self-colors and spotted. Our strains of Calceolaria are very fine.

HYBRIDA GRANDIFLORA.-Flowers of immense size; seeds saved from finest specimens.

\section{CALENDULA}

(Pot Marigold)

Hardy annual; one of the most universal garden flowers. The flowers appear in solitary heads on stout stalks; large, with flat, spreading rays; very showy; flowers the entire season; 1 foot.

Double Finest Mixed.

Pkt. 5c 1/4-0z. 20c

\section{CALLIOPSIS}

Showy and beautiful free-flowering annuals, of the easiest culture, doing well in any sunny position, blooming all summer and excellent for cutting and massing (see cut). Don't confuse this with the perennial Coreopsis, page 54 .

Finest Mixed.-Annual; all shades of yellow, red and brown. Pkt. 10c; 1/4-0z. 40c HYBRIDA SUPERBA. - Showy new shades in all of the choicest varieties.

Pkt. 10c; 1/4-0z. 75c

A Beautiful Flower Garden

Perhaps you have failed before, but if you will follow our "Cultural Directions" (free on request), we are sure you will be successful.

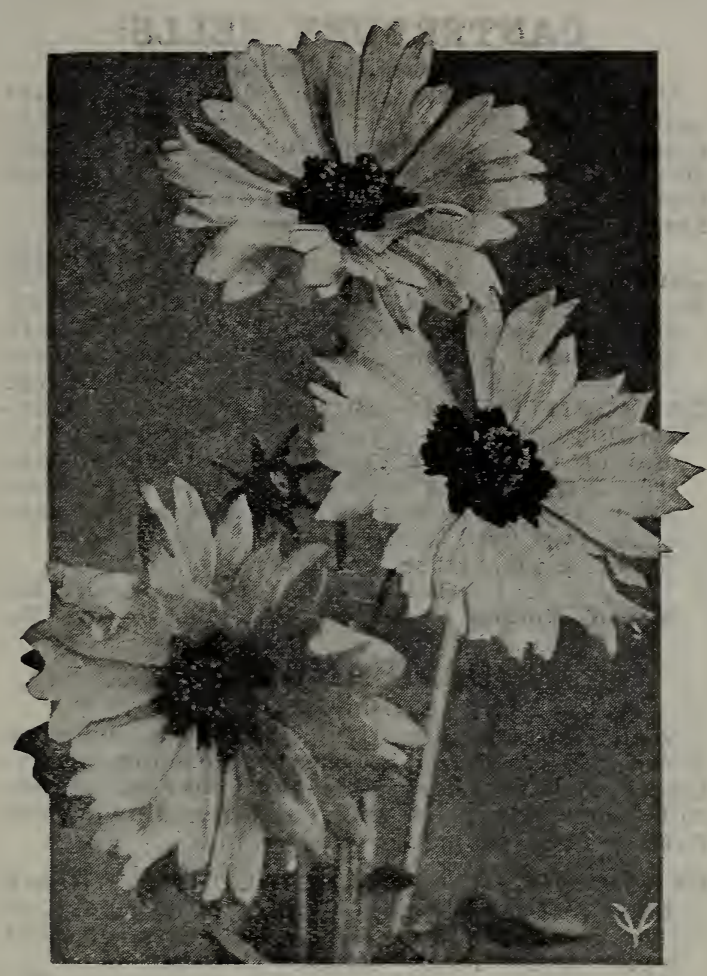

Calliopsls

CANNA

A beautiful, large-leaved, showy flowering plant. Seed must be soaked before planting and started in a hot bed under glass. (For Canna Roots, see page 89.) :ROZY'S HYBRIDS MIXED.

Pkt. 10c; oz. 50c

\section{CANARY BIRD VINE}

A rapid-growing summer-climbing annual, 10 to 15 feet high; it will cover trellis work in the most graceful manner, producing hundreds of pretty winged, bright yellow flowers. $\quad$ Pkt. 10c; 1/4-0z. 35c

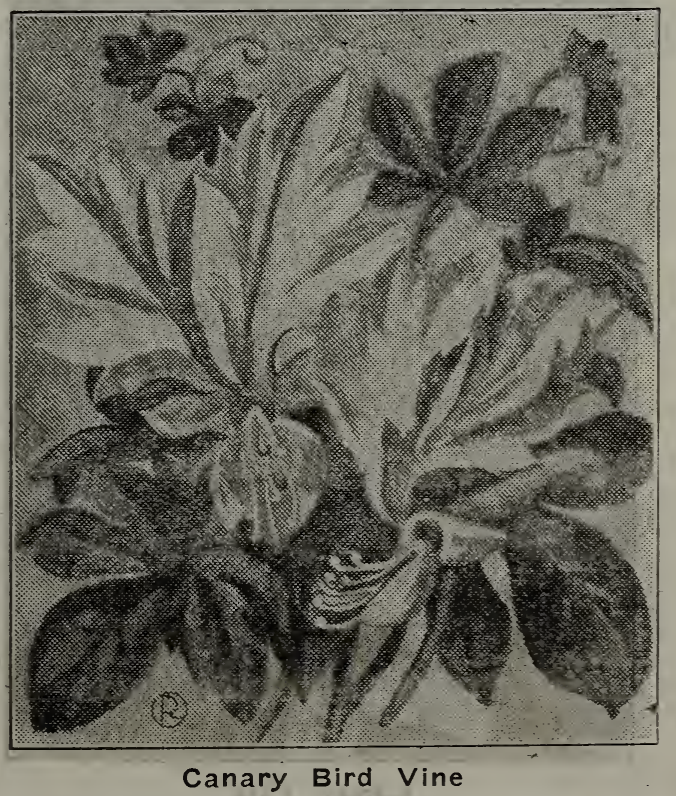

Perennial Flowers are rapidly gaining in favor. MORE should be planted; they are beautiful in borders, beds or among shrubbery, and flower each year. You gain 1 year by buying our field grown plants. See pages 80 to 85. 


\section{CANTERBURY BELLS}

\section{(Campanula Medium)}

Very ornamental garden plants of easiest culture; excellent for cutting; hardy biennial; $21 / 2$ feet high, producing large, bellshaped flowers of exquisite colors. Hardy biennials. (See plants, page 81.)

Single White, Blue, Rose or Mixed.

Pkt. 10c; $1 / 8-0 z .20 c$

Double Mixed, all colors. Pkt. 10c; $1 / 8-0 z .50 c$

R. R.'s PRIZE MIXTURE.-A mixture which contains every color and kind of both single and double biennial and perennials.

CALYCANTHEMA-(Cup and Saucer Can. terbury Bells). - This is unquestionably one of the finest types; they have an extra large calyx, which is of the same color as the flower, giving the appearance of a cup and saucer.

Pink, Lilac, Rose or White.

Mixed Colors.
Pkt. 15c; 2 for $25 c ; 1 / 8-0 z .50 c$
Pkt. $10 c ; 1 / 8-0 z .35 c$

\section{CAMPANULA}

\section{(Bellflower)}

Well known, beautiful, haldy herbaceous perennials, bearing a great profusion of attractive bellflowers; thrives best in light, rich soil; some of the varieties flower the first season if sown early.

PERSICIFOLIA GRANDIFLORA (Peach Bells).- Undoubtedly one of the finest of the hardy Bellflowers; grows 2 to 3 feet high, with large single flowers.

Blue, White or Mixed. Pkt. 10c; 1/8-oz. 50c

CARPATICA (Carpathian Hare-Bell).-Freeflowering, hardy perennial, continuing in bloom the whole season; color clear blue or white; grows 6 inches high; especially good for edging.

Blue or White.

Pkt. 10c; 1/4-oz. 50c

\section{CANDYTUFT-IBERIS}

Very popular free flowering annual, fine for beds or cutting; 1 foot. June to frost if sown early and late.

EMPRESS.-A large-flowered variety of purest white; grown extensively for cut flowers; very desirable. Pkt. 5c; $1 / 4-0 z$. 35c

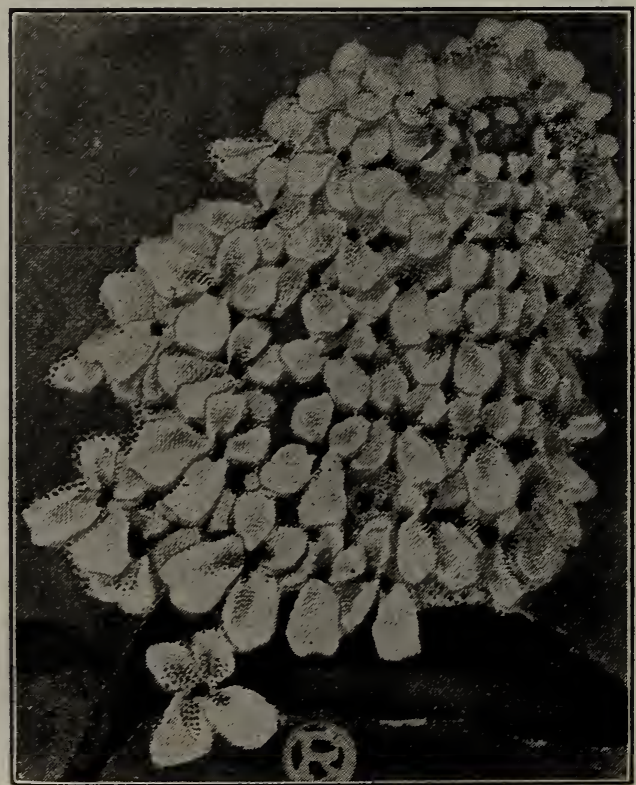

Candy Tuft

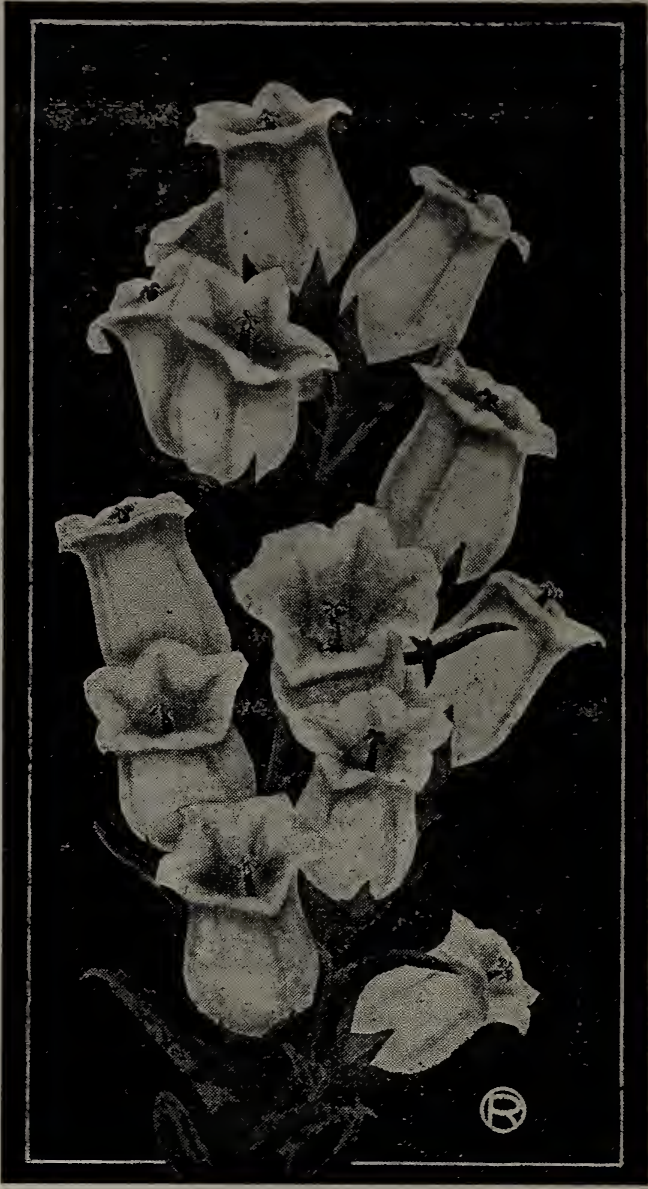

Single Canterbury Bells

DWARF WHITE LITTLE PRINCE.-Grows but 6 inches high and throws up strong trusses of pure white flowers; excellent for edging or bordering Pkt. 10c; 1/4-oz. 50c

PINK BEAUTY.-Fine, true pink, an exquisite flower. Pkt. $10 \mathrm{c} ; 1 / 4-0 z$. 50c

CRIMSON OR LILAC.-Very desirable colors; your choice.

Pkt. 10c; 1/4-oz. 25c

FINEST MIXED.-All colors. Pkt. 5c;oz. 35c

SEMPERVIRENS. - Perennial; pure white flowers, evergreen foliage; blooms in June; fine for edging, borders and rockeries; $i$ foot.

Pkt. 15c; 1-16-oz. 50c

\section{CARDINAL CLIMBER}

This glorious and absolutely distinct new annual climber is undoubtedly the greatest acquisition to the flower world in years, and the most beautiful and brilliant climber ever grown. It is a strong and rapid grower, attaining a height of 25 feet with beautiful fern-like lacinated foliage and literally covered with a blaze of fiery cardinal red flowers from mid-summer to frost. The flowers are about 1 inch in diameter and are borne in clusters of 5 to 7 blooms each. Like all "Ipornoeas," it delights in a warm, sunny situation and good, rich soil. The seed should be soaked in water a few hours before sowing and not planted outside until about May 1 .

Pkt. (15 seeds) 15c; 2 pkts. 25c; 1/8-oz. 75c

GREAT FOR FLOWER BEDS.-Read page 39, which tells all about our new product -_C-M"'-Kiln-dried Pulverized Cow Manure. 


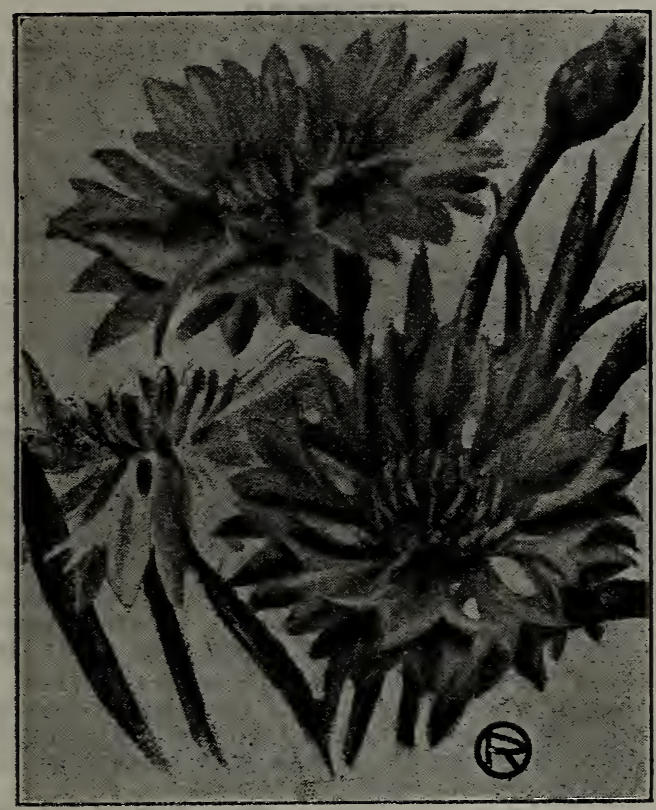

Centaurea Cyanus Bachelor's Button

\section{CARNATION}

Everyone loves Carnations. For started plants of the finest named varieties, see page 77.

MARGARET CARNATIONS. - The earliest to bloom, and producing large, double sweet-scented flowers; being half-hardy perennials, if they are slightly protected during the winter they will survive and flower profusely the next spring.

Red, White or Yellow.-Large flowers.

Choice Mixed. Pkt. 15c; 1/8-0z, 50c CASTOR OIL BEAN.-See Recinus, page 67 .

\section{CELOSIA CRISTATA}

(Cockscomb)

Showy annuals of easy cultivation; 1 foot; producing large, brilliant, comb-like flower heads.

GLASGOW PRIZE.-Showy, dark crimson comb. Pkt. 10c; $1 / 8-0 z$. 50c Finest Mixed.-Rich mixture of finest dwarf kinds. $\quad$ Pkt. 10c; 1/8-0z. 40c

\section{CELOSIA PLUMOSA}

\section{(Feathered Cockscomb)}

The plant grows 2 to 3 feet, is of handsome pyramidal form, and the numerous massive plumes, which resemble an ostrich feather waving gracefully above the foliage, make it one of the most effective; of easy culture.

THOMPSONI MAGNIFICA.-The most perfect. In constant bloom from July to November.

Finest Mixture.

Golden Plume.

Crimson Plume.

Pkt. 10c; 1/4-0z: 50c Pkt. $10 \mathrm{c}$ Pkt. 10c

\section{CENTAUREA}

\section{(Dusty Miller)}

These are grown for foliage only; half hardy annuals; leaves are silver-coated.

CANDIDISSIMA.-Thick, white, upright cut leaves; 1 foot.

Pkt. 10c

GYMNOCARPA. - Fine, fern-like leaves, very graceful and showy; $11 / 2$ foot.

Pkt. $10 \mathrm{c} ; 1 / 8$ oz. $25 \mathrm{c}$

\section{CENTAUREA CYANUS}

(Bachelor's Button-Cornflower)

Very popular annuals; will grow in the poorest of soil, either on seashore or mountains; seed can be sown either in fall or spring; sandy soil preferable; height $2 \frac{11}{2}$ feet.

Finest Single Mixed.

Pkt. $5 \mathrm{c}$; oz. $50 \mathrm{c}$

CENTAUREA CYANUS fl. pl. (Double Bachelor's Button). Beautiful large double flowers.

Double Blue. Pkt. 15c; 1/8-0z. 25c

Double Mixed.

Pkt. 10c; 1/4-0z. 25c

\section{Royal Sweet Sultans}

CENTAUREA IMPERIALIS (Giant Cornflower). - The flowers are of enormous size, fragrant and of charming colors; in form they resemble the fuzzy part of the thistle bloom. In colors from white to red to purple. Excellent for cutting.

Mixed Colors. Pkt. 10c; 1/4-0z. 35c

Marguerite.-Flowers 4 inches across; purest white.

Pkt. 10c; 1/4-oz. 50c

MOSCHATUS (Sweet Sultan.)-Hardy annual, with very fragrant and showy flowers; $11 / 2$ feet; June to September.

Finest Mixed. Pkt. 5c; $1 / 4-0 z$. 35c

SAUREOLENS (Yellow Sweet Sultan).Very showy. Pkt. 10c; 1/4-0z. 50c

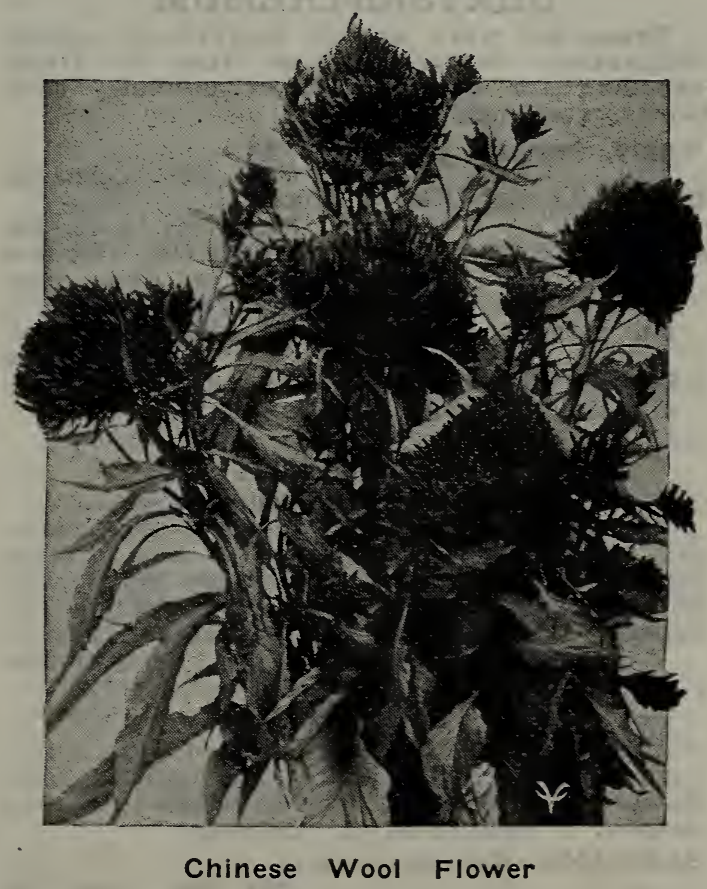

\section{CHINESE WOOLFLOWER}

A new annual flower. Very showy, odd and novel. The bunches of wool-like glowing crimson flowers are produced in profusion. Flowers come early and do not fade until hit by frost. Height 2 to 3 feet. Start early and transplant after danger of frost is over. A large bed of these plants certainly produce a magnificent display and will be a dazzling blaze of color from early, until frost.

Pkt. $15 c ; 2$ for $25 c ; 1-16-0 z . \$ 1.00$

We have Annual Flowering Plants in any quantity during April, May and June. See General Price List, page 79. 


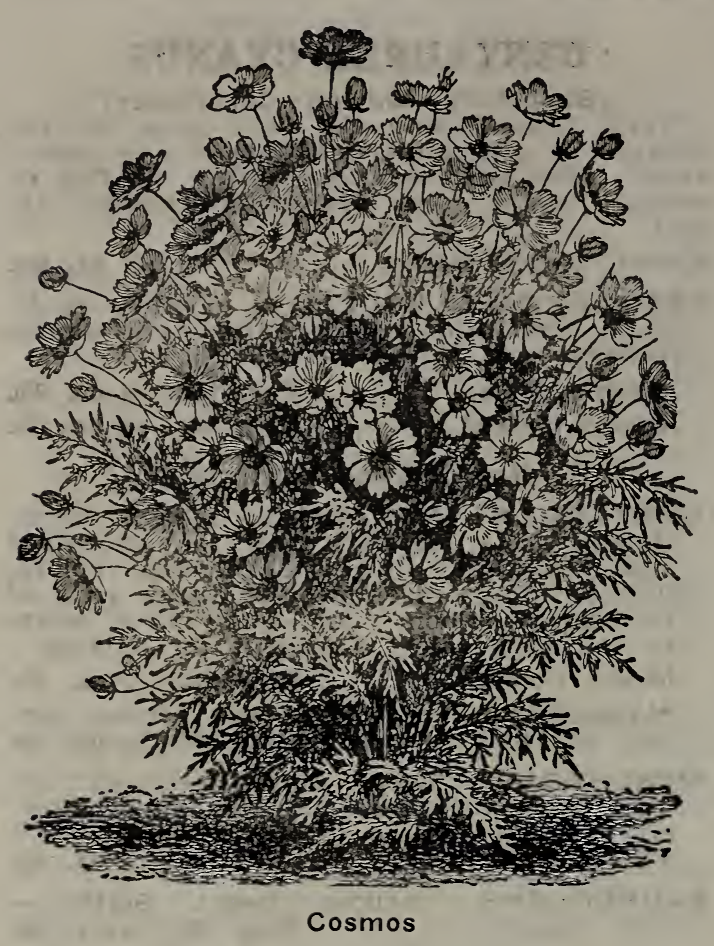

CHRYSANTHEMUM

These are very showy flowers of easiest cultivation, flowering from July to frost; excellent for cutting; height 2 feet. (For plants, see page 77.)

Single Annual, Finest Mixed.

Double Annual, Finest Mixed.

Pkt. 10c; 1/4-0z. 50c

Pkt. 10c; 1/8-0z. 20c

JAPANESE EARLY FLOWERING (Double Flowering.)-These flower in the open ground from August to November; splendid plants for show effect; height 3 feet. Pkt. 15c

LEUCANTHEMUM.-(See Shasta Daisy, under Daisies, page 57; Plants, page 84.)

\section{CINERARIA}

(Hybridi Grandiflora)

We pride ourselves in offering the choicest strain of this gorgeous flower; grand, large blooms in umbel spikes are porne way above the foliage; colors and markings art superb; $11 / 2$ feet; tender annual for pots.

Pkt. 35c

\section{CLARKIA}

A mighty handsome annual; of easy cultivation; flowers resemble carnations and flower freely; colors, white, crimson, orange shades; 2 feet; July to October.

ELEGANS.-Double · mixed.

Pkt. $10 c ; 1 / 4-0 z .35 c$

\section{COBAEA SCANDENS}

Our most popular and rapid climbing annual, flowering the first season. Pretty, purple, bell-shaped flowers appear in great profusion during the fall months; foliage very graceful; 20 feet. Start seed under glass. (For plant see page 79.)

Pkt. 10c; $1 / 4$ oz. 35c

\section{HAVE YOU PETS?}

Note what we have to offer in Kittens, Puppies, Birds, etc., see pages 151 to 160.

\section{COSMOS}

Beautiful autumn-blooming plants. They produce thousands of beautiful flowers in pure white, pink and crimson shades, furnishing an abundance of cur plooms for autumn decorations when other flowers are scarce. Can be sown in spring in the open ground, when danger of frost is past, or if wanted early the seed should we started under cover and afterwards transplanted. Set plants not less than 18 inches apart. When about a foot high the tops shoula be pinched out to induce a busny growtr. They do well almost anywhere.

EARLY FLOWERING MAMMOTH.-Claimed to be as lasge as the Mammoth Perfection and to flnwer in July and August. If sown early, flowers can be picked in July. Grows 4 feet high; flowers large and beautiful. Crimson, White, Pink or Mixed.

Pkt. 10c; 1/4-0z. $50 c$

KLONDYKE.-Golden yellow, flowers large and borne on long stems; mealum eariy

Pkt. 10c; 1/4-0z. 50c

GIANT PERFECTION. - Flowers often 4 inches across; plants 7 feet high; blooms do not appear until October. If toppea when half grown plants will bloom easlier. White, Pink, Red or Mixed.

Pkt. 1Uc; 1/4-0z. $40 \mathrm{c}$

PINK LADY LENOX-Gigantic flowers, with wide, overlapping petals of splendid substance, making a perfectly circular flower which is borne on very long stems, in color a beautiful deep rosy pink.

Pkt. 10c; 1/4-0z. 60c

\section{COREOPSIS}

\section{(Lanceolata Grandiflora)}

Hardy perennial, with large, showy, bright yellow flowers, produced in the greatest abundance from June till frost. As a cut flower they stand near the head among hardy plants, having long stems and lasting in good condition a week or more. Easily grown from seed, flowering the first year, if sown early under glass.

Pkt. 15c; 1/4-0z. $\$ 1.00$

(See illustration and plants, page 80. .)

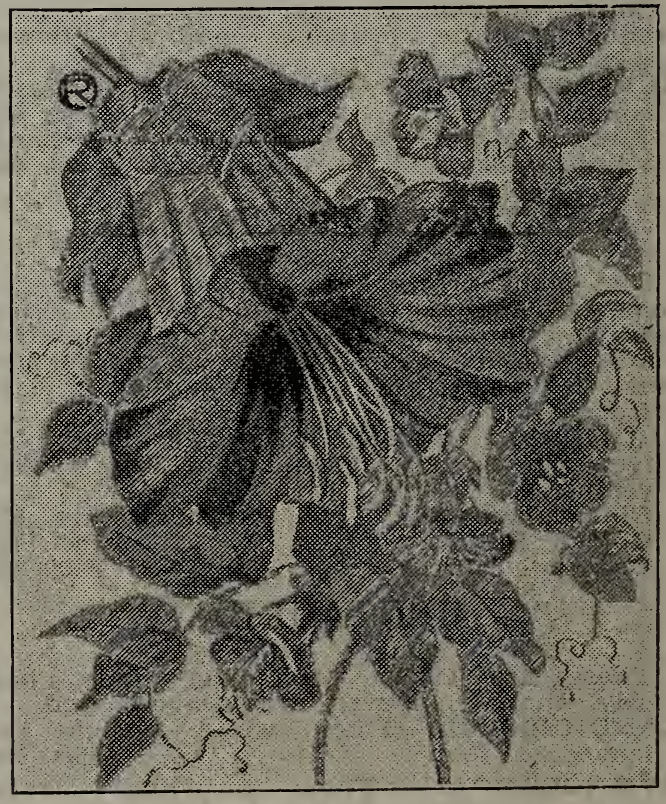

Cobea Scandens 


\section{CYPRESS VINE}

A fast-growing annual vine, with feathery, dark-green foliable and star-like flowers, July to October; 20 feet. Plant early in light soil and warm location.

Finest Mixed.

Pkt. 10c; 1/4-0z. 25c

\section{DAHLIA}

This very popular flower can easily be raised from seed; started insice in IIarch will produce flowers in August.

CACTUS MIXED. - Double flowers with pointed petals (see cut page 92.) Pkt. 15c DOUBLE FINEST MIXED.-Produce flowers of the "Show" or "Decorative Class." Pkt. $10 \mathrm{c}$

SINGLE GIANT PERFECTION. - Single flowers of great size and beauty. Pkt. 10c

DAHLLA BULBS.-Latest and best. (see pages 91 to 93.$)$

\section{DAISIES}

SHASTA DAISY-Very popular and desirable perennial; the large single white flowers are freely produced on long stems. We offer you the best strain in plants or seed. (See cut in Plant Department, page 84.) Pkt. 15c; 1/8 oz. $\$ 1.00$

Double Daisies.-(See Bellis, page 80.)

\section{DELPHINUM}

(Perennial Larkspur)

(See cut, page 81.) Handsome, hardy perennial plants for the herbaceous border and shrubbery, producing a profusion or splendid spikes of flowers throughout the summer. Tho beautiful, graceful, longstemmed flower spikes make handsome bouquets and last well when cut. If started early will bloom the first season from seea. (For large plants see page 81.)

R. R.'S PRIZE MIXTURE.-Superb collection of the choicest colors; new, rare and beautiful shades. Makes wonderful cut flower material and should be planted generously. Pkt. 15c; 1/8-0z. 75c

CHINESE AZUREUM.-Branches very freely, produces its flowers in greatest abundance; clear, deep blue; height 3 feet.

Pkt. 10c; 1/8-0z. 25c

BELLADONNA-Very free and continuous bloomer; delicate and beautiful; clear turquoise blue. Pkt. 25c; 5 pkts. $\$ 1.00$ FORMOSUM. - Long-spurred, brilliant blue flowers, with white center; 3 feet; Jufy to October. $\quad$ Pkt. $10 \mathrm{c} ; 1 / 8-0 z$. 35c

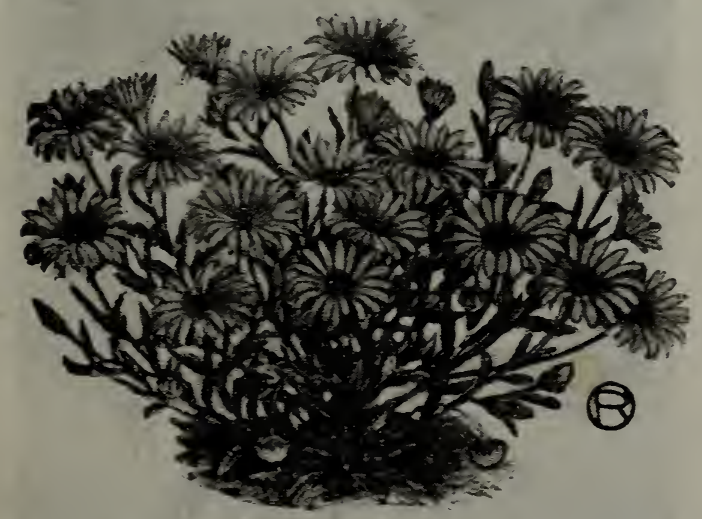

Dimorphotheca-African Solden Daisy

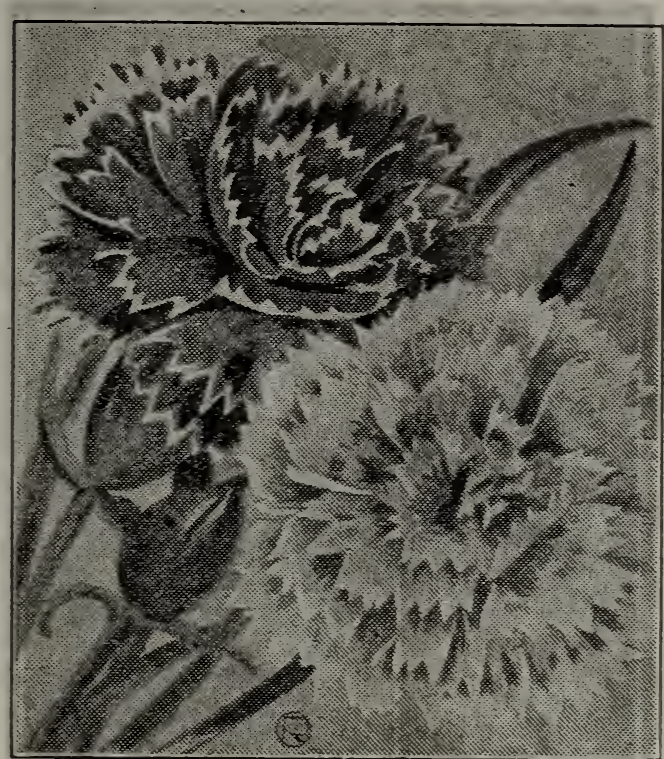

Dianthus

\section{DIANTHUS}

\section{(Garden Pink) -}

All the varieties listed below-are very desirable, and will flower the first season, even sown out of doors in May; they flower early and continue throughout the entire summer; they are excellent for eutting, and bedding; 1 foot. CINENSIS fl. pl. (Chinese Pink).-Large,
double flowers in unlimited variety of bright . colors.

Finest Mixed. Pkt. 10c; 1/4-0z. $50 \mathrm{c}$

HEDDEWIGII. - (Japan Pink.) Beautiful rich colors. A very popular variety.

Finest Mixed. Pkt. 10c; 1/4-0z. 75c

FIREBALL.-New, extra double, brilliant, dark scarlet; - very beautiful.

Pkt. 10c; $1 / 8-0 z, 50 c$

SNOWDRIFT (Lancineatus).-Extra large, pure white, double, fringed.

Pkt. 10c; 1/8-0z. 50c

PRIZE MIXTURE.-Very rich mixture, all kinds. Pkt. 15c; 1/4-0z. 75c

SEMPERFLORENS (Perennial Hardy Everblooming Garden Pinks).--Very beautiful, sweet-scented, double, semi-double and single flowers in great diversity of colors.

Pkt. 15c; 1/8-0z. 60c

\section{DIMORPHOTHECA}

\section{(African Golden Daisy)}

Hardy annual, a great favorite on account of its handsome golden-orange flowers, which are borne most profusely all summer; 15 inches. Does well in dry situations. (See cut.)

Pkt. 10c; 1/8 oz. 50c

Ashford, Wash., June 4, 1919.

Routledge Seed \& Floral Co.

Gentlemen: The bird came fine and I am very well pleased. He is a fine singer.

Thanks for your attention.

Yours truly,

W. S. VAN ETYKE.

See Bird and Pet Dept., pages 150 to 160 .

A HEDGE of Free Flowering Dahllas is AS BEAUTIFUL and more showy than a hedge of ROSES. They are in full bloom when other flowers ARE SCARCE. See pages 91 to 94. 


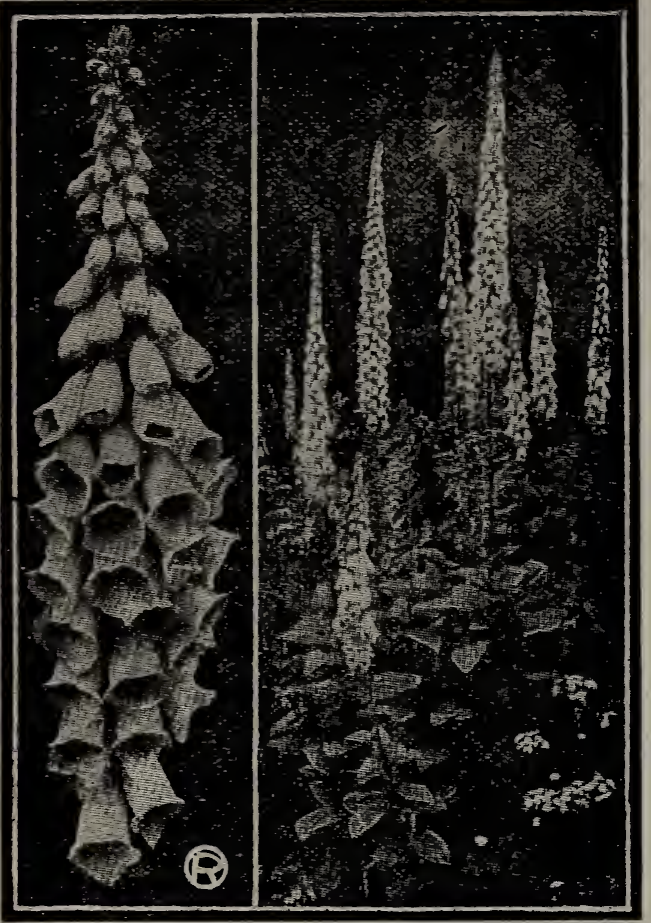

Digitalis-Foxglove Plant and Flower Spike.

\section{DIGITALIS}

(Foxglove)

Hardy perennials; very desirable for effective massing or grouping; invaluable either in the hardy border, between shrubs or in solid beds; 3 to 5 feet. For strong flowering plants, see page 81 .

BEAUTY MIXTURE. - Comprising all the choicest colors. Pkt. 10c; 1/4-0z. 75c GLOXINAEFLORA, Finest Mixed.-Flowers spotted similar to Gloxinias. White, pink and purple flowers. Pkt. 10c; 1/4-0z. 50c GLOXINIAEFLORA ROSEA. - Very desirable, flowers rosy pink.

Pkt. 10c; 1/4-oz. 75c

MONTROSA (Mammoth Foxglove).-The tall spikes of flowers are surmounted by one monstrous bloom; all colors mixed.

Pkt. $10 \mathrm{c} ; 1 / 4-0 z .60 \mathrm{c}$

\section{DOLICHOS}

\section{(Hyacinth Bean)}

Annual climbers; beautirul foliage and clusters of hyacinth-like purple and white flowers, borne in clusters; 10 feet; July to September.

White or Purple Mixed. Pkt. 10c; oz. 25c

\section{ESCHSCHOLTZIA}

\section{(California Poppy)}

One of the most popular garden annuals; 1 foot. Sow the seed where plants are to remain in the fall or early spring. It stands considerable cold and bloons early, profusely and continuously until July. Later sowings for late flowers. (See cut.)

Finest Mixed.-All shades. Pkt. $5 \mathrm{c}$; oz. $50 \mathrm{c}$ Californica.-Bright yellow. Pkt. $5 \mathrm{c}$; oz. $40 \mathrm{c}$ Alba.-Pure white. Pkt. 5c; oz. 40c Carmine.-A beautiful rose carmine.

Pkt. 10c; 1/4-oz. 40c

Golden West.-Very large, bright yellow flowers with orange centers.

Pkt. 10c; oz. 60c

\section{ECHINOCYSTIS LOBATA}

(Wild Cucumber)

The fastest-growing annual vine in existence; will grow 20 feet in six weeks; pretty foliage and inconspicuous white flowers; soak seed in water over night before planting in dry weather.

Pkt. 10c; oz. 35c

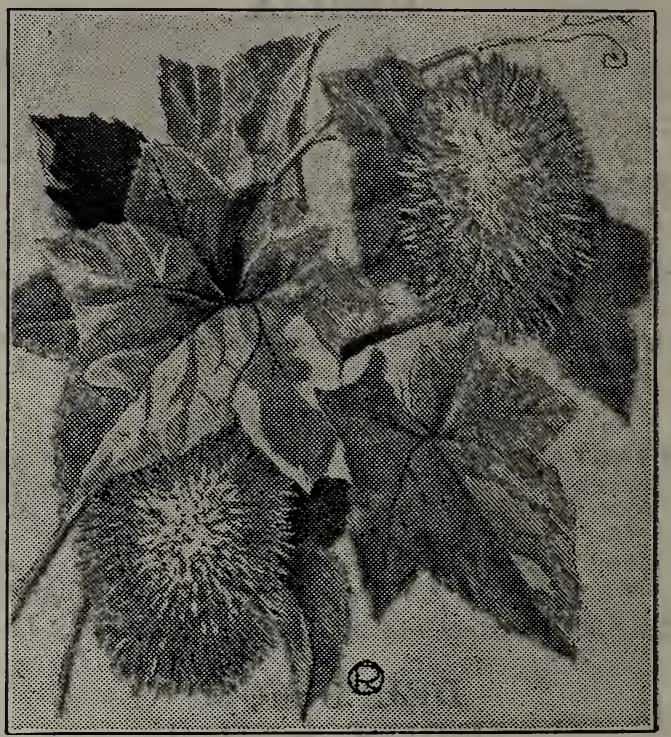

Echinocyslis-Wild Cucumber

\section{GAILLARDIA}

\section{(Blanket Flower)}

Splendid, showy plants for beds or borders; excellent for cutting; the hardy perennial varieties; if sown eariy will bloom the first season; July to frost; $11 / 2$ feet. (Fieldgrown plants, page 82.)

GRANDIFLORA SUPERBA.-Hardy perennial splendid mixed varieties; in crimson and gold; 2 feet. Pkt. 15c;1/4-0z. 50c LORENZIANA.-Hardy annual; double mixed colors; 2 feet. Pkt. 10c; 1/4-oz. 35c

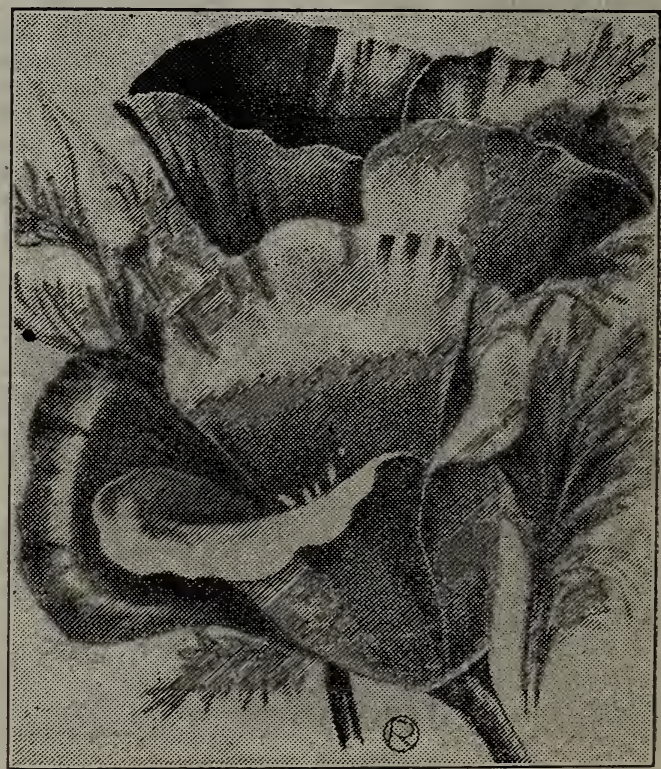

Eschscholtzia-California Poppy

FEED YOUR PLANTS. You must supply "food," in other words fertilizer, if you want the best results. Read about "Wonder" and "C.M," pages 39 and 40; 20-page "Booklet" free. 


\section{Wild Flower Gardens}

Try a packet of our "Wild Flower Gar den"; something new and interesting to see most every day. See page 73.

\section{GLOXINIA}

Showy free-flowering house plants with rich colored bell-shaped nlowers. Tender perennial that need greenhouse culture.

HYBRIDA GRANDIFLORA.-The best strain in existence, embracing all the choicest self-colored, tigeied and spotted flowers.

\section{GOMPHRENA}

(Globe Amaranth)

A dwarf hardy annual, with pretty cloverlike beads of purple, white and red flowers; 2 feet; flowers everlasting.

Finest Mixed.

PKt. 5c; 1/4-oz. 25c

\section{GODETIA}

(Satin Flower)

This showy, hardy annual deserves greater popularity. Attractive flowers of satiny texture, from white to all shades of pink and crimson. They grow rapidly, and flower profusely in poor soil; or easy cultivation. Fine for seashore or mountain resorts; 1 foot; July to October.

White, Bright Red or Finest Mixed. Pkt. $10 c ; 1 / 4-0 z .50 c$

\section{GOURDS}

These are desirable in many places where an immense arnount of vine is wanted quick1\%. Most sorts are good for 20 feet in a season and the blooms of some are quite striking and handsome. With many sorts the fruit is unique and ornamental and often useful. The small fancy gourds are excellent toys for children.

CALABASH.-The famous pipe gourd, dipper shaped.

Pkt. 10c; oz. 40c EGG, ORANGE, TURK'S TURBAN, PEAR, SPOON or MIXED, all kinds.

Pkt. 10c; 1/4-0z. 15c

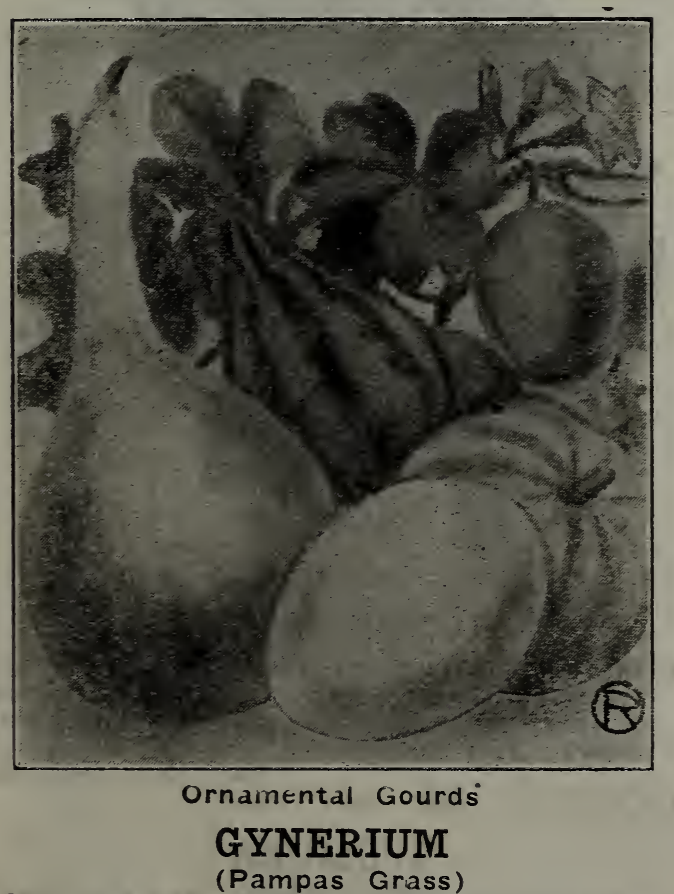

ARGENTEUM.-Hardy perennial; the famous Pampas Grass, with beautiful silvery plumes; 10 feet. (For strong plants see Pampas, page 82.)

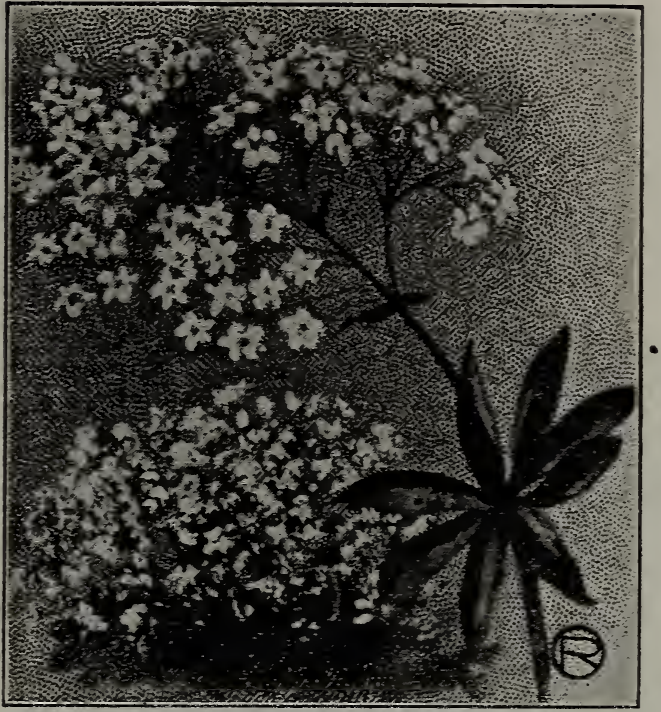

Gypsophila-Baby's Breath

\section{GYPSOPHILA}

(Baby's Breath)

Pretty free flowering, elegant plants, succeeding in any garden soil. Their misty white panicles of bloom are largely used for mixing with other cut flowers. The annuals should be sown early in the spring and midsummer for a continuous supply.

ELEGANS ALBA.-Hardy annual, easily grown from seed; flowers pure white; 2 feet; June. Pkt. 10c; 1/4-0z. 25c

ELEGANS ROSEA.-Hardy annual; flowers bright rose; very dainty; 2 feet.

Pkt. 10c; $1 / 4-0 z .40 c$

MURALIS.-Hardy perennisi; plants dwarf, about 6 inches; flowers shell pink; fine for borders or rock work.

Pkt. $10 c ; 1 / 4-0 z .50 c$

PANICULATA.-Hardy perennial; one of the finest for cutting; pure white flowers, very small, and borne in large, delicate sprays; June to September; 3 feet

Pikt. $15 c ; 1 / 8-0 z .25 c$

(For strong roots of G. Paniculata for immediate effect, see page 82.)

\section{HELIANTHUS}

(Sunflower)

The single annual Sunflowers are indispensible for cutting and a oright display of yellow flowers in the garden, borders or among shrubs. Plant early in a sunny place and they will come into bloom early in the summer and keep up a constant supply of flowers until cut down by severe frosts in the fall. We offer some improved types of special merit.

GLOBOSUS FISTULOSUS (Globe or Dahlia Sunflower). Flowers large, double, very full in the center and of a rich saffron color; 6 feet.

PERENNIAL MIXED.-A choice mixture of the best perennial varieties.

Pkt. 15c; 1/8-0z. $\$ 1.25$

CUCUMERIFOLIUS - STELLA (Improved Miniature Sunflower). Grows about 3 feet tall, covered with large single 5 to 6 -inch flowers of the purest golden yellow, with black disc. Pkt. 10c; 1/4-0z. 50c

MORE HARDY FLOWERING SHRUBS should be planted in the West-they give no trouble, increase in size and grow more beautiful year by year. See pages 100 to 108 . 


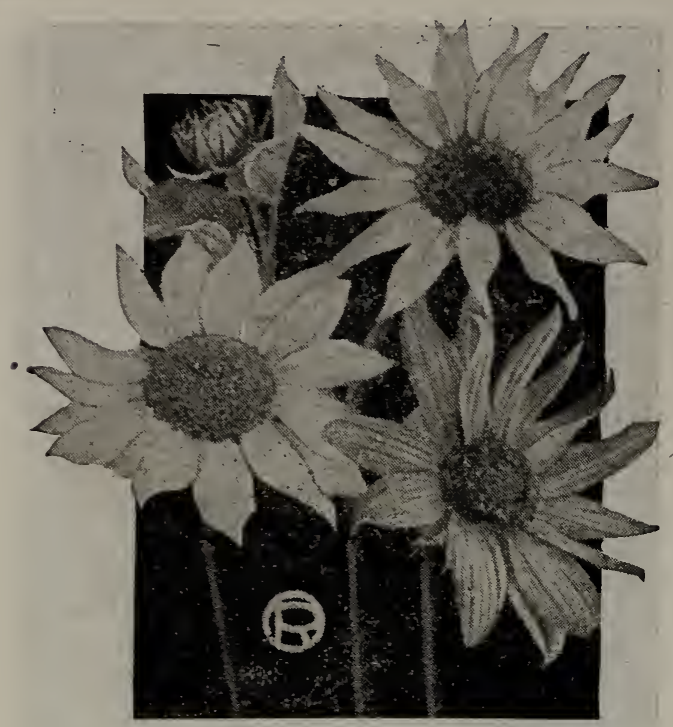

Helianthus-New Miniature

ORION-Artistic and effective new variety of "Stella." The petals are twisted like a Cactus Dahlia.

Pkt. 10c; 1/4-0z. 40c

NEW MINIATURE MIXED.-A multitude of new varieties have been raised from the popular Miniature Sunflower, which we offer in mixture. They all differ from the parent, most of them being larger, and many with curiously twisted petals. The prevailing colors are pale yellow, golden yellow and creamy white, some with black centers, and all beautiful; for cutting they are indispensable. Pkt. 10c; 1/4-0z. 50c

\section{HELIOTROPE}

Delightfully fragrant, tender perennial; popular pot and garden bedding plant; also for cutting. Some of the best plants may be raised from seed very readily; $11 / 2$ feet; start inside or under glass.

FINEST MIXED.

Pkt. 10c; 1/8-0z. 35c

MIDNIGHT.-New; handsome, large flowers, lively shade of purple, variegated with white; foliage beautiful.

Pkt. 15c

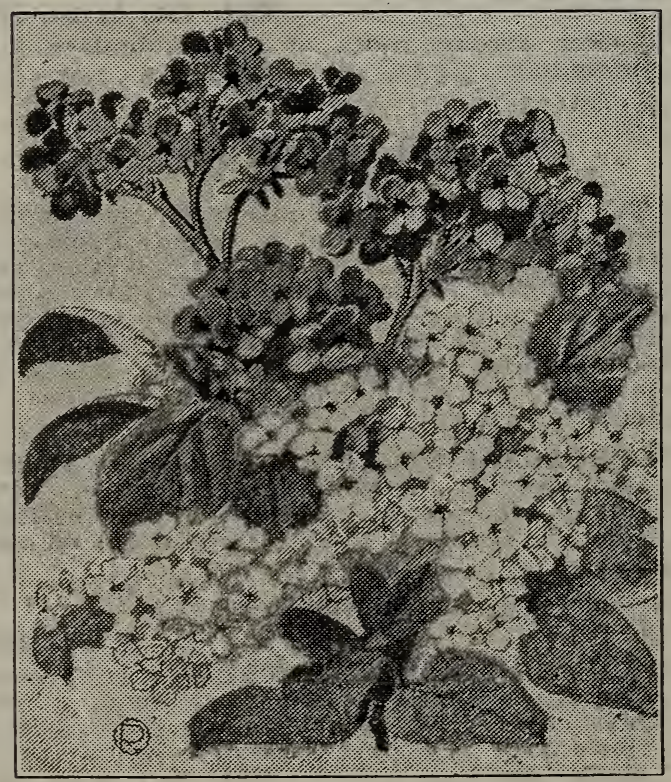

Hellotrope

\section{HOLLYHOCKS}

Very popular hardy plants. Easily grown. Seed sown any time before mid-summer will produce fine plants for flowering the next summer.

DOUBLE VARIETIES.-Our strain of this is the best that can be produced; seeds saved from the most double flowers.

White, Pink, Crimson, Yellow, Lllac or Mixed.

Pkt. 10c; 1/4-0z. $75 c$

ALLEGHENY.-Semi-double; mamomth flowers, having the edges of the petals finely fringed and lacinated; will bloom the first year if sown early.

Choicest Mixed Colors. Pkt. 10c; 1/4-0z. 75c

NEW ANNUAL EVER-BLOOMING.-This is one of the best introductions of late years. Seeds sown in the house in March will produce flowers in July on plants 4 feet high; the plants do not attain their perfection until their second year, when they grow 7 to 10 feet high, and flower continuously from June till frost.

Single Mixed. Pkt. 10c; 1/4-0z. 50c Double Mixed. Pkt. 15c; $1 / 4-0 z, 60 c$

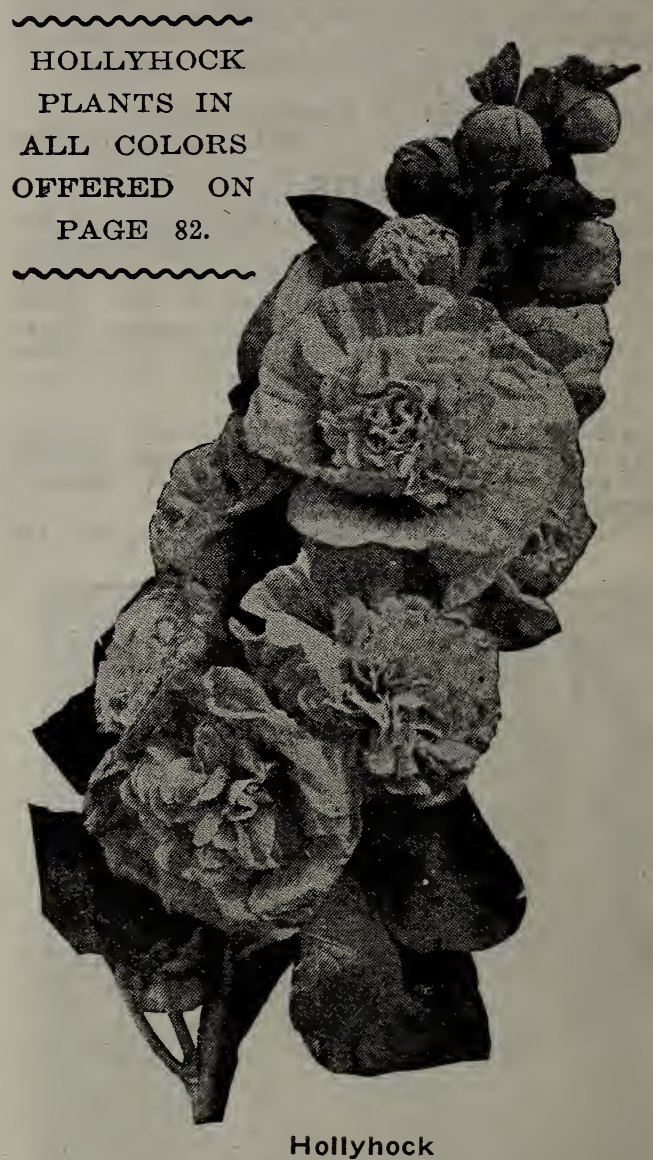

\section{HUNNEMANNIA}

FUMARIAEFOLIA (Giant Yellow Tulip Poppy.)-Hardy annual; foliage fern-like; flowers tulip-shaped, golden yellow; very showy; July to frost.

Pkt. 10c; 1/4-0z. 35c HUMULUS.-See next page.

\section{IPOMOEA}

\section{(Moonflower)}

GRANDIFLORA ALBA.-Large, heart-shaped leaves, and laige, pure white flowers, which open only late in the evening; 10 feet. $\quad$ Pkt. 15c; 1/4-0z. 25c 


\section{HUMULUS}

(Japanese Hop)

Hardy annual climber; of rapid growth; attains a height of 12 feet.

JAPONICA VARIEGATA. - Foliage green and white; very pretty and effective; not affected with insects. Pkt. 10c; 1/4-0z. 35c ENGLISH HOP ROOTS. Each 15c

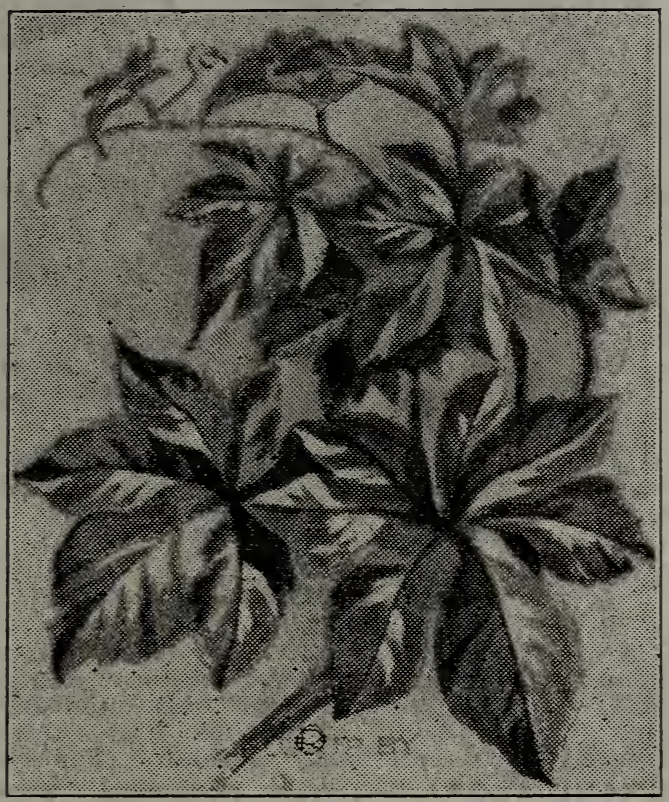

Humulus-Japanese Hop

\section{KOCHIA}

SUMMER CYPRESS Or BURNING BUSH.Annual; forms dense bushes of upright plumage-like foliage; during the summer they remain light green and in early fall they change to carmine and blood ied; 2 feet; makes a dainty and showy hedge or nice single specimens.

\section{KUDZU VINE}

Pkt. 10c; 1/4-oz. 25c

\section{(Pueraria Thumbergiana)}

To this must be awarded first place as the fastest growing hardy climbing plant. It will grow 8 to 10 feet the first year from seed, and after it has become established there seems to be no limit to its growth, 50 feet in a single season being not unusual. Its foliage is large and covers well; it bears small racemes of rosy purple; pea-shaped blossoms towards the close of August. A splendid subject for covering permanently verandas, etc.

\section{LARKSPUR}

These are splendid, hardy annuals, which, when grown in beds or borders, make a pleasing effect, and the slender flower stalks, when cut, are most desirable for vases; July to October.

DOUBLE DWARF ROCKET. -1 foot: compact growing bush; splendid spikes of double flowers in all colors.

Mixed.

Pkt. 10c: 1/4-oz. 35c

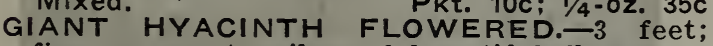
fine, compact spikes of beautiful flowers. Mixed.

EMPEROR - Tall slender Pkt. 10; 1/4-0z. 25c quisite double flowers in unlimited quantity and of delicate shades; 3 feet.

Mixed. Pkt. 10; $1 / a-0 z .25 c$ PERENNIAL LARKSPUR-(See Delphinium, page 57; plants, page 81.)

\section{LATHYRUS LATIFOLIUS}

PERENNIAL SWEET PEA.-Free flowering, hardy perennial climbers, bearing beautiful flowers all season.

White or Pink. Akt. 10c; $1 / 2-0 z .50 \mathrm{c}$ Mixed.

Pkt. 10c; $1 / 2$-oz. 35c

FLOWERING PLANTS. - During the months of April, May and June we have thousands of choice, well-grown plants. See page 79 .

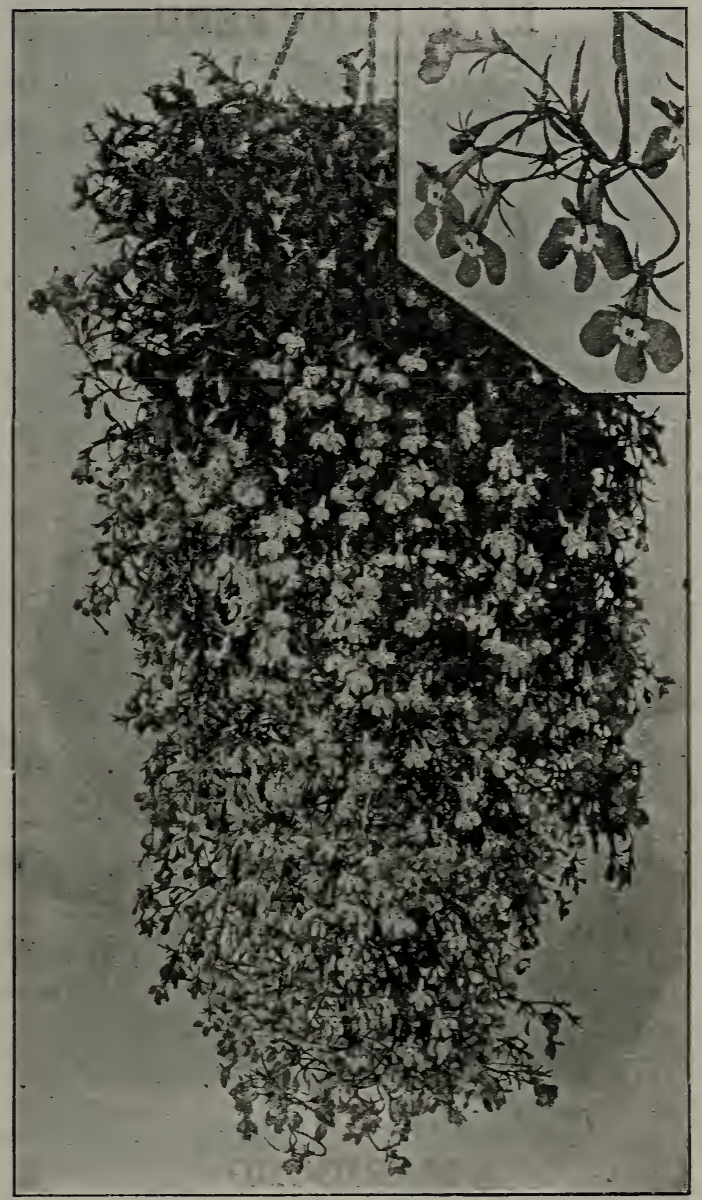

Trailing Lobelia

\section{LOBELIA}

ERINUS GRACILIS.-Trailing bright blue flowers; excellent for vases, hanging baskets and window boxes.

Pkt. $10 \mathrm{c} ; 1 / 8$ oz. $25 \mathrm{c}$ HYBRIDA SAPPHIRE (New).-This is by far the most beautiful trailing Lobelia to date; very large, deep sapphire blue flowers, with a large and clear white eye; very free and early flowering; extia long trailer, for baskets and boxes. Pkt. 25c CRYSTAL PALACE COMPACTA. - Little dwarf bedding plant; dark blue flowers cover the whole plant curing the entire season: very compact and used extensively in carpet bedding or edging; height 4 inches. $P$ Pt. 15c; 1/8-0z. 60c

WHITE GEM.-Compact little plants, covered trailer, for baskets and boxes.

Pkt. 10c

CARDINALIS (Cardinal Flower).-Hardy perennial, with spikes of deep cardinal red flowers; August and September; 3 feet.

BUY a package of WONDER ODORLESS FERTIIIZER and feed your plants according to directions. YOU WILL BE PLEASED at the results. See page 38 . 


\section{LUPINUS}

Ornamental, free-flowering, easily grown, with long, graceful, upright spikes of rich and variously colored pea-shaped flowers; valuable for mixed borders and beds.

ANNUAL DWARF MIXED.-Valuable for cutting: 2 feet. Pkt. 10c; 1/4-0z. 35c POLYPHYLLUS MUXED. - Showy perennials, growing stout and erect; good for cutting: flowers in great variety of colors; 3 to 4 feet; May and June.

Pkt. 10c; $1 / 4-0 z .20 c$

\section{MARVEL OF PERU}

\section{(Four o'Clock)}

Hardy annual, flowering erom July to October; brilliant colors; 3 1eet.

Finest Mixed.

Pkt. 10c; oz. 35c

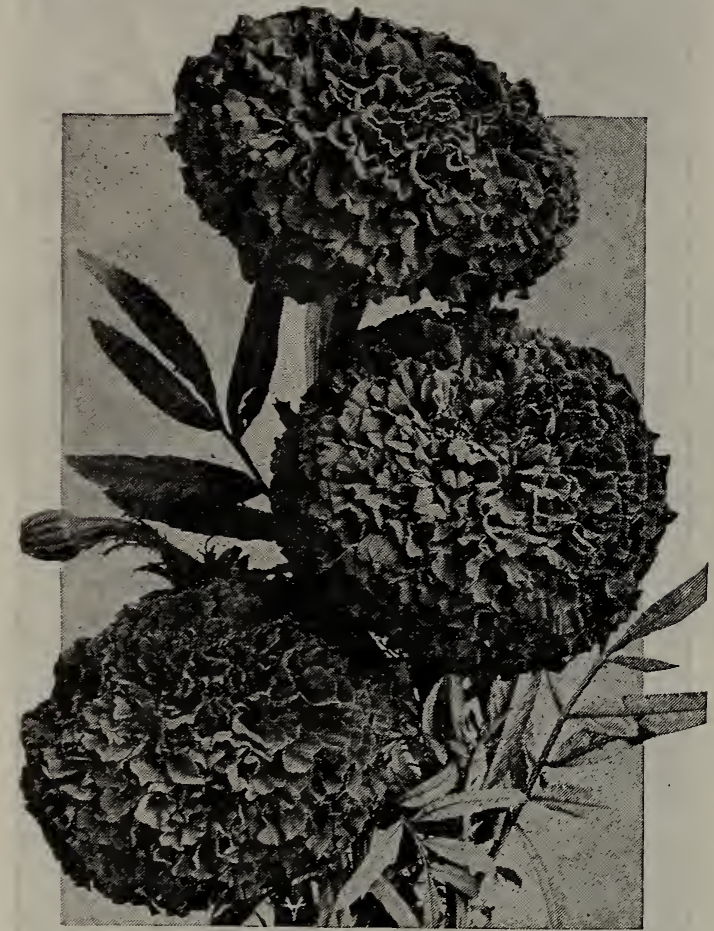

African Marigold

\section{MARIGOLD}

(Tagetes)

Widely grown, hardy annuals; invaluable for bedding and producing an elegant display of yellow, orange and brown flowers from early summer till frost.

MAMMOTH AFRICAN, Finest Mixed.-Very large and double, orange-yellow flowers : 2 to 3 feet. Pkt. 10c; 1/4-oz. 25c DOUBLE FRENCH.-Flowers double, brownred and golden-yellow; pretty. Tall or Dwarf Mixed. Pkt. 10c; 1/4-oz. 35c

\section{MESEMBRYANTHEMUM}

Dwarf trailing plants of great beauty, blooming the whole summer, thriving best in a dry, loamy or sandy soil; hardy annuals; 12 to 15 inches.

TRI-COLOR.-Very dainty, pointed petaled, salmon-pink flowers. Pkt. 15c CRYSTALLINUM (Ice Plant), - Flowers white, prized for its singular icy foliage.

\section{MIMULUS}

MOSCHATUS (Muskplant).-A pretty, trailing plant with small yellow flowers, giving forth a musk-like fragrance; fine for hanging baskets, etc. Annual. Pkt. 15c

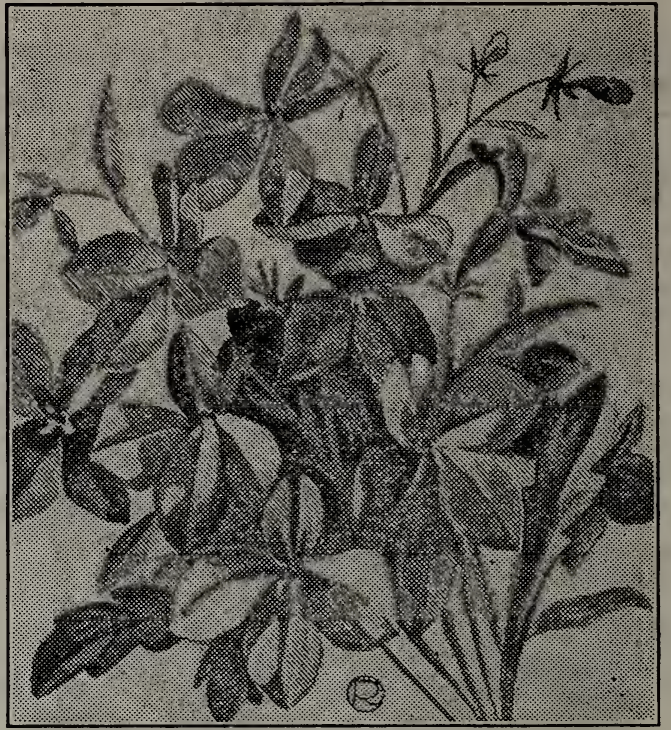

Lobelia Compacta, page 61

\section{MIGNONETTE}

\section{(Reseda)}

A universal favorite; very fragrant; no home garden is complete without Mignonette. It needs a cool soil only moderately rich; grows 6 to 12 inches high and is treated as a half-hardy annual. (See cut.) GRANDIFLORA. - Large - flowering, sweet, fragrant, spikes of greenish yellow color. Pkt. $5 \mathrm{c}$; oz. $25 \mathrm{c}$

DEFIANCE.-Giant spikes; flowers abundant and very fragrant. Pkt. 10c; $1 / 4-0 z$. 15c MACHET RED.-Excellent for pots or gerden; highly colored, fragrant flowers.

Pkt. 10c; 1/8-0z. 25c

WHITE PEARL.-New; the best white flower; very attractive. Pkt. $10 c ; 1 / 8-0 z$. 35c

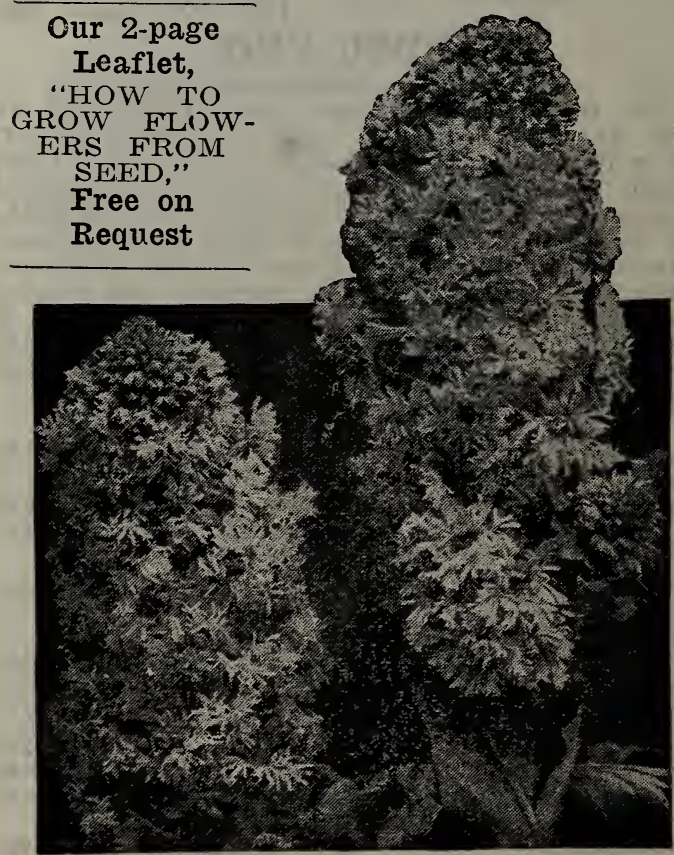

Mignonette-Flower Spikes

GLADIOLI BLUBS make a beautiful display when in bloom and are of the easiest culture and really not expensive, as they multiply rapidly. See pages 88-89. 


\section{MORNING GLORY}

\section{(Ipomoea)}

The tall varieties are popular, well known, rapid-growing climbers of the easiest cultivation; very fine for covering arbors, trellises, porches, etc.; give them rich soil and a warm situation. The Minor or Dwarf varieties flower very freely and do not require support.

CONVOLVULUS MAJOR.-Tall, choice, single mixed; all colors. Pkt. 10c; oz. 25c CONVOLVULUS MINOR.-Dwarf mixed.

Pkt. 10c; oz. 25c

IMPERIAL JAPANESE FRINGED. - These have very large fringed flowers in a great variety of the most esyuisite colorings; handsome foliage. Pkt. 10c; oz. 35c Double Mixed.

Pkt. 10c; oz. 50c

C. : PRIZE MIXTURE.-This is a mixture of both American and Japanese varieties; very choice. Large Pkt. 10c; oz. 25c (Note.-Soak the Japanese Morning Glory seed in warm water for 24 hours before planting.)

\section{MYOSOTIS}

\section{(Forget-Me-Not)}

Few spring flowers are more admired than the lovely Forget-Me-Nots, which are especially effective when grown in masses. Perennials and hardy if given slight protection through the winter. Seed may be sown any time from spring till mid-summer. The Alpestris and Dissitirlora come into bloom in April, and are largely used for bedding or borders in connection with spring-flowering bulbs, Pansies, etc. The Palustris sorts do not bloom till May, but continue till fall. Perennial plants, page 81 . DISSITIFLORA.-Rich blue; early flowers in fine sprays; 6 inches.

Pkt. 15c; 1/8-0z. $\$ 1.00$

ALPESTRIS VICTORIA.-Of bushy habit; bearing large, double, bright blue flowers; yellow eye; very fine; 6 inches.

rkt. $10 \mathrm{c} ; 1 / 8-0 z .50 \mathrm{c}$

ALPESTRIS ROYAL BLUE.-Rich indigo blue; 9 inches. $\quad$ Pkt. $15 \mathrm{c} ; 1 / 8-0 z$. 35c

FINEST MIXED.-A mixture of blue, rose

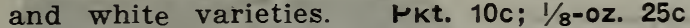

PALUSTRIS SEMPERFLORENS. - Perennial; flowers bright blue; blooms from early spring until autumn.

Pkt. 15c; 1/8-0z. $\$ 1.00$

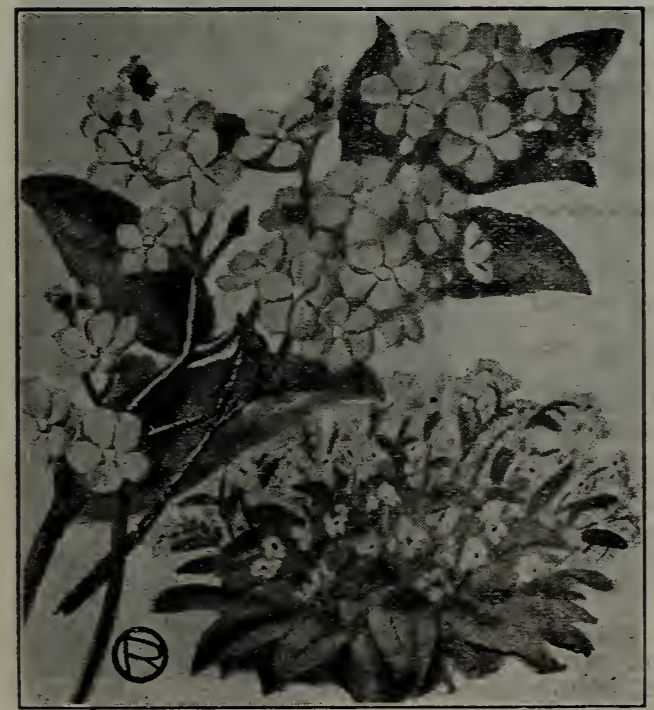

Myosotis-Forget-Me-Not

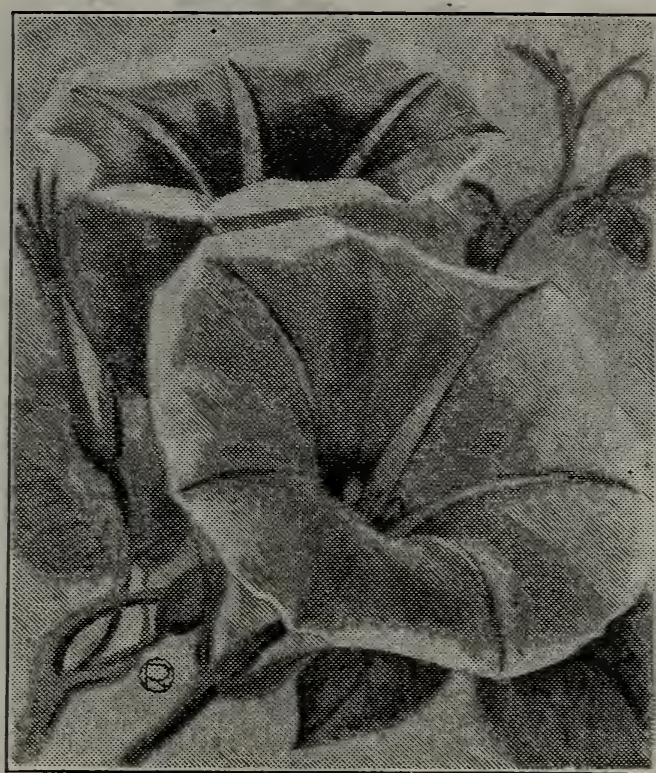

Morning Glory

NEMESIA

GRANDIFLORA COMPACTA TRIUMPHA very pretty, half-hardy, free-flowering annual; the plants grow about a foot high and the beautiful, dainty flowers are very varied in color, including rose, yellow, blue, orange, etc. An ideal bedding plant. Seed sown in the autumn makes beautiful pot plants for early spring blooming. Mixed Colors. Pkt. 15c; 1/8-0z. $\$ 1.00$

\section{NICOTIANA}

One of the easiest annuals to raise and one of the most effective. The blossoms in shape are not unlike a Petunia blossom but with a longer tube. The flowers open toward evening and emit a powerful perfume. AFFINIS (Tuberose-flowered Tobacco.)-Delightfully sweet-scented, pure white, tubular flowers, blooming continually: annuals; 2 to 3 feet. Pkt. 10c; 1/4-0z. 35c AFFINIS HYBRIDA.--Splendid hybrids in blue, red and rose, etc., shades. Pkt. 10c; 1/8-0z. 50c

SANDERAE.-A lovely hybrid Tobacco of elegant branching habit, and bearing on light graceful stems great quantities of very beautiful rosy carmine flowers; a valuable border plant, remaining decorative from summer to autumn.

Pkt. $10 \mathrm{c} ; 1 / 8-0 z .35 c$

\section{NIGELLA}

(Love in a Mist)

DAMASCENA. - A compact, free flowering plant with finely cut foliage, curious looking flowers and seed pods; hardy annuals: blue and white: 1 foot.

Mixed Colors. Pkt. 10c; 1/8-0z. 15c MISS JEKYLL.-A lovely variety with cornflower blue blossoms; splendid for cutring. Pkt. 10c; 1/8-0z. 25c

\section{HOUSE PLANTS}

Don't overlook the beautiful Ferms and Palms that we offer on pages 74 and 75 . The small sizes go safely by mail and are very pretty.

PERENNIAL FLOWERING PLANTS-By buying our strong field arown plants you save time and get a profusion of flowers the first season. See pages $80-85$. 


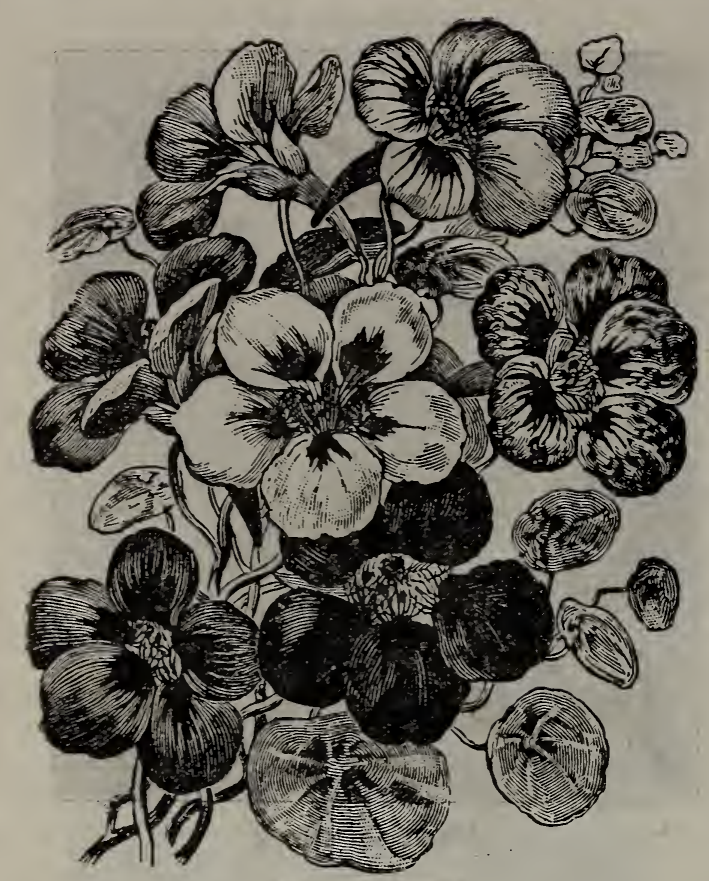

\section{NASTURTIUM-TALL OR CLIMBING}

The most popular and most beautiful freeflowering annual climbing vines. These are all of strong vigorous growth, throwing out running shoots that can be trained upon strings or wires, or can be readily made to climb ordinary paling fences or wire netting. They are very showy also planted at the top of a steep slope and allowed to run down the bank. We offer only the finest strains, producing the largest and richest flowers.

Your choice, Pkt. 10c; full collection, 8 kinds, 50c; per oz., any kind, $25 \mathrm{c}$.

Regina.-Brilliant salmon red, changing to almost cream.

Asa Gray.-Pale primrose yellow, almost white.

Black Prince.-Velvety crimson dark foliage.

Crown Prince.-Rich deep ruby garnet.

Golden Queen.-Very fine golden orange.

Margaret.-Yellow, spotted red and yellow.

Primrose.-Cream, brown spots.

Spitfire.-Bright vermillion scarlet.

TALL PRIZE MIXTURE.-This is undoubtedly the finest mixture of tall Nasturtiums offered anywhere; every shade is grown separately and then mixed.

Large Pkt. 10c; oz. 25c; 1/4-Ib. 75c

TALL CHOICE MIXED.-A very fine selection of beautiful varieties. Large Pkt. 10c; oz. 20c; 1/4-1b. 60c

IVY-LEAVED, FINEST MIXED.-The ivy leaves, borne on very slender stems, are of a dark metallic color, which forms a striking contrast to the beautiful flowers; an excellent variety for cases, hanging baskets, etc.

Pkt. 10c; oz. 25c

VARIEGATED QUEENS.-A new strain of tall Nasturtiums having beautifully variegated leaves; green, white and yellow; flowers large and of many bright colors. Superb Mixed.

Pkt. 10c; oz, 25c

\section{DWARF NASTURTIUMS}

These are of dwarf, compact, rounded Thth and are especially desirable for anting as borders to flower-beds or along in slightly raised beds.

Beauty.-Yellow and scarlet; very pretty.

mpress.-Deep crimson; extra dark leaved.

esuvius.-New salmon red; very beautiful.

rice, all above Dwarf varieties, Pkt. $10 \mathrm{c}$

R'S DWARF BEAUTY MIXTURE.Composed of new and rare sorts; exceedingly brilliant and beautiful.

Large Pkt. 10c; oz. 25c; 1/4-Ib. $75 c$

CHOICE DWARF MIXED.-Not equal to tar superior to most mixtures. Large Pkt. 10c; oz. 20c; 1/4-Ib. 60c

GOLDEN MIDNIGHT (New Dwarf).-A novof real merit. From an artistic point variegated, while the flowers are deep rimson, almost black, hence the name Pkt. 10c; oz. 25c

\section{PENTSTEMON}

\section{(Beard Tongue)}

handsome, brilliant flowers are borne yellow to red and purple. (See cut.)

For per. mand

hardy

flower-

ing and trailers

pages 106

and 107.

m 


\section{GIANT PANSIES}

This popular flower thrives best on a cool, moist, but well-drained soil enriched with well-rotted barnyard manure or fine ground bone. Seeds sown early will produce fine plants for summer blooming. The florists method, though, is to sow in July or August and protect the plants during the winter, and they will flower continuously early the following spring and summer.

EXHIBITION PRIZE MIXTURE.-For variety of markings, beauty of form, size and splendid texture, this superb strain cannot be excelled. Florists and gardeners will be pleased with this magnificent strain. Pkt. 25c; 1/8-0z. $\$ 1.50$

STEELE'S MASTODON.-This superb strain is becoming famous among professional florists everywhere. Flowers rare and rich in colors and of giant size; Oregon grown. Mixed.

Pkt. 20c; 1/8-oz. $\$ 1.25$

GIANT TRIMARDEAU.-The most popular bedding strain for this locality, and deservedly so, on account of the strong, sturdy plants and the enormous flowers of the greatest variety of colors; Oregon grown.

Finest Mixed.

Pkt. $15 c ; 1 / 8-0 z .75 c$

ENGLISH SHOW.-A magnificent strain; very large flowers; great diversity of colors.

Pkt. 10c; 1/8-oz. 60c

CHOICE MIXED.-A fine bedding strain.

Pkt. $5 \mathrm{c} ; 1 / 8-0 z .35 \mathrm{c}$

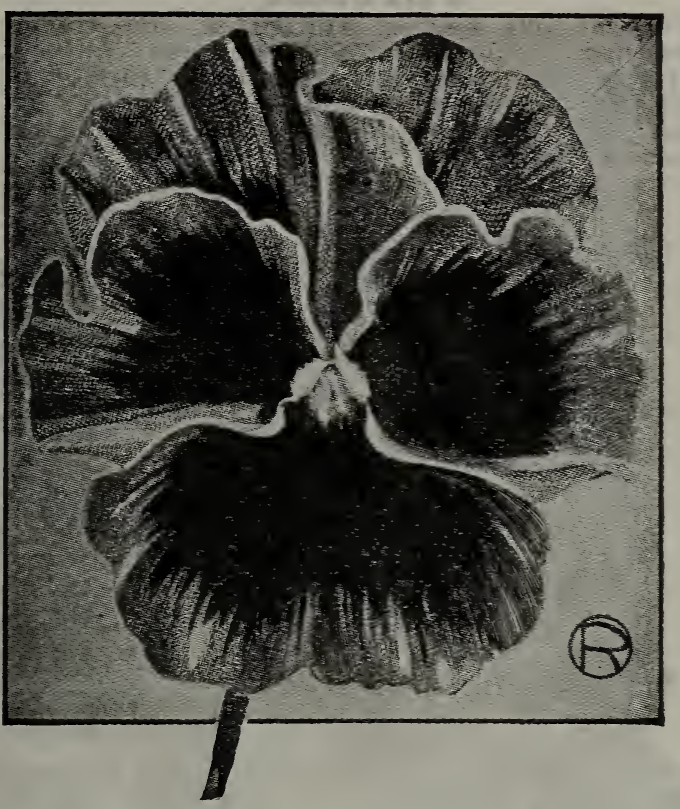

Our new product, "C-M," Dry-Kiln Pulver. ized Cow Manure, is the ideal fertilizer for your Pansy beds. (See page 39.) It makes those giant flowers you admire.

\section{New Giant Flowering Pansies. Collection, 1 pkt. each of the 10 kinds, $\$ 1.60$}

BLACK GIANT.-Nearly all are jet black: some very dark purple. Rare and rich. immense size. Very effective if planted with pure white or yellow.

BRONZE MASTODON.-Very large; all shades from bronze to gold, many wonderfully shaded. A color always in demand. Pkt. 20c

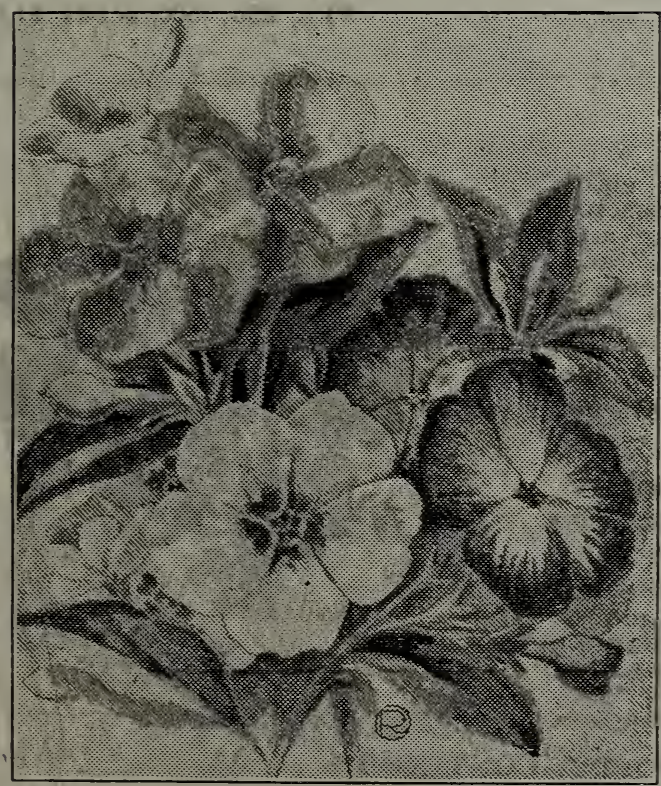

Phlox Drummondii

PINK.-(See Dianthus, page 57.)
GIANT WHITE.-Mammoth, pure white with a dark center.

Pkt. $20 \mathrm{c}$

MADAME STEELE.-“Elks Purple." A deep rich royal purple of giant size. Pkt. 20c

GRAND DUKE.-The finest and largest allwhite pansy in the world. Pkt. 20c

MADAME PERRET-Frilled.-Very distinct, frilled or ruffled, edged white, body color wine pink and red, beautifully veined.

Pkt. 20c

GOLDEN QUEEN.-Pure yellow, grand form and size; the finest yellow strain. Pkt. 20c METEOR.-A beautiful pure wine red, profuse bloomer. A favorite for borders.

Pkt. 20c

NEW ADONIS. -A giant light blue. Pkt. 20c PRINCE HENRY.-A splendid dark blue of immense size. The best blue. Pkt. 20c

\section{PHLOX}

Large flowering, hardy, annual phlox; are easily grown from seed. Their brilliantly colored flowers make a magnificent display through a long season. Give them a sunny position and light soil. Excellent for mass beds or borders 1 foot high.

DRUMMONDI GRANDIFLORA MIXED.-A splendid mixture of all colors.

Pkt. 10c; 1-0z. 35c Alba.-Pure white. Pkt. 10c; 1/8-0z. 50c Coccinia.-Bright scarlet.

Pkt. 10c; 1/8-0z. 50c Leopoldi.-Rosy pink, white eye.

Pkt. 10c; 1/8-0z. 50c

HARDY PERENNIAL PHLOX (Decusata.) -These rank among the finest herbaceous perennials for beds and borders; mixture of the finest colors; 3 feet. (See plants, page 83.) Pkt. 10c; 1/8-0z. 60c

PLANTS.-Large flowering, choice pansy plants, ready very early in the spring. Can be safely sent by mail. See page 79 . 


\section{PETUNIA}

One of our easiest cultivated and freest flowering annuals. Will succeed almost anywhere and give a continuity of the most brilliant bloom from June till killed by frost. The strains we offer are the very choicest obtainable.

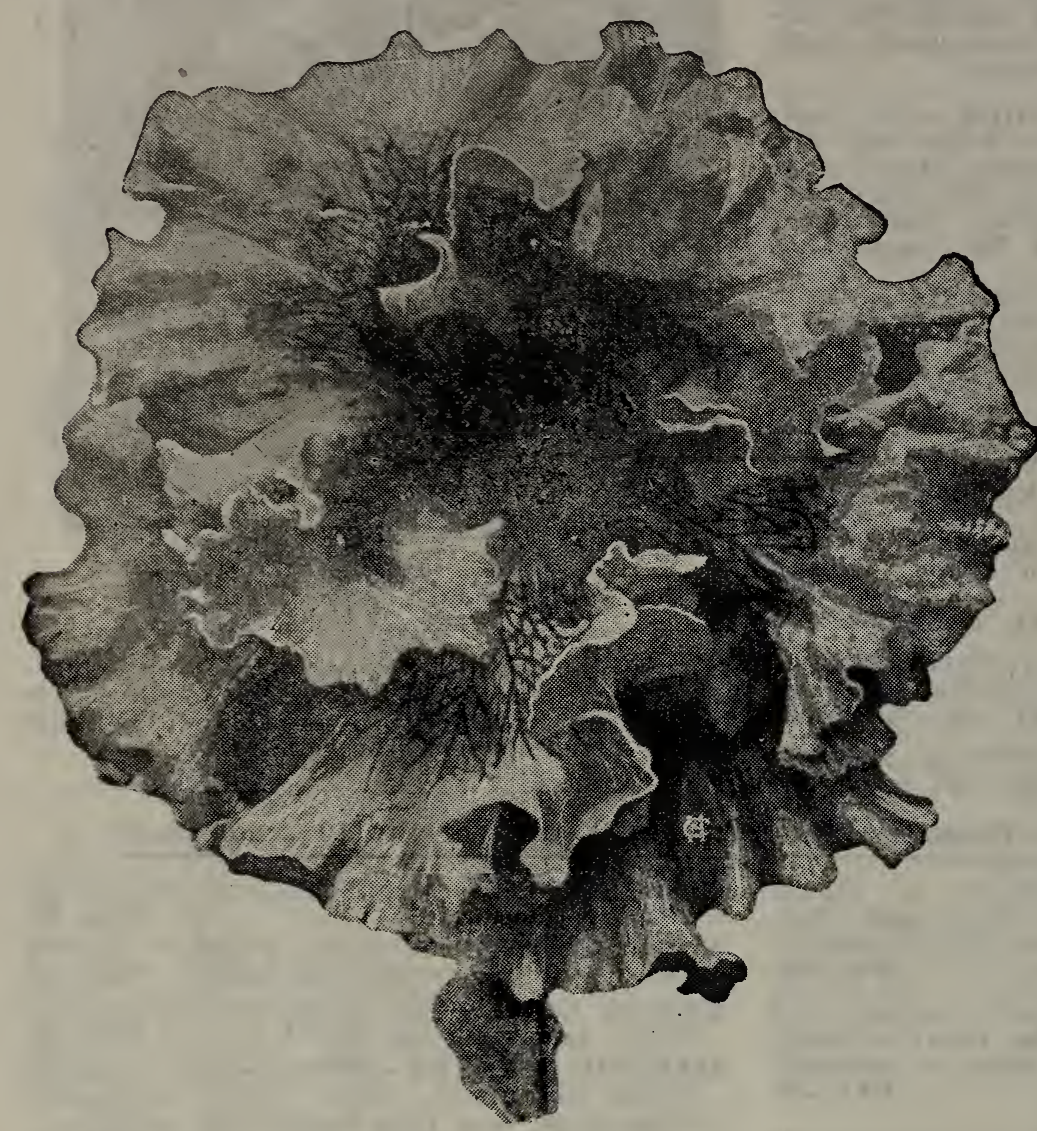

Ruffled Giant Single Petunia

\section{SINGLE PETUNIAS}

RUFFLED GIANTS PRIZE MIXTURE.This strain produces in great profusion enormous flowers, having edges of petals beautifully ruffled and fluted; of great variety of colors, many being beautifully veined; very showy and attractive.

Pkt. 35c; 1,000 seeds $\$ 3.00$ DWARF, LARGE-FLOW. ERING FRINGED. - A new dwarf selection of the most beautiful ruffled and fringed type; compact, free-flowering plants; excellent for bedding or pots.

Pkt. 25c

LARGE - FLOWERED FINEST MIXED.-Fine large flowers in superb mixture. Pkt. 15c

FINE MIXED. - An assortment of mediumsized flowers; fine for bedding.

Pkt. 10c; 1/8-0z. 25c

\section{DOUBLE PETUNIAS}

All of our Double Petunias are selected with greatest care, and contain as large a percentage of double flowers as it is possible to obtain.

GIANT DOUBLE, FIN.

EST MIXED HYBRIDS An exceptionally fine strain; remarkable for the large, beautifully colored double flowers. Pkt. $50 \mathrm{c} ; 500$ seeds $\$ 4.00$

GIANT DOUBLE MIXED -Fringed, unsurpassed. Pkt. 35c; 500 seeds $\$ 2.50$ CHOICE DOUBLE MIX. ED.-

Pkt. 25c; 500 seeds $\$ 1.50$

\section{PORTULACA}

Low-growing or creeping tender annual, six to eight inches high, and bearing glossy, cup-shaped blossoms in very brilliant and gorgeous colors. The foliage and stems are thick. The seed germinates slowly and should be started under glass or when the weather is hot. These flowers love the sunshine and do best on rather dry ground; excellent for embankments.

Single, Finest Mixed.

Double, Finest Mixed.

\section{POPPY-PAPAVER}

Universal favorite of the easiest culture. They produce a wealth of the most beautiful and showy blooms. Both perennial and annual poppies bloom the first year from early-sown seed. Perennial varieties will, but annuals will not transplant safely, therefore sow the annuals where they are to remain and thin out, giving each plant ample room to grow and develop.

ADMIRAL (Annual).-A single variety of surpassing beauty; large flowers of glistening white, with a broad band of brilliant scarlet around the top; produce a magnificent effect. Pkt. 10c; oz. 60c
POPPY

COLLEC.

TION

One Packet Each 6 A.n. nual Kinds only $35 c$.

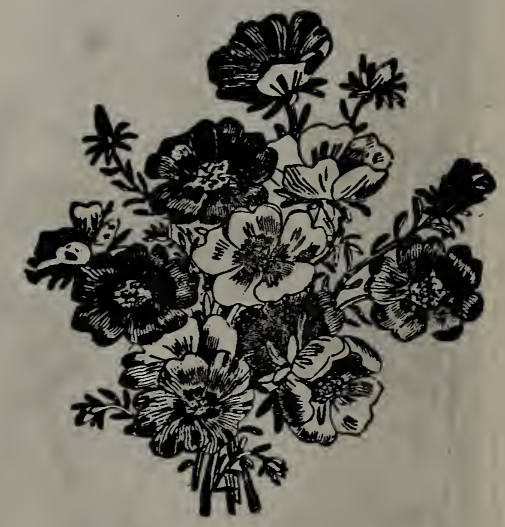

Single Portulaca

\section{POPPY-CONTINUED}

MISS SHERWOOD (Annual).-Single, bears large flowers of a satiny white, shaded a silky chamois rose, a combination of rare delicacy. 


\section{POPPY_Continued}

SHIRLEY (Annual). - Charming Poppies. Flowers single and semi-double, and range in color from the purest white through the delicate shades of pale pink, rose and carmine to the deepest crimson and bloodred, while many are daintily edged and shaded. The petals are like silk. Free blooming and fine for borders or beds; $1 \frac{1 / 2}{2}$ to 2 feet.

Mixed.

Pkt. 10c; oz. 40c

CARNATION FLOWERED (Annual).-Splendid double fringed flowers. Mixed Colors.

Pkt. 10c; oz. 50c

CALIFORNIA POPPY.-(See Eschscholtzia, page 58.)

ANNUAL SUPERB MIXTURE.-A superior strain, containing the choicest of single and double varieties in all of the brightest colors.

Pkt. 5c; oz. 40c

ICELAND, OR NUDICAULE (Perennial).These are of a very graceful, neat habit, with bright green, fern-like foliage, formed in tufts, from which issue slender stalks, about 12 inches in height, bearing beautiful brilliant single flowers in endless profusion, and most useful for cutting. (For plants, see page 82.)

Yellow, White, Scarlet.

Pkt. $10 \mathrm{c}$ Single Mixed.

Pkt. $10 \mathrm{c} ; 1 / 4-0 z .50 \mathrm{c}$

DOUBLE ICELAND MIXED,-Very choice. Pkt. $15 \mathrm{c} ; 1 / 8=0 \mathrm{z} .50 \mathrm{c}$

ORIENTALE BRILLIANT. - This is the most gorgeous perennial Poppy, flowering in June and July, with enormous vivid scarlet blossoms.

Pkt. $10 c ; 1 / 4-0 z .50 c$

\section{PRIMULA}

\section{(Primrose)}

The first two varieties named below are hardy, early-blooming, garden plants, and the others beautiful winter-blooming house plants. Their various forms and blending of colors are exceedingly preasing and effective. They thrive best in a rich, loamy soil.

POLYANTHUS (Veris Mixed.)-Early blooming, dwarf growing plants, valuable for outdoor bedding and edging, 8 inches, perennial. (See plants, page 83.)

Mixed. $\quad$ Pkt. 10c; 1/8-oz. 50c

VULGARIS (Veris Aureau).-Yellow, cornmon, English Primrose; hardy garden variety; perennial; 8 inches.

Pkt. 10c; 1/8-oz. 60c

OBCONICA GRANDIFLORA HYBRIDS.-A lovely, profuse bloomer, bearing beautiful clusters of single flowers for pots only.

Pkt. $15 \mathrm{c}$

SINENSIS OR CHINESE PRIMROSE. Beautiful, large, fringed flowers; especially fine for winter and spring flowers in the house; free bloomers.

Finest Mixed.

Pkt. 25c

\section{PYRETHRUM}

\section{(Golden Feather)}

AUREUM.-Half-hardy perennials, grown as annuals; valuable for edging, as their yellow foliage makes a fine contrast with other bedding plants; 6 inches. Pkt. 10c

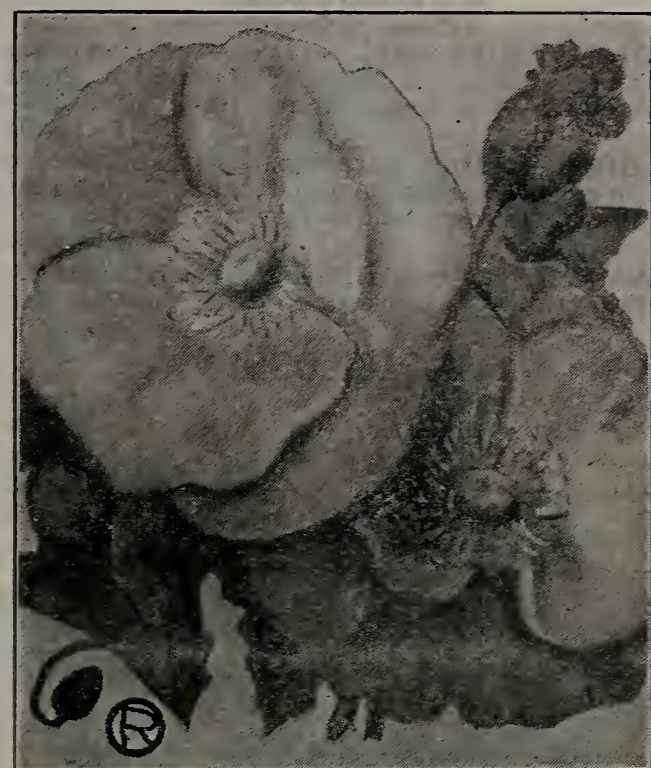

\section{Shirley-Poppy}

\section{RICINUS}

\section{(Castor Oil Bean)}

A magnificent and highly ornamental plant, with picturesque foliage and stately growth, combined with brilliant colored fruit of the giant varieties. Grown as single specimens on lawns and on pleasure grounds, they form a striking feature; hardy annuals.

ZANZIBARENSIS, Mixed.-Very ornamental dark bronzy green and red leaves; 8 to 10 feet high. Pkt. 10c; oz. 35c

SANGUINEUS TRICOLOR - Blood red stems, deep green leaves, with red veins; 6 feet. Pkt. 10c; oz. 35c

GIBSONI.-New dark red foliage; 5 feet.

Pkt, 10c; 0z, 35c FINEST MIXED.-All kinds. Pkt. 10c; oz. 25c

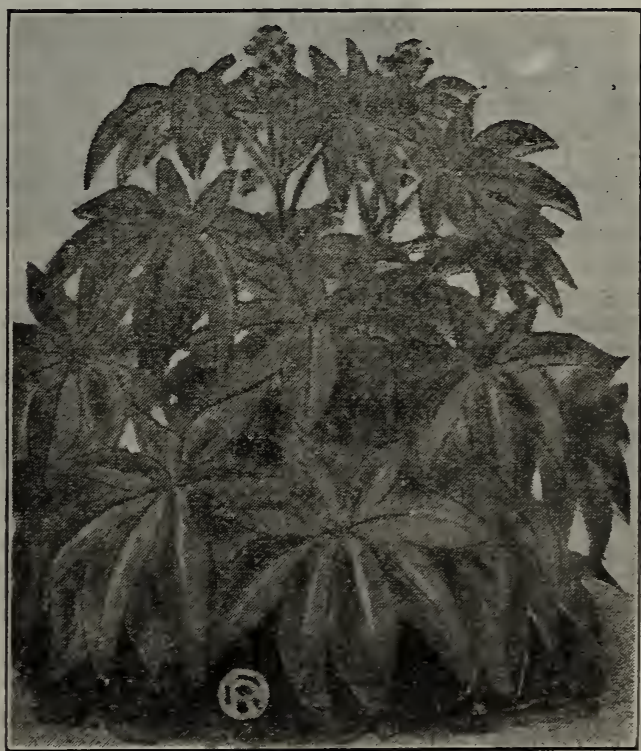

Ricinus (Castor Beans)

HOW TO GROW FLOWERS FROM SEEDS._Our two-page leaflet gives full information and is free on request. 


\section{RUDBECKIA}

(Cone Flower)

BICOLOR SUPERBA. - Fine free-flowering annual variety; 2 feet; producing in great abundance on long stems its bright yellow double flowers. (Plants, 83.) Pkt. 10c

FULGIDA.-Hardy perennial sort, producing in masses during August and september brilliant orange-yellow flowers; 3 feet.

Pkt. 10c

NEWMANI.-Perennial; large, bright orangeyellow flowers, dark centers. Pkt. 15c

\section{SALPIGLOSSIS}

Produces very showy, funnel-shaped flowers of large size; fine for beds; half-hardy annuals.

GRANDIFLORA MIXED. - Large flowering. Pkt. 15c; $1 / 8-0 z$. 35c

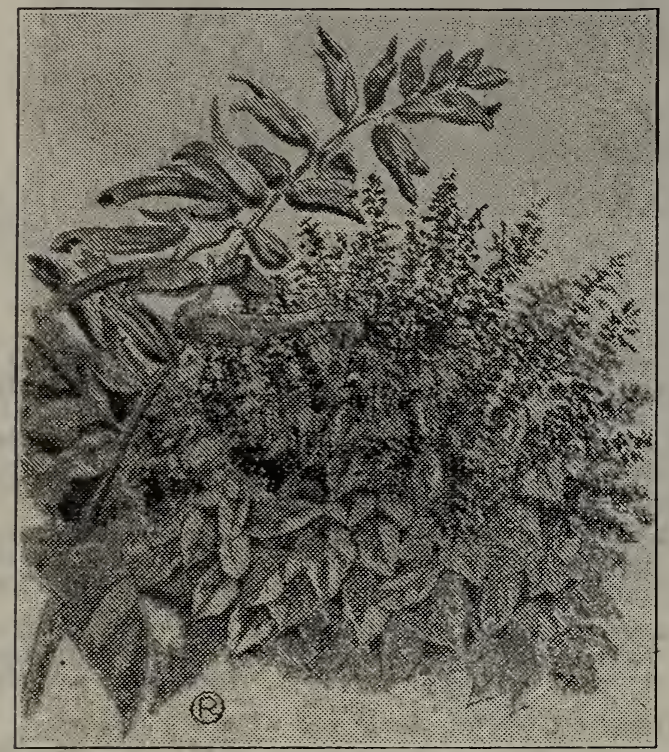

Salvia

\section{SALVIA}

(Scarlet Sage)

The Scarlet Sage has long been a favorite bedding plant, bearing long spikes of brilliant scarlet flowers in great profusion from July till frost; seed should be sown as early as possible, either indoors or in a hotbed, and the young plants transferred to their flowering quarters when the weather has become settled and warm.

SPLENDENS COMPACTA. - A splendid showy variety, with large spikes of bright rich scarlet flowers; 3 feet.

Pkt. 10c; 1/4-0z. $\$ 1.00$

ZURICH.-New dwarf, of speical merit; very early. Brilliant, free flowering; 15 to 18 inches.

Pkt. 20c; $1 / 8-0 z$. $75 c$

BONFIRE.-Of dense compact growth; useful for bedding or borders. Flowers dark scarlet, on spikes which stand clear of the foliage and attract attention at once; 2 feet. Pkt. 20c; 1/8-0z. 75c

\section{SCHIZANTHUS}

\section{(Butterfly Flower)}

Beautiful garden annuals; flowers charmingly fringed and delicately colored; 1 to 2 feet. Blooms quickly from seed.

GRANDIFLORA MIXED. Pkt. 10c $1 / 8-0 z$. 25c

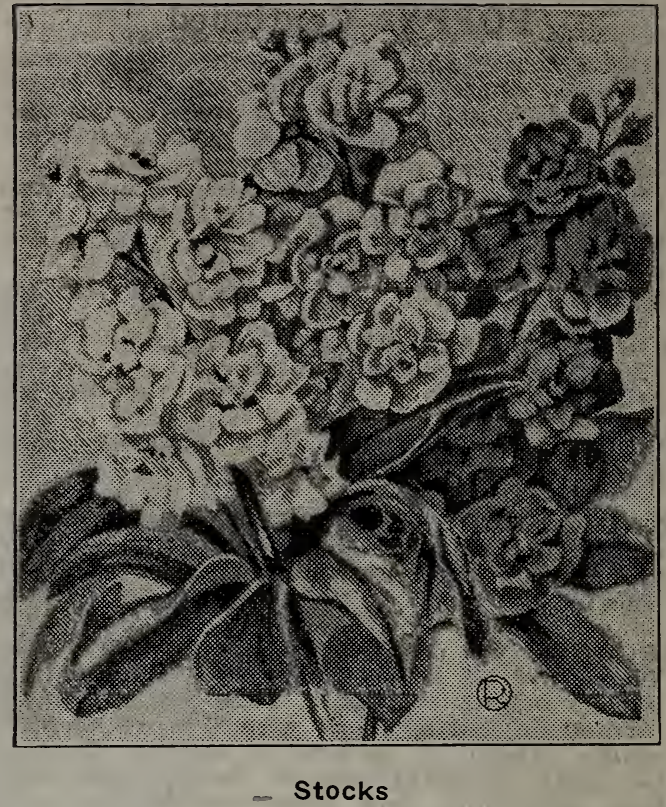

STOCK

(Gilliflower)

By far one of the most popular annuals for garden or greenhouse culture. They are superb for cutting and are of great value to florists for bouquet work. Flowers are of delicious fragrance, large, mostly double, and borne on handsome spikes. While ali will flower the first year, the winter stocks will last for 2 years. They are very hardy and often remain in bloom in the yard all winter in the vicinity of Portland. Sow early and transplant.

LARGE - FLOWERED TEN WEEKS. - A splendid double-flowered strain, especially adapted for bedding and pot culture; pyramidal spikes of brilliantly colored flowers; $11 / 2$ feet.

Finest Mixed. Pkt. 10c; 1/8-0z. 75c

GIANT PERFECTION, OR CUT-AND-COME AGAIN.-Grown for us by experts and the greatest possible care is taken in the selection of good seed. Of branching habit; two feet, and 85 to 90 per cent of large, double flowers; fine for cutting.

White, Light Blue, Crimson, Dark Blue, Pink, Yellow, or Finest Mixed.

Pkt. $15 c ; 1 / 8-0 z .75 c$

BEAUTY OF NICE.-A handsome, new winter and summer stock of quick growth; flowers of large size, double, and freely produced; 2 feet.

Mixed.

Pkt. $15 c$

Princess Alice.-Double white. Pkt. 15c Queen Alexandra.-Soft rosy lilac. Pkt. 15c Beauty of Nice.-Delicate flesh pink,

Pkt. 15c

SUNFLOWER.-(See Helianthus, pgs. 59-60.)

\section{SWEET WILIIAM}

Hardy biennial, widely grown for the handsome, showy heads of brilliant flowers from June to September; $11 / 2$ feet.

Double Finest Mixed.

Pkt. 15c

Mammoth Single Mixed. 


\section{EARLY FLOWERING, LONG SEASON, SPENCER SWEET PEAS}

This now class was first introduced in 1917. They are the best Sweet Peas for the florist to force under the glass for early blooms and very desirable for the garden in many sections where the season is too hot and dry for the regular later flowering "Spencers." Can be planted early or late and come into flower quickly. Especially recommended for the Southern States and the Orient. We do not believe they will ever replace our magnificent giant Spencers, in the Pacific Northwest.

We have secured true seed from the introducers and offer eight choice varieties:

Early Peace.-Large, rich cream pink.

Early Liberty.-Large, sunproof crimson.

Early Melody.-Beautiful, deep pink.

Early Flowering Mixed.-Very fine.

PRICE.-Your choice, 15c per pkt.
Lavender King.-Giant, true lavender.

Sweet Brier.-Distinct, lovely soft salmon.

Early Song Bird.-Splendid light pink.

Early Snowstorm.-Grand pure white.

Collection of all eight for $\$ 1.00$

\section{Prize Collection, New Giant Spencers \\ Rare, Rich and Wonderful}

Collection Price, 10 Lovely Kinds

(value \$1.20), ONLY 85c.

\section{Barbara}

Salmon-colored self of large size. It makes a "telling" bunch either for exhibition or table decoration, and is most effective.

Pkt. 15c; 0z. 75c

\section{Constance Hinton}

A new, very hardy variety claimed to be the largest White spencer to date. The buds are tinted with pink, but as the flower delevops the pink fades out, leaving a beautiful, large, pure white. Black seed, strong vitality. $\quad$ Pkt. 10c; oz. 50c

\section{Dobbie's Cream}

We consider this the best deep cream or primrose colored variety; nicely waved, abundance of four-bloom sprays and most floriferous. Strong and vigorous.

Pkt. 10c; oz. 50c

\section{Elfrida Pearson}

The flowers are of extra large size, great substance, and produced in fours on long stems and in wonderful profusion. Color lovely pink throughout; the buds and flowers tinted with salmonpink. Pkt. 10c; oz. 50c

\section{Fiery Cross}

The beautifully waved and fluted flowers are borne freely on long stems. Color a scorching firered, or scarlet, without any shading and which scintillates and glitters in bright sunlight, thus adding a glowing fire-like sheen which radiates over the flower. Pkt. 15c; oz. 75c

\section{R. F. Fenton}

Undoubtedly the best of the lavender varieties, grand for exhibition and garden decoration; strong grower, gives plenty of fours. The individual flowers are very large and refined; the color is a rich clear lavender.

Pkt. 15c; oz. 60c

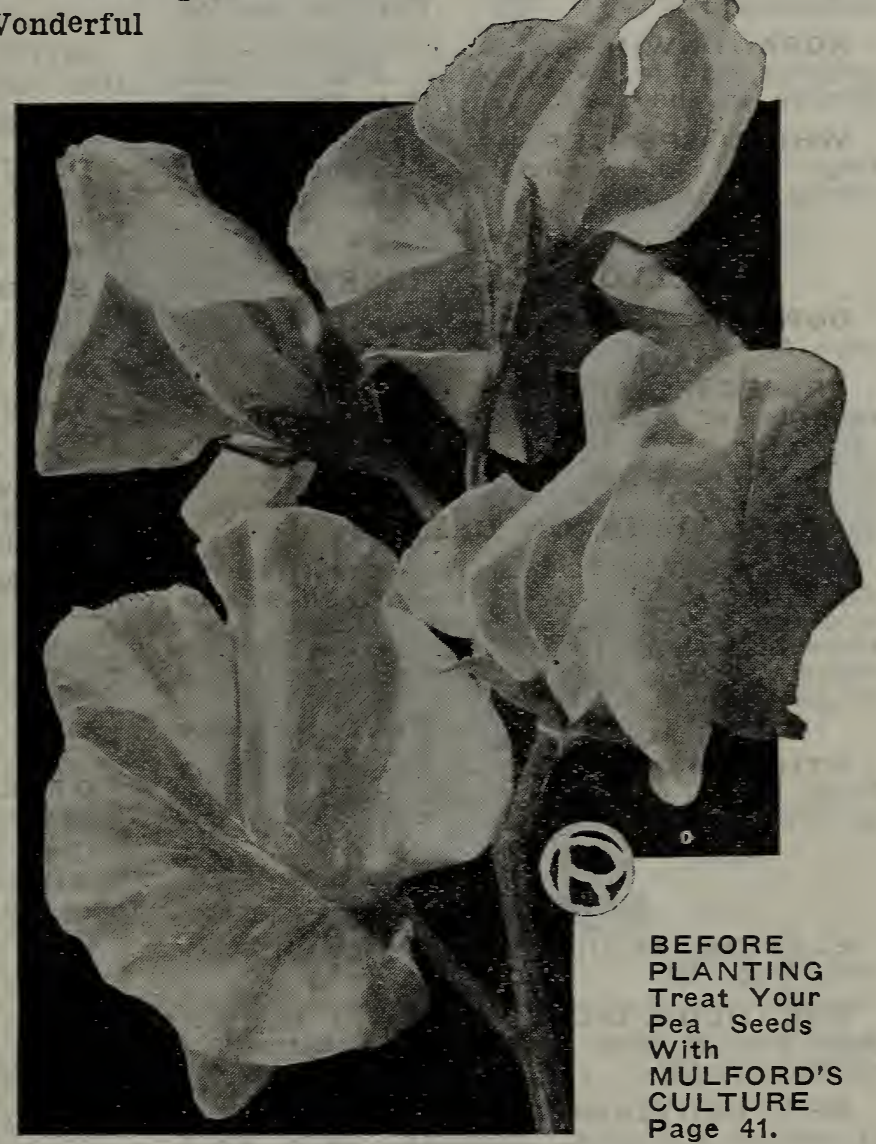

\section{WEDGEWOOD}

Flowers true light blue in color and of fine large full wavy form, some duplex. Pkt. 10c; oz. 50c

\section{HERCULES}

A magnificent soft rose-pink self, of truly giant proportions, undoubtedly the best of its class. A flower of great substance with broad spreading and beautifully waved standard. Pkt. 10c; 0z. 50c

\section{ROYAL PURPLE}

A recent novelty of great merit. A true, rich, royal purple that holds its color. Flowers of giant size a d elegant form, very beautiful bunched with white.

Pkt. 15c; oz. 75c

\section{KING MANOEL}

A giant-flowered maroon or deep chocolate colored variety that is sure to give pleasure to all who admire these rich shades. The flowers are of perfect form and borne in magnificent sprays of three and four.

Pkt. 10c; oz. 40c 


\section{UP-TO-DATE SPENCER SWEET PEAS OF REAL MERIT-Continued}

No seed house offers a more select list. We classify under colors for your convenience SPECIAL_Make up your own collections_60c worth for 50c; $\$ 1.25$ for $\$ 1.00$

\section{WHITE}

CONSTANCE HINTON.-See Prize Collection, page 69 .

ETTA DYKE.-One of the largest and most exquisitely formed pure white Spencers. Beautifully waved; color absolutely pure. Pkt. 10c; oz. 40c

KING WHITE.-Well and truly named; it certainly is "the king" of all white Sweet Peas. In color, size and beauty of flower, length of stem and vigor, King White is unsurpassed. Pkt. 10c; oz. 50c

NORA UNWIN.-Large, pure white, exquisitely crinkled wavy petals, four or more flowers to the stem. Pkt. 10c; oz. 35c

WHITE SPENCER. - A pure white, of large size and splendid substance; long, strong stems. $\quad$ Pkt. 10c; oz. 40c

\section{YELLOW-PRIMROSE}

DOBBIE'S CREAM.-See Prize Collection, page 69

PRIMROSE SPENCER. - A pronounced primrose or creamy white; excellent flower. Pkt. 10c; oz. $40 c$

\section{PINK ON CREAM}

MARGARET ATLEE.-This new, charming variety is one of the finest pink yet introduced. The giant flowers are rich, rosy, salmon pink on creamy buff, a bright yet delicate pink, immense wavy standards and wings inclined to double.

Pkt. 10c; oz. 50c

ETHEL ROOSEVELT.-Giant flowers of finest form. A most charming rich pink on cream. Magnificent. Pkt. 10c; oz. 40c

\section{LIGHT PINK}

ELFRIDA PEARSON.-See Prize Collection, page 69 .

MRS. HUGH DICKSON.-One of the best light pink to date. A European variety of sterling merit. Pkt. 10c; oz. 40c

MRS. ROUTZAHN.-A lovely combination of apricot and pink. Beautiful, large, wavy flowers.

Pkt. 10c; oz. 40c

\section{PINK}

69.

HERCULES.-See Prize Collection, page

COUNTESS SPENCER.-Flowers extremely large, beautifully expanded, crumpled and waved. Color soft shell pink, deeper at the outer edges.

Pkt. 10c; oz. 35c

MRS. A. IRELAND.-The form is beautiful; petals waved and crinkled. The extra large long-stemmed flowers are very attractive; the best rosy pink.

Pkt. 10c; oz. 40c

\section{IAVENDER}

ASTRA OHN SPENCER.-Color a beautiful lavender; flowers large, wavy and generally come four blossoms to the stem. Very popular.

Pkt. 10c; oz. 40c

FLORA NORTON SPENCER.-A beautiful shade of light blue or lavender; very desirable. $\quad$ Pkt. 10c; oz. 35c

R. F. FENTON. - See Prize Collection, page 69 .

\section{ORANGE AND SALMON}

NOTE.-To get the most delicate shade in this color, flowers should be lightly shaded.

BARBARA.-See Prize Collection, page 69.

DECORATOR.-The color is old rose with a sheen of terra cotta giving a bright orange effect. The placement and poise of the flower is perfect. Pkt. 10c; oz. 50c

EDROM BEAUTY.-The bold, majestic flowers are a rich, deep salmon orange. An excellent grower, producing fours in abundance.

Pkt. 10c; oz. 40c

ROBERT SYDENHAM.-This new Sweet Pea is a magnificent glowing, brilliant orange. The large flowers come four on a stem, well placed and beautifully waved. The vines are of vigorous growth, blooming profusely. $\quad$ Pkt. 10c; oz. 40c

THOMAS STEVENSON.-The flowers, of largest size and finest Spencer type, are of an intense flaming orange throughout. A grand exhibition variety. Unsurpassed in color and beauty. Pkt. 10c; oz. 40c

\section{DARK RED_MAROON}

OTHELLO SPENCER. - Free bloomer, Flowers very large and a rich deep maroon. Pkt. 10c; oz. 35c

KING MANOEL.-See Prize Collection, page 69 .

\section{Reports}

Portland, Ore., June 4, 1919.

Routledge Seed \& Floral Co.

Dear Sirs: I have found your seeds su. perior to any others.

Yours truly.

MRS. G. JOHNSON.

Raymond, Wash., March 17, 1919.

Routledge Seed Co.

Dear Sirs: I was very much pleased with the seeds I received last year.

Yours truly.

MRS. C. P. O'BRIEN.

Portage, Wash., February 14, 1919.

Routledge Brothers.

Sirs: Have always found your Seeds and Plants very satisfactory.

I want "Prize Winning" sweet peas, so come to you. Will send for vegetable seed later. Respectfully MRS. F. W. McREYNOLDS.

PRIZE SWEET PEAS.-If you want to grow giant flowers on long stems, you must give your sweet peas good soil, plenty of water at the roots in dry weather, some Wonder Fertilizer, and pick the flowers often. Our "leaflet" tells all_free with each order. Use "C. M." in the Sweet Pea trench. See pages 38-39. 


\section{UP-TO-DATE SPENCER SWEET PEAS OF REAL MERIT-Continued}

No seed house offers a more select list. We classify under colors for your convenience

SPECIAL_Make up your own collections$60 \mathrm{c}$ worth for $50 \mathrm{c}$; $\$ 1.25$ for $\$ 1.00$.

\section{BLUE-PURPIE}

NEW MARGARET MADISON.-Flowers clear azure blue self-a color that always attracts and is so effective.

Pkt. 10c; oz. 40c 69.

ROYAL PURPLE.-See Prize Collection, page

WEDGEWOOD.-See Prize Collection, page 69.

SCARLET_CRIMSON

FIERY CROSS.-See Prize Collec. tion, page 69 .

KING EDWARD SPENCER. - OI vigorous growth, profuse bloomer giant flowers; most popular scarlet: long stems. Pkt. 10c; oz. 40c

SUNPROOF CRIMSON. - An intense pure scarlet self-color of rare beauty and substance. Absolutely sunproof. A stocky, vigorous grower, profuse bloomer; the long, strong stems carry four perfect flowers.

- Pkt. 10c; oz. 40c

Routledge Seed \& Floral Co.

Jefferson, Ore.

Dear Sirs: The Sweet Peas I am growing from your seed are the most beautiful I have ever grown.

Yours truly, MRS. DORA DAVIS.

Bray, Cal., May. 8, 1919. Routledge Seed \& Floral Co.

Gentlemen: The little bird arrived o. $k$. and is a little beauty. Respectfully MRS. O. E. PILE.

La Grande, Ore., March 26, 1919. Gentlemen: I tried your special collection of Sweet Peas last year and everyone said they were the finest they ever saw.

Please send order as soon as you can and oblige,

MRS. THOMAS BRIDGE.

\section{PICOTEE-BI-COLOR \\ Shaded and Striped}

AMERICA SPENCER.-Bright and attractive; white striped bright red; very pretty. Pkt. 10c; oz. $35 \mathrm{c}$

SENATOR SPENCER. - Beautiful large flowers, claret and chocolate on light ground; distinct and greatly admired; a profuse bloomer.

Pkt. $10 c$; oz. $40 c$

WINNIFRED DEAL.-A most beautiful variety; pure white with a very distinct picotee-edge of rose-pink. The general effect is light and dainty.

Pkt. 10c; oz. 60c

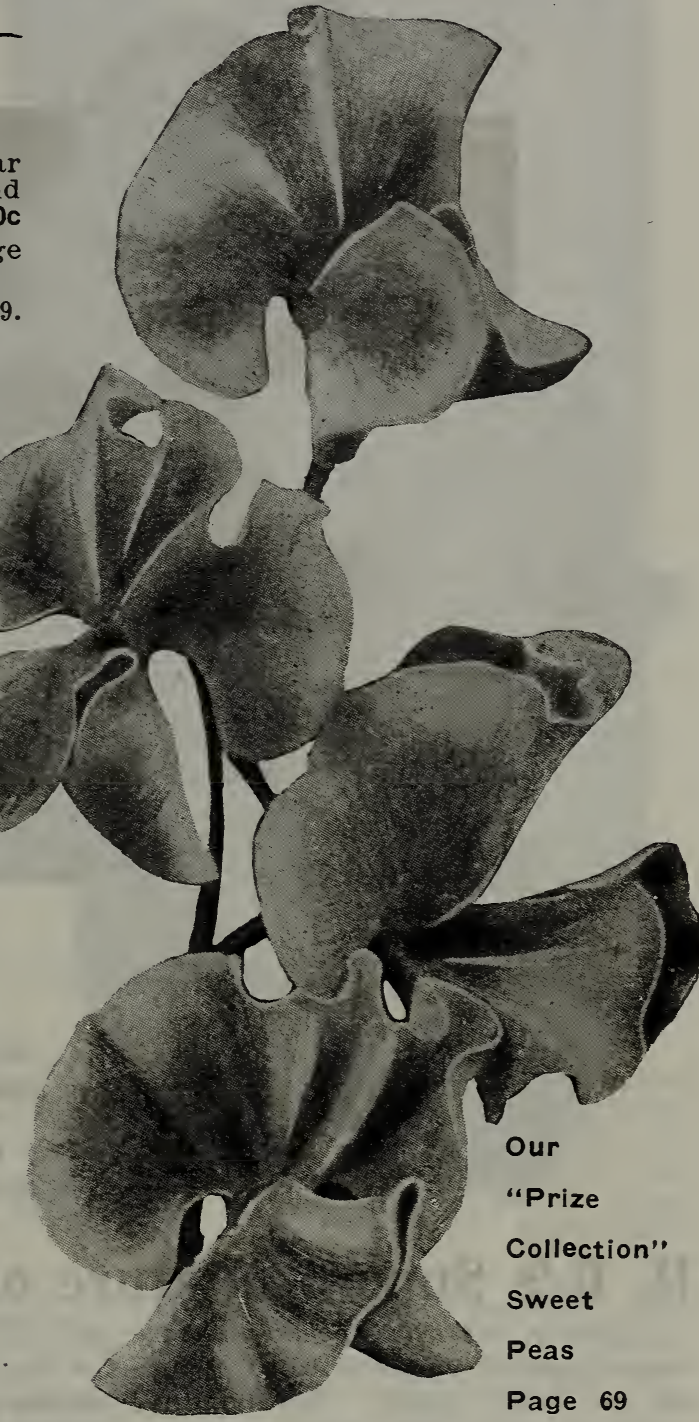

Treat your Sweet Peas with MULFORD'S CULTURE; makes stronger vines, more and larger flowers. (See page 41.)

\section{Cupid Sweet Peas}

Compact dwarf plants, not over six or seven inches high. Flowers of good size and substance. For edgings, low beds and pot culture they are unique and pretty.

Mixed, Pkt. 10c; 0z. 25c; $1 / 4-1 b .75 c$

\section{Rose City Mixture of Grandiflora Sweet Peas}

Extraordinary care has been taken in the selection of the varieties and the quantities of each to make up the mixture, and the result is one that cannot fail to excite the admiration of every flower lover. Of course the flowers of the Grandiflora type are not as large as the "Spencers," but the range of color is complete and they are hardy and very free flowering.

Large pkt. $5 \mathrm{c}$; oz. 15c; 1/4-Ib. 45c; lb. $\$ 1.25$

SEE 1920 SUPERB COLLECTION AND SUPERB MIXED NEXT PAGE.

QUALITY and TRUENESS is what makes the price in Sweet Peas. Low prices never bought "HIGHEST QUALITY" Seeds. Use Mulford's Culture; see page 41. 


\section{SWEET PEAS OF HIGHEST QUAIITY-Continued}

Some others may have as good, but none any finer Sweet Pea Seed than we.

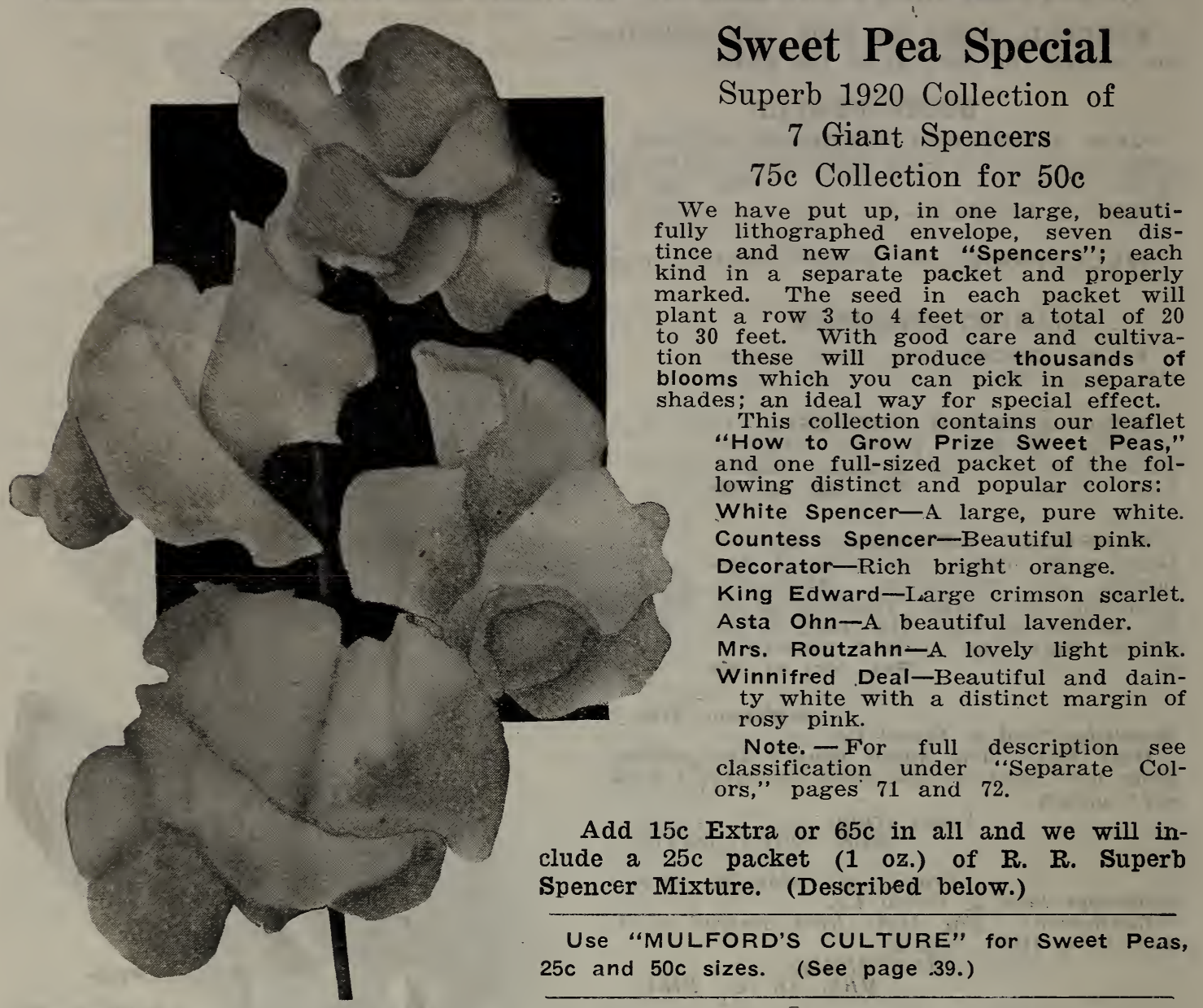

\section{R. R.'s Superb Mixture of Giant Spencer Sweet Peas}

This is our own special mixture and is composed only of the best giant orchid-flowering wavy Spencer varieties, also contains some'new seedlings of promising merit, that have not as yet been named. For healthy, robust growth, wealth of blooms, size of flowers and exquisite and rare colorings, this mixture is unequaled.

Put up and for sale in sealed packages only, 1/2-0z. pkts. 15c; oz. pkts. 25c each; 3 for 60 c; 6 for $\$ 1.00$.

\section{SCABIOSA}

(Morning Bride)

Elegant, hardy annual; fine for cutting and bedding; flowers quite large and very showy, blooming freely during summer and autumn, $2 \frac{1}{2}$ feet. All colors.

Finest Mixed.

Pkt. 10c; 1/4-oz. 35c

White.-Large flowers. Pkt. 10c; 1/4-oz. 50c

\section{SHAMROCK}

This is the genuine Shamrock, and is gathered by a connoisseur on the native land. True Irish.

Pkt. 25c 52.)

SNAPDRAGON. - (See Antirrhinum, page

OUR LEAFLET, "How to Raise Flowers Successfully from 'seed," is free and is OF REAL VALUE.

\section{THUNBERGIA}

Extremely pretty yellow flowers with dark eye; rapid-growing annual trailers; used largely for vases, window boxes, etc.; will flower all summer till frost; 5 feet.

Finest Mixed. Pkt. 10c; 1/4-oz. 50c

\section{TRITOMA}

\section{(Red Hot Poker)}

Striking and exceedingly ornamental autumn flowering plant. Showy flower spikes, shaded red and yellow; 3 feet. (See cut and plants, page 84.)

Pkt. 10c

\section{VALERIANA}

\section{(Garden Heliotrope)}

A fine old-fashioned hardy plant; flowers have a strong heliotrope odor; showy, red or white; fine for bouquets; 2 feet.

Mixed.

Pkt. 10c

A NEW STRAWBERRY-Read about the wonderful "Marvel," a new variety of sterling merit, most delicious of all. Get a start_you'll be delighted. See Page 115. 


\section{VERBENA}

One of the finest annual bedding plants and also suitable for borders, baskets and window boxes; its heads of brilliant-colored flowers produce one mass of bloom throughout the summer. (See cut.)

NEW GIANT.-The most beautiful and remarkable variety yet introduced.

Hybrida Mixed. Pkt. 20c; 1/8-0z. $\$ 1.00$

MAMMOTH.-A carefully selected and improved strain. The trusses and individual flowers are of the largest size, of brilliant colors; free blooming and of vigorous habit. Mammoth White, Scarlet, Rose, Purple or Mixed.

Pkt. $15 c ; 1 / 4-0 z .65 c$

FINE MIXED.-A choice mixture of largeflowering sorts. Pkt. 10c; 1/4-0z. 50c

\section{VIOLET}

Viola Odorata is the well-known English Violet, a free-flowering, hardy perennial. easily grown from seed, though somewhat slow in germinating; succeeds best in partially shaded moist places.

ODORATA.-Blue or White.

Pkt. 15c

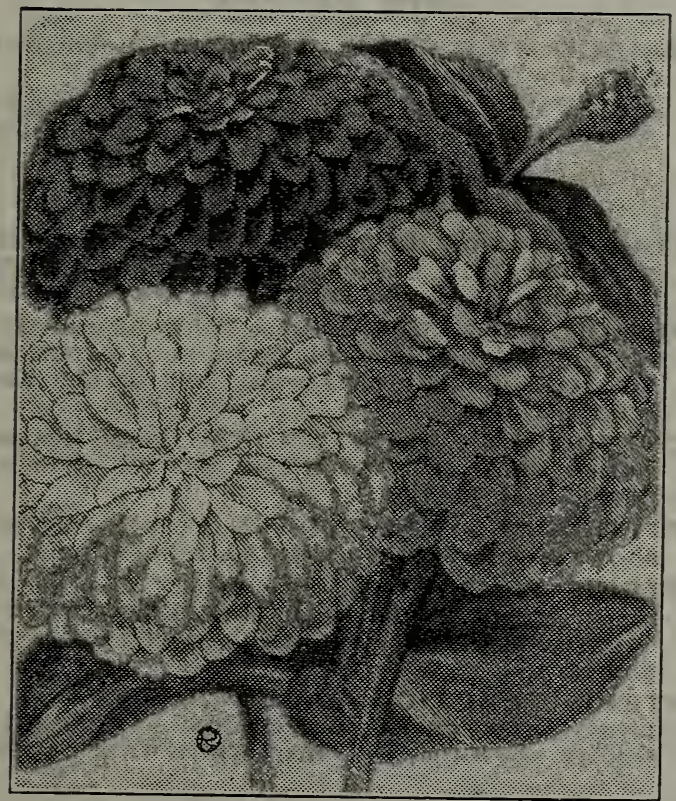

Zinnia

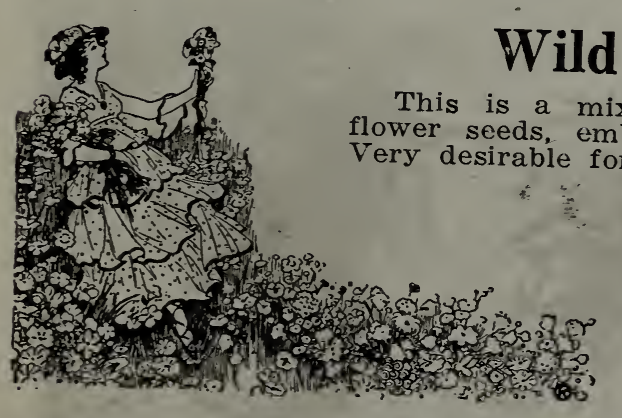

\section{Wild Flower Garden - Mixture}

\section{ZINNIA}

The plants come quickly from seed and make a fine display in a bed or border. Each flower lasts for several weeks, and the plants bloom abundantly until destroyed by frost; $21 / 2$ and 3 feet; annual.

MAMMOTH.-White, Golden, Yellow, Scarlet or Flesh; 3 feet. Pkt. 15c; 1/4-oz. $75 c$ ROBUSTA GRANDIFLORA.-A very selection of the largest showy varieties.

Double Mixed.

Pkt. 15c; 1/4-oz. 60c

TALL GIANT DOUBLE MIXED. Elegant strain, comprising all colors; 3 feet.

DWARF DOUBLE MIXED Pkt. 10c; 1/4-0z. 35c

Pkt. 5c; 1/4-0z. $35 c$

Can you think of anything nlcer than an abundance of flowers for yoruself and your friends who have no grounds? See our special Sweet Pea collectlon, page 69. 


\section{BEAUTIFUL ORNAMENTAL FERNS}

A home, no matter how lavishly furnished, is not complete without decorative plants and palms. The bold, majestic palms and delicate, feathery foliage of the ferns lend a grandeur and magnificence that cannot be obtained in any other way.

READ THIS-Specimen Plants-These are large, choice, well-shaped plants, growing in pots, and are very beautiful. They cannot be mailed. We wrap and pack carefully and ship by express at your expense.

OSTRICH PLUME (See cut)-The fronds of this popular variety are the most delicate and plume-like. They are beautiful, full and fluffy, well-grown plants; are truly magnificent and last well in the house.

Choice plants, $25 \mathrm{c}$ to $35 \mathrm{c}$, postpaid

Specimen plants in pots, $\$ 1.00$ to $\$ 2.00$ Extra large, $\$ 2.50$ to $\$ 3.50$

BOSTON FERN-One of the most beautiful and useful of house plants. It is of easy culture, and its sword-like fronds, in large specimens, attain a length of 3 to 4 feet, produced in a bewildering mass, arching, curving and interlacing in every conceivable direction.

Choice plants, $25 \mathrm{c}$ to $35 \mathrm{c}$, postpaid Specimen plants in pots, $75 \mathrm{c}$ to $\$ 1.00$ $\$ 1.50$ and up to $\$ 3.50$

ASPARAGUS SPRENGERI (Emerald Feath. er) (See cut No. 1)-This is undoubtedly one of the handsomest and most valuable evergreen trailing plants for the house and conservatory ever introduced. It is especially valuable for pots, vases, baskets, etc., covering all with its beautiful sprays of lovely green, feathery foliage; quite hardy and valuable for hanging baskets or porch boxes in summer if given partial shade and plenty of water.

Choice plants, $20 \mathrm{c}$ to $30 \mathrm{c}$, postpaid Specimen plants in pots, $35 \mathrm{c}$ to $75 \mathrm{c}$ Extra large pots or baskets, $\$ 1.50$ to $\$ 2.50$ ASPARAGUS PLUMOSUS (Climbing Lace Fern) (See Cut No. 3)-A finer and more delicate plant than the Sprengeri, but hardy and easily grown. Very satisfactory for window and house culture. An extremely graceful window climber, bright green, feathery foliage, as fine as the fin. est silk or lace.

Cholce plants, $20 \mathrm{c}$ to $35 \mathrm{c}$, postpaid Specimen plants in pots, $35 \mathrm{c}$ to $\$ 1.25$

\section{FILLED FERN DISHES}

These are pretty, popular, fashionable and very desirable for centerpieces for the tea or dinner table or as ornamental plants on the sideboard or center tables.

A choice collection of plants growing in pretty Fern Fillers, $\$ 2.25$ to $\$ 3.50$. (See cut No. 2.)

These must go by express-not mailable.

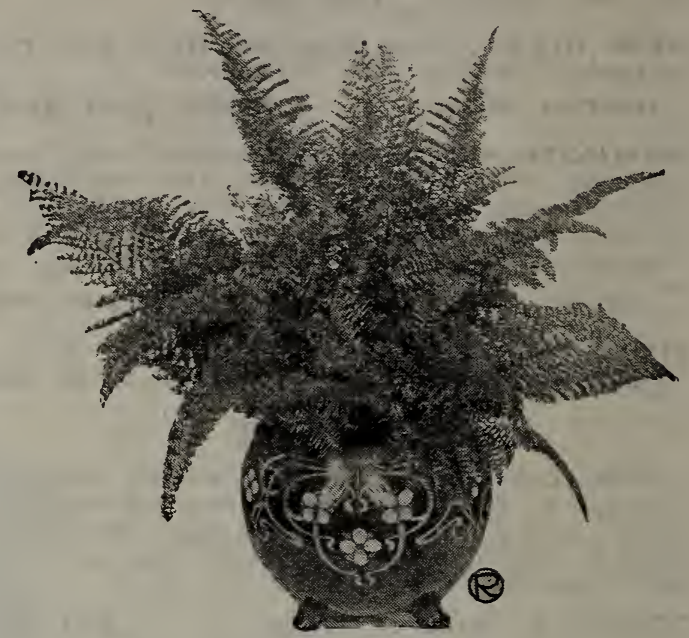

Specimen plant, Ostrich Plume Fern, in a fancy jardiniere

MAIDEN HAIR FERN (Adiantum Cuneatum). -A very beautiful and graceful fern.

Small plants, $25 \mathrm{c}$, postpaid Choice plants in pots, 50c to $\$ 1.00$ each

\section{CHOICE TABLE FERNS}

These handsome little ferns are used mostly in filling fern dishes. Your choice of the following $20 \mathrm{c}$ each; 3 for $50 \mathrm{c}$, postpaid

ASPIDIUM TSUSSIMENSE-Without question the most valuable of all ferns yet introduced for fern dishes; of strong but dwarf and graceful habit.

CRYTOMIUM FALCATUM (The Holly-Leaved Fern)-One of the most desirable; very hardy and pretty.

PTERIS ARGYREA (Silver Fern)-A very showy fern, with variegated foliage.

PTERIS WILSONI-A very pretty and useful fern; green leaves with the ends very peculiarly crested; beautiful sort for fern dishes.

PTERIS CRETICA ALBO-LINEATA - A pretty and useful variegated variety distinctly showing the clear white variegation.

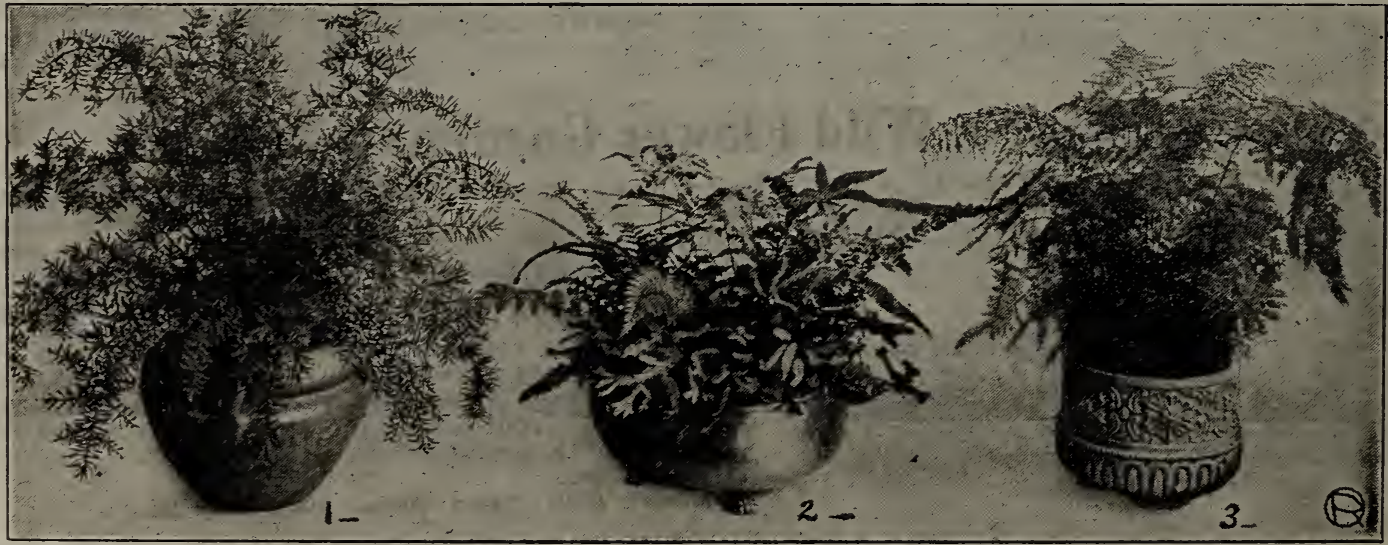




\section{PALMS AND DECORATIVE POT PLANTS}

Everyone knows how beautiful palms and decorative plants are, and how much they improve the parlor, hall or dining-room. We offer here only the best and most desirable kinds of the easiest culture.

NOTE-Specimen plants or plants in pots cannot be mailed. See note top opposite page.

ARAUCARIA EXCELSIA

(Norfolk Island Pine)-

No stock to be had this

year.

\section{m}

PET STOCK

We are headquarters for Birds of all kinds, Puppies, Kittens, Rabbits, Cavies, etc. Our line of pet stock foods, remedies, bird cages and supplies is complete. We issue a special Pet Stock Catalog free on request.

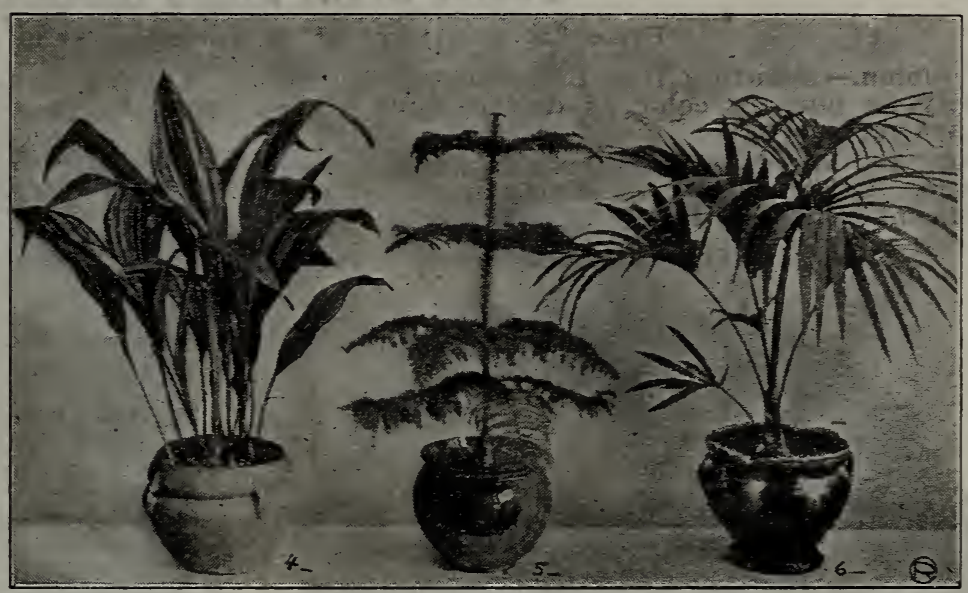

No. 4, Aspidistra

5, Araucaria Excelsior

6, Kentia Palm

KENTIA (See cut No. 6)-A beautiful, grace. ful, handsome looking, strong-growing palm, with deep green, crisp foliage; inclined to dwarf and spreading habit. One of the most popular for home culture, as they are very hardy, and stand the dry atmosphere. If we could have but one palm, it would be a Kentia. (See cut.)

$$
\text { Small plants } \$ 1.00 \text {, postpaid }
$$

Choice plants in pots, 18 to 24 in $\$ 2.50-\$ 3.00$

Specimen plants, $\$ 5.00$ to $\$ 25.00$

ASPIDISTRA (See cut No. 4)-Stately decorative house plant of rapid and hardy growth. The leaves grow quickly from the ground to a height of 18 inches or more. Will stand more gas, dust, cold and heat than any other palm we know of. We have both green and variegated green and white. Green or Variegated Leaves, fine specimens, in pots, $\$ 1.50$ to $\$ 3.00$ and up. Small plants, postpaid, $75 \mathrm{c}$ to $\$ 1.00$.

PHOENIX ROEBELENI (See cut No. 7)-A new palm. One of the most graceful and the hardiest. The horticultural world has enthused over this beautiful palm. It has the grace and lightness of Cocos Weddel- liana. but is more robust in growth and has ten-fold the foliage of that fine variety. Foliage from the ground up, graceful recurved and spreading in habit. It will be most popular for house decoration.

Choice plants in pots, $\$ 1.50$ to $\$ 2.00$ Specimens, $\$ 2.50$ to $\$ 5.00$

RUBBER PLANT (Ficus Elastica) (See cut No. 8)-This is certainly one of the best plants grown for decorative purposes. It succeeds well with ordinary treatment. Its glossy, thick, dark-green leaves are not affected by dust or gas.

Small plants, postpaid, $\$ 1.00$ Choice plants in pots, not mailable, 15 to 18 in., $\$ 1.50 ; 2$ foot up, $\$ 2.00$ to $\$ 5.00$ and up.

DRACAENA INDIVISA (Fountain Plant)This plant is unsurpassed for hardiness. Leaves graceful, long, narrow and pointed. Used extensively for centers in pots, boxes or urns with other plants. Perfectly hardy outside in summer.

Nice plants, 12 to 15 in., $40 \mathrm{c}$ to $60 \mathrm{c}$, postpaid Specimens in pots, 18 to $24 \mathrm{in}$. and up, $75 \mathrm{c}$ to $\$ 1.50$ and up to $\$ 2.50$.

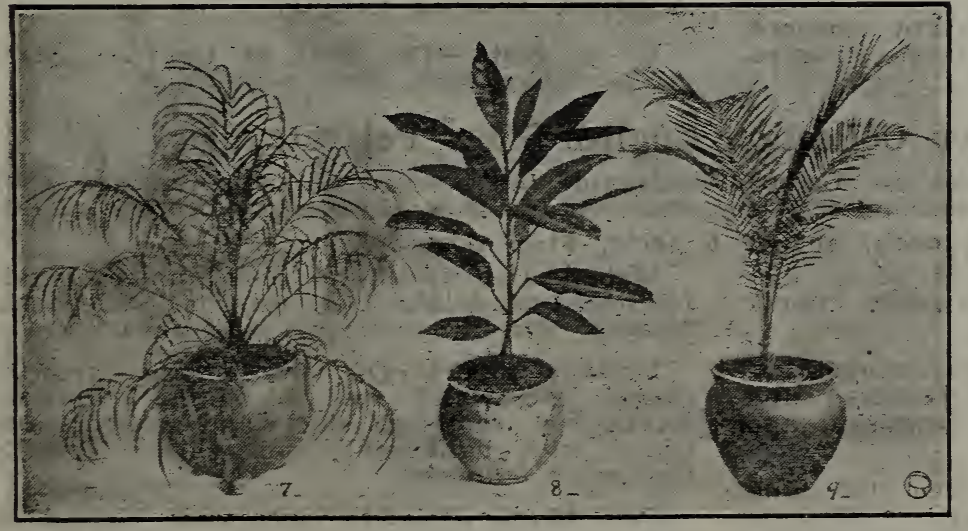

No. 7, Phoenix

8, Rubber Plant

9, Cocos Palm
COCOS WEDDELLIANA (See cut No. 9) - The most elegant and graceful of all the smaller palms. Its slender, erect stem is freely furnished with its graceful arching leaves of rich green color. Small plants are very desirable for centers in fern dishes. Choice plants, 9-inch.

Each $75 c$, postpaid

JARDINIERES, ETC. - We have a full line of standard and new styles Jar. dinieres, Flower and Bulb Pots, Fern Dishes, Japan Tubs, etc. 


\section{FLOWERING PLANT COLLECTIONS}

On this and the two following pages we offer plant"collections grown especially for our out-of-town customers. All orders for these plants are sent direct to the greenhouse where they are gathered, packed and wrapped with special care so they will travel in safety by parcel post. Every plant is carefully labeled. Order any time; we'll send "in season."

\section{Twelve Grand Single Geraniums}

\section{Price 15c each; set of 12 varieties, $\$ 1.50$ postpaid.}

Albion.-Beautiful free flowering white variety as pure in color as driven snow. Always in bloom.

C. W. Ward.-Rich salmon shaded to orange. Large trusses on strong stalks. Magnificent zoned foliage.

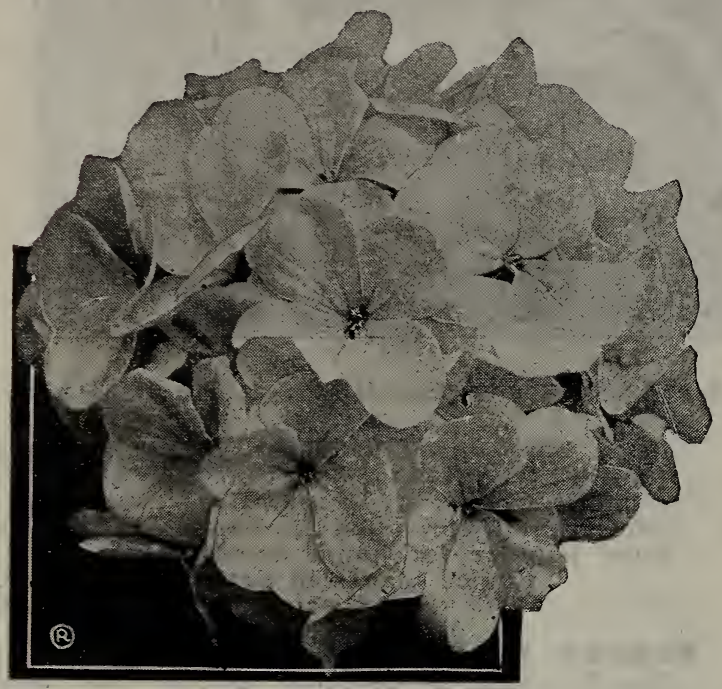

Eugene Sue.-A rare shade of russet orange, the nearest to a yellow geranium.

Jacquerie.-Rich, vivid crimson; immense trusses. Excellent for bedding; blooms freely, stands the sun well.

Mad Chapotan.-Beautiful pink upper petals, marked with white; very pretty.

Madame Mosnay.-Peculiar shade of carmine lake shaded to violet and white.

Maxine Kavolenski.-Odd shade of orange red, very distinctive, splendid bedder, vigorous, handsome, a dependable sort.

Mildred Rival.-Pure rose-pink, with conspicuous white blotch on two upper petals; flower beautifully formed, and the largest of its color.

Mrs. E. G. Hill.-Very large trusses; color, clear salmon, with a white center; one of the finest varietles.

Mrs. A. Blanc.-Silver salmon, shaded peach; glistening texture.

Mme. Cibiel.-Light salmon flesh color bordered orange. Grand trusses of very large florets.

Nuit Poitevine.-Fine, large flowers, lower petals rich violet, bordered with scarlet, upper petals orange scarlet, very distinct.

\section{Twelve Grand Double Geraniums}

Price 15c each; set of 12 varieties, $\$ 1.50$ postpaid.

Abbie Schaefer.-Beautifully formed flowers of a rich crimson scarlet of velvety texture. A grand sort.

Alphonse Ricard.-Rich velvety scarlet, extra large and brilliant.

Edmond Blanc.-Deep carmine red tinged.

Madame Charrotte.-Rosy salmon shaded and reticulated with white; very distinct.

Madame Landry. - Rich bright apricot, shaded with orange, very large trusses. One of the best.

\section{Lady Washington Collection}

These are commonly known as Lady Washington Geraniums. Like geraniums they flower during the summer months and are very ornamental either as house or bedding plants. Price 25c each; set of 6 sorts, $\$ 1.25$ postpaid.

Countess.-Very large flowers of a distinct shade of cerise salmon color; upper petals splashed with maroon.

Crimson King.-Superb dark colored variety. Flowers rich crimson, blotched and feathered maroon. Very free flowering and easy growing.

Easter Greeting.-A new free blooming variety of the greatest merit. Flowers amaranthe red with a well outlined maroon blotch on each petal. Blooms very large and in good-sized trusses.
Madame Recamier.-Ivory white flowers in very large trusses. Strong, healthy grower.

Marquis de Castellane.-Rich solferino color. Immense trusses on strong stalks. Robust grower and very free blooming.

Mrs. Gladstone. - Snow-white shaded to flesh pink in center; superb fancy sort.

Mrs. Lawrence.-Lovely satiny pink shaded to white. Its delicate color is delightful. A grand bedding variety.

S. A. Nutt.-The best of the rich, dark crimson varieties; very popular.

USE "WONDER"-The best Fertilizer and plant food known. A teaspoonful to a plant does wonders. Descriptive pamphlets on request. See page 38. 


\section{CARNATION PLANTS}

For beauty, fragrance and abundance of flowers, for its hardiness, easy culture and adaptability to outdoor or indoor cultivation, no plant excels the ever-blooming Carnation.

\section{Enchantress Collection Everblooming Carnations} Price, 15c each; 12 for $\$ 1.50$ postpaid.

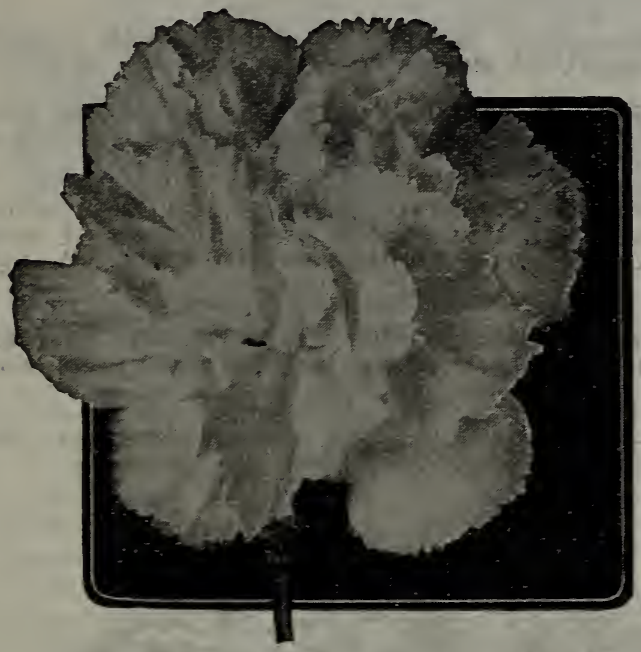

We have selected the varieties in this collection with much pride to ourselves, believing that we are giving to our patrons a set of Carnations which for general planting cannot be excelled. All have flowers of large size, strong and healthy growth and very free-blooming qualities.

Alice.-Delicate flesh pink, very sweet.

Bonora.-White flaked with scarlet.

Beacon.-A brilliant, deep scarlet.

Enchantress.-A superb flesh pink. Herald.-Large, bright scarlet, fringed. Lady Bountiful.-Pearly white; fringed. May Day.-Soft pink with silvery sheen. Mrs. C. W. Ward.-Bright, glistening pink. Pocahontas.-Bright, rich crimson.

Philadelphia.-Beautiful rose-pink, fragrant. Victory.-Intense scarlet, large, fragrant. White Enchantress. -A beautiful white.

\section{QUEEN COLLECTION GIANT JAPANESE CHRYSANTHEMUMS}

\section{Price, 15c each; sets of 10 sorts, $\$ 1.25$ postpaid.}

Artistic Queen.-Fine exhibition variety. Extra large blooms, loosely incurved, very strong stem. Color, rose pink, very fresh and beautiful.

George Bruzzard.-A beautifully shaped bloom; bronzy red in color with reverse side of petals old gold.

Golden Eagle.-Large in size, perfect in form and a superb golden yellow in color.

Harvard.-Produces a good medium-sized bloom of the darkest shade of crimson.

Kitty Lawrence.-Lovely shades of cream and fawn. Large, very graceful formed flowers, with irregular tubular petals of fine substance.

Naomah.-Incurved white. Petals broad and incurving. Flowers of excellent substance.

Chieftain.-A beautiful broad-petaled, incurving variety, round and ruffled; one of the prettiest forms.

Ramapo.-An excellent variety. The heavy golden yellow, richly colored.

Mancato.-An enormous exhibition variety with perfectly double flowers. Color, rosy purple.

William Turner.-Pure white in color. It is enormous in diameter, deep in build and very perfect in form.

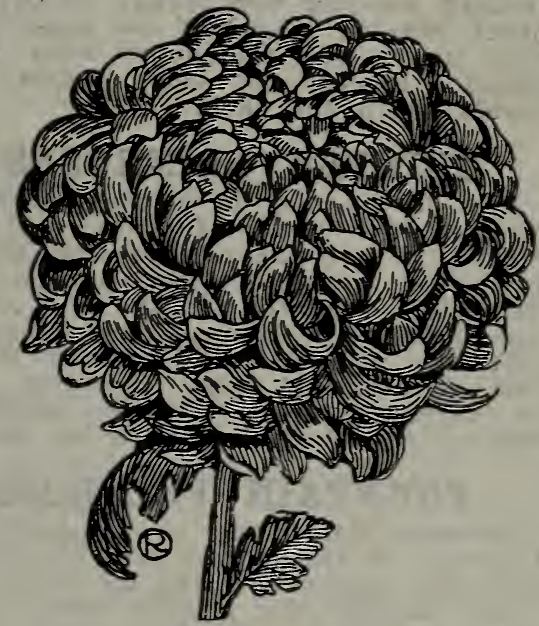

"Incurved" Chrysanthemum

\section{Countess Collection New English Garden Chrysanthemums}

To those persons who have planted the late flowering sorts and failed to get them into bloom before frost, these new imported sorts will appeal. All will flower readily in the garden during September and October, and while the flowers will not be as large as the Japanese, but their freedom of bloom will make up for anything that may be lacking in that respect.

Price, $15 \mathrm{c}$ each; full collection of 10 sorts, $\$ 1.25$ postpaid.

Carrie.-Bright golden yellow flowers in great profusion during September. Dwarf habit.

Cranford Pink.-Lovely silvery pink flowers of fine size, nicely incurved and very lasting. Fine for cut flowers.

Countess of Cariel.-A very free flowering sort of dwarf habit. Color, terra cotta and bronze. Rich and handsome.

Glory of Seven Oaks.-Deep golden yellow, very free flowering. Excellent dwarf habit.

Groachers Crimson.-Large handsome flowers of a rich shade of crimson. Blooms very early.
Leslie.-Light canary yellow. Covered with its pretty flowers early in the fall.

Mignon.- Rosy pink, shaded silvery. Strong, vigorous grower and very free.

Nina Blick.-Rich golden bronze shaded to yellow. Dwarf spreading habit and free flowering.

Normandie.-Delicate shell pink flowers of wax-like texture. Fine for cut flowers. One of the best of this type.

Queen of Whites.-Showy white flowers cover the plant early in the fall. A gem. in the garden. 


\section{BEAUTY COLLECTION CHOICE FUCHSIAS}

This graceful class of plants make especially fine subjects for house culture as well as for planting in the garden. They are almost continuous bloomers and are very easily raised. The single varietios are the most floriferous, while the double sorts bear the larger flowers. Price, 15c each; set of 6 sorts, $75 \mathrm{c}$.

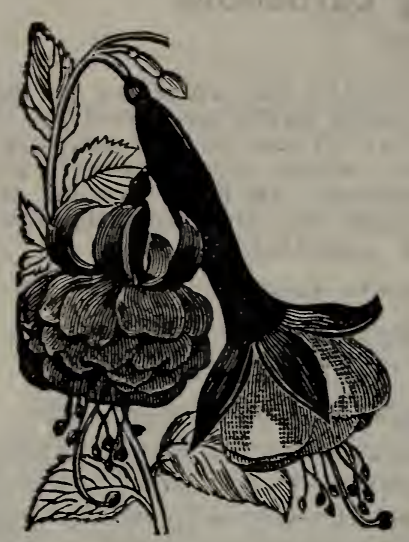

Fuchsia

Annie Earle.-Tube and sepals waxy white, corolla single, clear carmine; plant splendid and free blooming.

Dr. Brooks.-Rich, dark blue corolla, with crimson sepals. A beautiful single variety, never out of bloom.

General Roberts.-Flowers very large, corolla plum color, tube and sepals crimson; one of the finest double varieties.

Little Beauty.-A dwarf growing double. variety, producing with great freedom small flowers of great beauty. Purple corolla with scarlet sepals. A little gem.

Storm King.-Superb double white variety; tube and sepals bright scarlet; corolla large, double and waxy white.

Speciosa.-A winter-blooming variety of large size; tube and sepals blush, corolla bright crimson.

\section{PRIMROSE GIANT OBCONICA}

This is the freest flowering pot plant, blooming throughout the entire season, often having from 15 to 20 sprays of large lavender flowers on stems 10 to 15 inches high at one time, lasting in bloom fully four weeks without fading, continually sending new sprays all over the plant, making it one of the most desirable plants for the house ever introduced. Prices, 25c each; extra large plants 40 to $50 \mathrm{c}$ each.

\section{CHINESE PRIMROSES}

One of the best of all the plants we cultivate for winter flowers, and most worthy of recommendation for window gardening. They flower profusely all through the winter months and also in the summer, if given a cool place and sufficient moisture. We have a very fine selection of large flowering kinds in various shades of red, pink and white. Prices, 25c each; 3 for 50 c.

\section{FOUNTAIN PRIMROSE}

Primula Malacoides. A wonderful new Primrose of the eariest possible cultivation and remarkable for its freedom of bloom during the greater part of the year. Produces myriads of daint $v$ little pink blossams in umbels on stems well above the ornamental green foliage. Even the smallest plants will bloom freely. Prices, 20c each; large plants $35 \mathrm{c}$ each.

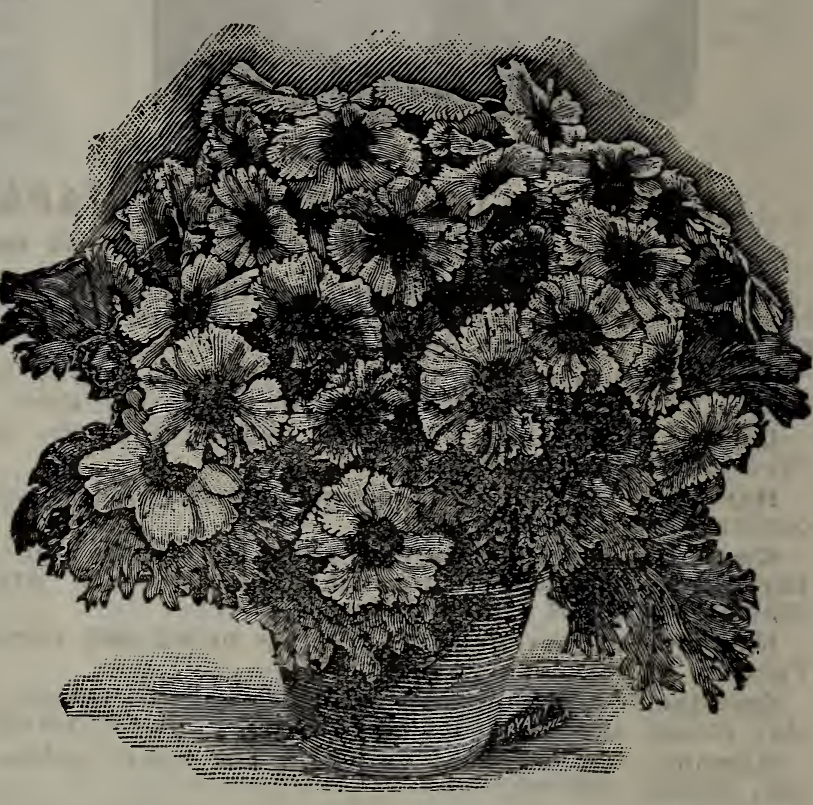

Chinese Primrose

Chelan Falls, Wash., April 4, 1919. Routledge Seed \& Floral Co. Dear Sirs: The lovely bird you sent me last fall is doing splendidly and sings beautifully.

Yours truly,

\section{BEAUTIFUL FLOWERING BEGONIAS}

$15 \mathrm{c}$ each; full collection of 6 for $75 \mathrm{c}$ postpaid.

Probably the most satisfactory class of plants for house culture obtainable. Of easiest possible culture; their waxy flowers produced in much profusion, together with their handsome foliage, make them most desirable subjects for the window garden.

Bertha Chaterocher. Covered all the year with bright scarlet flowers. Handsome green foliage. A fine house plant.

Dewdrop. Pretty ovate shining green foliage. Myriads of pure white flowers all the year. Never out of bloom.

Foliosa. The freest-flowering Begonia we have. Makes a handsome window plant; pink flowers.

Gloire de Chatelalne. Glossy green ovate leaves, flowers white heavily bordered with rose pink. A grand new variety from France.
Marguerite. Bronzy green, with purple cast; trusses of cream and rose-colored flowers.

Nitida. Glossy green leaves of wax-like substance. Clusters of pure white flowers produced freely for a great part of the year.

\section{REX BEGONIAS}

Grown for the beauty of the foliage. The leaves are large, variegated and margined with a peculiar silver-metallic gloss. Prices, $25 \mathrm{c}$ each; 3 sorts for $65 \mathrm{c}$. 


\section{GENERAL PRICE LIST OF ANNUAL BEDDING PLANTS}

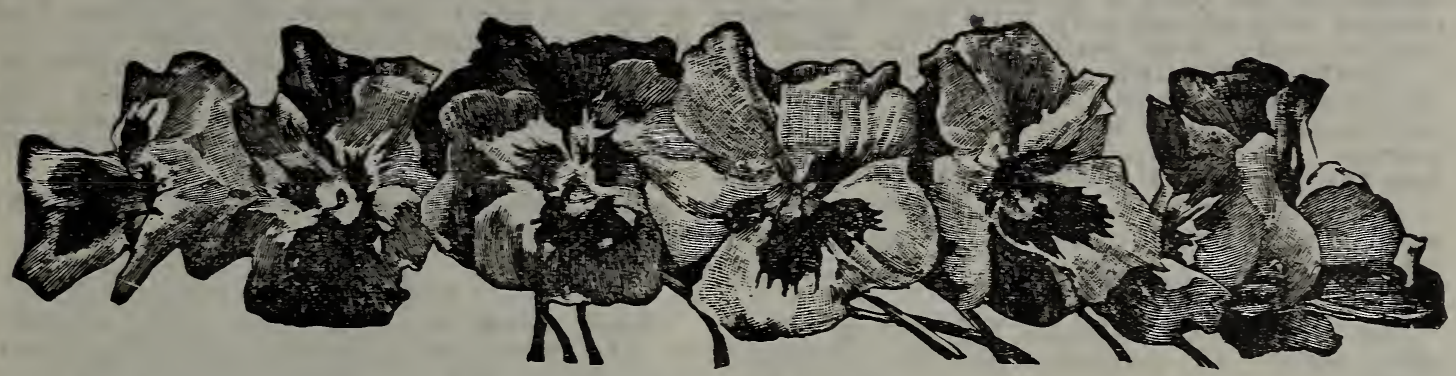

During April, May and June we have thousands of flowering and ornamental annual plants. No order too large or too small. Write for 100 prices if interested.

BY MAIL. - If you add $3 \mathrm{c}$ each or $30 \mathrm{c}$ per dozen we will prepay charges on above plants excepting those from pots (3 inches or over), which cannot be mailed safely and must go by express, you to pay transportation charges. No plants sent C. $O$. D.

For descriptions see Flower Seed Department of this catalog

Agerantum-

Blue or mixed, $T \ldots \ldots 3$ for .25

Alyssum -

Sweet, $T$. . . . . 20

Antirrhinum-

Snapdragon $\ldots \ldots \ldots \ldots \ldots 3$ for .30

Aster-

Giant Crego, white, pink. purple or mixed, T.......3 for .20

Candytuft-

Mixed or white, $T \ldots \ldots 3$ for .20

Carnation-

Named varieties (see page 77)

Chrysanthemum-

Named varieties (see pages $7 \overline{7}$ and 81 )

Cosmos-

Red, pink, white or mixed, T. .10

Cobea Scandens-

From 2-inch pots ........ .15

$\mathrm{F}_{\perp}$ Om 3 inch pots $\ldots \ldots \ldots \ldots \ldots . .25$

Coleus-

Choice colors, 2-inch pots..... .20

Choice colors, 3-inch pots..... .25

Dracenia Palm (Fountain Plant), (see catalog sizes, page 75).

Geraniums-(See collection, page 76.)

Single or double varieties in scarlet, red, salmon pink, deep pink, light pink or white or Ivy Leaved trailing, pink or red.

From 3-inch pots $\ldots \ldots \ldots \ldots . .20$

From 4-inch pots $\ldots \ldots \ldots \ldots . .25$

From 4-inch ext $\mathrm{r}$ a select plants in full bloom ..... .30

Pelegonium (Lady Washington) From 2-inch pots ........ .25 From 3 -inch pots .........

From 4 and 5 -inch pots, specimens in bloom ...550 to .75

Trailing Ivy-(For baskets and Boxes)

2-inch pots $\ldots \ldots \ldots \ldots \ldots \ldots \ldots . .15$

3 -inch pots $\ldots \ldots \ldots \ldots \ldots \ldots \ldots \ldots \ldots \ldots . .20$

Heliotrope-

Blue, $\mathrm{T} \ldots \ldots \ldots \ldots \ldots \ldots$ for .30

Blue, 2 -inch pots $\ldots \ldots \ldots \ldots \ldots \ldots . .15$

Blue, 3-inch pots $\ldots \ldots \ldots \ldots \ldots \ldots . .20 .20$

Blue, 4-inch pots $\ldots \ldots \ldots \ldots \ldots . .25$

Doz.

.60

Note.- "T" stands for transplanted
Doz.

1.50

2.50

2.00

2.50

2.00

2.50

3.00

2.50

3.50

1.50
2.00

.75

1.50

2.00

2.50
Each. Doz.

Compacta or Trailing, T...3 for .20

.50

Marigolds-

African-Double orange yellow

French-Double yellow marked

w it h brown - red, Tall or

Dwarf $\ldots \ldots \ldots \ldots \ldots \ldots$ for .20

Pansy-

Choice plants, blooming age, 12 in a basket, steel's Masto12 in a basket, Steel's Masto-
dons in full bloom, by express only (charges collect) ......

Petunias-

Single Ruffled Giants, or Dou-

ble, mixed colors only..... . .10 .75

From 2-inch pots ........ $15 \quad 1.50$

From 3 -inch pots $\ldots \ldots \ldots \ldots .25 \quad 2.50$

From 4-inch pots ........ $.30 \quad 3.00$

Phlox-

Drummondi, annuals mixed, $\begin{array}{r}\mathrm{T} \\ 3 \text { for }\end{array} .20 \quad .60$

Salvia (Scarlet Sage)

Splendens, tall $\mathrm{T} \ldots \ldots \ldots 3$ for $.20 \quad .60$

Zurich, a Fireball, new dwarf, T $\quad .10 \quad .75$

3-inch pots ............... .20 2.00

4 -inch pots $\ldots \ldots \ldots \ldots \ldots \ldots . .25 \quad 2.50$

Stocks-

Fine Mixed Colors, $T \ldots \ldots 3$ for $.20 \quad .60$

Verbena-

Fine Mixed, $T$........ for $.20 \quad .60$

From 2-inch pots ........... $.15 \quad 1.50$

Vinca-

Variegated, from small pots... $.15 \quad 1.50$

Variegated, from large pots... $.25 \quad 2.50$

Zinnias-

Giant Mixed ......... 3 for .25

.75

Plant Tubs or Japanese Kegs

Filled with large flowering plants and vines; for porch or garden display.

Size 13-in. $\$ 3.50$ to $\$ 5.00$ with Dracaena center Size 13-in. 3.00 to 4.00 with Daisy center

Filled with large flowering plants and vines.

Size 10 -in. $\$ 2.00$ to $\$ 2.50^{-}$(Cannet be

Size 12 -in. 3.00 to 3.50 shipped safely)

REMEMBER, we are not offering you little seedling plants, pulled from the seed beds. Our plants are strong, healthy, transplanted plants from flats or pots, raised from our HIGHEST QUALITY SEED Or propagating plants of SUPERIOR MERIT. 


\section{HARDY PERENNIAL FLOWERING PLANTS}

No class of plants enjoy greater popularity at the present time than the Hardy Perennials. They have made rapid strides into public favor the past few years, until now they may be considered to have a prominent and a permanent place in our American gardens. Once planted they require very little care, increasing in size of plant and profusion of bloom from year to year. Most varieties can be taken up, divided and reset every third year.

LARGE STOCKS-LOW PRICES.-We are in a position to supply unlimited quantities it special prices and you will find our plants are strong and well rooted. Our prices must not be compared to Eastern lists, for our plants are all hardy, field grown, worth double the average stock sold. Limited space will not permit us to list all varieties we can supply. Ask for any special varieties wanted.

PRICES.-AII prices postpaid-10 times the each price is dozen price. BY REQUEST we will send larger plants if you will pay express or freight charges.

\section{ACHILLEA}

The Pearl. Pure white flowers on long, erect stems all summer; fine for cutting; 2 feet.

\section{ANCHUSA}

Italica--(Dropmore variety.) New. The bright blue Forget-Me-Not-like flowers are clustered on graceful stems during the entire season and way late into the fall; 3 feet.

Each 20c

Myosotidiflora. - New; rich blue flower sprays in June; 1 foot. Each 30c

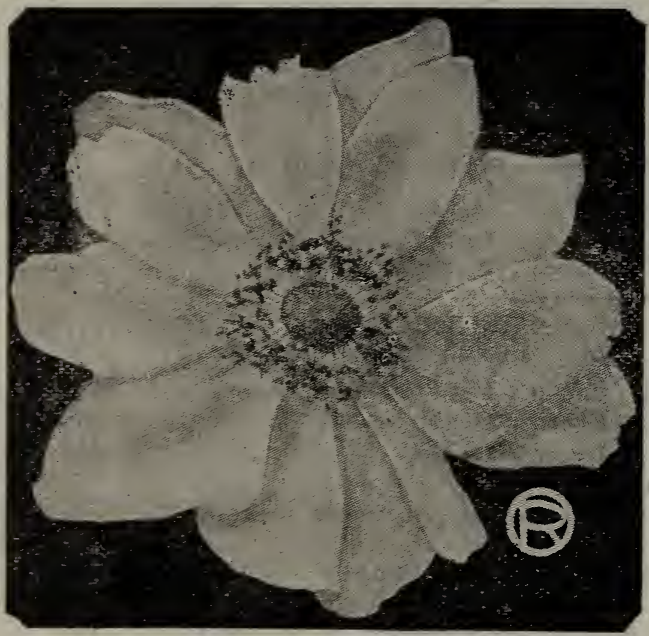

Anemone

\section{ANEMONE}

JAPANESE.-These beautiful Windflowers are one of the most important hardy plants. They begin blooming early in August and continue in full beauty until cut down by hard frost. Excellent for bouquets, lasting for days when cut; $2 \frac{1 / 2}{2}$ to 3 feet.

Geante Blance.-Very large, pure white.

Queen Charlotte.-Beautiful La France pink. Large, semi-double flowers.

Whirlwind.-Fall; pure white, semi-double.

Rosea Rubra.-Beautiful rosy red; stamens bright yellow.

Kriemhilde.-Lovely rosy pink.

Each 25c; Collection 5 Kinds $\$ 1.00$

PULSATILLA.-Dwarf, for rockery or borders, violet blue flowers in April and May. Each $35 c ; 3$ for $\$ 1.00$

\section{ALYSSUM}

Gold Dust (Saxatile Compactum).-Large heads of golden yellow flowers in May and June; silvery foliage; fine for rockeries; 10 to 12 inches. Each 25c; 3 for $60 \mathrm{c}$

\section{ARABIS}

Rock Cress.-One of the most desirable of the very early spring flowering plants for edging and the rock garden. Forms a dense carpet, completely covered with pure white flowers; 6 inches. Each 25c

\section{ASTERS-HARDY}

Popular and free flowering, fine for cutting or mass effect. We have eight varieties, in shades of rose, blue and pink; dwarf 12 to 15 inches, tall 3 to 4 feet.

Each 35c; 3 for $\$ 1.00$

Full collection 8 kinds $\$ 2.25$.

\section{Aquilegias}

\section{(Columbines)}

The Columbines are one of the most elegant and beautiful of hardy plants, producing their graceful spurred flowers on stems rising two feet or more above the beautifully divided foliage, and are highly prized for cutting; June to September

Mixed.-Very choice. Each 35c; 3 for $\$ 1.00$

\section{Bellis Perennis}

English Daisy.-Popular early flowering plants. Very pretty for small borders.

Double Red or White.

Each 15c; doz. $\$ 1.50$

\section{Coreopsis}

Lanceolata Grandiflora. - Popular hardy plants. The flowers are a rich golden yellow, of graceful form and invaluable for cutting; the main crop comes during the latter part of June, but it continues in bloom the entire summer and autumn; it succeeds everywhere; $11 / 2$ feet. (See cut.)

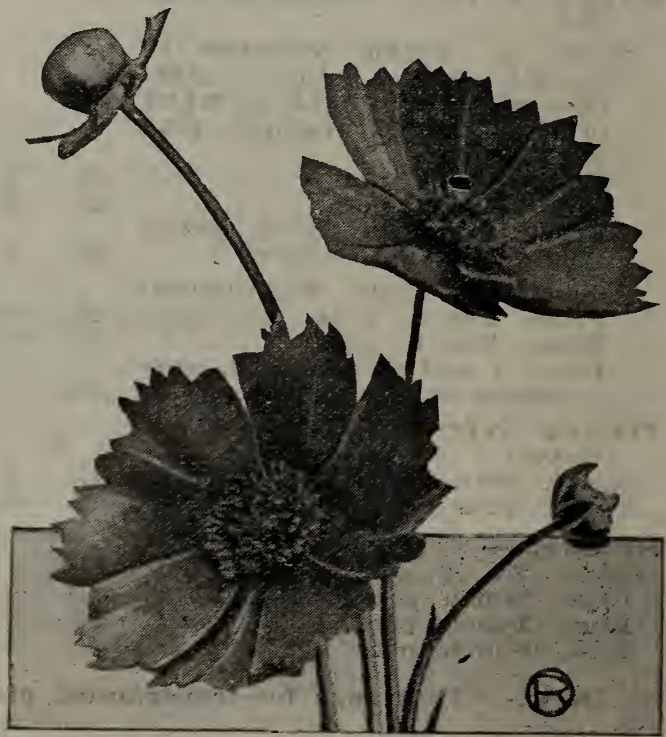

Coreopsis 
PRICES.-All prices postpaid-10 times the each price is dozen price. BY REQUEST we will send larger plants if you will pay express or freight charges.

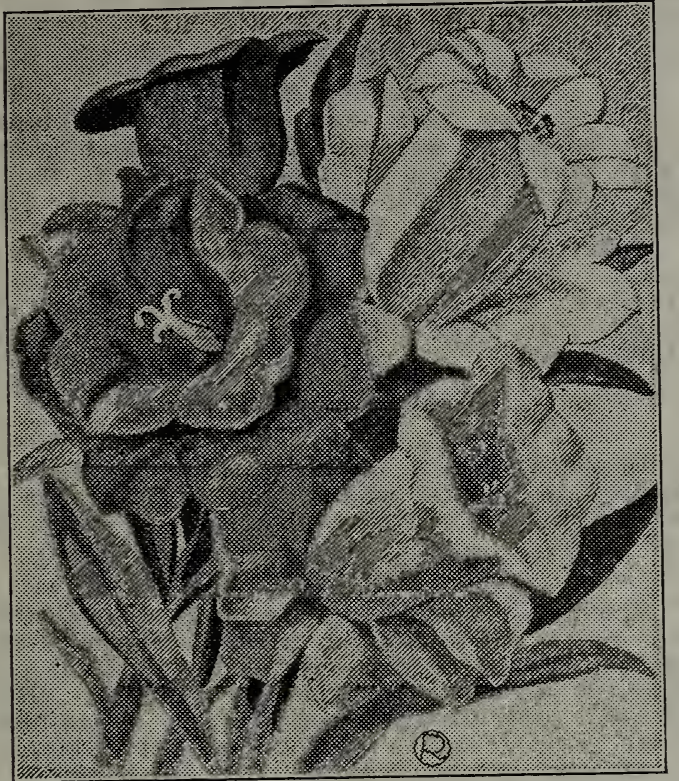

Canterbury Bells-Calycanthema

\section{Canterbury Bells}

(Campanulas-or Bellfiowers)

One of the most popular hardy garden plants on account of the beautiful clusters plants on account dainty yet large flowers. They are very showy. The "Calycanthema" are only "biennials."

PERSICIFOLIA (Peach Bells).-Large clusters of drooping bell-shaped flowers during June and July; 3 feet.

Blue or White.

Each 20c

CARPATICA (Carpathian Hare-Bell.) Free-flowering, hardy perennial, continuing in bloom the whole season; grow in compact tufts 6 inches high; flowers on wiry stems; 15 inches; especially good for edging.

Blue or White. Each 35c; 3 for $\$ 1.00$

CALYCANTHEMA (Cup and Saucer Canterbury Bells).-A beautiful form of this favorite flower. (See cut).

Blue, Rose or White.

Each 25c

\section{Chry santhemums}

They produce a lavish profusion of blooms after most flowers are gone; very popular.

Hardy Garden.-Small flowers.

Yellow, Bronze, Red, Pink or White.

Each 25c; 5 for $\$ 1.00$

\section{Doronicum}

One of the most effective and very early spring flowering perennials, growing about 2 feet high, producing a profusion of Marguerite-like golden yellow flowers of much buerite-like golden yend elegance. It is a splendid flower for cutting.

Each 20c

DAISY.-See "Bellis," page 84 for English, also page 80 for Shasta Daisy.

\section{Dianthus}

Deltoides (Maiden Pink.) - A charming creeping variety, with međium-sized pink flowers in June and July; especially suited for the rock garden or borders. Each 20c

\section{Delphinium}

(Hardy Larkspur)

These are deservedly one of the most popular subjects in the hardy border, bold, attractive and highly prepossessing plants of easiest culture; perfectly hardy; 3 to 4 feet. Fine for cut flowers, June to November; when the first blooms are faded, cut all foliage close to the ground and a second crop will come. (See cut.)

Mixed Hybrids, all shades.

Each 20c

\section{CHOICE NAMED VARIETIES}

Full Collection the following 6 kinds $\$ 1.50$

Belladona.-A free and continuous bloomer; flowers clear turquoise blue; very beautiful; long flower spikes. Each 25c

Carmen.-Flowers very large and semidouble; of a deep blue; center rosy plum.

Duke of Connaught -Very attractive, $25 \mathrm{c}$ oxford blue, with a bold white eye.

Each 25c

Formosum.-Dark blue, white centers; an old favorite; 3 to 4 feet high. Each 25c

King of Delpheniums.-New and distinct; giant, semi-double flowers on strong stems; deep blue, white eye; 5 feet. Each 35c

Moerheimi.-A new and continuous bloomer; pure white; 5 feet tall. Each $35 \mathrm{c}$

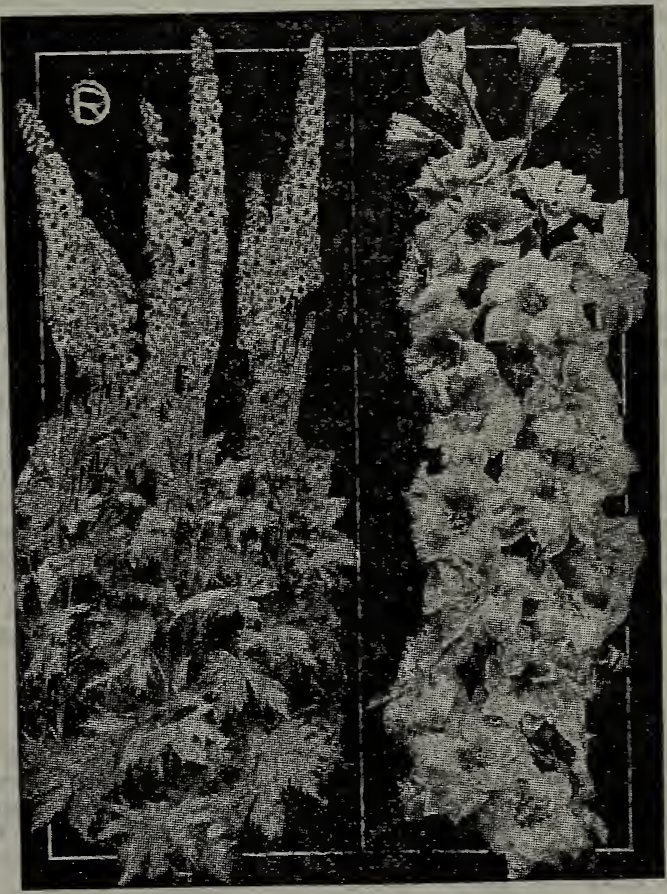

Delphinium (Plant and Elower Spike)

\section{Digitalis \\ (Foxglove)}

Old-fashioned hardy, desirable plants with broad foliage and showy flowers borne on spikes. June and "July; 4 to 6 feet. Mixed colors.

Each 20c

Montrosa (Glant Foxglove). - Handsome, variously colored flowers in spikes survounted with one large, saucer-shaped terminal flower Mixed. Each $25 \mathrm{c}$

FOR BEST RESULTS, plant these hardy perennials in the fall or early in the spring before new growth gets too far advanced. 


\section{HARDY PERENNIAL FLOWERING PLANTS-Continued}

NOTE._20c plants are $\$ 2.00$ doz.; $25 \mathrm{c}, \$ 2.50$ doz. See note top page 80

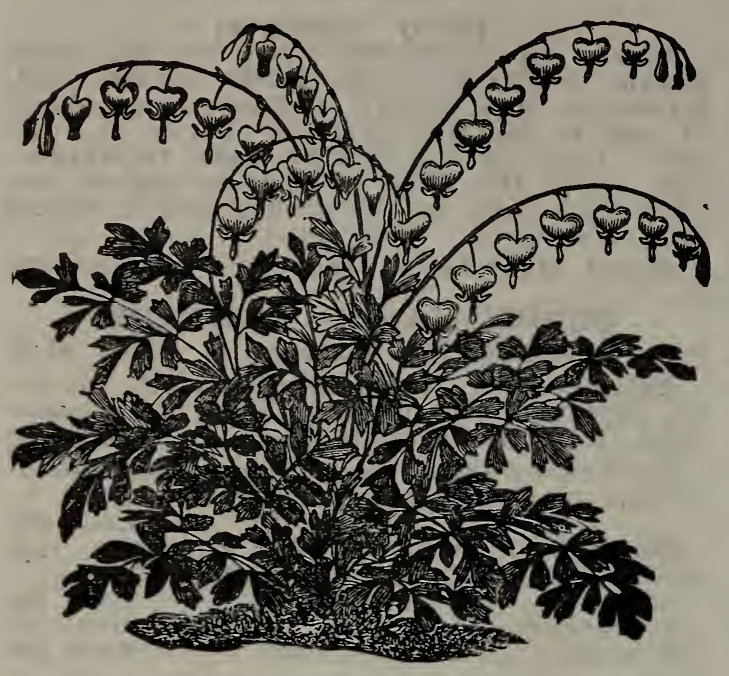

Dicentra-Bleeding Heart

\section{Dicentra}

(Bleediny ritart)

An old-fashioned favorite; its long racemes of graceful heart-shaped pink flowers are always attractive. Perfectly at home in any part of the hardy border, and especially valuable for planting in the shade. Each 50c; extra large 60c

\section{Gaillardia}

(Blanket Flower)

Among the showiest and most effective of perennial plants, blooming continually from early summer on through the season. Grows 2 feet high. Flowers about 3 inches across, dark red in center with rings of crimson and vermilion encircling same on a golden yellow ground.

Grandiflora.

Each 20c; 3 for 50c

\section{Geum}

A showy border plant, growing about 18 inches high and producing all summer and fall brilliant double scarlet flowers in large clusters. This new variety is a fine advance from the older sorts heretofore grown. We consider this the finest red hardy plant.

Mrs. Bradshaw. Each 20c; 3 for $50 \mathrm{c}$

\section{Gypsophila}

(Baby's Breath)

Fine, delicate foliage. Minute white flowers borne in enormous quantity in open panicles during summer months. $\mathrm{Be}$ sure and have a few plants of this for cutting, as it works up beautifully in bouquets of other flowers: 3 to 4 feet.

Paniculata.

\section{Hemerocallis}

Each 25c

Flava (Lemon Lily).-Three feet; May and June. Flowers clear, full, yellow; very fragrant; fine for cutting.

Each 25c

\section{Heuchera}

Sanguinea.-A most desirable dwarf bushy plant of robust constitution and easy culture. Bears during July and August, long graceful sprays of brilliant coral red flowers in great profusion. Excellent for rockery or border and of great value for cutting; 2 feet.
Each 25c

\section{Helenium}

(Sneeze Wort)

These are very desirable garden plants, succeeding in any soil in a sunny location, with broad-spreading heads of flowers, useful for cutting, each species covering a long blooming season.

Riverton Beauty.-Rich lemon-yellow, with large purplish-black cone; August and September; 4 feet.

Riverton Gem.-Old gold. changing to wallflower red.

\section{Helleborus Niger \\ (Christmas Rose)}

Flowers white, faintly tinged rose. If grown in partial shade they will flower at Christmas, or earlier. Try it.

Each 35c

\section{Hollyhocks}

Stately, majestic, hardy plants, necessary to every old-fashioned garden. Their large, brilliant flowers are very showy. Rich soil, plenty of water and a spraying of "Bordeaux" should they show rust or mildew, will grow them to perfection; 6 to 8 feet.

Double White, Yellow, Red or Pink. Each 25c; 4 colors $85 \mathrm{c}$

\section{Hypericum}

(St. John's Word)

Moserianum (Gold Flower)-Of drooping, training nature. Fine for rockeries, etc. Free flowering. Rich golden-yellow; June to frost. Each 25c; clumps $50 \mathrm{c}$ to $75 \mathrm{c}$

\section{Iberis}

(Hardy Candytuft)

Most desirable dwarf plants with evergreen foliage, which is completely hidden with dense heads of small flowers early in the spring; 8 to 10 inches.

Sempervirens.-Pure white. Each 25c

Glandulose.-Lavender blue. 'Each 30c

\section{Lavender}

Vera.-The true, sweet, fragrant lavender. Small plants 20c; large plants $25 \mathrm{c}$ to $35 \mathrm{c}$ each.

\section{Lychnis}

A very popular and easily grown hardy flower. June to August; 3 feet.

Chalcedonica (Maltese Cross).-Heart-lobed stars of brightest vermilion, arranged in large flat panicles. Each 25c; 3 for $60 c$

\section{Myosotis \\ (Forget-Me-Not)}

Palustris.-A variety that is hardly ever out of flower; useful in a shady spot in the border. Each 25c; 3 for 60c PINKS-HARDY GARDEN.-See Dianthus, page 81 .

\section{Pampas Grass}

Gynerium Argenteum.-A noble ornamental grass, easily grown, producing long, narrow pointed leaves and majestic, silvery white plumes, which are very valuable for winter decoration. Grows 6 to 8 feet high.

Young plants 25c; strong roots 35c to $\$ 1.00$; large specimen plants, $\$ 1.50$ to $\$ 2.50$ up.

\section{Poppy}

Orientale.-Very large flowers; bright red with a black blotch at the base of each petal. June to July; 3 feet. Each 20c 


\section{Phlox}

Among the hardy perennial plants no class is of more importance than the Phloxes, succeeding in almost any soil and position, and flowering through a long season. Excellent for cutting and decorating or for mass effects. Keep well in water.

\section{STANDARD COLLECTION}

A choice collection of standard varieties. Our selection 20c each; 8 sorts $\$ 1.35$

\section{Novelty Collection}

New, rare and rich; flowers of largest and best types; very choice.

Your choice. Each 25c; 1 plant of each variety (8) $\$ 1.75$ postpaid.

Asia.-One of the most valuable recent introductions, a delicate shade of mauve, with a crimson carmine eye. Very free blooming.

Europa.-A white variety with very decided crimson carmine eye; the individual flowers as well as the trusses are very large, entirely distinct.

Elizabeth Campbell.-Very bright salmon pink with lighter shadings and dark crimson eye; an entirely new and much wanted shade in Phlox.

Frau Anton Buchner.-The finest white variety yet introduced, having the largest truss and individual flower; of dwarf habit.

General Von Heutsze.--Immense trusses of very large flowers; color, the most brilliant salmon red imaginable. Simply grand.

Le Mahdi.-Immense panicles of deep velvety purple flowers. Very rich and striking.

Rynstrom.-An improved form of the popular variety Pantheon; fine for massing, of a Paul Neyron Rose color.

Sir Edward Landseer.-Rich bright crimson flowers in large panicles; 3 feet high. A rare and beautiful variety.

\section{Primulas}

\section{(Primrose)}

The hardy primroses are among the most beautiful and interesting of our early spring flowers. (See cut.)

Dern's Hybrids. - Pretty, low growing plants, bearing large numbers of beautiful flowers very early in the spring and having the old-fashioned cowslip fragrance so dear to the heart of every Englishman. The flowers are of the richest shades and of a very wide range of color, from pure yellow to the deepest crimson maroon.

Each 25c; 5 for $\$ 1.00$

Giant Yellow.-A grandly improved form of the genuine old English Primrose or Polyanthus, bearing during early spring large umbels of yellow flowers.

Each 25c; 3 for $60 c$

\section{Pyrethrum}

\section{(Persian Daisy)}

One of the most valuable of our early summer flowers. Charming shades of color. and. wonderful lasting properties as a cut flower. They flower in May and June and frequently in August and September the second time; the colors run into almost every shade, which makes them foremost of plants in this particular season.

Hybridium.-Mixed colors.

Each 25c; 3 for $60 c$

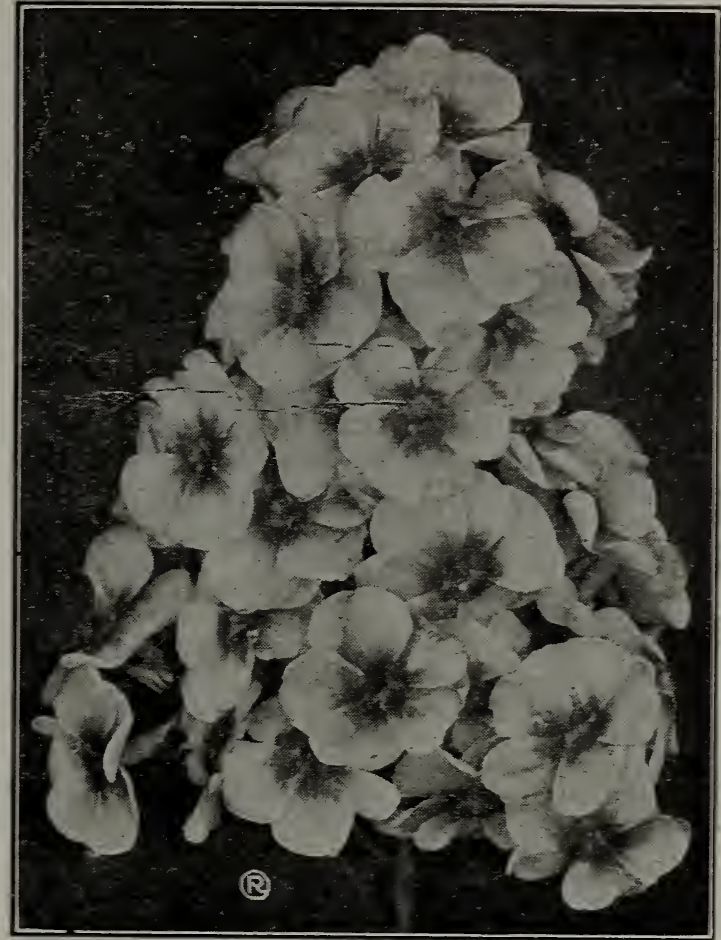

Phlox Decussata

\section{Rudbeckia}

Indispensable plants for the hardy border grow and thrive anywhere, giving a wealth of bloom, which are well suited for cutting.

Lancineatus (Golden Glow). - Flowers beautiful golden-yellow; very double. Marvelous continuity of bloom from June till late fall; 6 to 8 feet.

Small plants, 25c; large $35 c$

Newmani.-Grand sort entirely distinct, growing only $11 / 2$ feet high and bearing single anemone shaped flowers of a brilliant yellow color with a black center. A mammoth hardy "Black-eyed Susan." Flowers very lasting when cut. A profuse bloomer; August, September. Each 25c; 3 for $60 \mathrm{c}$

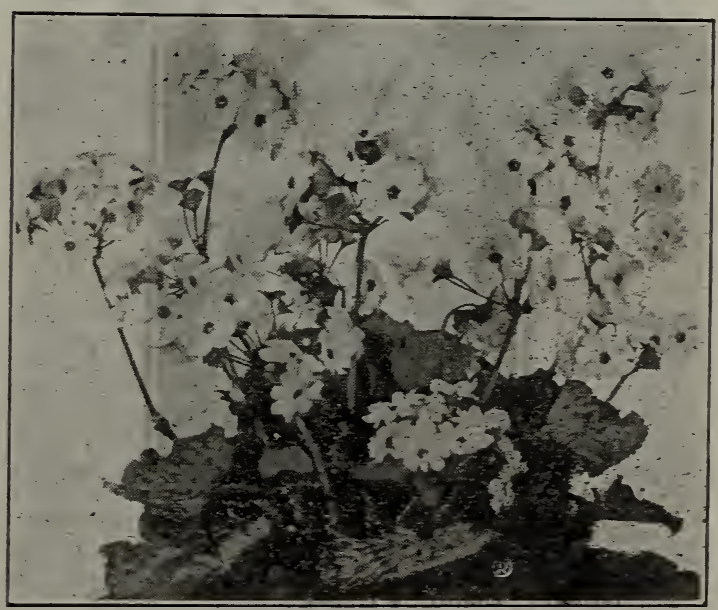

Primulas

FEED YOUR PLANTS.-You must supply "food," in other words fertilizer, if you want the best results. Read about "Wonder" and "C-M," pages 38-39. 
Routledge Seedpner, Ore., April 27, 1919.

Kind Sirs: Your card came tonight. Mr. H. got the Carnations. They were in fine shape; could not do better and are so nice. I am delighted to get them.

Respectfully Yours,

MRS. HAYLOR.

\section{Scabiosa}

Caucasica. - Handsome, artistic, single flowers about 3 inches across, which are borne continuously throughout the summer; fine for cutting.

White or Lavender.

Each 25c

\section{Saxifragas}

Umbrosa (London Pride).-A low-growing, spreading sort, throwing up stems a foot high of pretty pink flowers in dainty clusters. Small, dark evergreen leaves, a fine border plant or for rockeries. Each 20c Megasea.-Leaves large, round and flat, deep green; flowers in clusters very early; 1 foot.

\section{Shasta Daisy}

Very large daisy-like flowers, often measuring 4 to 5 inches across, having three or more rows of petals of the purest white. Flowers produced in great profusion on long strong stems. Very popular; 2 to 3 feet.

\section{Tritoma}

(The Everblooming Flame Flower)

Pfitzeril.-Blooms from August to October, with spikes 3 to 4 feet high, and heads of bloom of a rich orange-scarlet, producing a grand effect either planted singly in the border or in masses. (See cut.) Each 25c

\section{Veronica \\ (Speedwell)}

Rupestris.-A fine rock plant, growing 3 or 4 inches high, thickly matted deep green foliage, hidden in spring under a cloud of bright blue flowers.

Each 30c

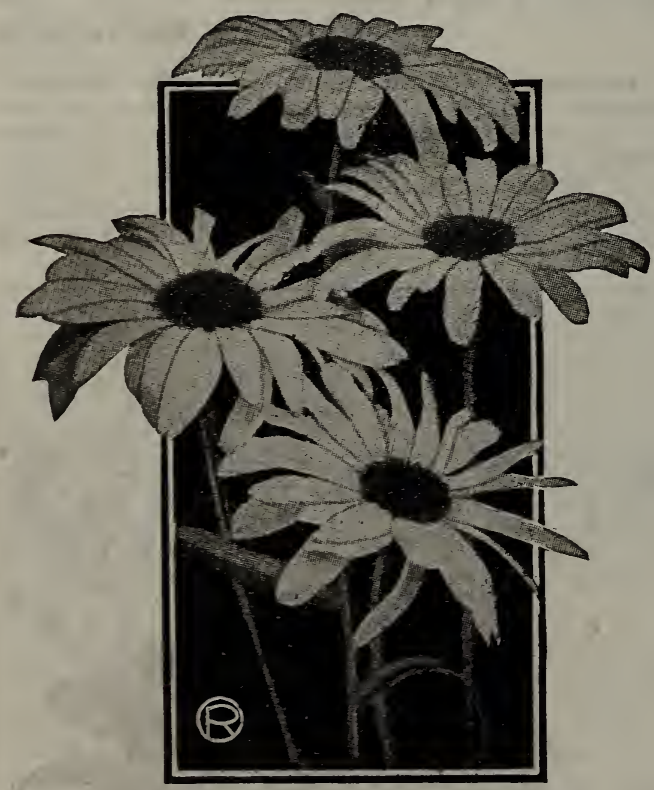

Shasta Daisy

\section{Vinca \\ (Myrtle)}

Minor.-An excellent dwarf evergreen trailing plant used extensively for carpeting ground under trees and on graves. Small dark green leaves.

Aurea-Variegated.-See page 79.

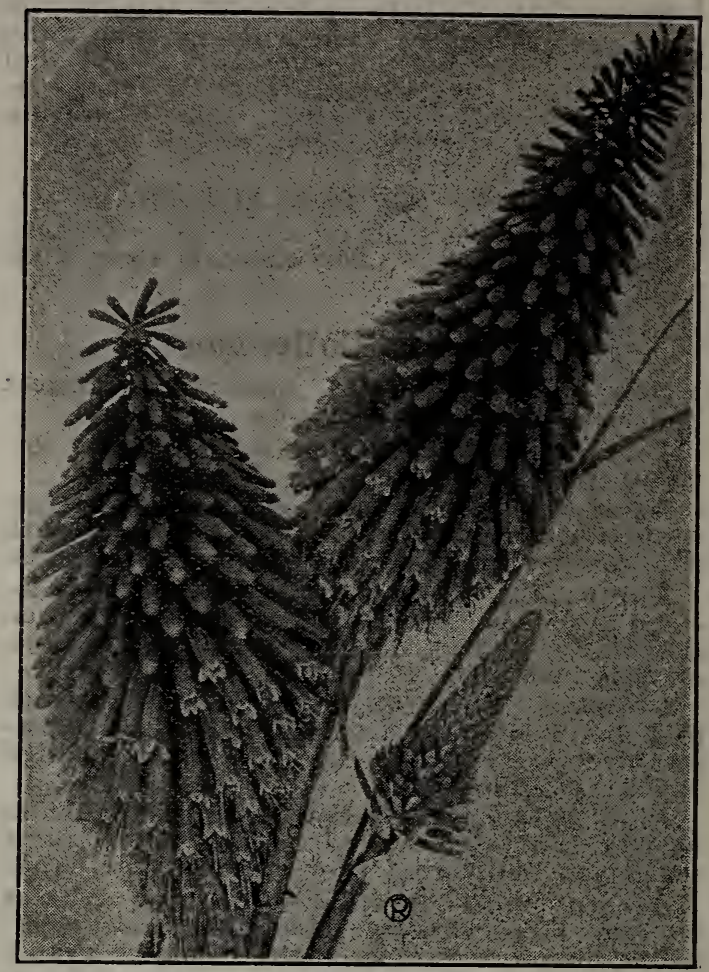

Tritoma

Amity, Ore., March 26, 1919.

Routledge Seed \& Floral Co.

Gentlemen: I had splendid success with your plants last year.

W. A. BAKER.

\section{Violets}

Price, 20c each; collection 6 sorts $75 c$

Of all the delightful perfumes, that of the Sweet Violet is the most delicate and pleasing, and places this modest flower among our greatest favorites. They commence to bloom as soon as the cold weather comes in the fall and flower even more profusely in the spring.

Alaska.-Hardy and robust and producing in spring great masses of enormous double flowers of a deep blue black color and powerful fragrance.

Lady Hume Campbell.-Large double flowers of a beautiful light blue color. Very free blooming.

California.-Very showy and beautiful flowers; enormous size, deep violet blue, and extremely fragrant.

Princess of Wales.-Flowers single, of gigantic size; color, a very rich shade of blue.

Peacock. -This is a charming variety and pleases everyone. It has lovely flowers of white, shaded with light blue.

Swanley Whlte.-The finest and best double white violet in cultivation.

\section{Wall Flower}

Double English.-A fine old hardy garden plant seen in every English garden. Grows about 18 inches high and produces early in the spring, rich colored spikes of bloom in various shades of yellow and brownish red.

Yellow or Red.

Each $30 \mathrm{c}$

Mixed. 25c each; 3 for $60 \mathrm{c}$ 


\section{BEAUTIFUL HARDY LILIES}

These are the most fragrant, beautiful and stately of all flowers produced from bulbs; they require vely little care. Do not disturb them oftener than every three to five years. Plant about six to twelve inches deep, according to size of bulb, and if the ground is not well drained use plenty of sand around the bulb, and lay it on its side. Plant in clusters or groups of six or more for best effect. They increase in size and beauty each year.

LILIUM CANDIDUM (St. Joseph or Madonna Lily.)-This is the ever popular, fragrant, snow white, hardy garden Iily. The large, trumpet-shaped flowers are produced in clusters at the top of 4 to 5 -foot stems; blooms in the open ground in June. A very hardy and popular Lily. Planted in beds or among shrubbery it makes a stately, majestic display. (See cut.)

Large. Each 35c; 3 for $\$ 1.00 ;$ doz. $\$ 3.00$

Small Bulbs. $25 \mathrm{c}$ each; doz. $\$ 2.50$

LILIUM WASHINGTONIANUM (Mt. Hood Lily.)-A beautiful Lily, native of Oregon; flower of open trumpet form; white, tinted with lavender pink; grows 3 to 5 feet high; the beautiful fragrant flowers are freely produced in graceful clusters. Few Lilies surpass it and it deserves to be planted much more extensively. Our bulbs are gathered in the foothills of Mt. Hood and grown one year in nursery rows. This makes them firmer, freer in bloom and sure to live.

Each 25c; 3 for $60 \mathrm{c}$; extra large bulbs $35 \mathrm{c}$; 3 for $\$ 1.00$.

Speciosum Henryi.-A splendid new rare Lily from China. It is so healthy and sturdy, so hardy and beautiful, so easy to grow, that it should be in every garden. It grows, when established, 3 to 5 feet high, each stem producing 5 to 8 large rich apricot yellow flowers. (See cut.)

Each $60 \mathrm{c} ; 3$ for $\$ 1.50$

Superbum.-Grows 3 to 5 feet high, producing from 5 to 40 nodding brilliant orange red blooms in July. Each $30 c ; 3$ for $75 c$

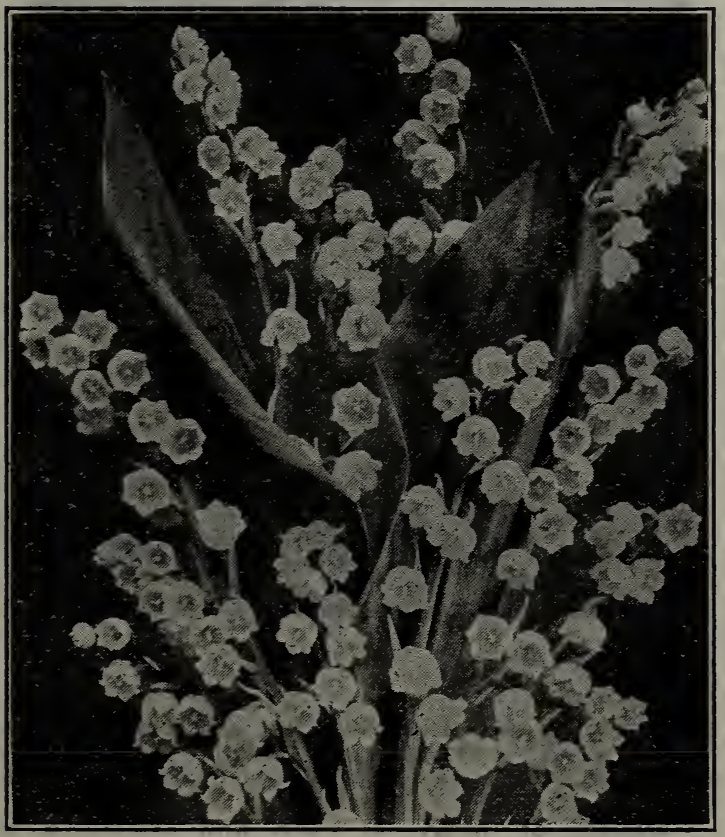

Lily of Valiey

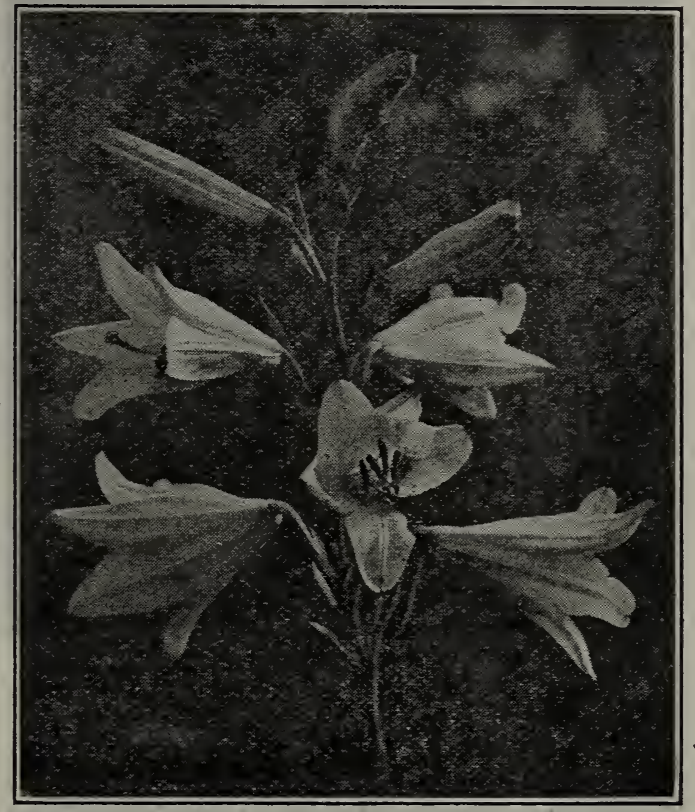

Candidum Lily

Lilium Pardalinum (Leopard Lily).-Very free flowering, hardy and easily grown. The beautiful flowers are orange scarlet with maroon spots. Each 20c; 3 for $50 \mathrm{c}$

Auratum.-The gold-banded lily of Japan. Immense flowers, borne in great clusters; color, rich, creamy white, thickly spotted with crimson and brown, each petal having a golden yellow band through the center.

Each $40 \mathrm{c}$

Speciosum Rubrum.-Flowers white, with a deep pink band in middle of each petal and numerous crimson spots towards the center of the flower.

Each $40 \mathrm{c}$

Monstrosum Album.- Similar to Speciosum Rubrum in growth and bloom except that the flowers are pure glistening white. Each 35c

Tigrinum Flora Plena.-The double-flowered Tiger Lily. Bright orange colored flowers. Each $35 c$

\section{Lily of the Valley}

One of the most charming spring flowering plants, producing in profusion its delicate bell-shaped, delightfully fragrant white flowers. Valleys thrive in any common soil, and will do well in shady situations, where few other plants will succeed. Highly prized for cutting purposes, and exceedingly well adapted for flowering in pots in the winter. Plant 6 pips to a 6 -inch pot.

They are perfectly hardy and most charming planted in beds or borders around the lawn, where they can remain, increase and bloom from year to year.

SELECTED PIPS, for forcing indoors or planting outside.

4 for $25 c$; doz. 70 c; $100 \$ 5.00$

NOTE.-The supply of Lily Bulbs is very short. Order early. 


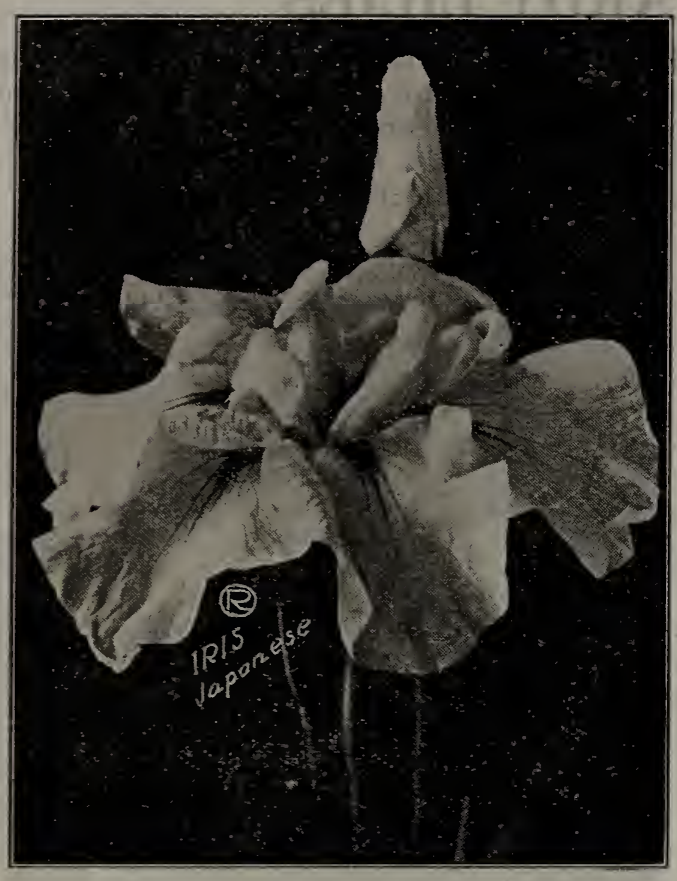

Japan Iris.

\section{LIBERTY IRIS-FLEUR-DE-LIS}

These are among the most desirable and easiest grown of our spring flowering hardy plants, producing in May and June their showy flowers of exquisite coloring, combining the richest and most delicate tints. Roots from October to April.

\section{Liberty Collection}

Each 25c; 7. sorts $\$ 1: 40$; doz. $\$ 2.00$

Albert Victor.-Soft blue, falls lavender; large and beautiful.

Junita.-Clear blue, fragrant, tall.

Mad. Chereau.-White, edged and veined with light blue; very pretty.

Florentina Alba.-A beautiful, free-flowering, early white; fragrant.

Nibelungen.-Fawn yellow; falls shaded violet blue; distinct and pretty.

Mrs: Neubronner.-A beautiful deep golden yellow throughout.

Princess Victoria Louise.-Sulphur yellow, edged cream.

\section{SUPERB NEW VARIETIES}

A splendid collection of the latest introductions, embracing not only new culors but improved forms.

Each $40 c ; 7$ sorts $\$ 2.50$; doz. $\$ 4.00$ postpaid

Catarina.-Clear blue, falls shaded lilac; distinct and beautiful; very free bloomer.

Her Majesty.-Bronze; very beautiful flowers.

Lohengrin.-Flowers of gigantic size; rosy mauve, shaded violet.

Pallida Dalmatica. - A superb variety; beautiful lavender; extra large and fine: fragrant.

NOTE-The 4-year-old clumps we offer will give a profusion of blooms quickly. We have a large supply of strong blooming clumps and will quote very low prices by the hundred.

\section{JAPAN IRIS-KAEMPFERI}

The Japanese Iris is quite distinct from all others, and never fails to excite the admiration of all who see it. It is becoming more popular each year. The enormous flowers produced in June and July display a marvelous blending of rich and rare shades. They like a rich soil and plenty of water when in bud and flower. Doubles have six petals, singles three.

\section{Victor Collection}

Each 35c; 6 kinds, $\$ 1.75$; doz. $\$ 3.00$, postpaid Distinction (Single).-Rarest and grandest color in Japan Iris; a lovely lilac-pink.

New Imperial.-Large and showy white center bordered with violet red.

Gold Bound.-Tall and showy, with double flowers of enormous size; pure snow-white, with large, gold-banded center.

Royal.-Light blue, shaded darker; rich, double flowers.

Pyramid.-Tall and showy, flowers very large double, light violet-blue, white veins.

Victor (Double).-White, veined purple; violet-purple center.

\section{Fine Mixed Japanese}

Finest sorts, double and single. 3 for $60 \mathrm{c}$; doz. $\$ 2.00$

Usk, Wash., April 17, 1919. en: I received my order in splendid shape last week and am much obliged. Yours truly, MRS. LEWIS LAFORCE.

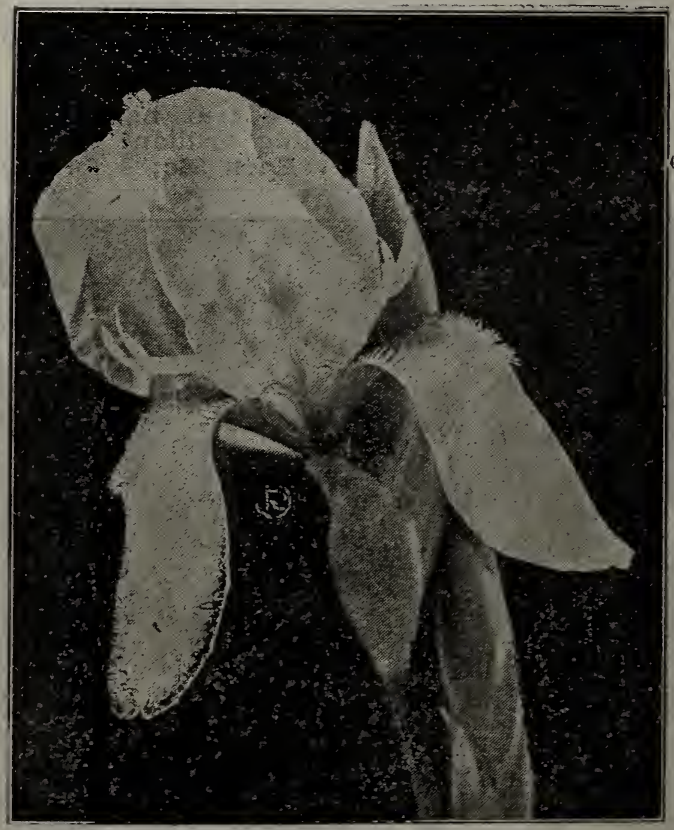

Fleur de Lis (Liberty Iris)

Rhein Nixe.-Pure white, falls violet-blue, with white margin; a beautiful, free-flowering variety.

Queen of-May.-A rare and lovely new variety, soft rose lilac, almost pink. 


\section{CHOICE HERBACEOUS PAEONIES}

Fine, hardy plants, rivaling the Rose in perfection of bloom, color and fragrance. They are at home in any climate or soil, but thrive best in deep, rich, well drained loam. They make a gorgeous display. The Paeony is perfectly hardy. Plant in the fall or early spring and do not cover the crown of the roots over 2 or 3 inches.

OTHER VARIETIES.-We can quickly supply from the largest Western paeony specialist any variety from his list of over 250 kinds; so ask for price on any variety you wish.

CLASSIFIED UNDER COLORS FOR YOUR CONVENIENCE

Every variety in the following collection is a beauty. PRICES are postpaid.

NOTE-(1) blooms early; (2) mid-season; (3) late.

\section{White}

FESTIVA MAXIMA (1)-Enormous, full, double blooms; petals very broad; color pure white with an occasional carmine spot on the edge of the center petals; very vigorous grower; one of the best white Paeonies, early, fragrant.

Each $60 \mathrm{c}$

MAD. CROUSSE (2)-Extremely large and full flower; snow-white, edged in center with bright carmine; delightfully fragrant; beautiful both in bud and open flower, and coming on good, strong stems, it is most valuable for cutting and general purposes.

Each 60c

DUKE OF WELLINGTON (3)-Guard petals white, very broad; center petals sulphur-white, narrow and very full. The large, finely-formed flowers come on long, firm stems. A good, free bloomer; deliciously fragrant and handsome flower.

\section{Light Pink}

REINE DES ROSES (2)-A large handsome, full flower of a lovely pale pink, with a. cream collar; a very good bloomer and popular sort.

Each 60c

GLORY OF SUMMERSET (2)-The large, bomb-shaped flowers are freely produced on long, strong stems; color, beautiful soft pink; a delightful flower. Each 75c

MONSIEUR JULES ELIE (1-2)-This is the king of all Paeonies, and is without question $M$. Crousse's masterpiece. Color, an ideal glossy lilac-pink, shading to amberyellow at the base of the entire flower, overlaid with a sheen of silvery rose that fairly dances and shimmers in the sunlight; an unapproachable variety.

Each $\$ 1.25$

\section{Dark Pink}

EDULIS SUPERBA (1)-Beautiful, brilliant mauve-pink, silvery reflex; large, wellformed full flower on strong stem; blooms very early, usually by Decoration Day; lasts well; fragrant and good in every way. A much worthier sort than its price would seem to indicate.

Each 60c

GENERAL BERTRAND (2)-A handsome, large, compact, globular, typical bomb-shaped flower; color, solferino red or rose-pink; distinct; very fragrant; of splendid habit and foliage. Each $\$ 1.00$

\section{Red}

LOUIS VAN HOUTTE (3)-One of the most conspicuous of the dark-colored varieties. The fine, shapely blooms are freely produced on strong, upright stems well above the foliage; color, rich dark crimson. A very popular dark variety.

Each $75 \mathrm{c}$

OFFICINALLIS RUBRA (1)-Mediumsized, deep crimson flowers, in great profusion. One of the oldest and best varieties; the earliest sort to come into bloom. This is the "piney" of your grandmother's garden and its color cannot be surpassed by any of its newer rivals. Always in bloom for Decoration Day and very popular cut flower on that day.

Each $60 \mathrm{c}$

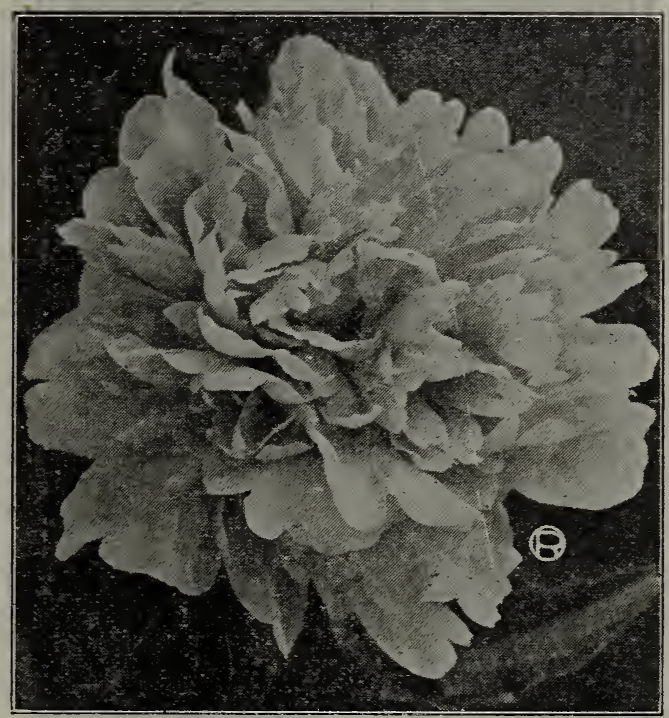

Paeony-Festiva Maxima

MODESTE GUERIN (2)-Very large, ballshaped bloom, perfectly built; bright lilac, carmined rose or solferino red; fragrant; splendid habit and foliage. This is a superb and distinct Paeony, very superior to one offered under this name by some other growers; one of the best all-around varieties we possess.

Each $\$ 1.00$

\section{Multi-Colored}

MARION DOLORES (2)-A large, handsome, showy flower, very beautiful and desirable; color pink, nicely shaded and marked with yellow and cream. Each 60c

TRI-COLOR GRANDIFLORA (3)-A grand variety; color lovely pink, center of flower intermixed with salmon; very distinct and desirable.

Each 60c

\section{Japanese Paeonies}

This class of Paeonies is much admired by all who see them. They are of a distinct type, midway between the single and double; graceful and pretty. Try this collection of 3 .

Collection of 3 sorts, $\$ 1.60$, postpaid

APPLE BLOSSOM.-Guard petals white, shaded light pink; as its name implies, like an apple blossom; early and very free bloomer. Each 60c

DAYBREAK.-A very handsome variety; beautiful pink, center filamental petals yellow.

Each 75c

SUNRISE. - Crimson, center filamental petals tipped yellow; large and free bloomer. Each 75c 


\section{ROUTLEDGE'S SUPERB GLADIOLI BULBS}

Plant 4 to 6 inches deep and as close as 6 inches in beds or borders or among the roses or shrubs. Planted at intervals from very early spring until July 1, they will give a profusion of flowers until the first frosts. All prices postpaid.

HIGHEST QUALITY BULBS.-Remember, the Gladioli Bulbs we offer are large blooming age, healthy, vigorous and free of disease, Western grown and worth double most Eastern or imported stock.

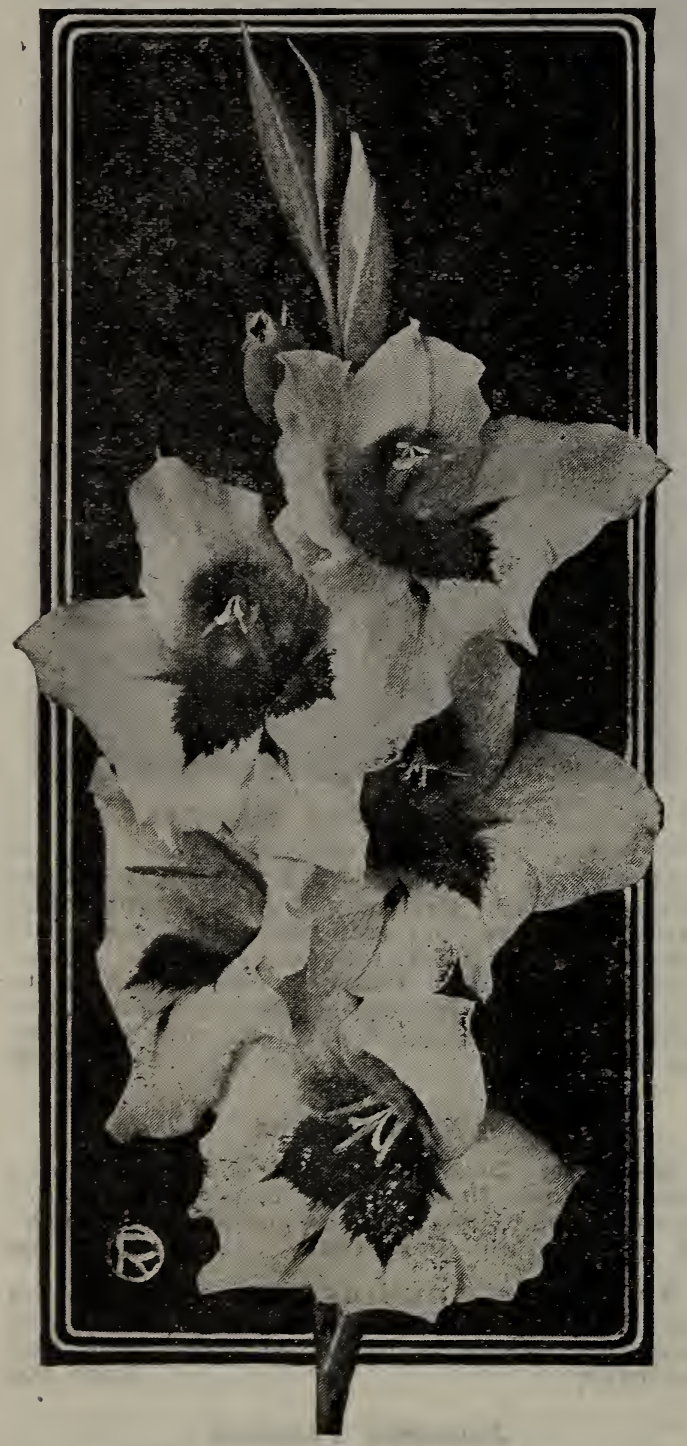

Mrs. Frank Pendleton, Jr.

AMERICA.-Conceded to be one of the finest varieties for cutting or bedding ever sent out; color, a beautiful soft flesh pink. 3 for $25 c$; doz. $75 c ; 100 \$ 5.00$

BALTIMORE.-Lovely flowers of immense size; color, light salmon, throat cream, marked with deep salmon.

Each 15c; doz. $\$ 1.50$

BARON HULOT.-Long, graceful spikes of good-sized, well-opened flowers, having a rich indigo-blue color. It. stands alone as a unique and beautiful shade, and never fails to attract attention. Each 10c; doz. \$1 CHARLEMAGNE.-French novelty of real merit; large open flowers; colors, sunrise red, flaked and marked cream and carmine. Each 40c; 3 for $\$ 1.00$
CRACKERJACK.-Rich velvety dark red, golden throat; a large and very beautiful flower.

Each 15c; doz. $\$ 1.50$

FAUST.-Rich wine color, immense flowers. Each 10c; doz. $\$ 1.00$

GLORY. - Ruffled. Cream-colored ruffled petals, with apricot throat; robust grower. Lovely and distinct. 2 for 25c; doz. \$1.25

GLORY OF HOLLAND.-White with red penciled throat; lovely flowers; very popular. Each 10c; doz. $\$ 1.00$

GOLDEN KING.-Massive yellow flowers, maroon throat; very striking.

Each 20c; doz. $\$ 2.00$

HALLEY.-Clear coral, enhanced by pale yellow markings in the throat. One of the most beautiful, regardless of price; early. Each 10c; 3 for 25c; doz. 75c

HERADA.-Very distinct. Flowers of giant size and of a clear glistening mauve.

Each 35c; 3 for $\$ 1.00$

MRS. FRANCIS KING.-Very large open flowers of great merit; light scarlet or flame color. 3 for $25 \mathrm{c}$; doz. $75 \mathrm{c} ; 100 \$ 5.00$

MRS. FRANK PENDLETON.-Tender pink with a crimson velvet blotch on lower petals. Flowers of elegant form and very beautiful; nothing finer.

Each 20c; 3 for $50 \mathrm{c}$; doz. $\$ 2.00$

NORMA DEE CHILDS.-Extra large flower and spike. Color delicate white, softly penciled with rose and with large sulphuryellow throat. Perfectly exquisite and distinct. Each 20c; doz. $\$ 2.00$

PEACE.-Massive, strong growing, stately white, with lilac feathering in throat.

Each 15c; doz. $\$ 1.50$

PANAMA.--Soft deep pink, showing in the sun a silver-frosted effect; beautiful at night. Each 15c; 3 for 40c; doz. \$1.25

PINK PERFECTION.-Charming; apple blossom pink. The large beautiful flowers are delightful.

Each 20c; 3 for 50c; doz. $\$ 1.00$

PRINCIPINE.-Crimson with white throat; nothing will brighten your garden more effectually.

Each $15 \mathrm{c} ; 3$ for $40 \mathrm{c}$; doz. $\$ 1.50$

ROUGE TORCH.-A charming French variety. Creamy petals and crimson throat. Stems slender and graceful. A lovely combination of colors and very beautiful.

Each 15c; doz. $\$ 1.50$

SCHWABEN. - Magnificent, clear creamy yellow immense flowers with petals like wax; most charming. Do not fail to plant this one. Each 15c; 3 for $40 \mathrm{c}$; doz. $\$ 1.50$

WILLY WIGWAM. - Blush with crimson throat; a splendid table decoration, arranged flat. 2 for 25c; doz. $\$ 1.00$

WAMBA.-A distinct and artistic flower of large size and of a beautiful salmon shade. $\quad$ Each 25c; doz. $\$ 2.50$

WAR.-A magnificent dark variety with tall spikes well filled with large flowers of a rich blood-red shaded with crimson-black. Each 20c; doz. $\$ 2.00$

WHITE AMERICA. - New 1920 novelty. Claimed to be equal to Pink America in size of flower and sturdy growth, and that it will soon be the leading white gladioli. Try it.

Each 35c; 3 for $\$ 1.00$

REMEMBER there is a big difference in Gladioli bulbs. Buy our strong, vigorous, free flowering, first size bulbs and get REAL VALUE. 


\section{GLADIOLA BULBS-Continued}

CHOICE MIXED GLADIOLI.-Our choice mixture is composed of all large and upto-date varieties and our customers can depend upon having a large and magnificent variety of colors.

Doz. $75 c ; 100 \$ 6.00$
POPULAR MIXTURE.-This mixture will produce a large variety of flowers at a little expense; unequaled for the price. First size bulbs. Doz. 60c; $100 \$ 4.25$ Second size bulbs, but of blooming age.

Doz. 40 c; $100 \$ 3.00$

\section{CANNAS}

Everyone knows the value and beauty of Cannas for bedding. Their large, massive tropical looking leaves and magnificent flowers cannot be equaled in any other plant, of such easy culture. Plant outside after danger of frosts is past, 18 inches apart, in rich, deeply dug, well-prepared bed (18 plants required for a 7 -foot circular bed). Plant the taller kinds in the center.

While there are many varieties of Cannas, we offer only the "very select"; they can be depended upon to be the most showy and desirable, with giant flowers, elegant foliage and especially adapted to Western conditions.

PLANTS IN SEASON.-Plants give quicker and better results than dormant roots. We send out growing plants only.

\section{Our 1920 Collection New Cannas}

\section{Prices, 35c each; $\$ 3.50$ per dozen postpaid}

Firebird.-Flowers in immense trusses well above the foliage on tall stalks. Petals of great breadth and substance forming a magnificent flower. Color clear brilliant scarlet without streaks, spots or blotches. Grows five feet high. A wonderful variety.

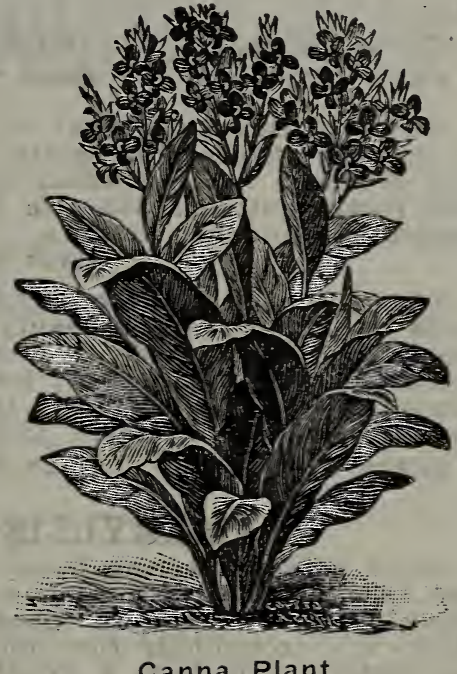

Canna Plant
Gladioflora.-Orange pink with dashes of golden yellow on each petal. Distinct yellcw, throat mottled with pink. Beautiful; 3 feet.

Gladiator. - Golden yellow netted and spotted with orange scarlet. A popular bedder. Very handsome; 4 feet.

Hungaria.-Irnmense spikes of bloom of a beautiful light pink color. Fine leathery leaves of massive proportions. A glorious bedding variety; $31 \frac{1}{2}$, feet.

Indiana.-Giant flowers of soft orange lightened by flecks of gold, penciled and slightly margined with deep rose; 4 feet.

Juanita.-A grand new bronze-leaved Canna growing to over four feet high and producing fine trusses of finely formed flowers.
Color bronzy-orange and chrome-yellow. A wealth of color for bedding purposes.

Louisiana.-Beautiful and showy; green leaves edged bronze, strong and healthy; very fine bloomer. The mammoth flowers are of fine form and a vivid scarlet; 5 feet.

Niagara.-Grows 3 feet high; large green foliage. Flowers very large, deep rich crimson, widely bordered with golden yellow.

Rosea Gigantea.-Deep rich dark pink, shaded to coral. Immense spikes of bloom in great freedom; 4 feet.

Yellow King Humbert-Immense spikes of golden yellow flowers spotted in throat with scarlet. Massive green foliage. A grand variety; 5 feet.

\section{King Humbert Collection of Cannas \\ Prices, 25c each; $\$ 2.50$ per dozen postpaid}

David Harum.-Foliage dark, glossy bronze and plum; great bloomer; flowers orangescarlet, spotted vermilion; 4 feet.

General Merkel.-Large spikes of bright scarlet flowers suffused with orange; golden yellow marbling in throat of each floret. First-class bedding variety; 4 feet.

King Humbert.--Immense spikes of bloom of a bright orange scarlet streaked with crimson. Magnificent bronzy-green leaves with brownish-green stripes; large, bold and effective; 5 feet.
J. D. Eisele. - Bright vermilion scarlet. overlaid with orange. Large spikes of bloom well above the handsome green foliage. A fine bedding sort; $4 \frac{1}{2}$ feet.

Mrs. Karl Kelsey.-Orange scarlet flowers flashed with stripes of golden yellow and tinted with rose. One of the most beautiful sorts in our collection; $4 \frac{1 / 2}{2}$ feet.

Queen Charlotte.-A bright orange scarlet, deeply edged with bright canary-yellow. The plant is of dwarf habit, with flowers from June to October. 


\section{CALLA LILIES}

The Calla is one of the best winter flowering plants for room culture, needing little care "beyond abundant water and an occasional washing of the leaves to keep them free from dust. Plant 1 bulb in a 6-inch pot. As soon as it starts growing bring to the light and heat and the result will be most satisfactory.

WHITE CALLA. - The most extensively grown; bulbs in season from September to May.
Choice Bulbs.
Each 25c; large 30c
Extra large.
Each 35c; 3 for $\$ 1.00$

NEW GODFREY.-Plant is more dwarf in growth; flowers lily white, very gracefur and produced in astonishing numbers: come into flower quicker; will also do well in the garden for summer flowers.

Each $35 e ; 3$ for $\$ 1.00$

YELLOW ELLITIANA.-This new Yellow Calla is of marvelous beauty; flowers are large, rich, dark golden yellow, often 4 to 5 inches across the mouth; leaves are beautifully spotted with white. Bulbs in stock from November to May. (See cut.)

Select Bulbs. Each 35c; 3 for $\$ 1.00$

\section{AMARYLLIS}

These hardy flowering bulbs are very popular for pot culture and garden. Their giant, Lily-like flowers produced on tall stems are exceedingly rich and lasting. For pot culture, 1 bulb to a 6 -inch pot. In the garden, plant 1 foot apart and cover bulo about 4 inches.

DEFIANCE.-Wide open flowers of rich crimson scarlet, lined and penciled white and maroon. Blooming bulbs. Each $40 \mathrm{c}$

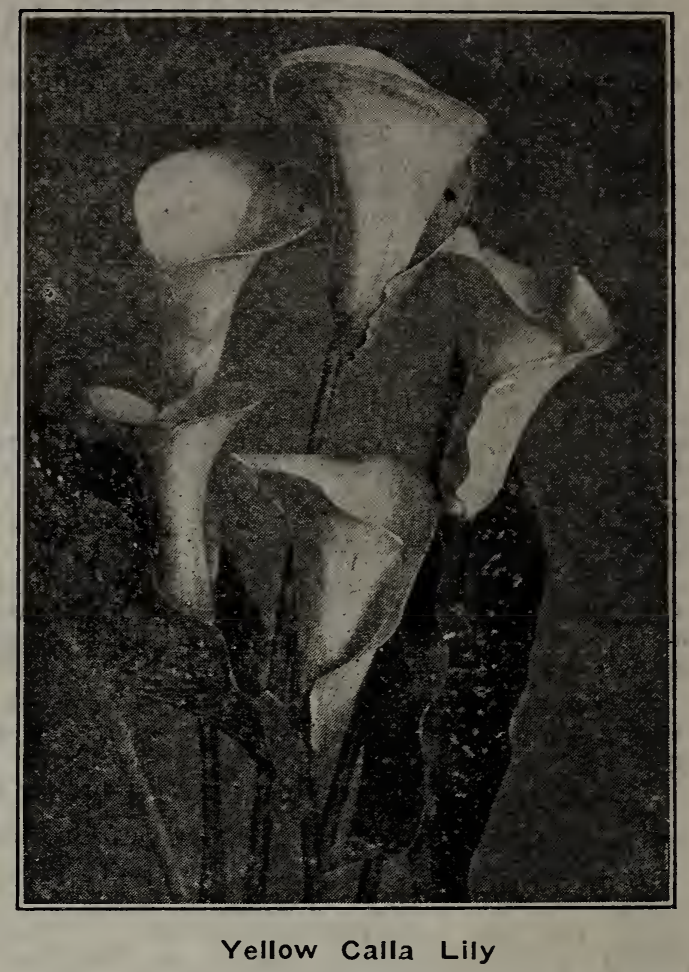

BELLA DONNA.-One of the most satisfactory, bearing on long stems clusters or 8 to 10 superb, large, beautiful pink, Lilylike flowels with a delightful fragrance.

\section{LANTANAS}

Lantanas are showy bedding and basket plants that are being used more extensively than ever. They are strictly everbloomers, flowering continually from early summer until frost cuts them down in the fall. They withstand the hottest sun and dry weather remarkably well. A bed of these Lantanas which we displayed at the 1916 Portland Rose Festival Center was the most talked-of exhibit in the show.

$$
\text { Price, } 15 \mathrm{c} \text { each; } \$ 1.50 \text { per doz.; set of } 6 \text { sorts } 75 \mathrm{c} \text {. }
$$

Ameil.-A beautiful dwarf growing variety, among the very finest of bedding plants. Grows eight inches high. Covered all summer with umbels of little florets red on the outer edge and orange-yellow in the center. A little gem for bedding.

Courbeille d'Argent. - A free blooming pure white sort; dwarf and compact grower; never out of flower.

Iolande.-Rich colored umbels, a beautiful mingling of crimson, orange and yellow. Fine robust grower and free bloomer. Very showy sort.

Delicatissima (The Weeping Lantana.) In addition to being a fine bedding plant, its prostrate habit makes it also a fine basket and vase plant. Pretty umbels of rosy-lilac flowers all season.

Jaun d'Or.- Isarge umbels of light sulphur yellow flowers changing to a beautiful shade of pink. One of the most distinct and beautiful varieties we have seen.

Leo Dex.-A gorgeous combination of crimson-violet and bronze. Nothing in bedding plants reaches this in gorgeous colorins.

\section{DOUBLE FRINGED PETUNIAS}

Double Petunias make excellent bedding plants as well as being suitable for window boxes and tubs. The flowers are quite double, nicely fringed about three inches in diameter and are produced freely all through the summer months. We offer a set of six choice varieties produced by a noted specialist in these fine flowering plants.

\section{Price, 15c each; 6 sorts for $75 \mathrm{c}$}

Ceres.-Lovely mellow-rose color. Flowers finely fringed.

Dotty.-Beautifully variegated white and mauve pink.

Harold.-Pure white blotched with purple. Petals heavily laciniated.

PETUNIA (Pride of Portland).-A beautiful new single-flowered variety, very popular in Portland last season for bedding and window boxes. Large fringed blooms of a soft bright pink shaded yellow and white in the center.

Each 15c; doz. $\$ 1.50$
Snowball.-A beautiful pure white sort with finely fringed petal:

Undine.-Large self-colored flowers. Color reddish purple. Very rich and handsome.

Venosa.-Pure white with blue suffusions and purple veins.

PETUNIA (EIks' Pride).-Another popular single flowered Petunia producing all summer rich, dark purple flowers in great profusion. Fine for beds, borders, window boxes and baskets. Each 15c; doz. $\$ 1.50$ 

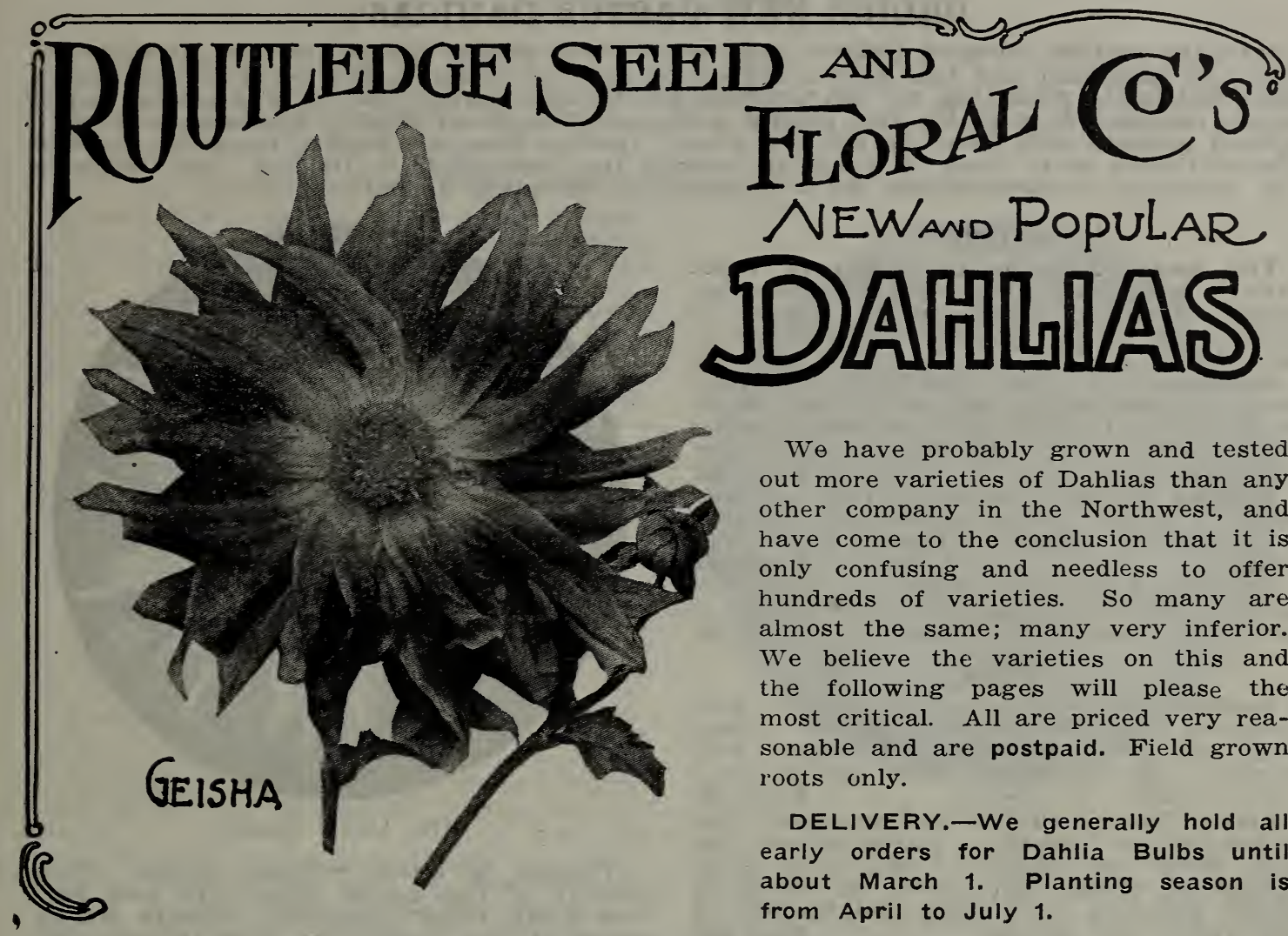

We have probably grown and tested out more varieties of Dahlias than any other company in the Northwest, and have come to the conclusion that it is only confusing and needless to offer hundreds of varieties. So many are almost the same; many very inferior. We believe the varieties on this and the following pages will please the most critical. All are priced very reasonable and are postpaid. Field grown roots only.

DELIVERY.-We generally hold all early orders for Dahlia Bulbs until about March 1. Planting season is from April to July 1.

\section{PAEONY FLOWERED DAHLIAS}

One of the most popular classes of Dahlias. The form and style of the flowers vary greatly; some have flat petals, others are pointed and twisted in most fantastic style. All are beautiful and produced in profusion on long slender stems; fine for cutting.

Andrew Carnegie.-Beautiful salmon-shaded bronze-pink; flowess of fine size, borne freely on long, straight stems. Each 25c

Avalanche. - Large, massive flowers of wonderful substance and full to the center. Color, snow white. Remarkable for its strong growth and free-blooming qualities. A fine novelty from Holland. Each $50 \mathrm{c}$

Beacon.-A glorious new English variety, the most brilliant shade of scarlet yet produced in this section. Of fine size, freely produced. One of the most showy in the garden.

Each 60c

Duchess of Brunswick.-Indian red, shaded apricot. Immense blooms on stout long stems. A great acquisition, being entirely distinct from other kinds. Each 75c

Geisha.-The showiest and most attractive of this type yet produced. Giant blooms of fantastic shape with broad petals curiously twisted and curled, forning a flowei entirely or ginal. Color br ght golden ellow suffused and marked with Indian red; harmonious and very straking.

Each $15 \mathrm{c}$

Golden Potlach.-Immense blooms of the most refined form produced on long stems well above the foliage. Rich golden yellow shaded with streaks of bronze. Large flat petals curling in beautiful manner. Made a fine show in our field the past year.

Each $75 c$

$\mathrm{Hi}$ Gill.-Magnificent blooms of a rich golden yellow shaded with deep rosy copper. Flowers massive, produced on very long, stout stems with a great freedom. One of the finest varieties in any class of Dahlias.

Each $75 c$

Insulinde-Grand novelty from Holland. Colossal flowers of a rich golden orange color. Form of flower everything which could be desired. Admirable for cutting and exhibition. One of the very finest sorts yet produced.

Each $\$ 1.00$

King of Autumn.-Buff yellow shaded with orange and terra cotta. Unique in color and wonderful in growth, a veritable giant among Dahlias. A fine Holland novelty.

Each $\$ 1.00$

La Conner.-Very prolific; dark green foliage and graceful flowers of fine size and heavy texture. Color a beautiful shade of coral or shrimp-pink with golden suffusions. Just about the color of Lyon Rose. Each 50c Leo XIII.-First-class yellow pa e o n Dahlia. One of the best-known sorts.

Each $50 c$

Monschelbe. - Giant flower with broad twisting petals of a rich golden yellow color. Fine sturdy grower and free bloomer. Undoubtedly the finest sort of the color in this section of Dahlias.

Each 50c

Mrs. T. G. Baker. -A fine pure white variety of much grace and charm. Each 25c

P. W. Jansen.-Color, orange cerise shaded yellow. Heavy wide petals, nicely arranged. Flowers large and freely produced on stout long stems.

Each $35 \mathrm{c}$

Rheingau.-A large, bold and most effective brilliant scarlet variety, raised well above the foliage on strong, stiff stems; splendid for cutting and for garden decoration. Each $35 c$

Terra Cotta.-As its name implies, of a rich shade of terra cotta. Very wide, massive petals forming large, handsome flower. Superb variety.

Each $75 c$

Van Dyke.-Lovely salmon, rose-tinted heliotrope. Of immense size, of distinct twisted form. Fine. long, stout stems; a grand exhibition variety. Each 75c 


\section{CHOICE NEW CACTUS DAHLIAS}

Of the various types of Dahlias those of the well-known Cactus form are undoubtedly the most important and best liked. There is a great diversity in the forms of the various sorts, but in the main they are characterized by the long, narrow, twisted and pointed petals of the flowers. Most of the fine petaled sorts are products of English hybridists who have worked wonders with them the last few years. Distinct from the English types are the new Hybrid Cactus sorts, most of which are coming from specialists in Holland. The following fine novelties are undoubtedly the very acme of perfection in Dahlia growing.

\section{WHITE}

The Swan.-A beautiful new pure white variety from the famous English specialist, James Stredwick. Snow white flowers of most approved cactus form borne on stout, stiff stems.

Each 50c

Snowdon. - A fine free-flowering pure white Cactus Dahlia, having all the requisites of a good garden sort. Sturdy growing. free-blooming long, stiff stems, finest form and good size.

Each $50 \mathrm{c}$

Frances White.-Flowers of fine size and depth. Narrow petals curling and twisting in corkscrew fashion. Color, pure snow white.

Each $35 c$

Lawine.-A fine pure white, of large size, perfect form and great substance, lasting in good condition for two weeks. Each 25c

\section{PINK}

Neptune.-Flowers large and massive with incurving petals which twist spirally. Color deep rose pink, speckled and striped with carmine. Strong grower. The largest fancy Cactus Dahlia yet seen. Each $75 \mathrm{c}$ Lor'na Doone.-Pretty medium-sized true cactus-formed flowers on strong stems held well above the foliage. Color, coral pink, shaded to bronze and yellow at center of bloom, which is very double and lasting. A fine variety for cutting. Each 60c

Mrs. Henry Randle.-Flowers of fine size and form produced with great freedom. Color, pale cream, changing to a lovely pink with age. A gem among Cactus Dahlias.

Each 50c

Miss London.-Finely formed flowers with tubular incurved petals nice:y pointed. Color deep rose pink; tips of petals tinted yellow. Each $50 \mathrm{c}$

Sweetbriar.-Charming flowers of an exquisite shade of pink. Fine for both garden and exhibition and greatly admired.

\section{YELLOW-ORANGE}

Each $35 c$

Magnificent.-In strong contrast to the incurving varieties, this is a cactus having perfectly straight petals of great length, the flowers often measuring 9 inches. Color, bronzy-orange. Each $\$ 1.00$

Melody.-Very distinct, greatly admired. Flowers of fine size, of true cactus form, with great depth of bloom and petals twisted and curled in exquisite manner. Center of flower bright golden yellow, while the outer half of bloom is pure white. Each 75c

Falcon.-Long stems perfectly rigid holding large flower of finest Cactus type and form. Color, bright yellow, shaded to reddish bronze at tips of petals. A charming and distinct variety. Each $75 \mathrm{c}$ Cambrian.-Clear salmon, lightening to yellow at tips of petals. Flowers irregularly incurved with hooked petals of great substance. Habit of growth ideal and flowering stem good. Each 60c

Richard Box.-Beautiful clear light yellow flower of immense size and the finest incurved form. Fine erect-growing habit with flowers on stout stems well above the foliage.

Mrs. Charles Cooper.-Flowers of the largest size and perfect cactus form with long very narrow and pointed petals finely arranged. Color, creamy-yellow, flushed with salmon in center.

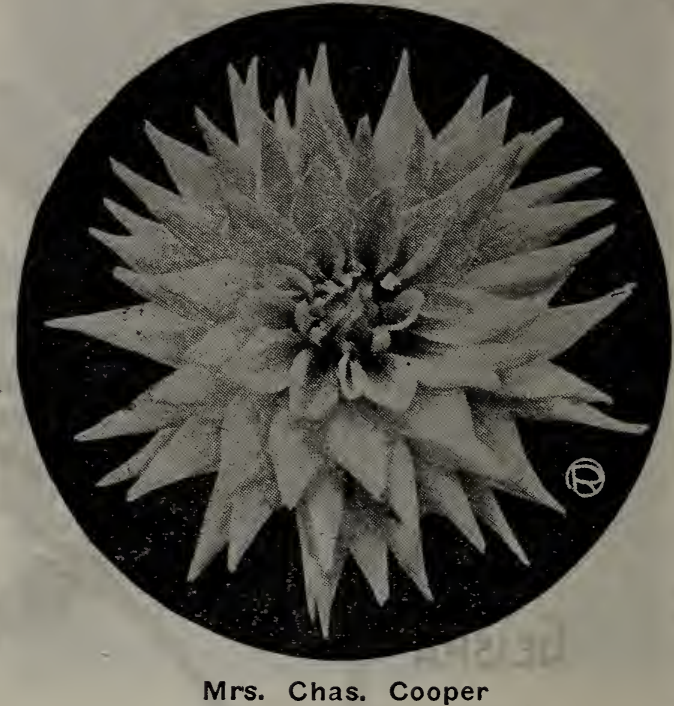

Thomas G. Baker. - Bright golden yellow flowers of fine cactus form with long narrow petals finely incurving. Growth sturdy, stems strong holding the large flower erect.

\section{SCARLET_CRIMSON}

Each 25c

Soldier's Lass.-Brilliant scarlet distinctly tipped with white on point of petals. A garden cactus flowering in great profusion and on fine stout stems. Very distinct and showy novelty.

Each 75c

Patriot.-Glorious bright scarlet flowers of most perfect cactus forms, produced in great profusion. Fine stout stems. Admirable for cutting and a fine decorative garden variety.

Each 75c

F. W. Fellows.-This variety produces huge flowers with surprising freedom. Of true cactus form, with narrow curling petals. Color, bright orange-scarlet throughout. Each 50c

John Riding.-Sturdy growing, free-blooming long stout stems carrying immense flowers of the richest crimson. Each 50c

W. E. Peters.-A charming new variety with deep scarlet crimson flowers of the largest exhibition size. The long pointed petals are beautifully arranged, forming a magnificent incurved . bloom; every flower comes perfect.

Each 50c

Herbert Raby. - A giant among Cactus Dahlias, the flowers being of mammoth size and held upon fine erect wiry stems. Color rich purplish crimson throughout. One of the finest dalk colored sorts to date.

Each $50 \mathrm{c}$

Conquest.-Immense blooms of deep crimson-maroon on fine long stems. Petals very long, twisted and pointed. Each 50c Othello.-A glorious full large flower of deepest, richest crimson, center almost black; finest true cactus form; petals of great substance, free and continuous bloomer; producing the most perfect flowers.

Each $35 \mathrm{c}$

Harbor Light.-Orange scarlet; one of the finest for cut flowers; dwarf habit, free bloomer, with large perfect flowers on long stiff stems.

Each 35c 


\section{FINE DECORATIVE DAHLIAS}

In this class of Dahlias will be found those sorts which florists and gardeners prize most highly for cut flowers. At recent Dahlia shows in Portland the sorts from this class have drawn much attention and are being widely called for. These Dahlias are characterized by their strong, erect growth and their very large, loosely formed flowers on strong, stiff stems far above the foliage.

\section{Price, Field Grown Roots, 25c each (except where noted).}

Boreel Van Hoogelanden. - Inner petals golden yellow bordered and reversed with terra cotta. Outer petals bronze and terra cotta. Large massive flower of great refinement. Superb variety. Each $\$ 1.00$

Cuban Giant. - This is well named, a veritable giant among Dahlias. Flowers very large, of a rich deep crimson maroon color. Delice.-Pure bright rose pink; large massive flower with broad petals; beautiful form; the best of its color.

George Walters.-Superb new sort hailing from California. Flowers of gigantic proportions on fine long stems. Color rich golden bronze shaded with salmon. This variety was the center of attraction at the recent dahlia show in Portland.

Each $\$ 1.50$

Glen Eyrie.-A superb new lemon-yellow. A large finely-formed flower borne on good stout stems. Some of the flowers show tips of white.

Hortulanus Fiet.-Colossal flower of delicate shrimp pink, the tip of each petal touched with gold. Each 50c

Hortulanus Witte. - Giant white variety. Splendid for cut flowers and exhibition purposes. Each 50c

La France.-Its beautiful soft yet lively color, a glowing rose pink, together with its perfect shape. stout stiff stems, makes this one of the most valuable for cutting.

Le Grande Manitou.-Immense blooms on stout stems. Color, blush white, distinctly splashed with violet red.

Mina Burgle.-A giant in growth and bloom. Immense deep scarlet flowers of finest cut-flower grade with long stout stems holding flowers erect and possessing remarkable keeping qualities when cut. The foliage is also very ornamental, very dark green and of heavy texture. Every shoot bears a flower. Florists are growing this fine Dahlia exclusively for cut flowers.

Mrs. Winters. - Very large, waxy white flowers on stately and erect stems. No finer white Dahlia than this superb decorative variety.

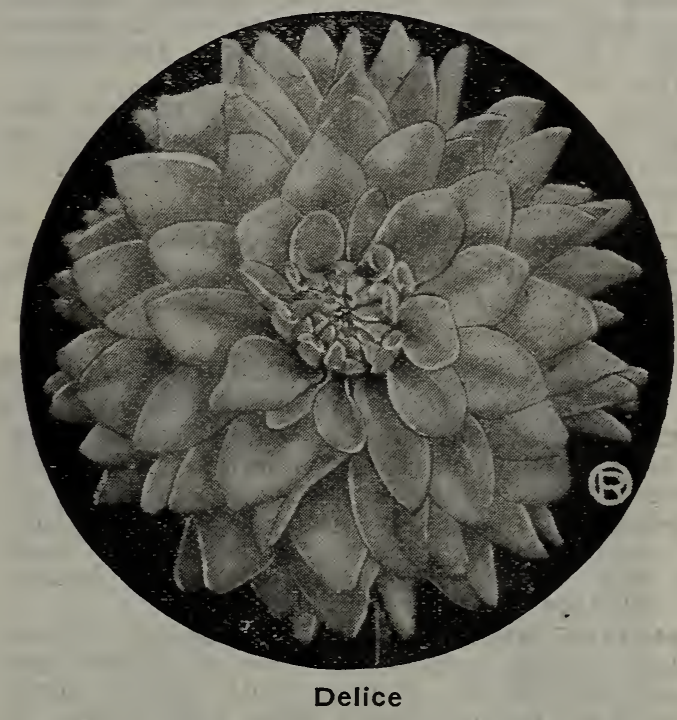

Sulphurea.-A superb new English sort of great merit. Flowers very large, pure sulphur yellow. Very early and free blooming. A real acquisition to this class. Fine for cutting. Each 75c

Vesuvius.-Orange scarlet of the most brilliant shade. Large flowers on stout straight stems. Of fine decorative form and produced in the greatest profusion. Fine for cutting. A new Holland introduction.

Each $\$ 1.00$

Wm. Agnew.-Large stately flowers of a rich glowing crimson. One of the best.

Yellow Colosse.-Immense blooms, primrose yellow. One of the largest varieties Each 40c

Willmore's Masterpiece. - Honey yellow. overlaid with golden rose or tango color. A giant in growth and size of bloom and a variety of the highest degree of merit.

\section{FINE SHOW AND FANCY DAHLIAS}

In this section we have the Dahlias of our grandmother's garden, with their richly colored flowers of rounded form and quilled petals. Some are delightfully edged and splashed with contrasting colors, and all are as beautiful as it is possible to imagine for garden decoration.

Field Grown Roots, 25c each; set of 12 sorts, $\$ 2.50$ postpaid

Juanita Ford.-Very large round flowers on long stems; deep cardinal red. One of the best dark varieties.

Lucy Fawcette. - Beautiful fancy show Dahlia. Delicate sulphur yellow, lightly flaked and striped with crimson. Very handsome.

Margaret Bell.-Bright carmine rose color. A fine show Dahlia.

Pioneer. - Large. round flower of rich crimson maroon, of velvety texture. A grand dark sort.

Yellow Beauty.-Golden yellow. Produced on long straight stems. A gem for cutting.

Snowball.-Large round flowers of snowy whiteness. Wonderfully free in bloom and healthy grower.

Susan.-Delicate shell pink flowers of the most perfect outline. Robust in growth and very free. A fine variety.
A. D. Livoni.-Soft shell pink, of medium size and rounded form. One of the most beautiful. Grown extensively by florists for cut flowers. Its pretty quilled petals form an elegant flower.

Arabella. - Y e $110 \mathrm{w}$ ground tipped and shaded with pink, an unusual combination of colors. A beautiful variety.

Bon Ton.-Bright scarlet flowers of perfect outline in great profusion. An old but fine variety.

Frank Smith.-Deep crimson, petals tipped white. The finest fancy Dahlia in cultivation. Dwarf, very early and continuous bloomer.

Gloire de Lyon. - Large globular pure white flowers of waxy substance. An old but still one of the very best Show Dahlias. 


\section{CHOICE ROSE PLANTS}

\section{For Spring and Early Summer Planting} Only and NOT for Fall Delivery

On this page we are offering four choice collections. This is the popular mail order size that we send by mail prepaid. They are grown in 3 -inch pots, are strong, healthy and well rooted and from 10 to 12 inches high. To be planted outside in the warm spring or early summer months.

These will not produce many blooms the first season, but you will be surprised at the results you can obtain, and at quite a caving in prices.

NOTE.-Order any time convenlent and we will forward "in season." NO ORDER FILLED FOR LESS THAN 50c.

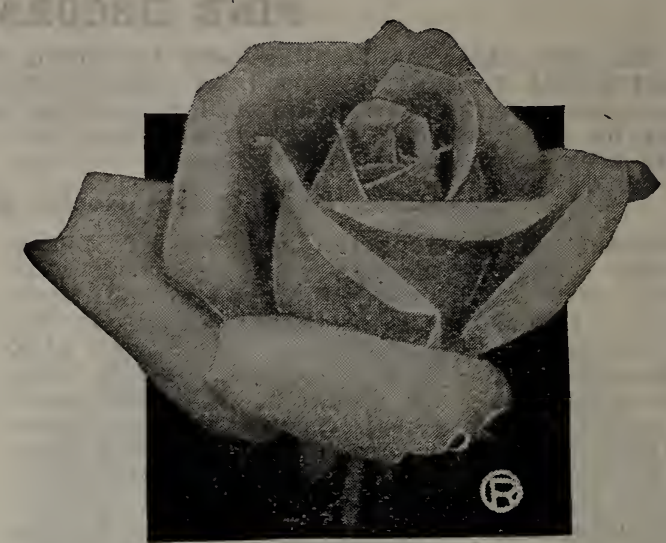

\section{Sunburst Collection of New Roses}

Price, 35c each; set of 6 sorts, $\$ 1.50$ postpaid

Duchess of Sutherland.-Color, warm rosy pink with lemon-yellow shadings. Exceedingly sweet scented.

Hoosier Beauty. - Glowing crimson-scarlet with maroon shadings. Beautiful buds on long stems. Wonderfully free in bloom. A valuable new American rose.

Madame Melanie Soupert.-Superb. Color, golden yellow shaded to orange yellow, the whole beautifully flushed with orange-pink. Fine long pointed buds, large full flower.
Ophelia. - Salmon, flesh, shaded rose, base of petals apricot yellow. Fine shaped flowers. Excellent habit.

Sunburst.-Without doubt the finest yellow rose in existence. Large buds and flowers of an orange copper color, shadea golden yellow. Superb.

Tipperary. - Bright lemon yellow; exquisitely shaped buds opening into finely formed flowers. A fine decorative rose.

\section{Beauty Collection Choice Roses}

Price, $25 \mathrm{c}$ each; set of 12 sorts, $\$ 2.50$ postpaid

Americán Beauty. - Large rosy crimson flowers; sweet-scented.

Betty-Coppery pink; long, beautiful buds.

Florence Pemberton.-Large white flushed peach. Strong grower.

General McArthur. - Grand crimson scarlet. One of the finest.

Helene Cambier. - Coppery yellow, beautifully shaped buds.

Mad. Abel Chatenay.-Salmon pink, shaded darker. Always in bloom.
Mad. Caroline Testout.-The famous Portland rose. Large, bold, bright pink flowers. Maman Cochet.-Beautiful rosy pink. Long pointed buds.

Richmond. - Crimson scarlet buds. A beautiful free flowering variety.

Souv. de P. Notting. - Rich yellow, bordered pink.

Souv. de President Carnot.-Shell pink and fawn.

White Maman Cochet.-Pure white; elegant buds.

\section{Rainbow Collection Everblooming Roses}

Dean Hole-Bright calmine with silvery shadings.

Earl of Warwick. - Salmon pink, shaded with vermilion and gold.

Kaiserine Augusta Victoria. - Large pure white; very free and constant.

Lady Ashtown.-Silvery pink, shaded yellcw. Fine large bloom.

Lady Battersea. - Bright cherry crimson, long pointed buds.

La France. - Silvery pink, large and very sweet-scented.
12 sorts, $\$ 2.50$ postpaid

Marie Van Houtte.-Light yellow, flushed carmine.

Papa Gontier.-Cherry red, shaded yellow. Grand bedder.

Rainbow.-Creamy pink striped and mottled crimson.

Safrano. - Apricot yellow, tinged fawn; beautiful buds. Virginia R. Coxe (Gruss an Teplitz.) Fiery scarlet.

Viscountess Folkstone. - Delicate flesh pink; full and handsome.

\section{Glorie Collection Hardy Roses}

Price, 25c each; set of 12 sorts, $\$ 2.50$ postpaid

Anna de Diesbach. - Beautiful clear carmine pink.

Baron de Bonstettin.-Dark, rich red; very large.

Clio.-Massive, light pink flowers.

Conrady F. Meyer.-Beautiful silvery pink.

General Jacqueminot.-Bright crimson.

Glorie Lyonnaise.-Chamois yellow; full, sweet, distinct.

Margaret Dickson. - Ivory white, shaded flesh.
Mrs. R. G. J. Crawford.-Silvery pink; fine form.

Mrs. John Laing.-Soft, delicate pink; free flowering.

Paul Neyron. - Large, deep rose; double and. handsome.

Prince Camile de Rohan.-The best dark maroon.

Ulrich Brunner. - Rich, glowing crimson; large.

RAMBLERS OR CLIMBERS, 1 YEAR OLD, $1 / 22$ YEAR OLD PRICES. SEE PAGE 99.

PLEASE REMEMBER-We cannot afford to pack and wrap a single Rose Plant; no order filled for less than $50 \mathrm{c}$ 


\section{CHOICE OREGON - GROWN ROSE BUSHES}

We make a specialty of Rose Bushes and sell thousands upon thousands. Our bushes are strong, healthy, field-grown stock, well rooted, and will produce a profusion of bloom the first season, if given good care and cultivation. We enjoy the reputation of supplying the best stock at reasonable prices. The following list is the choicest of American and European introductions. All Oregon-grown; worth double Eastern or California.

\section{FOR YOUR CONVENIENCE-CLASSIFICATION UNDER COLORS}

This year we have arranged our Roses all under their predominating color, which appeals to us as the most convenient way. While the descriptions are necessarily short on account of limited space, you will get class (read abbreviations below), color and main points of merit.

\section{SHIPPING AND DEIIVERY}

We can fill orders for our large 2-year-old Rose Bushes any time from October to Mayaround Portland the best planting time is during favorable weather from November to April, the earlier the better. structed.

BY EXPRESS.-We ship all 2-year-old Rose Bushes by express, unless otherwise in-

BY PARCEL POST.-By request we will wrap and pack for mailing for 10c each, $60 \mathrm{c} \mathrm{doz.}$ extra, plus the postage at postage rates, figuring 2 Ibs. per bush, 15 Ibs. per doz.

\section{ABBREVIATIONS}

T.-TEA-One of the best classes of Roses and truly ever blooming. They are hardy in this section, although during our coolest weather and in cold sections they should be protected with a covering of fir boughs, straw or burlap.

H. T.-HYBRID TEA-Most of these are as free flowering and as constant bloomers as the teas, and are hardier, stronger growers.

H. P.-HYBRID PERPETUAL-The hardiest of all roses, vigorous in growth, free blooming.

\section{WHITE ROSES}

Alice Grahame (H. T.)-Ivory white, tinted salmon; a free and continuous blooming rose of great merit.

Each $75 \mathrm{c}$ and $85 \mathrm{c}$

Frau Carl Druschki (H. P.) - A large, grand, hardy, pure white; best and most pop-
ular.

Kaiserine Augusta Victoria (H. T.) - A strong, vigorous grower, producing buds and flowers of enormous size; color, pure white. We have no hesitancy in saying that this rose is unequaled by any other variety of its color.

Each $60 \mathrm{c}$ and $70 \mathrm{c}$

White Maman Cochet (T.)-Has all the good qualities of Maman Cochet, but pure white, equally large and fragrant, hardy and productive. One of the very best white ever-blooming roses for bedding, flowering all season long and until late in the fall.

Each $60 \mathrm{c}$ and $70 \mathrm{c}$

Mabel Morrison (H. P.)-Splendid white garden and exhibition rose. Flowers large, globular, full and sweet. Each $50 \mathrm{c}$ and $60 \mathrm{c}$

Mrs. Foley Hobbs (T.)-Immense flowers of ivory white, delicately tinged pink on edge of petals. A great bedding rose.

Each $90 \mathrm{c}$ and $\$ 1.00$

William R. Smith (H. T.)-A cross between Kaiserine Augusta Victoria and Maman Cochet; one of our best bedding roses; flowers large, of elegant form; creamy white with rose shadings. Each $75 c$ and $85 \mathrm{c}$

\section{YELLOW ROSES}

Alex. Hill Gray (T.)-Vigorous, free flowering, very fragrant and of a deep lemor yellow.

Each $75 c$ and $85 c$

Constance.-Buds long and pointed, of a rich orange yellow color distinctly streaked and splashed with crimson near base of petals, passing to large full flowers of bright cadmium yellow. Very free in bloom. A glorified Rayon d'Or. Each $\$ 1.00$

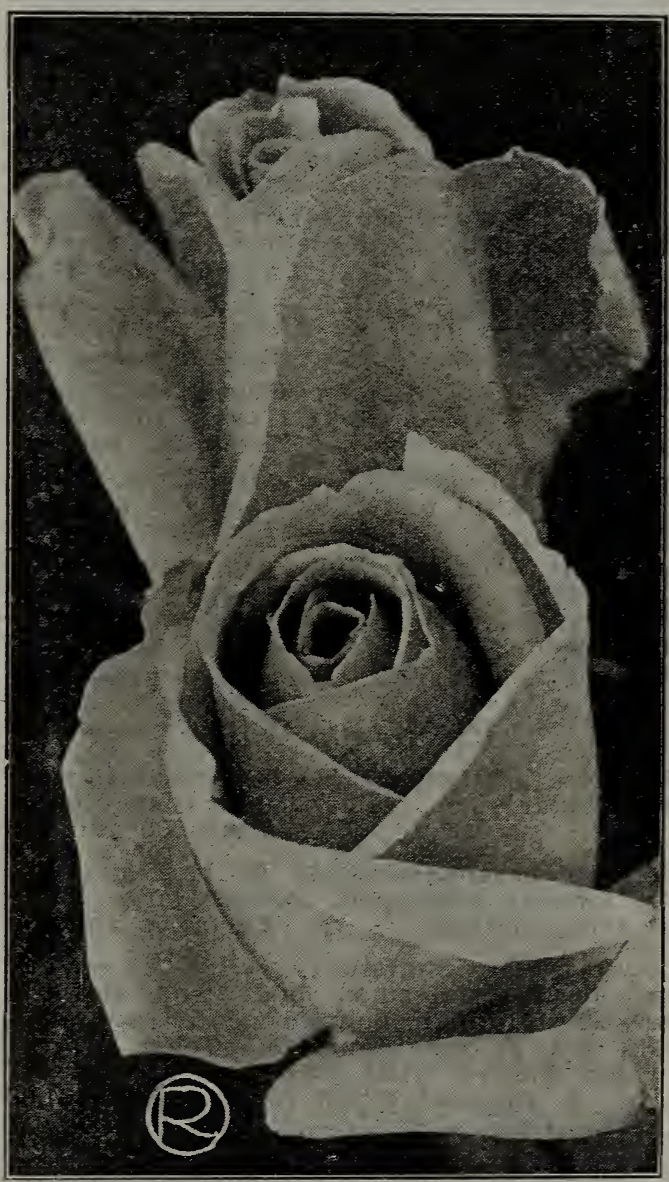

\section{Constance}

Etoile de Lyon. - Of vigorous, sturdy growth; it blooms freely, producing beautifully formed flowers of a rich, golden yellow. A great favorite everywhere.

Each $60 \mathrm{c}$ and $70 \mathrm{c}$

Harry Kirk (T.)-Magnificent long pointed superb buds of a lovely deep sulphur yellow color, becoming lighter at the edges of the petals. Of fine substance and very lasting. Each $\$ 1.00$

Le Progress.-Nankeen yellow bud, opening to saffron yellow. Flowers large and full on long erect stalks clothed with beautiful green foliage. Always in bloom. It should become popular in our Pacific Northwest gardens.

Each $\$ 1.00$

TWO PRICES. - We quote two prices on most varieties. The higher prices is for "EXTRA SELECTION" in root, top and shape; lower prices, regular run of 2-year-olds. 
PLEASE NOTE.-Should we be sold out and unable to obtain tre varieties of Roses ordered, others similar or better and CORRECTLY LABELED will be substituted, UNLESS OTHERWISE ORDERED.

\section{YELLOW ROSES-Continued}

Lady Hillingsdon ( $H$. T.) - Deep apricot yellow, long pointed bud. Each $70 \mathrm{c}$ and $80 \mathrm{c}$

Mrs. Ambrose Riccardo (H. T.) -A beautiful new yellow Hybrid Tea Rose from continental Europe. Wonderfully free blooming and vigorous growing for a rose of its class. Buds beautifully formed, honey yellow; very sweet scented.

Each $\$ 1.00$

Melody (H. T.)-Beautifully shaped buas of a rich saffron-yellow shaded to primrose at edge of petals. Wonderfully free in bloom all through the season. A fine garden rose, which will become a general favorite when its merits become known.

Each $\$ 1.00$

Madame Hector Leuilliot (H. T.)-Fine large flowers of a bright golden-yellow, heavily smeared with red at base of petals. Shows up finely in our trial grounds and impresses us as being one of our finest fancy roses.

Each $\$ 1.00$

Mad. Melanie Soupert (H. T.) - Saffron yellow suffused with carmine and pink. A great favorite.

Each $90 \mathrm{c}$ and $\$ 1.00$

Marquis de Querhoent.-Lovely golden yellow, copper, salmon and china-rose; superb. Each $90 \mathrm{c}$ and $\$ 1.00$

Perle des Pardins (T.) - Beautiful, clear, golden yellow, entirely distinct from any other variety. Each $60 \mathrm{c}$ and $70 \mathrm{c}$

Rayon d'Or or Golden Rays (H. T.)-A gorgeous new golden yellow rose; superb.

Each $75 c$ and $85 c$

Safrano (T.)-Bright apricot yellow tinged orange; beautiful buds; delicious tea scented. Each $60 \mathrm{c}$ and $70 \mathrm{c}$

Sunburst (H. T.)-Rich cadmium yellow, shaded orange. The buds are vêry long and beautiful form, opening into a gorgeous colored flower.

Each $75 c$ and $85 c$

\section{PINK ROSES}

Baroness Rothchild (H. P.) - Large size, fine globular form; color bright rosy pink. Each $50 \mathrm{c}$ and $60 \mathrm{c}$

Belle Siebrecht.-Superb; of brilliant pink color, sweetly perfumed, flowers large, buds long and tapering.

Each $60 \mathrm{c}$ and $70 \mathrm{c}$

Countess of Shaftsbury (H. T.) - Very large, perfectly formed buds and flowers. Possesses the high pointed center so much sought for by rose fanciers. Color silverycarmine, flushed with shell-pink at edge of petals. A fine exhibition rose. Each $\$ 1.00$

Countess of Gosford (H. T.)-Clear salmon pink, base of petals shading to saffron yellow, very vigorous; perpetual bloomer. Each $75 \mathrm{c}$ and $85 \mathrm{c}$

Edgar M. Burnett (H. T.)-Very large full flowers of fine shape and form, with large flesh-colored petals tinted rose. A great improvement of "La France," the sweetestscented rose in existence; a really superb rose.

Each $\$ 1.00$

Duchess of Sutherland.-Growth erect and vigorous, with large full finely formed flowers on stout canes. Color, warm rosy pink with lemon yellow shadings; sweet scented.

Each $\$ 1.00$

George Arends or Pink Frau Karl Druschki -A beautiful pink variety; different in color from any other rose; a free bloomer and one of the best.

Each $75 c$

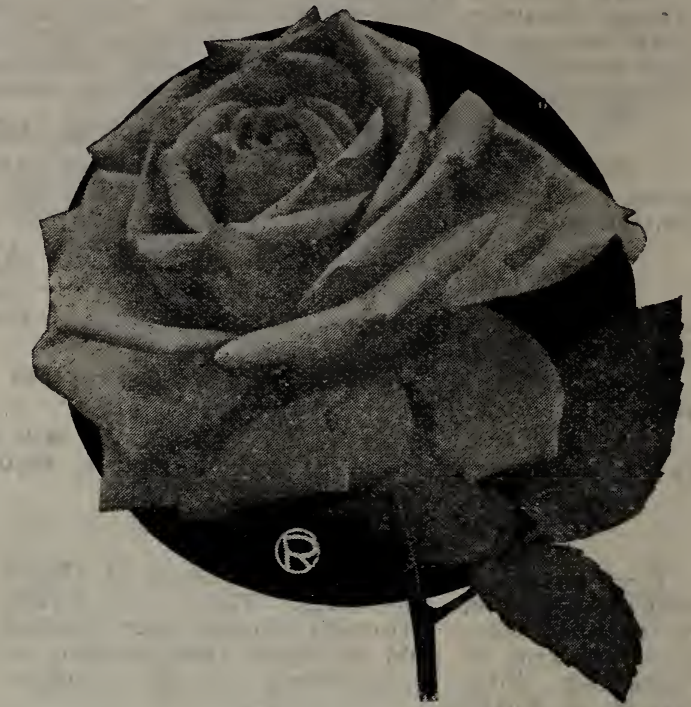

Edgar M. Burnett

Marshfield, Ore., March 17, 1919.

Routledge Seed \& Floral Co.,

Gentlemen: I was so pleased with all of my order of trees, berry plants and seeds last year. All the trees are doing fine, also strawberry plants bore profusely, and sent out many runners. Was especially pleased with the Black Raspberries.

Yours truly,

MRS. F. L. LATTIN.

Killarney (H. T.)-An exquisite shade of deep, rich pink, lightened with silvery pink. Each $60 c$ and $70 c$

Maman Cochet (T.)-This with its white sport'.we consider the finest Tea 'Rose ever produced; very rank growing for a variety of its class; strong.

Each 60c

Lady Alice Stanley (H. T.)-Delicate flesh pink, outside of petals deep coral rose. Beautiful long pointed buds opening into a fine, large, well-formed flower, having a delightful fragrance; fine, strong-growing variety, with beautiful leathery green foliage upon straight upright canes of good length. Each $75 \mathrm{c}$

Madame Caroline Testout (H. T.)-Portland's famous brilliant pink rose.

Each $50 \mathrm{c}$ and $60 \mathrm{c}$

Mme. Gabriel Luizet.-Light silvery pink; grand flower; free bloomer; fragrant; hardy plant. One of the best. Each $50 \mathrm{c}$ and $60 \mathrm{c}$

Paul Neyron (H. P.)-Deep, shining rose, double and handsomely formed; blooms freely, and is unusually strong and vigorous; the largest variety in existence and one of the most desirable for the garden.

Each $50 \mathrm{c}$ and $60 \mathrm{c}$

Souvenir President Carnot (H. T.) - A strong, clean, healthy grower, with handsome bronze-green foliage and large, elegantly shaped buds. The flower is of large size, with heavy, thick, shell-like petals; buds long and pointed; color delicate rosy flesh, shaded a trifle deeper at the center.

Each $60 \mathrm{c}$ and $70 \mathrm{c}$

William Shean. - A fine grower; large pointed flowers of purest Killarney pink, full, free and a perpetual bloomer; immense size, perfect form. Each $75 c$ and $85 c$

Prune your rose bushes when planting-don't leave over 8 to 12 inches of top growth. Try it; you'll get better results. 
All 2-year-old rose bushes by express unless otherwise ordered. Read about shipping, top of page 95, and inside front cover.

\section{RED, SCARLET AND CRIMSON}

Augustus Hartmann. - Brilliant geranium red flushed orange; very large, well-formed flowers with high pointed center.

Each $\$ 1.00$

Avoca (H. P.)-Brilliant, velvety crimson; buds long; flowers large, sweetly perfumed.

Captain Hayward. - This is probably the grandest of all red hybrid perpetuals. The bloom is of the largest size. Color, deep glowing red, flushed with crimson; delciously perfumed. Each 50c and 60c

Chateau de Clos Vougeot (H. T.)-A very rich, fiery scarlet shading to deep velvety crimson. It is delightfully fragrant, a prolific and continuous bloomer.

Each $60 \mathrm{c}$ and $70 \mathrm{c}$

Edward Mawley (H. T.)-This fire Irish Rose justly deserves all the praise bestowed upon it in Europe last season. Creater a furore at the English rose shows. Of grand size and build and a free, continuous bloomer. Color intense crimson scarlet and of velvety texture. Each $75 \mathrm{c}$

Farbenkonigen (Queen of Colors).-This is well named the Queen of Colors; there is no finer rose grown than this beautiful sort. It is large and full; color bright carmine and rosy crimson overlaid with a satiny silver sheen. Very floriferous; simply grand.

Each $\$ 1.00$

George Dickson (H. T.)-A velvety blackish crimson with the back of the petals heavily veined with pure crimson maroon. A large, grand, magnificent flower.

Each 650 and $75 c$

George C. Waud.-Glowing orange vermilion shaded bright scarlet; one of the richest colored roses in existence. Each $75 \mathrm{c}$ and $85 \mathrm{c}$

General McArthur (H. T.)-A grand crimson scarlet Hybrid Tea Rose. It is very free-blooming, every shoot producing a beautiful and richly-colored bud and flower, which does not fade in the hottest sun. 'Ihe flowers are large, double, of fine form and very fragrant.

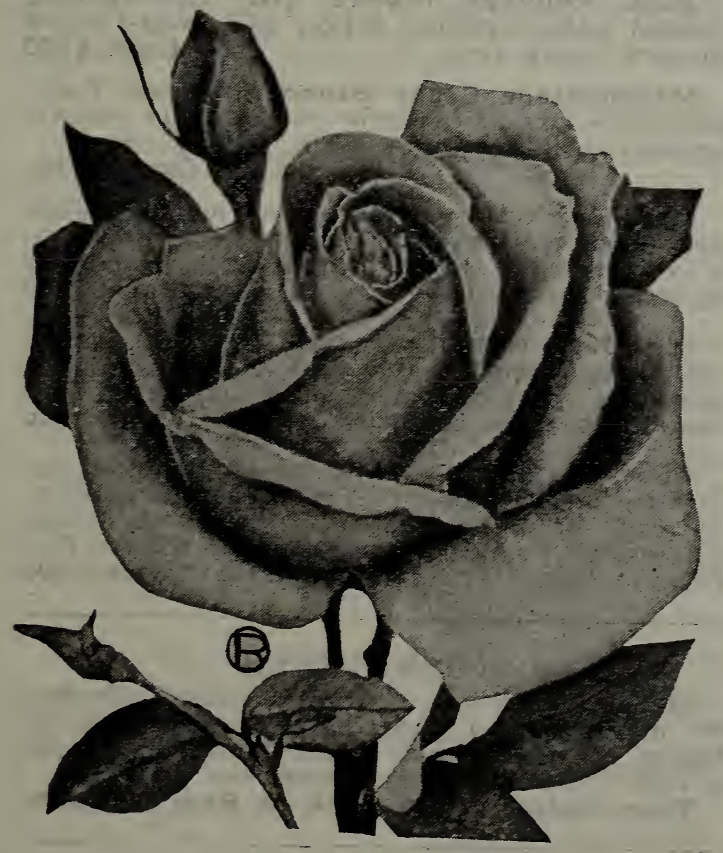

Hoosier Beauty

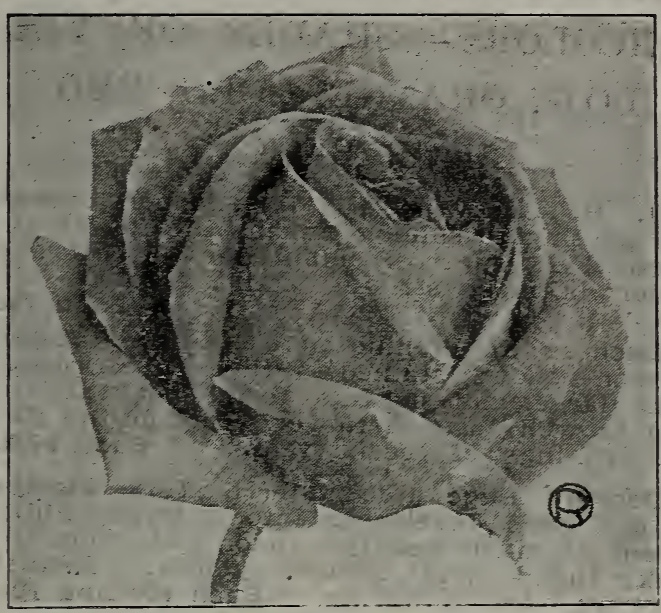

George Dickson

General Jacqueminot (H. P.)-Bright, shining crimson, very rich and velvety, exceedingly brilliant and handsome; makes magrificent buds, and is highly esteemed as one of the best and most desirable.

Each $50 \mathrm{c}$ and $60 \mathrm{c}$

Hugh Dickson (H. P.)-This superb new Irish rose stands in the front rank as a producer of the very finest brilliant crimsonscarlet roses. Of strong, vigorous growth and free-flowering habits, this great Hybrid Perpetual Rose is bound to become one of our most favorite-varieties.

Each $60 \mathrm{c}$ and $70 \mathrm{c}$

Hoosier Beauty (H. T.)-A grand new hybrid tea rose of American origin, having been produced by a well-known hybridist in the State of Indiana. Flowers dark crimson, shaded with maroon and veined with black; petals of remarkable substance-like so much crimson velvet; buds beautifully formed, with fine, pointed shape, opening into large, double flower.

Each $\$ 1.00$

J. B. Clarke (H. T.)-New Irish variety of great merit either for garden decoration or for cut flowers. The color is bright crimson, shaded maroon; petals large, well-shaped and of immense substance; flowers very full and perfectly formed. Growth vigorous and tree-branching habit; flowering freelv and continuously from early summer until late autumn.

Each $50 \mathrm{c}$ and $60 \mathrm{c}$

Papa Gontier (H. T.)-A magnificent red rose; flower large and semi-double; a vivid cherry red color, shaded yellow, reverse of petals crimson; free-growing and flowering very profusely.

Each $60 \mathrm{c}$ and $70 \mathrm{c}$

Lady Battersea (H. T.)-This variety has long, oval buds, sharply pointed, very striking in form; the color is a bright, cherry crimson.

Each $60 \mathrm{c}$ and $70 \mathrm{c}$

Mad. Abel Chatenay (H. T.)-A rose of extraordinary merit. A free bloomer, with flowers of good size and substance. Color, beautiful rosy carmine with darker shadings. Each $60 c$ and $70 c$

UIrich Brunner ( $H_{\text {. P. }}$ )-Extra large bold flowers, full and globular: color, rich glnwing crimson, elegantly flamed with scarlet; a good grower and free bloomer. Each $50 \mathrm{c}$ and $60 \mathrm{c}$

SHOULD BUSHES. ARRIVE. VERY DRY, bury tops and all in damp ground or immerse in a tub of water for a few days. It will benefit them very much. 
PLEASE NOTE.-Should we be sold out and unable to obtain some certain varieties of Roses ordered, others similar or better and CORRECTLY LABELED will be substituted, UNLESS OTHERWISE ORDERED.

\section{TRICOLORS - SHADES OF YEL- \\ LOW, ORANGE, GOLD, RED \\ OR PINK}

A. R. Goodwin (H. T.)-Coppery-orange red passing to salmon-pink as the flower expands A superb combination of coloring which is most striking and attractive.

Each $75 \mathrm{c}$

Duchess of Wellington $\left(H . T_{0}\right)$-Intense saffron-yellow, stained with rich crimson; very large and of fine form; beautiful in bud as well as open flower. One of the finest offerings of recent years. Each $\$ 1.00$

Dorothy Page Roberts (H. T.) - Finelyshaped buds developing into a large, fluffy bloom of much beauty. Color rich copperypink, tinted with apricot yellow. Robust growing, free-flowering. Each $60 \mathrm{c}$ and $70 \mathrm{c}$

Edith Part (H. T.)-Another grand exhibition rose as well as an ideal garden variety. Free-branching growth with well built-up flowers of great substance; color, rich red, suffused with deep salmon and copperyyellow.

Each $75 c$

Hugo Roller. - Color, rich lemon yellow, petals edged and suffused with crimson; a most distinct and beautiful variety.

Each $\$ 1.00$

Irish Fireflame.-These buds are wonderfully rich in coloring; opening to a large single flower; old gold, shaded ochre.

Each $75 c$

Gorgeous (H. T.)-Flowers large and full, freely produced on stiff, erect stems; color deep orange yellow, flushed copper yellow, and veined with reddish copper.

Each $\$ 1.00$

Jonkheer J. L. Mock (H. T.)-It is of the type of La France, with large, round blooms surmounting its stout, almost thornless, canes; color, rich bright pink, reverse of petals carmine.

Each $70 \mathrm{c}$ and $80 \mathrm{c}$

Joseph Hill (H. T.)-Salmon pink, shaded with yellow, outer petals tinted coppery pink, long bud; very large, full flowers.

Each $70 \mathrm{c}$ and $80 \mathrm{c}$

Lady Pirrie (H. T.)-Deep coppery-salmon, shaded to apricot and fawn; strong, erectgrowing and free-blooming. An ideal variety.

Each $\$ 1.00$

Lyon (H. T.)-Distinct; shrimp pink with salmon and chrome yellow shadings; beautiful beyond description.

Each $\$ 1.00$

Lady Greenall (H. T.)-Intense saffron orange, heavily zoned and overspread on deep creamy white; reflex of petals faintly suffused delicate shell-pink; large, perfect, fragrant. A truly magnificent rose.

Each $\$ 1.25$

Madame Edouard Herriot (T.) - Long, pointed buds, a deep colal red color, shaded to yellow at the base; flower of a rare shade of rosy scarlet, flushed with shrimp and apricot tints.

Each $75 c$

\section{"C-M" YOUR ROSE BEDS}

The most beautiful roses are produced by care, cultivation and fertilizer. "C-M" kilndried (weed free) ground cow manure, better than the raw material, will do wonders and is much cleaner and nicer to handle.

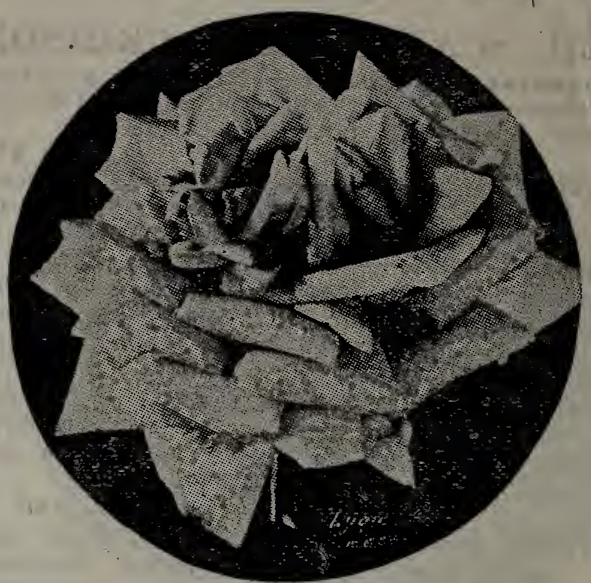

Lady Greenall

Marquise de Sinity (H. T.)-A grand new French Rose coming from the raiser of the Lyon Rose. Color, a beautiful intermingling of copper and yellow; flowers very large and perfectly formed.

Each $\$ 1.00$

Mrs. Aaron Ward (H. T.)-One of the most delightful roses. A deep golden-orange color, shading out to lemon or creamy-yellow at the edge of the petals.

Each $70 \mathrm{c}$ and $80 \mathrm{c}$

Mrs. F. W. Vanderbilt.-Fine, long-pointed buds, full, well-formed flower, deep orangered, shaded bronzy-apricot; very free and perpectual. Very desirable. Each $\$ 1.00$

Souv. de Pierre Notting (T.)-This variety is a seedling of $M$. Neil and Maman Cochet, with beautiful closely-set foliage and a strong, sturdy habit of growth. The bloom is very large, perfectly full, of elegant form; has a beautiful long bud; color, orange-yellow, bordered in carmine rose.

Each $70 \mathrm{c}$ and $80 \mathrm{c}$

Mad. Phillippe Rivoire (H. T.)-Apricot, shaded pale carmine; large, full, well-formed flowers; very free.

Each $\$ 1.00$

Mademoiselle Cecile Brunner (Dwarf Polyanthus).- Exquisite little roses, buds dainty, pointed, bright salmon pink, yellow center.

Each $60 \mathrm{c}$ and $70 \mathrm{c}$

Mrs. Frank Bray (H. T.)-A rich deep coppery ecru, developing as the flower opens to a very delicate coppery fawn with a shading of ivory shell pink.

Each $\$ 1.00$

Old Gold (New).-A vivid reddish orange with rich coppery red and coppery apricot shadings. Long dainty buds lasting a long time in perfect condition. Each $70 \mathrm{c}$ and $80 \mathrm{c}$

Ophelia (H. T.) - The most popular cut flower variety today. Buds orange salmon, opening to a perfect full flower of dainty salmon pink and cream; elegant shape, fine foliage; superb.

Each $70 \mathrm{c}$ and $80 \mathrm{c}$

\section{MOSS ROSES}

Strong, vigorous growers, much admired for moss-covered buds; hardy; most varieties bloom but once in a season, but remain for a long time and very handsome.

Your choice, White, Pink or Red, 50c each. ordered. Read about shipping, top of page 95 and inside front cover. 


\section{CLIMBING ROSES. HARDY, LARGE FLOWERING}

The lavish profusion of bloam on climbing Roses, literally hundreds of flowers on each plant, their beautiful colors and exquisite fragrance render them unequaled for covering houses, arbors, pergolas, fences and boundary walls.

1-YEAR-OLD PLANTS (except Climbing Sunburst and Billard et Barre), your choice at one-half the 2-YEAR-OLD PRICES.

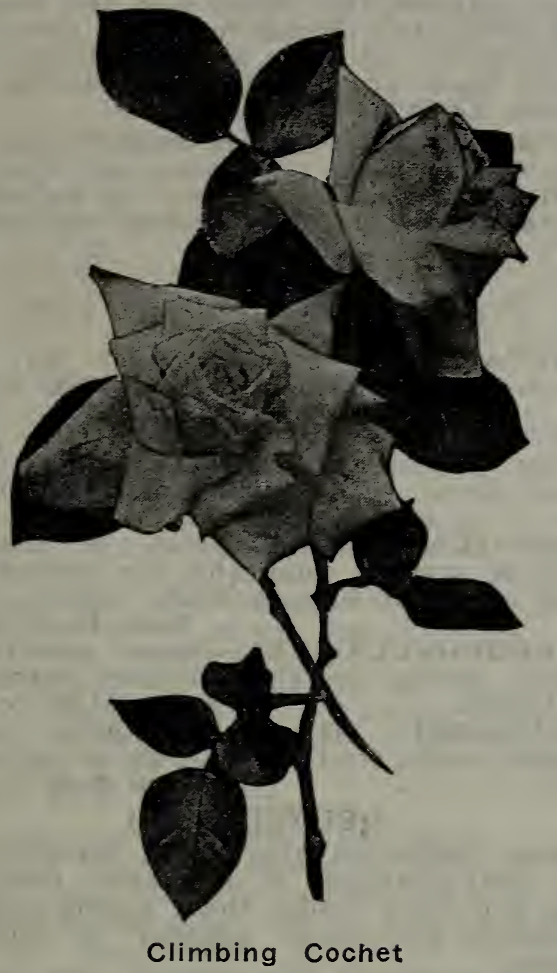

American Pillar.-Flowers saucer-shaped, three to four inches across, and very lasting. They hang in immense clusters all along the branches, and make a remarkable sight, a veritable sheet of bloom. Color, clear bright rosy pink.

Each $60 \mathrm{c}$ and $75 \mathrm{c}$

Climbing American Beauty.-A new pillar rose of great merit. Of very strong habit of growth, producing shoots ten to fifteen feet long in a single season and as hardy as an oak tree. The flowers are of elegant form and exceedingly fragrant. The color is a rich, rosy crimson of dazzling brilliancy. Each 60 c and $70 c$ Billard et Barre (T.)-Orange yellow; distinct. very charming; rare, moderate climber.

Climbing Sunburst.-A climbing Each $\$ 1.00$ that peer of yellow roses - Sunburst - the much-sought new French rose. A true pillar rose of strong growth, bearing freely; very large cadmium yellow flowers, beautiful either in bud or open flower. Two-year-old plants only of this variety. Each $\$ 1.00$

Climbing Killarney.-A climbing sort of the famous Irish rose, Killarney; rank in growth and fiee blooming; flowers a beautiful shell pink color; finely shaped buds. Each $60 \mathrm{c}$ and $70 \mathrm{c}$

Climbing Papa Gontier.-Splendid cherryred flowers; strong climbing habit.

Climbing Each 75c orous; bright crimson. Each $60 \mathrm{c}$ and $75 \mathrm{c}$ Climbing Safrano (Reve d'Or).-A beautiful saffron yellow, very desirable.

Climbing White Cochet Each $70 \mathrm{c}$ and $80 \mathrm{c}$ edged pink; beautiful form and substance; strong grower, perpetual bloomer.

Each $75 \mathrm{c}$ and $85 \mathrm{c}$

Madam Alfred Carriere._Extra Iarge, very double and sweet, profuse bloomer, white, tinged pale yellow. Each 60c and 70c

Marechal Neil. - The popular fragrant golden yellow climber, but not as hardy as others. $\quad$ Each $90 \mathrm{c}$ and $\$ 1.00$

Pillar of Gold.-A most vigorous climber; produces large double buds and flowers of perfect form. Color, rich apricot shaded with carmine and Indian red.

Each $70 \mathrm{c}$ and $80 \mathrm{c}$

Silver Moon.-Large, semi-double blooms of good substance with golden stamens. Foliage bronze green and is immune to mildew. $\quad$ Each 50c and 60c

William A. Richardson.-Color, rich coppery yellow flushed with carmine; a very beautiful variety.

\section{RAMBLER OR PILLAR ROSES}

The following climbing Roses all grow vigorously, and are profuse bloomers and very hardy anywhere. The flowers are borne in large clusters. 1-YEAR-OLD PLANTS 25c EACH POSTPAID.

Crimson Rambler.-This grand rose is well known and very popular of rapid growth. flowers in trusses, fairly covering the plant from the ground to the top.

Each $50 \mathrm{c}$ and $60 \mathrm{c}$

Dorothy Perkins.-(See illustration). Flowers in immense clusters, beautiful shell pink, very double with petals artistically crinkled. Each $50 \mathrm{c}$ and $60 \mathrm{c}$

Thousand Beauties. - Entirely distinct. Large single flowers fully 3 inches across; a delightful shade of soft pink, shaded carmine and produced in trusses of from 10 to 15 flowers, each truss a veritable bouquet.

Each $50 \mathrm{c}$ and $60 \mathrm{c}$

White Dorothy.-As its name indicates, it is a sport from Dorothy Perkins, possessing all the fine qualities of that grand variety, but having pure snow white flowers.

Each $50 \mathrm{c}$ and $60 \mathrm{c}$

Yellow Rambler (Aglaia).-Strong grower, profuse bloomer. Each $50 \mathrm{c}$ and $60 \mathrm{c}$

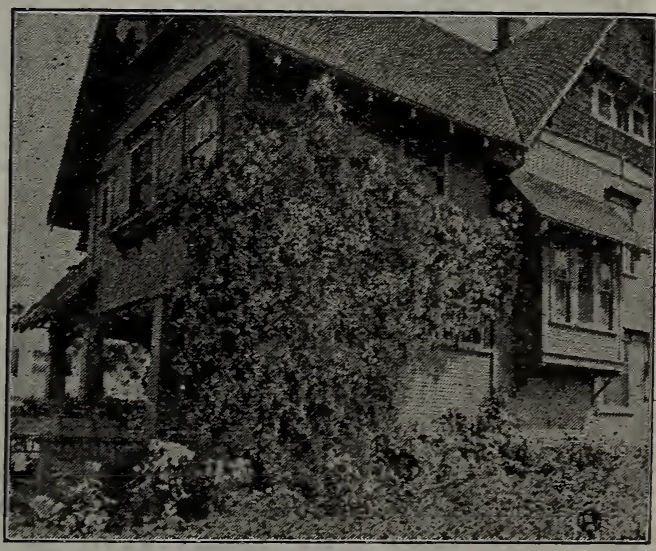

Dorothy Perkins, $30 \mathrm{ft}$. High, Thousands of Blooms

All 2-year-old rose bushes by express unless otherwise ordered. Read about shipping, top of page 95 . For rose fertilizers, see pages 38 and 39. 


\section{HARDY FLOWERING \& ORNAMENTAL SHRUBS}

NOTE- "D" following the name stands for Deciduous, "E" Evergreens.

Shrubs, deciduous and evergreen, are as much a part of the well-balanced gaiden as the lawn or flower borders. They are ornamental and highly useful as cut flowers. A. wellarranged planting presents an attractive appearance thioughout the entire year.

Shrubs have many uses, such as a dividing line between the flower and the vegetable garden, or between the lawn and uncultivated land beyond; as a background to a flower border; for hiding an unsightly building, fence or foundation, or they may be planted in a mixed shrubbery border, in which case those of short, dense growth should be planted along the front of the burder, graduating to the tall-growing kinds at the back.

SHIPPING.-At the prices given we send large, well-branched bushes from 2 to 5 years old, grown in the open ground. As our shrubs are for the most past large and heavy, we usually send them by express or freight. By request, small sizes can be sent by parcel post, but you should add at least $10 \mathrm{c}$ to $20 \mathrm{c}$ extra per single plant to cover packing and postage.

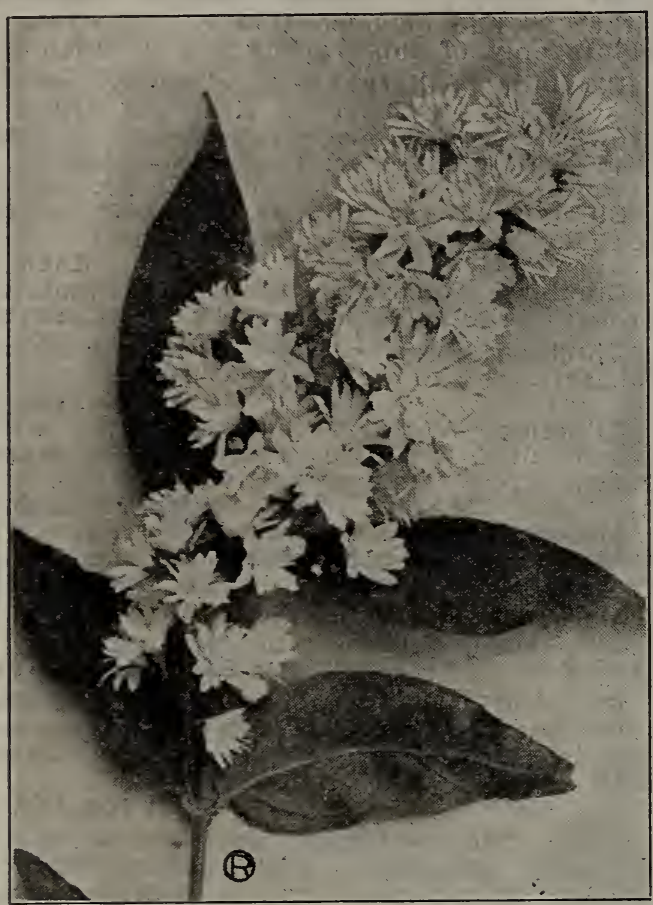

Flower Spray of Crenata Deutzia

ALTHEA (D)

These beautiful shrubs bluom very freely in August and September; worthy of a place in every garden. Our collection comprises double varieties. Pink and White.

Each, 3 to $4 \mathrm{ft} ., \$ 1.00$

AZALEA (D)

MOLLIS.-Blossoms in early spring, before the leaves appear. Pink or White only.

Each $\$ 1.00$ to $\$ 1.50$

\section{BARBERRY (D)}

Fine for massing, banking, hedges or even as single specimens. Dainty, early flowers, showy small leaved foliage and berries in the fall and winter make them very popular.

THUNBERGII.-A beautiful Japan variety of dwarf habit. Small foliage, changing to beautiful red in autumn. Bright scarlet berries all winter. Each $75 \mathrm{c}$ to $\$ 1.00$

VULGARIS (Common European).-Yellow flowers in drooping racemes in early summer, followed in autumn by orange-scarlet fruit. Each $\$ 2.00$

PURPUREA (Purple Barberry).-Foliage a beautiful deep purple all the year; a splendid specimen shrub and almost indispensable in contrastive groupings.

Each $60 c$ and $75 c$

\section{BAMBOO}

A very ornamental Oriental plant. Excellent for certain effects.

METAKE.-Small plants, each 35c; large, $50 \mathrm{c}$ to $\$ 1.50$; specimen clumps, $\$ 2.00$ to $\$ 5.00$

\section{COTONEASTER}

Very popular plants with minute, deep, glossy green foliage and bright red berıies that hang on all winter.

HORIZONTALS.-A plant of prostrate habit of growth; admirable for covering low walls or to use in rock work. Choice plants. Each $\$ 1.00$ to $\$ 2.00$ MYEROPHYLLA (E).-Same growth as above, variety evergreen leaves; berries not so bright. Each $\$ 1.00$ to $\$ 2.00$

SIMONDSII (D). - A beautiful upright growth with fruit of a rich, deep orange color.

Each $\$ 1.00$ to $\$ 2.00$

\section{DEUTZIAS (D)}

Their hardihood, fine habit, luxuriant foliage and profusion of attractive flowers in May and June render them among the most beautiful and most popular of flowering shrubs.

Price, your choice, $60 \mathrm{c}$ to $75 \mathrm{c}$ and up CRENATA ROSEA.-Grows 4 to 6 feet tall. Flowers very dainty and pretty; white, tinged rose; very double and full.

CANDIDA.-Low growing, compact; covered all over with pure white, bell-shaped flowers.

LEMOINEI.-Flowers very large and produced in broad-based, cone-shaped heads of from 20 to 30 flowers each, of purest white. 3 to 4 feet.

PRIDE OF ROCHESTER.-Flowers very double and full; pure white, tinged with blush; great profusion. Grows 4 to 6 feet.

\section{DOGWOOD (D) Cornus}

SIBIRICA (Red Siberian Dogwood).-A rare and remarkable variety with bright red bark in winter.

\section{EUONYMOUS (E)}

Compact growing evergı een shrub.

JAPONICA.-Green or Variegated. Very attractive. 2 feet. $\$ 1.25$

RADICANS (E).-Very hardy trailing plant for banks or rockeries. Silver color or variegated. Large, $75 \mathrm{c}$ to $\$ 1.00 \mathrm{each}$

\section{FLOWERING CURRANT (D)}

REBIS.-The Flowering Currants are gay, beautiful shrubs in early spring; crimson flowers.

\section{FLOWERING CHERRY}

Red or white. Each $\$ 1.50$ FLOWERING CRAB

Each $\$ 1.00$

FORSYTHIA (D) Golden Bells

VIRIDISSIMA.-Blooms early in spring, before the leaves appear, when it is covered with golden, bell-like flowers. 2 to 3 ft.

ABOUT PRICES.-The higher prices are for specimen plants, for a large display and immediate effect. 
Mt. Angel, Ore., February 17, 1919. Routledge Seed \& Floral Co.

Gentlemen: Have been very well pleased with the Seeds and Plants I have received.

The Gladioli Bulbs were fine and I'm sending for another dozen.

Sincerely yours,

MRS. E. J. ANDERSON.

\section{GEINSTA (E) Broom}

Large plants of the following, 3 to 4 feet, bushy.

ALBA.-Pure white.

Each $\$ 1.25$

Each 50c

ANDREANA.-Red and yellow flowers;
very pretty.

SCOPARIA (Scotch Broom).-Rapid growing; yellow flowers in May. Each 35c to 50c

\section{HAWTHORNE (D)}

A beautiful flowering shrub that grows to be a fair-sized tree.

DOUBLE WHITE or RED. -5 to $6 \mathrm{ft}$., $\$ 1.00 ; 6$ to $8 \mathrm{ft}$., $\$ 1.25$ to $\$ 1.50$.

\section{HYDRANGEA (D)}

HORTENSIA.-One of our most popular and showy lawn plants. Often grows in pots or tubs. Ornamental foliage and beautiful flowers in large, flat trusses. (See cut.) The beautiful pink variety is most popular, but we can supply White, Pink or Blue. Young plants, 35c. Large plants, according to size and number of flower shoots, $50 \mathrm{c}, 75 \mathrm{c}, \$ 1.00$ and up. Large specimen plants, $\$ 2.50$ to $\$ 4.00$.

PANICULATA GRANDIFLORA. - The grandest as well as the most popular of all shrubs, and hundreds of thousands of them are sold every year; excellent for hedges or massing; unsurpassed for the lawn; blooms in July and August, and continues in bloom for two or three months. The flowers are massive, cone-shaped, sometimes 10 inches in length, and changing from the original pure white to pink, and finally to a beautiful rich coppery red. Strong plants, 2 to 3 feet and up, each $75 \mathrm{c}$ to $\$ 1.00$.

\section{LABURNUM (D)}

Small growing tree with long drooping racemes of fragrant yellow flowers in June; very attractive. 4 to $6 \mathrm{ft}$., each $75 \mathrm{c} ; 6$ to 8 ft., each $\$ 1.00$.

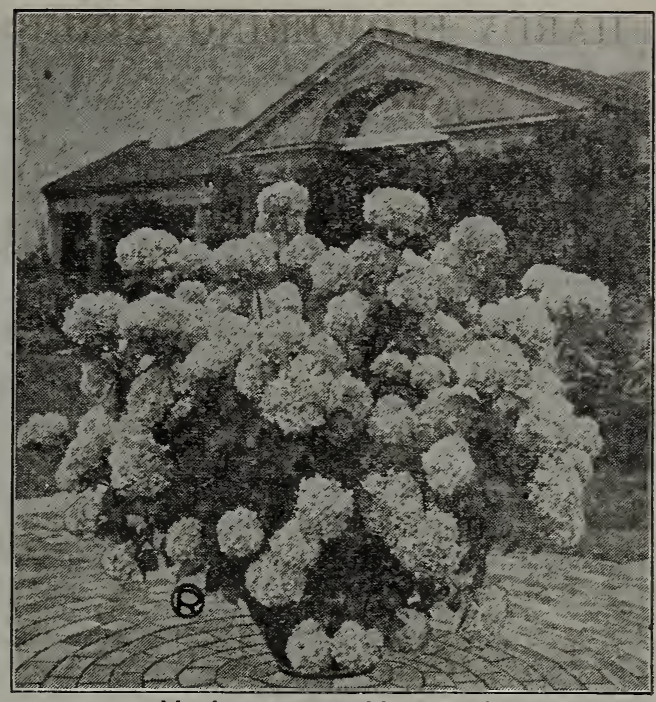

Hydarangea Hortensia

IILACS (D)

Everyone loves the lilac and no garden is complete without one or more. The new imported grafted varieties are very beautiful and produce magnificent large flowers.

COMMON WHITE OR PURPLE.

Each 50c to 75c; large specimens, $\$ 1.00$ to $\$ 2.00$.

IMRORTED BUDDED VARIETIES.-Your selection following named varieties, 3 to 4year-old select plants, 3 to 4 feet and up, $\$ 1.00$ to $\$ 1.25$; specimens, 4 to 6 feet, branched, $\$ 1.50$ to $\$ 2.00$ (not mailable).

GEORGE BELAIR (Single). - Beautifu] flowers, purple.

MARIE LE GRAYE (Single). - Beautifu] creamy white flowers of immense size.

MME. LEMOINE (Double).-Fine double white variety; very fragrant.

MAD. CASIMIER PERIER (Double).-Fine creamy white.

MICHAEL BUCHNER (Double.)-The best pale lilac or lavender.

CHARLES BALTET (Double).-Long trusses; double; beautiful rosy lilac or purple.

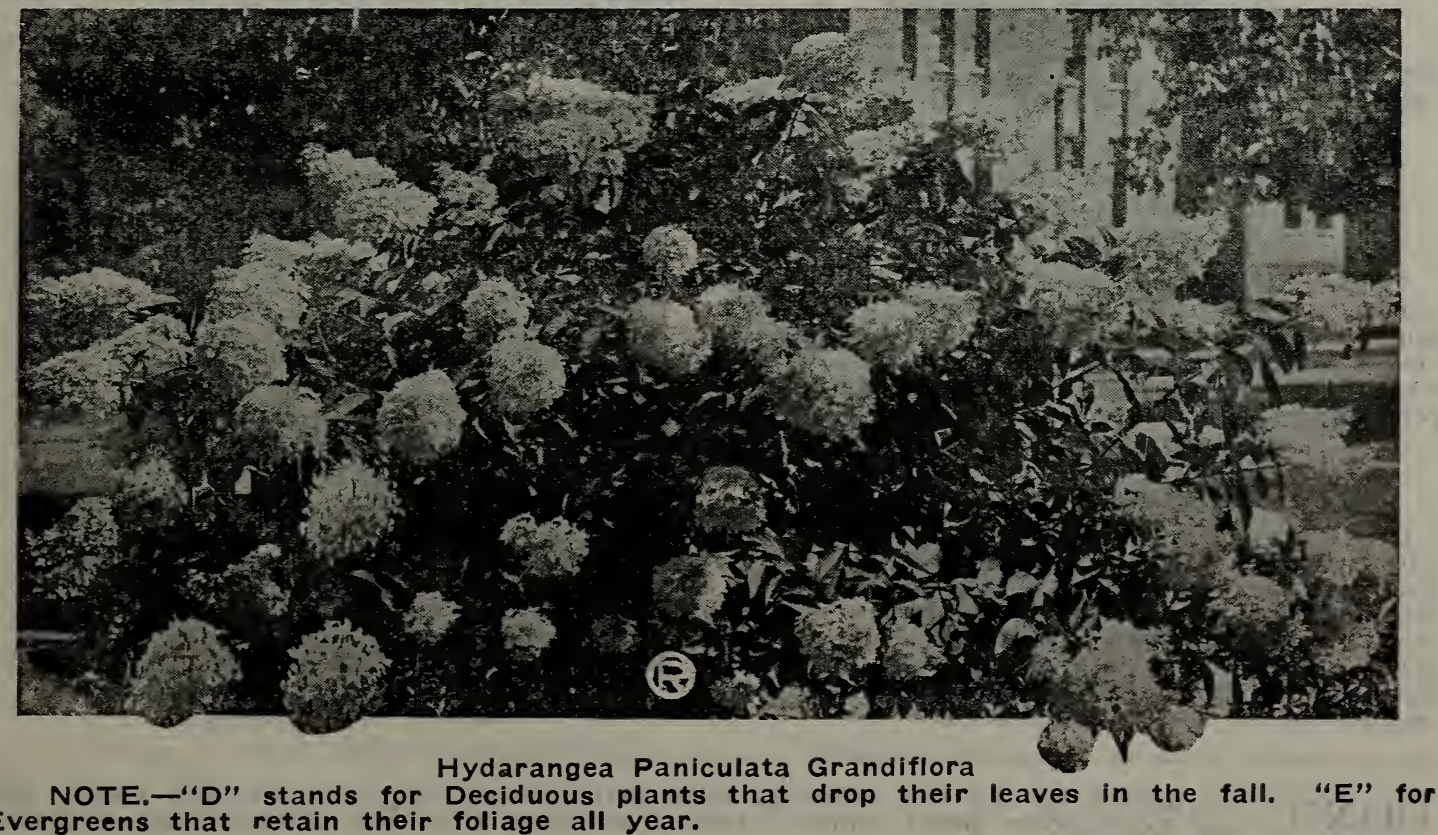

Evergreens that retain their foliage all year. 


\section{HARDY FLOWERING SHRUBS AND ORNAMENTALS-Continued}

\section{MAPLE (D) Acer}

JAPANESE.-A beautiful class of lowgrowing, shrub-like trees, having brilliant colored leaves, which retain their brightness from spring until fall. Red, Variegated or Cut Leaf, 2 to $3 \mathrm{ft}$., $\$ 2.00 ; 3$ to $4 \mathrm{ft}$., $\$ 2.50$ to $\$ 3.00$.

\section{PHILADELPHUS (D)}

MOCK ORANGE.-The flowers are sweet scented, milk-white and bloom from May to July. Wve have five choice varieties. Each $50 \mathrm{c}$ and $75 \mathrm{c}$.

\section{QUINCE (D) Cydonia}

JAPONICA.-Bright scarlet single, flowers very early in the Spring, befo.e the leaves appear. Thorny, compact growth. One of our best hardy shrubs. Smail, each 50c; large, 3 to $4 \mathrm{ft}$., each $75 \mathrm{c}$ to $\$ 1$.

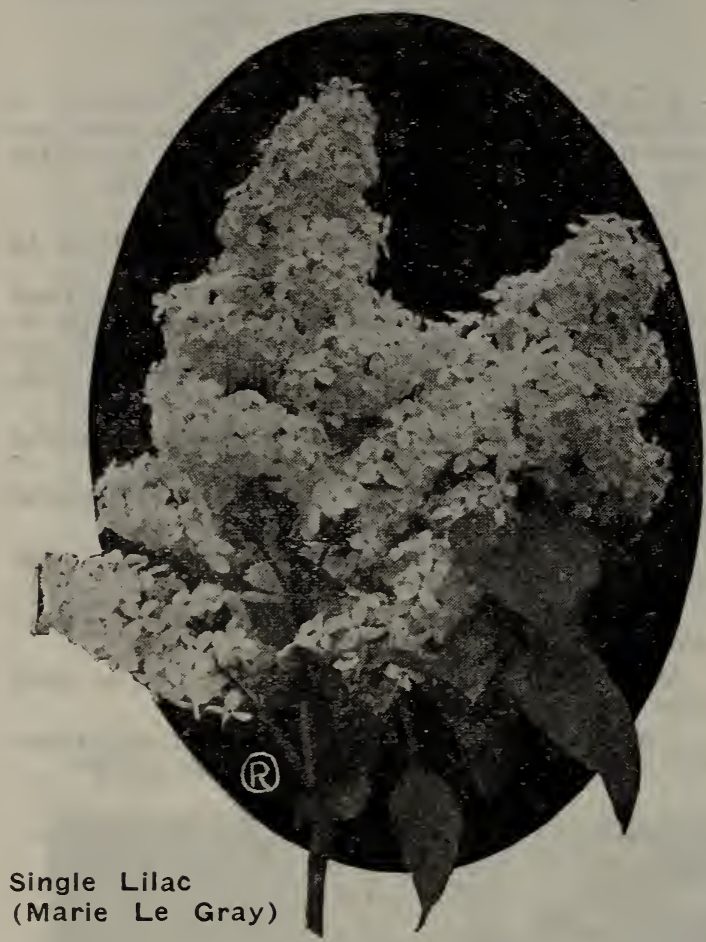

Lilac, see page 101

\section{PRUNUS (D)}

PISSARDI.-The purple leaved plum of Japan, growing into a shapely small tree of much merit, covered in the spring with clouds of white flowers, followed by leaves which turn a beautiful bronzy purple color, remaining beautiful a long time.

Each, \$1.25; extia select, $\$ 1.50$

\section{SPIREAS (D)}

Graceful shrubs, everyone should plant. They are of the easiest culture, and very desirable in collections. All the Spireas bloom with a riotous extravagance which makes them quite striking. Their individual style, color and habits of growth differ so markedly, that a collection of varieties will ensure bloom the entire season.

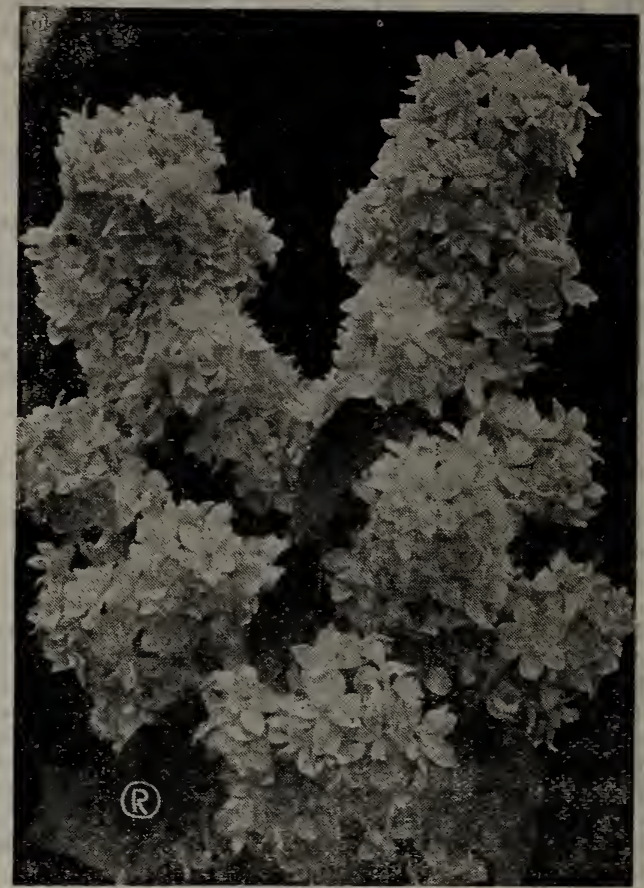

Double Lilac, Mad. C. Perier, page 101

ANTHONY WATERER (Bumalda).-Covered nearly the whole giowing season with large umbels of deep crimson flowers. Small, 60c; Large, $75 c$ to $\$ 1.00$

VAN HOUTTEI (Bridal Wreath.)-The grandest of all the Spireas. It is a beautiful ornament for the lawn at any season, but when in flower it is a complete fountain of white bloom, the foliage hardly showing perfectly hardy and an eaily bloomer. See cut.) Small plants, 50c; Large, 60c to $75 c$

THUNBERGII. - Of graceful habit; the branches are slender and somewhat drooping; foliage in autumn changes to bright red and orange; flowers in feathery masses, white, appearing early.

Small plants, 50c; Large, $75 c$ to $\$ 1.00$

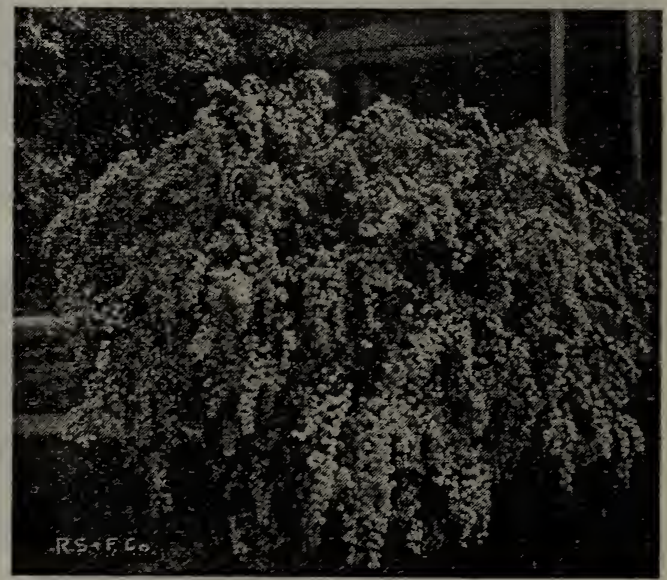

Spirea Van Houtie

DOT'T Be misled by the fine catalogs with little prices sent out from the East. Buy Be misled by the fine catalogs with little prices sent out from the East. Buy
our field-grown plant, much larger and better than the weakly Eastern stock. 


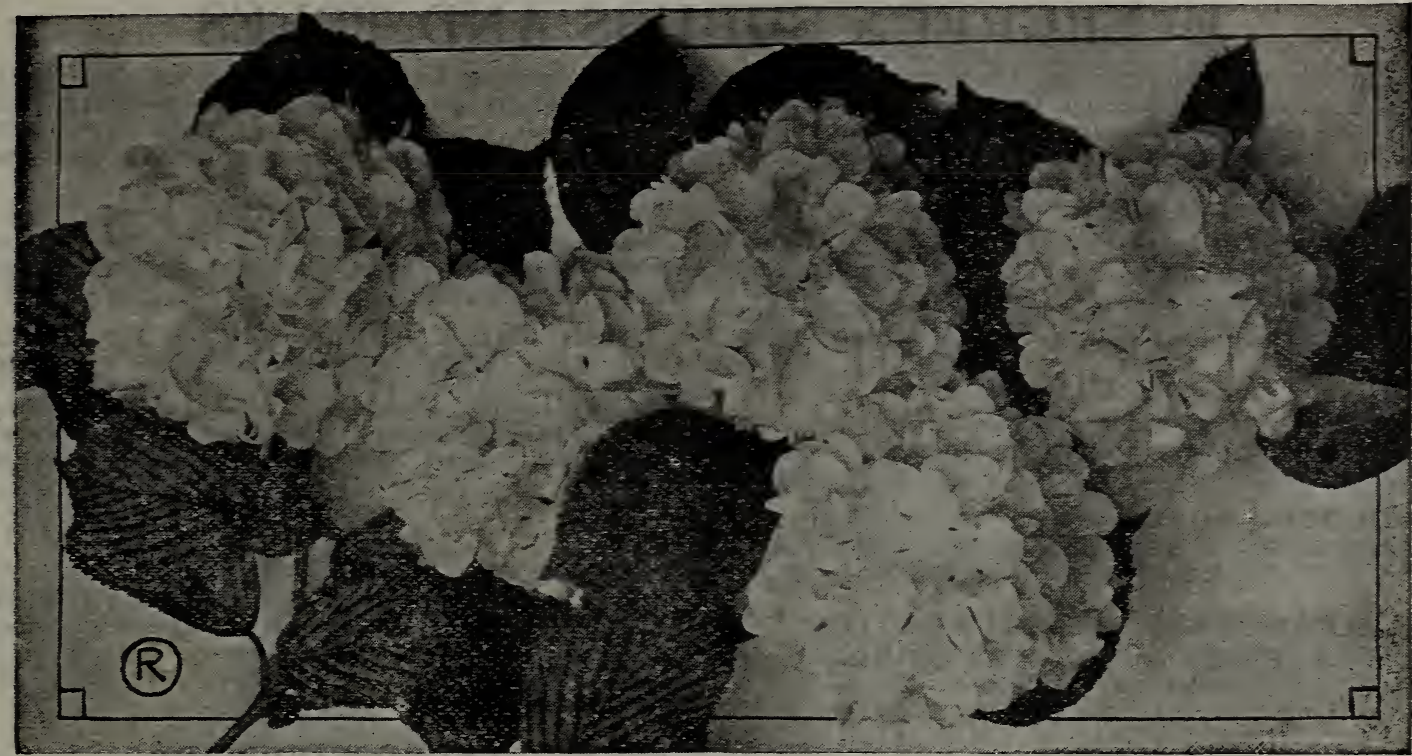

Viburnum Plicatum-Japanese Snowball

\section{SNOWBALL (D)}

STERILIS (Common Snowball).-Blooms in latter part of May. Flowers pure white, large balls. Every one should plant a Snowball. Each, small plants, $50 c$; 3 to $4 \mathrm{ft}$., each, $60 \mathrm{c}$ to $75 \mathrm{c}$; extra choice, 5 to $6 \mathrm{ft}$., $\$ 1.00$ to $\$ 1.25$.

PLICATUM (Japanese Snowball).-One of the most charming hardy flowering shrubs in existence; bears great wreaths and clusters of pure white globular masses of flowers; covered with bloom for weeks in the spring: grows 4 to 6 feet high; entirely hardy. Each, $2 \mathrm{ft}$., $75 \mathrm{c} ; 2$ to $3 \mathrm{ft}$., $\$ 1.00$.

\section{TAMARIX}

AFRICANA.-A tall slender growing shrub with fine feathery foliage on long graceful branches covered in the early summer with delicate pink flowers; a graceful and beautiful shrub. Each, 3 to $4 \mathrm{ft}$., $75 \mathrm{c}$; laige, $\$ 1.50$.

\section{WEIGELA (D)}

Beautiful shrubs that bloom in May, June and July. The beautiful trumpet-shaped flowers are produced in so great profusion as to almost entirely hide the foliage. They are very desirable for the border or grouping, and as specimen plants.

Prices: Following kinds, each $60 \mathrm{c}$ to $75 \mathrm{c}$.

CANDIDA.-Beautiful white flowers; a continuous and profuse bloomer; very hardy.

ROSEA V. - Lovely, large, rose-colored flowers, borne in such profusion that the whole bush appears a mass of rosy bloom.

EVA RATHKE. - This variety is quite scarce and rase. Has beautiful blood-red flowers. Free bloomer. Each $\$ 1.00$.

Routledge Seed \& Floral Co.,

Beaver, Ore., March 17, 1919.

Kind Friends: I received the trees in fine shape and also the ten fine roses I received a month ago, are growing nicely.

Yours truly.

MRS. SARAH KINNAWAN.
SUMAC (D)

CUT-LEAVED (Rhus Glabra Laciniata.)A beautiful shrub, with large leaves, deeply and finely cut, and drooping graceful habit. Leaves assume a gorgeous erimson color in autumn. Each, 5 to $6 \mathrm{ft}$., $\$ 1.25$ to $\$ 1.50$.

STAG HORN.-Picturesque and rugged in all stages. Flowers in June and July, followed by impressive red fruits. Each, 5 to $6 \mathrm{ft}$., $\$ 1.25$.

Always remove the packing and moss from the trees before planting. Never put manure sc as to come in contact with the roots of any plant or tree. Use only good soil on and around the roots.

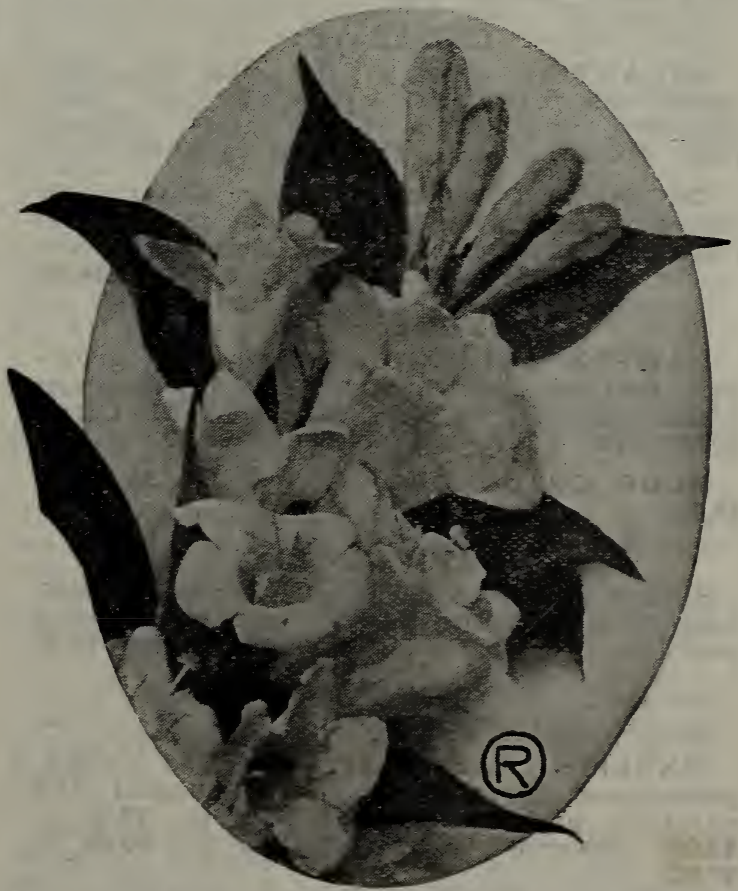

Weigela (Flowers one-half Size) 


\section{EVERGREEN SHRUBS AND TREES}

In moving evergreens, they are generally taken up with a ball of earth about the roots; this makes it necessary to ship them by express or freight only. The stock we offer has been moved in the nursery every two years. This insures their living, and they are worth double the ordinary stock. NOTE-Add $25 \%$ to the prices for packing and shipping charges.

\section{ACUBA (E)}

JAPONICA.-Beautiful broad leaved evergreen.

Each $\$ 2.50$

VARIEGATED.-With leaves speckled and striped in golden yellow. Each $\$ 2.50$

\section{ARBOR VITAE (E)}

AMERICAN. - A most valuable upright evergreen of dense, compact habit.

Each, 2 to 3 ft., $\$ 1.50$

GOLDEN.-An attractive, hardy, compact evergreen of a beautiful golden yellow.

Each, 2 to $3 \mathrm{ft} ., \$ 2.00$ to $\$ 3.00$

ARAUCARIA, IMBRICATA (E)

CHILE PINE, or MONKEY TREE.-Very rare and beautiful; pointed, needle-like leaves. $3 \mathrm{ft}$. up, specimens, $\$ 3.00$ to $\$ 5.00$

\section{AZALEA (E)}

A. CRIMSON.-A hardy evergreen species. These are dwarf, compact growers. Foliage small; flowers dazzling crimson. Each $\$ 2.50$

\section{BOXWOOD (E)}

A compact, small leaved evergreen that can be trimmed into balls, box or pyramidal shape.

DWARF, COMMON. - Fine for borders, edgings or low hedges. Hedge plants, 6 in., each 30c; per 100, $\$ 25.00$. Specimen plants shaped, $1 \mathrm{ft}$. up, $\$ 1.00$ to $\$ 2.50$.

\section{CAMELLIA (E)}

Beautiful for the house or garden; evergreen foliage; wax-like flowers.

JAPONICA. -Double, White, Pink or Red. Each, 2 feet, $\$ 2.50$ to $\$ 3.00$; extra select, 3 to 4 feet, $\$ 4.00$ to $\$ 5.00$.

\section{CEDAR (E)}

ATLANTICA.-One of the most beautiful evergreens. Upright $\mathrm{grow} \mathrm{th}$, but lowbranched and of compact habit. Foliage light green. 2 to $3 \mathrm{ft}$., $\$ 2.50$ to $\$ 3.00$.

DEODORA (Deodar or Indian Cedar).-Of vigorous growth; pyramidal form; graceful foliage of a light, silvery or glaucous green. Each, 3 ft., $\$ 3.00$ to $\$ 4.00$

\section{CYPRESS (E)}

LAWSON'S.-Hardy, graceful, rapid growing evergreen with feathery bluish-g ineen foliage. Each, 2 to $3 \mathrm{ft}$., $\$ 2.00$ to $\$ 2.50$. Large specimens, 5 to $6 \mathrm{ft}$., $\$ 3.50$ to $\$ 5.00$. $\$ 5.00$.

BLUE OR GOLDEN.-2 to $3 \mathrm{ft}$., $\$ 3.00$ to

\section{DAPHNE (E)}

Superb evergreen shrub of compact growth; very fragrant white flowers; very scarce this year.

Each $\$ 2.50$

\section{HOLLY (E)}

Very popular everywhere.

ENGLISH (Aquifolia). - Budded stock, guaranteed berry-bearing. Well balled and carefully packed. Each, 2 to $3 \mathrm{ft}$., $\$ 2.50$ to $\$ 3.00$. Specimen plants, 3 to 5 ft., $\$ 5.00$ to $\$ 7.50$.

\section{JUNIPER (E)}

Very desirable evergreens for the lawn; generally grown in pyramidal form; foliage fine and beautiful.

IRISH AND ENGLISH. $-11 \frac{1}{2}$ to $2 \mathrm{ft}$., \$1.25; 2 to $3 \mathrm{ft}$., $\$ 2.00$. Specimens, $\$ 2.50$ to $\$ 4.00$.

COMMUNIS P.-Low, graceful spreading branches; almost of trailing nature; very handsome. 3 to $4 \mathrm{ft}$. spread, $\$ 5.00$ to $\$ 7.50$ each.

\section{LAUREL (E)}

ENGLISH.-A small tree, or bush, with handsome shining thick foliage. Excellent for large hedges or screens or as single specimens. 18 to 24 inches, each, $75 \mathrm{c} ; 2$ to 3 ft., $\$ 1.00$ to $\$ 1.50$. Specimens, 4 to $5 \mathrm{ft}$., $\$ 4.00$ to $\$ 6.00$.

\section{IAURUSTINUS (E)}

Beautiful evergreen shrub with bright shining green leaves and covered in the late fall, winter and early spring with large panicles of fragrant white blossoms. 1 to $11 / 2 \mathrm{ft}$., $\$ 1.00 ; 2$ to $3 \mathrm{ft}$., $\$ 1.50$ to $\$ 2.00$.

MAHONIA AQUILFOLIA (E)

OREGON GRAPE.-Native of Oregon, and our state flower. Very valuable and desirable on account of its beautiful foliage and clusters of yellow flowers in spring, followed by blue-black berries. Choice plants, nursery grown, each $75 \mathrm{c}$ to $\$ 1.00$; large, $\$ 1.50$.

\section{PINE (E)}

AUSTRALIAN.-Robust, hardy, spreading, long, dark green needle-like foliage. 2 to 3 ft., $\$ 1.50$ to $\$ 2.00$.

MUGHO.-Dwarf, upright, but spreading habit; its silvery blue foliage makes it ve $\mathrm{e}_{1} \mathrm{y}$ desirable; bushy. 2 to $3 \mathrm{ft}$., $\$ 3.00$ to $\$ 5.00$.

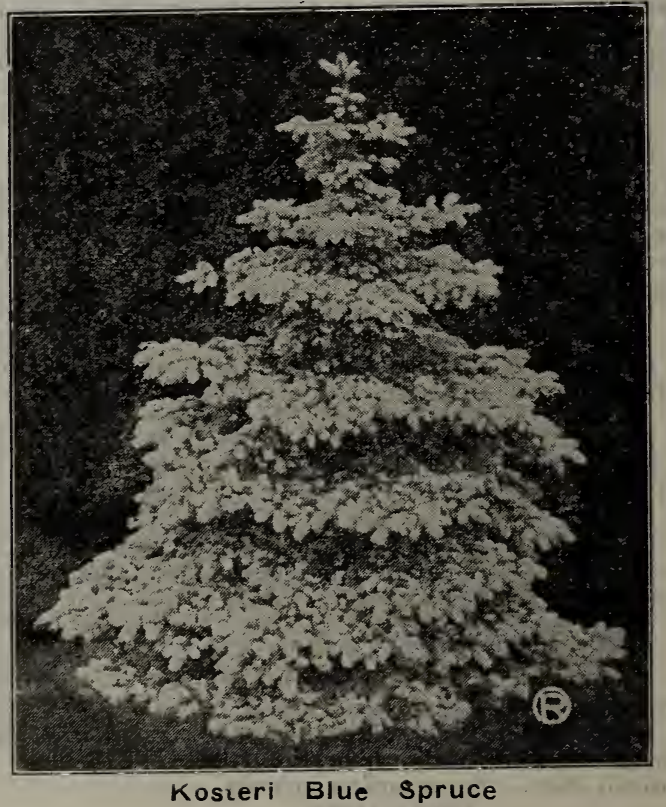

If there is any information or advice that you wish, we will be glad to serve you to the best of our ability. Twenty years' practical experience on the coast enables us to serve you intelligently. 


\section{EVERGREEN SHRUBS AND TREES-Continued}

\section{PRIVET (E)}

One of the best hedge plants; has small, pointed, evergreen leaves; grows rapidly and compactly; stands severe pruning, and can be kept in fine shape with little care. Cali. fornia.

Strong field plants, 12 in. up, per $10, \$ 1.50$ per 50, $\$ 5.50$; per 100, $\$ 10.00 ; 2$-year-old plants, 24 in., per 10 , $\$ 2.00$; per 50 , $\$ 7.50$; per $100, \$ 12.50$.

\section{RETINOSPORA (E)}

One of our most showy and graceful evergreens. There is a large class of Retinosporas, but the most popular are those of compact, tufted character. Choice, wellshaped plants in Green or Golden, 2 to $3 \mathrm{ft}$., $\$ 3.00$ to $\$ 3.50$.

\section{RHODODENDRONS (E)}

Stock very scarce. We have a limited number of budded plants in White, Lavender, Pink and Red at $\$ 3.00$ to $\$ 5.00$ each.

\section{SPRUCE (E)}

EXCELSA (Norway Spruce).-One of our most popular evergreens; dark green. Specimen plants, $\$ 1.50$ to $\$ 4.00$ each.

KOSTERI PUNGENS, GLAUCA.-A beautiful variety on account of its magnificent, rich, silvery blue color. We offer only the "true blue" imported from Holland. Each, 2 to $3 \mathrm{ft}$., $\$ 7.50 ; 4$ to $5 \mathrm{ft}$., $\$ 10.00$ to $\$ 12.00$. COLORADO BLUE.-In color resembles the above, but shows less color. $2 \mathrm{ft}$., $\$ 2.50 ; 2 \frac{1}{2}$ to $3 \mathrm{ft}$., $\$ 6.00$.

\section{YUCCA (E)}

A stately foliage and flowering plant equally imposing in solitary or group plantings, always conspicuous. The broad, swordlike foliage is evergieen; while midsummer shows great erect branching stems bearing a showy display of pendant, creamy-white bells.

Prices: 2-year and up, 35c to $50 \mathrm{c}$; 18 to 24 in., $75 \mathrm{c}$ to $\$ 1.50$. Specimen plants, $\$ 2.00$ to $\$ 3.00$.

\section{SHADE AND ORNAMENTAL TREES}

The following are our most popular varieties. If you want some other kind, inquire; we, no doubt, can supply.

NOTE.-We make a delivery charge in the city, rate on request; also a packing and shlpping charge on out-of-town orders as follows: One tree, $50 \mathrm{c} ; 6$ for $\$ 1.00 ; 12$ for $\$ 1.50$.

\section{BIRCH (D)}

Remarkable for its elegance; very graceful; silver bark and slender branches.

EUROPEAN WHITE. -7 to $8 \mathrm{ft}$, each $\$ 1.50 ; 9$ to $10 \mathrm{ft}$, each $\$ 1.75$ to $\$ 2.00$.

WEEPING CUT-LEAVED (alba lancinita pendula).-Charming tree; gracefully drooping branches, silvery white bark and delicately cut foliage present a combination of attractive characteristics ralely met with in one tree. 7 to $8 \mathrm{ft}$., $\$ 2.00 ; 10 \mathrm{ft}$., $\$ 2.50$.

\section{CATALPA (D)}

A beautiful shade tree. White flowers in July.

SPECIOSA. 6 to $7 \mathrm{ft}$., each $\$ 1.25 ; 8$ to 10 ft., $\$ 1.50$ to $\$ 1.75$.

\section{CHESTNUT (D)}

Very popular, stately shade trees. Extensively planted for shade.

HORSE, EUROPEAN, RED FLOWERING. -Much slower grower than the white. 5 to $6 \mathrm{ft}$., $\$ 1.25$ to $\$ 1.50$.

HORSE, WHITE FLOWERING.-4 to 5 ft., $\$ 1.00 ; 6$ to $8 \mathrm{ft}, \$ 1.25 ; 9$ to $10 \mathrm{ft}$., $\$ 1.50$; 10 to $12 \mathrm{ft}$., $\$ 2.00$.

AMERICAN SWEET.-4 to $6 \mathrm{ft}$, each $\$ 1.00$.

\section{DOGWOOD, OREGON}

4 to $6 \mathrm{ft}$., each $\$ 1.00$ to $\$ 1.50$.

$$
\text { ELM (D) }
$$

One of the most popular and best shade trees. Very desirable for street.

AMERICAN WHITE.-6 to $7 \mathrm{ft}$, each $\$ 1.25 ; 8$ to $10 \mathrm{ft}$., $\$ 1.50$ to $\$ 2.00$.

WEEPING ELM (Camperdown). - Each $\$ 2.50$.

\section{IINDEN (D)}

Very desirable and beautiful trees for park or street planting; large heart-shaped leaves, white flowers; rapid growers. 7 to $8 \mathrm{ft}$., each $\$ 1.50$.

\section{MAPLE}

SILVER VARIEGATED (A. Negunde Varlegatum).-Most attractive; leaf is variegated white and green 4 to $6 \mathrm{ft}$., $\$ 1.50 ; 6$ to $8 \mathrm{ft} ., \$ 2.00$.
LARGE GROWING MAPLES FOR SHADE Your choice of the following kinds: 7 to $8 \mathrm{ft}$., $\$ 1.50 ; 8$ to $10 \mathrm{ft}$, $\$ 1.75 ; 10$ to $12 \mathrm{ft}$., $\$ 2.00$.'

NORWAY.-Of large, compact habit; broad, deep green shining foliage, and stout, vigorous growth.

OREGON. - Wide-spreading branches and large foliage; very rapid growth.

SILVER OR SOFT.-Native tree of rapid growth; foliage bright green above and silvery white beneath

SUGAR or HARD.-Of upright habit of growth; dense shade; extensively used.

ASH-LEAVED.-A fine, rapid-growing variety, with handsome, light green foliage and spreading head; very hardy; desirable for street planting.

PURPLE-LEAVED SYCAMORE MAPLE. -A purplish tone is imparted to the tree by the purple under-surface of its leaves; the effect being very fine when the leaves are in motion.

WIER'S CUT-LEAVED (Weeping).-Berutifully disseeted foliage; shoots slender and drooping; of rapid growth; makes a large tree if undisturbed; adapted to small lawns. 6 to $8 \mathrm{ft}$., $\$ 2.00$.

\section{MOUNTAIN ASH (D)}

Very ornamental trees, especially when covered with its clusters of red berries in the fall. 7 to $8 \mathrm{ft}$., $\$ 1.50 ; 8$ to $10 \mathrm{ft}$., $\$ 2.00$. POPLAR (D)

These well known trees are planted largely for windbreaks and ornamental purposes; very rapid growers.

CAROLINA.-Pyramidal; Lombardy.-Tall and spiral, 7 to $8 \mathrm{ft}, 75 \mathrm{c} ; 8$ to $10 \mathrm{ft}$., $\$ 1.00$. TULIP TREE (D)

A rapid-growing tree, with rich, glossy foliage; flowers tulip-shape, greenish yellow; a fine shade tree. 7 to $8 \mathrm{ft.}, \$ 1.50 ; 8$ to 10 ft., $\$ 2.00$.

\section{WILLOW (D)}

BABYLONICA (Babylonian or Weeping Willow). - Foliage is bright green and has a wavy appearance. A well known and graceful variety. 6 to $8 \mathrm{ft}$., $\$ 1.25 ; 8$ to $10 \mathrm{ft}$., $\$ 1.75$. 


\section{RAISE ENGLISH WALNUTS}

We can successfully raise English Walnuts here in the Pacific Northwest, and the quality of the nuts is superior to most other sections. Plant a tree or two, at least, for your own use and, if you have a large place, plant more. While the cost of grafted stock is more, we advise you to plant them, as there is "no chance" as to quality of the nuts.

WALNUTS (D). Grafted Stock.-This year we are prepared to supply you with Oregongrown trees that are extra select and ESPECIALLY FINE ROOTED, much superior to the California trees on account of the fine growth of strong fibrous roots. The stock we offer is Voorman's famous Franquette grafted on California black walnuts roots.

Prices: 4 to $6 \mathrm{ft}$, each $\$ 2.50$; per $10 \$ 20.00 ; 6$ to $8 \mathrm{ft}$., each $\$ 3.00$; per $10 \$ 25.00$.

English.-Nut-bearing, second generation stock, not grafted. Prices: Each, 4 to $6 \mathrm{ft}$. $75 \mathrm{c}$; 6 to $8 \mathrm{ft}$. $\$ 1.00, \$ 1.25$.

\section{BEAUTIFUL HARDY CLIMBING VINES}

\section{AMPHELOPSIS}

VEITCHI (Boston IVy, or Japan IVy). -The most popular and desirable climbing plant for covering brick, stone or cement walls, etc. : when it becomes established at the root it is of very rapid growth and clings to the smoothest surface. The foliage is of a rich olive green during the summer, changing to various shades of bright crimson and scarlet in the fall. In planting cut back to within 6 inches of the ground, so that the new growth may cling to the wall from the bottom up. Strong plants, 50c; extra strong, 75c.

QUINQUIFOLIA (Virginia Creeper, or American Ivy).-This well-known climber is one of the best and quickest growing varie-

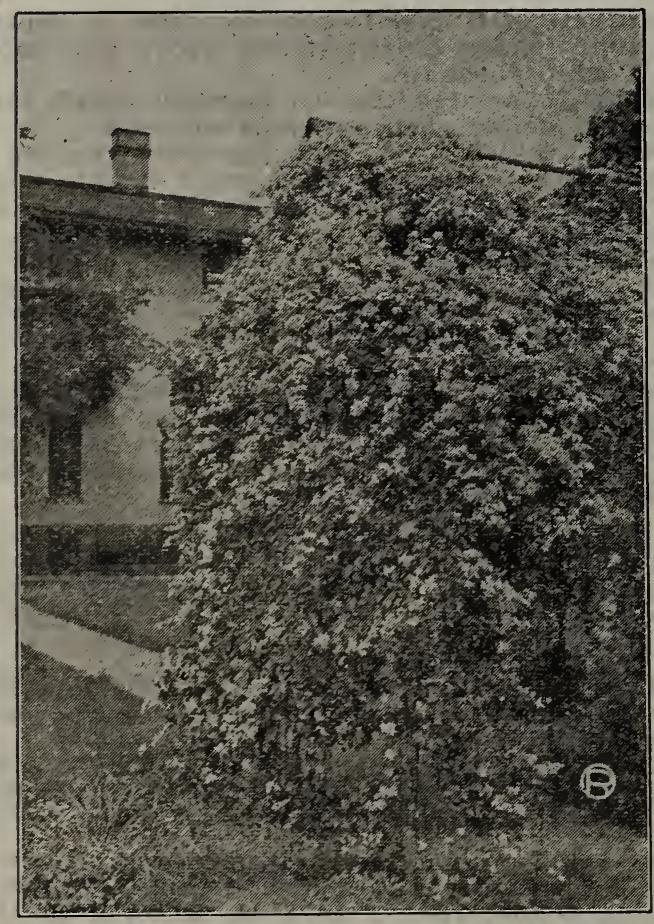

Clematis Paniculata. ties for covering trees, trellises, arbors, etc.; its large, deep green foliage assumes brilliant shades of yellow, crimson and scarlet in the fall. Strong plants, 50c; extra strong, $60 \mathrm{c}$.

\section{EUONYMUS RADICANS}

One of the finest evergreen vines, with small, rich green foliage. For covering rocky banks, rough walls, tree trunks, etc. also for vases, boxes and borders of beds. 18 to 24 in. (bushy), $75 \mathrm{c}$ each; $\$ 7.00$ doz.

VARIEGATA.-Foliage edged with creamy white, which takes on a pinkish tinge in winter. 18 to 24 inches (bushy), $75 \mathrm{c}$ each; $\$ 7.00 \mathrm{doz}$.

\section{JASMINE}

Graceful, pretty flowers with fine foliage, clean, neat, attractive and hardy. Each $75 \mathrm{c}$.

\section{KUDZU VINE}

THUNBERGIANA.-Foliage large, affording dense shade. Bears small racemes of rosy purple blossoms in August. The most remarkable rapid growing vine in existence and unparalleled for ornament and shade. Exceedingly valuable for covering arbors, verandas and pillars. Each $40 \mathrm{c}$.

\section{IVY EVERGREEN}

COMMON ENGLISH. - Thick, leathery evergreen leaves: strong grower. Doz. \$2.25. Good roots, each 25c; large 50c.

\section{CLEMATIS}

No hardy flowering climbing vine excels in beauty and effectiveness the finer sorts of Clematis. As a climber for the veranda, a screen for fences, for pillars along the garden walks, for training on walls or arbors or in masses on rockwork, it has no rival among strong growing blossoming plants. The Clematis should be grown in rich, deep, sandy loam and well mulcted with rotten manure in winter. The richest sheets of bloom and largest flowers are obtained where it has partial shade and a liberal supply of water at the roots.

PANICULATA (Sweet-Scented Japan).-Of very rapid growth, quickly covering trellises and arbors with handsome, clean, glossy, green foliage. The flowers are of small size, pure white, borne in profusion in September and October, and of a most delicious and penetrating fragrance. Choice plants, 50c; large, field-grown plants, $60 \mathrm{c}$ to $75 \mathrm{c}$ each.

Important.-When planting Clematis and other vines be sure you spread out the mat of fine roots so that the soil comes in contact with all of them, otherwise they will dry out and die. Be very careful with Clematis especially. Use "Wonder" and "C-M," pages 38-39. 


\section{HARDY CLIMBING VINES-Continued}

\section{CLEMATIS_Continued_Large Flowering}

These bear large and beautiful flowers of various shades of color through the latter part of the summer and early fall. The following varieties are the very best and our plants are all two years old.

Your choice of the following strong field-grown roots, $75 \mathrm{c}$ to $\$ 1.00$ each postpaid:

Ramona.-The best light blue or lavender.

Ville de Lyon.-The best bright red; equal to Jackmanii in size.

Henryi.-Fine large creamy white flowers. A fine strong grower.

Jackmanii.-Intense violet purple; most popular variety.

Duchess of Edinburgh.-A free flowering double white variety; very fragrant.

Caution.-In planting Clematis dig a large hole and spread the roots out very carefully and cove crown of plant about four inches. Keep watered if set close to a dry wall.

\section{HONEYSUCKLE}

A beautiful climber, rapid grower and very desirable; flowers very fragrant, and produced in great profusion.

Your choice of the following, 65c each; extra strong, 75c.

Halleana.-Very popular; almost evergreen; profuse bloomer; flowers white, passing to yellow.

Belgica (Monthly Fragrant).-Flowers are large; color red and yellow.

Sempervirens (Scarlet Trumpet Honeysuckle.) Flowers of a bright scarlet.

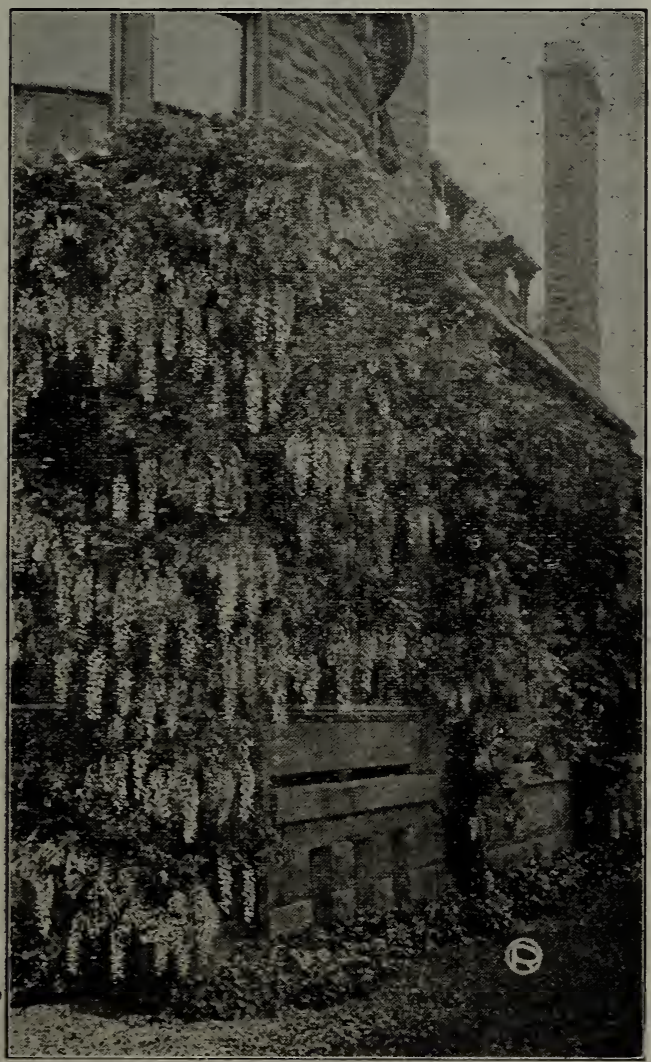

Wistaria Vine in Bloom

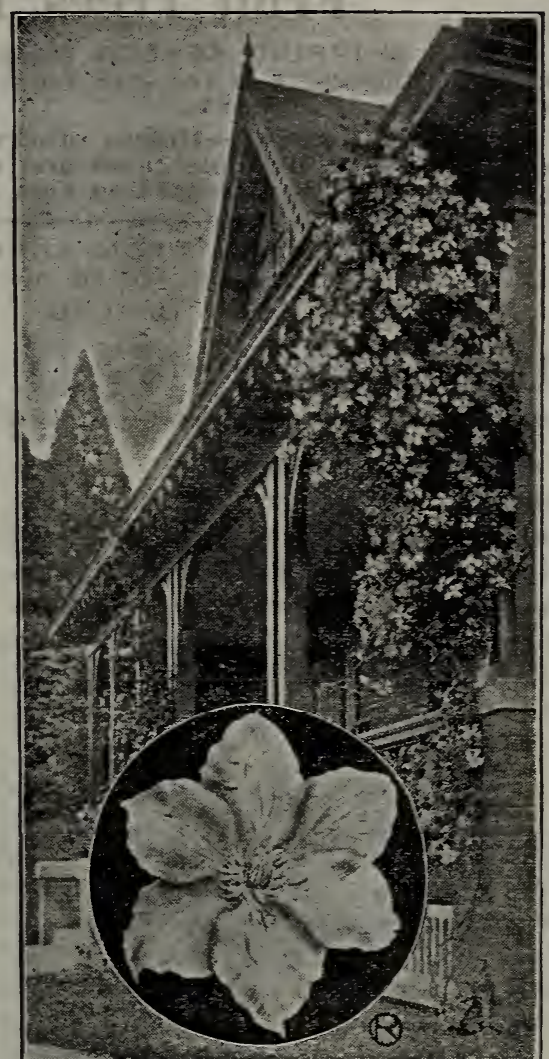

Clematis Jackmanii Vine and Single Flower, $1 / 4$ Size

\section{TRUMPET VINE}

BIGNONIA.-For covering unsightly places, trellises, rockwork or wherever a showyflowering vine is desired, the Bignonias will be found very useful. The flowers are large. attractive and borne profusely when the plants attain a fair size. Strong plants, each, 75 c.

\section{WISTARIAS}

WISTARIAS.-The strongest growing of all hardy vines, easily reaching the roof of a two-story building in a few years if given a chance to climb. Our illustration gives an idea of the value of these vines as a decorative subject. They are as hardy as an oak tree and will grow and bloom in any locality. The flowers appear with the first leaves late in the spring and hang like great bunches of grapes, to the admiration of all who see them. All the varieties are very sweet-scented, as can be attested to by the bees, who are attracted to them when in bloom in the spring.

SINENSIS BLUE.-A very rapid growing, hardy climber; lovely long panicles of dark blue flowers, produced in the most wonderful profusion. Strong vines. each $\$ 1.50$.

SINENSIS ALBA.-Like the preceding, but with beautiful white flowers in long panicles. A veritable sheet of bloom in late spring. Strong vines, each $\$ 1.50$.

Note.-We have a limited number of extra large specimens 5 years old at $\$ 5.00$ each.

"MAKE 'EM HOP."-If you will mix a cup full of Wonder Fertilizer with 5 lbs. "C-M" and woik both thoroughly into the soil around your climbers you will get wonderful growth and lovely flowers. See pages 38-39. 


\section{Fruit Trees, Bushes, Vines and Plants}

OUR SHIPPING SEASON for the above is from November 1 to April 1 . Some seasons May 1, although it is too late for best results. We advise late fall or early spring planting while stock is dormant.

HOW WE SHIP.-Unless otherwise instructed we ship by express or freight, whichever is cheapest. In extreme cases and when necessary, 1-year fruit tree, 3 to $4 \mathrm{ft}$. only, can go by parcel post at an increased cost of $25 \%$ on per 10 or dozen prices, or $15 \mathrm{c}$ each on single trees, to cover postage and careful packing.

CAR : OF STOCK UPON ARRIVAL.-If you are not ready to plant, dig a trench and "heel" in. If ground is frozen put in a cellar and keep roots damp.

NO STOCK SENT C. O. D.

SUBSII'IUTION, ies of the tree ordered cannot be supplied or bought UBNIIIU1U1 locally, others equally as good and correctly labeled will be substituted, unless otherwise ordered.

OTHER VARIETIES.-On this and the following pages you will note that we give full description of only a few varieties under each heading. These, we believe, are the best for general or home planting, and you will not miss it by selecting them. We, however, will try and secure for you any variety grown in the West.

\section{APPLES}

Uriess otherwise priced Each Per 10

One year old, 3 to 4 feet.....\$.60 $\$ 5.00$

One year old, 4 to 6 feet..... $.65 \quad 6.00$

Two year old, branched....... .75 $\quad 6.50$

Selected, 2 to 3 year........ 1.00

Write for our low prices per 100.

SUMMER VARIETIES.

RED ASTRACHAN. Medium deep crimson, flesh white, moderately juicy, with an agreeable rich acid flavor: very productive.

YELLOW TRANSPARENT. Medium size, roundish, slightly conical; skin pale yellow, flesh tender, juicy, sub-acid; good.

\section{AUTUMN VARIETIES.}

GRAVENSTEIN. Large, beautiful yellow, dashed with deep red and orange; tender and crisp, with a highly aromatic flavor; tree very vigorous; very popular sort.

KING OF TOMKINS COUNTY. Very large, globular; yellowish, shaded with red; flesh yellowish, rather coarse, juicy, rich flavor.

WEALTHY. Medium, whitish yellow, shaded with deep red; flesh white, tender and juicy.

\section{WINTER VARIETIES.}

BALDWIN. Large, rounded; deep, bright red; very productive; one of the best and most popular winter apples.

DELICIOUS. A splendid apple; coming into prominence rapidly. Tree vigorous and hardy and the fruit equals the name in every respect. Fine for market and home use; late; keeps till April.

NORTHERN SPY. Large, round, greenish-yellow, stripes of purplish red; flesh white, juicy, brisk sub-acid; valuable for market and cooking.

ORTLEY (White Bellflower). Fruit medium to large, yellow; sometimes with a sunny cheek; flesh white, fine-grained, tender, juicy, sub-acid.

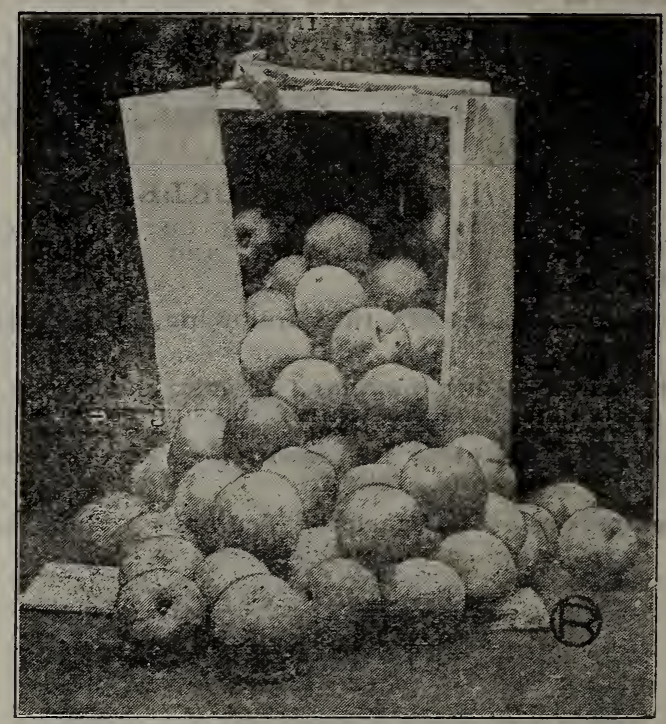

Salmon, Idaho, A pril 20, 1919.

Routledge Seed \& Floral Co..

Gentlemen: I saw some of your trees today and I consider them the best that have come here this year.

Yours truly,

$$
\text { PYEATTL'S PHARMACY. }
$$

WINTER VARIETIES-Continued.

SPITZENBERG. Large, oblong, yellowish ground with broken stripes of bright red; flesh yellow, juicy with a delicious rich flavor.

WINTER BANANA. Winter; yellow; blush cheek; sub-acid; medium size; a good keeper; a handsome apple; fine flavor, tender and delicious.

YELLOW NEWTOWN PIPPIN. Large skin smooth, golden yellow; flesh firm, crisp, juicy; one of the standard varieties.

ARKANSAS BLACK. Dark maroon, long keeper; flesh firm, fine grained and juicy.

GRIMES' GOLDEN. Of the highest quality; large, yellow; very productive.

JONATHAN. Yellow, covered with red; of excellent quality and heavy cropper.

RHODE ISLAND GREENING. Greenish yellow; large; very rich flavor.?

ROME BEAUTY. Large, yellow, shaded bright red; juicy sub-acid, good bearer.

WINESAP. Medium size, deep red; firm, crisp and excellent; widely cultivated. 


\section{CRAB APPLES \\ Prices the same as Apples}

TRANSCENDENT.-Fruit very large, skin yellow, striped with red; the best of its class for cider. September.

YELLOW SIBERIAN.-Fruit small, golden yellow. Good variety, ripens in August.
FLORENCE.-Size medium, red striped, early bearer; bearing full crop each year; tree immensely productive; juicy and crisp. September.

HYSLOP.-Large, dark crimson; popular. A hardy variety. Late.

\section{APRICOTS}

Unless otherwise priced Each Per 10

1 year old, 4 to 5 feet.......\$1.00 $\$ 9.00$

1 year, 3 to 4 feet........... .90 7.50

MOORPARK. - Very large, yellowishgreen; brownish red on the sunny side; flesh bright orange; fine for canning and drying; freestone.

Tacoma. Wn.; March 3, 1919.

Routledge Seed \& Floral Co..

Sirs: I received the strawberry plants all $O$. $K$. and many thanks for same.

I am looking forward now for the time when they will bear fruit.

Thanking you, I remain.

Yours truly.

MRS. FRED GRAHAM.

\section{CHERRIES}

Unless otherwise priced Each

1 year old, 3 to 4 feet......\$ .85

Per 10

1 year old, 4 to 6 feet....... .90

$\$ 7.50$

2 year old, branched ....... 1.00

8.50

Selected, 2 to 3 year......... 1.25

9.00

Write for our low prices by 100 or 1000 .

NEW - ABUNDANCE (Burbank produc. tion).-A seedling of Royal Ann, larger, handsomer, sweeter and more delicious than this great favorite; ripens a week later. Price, each, 1 year, 4 to $6 \mathrm{ft}$., $\$ 2.00$

BING.-Originated in Oregon: fruit large, dark brown or black; very fine; late; a good shipping variety.

KENTISH (Early Richmond).-Light red, juicy one of the best acid cherries and unsurpassed for cooking purposes; very productive.

LAMBERT.-Fruit of largest size and of fine quality; color deep, rich red; flesh firm and of fine flavor: a fine market variety; ripens two weeks later than Royal Ann.

NEW-THE "BURBANK."-A rich, fine flavored dark red cherry, sweeter than other early varieties; a good shipper, vigorous grower and never failing producer.

Price, 1 year 4 to $6 \mathrm{ft}$,, select trees, each $\$ 2.00$.
LEWIS.-One of the largest apricets known; handsome in appearance; flavor excellent. If you have room for only one apricot tree, plant the Lewis.

ROYAL.-Above medium size; sweet, rich and juicy.

TILTON.-Large, rich color, high flavor; very productive.

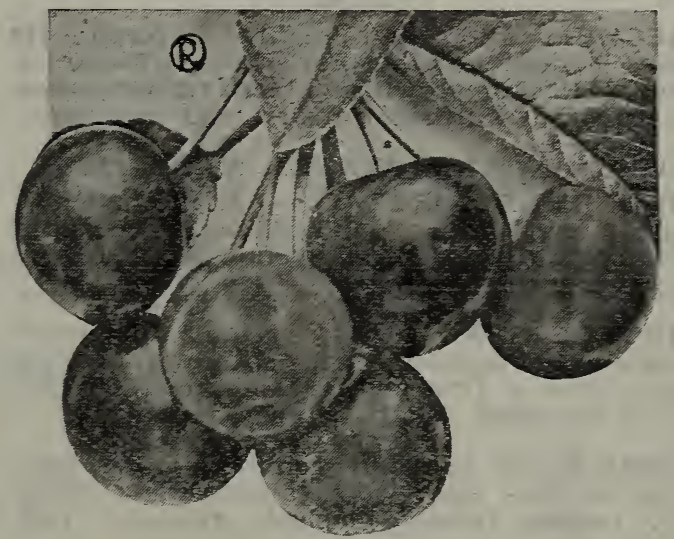

Wallace, Idaho, April 22, 1919. Routledge Seed \& Floral Co..

Gentlemen: All of the plants and the tree arrived in good condition and have transplanted well.

Respectfully yours. MRS. H. J. HULL.

LATE DUKE. - Large, light red; late and excellent; sub-acid.

MAY DUKE.-Large, rich, dark red; flesh tender, juicy, and sub-acid; an excellent variety, and one of the earliest of its class.

ROYAL ANN (Napoleon Bigarreau).-A magnificent cherry of the largest size; pale yellow, becoming amber in the shade; richly dctted and spotted with deep red, and with a bright red cheek; flesh very firm, juicy and sweet; tree a rapid grower and immense bearer.

OTHER VARIETIES. - Black Republican, Montmorency, etc.

\section{QUINCE}

1 year old ............Each 75 c to $80 \mathrm{c}$

2 year old branched ............\$1.00

Extra select ................. \$1.25

CHAMPION.-Large, yellow; flesh cooks very tender; flavor is most delicious: more productive than the orange, ripening two weeks later.
PINEAPPLE.-The fruit in form and size resembles the Or:nze Quince but is smooth$\mathrm{er}$ and more y!obular. Mikes a superior jelly. Can be eaten raw, and is said to conk as tender in five minutes as the best cooking apple, possessing a most exquisite and delicious flavor, not equaled by any other quince. September.

RAISE CLEAN, PERFECT FRUIT BY SPRAYING-Don't let the bugs get started. SPRAY EARLY. We offer you a complete line of insecticides and sprayers at low prices. See pages 123 to 125 . 


\section{PEARS}

Unless otherwise priced Each Per 10

One year old, 3 to 4 feet.....\$.80 $\$ 7.50$

One year old, 4 to 6 feet..... $.90 \quad 8.00$

Two year, branched ........ $1.00 \quad 9.00$

Selected two year 1.25-1.50

Write for low prices per 100 .

\section{SUMMER VARIETIES}

BARTLETT.-Large, skin thin, clear, lemon yellow, with soft blush on the sunny side; flesh white, buttery, very juicy and highly flavored; the best summer pear in existence.

BEURRE BOSC.-Handsome deep yellow, slightly russet; high quality, tender, aromatic. September.

FALL BUTTER.-Favorite fall pear; yellow, smooth and juicy; September.

SECKEL.-Rich and highly flavored; its highly concentrated, spicy, honey flavor is unequaled; skin brownish green, russet brown cheek; flesh whitish, buttery and melting.

\section{AUTUMN AND WINTER VARIETIES}

BEURRE CLAIRGEAU.- - Large, yellow, shaded with orange and crimson; covered with russet dots; flesh yellowish, buttery, juicy; October-November.

BEURRE D'ANJOU.-A large, fine pear, buttery and melting with sprightly, vinous flavor; tree a fine grower and good bearer; ine of the very best; October-January.

COMICE.-A splendid commercial variety, being of fine size; good appearance; ships well; yellow, faintly blushed crimson. Oct.

WINTER BARTLETT.-Originated in Eugene, Oregon. Fruit large, closely resembling the famous Bartlett in shape and appearance, but ripening considerably later; tender, juicy and melting and with a most pleasing flavor.

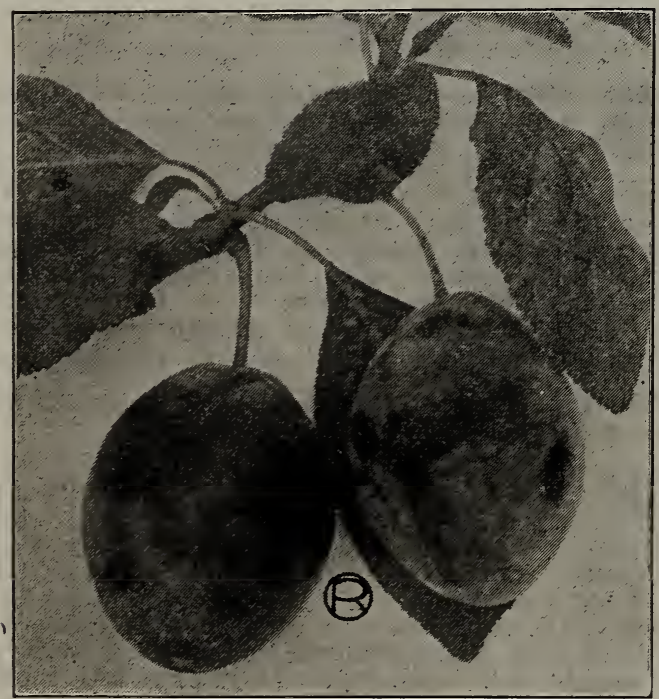

Italian

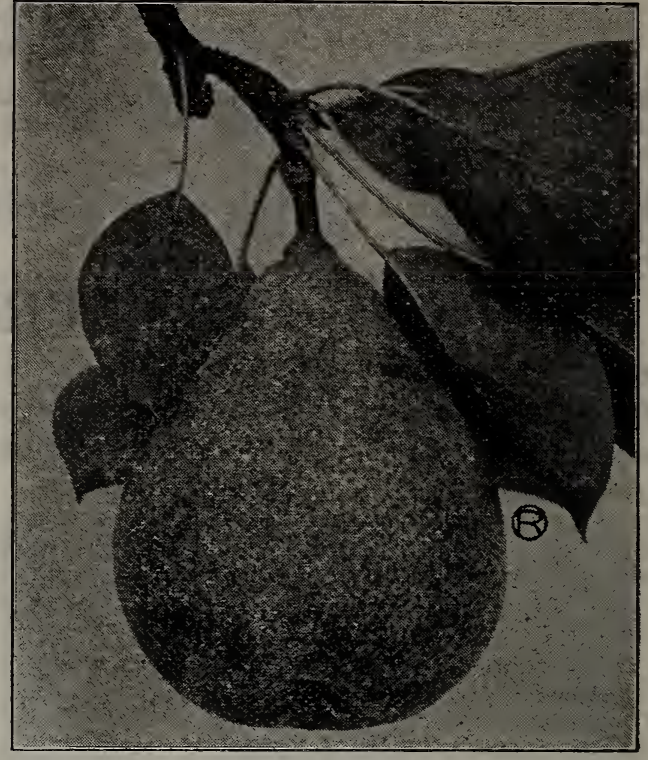

Bartlett

FLEMISH BEAUTY.-Large, juicy, rich, very hardy, productive and profitable. September-October.

WINTER NELLIS.-Medium; skin yellowish green, dotted with gray russet: flesh yellowish white; fine grained and abounding with juice of a rich saccharine, aromatic flavor; especially adapted to this valley, proaucing large crops every year; an excellent shipper and good keeper; November-December.

\section{PRUNES}

Unless otherwise priced Each Per 10

One year old, 3 to 4 feet.....\$.60 $\$ 6.00$

One year old, 4 to 6 feet..... $.75 \quad 7.00$

One year old, 6 to 8 feet..... $1.00 \quad 9.00$

Two year old ........... 1.50

Write for our low prices by 100 .

GIANT.-New; of immense size, dark crimson on yellow ground; good yielder: flesh firm, rich, sweet, delicious; good shipper.

HUNGARIAN.-Very large, dark red; juicy and sweet.

ITALIAN (Fallenberg). - Medium, oval, tapering at both ends; dark purple; flesh greenish yellow; separates freely from the stone; best for drying.

PETITE (French). - Small size, eggshaped; violet purple; sweet, rich and sugary; very productive; standard for drying.

SILVER.-Seedling of the Coe's Golden Drop; excellent for drying or canning. September.

SUGAR. - Tree vigorous grower; early bearer; fruit ripens earlier than the French; is four times as large and dries in half the time; flesh tender and rich in sugar; color dark purple; August.

NEW STANDARD.-Burbank production. $\$ 2.00$ Each 


\section{PEACHES}

Unless otherwise priced Each

One year old, 3 to 5 feet.....\$.75

Selected $\ldots \ldots \ldots \ldots \ldots \ldots \ldots 1.00$

Write for our low price by 100 .

EARLY CRAWFORD.-Very large, yellow; with red cheek; ;flesh sweet and excellent; our most popular peach for table and canning; freestone.

EARLY ALEXANDER.-One of the largest and best of the extra early varieties; almost freestone; tree bears young.

ALBERTA.-Very large, bright yellow, red cheek; flesh yellow, juicy, sweet; regular bearer; fruit very showy and perfect; freestone early.

EARLY CHARLOTTE.-An improved seedling from Early Crawford, originated at Salem, Ore. This remarkable peach succeeds in Oregon, where many other varieties fail. Flesh yellow, melting and juicy, with a rich and excellent flavor; freestone; ripens ten days after Crawford's Early.

LATE CRAWFORD.-Very large, roundish; yellow, with dark red cheeks: flesh deep yellow, juicy and melting; flavor rich and excellent; very popular; valuable for canning and drying; freestone; September.

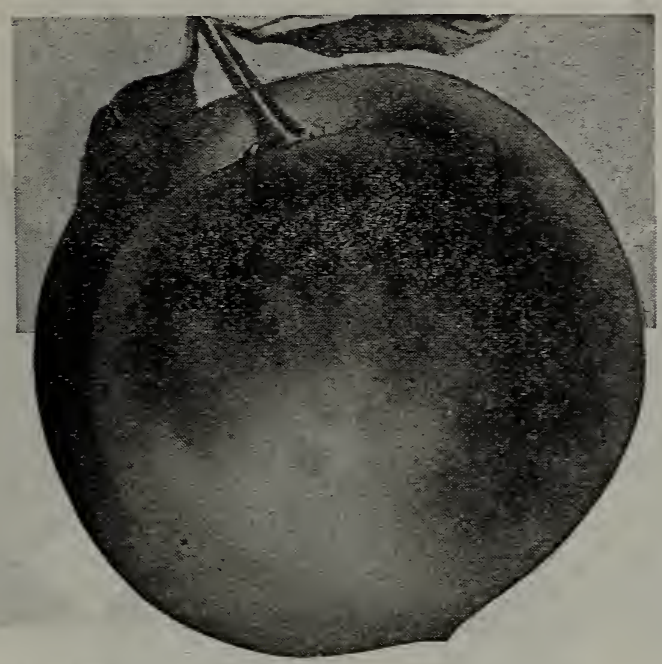

HALE'S EARLY.-Skin greenish white, red cheek, flesh white; juicy and sweet; semi-freestone; very early and good.

MUIR.-Iarge, pale yellow, very firm and sweet; best for drying; freestone; August.

SALWAY.-Creamy yellow, red cheek; flesh deep yellow, red at the pit; rich and sweet; a standard late peach; freestone.

\section{PLUMS}

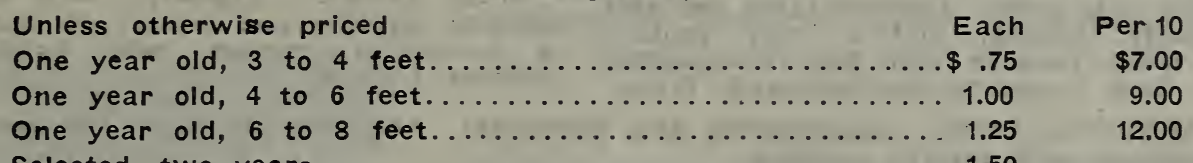

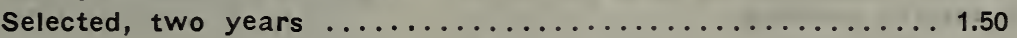

Write for our low prices by the hundred.

BURBANK.-Largest and handsomest of the new plums; perfectly hardy, free from disease; juicy, tender and sweet; ripens early July; as fine eating as a peach; freestone should be in every collection.

COLUMBIA (Shipper's Pride). - Largest size, nearly globular; brownish purple; rich, sugary, freestone; August.

GREEN GAGE.-Small, round; flesh pale green, melting and juicy; freestone; August.

PEACH.-Very large; skin brownish-red, slightly coarse-grained, but juicy; freestone; very popular as a home and market variety; August.
DAMSON.-Small, oval; skin purple; flesh melting, rather tart; September.

YELLOW EGG.-Very large, skin of a deep golden color, but rather acid; excellent for cooking; very showy; August.

MAYNARD.-Originated by Luther Burbank. Very large, nearly round flattened at ends. Of richest crimson-purple, deepening to royal damask. Tree hardy, vigor ous and ccmpact grower; bears immense crops while very young; never fails; flesh firm, even when dead ripe, but melting and juicy with a deliciousness indescribable; July.

SATSUMA (Blood Plum).-Japanese variety. Quite popular, large dark red from skin to pit, which is small, firm and juicy; tree productive. Early July.

\section{NECTARINES}

Prices: 3 to $5 \mathrm{ft}$, each $75 \mathrm{c}$; per $10, \$ 6.50$.

BOSTON. - Large, deep yellow, bright blush; flesh yellow; very rich and luscious. Best for Oregon; Áugust.

EARLY VIOLET. - Medium; skin pale, shaded violet; flesh white; good; July.

\section{ALMONDS}

Almonds can be grown successfully in most sections of Oregon and Washington, and are attracting much attention from commercial orchardists. Select Trees, 4 to 5 feet, each $\$ 1.00$; per $10, \$ 9.00$.

I. X. L.-A vigorous grower and sure cropper, producing nuts of large size and handsome appearance; shell thin; most popular.

TREE SUPPLY SHORT_There is not enough fruit trees in the Western nurseries to slipply the demand. Have your order booked early. 


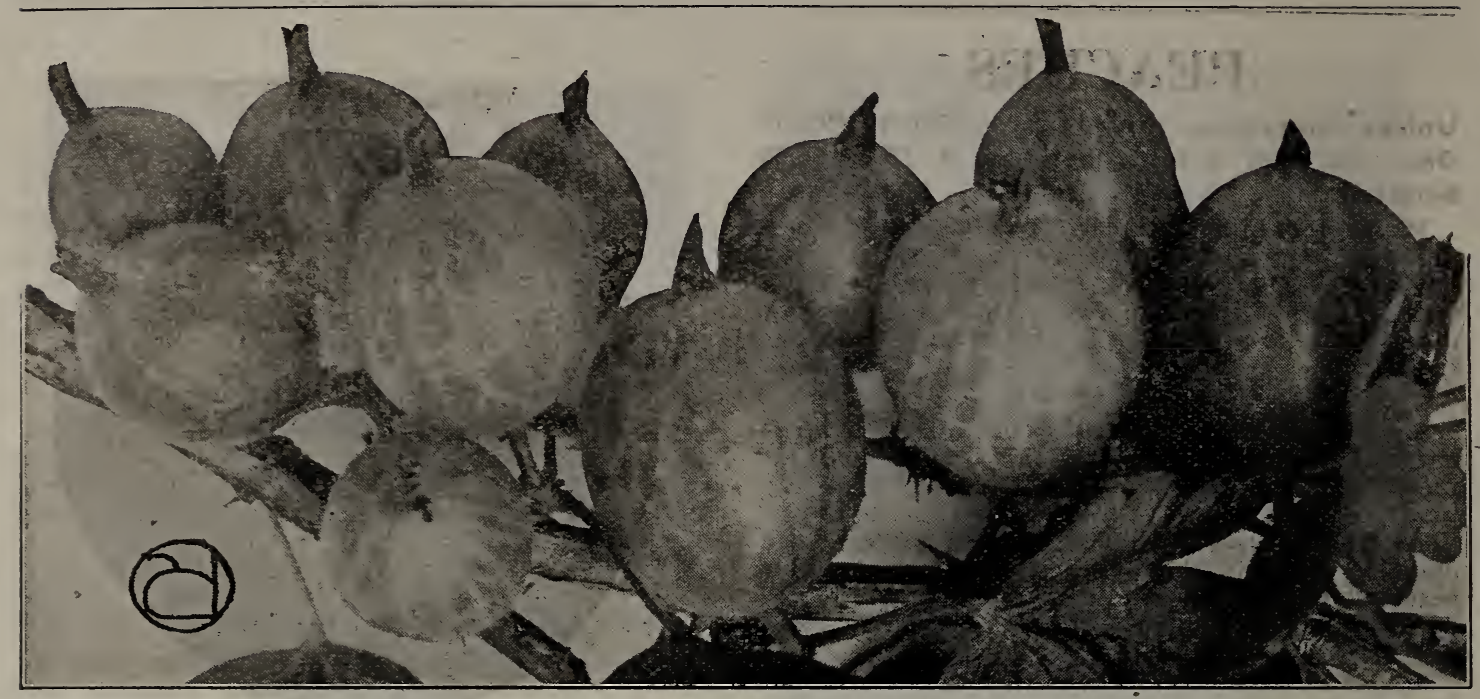

Oregon Champion

\title{
GOOSEBERRIES
}

\author{
Unless otherwise priced Each $12 \quad 100$ \\ One year old $\ldots \ldots \ldots \ldots \ldots \$ .35 \quad \$ 3.50 \quad \$ 20.00$ \\ Extra Selected $\ldots \ldots \ldots \ldots .40 \quad 4.00 \quad 25.00$
}

Write for our low price per 1000.

OREGON CHAMPION. - Berries large round and pale green; fine for table use and pies; hardy, strong, and a very prolific bearer; most popular and best commercial variety. Low pices by the thousand. Write.
RED JACKET (Josselyn).-Of large size, smooth, prolific and hardy; of best quality; a wonderful cropper, with bright, clean. healthy foliage.

BY PARCEL POST.-Gooseberries and Currants: Add 10c per bush, 70c per doz., to cover postage and careful packing.

\section{CURRANTS}

Low prices by the thousand.

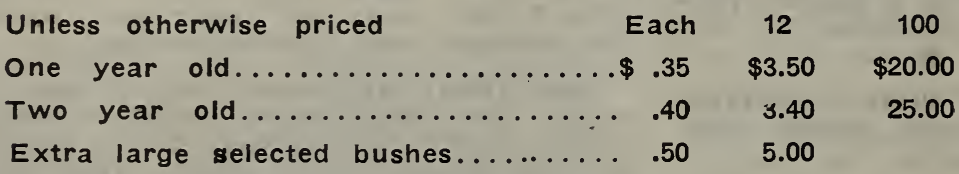

BLACK NAPLES.-Very large, black; valuable for jams and jellies.

CHERRY.-Large, deep red; rather acid; fine for preserving; valuable market variety.

FAY'S PROLIFIC.-A new Currant, larger than the Cherry; has less acid, and is more prolific.

WHITE TRANSPARENT.-Large; valuable for the table and market; the finest of the white sorts.

PERFECTION.-New; a late introduction of great merit. Our grower says: "You cannot say too much about the good qualities of this grand new sort." So, whether you plant ten or a hundred. plant a good proportion of Perfections, which is the largest, most productive, finest-flavored, rich, mild, sub-acid; plenty of pulp; few seeds, healthy, bright red currant to date.

\section{FILBERTS}

These nuts do well on this coast. We can supply Barcelona and Du Chilly, the most popular sorts. 2 to $4 \mathrm{ft}$, each $\$ 1.00$; doz. $\$ 10.00$.

WALNUTS.-See page 39.

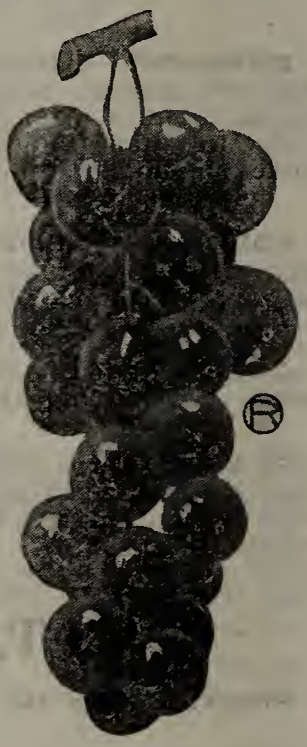

\section{PERSIMMONS}

These are perfectly hardy and do well here. We can supply the American or larger Japanese varieties. Price, $4 \mathrm{ft}$., each $\$ 1.50$.

FERTILIZE the ground and SPRAY the fruit if you want a large, profitable; satisfactory crop. See Fertilizers, pages 38-39_Sprays, 124-125. 


\section{BLACKBERRIES}

Unless otherwise priced Each Doz. 100

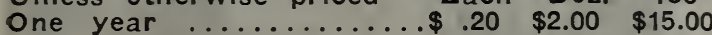
Extra Strong $\ldots \ldots \ldots \ldots \ldots, .25 \quad 2.50 \quad 18.00$

BY PARCEL POST.-Add $10 \mathrm{c}$ each, $70 \mathrm{c}$ per doz., extra to cover postage and careful packing, if wanted by mail.

LAWTON.-The favorite market variety; large, good quality, uniform, hangs long on vine when ripe, productive and profitable. The most generally planted for commercial markets in the Pacific Northwest. Oregon's most popular kind.

ELDORADO.-New. Very vigorous and hardy; yield is enormous; berries large, jet black, boine in large clusters, and ripen well together; sweet, melting and pleasing to the taste; no core, and keep eight or ten days after picking with quality unimpaired.

EVERGREEN.-Introduced from Oregon; beautiful lacinated foliage, which it retains all winter; berries long, black. sweet, rich and delicious; ripens from July to November; a fine berry for family use. One year, each 15c; doz. \$1.25; per 100, $\$ 8.00$. Low price per 1000 .

HIMALAYA GIANT.-A rampant grower of a trailing nature; a heavy $c_{\iota}$ opper; the berries are large, juicy, coreless, sweet and firm, with a delicious aromatic flavor. Its deep-rooting qualities enable it to produce a large, firm berry even in a very d, $y$ season. 2 year, each 20c; per doz. \$2.00; per 100

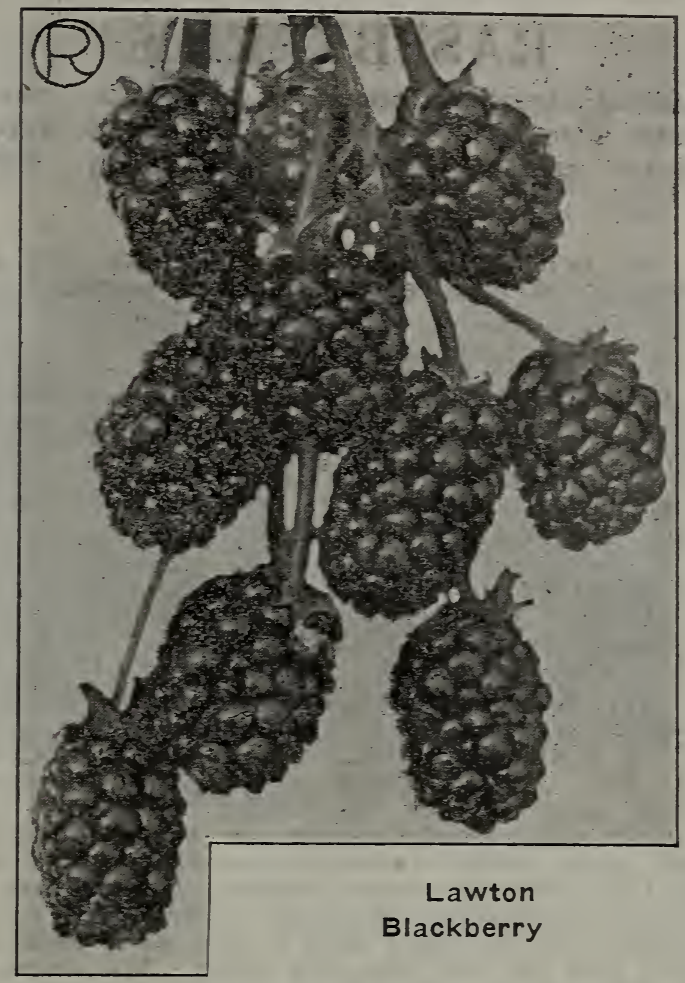
$\$ 10.00$.

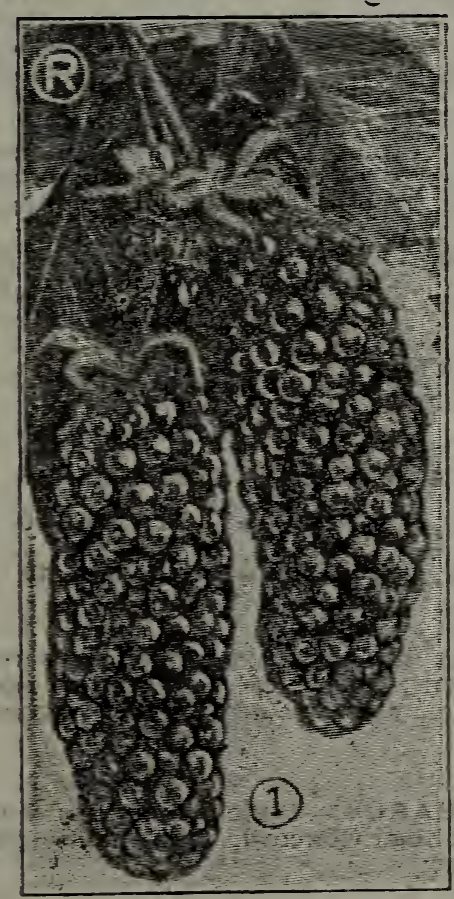

New Mammoth
Plant a Few of These Delicous Berries Trail Them On the Garden Fence or Over a Trellis. Loganberry

In great demand again for canning and drying. An exceedingly strong grower and an enormous bearer. The fruit is larger and longer than the blackberry and produced in immense clusteıs; color, dark red. Has a pleasant, vinous flavor, delicious and peculiar to this berry alone; fruit ripens early. It is excellent for the table, eaten raw or stewed, and for jelly or jam is without an equal.

Prices-Strong, transplanted 2-year plants $50 \mathrm{c}$ each, $\$ 5.00$ doz., prepaid. Per 100 , not prepaid, $\$ 25.00$. Stock is very scarce.

Tips or 1-year roots give poor results when shipped. We dc not like to sell them. They are ready to dig after March 1st. Prices, each 25c; doz., \$2.50; per 100, $\$ 20.00$.

\section{Burbank's Phenomenal}

A most desirable, refreshing berry for the home garden. Of a bright crimson raspberry color; very productive, and most delicious of all berries for pies, canning, jellies or jams. Sweeter than the Loganberry and fine as a fresh táble fruit. Each, 50c; doz., \$5.00.

\section{New Mammoth Blackberry}

A grand addition to the list of Blackberries. The handsome, large juicy berries are delicious. It is a rampant grower, of trailing habit; enormously productive and early:- Fruit is enormous, specimens measuring two and one-half inches long; seeds small, soft and abundant; cores small and soft. In size and flavor it surpasses all other varieties of blackberries. Excellent for home use. Each, 50c; doz., \$5.00.

\section{Dewberry}

LUCRETIA. - Fruit ripens between the raspberry and blackberry. Berries large, handsome, sweet and luscious; trailing' vines. Selerted, each 25c; per doz. \$2.50; $\$ 18.00$
NOTE.-Our, 2-year-old Logan-Phenomenal and Mm, Blackberry plants are transplanted tips grown 1 year in nursery row and all will "Hue. "They are cheaper than "tips" at any price. "Tips" will not ship safely. Two. year-old plants mighty's scarco this season. 


\section{RASPBERRIES}

Unless otherwise priced Each 12

One year ............ \$ $15 \quad \$ 1.00$

Extra strong ............. $15 \quad 1.25$

100

$\$ 4.00$

8.00

Very low prices per thousand.

BY PARCEL POST.-Add 7c each, 50c a doz., extra to cover packing and postage.

\section{Red Varieties}

CUTHBERT.-Berries very large, deep rich crimson; good for shipping; the most popular of all commercial sorts of raspberries; stands the sun and heat well; flavor rich, sweet and delicious; mid-season. Very low prices per 1000 . Write.

MARLBORO.-Very large and earlier than Cuthbert; beautiful, bright scarlet; good quality; hardy and productive.

ST. REGIS (New).-The St. Regis everbearing red raspberry. The demand is great. It is a very valuable variety. It originated in New Jersey among a colony of Italians who made money by selling the fruit to hotels and restaurants late in, the fall after all other kinds of berries were gone. It is a fine berr $y$ in every respect, being hardy, very productive. of good colnr and fine flavor. It produces well in the early season and you get the fall crop extra. We unhesitatingly recommend this variety.

Price, 15c; doz. $\$ 1.25$; per $100 \$ 10.00$. Select, extra strong, each 20c; doz. \$1.50.

GOLDEN QUEEN.-A handsome yellow fruited raspberry; excellent quality, pioductive and hardy.

Tyll, Ore., March 31, 1919.

Routledge Seed \& Floral Co.,

Dear Sirs: I received my last order, a few trees and strawberry plants and seeds, all in good condition. The trees and plants were certainly nice.

Yours truly,

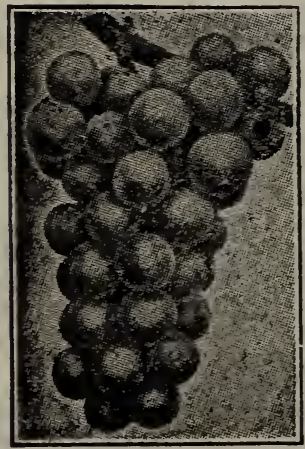

CHAS. B. RADER.

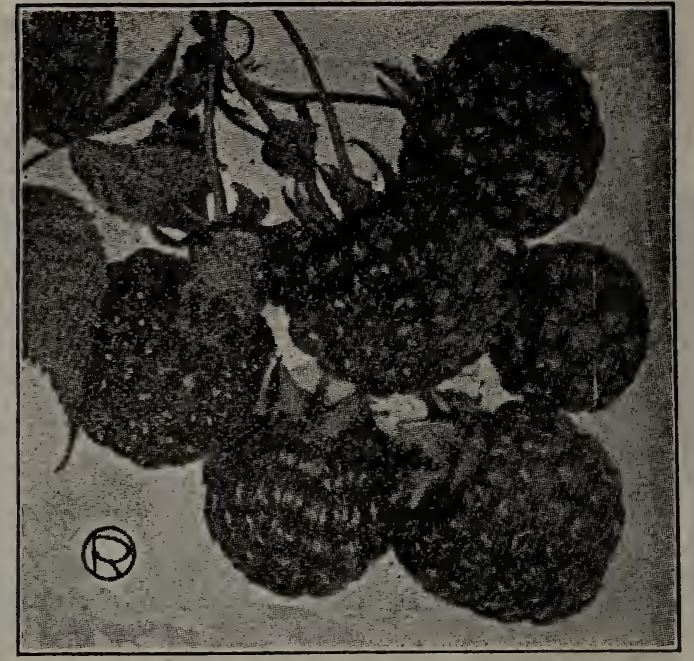

Plum Farmer

\section{Black Raspberries}

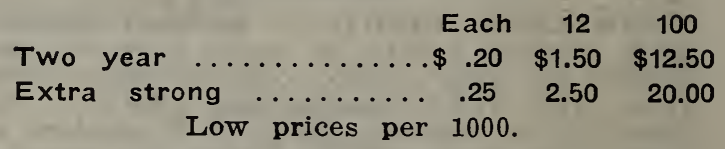

BY PARCEL POST.-Add 7c each, 50c a doz., extra to cover packing and postage.

PLUM FARMER.-Excellent, very productive, maturing the entire crop in a sho, period, making one of the most profitable early market sorts. The berries are thickmeated, firm, with a bloom similar to Gregg. Berry large, fine flavor, and very attractive when picked.

GREGG.-A standard and well known market sort. Very productive, large size, firm meaty berries, covered with heavy bloom.

KANSAS.-Strong, vigorous grower, early and productive. Berries of good size and color, firm and of best quality.

\section{GRAPES}

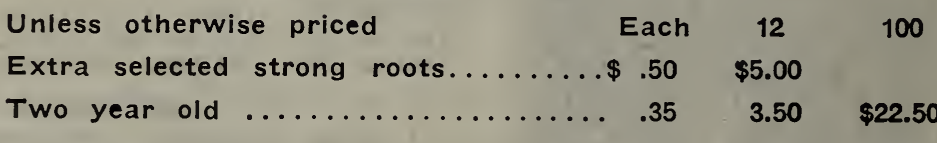

BY PARCEL POST.-Add 7c each, 75c a doz. extra to cover packing and postage.

CAMPBELL'S EARLY. Clusters large and handsome; berries large, round, black, with purplish bloom; flesh firm but tender; seeds few; flavor rich, sweet and slightly vinous. A strong and vigorous grower and ripens its fruit early.

CONCORD.-Large, black grape, bunches compact, berries round, sweet and pleasant; very popular.

DELAWARE.-Best of our native grapes; grows freely and is perfectly hardy; ripens early; berries small, light red.

EATON.-A strong, sturdy grower, immense cropper, fruit is large and handsome, firm, and of the highest quality. Deep rich red when fully ripe, and of sprightly exquisite flavor.
MOORE'S EARLY.-Bunch medium; berry large, resembling Concord, but more pulp, and is earlier.

NIAGARA.-Berry large, pale greenish yellow; flesh tender and sweet; productive.

WORDEN.-Bunch very large and compact; berry large, black; an improved Concord: earlier and excellent home variety.

OTHER GRAPES. - Wo list the most popular hardy sorts for general use, but can supply Isabolla, Catawba, Flaming Tokay, Muscat, Black Mamburg and others at prices above. 


\section{SELECTED}

STRAINS

STRAWBERRY PLANTS

NONE

Our strawberries are carefully grown, trimmed and packed in the best manner to insure their arrival in good, fresh condition. If you want good, strong, healthy, vigorous plants and true to name, send to us. Our prices are right; our plants are $O$. $K$.

Don't use plants from old berry fields. Buy our healthy vigorous, properly grown plants. The most profitable kind.

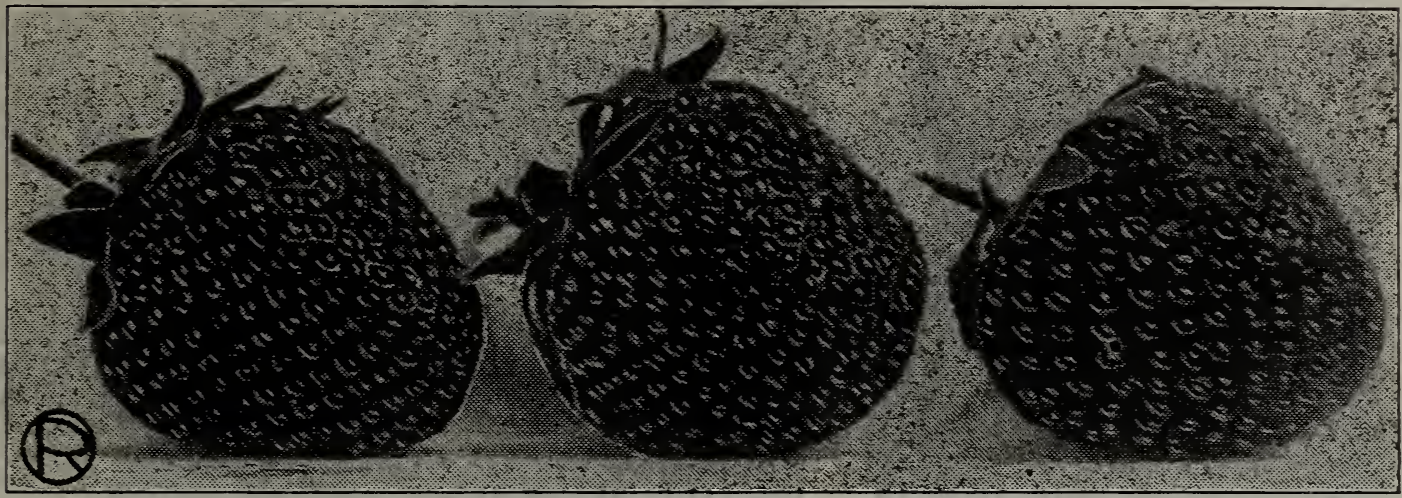

"Wellington Marvel," a New Strawberry of Great Merit

\section{WEITINGTON MARVRI}

This new variety was originated by Wellington $\mathrm{S}$. Butler of Merlin, Ore., a straw. berry speclallst. We have the exclusive sale of all his plants, and take great pleasure in introducing this really superb and meritorious new variety. In all our experience and observation, we have never seen the equal of the "Marvel" in color, shapo, flavor and good quallties. The ripe berries command instant attention on account of the bright, fresh, delightful appearance and fragrance.

The plant has a multiple crown system, which, under restriction, stools up to mammoth proportions and circles itself with a masslve wreath of large crimson berries, sparkling like rubles in the sunlight.

When we observe the penetrating power of the Marvel's enormous root growth, we cease to view the festive array of the striking red beauties with astonishment, and think of the persistent toil and painstaking care exercised by the originator for the purpose of eliminating, objectionable features and placing on the market an Ideal straw. berry, absolutely immune from all lopsided, scrubby, defective specimens.

Wellington's Marvel is almost frost-proof. Frosts that have ruined other varieties have not harmed the Marvel. The foliage is heavy and spreading, and each fruit-stalk of blossoms or fruit seems to be perfectly covered and protected. Fruiting season is very early, long and marvelously productive. A second crop will come on in the fall, lasting until winter.

The ruddy glow of the Marvel spreads evenly and leaves no white tlps. It is unequaled for table and excellent for canning. Heat does not impair its quality, but intensifies the color to deep red. The flavor of the Marvel ls distinct and, when once tasted. strawberry lovers will pay a premium for it For private trade it is a wonder, as the flavor when fully ripe is incomparably doliclous and sweet... For fruit juices, light wine or preserves the Marvel will demand the "top" prices.

BEST BY TEST.-We have, in the field, during the fruiting season, tested the "Marvel" with Clarks, Magoons, Oregon, Gold Dollar and such varieties, and we claim
Mr. Butler has produced hundreds of new seedlings in recent years, but it has been his policy to allow no new variety to be sold until it proved its superior merits. He certainly produced a ruby "gem" in the "Marvel."

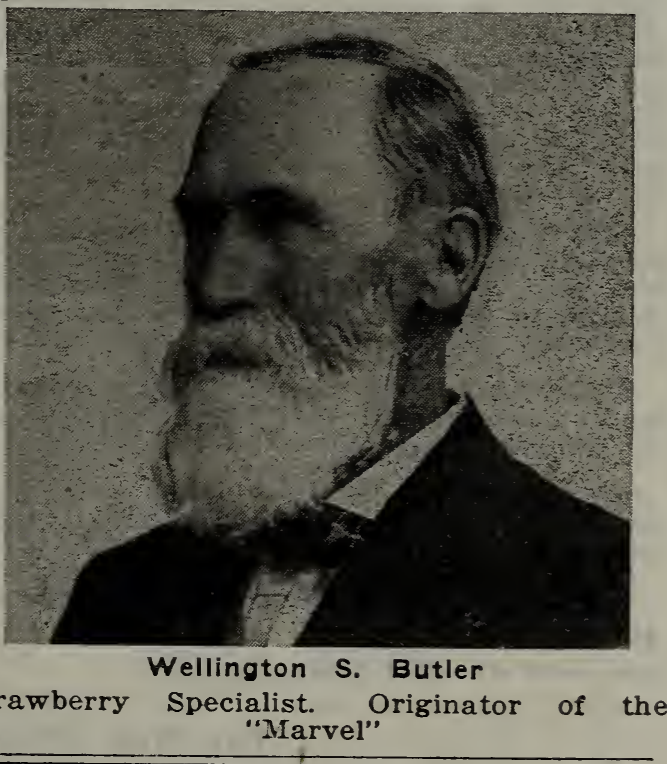

there is no comparison at all In beauty, flavor and production. The "Marvel" is in a class by Itself, and head and shoulders above all. A trial will convince you.

\section{PRICES FOR 1920}

NOTE.-We have each year reduced the selling price of this wonderful beriy, just as much as our contract price with Mr. Butler would permit. At these low prices do not delay planting liberally.

Three for 25c; 12 for $75 c ; 100$ for $\$ 4.00$, postpaid; per $1000, \$ 30.00$.

BEWARE! To protect our customers, all Wellington Marvel strawberry plants will be marked with a printed wooden label, as follows: Origlnator's Stock Wellington Marve on one side and our name, Routledge seed \& Floral Co., on the other. Plants not marked thus ARE' NOT OUR TRUE STOCK.

SELECT PLANTS.-There is a big difference between strawberry plants dug from between the rows of old bearing plants and our stock from plants set especially for reproducIng young plants. 


\section{STRA WBERRY}

PLANTS

CONTINUED

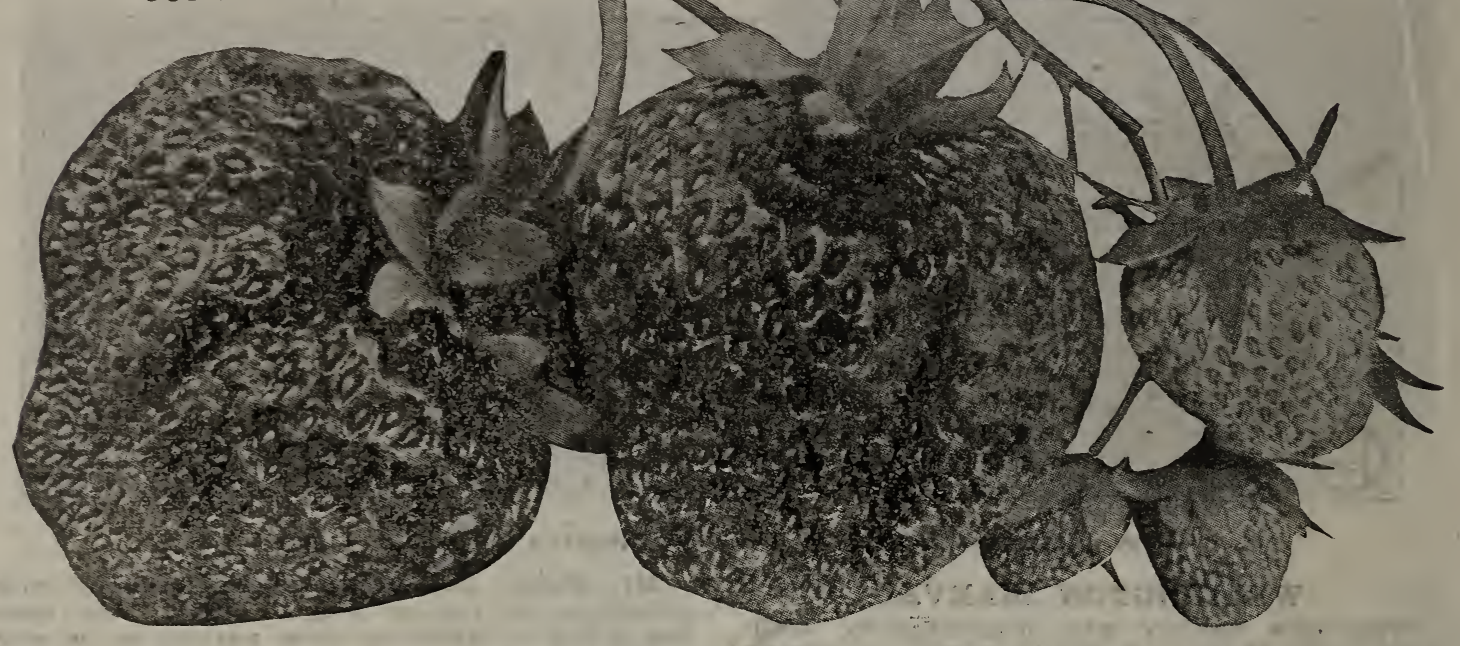

OREGON IMPROVED.-One of the finest and most satisfactory strawberries ever. introduced. It always looks bright, fresh and attractive. The berry is very large, firm and handsome; rich, dark red, extending to the center. The flavor is rich, sweet and delicious. For table use and canning, it cannot be surpassed. The "Oregon" ripens early and continues in bearing until late in the season.

GOLD DOLLAR.-One of the earliest berries on the market. Fruit good, medium size, and attractive; rather tart; fine flavor; foliage, heavy, large and spieading, which protects the blooms from early frosts.

MAGOON.-Berry large, fine and excellent; sub-acid flavor; bears heavily and throughout the season.

WILSON.-A heavy bearer of fine, moderate-sized berries; sharp acid flavor. Many prefer this sort for canning.
MARSHALL.-One of our best Westeri, varieties and very popular wherever known. Marshall is one of the blood-red vaileties that never fails to attract the eye and to satisfy the taste. It is deliciously sweet, generously prolific, and is in every way an ideal variety for extensive planting or home garden. Excellent for canning, as it holds its color, shape and flavor.

CLARK'S SEEDLING.-The berry that has made Hood River famous; excellent shipper; berries large, firm and of delicious flavor; vines bear large crops; is especially adapted to the Pacific Coast.

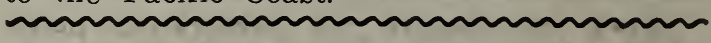

\section{New Fruit Picking Bag}

This year we are offering our customers a new outfit that has real merit. It certainly makes the picking of fruit much easier. See page 123 for full description.

PRICE LIST.-Your choice of above varieties PREPAID, doz. 40c; 50 plants, $\$ 1.25$; 100 , $\$ 2.00$. NOT PREPAID, doz., 30c; 50 plants, $\$ 1.00 ; 100, \$ 1.50 ; 1,000, \$ 10.00 ; 500$ plants all one kind at 1,000 rate.

\section{The New Everbearing Strawberries}

This "new class" of strawberries is becoming more popular each year. Their long fruiting season and the grower's ability to secure berries when the market is high is their real value. Left alone they will flower and fruit the whole season, but to secure a large crop in the late fall keep the blooms off until the last of June.

Your choice, doz. $60 \mathrm{c} ; 25$ plants $\$ 1,00 ; 100 \$ 3.50$, prepaid. Not prepaid, $\$ 3.00$ per 100 ; $\$ 20.00$ per 1,000 .

\section{SUPERB-EVERBEARING}

This we believe is the best of the everbearing kinds. Superb is a truly wonderful fall bearing variety: It is doubly valuable as it yields heavily, early as well as late. This new superb is really a true everbearer and gives a good supply of choice, rich, red berries, until stopped by heavy frosts in the fall. This everbearing strawberry has real merit and a good flavor and color. Growers who have tested it on this ccast are enthusiastic over It. A very profitable variety.

\section{PROGRESSIVE EVERBEARING}

A leading and popular variety in this class. Berries, rich red in color, firm and of delicious flavor. Good keepers and shippers. You will find this berry in the Portland markets late in the fall when prices are very high.

\section{The Garden Guide}

This new book is a real guide to those who need help in fruit or vegetable gardening. See page 130 . 
Why Not Raise Some Asparagus and Rhubarb?

Every garden large or small should have at least a small supply. If you want special Information on culture of these rọots, we have ASPARAGUS CULTURE by Hexamer, 174 pages, 60c, and NEW RHUBARD CULTURE, by Morse and Fiske, 130 pages, 60c.

\section{ASPARAGUS ROOTS}

Buy Roots and Save 2 to 3 Years

One of the earliest and finest of spring vegetables; very easily grown. A bed once planted is good for years if properly attended to and well manured. Set plants 18 inches apart, in rows 3 feet apart.

ONE YEAR OLD.-Prepaid, doz., 50c; 50 , $75 \mathrm{c} ; 100, \$ 1.25$. Not prepaid, doz., 40c; 100 $\$ 1.00 ; 1,000, \$ 7.00$.

TWO YEAR OLD.-Prepaid, doz., 75c; 50 $\$ 1.50 ; 100, \$ 2.50$. Not prepaid, doz., 50c; 100 $\$ 2.00 ; 1,000, \$ 10.00$.

THREE YEAR OLD, SELECT.-Grown especially for our private trade; large and strong for quick crop. Prepaid, doz., \$1.00; $50, \$ 2.50 ; 100, \$ 3.50$. Not prepared, doz., $85 \mathrm{c}$; 50 . $\$ 2.00 ; 100, \$ 3.00 ; 500, \$ 10.00$.

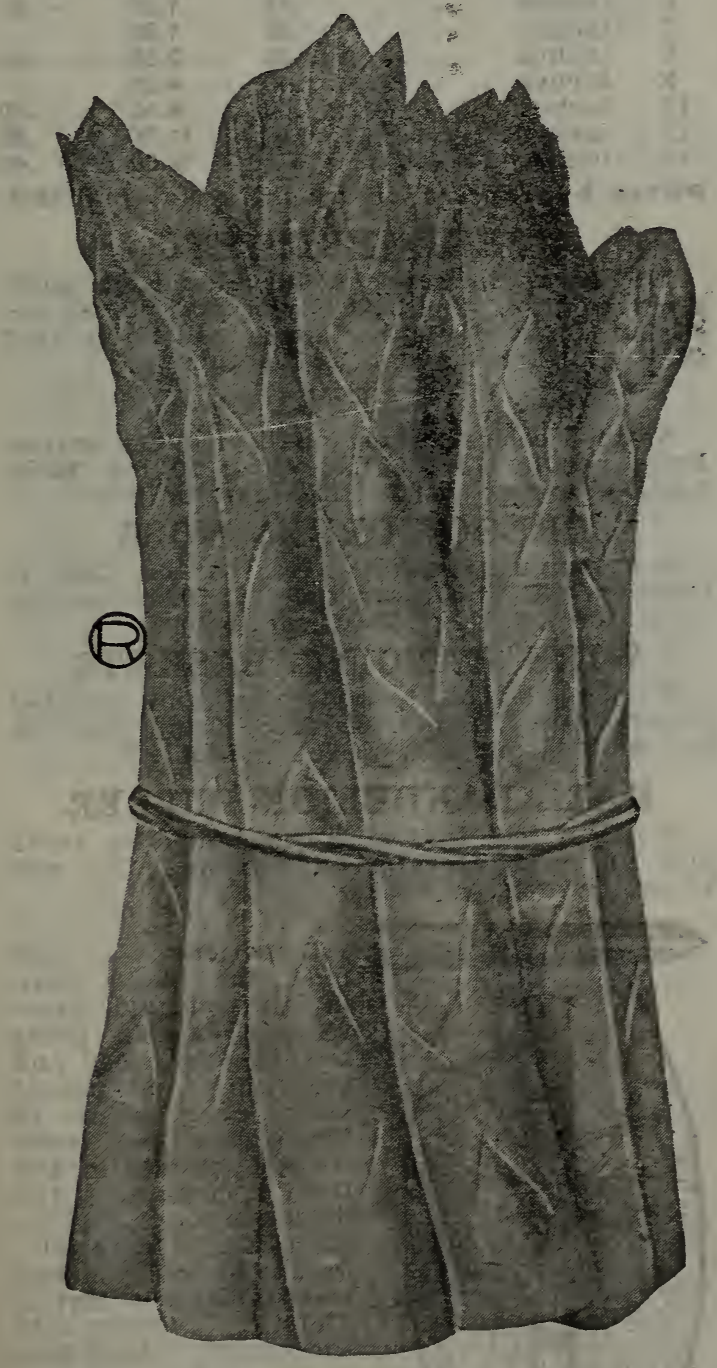

Asparagus Tips

\section{HOP ROOTS}

Oregon's Famous English Cluster Hops.

Regular Root Cuttings, $10 \mathrm{c}$ each, 3 for $25 \mathrm{c}$ $\$ 1.00$ doz., postpaid. Low prices by the hun: dred.

Crown Roots give quicker results; eacb $15 \mathrm{c}$; 2 for $25 \mathrm{c}$; doz. $\$ 1.25$, postpaid.

\section{HORSE-RADISH ROOTS}

Plant in the spring 18 by 24 inches apart. Set the whole root small end down.

Prices: 2 for $15 c$; 50c per doz.; $\$ 2.50$ per 100. Low prices by the 1000 .

\section{RHUBARB}

PIE PLANT-WINE PLANT

Plant in the fall or early spring from 3 to 4 feet apart, in the richest soil you have, or can prepare. New book: "Rhubarb Culture," a complete guide to dark forcing and field culture (well illustrated), 130 pages, 75c.

\section{Banwine Rhubarb_A Moneymaker}

This comparativey new and very profitable rhubarb is claimed by our grower to be superior to all ordinary varieties and unequalled by any known marketable sort. The trueness of the strain is unquestionable, as it is only propagated from root diversions or growing buds from stock, that shows the superior merits of the parent stock.

Banwine is a quick, very early grower producing very freely giant heavy stalks, that are exceedingly tender, brittle and of the finest flavor and color. A "peerless" rhubarb for home gardens or commercial plantings.

We supply divided roots, the only safe way. Seedlings do not come true.

PREPAID. -1 year (single bud), each 20c; doz. \$1.75. NOT PREPAID, each 15c.; doz $\$ 1.50 ; 100 \$ 8.00$.

Two year (doubel buds), PREPAID, each 25c; doz. \$2.25. NOT PREPAID, each 20c; doz. $\$ 2.00 ; 100 \$ 12.00$.

\section{Victoria Mammoth}

A popular variety that has been. grown for years.

One Year.-Each 10c; doz. \$1.00, postpaid. Not prepaid, each 10c; doz. $\$ 1.00 ; 100 \$ 7.50$.

Two Year.-Each 15c; doz. \$1.50, postpaid. Not prepaid, each $121 / 2 \mathrm{C} ;$ doz. $\$ 1.25 ; 100$ $\$ 10.00$.

Large Clumps (4 buds up), NOT PRE PAID, 50c, $75 c$ and $\$ 1.00$ each.

Rhúbarb.-If wanted in larger quantities, write for special price.

Etna, Wash., April 16, 1919

Routledge Seed \& Floral Co.

Gentlemen: The other Seeds and Bulbs were all satisfactory. I am always pleased with your seeds and plants. Yours truly,

MRS. N. OLSON.

COW MANURE.-It is troublesome, disagreeable and expensive for the city gardener to get it. We offer "C-M," THE REAL PRODUCT, in most convenient form, free from weeds. Read page 39 carefully. YOU NEED THIS AND ALSO “WONDER," p. 39, FOR YOUR ASPARAGUS AND RHUBARB. 


\title{
Miscellaneous Supplies and Tools You Need
}

\author{
Remember to add postage If wanted by mall
}

\section{PLANT AND ROSE STAKES}

\section{Prices Not Prepald}

CEDAR-Round: painted green, white top: last and look well. Per doz. 3 ft. $\$ 1.00 ; 3 \frac{1}{2}$ ft. $\$ 1.25 ; 4$ ft. $\$ 1.50 ; 5$ ft. $\$ 2.00 ; 6$ ft. $\$ 2.75$; $8 \mathrm{ft}$. 4.00 .

BAMBOO-Inexpensive and very desirable for pole beans, etc., or flowering plants or shrubs.

Prices per dozen: $2 \mathrm{ft}$. 25c; $3 \mathrm{ft}$. $30 \mathrm{c} ; 4 \mathrm{ft}$ $40 \mathrm{c} ; 5 \mathrm{ft}$. $50 \mathrm{c} ; 6 \mathrm{ft}$. $60 \mathrm{c}$; 25 per cent less for pencil size green. Write for low price by 100 or 1,000 .

Note.-State for what purpose you want them, as we have them stained greon, pencil thickness, and natural color, $3 / 8$ to $\% / 8$ inch thick.

\section{WOODEN LABELS}

The tree and pot labels we offer below are strictly No. 1 labels, smooth and well made. The painted labels are "really painted," not dipped in oll. Ordinary lead pencil writing on the painted labels is always readable; it will not wash off.

\section{P. P. Wgt. 4 lbs.}

\section{Treo Labels}

Painted, copper wired.....\$0.20 $\$ \$ 0.50 \quad \$ 3.00$ Unpainted. copper wired.. $.20 \quad .40 \quad 2.50$ Unpainted, iron wired.... $.15 \quad .35 \quad 2.25$

\section{Pot Labels}

Wgt. per M. $25 \quad 100 \quad$ M

Fainted. 4 in. (P. P. $31 / 2$ lbs.) $\$ 0.15 \$ 0.40 \$ 2.25$ Painted, 5 in. (P. P. $41 / 2$ lbs.) $.20 \quad .502 .50$ Painted, 6 in. (P. P. 5 lbs.) $.25 \quad .603 .50$

Garden Labels

Same style as above, but thicker and wider. Wgt. per M. $25 \quad 100 \quad M$

Painted, 8 in. (P. P. 15 lbs.) $\$ 0.40 \$ 1.25 \$ 9.00$ Painted, 9 in. (P. P. 17 lbs.) $.50 \quad 1.75 \quad 10.00$ Painted, 10 in. (P. P. 20 lbs.) .601 .8511 .00
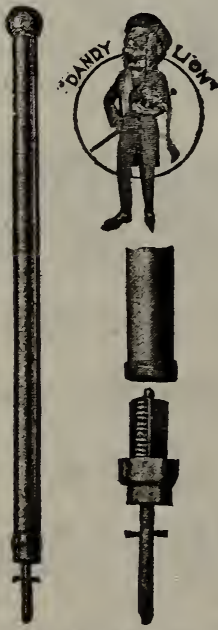

\section{DANDELION AND \\ WEED KILLER}

A new, simple, yet practical tool that is automatic, quick and sure in its work. Cutting or pulling off the tops of weeds only makes the roots grow more vigorously; digging them out with a knife gives one the backache or lame knees, therefore use the "Dandy. Lion" same as a cane.

You simply fill it with solution of gasoline or weedkiller, put the point on the root crown of the weed press until the cross bar on the point (see cut) releases the fluid. (Dir ections tell how.) The solution kills the root and all.

Spring valve and base removable. Length 34 inches. PRICE, NO. 1. Brass Covered, $\$ 1.75$; NO. 2, Solid Brass, \$2.00. Weight packed, 3 lbs.; add postage.

\section{POTS AND SAUCERS}

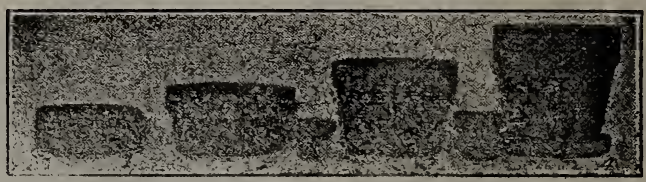

No. 1 No. 2 No. 3 No. 4

Fig. 1-Fern Dish Flller; 2-Bulb Pan; 3Azalla or Fern Pot; 4-Standard Flower Pot. All styles same prices.

PRICES

\begin{tabular}{|c|c|c|c|c|}
\hline \multirow[b]{2}{*}{ Ain } & & & & \multirow{2}{*}{ Saucers } \\
\hline & & Each & & \\
\hline & inches &.$\$ 0.03$ & $\$ 0.25$ & \\
\hline $21 / 2$ & inches & $\ldots \ldots \ldots \ldots \quad .04$ & .30 & \\
\hline & inches & $\ldots \ldots \ldots$ & .35 & \\
\hline $31 / 2$ & inches & …..... & .40 & \\
\hline & inches & $\ldots \ldots \ldots$ & .50 & $\$ 0.05$ \\
\hline $\mathbf{5}$ & inches & $\ldots \ldots \ldots \ldots$ & .85 & \\
\hline 6 & inches & $\ldots \ldots \ldots$ & 1.25 & .07 \\
\hline 7 & inches & $\ldots \ldots \ldots$ & 1.80 & \\
\hline 8 & inches & $\ldots \ldots \ldots$ & 2.50 & .10 \\
\hline 9 & inches & $\ldots \ldots \ldots$ & 4.25 & \\
\hline 10 & inches & $\ldots \ldots \ldots \ldots . \quad 60$ & 6.50 & .20 \\
\hline 12 & inches & $\ldots \ldots \ldots \ldots 1.00$ & 11.00 & \\
\hline 15 & inches & $\ldots \ldots \ldots \ldots 1.75$ & 18.50 & 40 \\
\hline
\end{tabular}

Prices by express or freight. Not mallable.

\section{JARDINIERES, ETC.}

Wo carry in stock a large and complete assortment of the best styles and latest designs. Limited catalog space will not permit us to illustrate and describe them.

\section{RAFFIA}

Natural color, highest quality. Very arce. Price per lb. $75 \mathrm{c} ; 5$ lbs. $\$ 3.50 ; 10$ lbs. $\$ 6.50$; postage extra. Write for quantity price.

\section{OREGON GREEN MOSS}

For hanging baskets, etc. 3 lbs. 25c; 2bushel sack, $\$ 1.50$; per bale, $\$ 3.50$. Spagnum moss for packing, $\$ 2.50$ per bale.

\section{WIRE HANGING BASKETS}

Well made of heavy wire and painted green. 6-in., 20c; 8-in., 25c; 10-in., 35c; 12in., 40c; 14-in., 50c. (Not mailable.)

\section{HALL DANDELION PULLER}

Here's a tool that gets the dandelion, roots and all, and operator stands up. No wet knees or aching back.

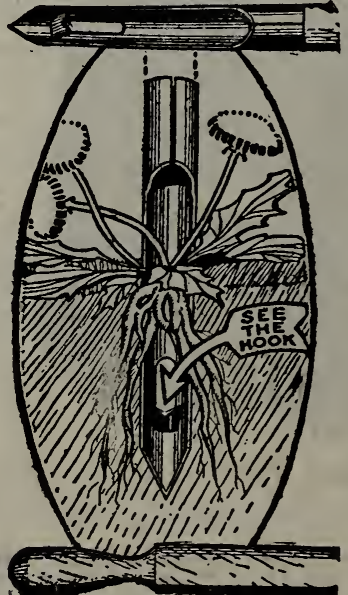

Directions. - Just push the blade down in the ground close to the weed, press towards the weed and pull up. A patent hook near point of blade does the trick. A slot prevents dirt from clogging the hook. Study the illustration carefull $y$. Is made of polished steel and will last a lifetime. The only successful dandelion weeder to date. Wooden handle 30 inches long, steel part 8 inches. Price $75 c$ : postpaid, $85 \mathrm{c}$.

We give the P. P. (Parcel Post) weight so you can add postage if $w$ anted by mail Don't forget to send it extra. 


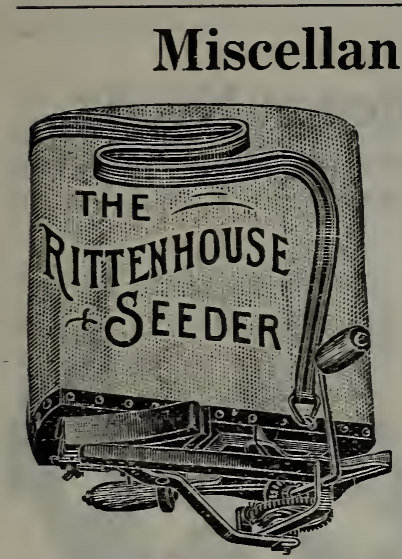

RITTENHOUSE BROADCAST SEEDER NO. 3

A great favorite with farmers the world over. Works easily, automatic stirrer, anti-clogging, allsteel frame, strong cogs and gear. The lightest yet strongest and best. For seed or fertilizer. Sack holds $1 / 2$ bushel. Descriptive pamphlet on request. (P. P. wgt. 4 lbs.) Price $\$ 2.50$.

\section{Remember to add postage if wanted by mail}

Need

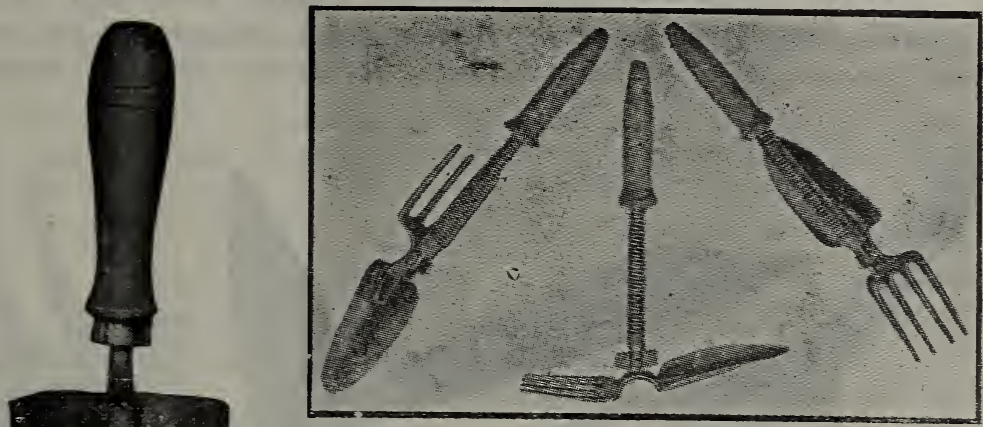

"ALCA" GARDEN TOOL

Best all-around garden tool made. This remarkable combination tool is a trowel, fork, hoe, weeder and dibble-all in one. A spring releases the particular tool you desire. Light but strong and handles nicely. (15 inches long-see cut.) Price $65 \mathrm{c}$, postpaid $75 \mathrm{c}$.

\section{GARDEN TROWELS}

Good, reliable, cheap trowels, $25 \mathrm{c}$ to $50 \mathrm{c}$; extra strong and best made, $60 \mathrm{c}$ to $75 \mathrm{c}$. Mailing and postage i0c extra.

\section{HAND WEEDERS}

Several good styles-Diamond, 35c; Beet, hoe style, very good, 25c; Fork, 35c; Excelsior, five-claw, 35c; and Lang's. Postage and packing $10 \mathrm{c}$ extra.

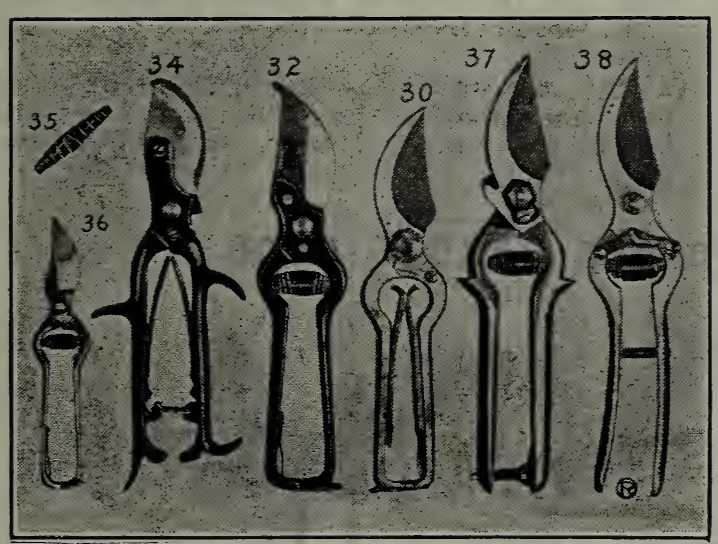

\section{TRET PRUNERS}

Long handle tree pruners indispensable for pruning tall trees.

Reliable make, with spring: 6 feet, $\$ 1.50$; 8 feet, \$1.75; 10 feet, \$2.00; 12 feet, \$2.25. Cannot go by mail. Extra blades $60 \mathrm{c}$ each, postpaid.

\section{NASH MOLE TRAP}

Catches them coming and going. Highly satisfactory. We will have stock again this year. Descriptive leaflet on request. Price, $\$ 1.60$; postpaid $\$ 1.75$.

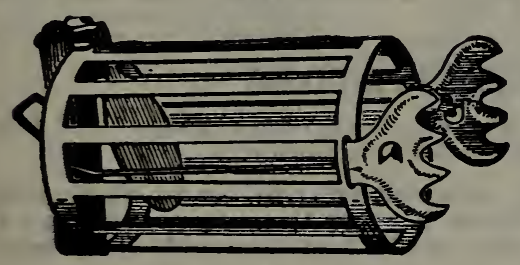

The Ideal Trap

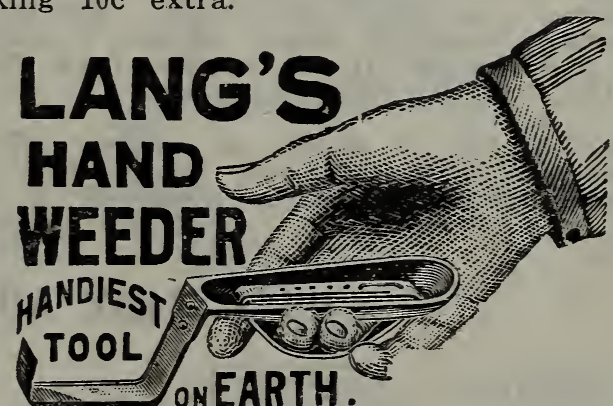

HIGH-GRADE PRUNING SHEARS

\section{All prices postpaid}

No. 36. Nickel plated 6-inch, fine for cutting roses and light work, $\$ 2.00$.

No. 34. Same as illustration, except spiral spring; good, cheap shears. $\$ 1.00$.

No. 32. Strong, durable, black handle, polished blade; 81/2 inches. Price, \$1.35.

No. $321 / 2$. Nice finish, half polish, good blade; handles nicely; same style as No. $32 ; 9$ inch. $\$ 1.50$.

No. 33. Same style as No. 32, full polish; very strong and serviceable; 9 inch. Each, $\$ 2.25$.

No. 30. Full polish, double brass springs, lock nut, one extra blade; steel band lock, Swiss style, 8 inch, $\$ 3.25$; No. 30,9 inch,

$\$ 3.50$. Nos. 37 and 38 not obtainable now.

\section{THE IDEAL GOPHER TRAPS}

The only trap guaranteed to catch small or large pocket gophers. Being round, with thin edges, gopher walks into trap before detecting anything in runway. 100 per cent efficient-catches the gopher every time. Set one trap each way in the runway and you "get 'em going or coming." Far safer and surer than poisons or gas. Hundreds of users have recommended the Ideal. Full instructions with each trap. Pamphlet on request.

Price, 60c postpaid, 2 for $\$ 1.00$

CORN AND POTATO PIANTERS.-We expect to have some stock. Write for Ulustrations and prices. 


\section{Miscellaneous Tools That Every Gardener Needs}

Note.-We give the P. P. (Parcel Post) weights so you can add postage if wanted by mail. Don't forget to send it extra, otherwise we will express them.

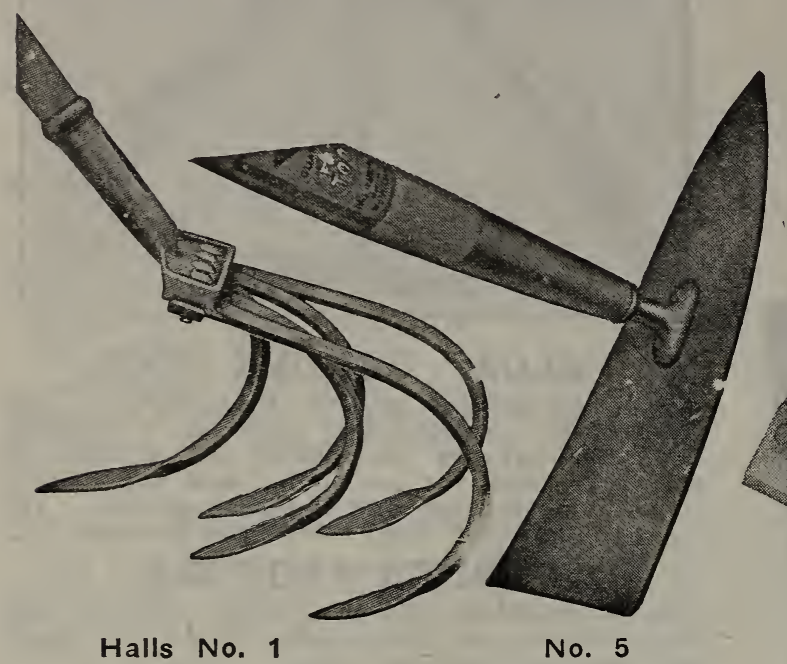

HALL'S GARDEN' TOOLS

Very popular, handy, light and good.

HALL'S NO. 1.-This has 5 adjustable steel spiing teeth or cultivators. Spread 7 inches; length 6 inches; height 6 inches; 4 foot handle. (P. P. wt. $3 \frac{1 / 2}{2}$ lbs.) Price $\$ 1.50$.

HALL'S NO. 2.-Same as above, only 3 prongs A smaller and lighter tool for small gardens or narrow rows. (P. P. wt. 2 lbs.) Price $\$ 1.25$.

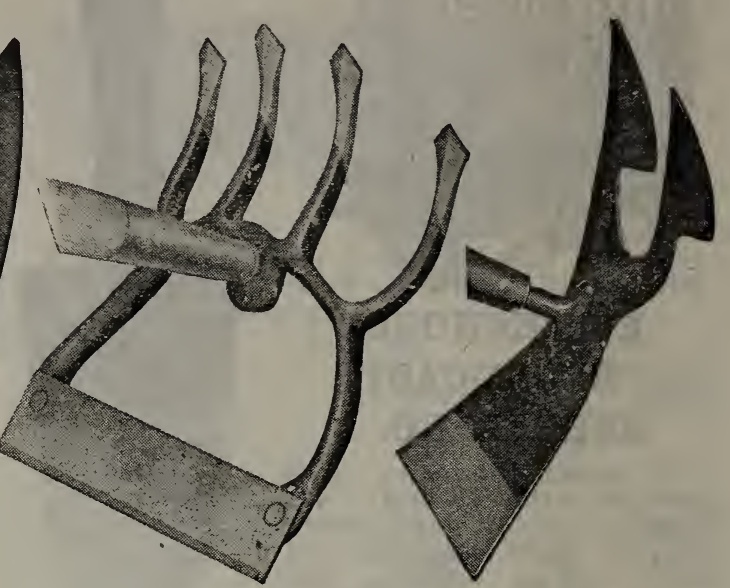

No. 6
No. 4
HALL'S NO. 4.-A double tool; a square hoe blade $4 \frac{1}{4}$ inches wide on 1 side and 2 cultivator teeth on other end. Full length handle. (P. P. wt. $21 / 2$ lbs.) Price \$1.20.

HALL'S NO. 5.-A double tool; a square 3inch hoe tapering to a point on other end. Full length handle. (P. P. wt. 21/4 lbs.) Price 90c.

HALL'S NO. 6.-A combination tool; a 6inch hoe blade on one side and a 4-tooth hoe or rake on other end. Full length handle. (P. P. wt. 4 lbs.) Price \$1.25.

\section{PULL EASY ADJUSTABLE GARDEN TOOL}
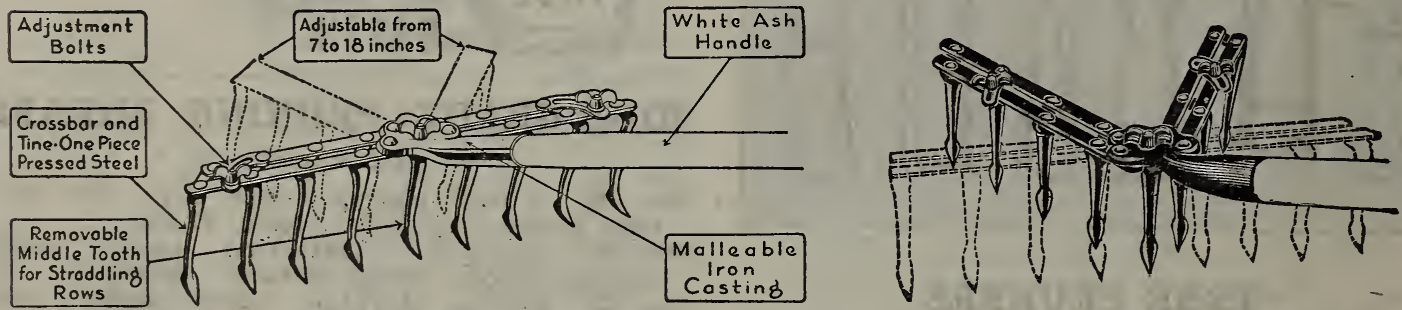

Study the illustrations above carefully and you will understand the make-up of this new tool. We used them in our gardens last year and were more than pleased. For raking, cultivating, leveling and preparing the soil it has no equal. You can do more and better work with this tool than with any other that we know of. It is adjustable from 6 to 18 inches in width. It is not as heavy as it looks, and the construction of the teeth keeps it in the ground, and you can cultivate between the rows as fast as you can walk. Polished hardwood. $41 / 2 \mathrm{ft}$. handle. Try it; if not satisfied, we'll trade.

NO. 1 PULL. EASY -9 teeth (P. P. wgt. 4 lbs.), $\$ 1.75 ;$ NO. 2 JUNIOR or ladies' size (P. P. wgt. $21 / 2$ lbs.) $; \$ 1,00$

Cultivator attachment for fastening No. 1 or No. 2 to Planet Junior Wheel Hoe. 50c.

\section{PLANET JR. SEEDERS AND CULTIVATORS}

For 40 years Planet Jr. Garden Tools have stood the test of world-wide usage and are recognized in every known country as the highest type of garden implements.

FREE.-1920 Planet Junior 72-page Catalog, illustrated, descriptive and up-to-date, with complete price list, on request. NOTE.-All dealers sell Planet Jrs. at the same price; so if you happen to know the price on the Implement, you want, remit and we will ship from Portland stock $\rightarrow$ otherwise we'll gladly send 1920 catalog.

$$
5, t^{7}, 5,4,2,2 x^{7}
$$

STANDARD MAKES OF HOES, RAKES, SPADES, SHOVELS, FTC, ON HAND AT ALL TIMES. CALL OR WRITE IF INTERESTED. 


\section{WHEEL GARDEN CULTIVATOR}

Just the right size and the right price for the average garden maker. Everyone who makes much garden should have one, as it reduces the labor one-half. Makes gardening a pleasure. Combination tools for all kinds of garden work. Does away with the tiresome hand hoeing, weeding, etc.

NO. 6 HALL.-Double handles quickly adjustable to fit man.or child-adjustable draft for light and deep cultivation. Swing Frame gives the plow a hang or balance-making it easiest running plow on market. The double extended curved handles insure steady, even work. Each tool furnished is carefully sharpened, polished, and will scour in any soil.

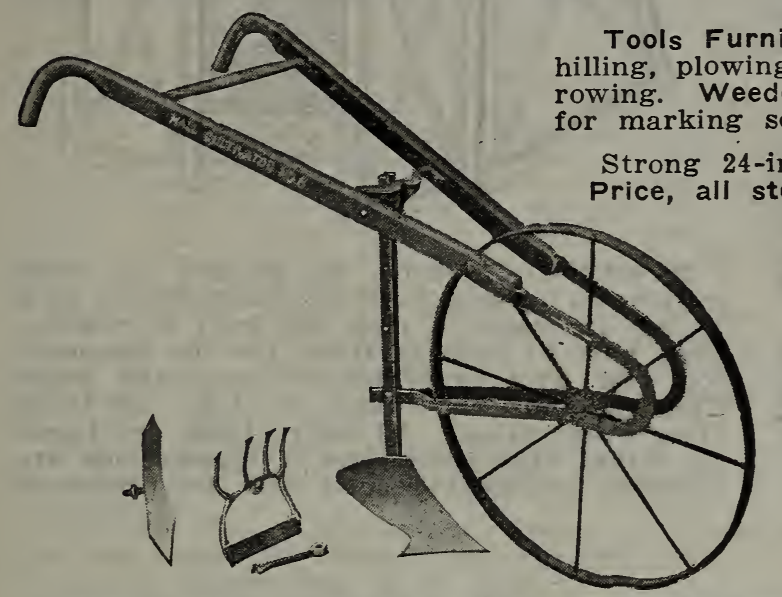

, Wake for cultivating, harrowing Weeder for cutting weeds. Double Diamond Point or marking seed rows, etc.

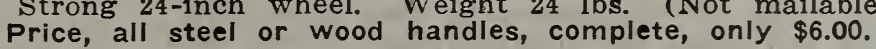

NO. 1 HALL.-This is a favorite with the ladies and children as it is smaller and lighter. It has a "straight to axle" adjustable handle and a 16-inch wheel. Can be taken apart and sent bv parcel post. (P. P. wt. 14 lbs.) Price complete, $\$ 5.00$. This tool can go by parcel post.

Hall's No. 6 Garden Plow and Cultivator

\begin{abstract}
SPECIAL Hall Cultivator Attachments $\mathrm{T}$ e e th similar to Hall's No. 1 Tool. 4 prong $\ldots \ldots \ldots \$ 1.00$ 5 prong $\ldots \ldots \ldots 1.20$ 7 prong $\ldots \ldots \ldots 1.35$
\end{abstract}

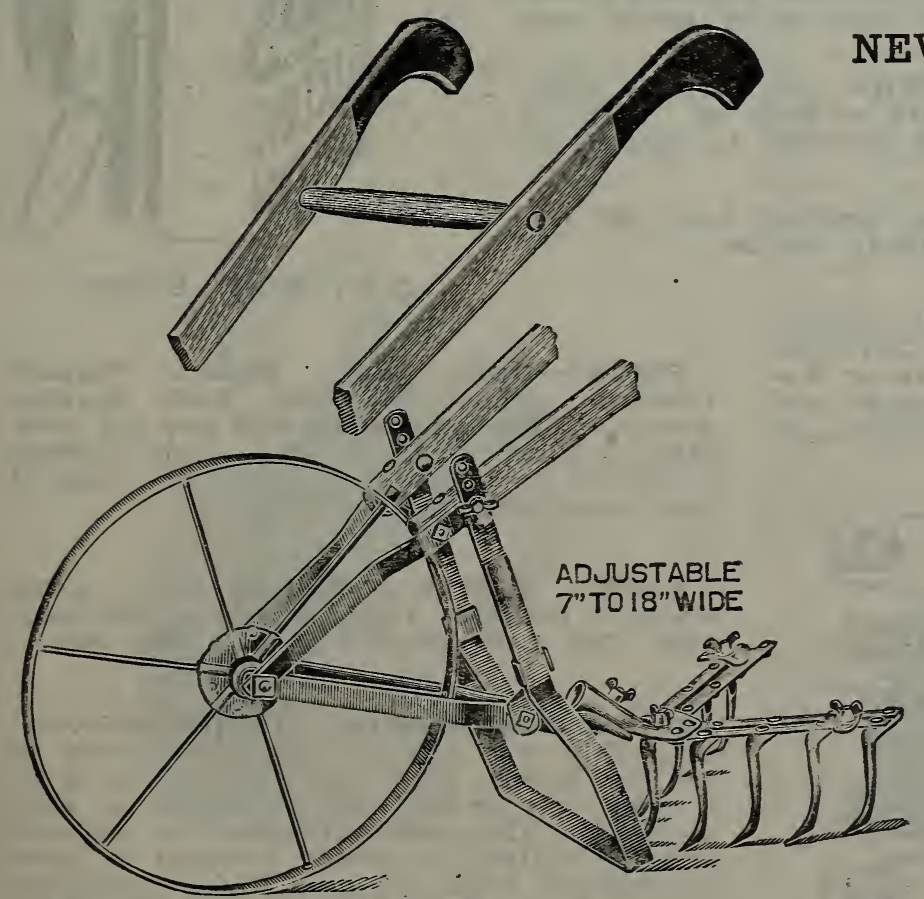

Hall's No. 1 Garden Cultivator
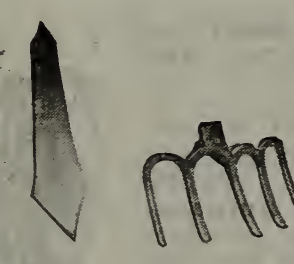
durable. not work.
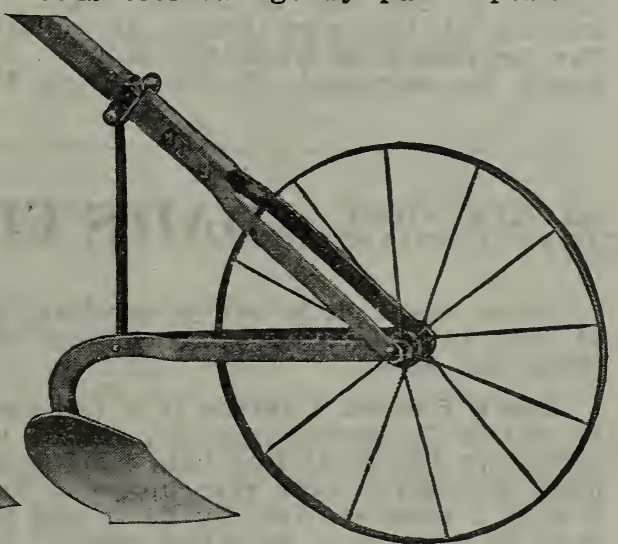

\section{NEW PUSH-EASY WHEEL CULTIVATOR}

In this new garden tool you get a sturdy weed and grass cutter and an ideal adjustable cultivator that will stand rough usage, yet so designed that it will do perfect and rapid work with little labor. It is light, strong and

The weeder or cultivator can be used together or separately. The cultivator can even be detached and fitted on a hoe handle and used as a hand tool in beds or corners where a wheel hoe will

For more information about the adjustable spreading cultivator attachment, see description of the Pull-Easy Garden Tool, page ....

SPECIFICATIONS. - $4 \frac{1}{2}$-foot maple handles; electric welded, 14 -inch iron wheel: high grade steel cultivator adjustabe 7 to 18 inches wide; keen edge weed slayer of high carbon steel, $71 / 2$ inches wide. (Weight 12 lbs.) Not mailable. Price $\$ 5.00$. 


\section{HOME FRUIT AND VEGETABLE EVAPORATOR}

Dry your surplus fruit and vegetables by the latest method of evaporation. This outfit comes to us with a money-back guarantee that it will do perfect work if directions are followed. It costs nothing to ope $e_{1}$ ate the "Home," as it sets on the back of your cook stove and uses the surplus heat when you have fire for other purposes. It is not necessary that a continuous fire be kept in the stove. Of course, it is natural that the more continuous the heat the quicker the fruit or vegetables will dry.

Operators of the "Home" claim that apples dried or evaporated by this new process will make up into pies that cannot be distinguished from those made from fresh fruit; that beets, peas, beans and other vegetables can be freshened up in water and be the equal of "fresh picked."

Specifications.-Made of 28-gauge, polished blue steel, $18 \times 20$ inches at the bottom, $12 \times 20$ inches at the top, 24 inches high. Drying surface of the wire trays, 14 square feet. Can be folded up when not in use. Weight, boxed for shipment, 35 lbs. Price $\$ 12.50$.

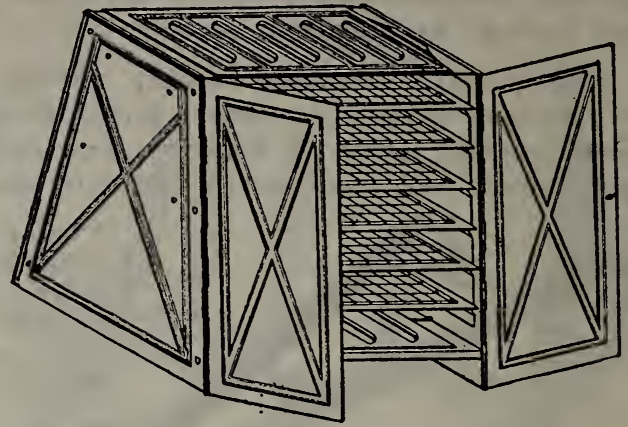

Directions.-A book is packed in each evaporator, giving complete instructions how to use it, when to pick the fruit or vegetables, how to prepare them for the evaporator, how. long to evaporate them and when finished and what care to take of them after evaporating. All instructions are based on actual experience, and if instructions are followed excellent results will be produced.

\section{$\begin{aligned} & \text { SAFETY } \text { FIRST } \\ & \text { CHEAPER THAN OIL DAD'S ELECTRIC LANTERN THE LIGHT OF }\end{aligned}$}

These are a little out of our line, but of great merit and of such value to the majority of our customers that we offer them for sale.

Dad's Electric Lantern is a full-sized searchlight lantern. It stands $71 / 2$ inches tall, $51 / 4$ inches wide, $23 / 4$ inches thick, excluding the projecting bail, headlight and handle. It's the most wonderful light ever invented for all general purposes. It's in a class entirely by itself and should not be confused with flashlights or so-called electric lanterns using one cell.

Dad's Electric Lantern uses two ordinary standard 6-inch dry cells (or batteries), obtainable from us by parcel post or in any town or village.

DAD'S NO. 1 ELECTRIC LANTERN (See cut).-A wideangle, real light, that you can work or read by. Light is turned on or off in a second-no matches to scratch or danger from fire.

Throws a powerful, illuminating, brilliant light 200 feet or more. Sure, safe and always ready for use.

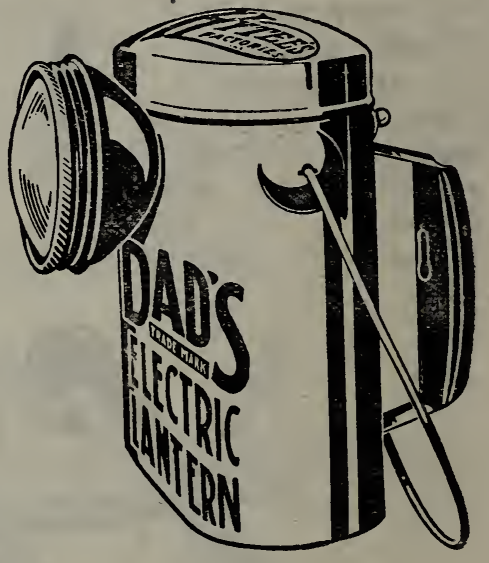

Dad's No. 1 Electric
Can be set down or carried by the bail or handle on the back. Ideal for Dairymen, Poultry Keepers, Campers, Travelers or Au. toists. We use these around the store and on all our outing trips. We couldn't do without our "Dad."

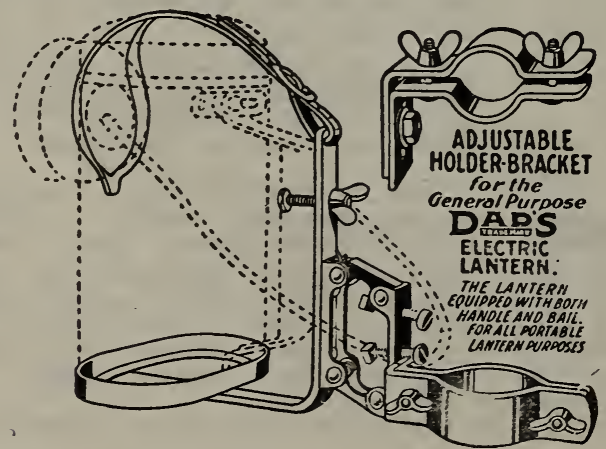

PRICES-Dad's No. 1. General Purpose Lantern, without dry cells, $\$ 3.00$ (mailing weight $21 / 2$ lbs.); complete with two dry cells, $\$ 4.00$ (mailing weight 7 lbs.). Add postage if wanted by parcel post. (Get dry cells at your store and save postage.)

EXTRA PARTS-Reflectors, 75c; Lens, white or red, 35c; Tungsten Bulbs, 40c, postpaid; Dry Cells (wgt. 21/2 lbs.), 60c each.

DAD'S ADJUSTABLE HOLDER BRACK. ET.-This is a strong, well made holder to set the lantern in if you want to use it as a head light or tail light on a vehicle, auto or boat. The holder fastens on securely and the lantern is quickly fastened in place or removed when you need it for other purposes. No. 1, Price $\$ 1.00$ (weight $23 / 4$ lbs.) add postage if wanted by parcel post. 


\section{NEW FRUIT PICKING BAG}

SAFE, QUICK AND LASTING, "An egg will go through it without cracking.'

This ingenious invention will reduce your picking cost about one-haif and at the same time eliminate absolutely all danger of bruising the fruit. Equally good for Apples, Pears, Plums, Prunes, Cherries and Peaches.

This outfit does away with all carrying of fruit down the ladder. You simply drop the fruit into the "hopper-like top" of the long bag and it quickly rolls out of the bottom into the fruit box. The secret in this is that the fruit rolls from side to side down and through a series of slanting canvas partitions. Fruit will not clog or stop up this bag.

Another valuable feature-The lower section connected by a rope to the ladder top, holds just enough to fill one regulation size apple box, so that when it is full the picker, up on the laditer, simply pulls up on the rope, the fruit all rolls out and the sack is dropped into another box. You can, without getting off the ladder, pick all fruit within reach and fill as many boxes as required.

The bag is made of st ong, heavy canvas, well sewed and bound in such a manner as to remain open and in place. The two sections as shown stand six feet high. Fxtra section can be quickly attuched for extra high picking.

SPECIFICATIONS-Top of hoprer is 18 inches and the lower part 9 inches in diameter, length of sections 36 inches.

PRICES: 'Two sections, with rope and attachments "A," "B" and "C," $\$ 10.00$ (wgt. 10 lbs.).

EXTRA SECTIONS, $\$ 4.00$ each

We guarantee satisfaction or money refunded, upon return of picker in good condition. Order early. Test it and be ready for your fruit harvest.

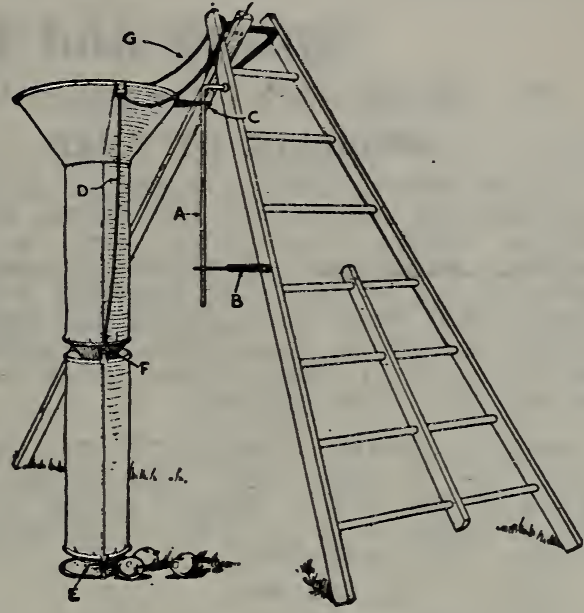

H. R. Picking Bag

The above illustration also shows the style of Nelson Fruit Ladder

\section{NELSON LADDERS}

Here is a good, strong, well made fruit picking ladder. Spruce uprights, oak rounds-a handy, dandy, adj.+stable ladder. See illustration above. Prices: $6 \mathrm{ft}$. $\$ 3.00 ; 8 \mathrm{ft}$. $\$ 4.00 ; 10$ ft. $\$ 5.00 ; 12$ ft. $\$ 6.50 ; 14$ ft. $\$ 8.00$.

\section{SPRAYS, INSECTICIDES, ETC.}

Spray material subject to market changes. Write for quantity prices. Poisons not mail. able. Add postage if small pkg. of mailable sprays or powders are wanted by mail.

\section{HELCEBORE-Kej-Brand Powdered}

For the destruction of slugs, currant worms, etc. Poisonous to insects but not to human beings, therefore safe to use when fruits or vegetables are nearly ripe. Use as a powder or spray, 1 oz. to 3 gal. of water. Price: $1 / 2$ lb. $40 \mathrm{c} ; 1 \mathrm{lb} .75 \mathrm{c}$.

\section{CUT WORM KILLER_Key-Brand}

A very effective poison bait against cut worms, slugs, etc. Place it around plants subject to attack. Worms prefer it to vegetaticn. Prices: 1 lb. 35c; 5 Ibs. $\$ 1.50$.

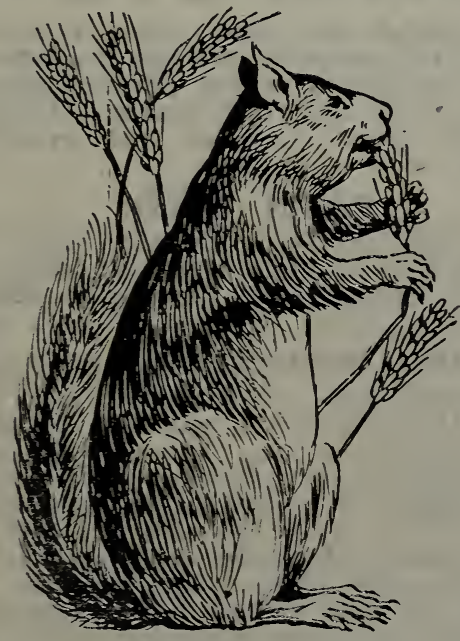

WEED KILTER_-Liquid

For Lawn Tennis Courts, Paths, Roadways ana any other place where you do not want grass or weeds to grow

Guaranteed to destroy weeds, grass poison ivy and all undesirable vegetation. Keeps roadways and poths free from weeds. Cleans tennis courts and ball diamonds. An effective combination of high grade chemicals which diluted in water at 1 to 40 destroys the roots as well as the tops of all vegetation. One gallon diluted will cover 1.000 square feet; and one or two applications are sufficient for an entire season. (Not mailable.) Most effective when $g_{1}$ ound is dampuse an ordinary sprinkling can.

Price: Qt. 70c; gal. $\$ 1.75 ; 5$ gals. $\$ 7.00$. Write for price per barrel.

\section{"WOOD-IARK"}

\section{Squirrel and Gopher Poison}

Guaranteed quick and sure, also very effective on wood rats, mice, etc. Use it so that the chickens or birds will not get it. Prices, by express only: $1 \mathrm{lb}$. can 60c; 10 lbs. $\$ 4.75 ; 25$ lbs. $\$ 10.00$.

\section{TREE TANGLEFOOT}

A sticky compound, easily applied in a band around the trunks of trees as a protection against all crawling insects. One pound makes about 10 lineal feet of bands and one application remains sticky 3 months or longer, rain or shine. Apply with a wooden paddle. Fxcellent to apply over fresh cuts after pruning or trimming. Keeps well. Prices: 1 lb. can $50 \mathrm{c}$ : 10 lbs. $\$ 4.50$; 20 lbs. $\$ 8.75$.

DON'T WAIT until the fungi, such as mildew, rust, black spot, etc., have atta.cked your roses and trees; the fungicide sprays are merely preventives and should be used in the fall or early in the spring. After the disease has developed, it may be too late to save the plant. 


\section{Sprays and Insecticides - Continued}

The best and mist economical method of spraying is with a hand or power sprayer.

\section{ARSENATE OF IEAD}

For spraying trees and shrubs or plants against the attacks of leaf-biting or leafeating insects of all kinds, such as green worms, slugs, etc. Especially valuable for spraying to prevent the coddling moth on Apple and Pear, and should be used just before the calyx cups close, for eating insects, whenever they appear. Can be combined with other sprays.

PASTE FORM ARSENATE OF LEAD.It comes in paste form and is diluted in water at the rate of about 1 ounce to a gallon of water, or 2 to $3 \mathrm{lbs}$. to 50 gallons of water. (Not mailable.)

Price, 1 lb. Jar, 40c.

DRY POWDERED ARSENATE OF LEAD. - Has many advantages over the paste, easier to mix and requires less, is more efficient on account of its extreme fluffiness and will adhere longer. Does not deteriorate. Use 1 to $2 \mathrm{lbs}$. to 50 gallons of water. 1 to 2 tablespoonsful to a gallon. (Poison, not mailable.)

Price, $1 / 2-1$ b. can $35 c ; 1$ lb. $65 c ; 5$ lbs. $\$ 3.00$. Quantity price on request.

\section{LIME AND SULPHOR SPRAYS}

Particularly effective in the control of the following: San Jose Scale, Oyster Shell Bark Louse, Scale Insects, Fungus Diseases such as Peach Leaf Curl, Applo and Pear Canker, Apple Scab, Brown Rot of Peach or Plum, Blister Mite, etc.

LIME AND SULPHUR SOLUTION.-The original and old form liquid spray for San Jose Scale. Use 1 part of this liquid to 9 parts of water for dormant spraying. We offer high grade quality. (Not mailable.)

Price, Qt. $30 \mathrm{c}$; gal. $75 \mathrm{c} ; 5$ gals. $\$ 2.50 ; 10$ gals. $\$ 4.50$. Write for price per barrel.

\section{DRY LIME-SULFUR}

Sherwin Williams' high grade dry powder. Overcomes disadvantages of the liquid material such as the possibility of freezing, leaky packages, hauling bulky packages, extra freight, etc. Has all the insecticidal and fungicidal qualities of the liquid material. Is absolutely safe and effective. From 10 to 12 lbs. Dry Powdered Lime-Sulfur dissolved in 50 gallons of water should be used as a dormant spray; from 2 to 3 lbs. to 50 gallons of water in combination with the usual proportion of arsenate of lead should be used for summer spray on all seed fruits such as apples, pears, etc. One-half this amount for peaches, plums, and all stone fruits. (Mailable, postage extra.)

Prices, 1 lb. 30 c; 5 lbs. $\$ 1.35$; 10 lbs. $\$ 2.25$. Write for quantity price.

\section{SCALE DESTROYER}

"TARGET BRAND."-A soluble oil spray of decided merit for San Jose scale, the most effective for leaf roller, all tree infesting scale and most soft bodied sucking insects. Has many advantages over Lime and Sulphur Solution, as it spreads more readIIy, getting into every little crevice. Will go twice as far. Has no had odor, does not discolor and much more agreeable to apply as it does not burn the eyes and skin: no clogging of nozzles, mixes easily. Use I gallon to 20 of water, after the leaves are off and up to time buds appear. For sum. mer spray use 1 gallon to 100 gallons of water. (Not mailable.)

Price, Qt. $65 \mathrm{c}$; gal. $\$ 1.65 ; 5$ gals. $\$ 6.50$; 10 gals. $\$ 11.50$. Write for price per barrel.

\section{S. W. INSECTO-Powdered}

This combines the insect destroying properties of Arsenate of Lead and the fungus preventative qualities of Bordeaux Mixture. It is put up in dry, powdered form for convenient use, and can be used for either dry dusting or wet spraying. It is safe and efficient. Used as a powder just as it comes from the package, in solution same strength Arsenate of Lead powder.

Price, lb. $65 \mathrm{c} ; 5$ lbs. $\$ 2.75$.

\section{BORDEAUX MIXTURE}

For Blight, Mildew, Rust and Fungus Diseases. Also prevents and cures Black Rot and Scab, and acts as a deterrent for in. sects on fruits and vegetables.

BORDEAUX MIXTURE - POWDERED. This is a perfect dry Bordeaux mixture concentrate in a dry powder. It is scientifically founded to insure perfect results, stays in suspension well and adheres to the foliage. It can be used in combination with other insecticides with an extraordinary degree of safety. - For general winter use, 8 lbs. to 50 gals. of water; one-half strength for summer. (Not mailable.)

Price, 1 lb: 60c; 5 lbs. $\$ 2.75$; 10 lbs. $\$ 4.50$.

\section{BLACK IEAF " 40 "}

A concentrated solution of nicotine sulphate containing 40 per cent nicotine. Indorsed by the foremost experts of the U. S. for red bug, green and wooly aphis, trips, plant lice, codling moth, pear, psylla and all sucking insects. Descriptive pamphlet on request. (Not mailable.)

Also an excellent dip for animal parasites, such as scab and lice on sheep and cattle, sheen ticks, etc.

Prlce, 1 oz. bottle 30c; makes 5 gal. spray; $1 / 2$ lb. can $\$ .00$, makes 47 gals. spray; 2 Ib. can, $\$ 3.25$, makes 240 gals. spray; 10 Ib. can, $\$ 13.75$, makes 1000 gals. spray. Full instructions with each can.

NOTE.-Fish oil soap (see next page), mixed in this solution makes it more effective and is necessary for perfect results. It makes it stick and last longer. Use $4 \mathrm{lbs}$. to 50 gals. solution. Full and detailed in. structions with each can.

\section{PARIS GREEN}

Poison, be careful. Usually four to six ounces to fifty gallons of water will be satisfactory. Price, $1 / 4$ lb. $25 \mathrm{c} ; \mathrm{l} / 2 \mathrm{lb}$. $40 \mathrm{c} ; 1 \mathrm{lb}$. $75 \mathrm{c}$.

\section{PRUNING COMPOUND OR PAINT}

This paint has a heavy oil body which dries on the cut with a rubbery, elastic film that will last as long as a paint can be made to last. It will thoroughly seal up the open wound. In addition to its covering capacity it has other splendid qualities which make it more adaptable than tar or white lead. It is dark olive green in color, comes ready to use and should be applied with a stiff brush. Its low price and merit should appeal to every orchardist.

Price, qt. 60c; gal. $\$ 2.00$ 


\section{Sprays and Insecticides-Continued}

FREE BOOKS AND PAMPHLETS

The manufacturers of the insecticides we sell furnish us descriptive and instructive pamphlets on spraying, etc., and we will gladly pass them on to our customers. Although they are not prepared especially for the Pacific Coast, you will gain by reading them.

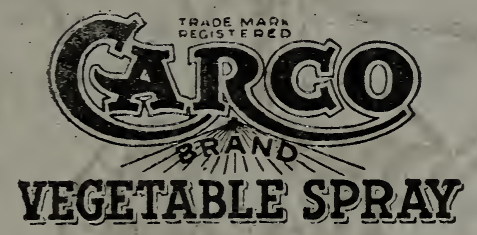

For many years the gardeners of the Pacific Coast have suffered from a scourge of root-maggots and worms that has made gardening, if not impossible, much more unprofitable than it should have been. Many remedies have been tried with little success until the "Carco" formula was discovered.

A wonderfully successful spray for destroying ROOT MAGGOTS, GRUBS, ETC., that infest Turnips, Radishes, Beets, Rutabagas, Cauliflower, Cabbage, Onions, etc., and also recommended for combatting CROWN BORERS in Strawberries.

To get best results, the ground should be sprayed freely with Carco solution before planting, then again as soon as the vegetables come up. "Carco" is highly concentrated; use 1 part "Carco" to 100 to 125 parts of water. Descriptive pamphlet and testimonials on request.

Prices, 1/2-pint cans, prepaid 45c; larger sizes by fieight or express only; $1 / 2$ pints $35 \mathrm{c}$; pints $65 \mathrm{c}$; quarts $\$ 1.00 ; 1 / 2$ gal. $\$ 1.50$; gal. $\$ 2.50$.

\section{BUG DEATH}

NON-POISONOUS.-A most effective powder for tomato, squash, cucumber and cabbage bugs, currant worm and all bugs and worms that eat the leaves of plants and vines. Bug Death is a wonderful protection against insects. Absolutely non-injurious. Contains no arsenic. Kills the bugs, prevents blight, revives and aids the healthy growth of plants and shrubs.

Prices, $1 \mathrm{lb}$. cans with perforated shaker tops, postpaid, 35c. By express, $1 \mathrm{lb}$. 25c; 5 . lbs. $\$ 1.00 ; 10$ lbs. $\$ 1.75 ; 25$ lbs. and up $16 \mathrm{c}$ lb. Add postage if wanted by mail.

\section{NTCO-FUMT}

The purest and most highly refined nicotine product offered for spraying, vaporizing and fumigation in Green Houses. Our Florists like NICO-FUME better than other similar preparations such as Nicoticide, To-bak-ine, etc., because it is safe and less expensive. Read descriptive pamphlet and be convinced. Free on request.

NICO-FUME LIQUID for spraying or vaporizing; $1 / 4 \mathrm{lb}$. tin $65 \mathrm{c}$; $1 \mathrm{lb}$. tin $\$ 2.00 ; 4 \mathrm{lb}$. tin \$7.50; 8 lbs. (gal.) \$14.50. (Cannot mail.)

NICO-FUME FUMIGATING PAPER. Quick, safe and effective for greenhouse work. Price per can of 24 sheets $\$ 1.25$ (wgt. 1 lb.); 144 sheets $\$ 5.00$ (wgt. 4 lbs.). Add postage. 288 sheets direct from factory prepaid for $\$ 9.50$, guaranteed fresh.

\section{FUMOTH FUMIGATORS}

For kill.ng moths, miliers, mosquitoes, mites and lice in hen house, etc. Vapor does not injure clothing, furniture, etc. Full directions on the can. Price 50c; postpaid $60 \mathrm{c}$.

\section{NIAGARA 3 IN 1-Dusting Mixture}

This new preparation is meeting with great success everywhere. It is a combination of Sulphur, Arsenate of Lead and Tobacco dust. It is specially prepared and exceedingly fine, which insures a good even distribution and splendid sticking qualities.

A combined insecticide and fungicide for mildew, green or black lice or any leafchewing insects. Apply with a powder gun (see page 130). No muss or slopping liquids to contend with. (Not mailable.)

Prices in bulk: 1 lb. 25c; 5 lb. sack \$1.00; $10 \mathrm{lb}$. sack $\$ 1.50$. Write for quantity prices.

\section{SULPHO-TOBACCO SOAP}

For spraying or sponging or dipping ferns, palms or potted plants, or spraying loses, shrubs or vines it is invaluable. Kills Aphis, Red Spider, Plant Lice and Sucking Insects. Acts quickly and effectively against these pests. Will not injure the tenderest plant. 'Two ounces of soap make a gallon of solution. Non-poisonous, perfectly safe and yet very efficient.

Prices: Postpaid, 3-0z. bar 15c; 8.0z. bar $25 c$.

\section{RAT CURE}

Never fails. It is in tablet form, ready to feed from the can;... no mixing. No odor after death. A rat or mouse less for every tablet at a cost of less than 1 cent.

Price: $30 \mathrm{c}$ per can; 4 for $\$ 1.00$, postpaid.

\section{GRAFTING WAX}

We sell Target Brand, a high grade preparation. Easy to handle. For pruning or grafting or for covering fresh cuts.

$3 / 4$ Ib. 20c; 1/2 Ib. 30c; Ib. 40 c; postage extra.

\section{FISH OIL SOAP}

For aphis, plant lice, etc. Best grade. $1 / 2$ lb. bar 15c; 1 Ib. 25c; 10 lbs. \$2.00; 100 Ibs. market price.

\section{PHENOLA}

A cold-water disinfecting white paint. It looks better and will outlast whitewash. Paint or spray it on any surface. For poultry houses, barns, public buildings, cellars, dairies, etc. Takes the place of paint and disinfectant. Easier to use, quicker and much cheaper. Use 1 to 2 lbs. to a gallon of water, enough to cover 200 to 300 square feet.

Price, $1 \mathrm{lb}$. can 25c: $5 \mathrm{lb}$. can $\$ 1.00 ; 10 \mathrm{lb}$. can $\$ 1.75$; postage extra. Quantity price on request.

UNSLACKED LIME.-For making whitewash, etc.

Price, 5 lbs. 25c; 10 lbs. 40c. Add postage. Barrel price on request.

SULPHUR POWDER.

Lb. 10c; 100 lbs. market price

SULPHUR CANDLES.

Each 10c; postpald 15c; 3 for $35 \mathrm{c}$

TOBACCO DUST.-Valuable as an insecticide.

Lb. $15 \mathrm{c} ; 10$ Ibs. $\$ 1.25$

BLUE STONE-VITROL.

1 lb. 25c; 10 lbs. market price

FREE ADVICE.-If you will write and tell us what insects or plant disease you want to combat, we will advise you to the best of our ability. 


\section{SPRAY PUMPS AND SPRAYERS}

Our experience shows us that if you get a good outfit, one large enough to do your work. you will spray well and as often as necessary; but if you get a cheap outfit or one that is too small, you will become disgusted throw it aside and let this most important work go undone. Hardie Mfg. Co.'s handsomely illustrated spray pump catalog on request.

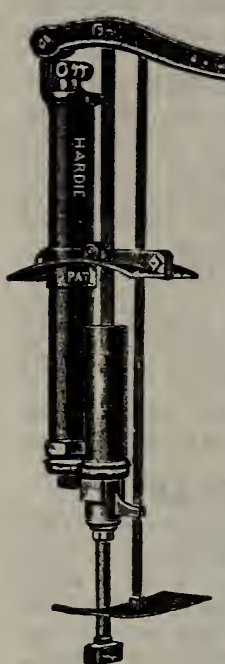

No. 6 Hardie

Catalog

No. 5

No. $5 \ldots \ldots \ldots \ldots 25$ to 30 for

No. $6 \ldots \ldots \ldots \ldots .30$ to 75

NO. $7 \ldots \ldots \ldots \ldots$ up 100 up

The strongest, most powerful and satisfactory spray pumps for barrels or tanks. All working parts are of brass. Perfect agitation of the spray mixture is secured by a mechanical agitator, which works with each stroke of the handle (notice cut carefully). The construction is simple. The pump can be repacked or plunger tightened easily and quickly. No pipe wrench needed. All the valves are round, hard brass balls.

NOTE.-A. B., all brass-W. I. C., with iron air chamber

BARREL OUTFITS.-Most every one has different ideas and opinions as to just what kind of an outfit they require, therefore we offer no combination, but you can figure outt the cost as follows: Price of pump, spray, hose, extension rods, nozzles, and then take 10 per cent off. Free instructions for mounting. Barrel "pump plates" or holders for end or side; state which you prefer. For nozzles, hose, extension rod. etc., see following pages.

Free instructions for mounting. Barrel "pump plates" or holders for end or side; state which you prefer. For nozzles, hose, extension rod, etc., see following pages.

If you want the pump mounted on a barrel with side non-roller cleats, hinged filler door, with strainer, add $\$ 7.00$.

WHEEL OUTFIT NO. 21

A most satisfactory outfit and one of our best sellers. Especially designed to meet the needs of the small fruitgrower, gardeners and florists, for all-round spraying. It has the capacity and power to do good work rapidly. Dairymen, poultry keepers and farmers will find this outfit most useful for whitewashing, disinfecting and general spraying. The 30 -gallon barrel is mounted on strong wiought-iron wheels, 26 inches in diameter, with $1 \frac{1}{2}$-inch tires. No. 5 puinp, 5 feet best hose and couplings, 8-foot bamboo rod and leakless stopcock. 1 Vermorel nozzle.

\section{HARDIE BUCKET PUMP}

Price $\$ 30.00$

A high-grade, all brass bucket pump, especially designed to meet the long-felt want in this line. It is the only bucket pump on the market that has a mechanical agitator and that is so designed as to always stand in position in the center of the bucket. This new device for holding the pump firmly in place in the center of the bucket enables the operator to move or carry the whole outfit with one hand. A practical outfit for light work. This is the only bucket pump in the market that is giving entire satisfaction. Good-sized air chambers enables one to maintain a high pressure and continuous spray.

To reach the tops of tall trees, you should order, extra, an extension rod. For price of extension rods, see page 129.

LARGER PUMPS.-For larger pumps and power outfits ask for Special Spray Pump. Catalog-Free on request.

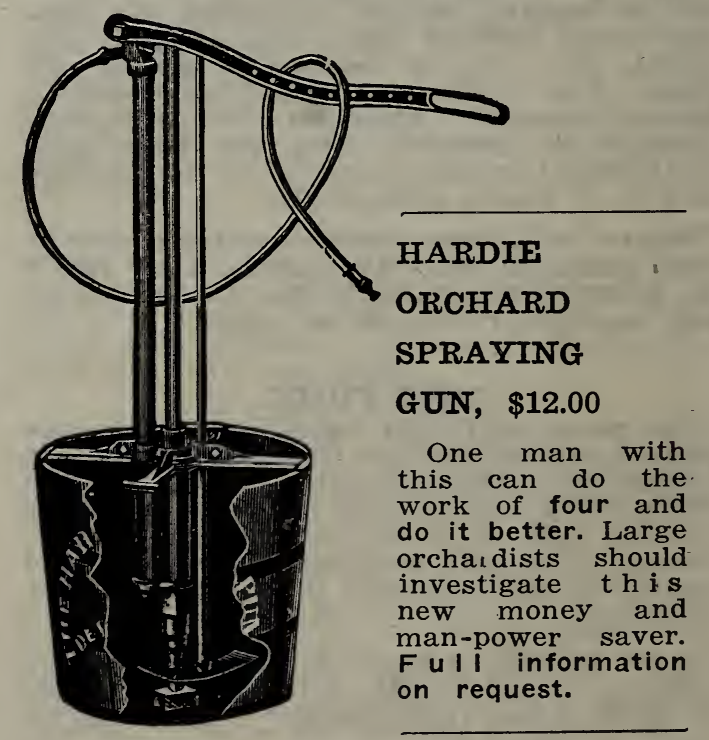

BUCKET OUTFIT NO. 10

Price, including No. 4 Pump, one 5-gallon: heavy wooden bucket, three feet best $1 / 2$ inch hose, one spraying lance 18 inches long, one Vermorel nozzle, price $\$ 12.00$. 


\section{IOWELI FOUNTATN SPRAYER}

Every city gardener, florist and poultry leeper needs a Lowell Fountain Sprayer; clean and easy to operate; no need to get any spray on your hands or clothes; will last a lifetime with reasonable care. (Try one at our store.)

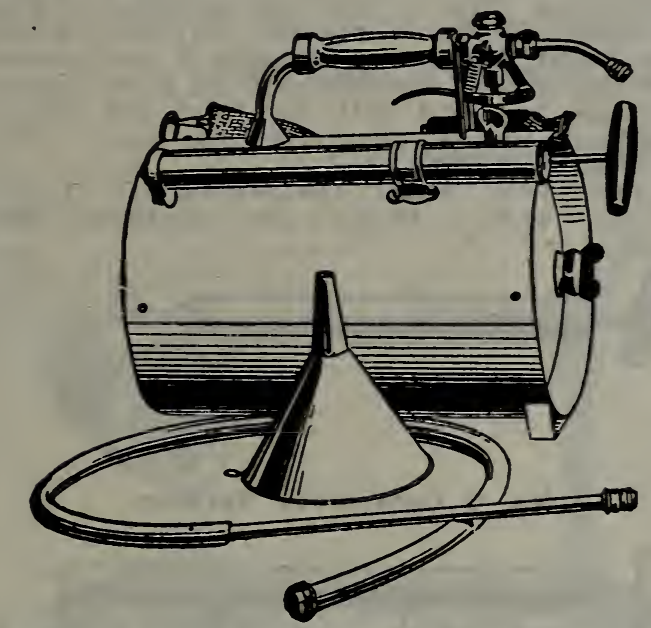

Lowell Fountain Uu.upressed Air Sprayer

Special Features: Capacity 3 gallons; can be carried by the handle (see cut) or a strap that goes over the shoulder. The automatic controlling valve under the handle gives instant and perfect control of the spray and don't waste any. The air pressure nump is outside where you can get at it, the filler plug is well made and fits tight. The tank after being seamed and riveted is dipped into molten solder, making it absolutely air tight and the strongest Air Pressure Sprayer made, standing five times the air pressure necessary to operate.

Hose with a 4-inch rod 2 nozzles and filler funnel, with each outfit. The short crook and nozzle shown in the cut is used without the hose when spraying vegetahles. For reaching the under side of leaves of low bushes, attach the hose and use the vine attachment extension rod. For high spraying use as many two-foot extensions as needed. Descriptive booklet on request.

Prices: No. 111 brass tank \$10.00; No. $\$ 10$ galvanized tank $\$ 7.00$. (Wgt. boxed 14 1bs.)

Extras-2-foot brass extension rods, each $75 \mathrm{c}$; vine attachment, 2-foot extension with bent reck, each $\$ 1.00$. (P. P. 1 lb.)

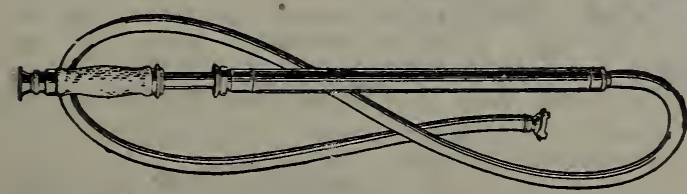

Standard

Brass Spray Pumps

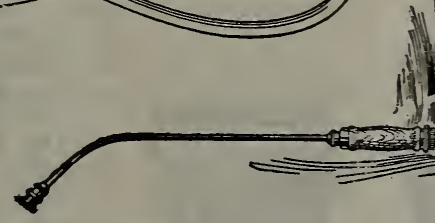

Standard, with Knapsack Reservoir

A simple, strong, low-priced pump for every kind of spraying. Adjustable nozzles from fine mist to solid stream; brass ball valves; $31 / 2$-foot suction hose, which is placed in a bucket, barrel, knapsack or water trough. As a handy all-around fruit or garden sprayer and for washing windows, buggies, autos or as a fire extinguisher it has no equals.

Prices: Pump Only (wgt. 6 lbs.), \$5.00. With Knapsack Reservoir,, \$9.00. Extension Rod, \$1.00; Extra hose. per foot, 20c.

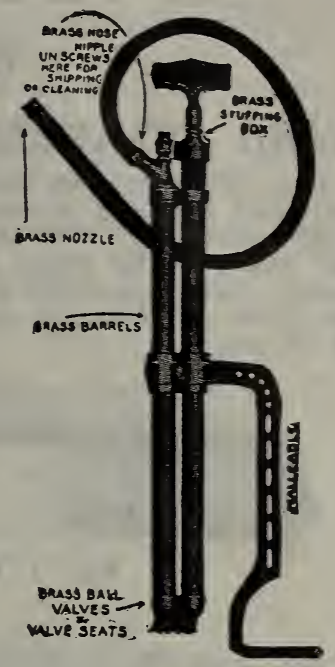

to most pumps of this Price 8 lbs.)

o. K. Bucket Pump

\section{NO. 29, BRASS BUCKET PUMP}

The best low-priced spray pump on the market. Double air chamber enables the operato keep constant pressure with little One fine, one coarse nozzle, 3-foot

NO. 32, BRASS BUCKET PUMP

Well made; all working parts brass; larger capacity; bulb air chamber produces contin12 lbs.)

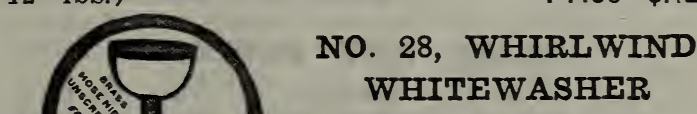

Galvanized tin, bras $\mathbf{s}$ plates, steel footrest, $3 \mathrm{ft}$. hose, double nozzle (Wgt. 5 lbs.) See illustration, page 138 . Price $\$ 3.00$

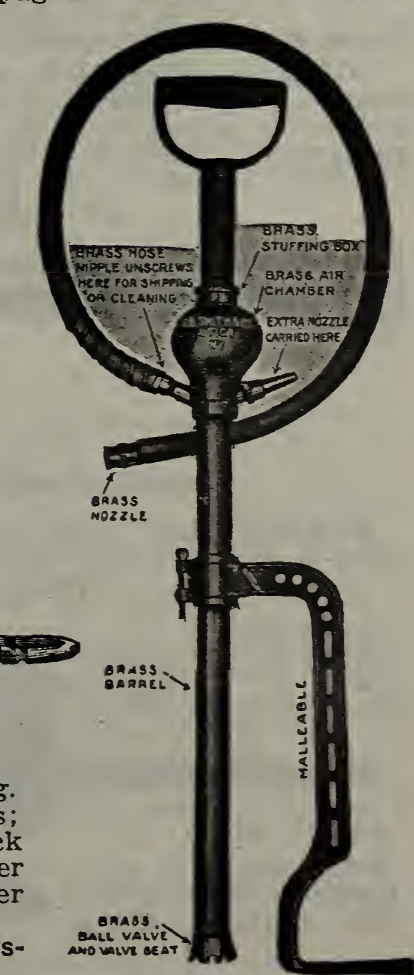

No. 32 


\section{SPRAY PUMPS-Continued}

\section{HAND SPRAYERS OF "MERIT"}

The "Perfect" Sprayers offered below are well and properly constructed of heavy, high grade material. We offer the "Lowell" line. far superior to most makes. Full size, 20 inches long, capacity 1 quart. Adapted for all kinds of general spraying. Your choice of styles.

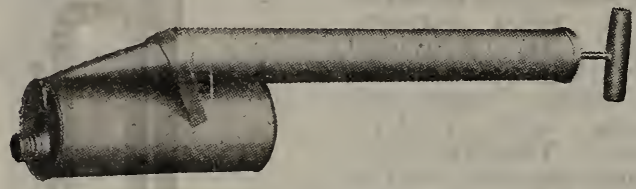

No. 7 Perfect

No, 6 or No. 7 (P. P. weight 2 lbs.) your choice, each $75 \mathrm{c}$. Boxed and postpaid $\$ 1.00$.

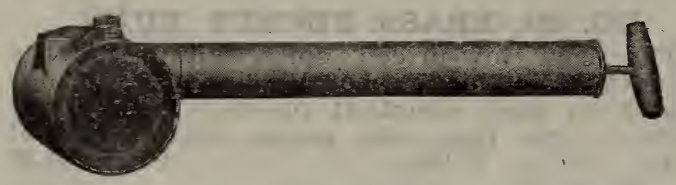

No. 6 Perfect

MIDGET SPRAYER.-Same style as No. 7 Perfect, but smaller; capacity, pint.

Each 50c; postpaid $70 \mathrm{c}$

\section{RAISE ANY FRUIT?}

If you have any amount of fruit to pick you need one of our new Fruit Picking Bags and a good, safe, handy ladder. Just look at our new outfit on page 123 .

\section{NO. 5 CONTINUOUS SPRAYER}

Has 2 spray caps for spraying up, down, straight ahead or at any angle and is so constructed that it not only sprays on the downward stroke of plunger, but also when it is drawn back, thus causing a continuous mist-like spray, enabling one to spray three times as fast and with one-third the labor. Length 20 inches. Capacity, one quart. (P P. weight, 2 lbs.)

Each, TIN, \$1.25; GALVANIZED, \$1.50; BRASS, \$1.75. Boxed and postpaid, 25c extra.

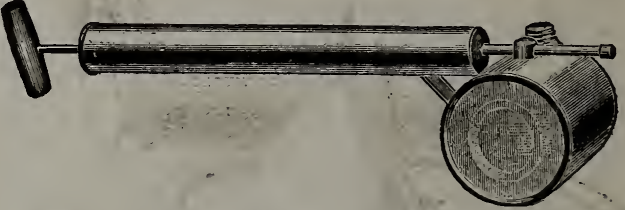

No. 5 Continuous Sprayer

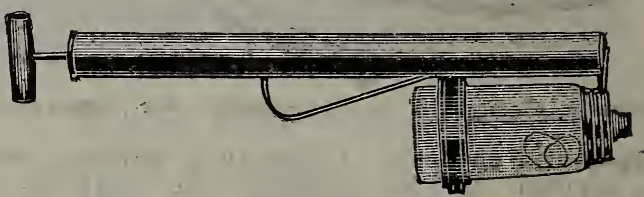

NO. 3 GLASS TANK

Well constructed, the glass reservoir which is a quart Mason jar, is not affected by any kind of spray. You can have several jars of different sprays (already prepa ${ }_{1}$ ed) and when you wish to change, take out one and put in another. No delay. Extro long air chamber, special plunger and throws a strong, fine spray in any direction. (P. P. Weight, packed, 5 lbs.)

Each, $\$ 1.25$; Boxed and prepaid, $\$ 1.60$

\section{Powder Sprayers, Blowers and Dusters}

These are used for applying Sulphur, Bug Death, Dry Bordeaux or insect powder of any kind.

LOWELL POWDER GUN (See cut).Heavy tin. Finished in aluminum. If the powder is sifted and dry it will not clog: guaranteed. Throws a fine cloud of powder. Capacity 1 quart. (P. P. 21/2 lbs.)

Price $\$ 1.25 ;$-postpaid $\$ 1.50$

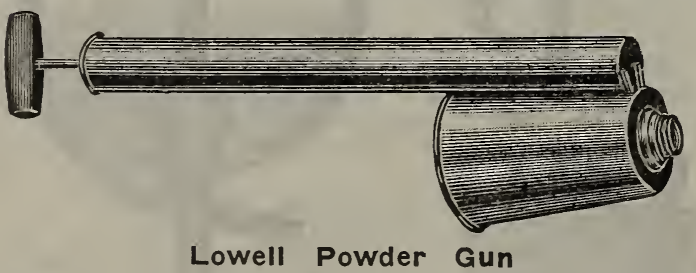

PERFECTION DUST GUN.-A new style, light weight, durable and powerful dust gun. Price $\$ 3.00$; prepaid $\$ 3.50$

\section{DEFENDER.}

Holds about 1 oz.

$20 \mathrm{c}$; postpaid $25 \mathrm{c}$.

WHIRLWIND.

Holds about 4 oz. Larger, B e t t e $r$. $50 \mathrm{c}$; postpaid $60 \mathrm{c}$.

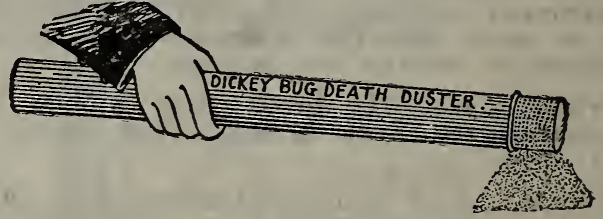

DICKEY BUG DEATH DUSTER.-For USing when applying Lime, Dust or Powder of any kind. For use on small gardens this is very handy. Saves powder, puts it on evenly and just where you want it

(P. P. $8 / 4$ lb.) Each 50c; postpaid $65 \mathrm{c}$

Dry powder insecticides are becoming more popular each year as very effective results can be obtained. 


\section{BAMBOO EXTENSION RODS}

These are necessary for spraying trees. Our stock is made up in the best possible manner. No. 1 bamboo poles lined with either aluminum or steel tubing, screw threaded into trass connections at either end. Stopcock or cutoff necessary to make connections complete. $\begin{array}{llll}6 \mathrm{ft} . & 8 \mathrm{ft} . & 10 \mathrm{ft} . & 12 \mathrm{ft} .\end{array}$ ALUMINUM LINED ................. Brass lined 25c less) $\$ 3.10 \quad \$ 3.50 \quad \$ 3.75 \quad \$ 4.00$ STEEL LINED .......................... $1.75 \quad 2.00 \quad 2.25 \quad 2.50$ EXTRAS FOR EXTENSIONS.-Stopcock, each \$1.25; Angle Cutoff \$1.50; Drip Guard 30c.

\section{NOZZLES, SPRINKLERS, RODS, EXTRAS, ETC.}

ROSE AND PLA N'T STAKES, WEED KILLERS, ETC., see pages 118-123.

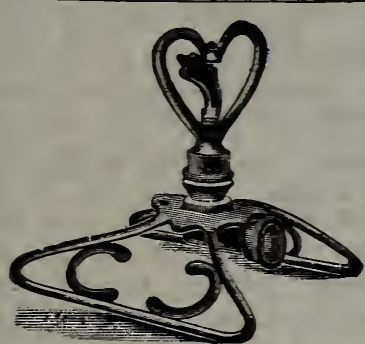

Busy Sprinkler

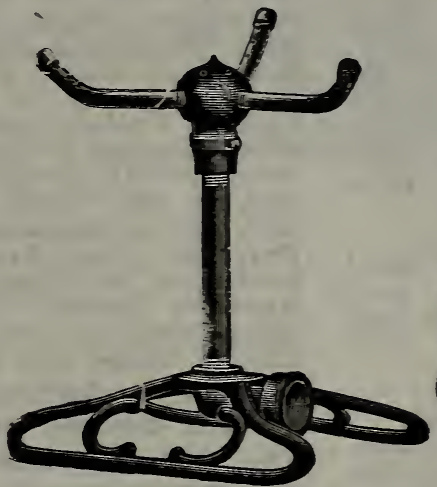

Pluvius Sprinkler

\section{LAWN SPRINKLER}

Don't waste time holding the hose nozzleuse lawn sprinklers, and change positions as often as necessary.

Pluvius Lawn Sprinkler.-11 inch, upright standard, 3 brass arms. (P. P. 4 lbs.)

Each $\$ 2.00$

Monarch or Midget.-Same style as above, $51 / 2$ inch. (P. P. $21 / 2$ lbs.) Each $\$ 1.50$

Busy Lawn Sprinkler.-Covers 25-foot circle. Very desirable for medium sized yards. (P. P. 3 lbs.) Each $\$ 1.75$

Fountain Sprinkler.-Circular brass tube. Large \$1.50; Small, sprays square, $85 \mathrm{c}$; Half Circle 75c (postage 10c, any style).

Little Wonder.-Cheap, but good. Excellent in small yards. Covers 20 feet. (P. P. 1 Ib.) Each $50 \mathrm{c}$

No. 31-Diamond Hoze Nozzle,-Best for sprinkling; adjustable from solid stream to a fine spray. (P. P. $1 / 2$ Ib.) $\quad$ Each $75 \mathrm{c}$
THE RAIN MAKER,-This is a large automatic whirling garden or lawn sprinkler covering a large space. Price $\$ 12.00$. Descriptive leaflet on request.

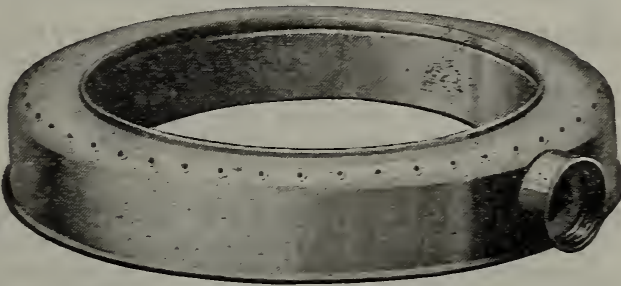

Fountain Sprinkler

Fountain Shower Hose Nozzle - Makes a very fine mist-like spray. 35c; $50 \mathrm{c}$ postpaid

No. 41-Dandy Hose Clinchers.-Best mender made, simple and quick; nothing to catch; sure to hold.

Postpaid, $1 / 2$ in., $15 c ; 3 / 4$ in., $20 c$

Dandy Hose Couplings.-(Clinchers.) Each 60c

No. 40-Garden Hose Connections.-Both male and female couplings. $1 / 2$ in. or $3 / 4$ in., pair $50 \mathrm{c}(6 \mathrm{oz}$ )

Hose Washers. Doz. 10c, postpaid No. 45-Metal Mender Tubes. $1 / 2$ in. or $3 / 4$ in., each $10 \mathrm{c}$, postpald

No. 42-Hose Clamps, single band. $1 / 2$ in. or $3 / 4$ in., each $10 \mathrm{c}$, postpaid

No. 44-Hose Clamps, double band. $1 / 2$ in. or $3 / 4$ in., each $15 \mathrm{c}$, postpaid SPRAY PUMP NOZZLES

Single Bordeaux (Best for Whitewash).\$1.25 Single Vermorel (Very Fine Spray)... 1.10

\section{Spray and Garden Hose}

We offer new stnck only of high-grade hose for spray pumps and garden purposes. We advise our customers to buy the best. It is cheapest in the end. Don't buy old stock.

XXX GRADE (Non-Kinkable). - Guaranteed. This hose gives excellent satisfaction. Good enough for any ordinary spraying outfit, and by far the best hose for florists' or gardeners' use. One customer reports that he used a 50-foot length of this grade for 3 seasors continuously, which proves that it is the cheapest hose to buy. We have this on 500-foot reels, and cut any length wanted.

Price per foct, smooth or moulded, $1 / 2$ inch, 20c; $3 / 4$ inch, 221/2c; corrugated, $2 c$ per foot higher.

(Couplings free on $50 \mathrm{ft}$. lengths.)
SPECIAL SPRAY HOSE.-The highest grade extra heavy spray hose made; guaranteed. $\quad$ Price, $1 / 2$ in. only, $24 \mathrm{c} f$. year.

COTTON HOSE is too high to list this

I.AWN MOWERS

Space in this catalog does not permit us to list the Lawn Mowers we handle, but if you can call we will be glad to show you good easy running kinds, priced very reasonable.

PIANT SMALI FRUTTS around your garden. What's nicer than delicious fresh fruit, fresh from your own garden? See Fruit Department, pages 108 to 116. 


\section{Books You Should Read}

The following list comprises the newest and best books covering the different subjects Many of them we have in stock, others we have mailed direct to you by the publishers. All prices postpaid.

NEW GARDEN GUIDE

The amateur gardener's Handbook. Thoroughly covering Vegetable and Fruit Raising. How to Plan, Plant and Maintain the Home Grounds, the Suburban Garden, the City Plot. How to Care for Roses and Other Favorite Flowers, Hardy Plants, Trees, Shrubs, Lawns, Porch Plants and Window Boxes. With Chapters on Pruning, Propagation, Fertilizers, Insect Pests, Tools, Winter Storage, Canning, Bilds, Garden Furniture and 1001 Practical Pointers. Heavily illustrated with over 275 teaching plans and diagrams and reproduced photographs, all made expressly for this Standard Text Book.

Prices: Paper covered $85 \mathrm{c}$; cloth cover $\$ 1.10$

\section{COMMERCIAL PLANT PROPAGATION}

$A$ new and up-to-date book so fully illustrated and plainly written that the professional as well as the amateur will find it of great value. Cloth. 180 pgs., $\$ 1.50$ postpaid.

\section{PRACTICAL LANDSCAPE GARDENING}

This new book, written by Robt. B. Gridland, is without a shadow of a doubt the best book we have read. Contains 91 illustrations, 67 sketches and 33 plans. Enamel paper, well bound, 266 pgs.. Price, $\$ 2.00$ postpaid.

\section{New and Practical Book}

\section{Egg Production}

The best book on the subject to date-in fact, THE ONLY COMPLETE ONE. Just off the press. Gives complete information on every important detail of the practical use of lights. Special attention to methods in use in the Northwest. Grant M. Curtis. 120 pages, $9 \times 12$ inches, profusely illustrated

Profitable Culling and Selective Flock Breed-

ing Homer W. Jackson. Nothing equal to this money-making book has been published in years. Only complete work published on culling. Fully describes all approved methods of selecting layers. 120 pages, $9 \times 12$ inches, illustrated with 18 color plates and many half-tone engravings. $\$ 1.50$

How to Feed Poultry for Any Purpose With Profit

By John H. Robinson. Complete, authoritative book on feeding all kinds of poultry -just off the press and down to date in every respect. Tells what to feed and how to feed. Complete table showing nutritive values of all poultry feeds. 112 pages, $9 \times 12$ inches, beautifully illustrated... \$1.25

A Living from Eggs and Poultry. 188 pgs., $5 \times 7$ inches..............\$1.35 Back Yard Poultry Feeding. 12 pgs., $5 \times 7 \quad .50$ Ducks and Geese... 104 pgs., $9 \times 12 \ldots \ldots .75$ Eggs and Egg Farms. 96 pgs., $9 \times 12 \ldots .50$ Poultry Architecture. Fiske. 125 pgs.

$5 \times 7 \ldots \ldots \ldots \ldots \ldots \ldots \ldots \ldots \ldots . . . \ldots \ldots$

The Call. of the Hen. Water Hogan... 2.00 Success With Hens. New. Robert Joos 1.10 Successful Poultry Keeping. 176 pgs.,

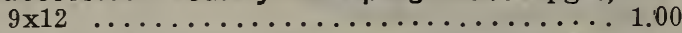

War-Time Poultry Feeding. 32 pgs., $5 \times 7.25$

Save time, energy and money by readin you ever stop to think that a few hours' reading mation that it has taken others YEARS OF LABOR AND EXPERIENCE to obtain?
MILADY'S HOUSE PLANTS

This new book, written by an expert on: house plants, is fully illustrated and gives the information every lover of plants needs. to be successful. Don't let your beautiful palms, ferns and plants die. 180 pages. Cloth bound. Price $\$ 1.10$ postpaid.

Other Valuable and Worth While Books

Asparagus. Hexamer................ 80 Barn Plans and Out Buildings. Powell. 1.75 Beginners' Guide to Fruit Growing.....\$1.10 Butter Making. C. A. Publow...........85 Federal Farm Loan System. Myrick... 1.35 First Lessons in Dairying. Van Norman .80 Home Fruit Grower. Kains......... 1.10 Making the Farm Pay. Bowsfield..... 1.10 New Onion Culture. Greiner.......... 1.80 Practical Fruit Grower. Maynard........ .85 Profitable Dairying. C. L. Peck........ 1.10 Rhubarb Culture. New. Morse \& Fiske .80 Silos, Ensilage and Silage. Miles..... .85 Soiling Crops and the Silo. Shaw..... 1.85 Strawberry Culturist. Fuller....................... Tomato Culture. Tracy .......... .80 The Potato. Frazer ...............10

The Right Use of Lime for Soil Improve-

ment. Agee 1.35

Window Flower Gardening. Heinrich.. .80

Artificial Incubating and Brooding

Tells how to obtain strong-germed, fertile eggs; how to operate incubators and brooders. If you want to get good hatches and raise the largest possible percentage of chicks hatched, you need this down-to-date book. 112 pages, 9x12 inches......\$1.00

\section{Poultry Houses and Fixtures}

Shows plans of low-cost, practical, and labor-saving houses, designs for inside fixtures, roosting coops, and coops for young chicks, and appliances for the poultry yard. 1920 Edition; completely rewritten from cover to cover. The latest and best book on the subject. 112 pages, $9 \times 12$ inches. $\$ 1.00$

Poultry Breeding and Management

By James Dryden. This book is written for the man or woman on the farm who is interested primarily in making poultry pay. The author's experiments at the Oregon Agricultural College, which have resulted in the creation of phenomenal strains of layers, among them a number of hens with records of 300 eggs in a year, and several with records of more than a thousand eggs in less than six years' laying, as well as chapters on systems of poultry farming, housing, feeding and incubation, are fully treated. Illustrated. $51 / 2 \times 71 / 2$ inches. 416 pages. Cloth.........\$2.10

THE "BREED" BOOKS, ALL LATE AND "UP-TO-DATE"

Asiatics. $100 \quad$ Price Postpaid Leghorns. 144 pgs., $9 \times 12 \ldots \ldots \ldots \ldots 1.00$ Orpingtons. 80 pgs., $9 \times 12 \ldots \ldots \ldots \ldots \ldots .75$ Plymouth Rocks. 144,pgs., $9 \times 12 \ldots \ldots 1.00$ Rhode Island Reds. 88 pgs., $9 \times 12 \ldots . .75$ Turkeys. 96 pgs., $9 \times 12 \ldots \ldots \ldots \ldots \ldots \ldots . .75$ Wyandottes. 160 pgs., $9 \times 12 \ldots \ldots \ldots 1.00$ these practical and up-to-date books. Did 


\section{QUEEN INCUBATORS}

EVERY M A NU F A C T URER CLAIMS HIS MACHINE IS THE BEST. The most extravagant claims are generally made for the cheapest and most flimsy machines. Unfortunately, there is at present no law to protect the public against irresponsible exaggeration, and it is wise for you to make thorough investigation.

WE WELCOME ANY SUCH INVESTIGATION a n d comparison, for you will find MORE GENUINE VALUE IN THE QUEEN, for the amount of money you pay, than in any other incubator on the market. Our 20 years' experience proves it.

Queen Incubators are famous for big hatches of strong, healthy chicks that live and grow. The QUEEN is accurately regulated-taking care of a temperature variation of 70 degrees without danger. It is built of genuine California Redwood-very scarce in these days of imitation and cheap substitution. Redwood does not absorb the odor from the hatching eggs. Cheaper woods, and pasteboard lining in most other makes, retain the odors which certainly weaken and kill the hatching chicks.

REMEMBER, it is not how many you hatch that counts, but how many you raise. Chicks that hatch out WEAK AND WOB$B L Y$, live but a few days and mean nothing to you except trouble and loss. They make one sick of the poultry business. Most of the chicks you lose in the first two weeks die because they did not hatch out with enough vitality or strength for a good start.

\section{Insulation}

Many incubators, nowadays, are not weil insulated. Proper insulation adds considerable expense to the manufacturing cost, and the manufacturers of cheap, low priced machines dispense with it, or use an inferior substitute. Investigate this most important feature very carefully.

Good insulation means a proper maintenance of uniform heat throughout the hatching period, less fuel and stronger chicks.

The QUEEN is doubly insulated. First, we use double walls of California Redwood, forming a dead air space. Second, we use corrugated strawboard between the wooden walls.

We will gladly mail to you a copy of the Queen Incubator Co.'s illustrated

and descriptive catalog. It goes into detail and plainly shows you Just how
they are constructed and why they are so successful. Write us today; a postal will do.
The QUEEN Heater, tank and water pipes are made of genuine copper, the best material for this purpose. Every outfit tested under heavy pressure and guaranteed perfect.

The QUEEN Hot Water system elim. inates the injurious drying out tendency found in all hot air incubators and provides a soft, uniform heat over every part of the egg chamber that is most natural for the hatching eggs. This form of heat under ordinary conditions makes unnecessary the application of moisture.

The QUEEN is not a cheap incubator, compared with many of the cheaply constructed machines on the market, but it is the "Best Bargain," as it will be turning out high percentage hatches years after the cheap machines have been junked.

\section{Portland Prices}

We order in carload lots and can make prompt shipments. All machines fully guaranteed.

No. 1 Queen - 85 egg capacity.....\$26.50

No. 2 Queen- 135 " “ “ ..... 39.50

No. 3 Queen-180 " " " $18 . .445 .00$

No. 4 Queen- 275 " “ “

No. 5 Queen- 400 " “ “ ....67.50

No. 25 Queen-600 " " " $60 . \ldots 110.00$

No. 45 Queen-1000 “ “ " ....180.00

\section{Style K Queen Incubators}

These are built to sell at a lower price and are, we believe. the equal of any other incubators sold with the exception of our Standard Queen line. They have double walls, copper pipes and heater, same style regulator, but of lighter construction, double doors, etc. Queen catalog tells all. Made in three sizes only, priced as follows:

No. 20 Style $K-70$ eggs.........\$17.50

No. 21 Style $K-130$ eggs........... 29.50

No. 22 Style $K-220$ eggs.......... 38.00 


\section{QUEEN BROODER STOVE}

\section{The only Coal Burning Brooder Stove with Automatic Control of Both Check and Draft}

\section{Don't Hatch Chicks and Lose Them-Use a "Queen"}

The Queen burns any kind of fuel with equally satisfactory results. We recommend chestnui sizes in all kinds of fuel, hard or soft coal, coke, charcoal, or briquettes burn equally well. Of course, hard coal will not cause the pipe to become sooty as quickly as others.

Without a question the "Best" coal burning brooder stove on the market today. Note the improvements-the self-feeding, straight, flaring fire bowl, no clogging like in the old barıel-shaped bowls. A full-size rocker grate, a real automatic wafer regulator that really works in connection with a rightprinciple damper or check valve. A fireproof. ventilated stove base and a collapsible, four-piece hover (to save freight charges and to save room when not in use).

The QUEEN Colony Brooder is a new and improved design of brooder stove. It is made cf highest quality iron castings that will wear and last indefinitely.

There are no drafts on the smoke pipe of the QUEEN. The check rests on top of the stove and opens outward when fire is too waı $m$, thus giving a gentle inflow of air to retard the heat. While the opening of the draft to increase the fire is located on the ton of the stove, it opens into the fire at the base through an opening extending down the side to the bottom. This feeds the draft into the fire from underneath with no opening below the hover. As will be seen from the illustration, the check and the draft lids are cast together and operated together. Thus when the fire is too hot, the wafer automatic regulator expands and closes the draft and opens the check, but if at any

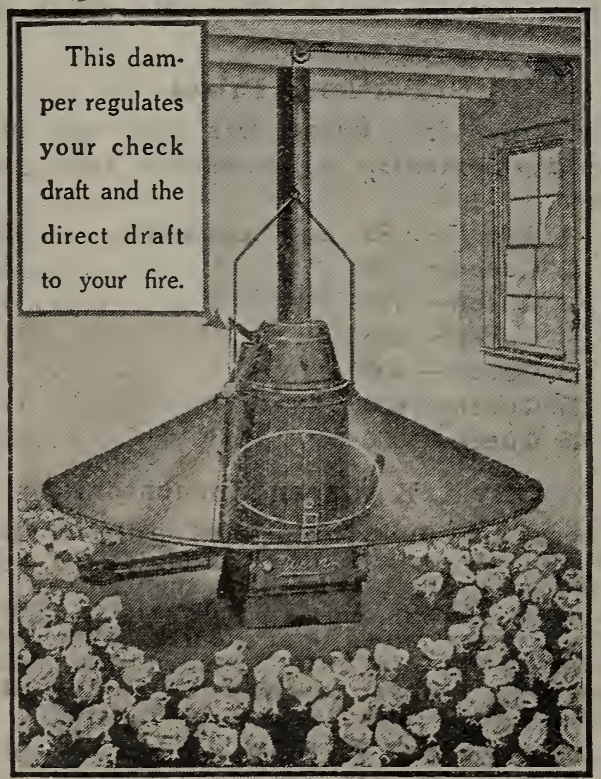

time it gets too cool, the wafer contracts and closes the check and opens the draft. This keeps an even heat all the time, both night and day, in cold weather or warm, and does it automatically. You don't have to pay any attention to it whatsoever. Just set the regulator for the proper temperature at the start of the season-it will do the rest.

Next to a good draft through the chimney, the principal secret of a good fire in any stove is a good grate that will free the fire from ashes properly and prevent clinkers. The grate in the Queen stove is the rocker type and strikes the fire at four points. This is far superior to any draw-center or shaker grate, because it cleans the fire thoroughly and by striking at four points will break up and remove all clinkers.

The hover used on Queen stoves is collap. sible and made of four pieces of galvanized iron. This hover comes knocked down, with holes punched and stove bolts attached, ready for putting together. By being collapsible, it enables you to save room when storing and lessens the danger of damage when not in use. Hover has a cast-iron ring on top which sets firmly around the top of the stove. It is furnished with a wire hook to which rope and pulleys may be attached, but it is not necessary to raise the hover to put in coal.

The Queen stove provides a constant, correct heat, and a constant distribution that makes the chicks develop into STRONG, HEALTHY CHICKS. By brooding with a "Queen," the chicks get plenty of pure, fresh air, plenty of exercise, and there is no POSSIBLE CHANCE OF THEM CROWDING OR SUFFOCATING.

\section{Queen No. 2 Brooder Stove}

This is the most popular size and will brond any number of chicks up to 1200 . Diameter of grate, $103 / 4$ inches; diameter of hover, 52 inches. Price, \$27.75.

\section{Queen No. 1 Brooder Stove}

This size is made for those who have limited room and do not need so great a capacity. No. 1 will brood any number of chicks up to 600 . Diameter of grate, 9 inches; diameter of hover, 42 inches. Price, $\$ 21.75$.

\section{Perfect Satisfaction}

Last season we handled a full carload of Queen Stoves and did not get a single com=plaint. Queen Service Is O. K.

$$
\text { The Dalles, Ore., May 8, } 1919 .
$$

Dear Sirs: I am running a 250-egg Queen Incubator and have had fine luck. Am selling baby chicks. I want to buy a larger size. Respectfully

MRS. MINA TAYLOR.

NOTE.-Order What 3 -inch stovepipe you need at $30 \mathrm{c}$ per 2 -foot lengths; elbows, $50 \mathrm{c}$.

Every chick hatched represents possible profit. The work laid out before you is to get this chick into a vigorous laying hen, or fit for market in the SHORTEST TIME possible. Start and finish them with "Queens.". 


\section{THE NEWTOWN COLONY BROODER}

A Blue Flame, Wickless, Oil Burning Colony Brooder-Automatic Regulator-Practical, Safe and Successful

For several years the coal-burning colony brocder has been generally recognized as the "acme of brocding efficiency," and we are still selling hundreds of them. The only trouble is that in some sections of this Western country it is troublesome to secure the proper grade of coal. Coal oil is obtainable anywhere. The Newtown is not an untried substitute. It is a success and today the Newtown is giving efficient service in every state of the Union and nine foreign countries. It is simple, safe, and durable-a real practical device.

Heat Properly Distributed.-The construction of the Newtown heater is such that the highest temperature is maintained near the outer edge of the deflector. There is no hot center, and consequently there is no crowding or piling up. The chicks hover in a circle arourd the outside edge of the deflector and each selects the temperature best suited for its individual need. This feature gives absolute comfort and fine growing conditions.

Air Always Fresh and Pure.-It is as impossible to keep foul air under the Newtown hover as it is to keep a rock from sirking in water.

The arrangement of the burner and heat radiator was designed especially to provide warm, fresh air under the hover.

The Glass Fount is easily filled, holds one gallon, and is located outside the hover This prevents any possibility of over-heating the oil and absolute safety is the result.

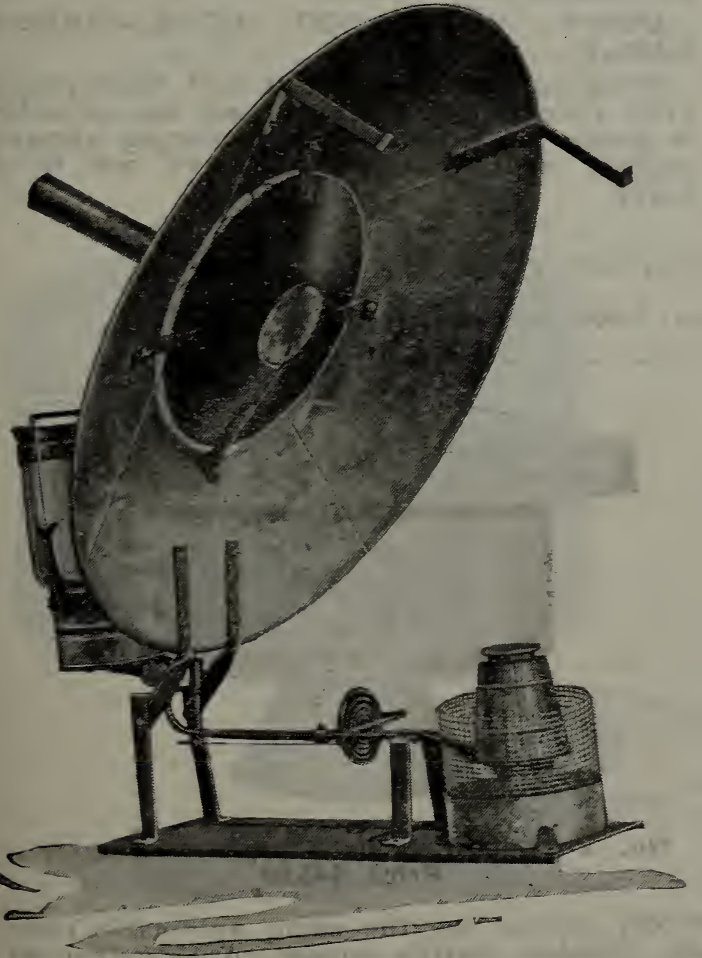

Hover russed permitting free access to the burner and for cleaning beneath the hover.

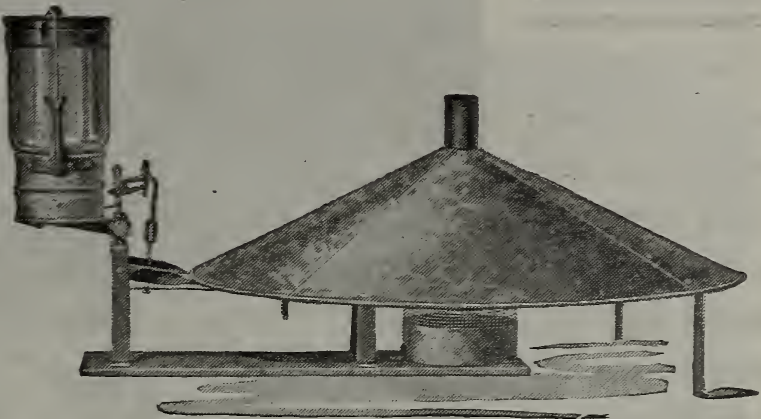

The Heat Radiator is bolted into the top of the deflector. The heat from the burner passes into this radiator which assists the deflector in distributing it evenly over a large floor space. It also provides a larger radiating surface, and consequently insures the maximum heat with the minimum amount of fuel.

The Blue Flame Wickless Burner.-No dangerous gasoline is required to start the Wickless Burner. It burns coal oil (kerosene) with a steady blue flame. Conibustion is so perfect that it gives off no smoke or odor and is perfectly noiseless in operation. The burner is surrounded by a safety jacket and when the deflector is in position the heat radiator-also surrounds the burner, thus entirely and safely enclosing it.

Automatic Regulator - The flow of oil through the sight feed dropper is automatically controlled by a powerful thermostat under the hover. This dropper is also provided with safety adjustments which make it impossible to feed too much or too little oil to the burner. This not only insures safety, but provides a constantly correct brooding temperature.

An Abundance of Heat.-In the matter of "spitting out heat." the Newtown is the most efficient brooder ever made. Every particle of heat produced by this powerful bnrner passes directly into the heat radiator. This radiator was designed especially to cause the heat to circulate so that practically every heat unit is utilized. Because of this exclusive Newtown feature these brooders can be operated in large buildings with larger flocks, with a minimum quantity of fuel.

There is no dirt from coal and no ashes to remove. You adjust the regulator at the start of the brooding season, light the burner, and all that is necessary is to fill the oil fount once every 24 to 36 hours.

\section{Right Sizes_Right Prices}

Each brooder is shipped with everything complete in one crate, all ready to operate. A thermometer and full instructions for cperating are furnished with each brooder.

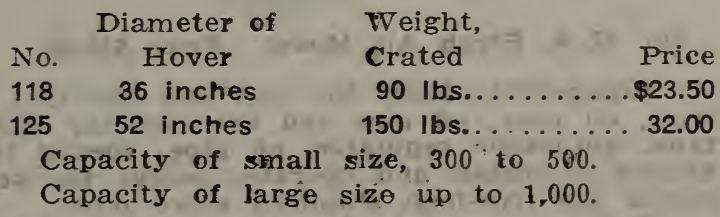

If in doubt as to the value of the "Newtown," write to Poultry. Dept. of the Oregen Agricultural College, Corvallis. They used one last seasion. 


\section{Kresky's "Pride of Petaluma" Brooder Stoves}

They bum oil, are self-regulating, work automatically, and give perfect satisfaction.

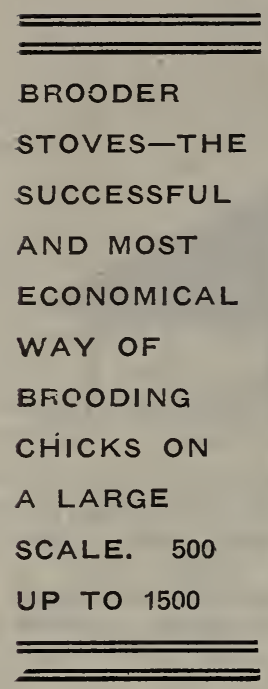

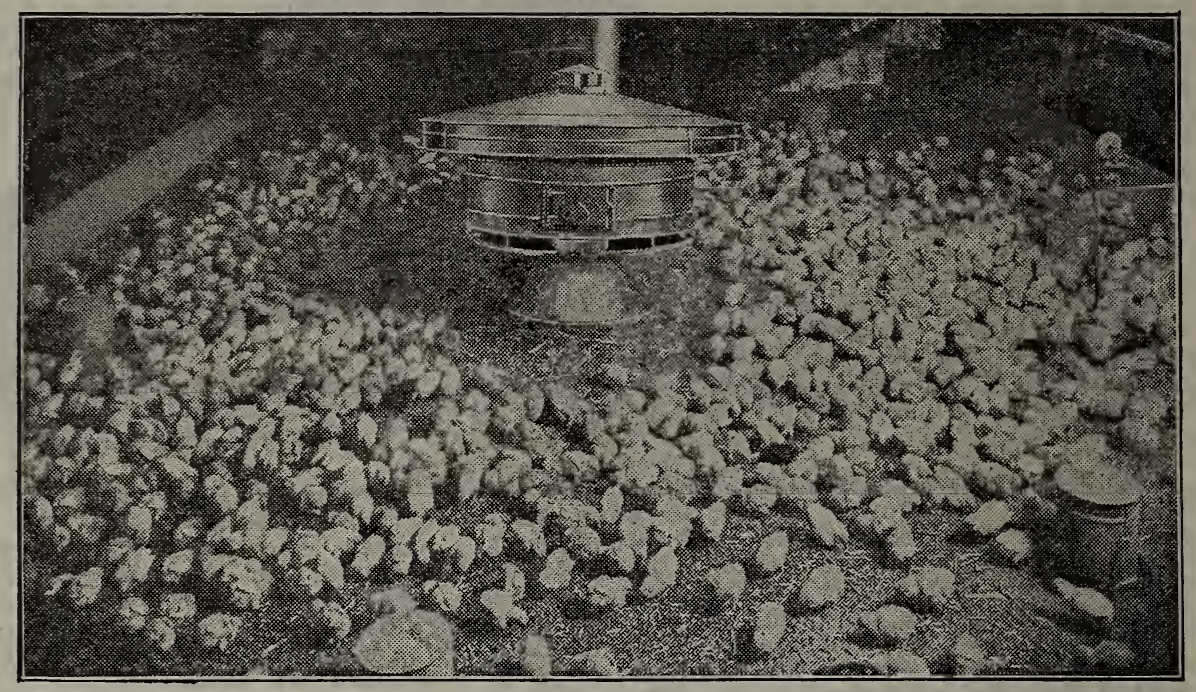

The Kresky's at Work. "Some" Family, eh?

\section{Kresky and His Brooder Stoves}

We have sold his Brooder Stoves to many of our customers, and so far have not had a complaint; on the contrary, we have only heard praises.

We cannot in the limited space on this page give you the details of construction of these wonderful brooders, but we do show you illustrations to give you an idea of what they are like.

NoW-if you are further interested anl would like to learn more about the "Pride of Petaluma's" and "Kresky's idea" of the proper method of brooding chicks, arop us a card request and we will mail Kresky's large illustrated and descriptive 24-page catalog.

If you want a large capacity, perfectly reliable, economical and satisfactory oilburning brooder, buy a Kresky. They have given excellent satisfaction. We can refer you to those who are operating them, if you wish.

All we ask is that, should you decide to buy one of these outfits, that you don't slip one' over on us by ordering direct from Kresky, as we make the same price and have the freight prepaid to your nearest station. You should allow us about 10 to 12 days' time to be sure of delivery.

We keep stock at our Portland warehouse and samples on display at our store, and will gladly show them.

DON'T WAIT TOO LONG-ORDER EARLY.

Freights are slow and it will take you a little time to get the outfit set up, so order in plenty of time. Freight charges allowed against express charges if you are in a hurry.

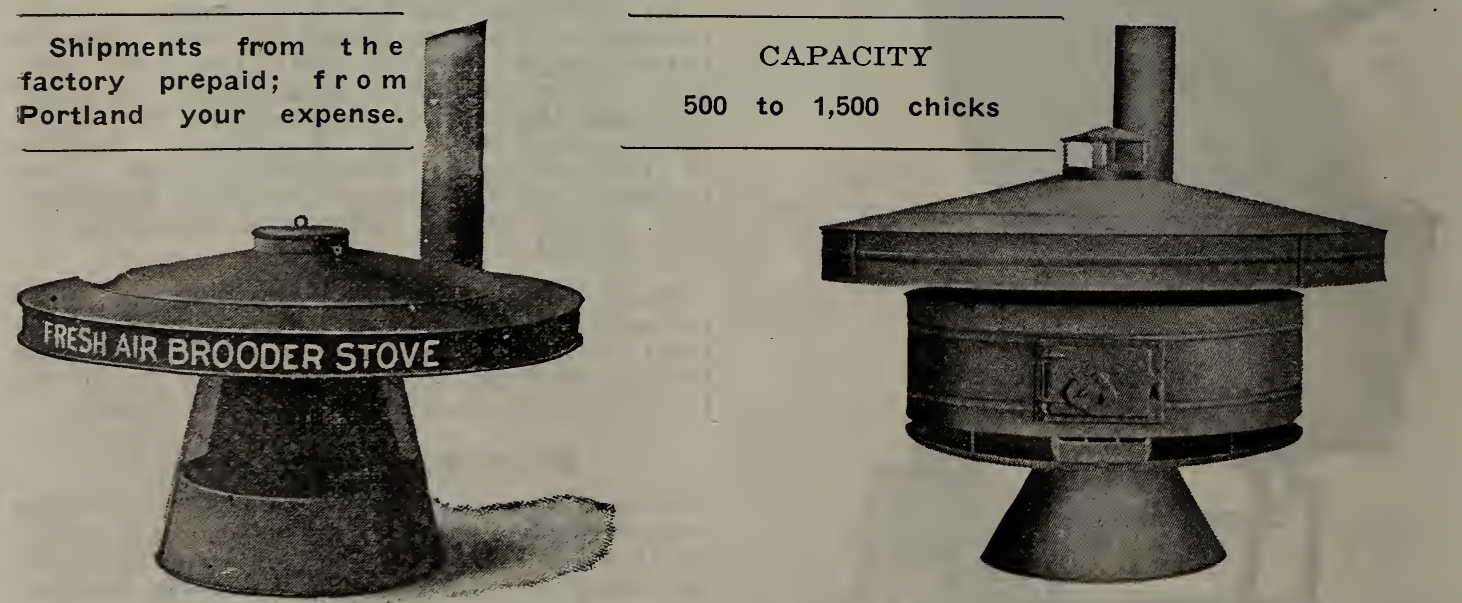

No. 12-A, Fresh Air Model. Price $\$ 36.50$

No. 2-B, 1920 Model Triple Ventilator.

Equlpment.-Both No. 2-B and the 12-A brooder stoves use the same automatic regulator, oil tank, oil pipe and thermometer and the complete outfits consist of 15 gallon oil tank, automatic regulator, oil pipe, special tested Kresky thermometer and all accessories needed to install and operate, except the stove pipe, which we do not furnish. All our stoves use five-inch standard stove pipe.

Fill and complete directions for installing and operating are furnished and found contained in the oil tank. 


\section{OAKES ECONOMY HOVER}

\section{ALL STEEL, LIGHT, STRONG AND DURABLE}

It furnishes plenty of heat with a small lamp flame and is guaranteed to give satisfaction in every respect. It is complete in itself and can be used anywhere, without any preparation, other than lighting the lamp.

It is made of steel throughout, and all parts are seamed or welded together, strong and durable. It is compact, light and all in one piece, so that it can be conveniently lifted by the two handles and moved from one place to another without even disturbing the lamp.

SAFE, CONVENIENT AND ECONOMICAL

The lamp, lamp slide and lamp box form a very convenient combination, the lamp has Safety Burner, and the lamp box is fireproof.

The Economy Hover can be used anywhere with perfect safety and ONLY A VERY SMALL FLAME is required to keep up the temperature as the lamp is inside, and no heat is lost.

PRICES ECONOMY HOVERS AND CAGES No. 2-100 chick size (22-in. hover). \$11.00 No. $1-50$ to 60 chicks (18-in. hover). 8.00 No. 2-Wire cage, large size....... 3.00 No. 1-Wire cage, small size....... 2.75

\section{Oakes Electric Hover}

The Oakes Electric Hover is made on the same general principles and of the same high grade material as the Oakes Economy but as it is lampless there is more room under it. It has a very sensitive and accurate regulator equipped with platinum contact points: heavy double curtain attached with large eyelets and hooks.

The Oakes Electric Hover will give you the best results with the least possible care and trouble. Has many valuable features for the city operator.

ELECTRIC NO. 2, 22-inch hover, \$15.50.

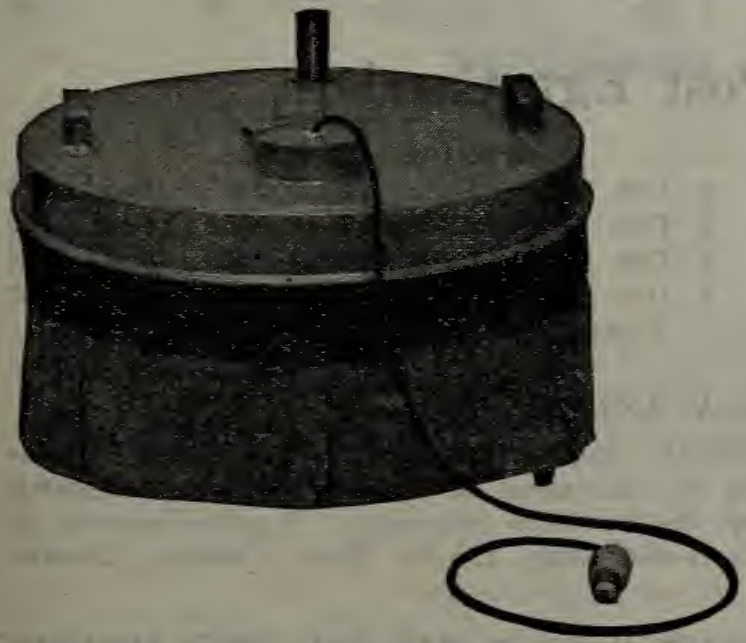

Oakes Electric Hover

NOTE.-Cages described above will fit this hover.

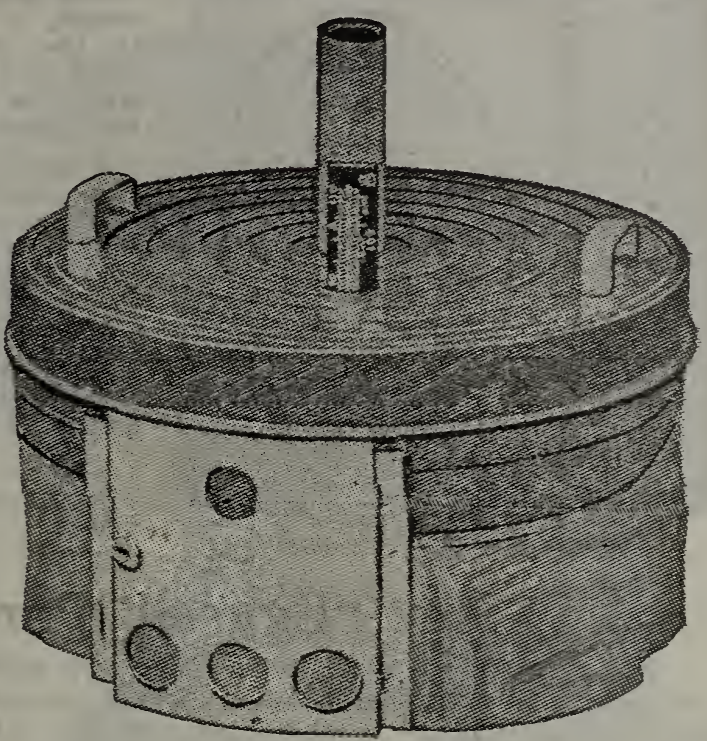

Economy Hover Without Wire Cage

Perfectly Satisfactory

For the past two seasons we have operated the Economy hovers and found them very satisfactory. We like them better than any hover of this style or type. We recommend them.

\section{Wire Rat-Proof Cage}

Thousands of chicks are killed every year by rats-probably half the failures are due to that cause. The wire cage for the Economy Hover, if closed at night, prevents the possibility of any such losses.

The cage is also a great convenience in preventing the chicks from going too far from the hover during the first two or three days. The two halves of the cage are hinged to the lamp box, and can be opened during the day to allow the chickens to run out and in.

With each cage we furnish an extra panel, which closes the opening between the two halves of the cage and makes quite a little yard that is convenient when you do not wish to let the chicks at large.

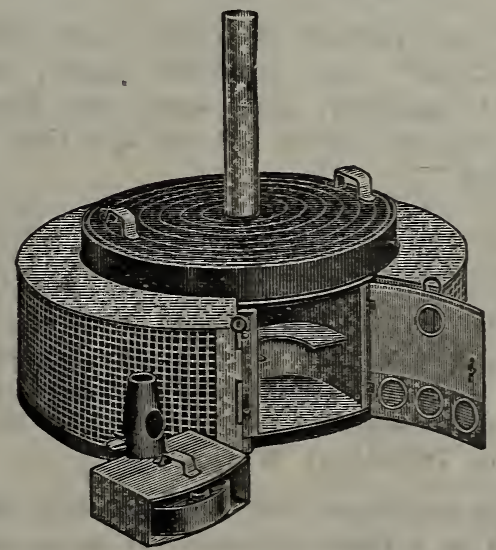

Economy Hover with rat-proof wire cage; showing construction of lamp and lamp box.

WE used Oakes Hovers in our store last season and can heartily recommend them as being 0 . K. IN EVERY WAY. 


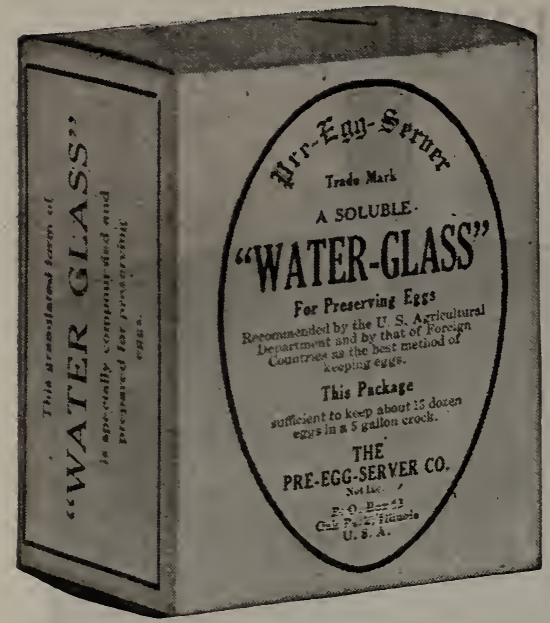

\section{Egg Preservers}

Pre-Egg-Server.-Soluble Water-Glass. This powder comes to us highly recommended, equal in every way to the old form liquid Water-glass. Will keep eggs fresh for a whole year. One package to 10 quarts water is enough for a 5-gal. crock, or 1 ; dozen eggs. Full directions on each package. Price postpaid 25c pkg.

Fleming's Egg Preserver.-Comes in flat tins and you simply rub it on the eggs, a child can do it. It will preserve the eggs for nine months or longer and they will cook and taste same as newly laid eggs. No cold storage or special care required.

Price: Per Tin (enough for $3 \mathrm{doz}$. eggs), $50 \mathrm{c}$ postpaid

Water-Glass (Liquid.)-This is the old, well-known egg preserver in liquid form. Use 1 part Water-Glass and 9 parts water to make the solution to cover the eggs. (Cannot be mailed.)

Prices: Qts. 55c; gal. $\$ 1.25 ; 5$ gal. $\$ 5.25$

NOTE.-If you want 5 or 10 gal. crocks write for prices.

\section{New "Eggsell" Parcel Post Egg Carrier}

A perfectly safe, inexpensive egg carrier for mailing eggs in for table use The unique construction of this box affords the maximum protection to the eggs. None of them ever come in contact with the side wall of the box and the diagonal crossing of the divisions prevents the weight of the eggs above from crushing those below. If your eggs are in perfect condition when you pack them, you can rest assured they will arrive at destination without breaking. Owing to the special construction of the box, the length and width is always the same, consequently the flaps form double thickness on top and bottom.

You can now ship eggs by express or parcel post with absolute safety. No more breakage Note the construction. Not one egg touches the outer wall. Protection on every side. Absolutely safe. Made of heavy, corrugated fiber board to stand rough handling and hard knocks. Comes to you knucked down to save space. - Nothing like it ever shown before.

If you are not satisfied that it is the best egg carrier that you have ever used, we will return your money. Be sure to send for a sample if you do not order a dozen.

The boxes come complete with instructions for properly packing and sealing.

Carrier
capacity
1 Doz.
2 Duz.
3 Doz.
4 Doz.
6 Doz.
8 Doz.

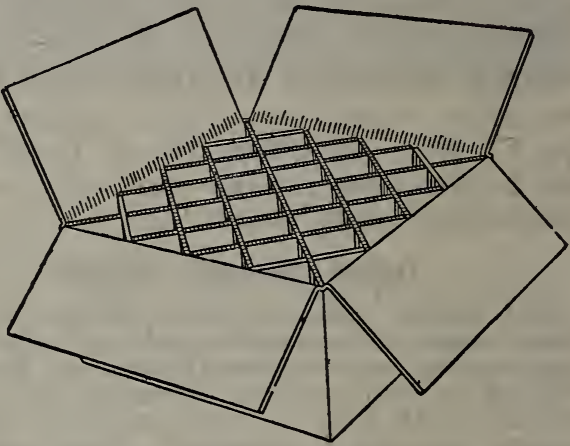

Weight empty

10 lbs. Doz.

15 lbs. Doz.

20 lbs. Doz.

25 lbs. Doz.

30 lbs. Doz.

35 lbs. Doz.

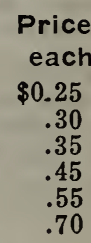

Price, Per doz. $\$ 2.25$ 3.00 3.75 4.50 5.50 7.00

\section{"Safety First" Parcel Post Egg Carriers}

This egg packer is made just like our "Up-to-Date" (see cpposite page), but of different capacity, and does not have the extra "slip-on" cover. Some say they prefer "Eggshell."
PRICES 4 SIZES

1 Doz. size.......... Each 25c

2 Doz. size......... Each $30 \mathrm{c}$

3 Doz. size......... Each 35c

4 Doz. size......... Each $45 c$

Add postage if ordering by mail.
Doz. $\$ 2.25$

Doz. $\quad 3.00$

Doz. $\quad 3.75$

Doz. 4.50

\section{$\longrightarrow$ MILLIONS WASTFD}

HOW TO SAVE IT.-Plagues annually cost the poultry men of America many millions of dollars. Are you, dear poultry raiser, saving to the extent of your ability? CHOLERINE is the tonic that will put you right and keep the business humming. A great portion of the crop is destroyed each year by White Diarrhoea, Roup, Limber Neck, Cholera, Chicken Pox and Intestinal Worms.

This enormous loss is absolutely waste, because it can be easily and cheaply prevented. Cholera is a Germ disease. It is second to White Diarrhoea in destructiveness. The germs of the two diseases are very similar. White Diarrhoea attacks little chicks. Cholera strikes the grown fowls. Frequently both diseases are epidemic at the same time.

CHOLERINE prevents these diseases just as surely as vaccination prevents Smallpox. And if your chickens, ducks, geese, turkeys or pigeons are already sick, CHOLERINE Will make them well. WE GUARANTEE THIS. Read pages 1 and 161 . 


\section{Up-to-Date Egg Carriers}

Order early so you will not be disappointed in your delivery. Prices below subject to changes.

\section{UP-TO-DATE EGG CARRIERS}

Do not class these "Up-to-Date" boxes with the cheaply constructed egg boxes that are made along similar lines. These are double strength and cushion frame on all sides. Note the illustrations carefully. Safe and reliable for the mailing or expressing of table or hatching eggs.

Note.-Center box open, to the left "slip on" cover, to the right box closed, ready to ship.

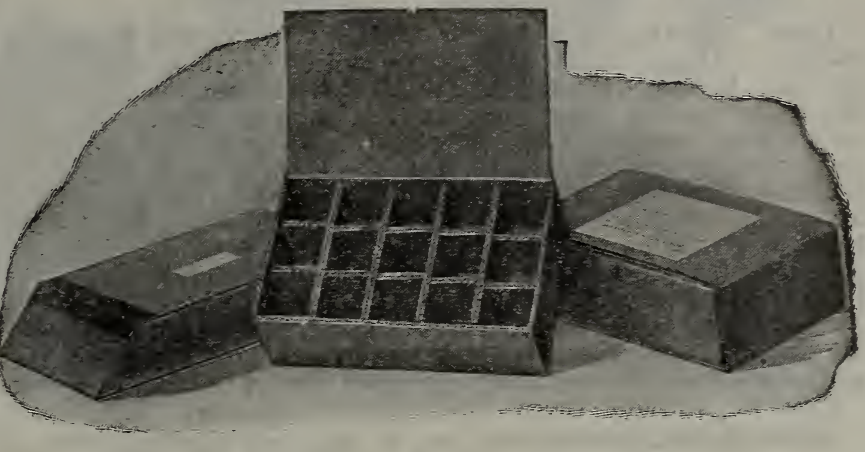

15-Egg Size. Open Corner Showing Egg Cells

This has been a popular egg box for several years. Note the extra outside "slip-on" cover. A safe box for the expressing of fancy eggs, for hatching. Each egg can be wrapped in paper before dropping into its place.

\begin{tabular}{|c|c|c|c|}
\hline Size & Weight, Empty & Each & Doz. \\
\hline $15 \mathrm{egg}$ & 1 lb. each & $30 c$ & $\$ 3.00$ \\
\hline egg & $11 / 2$ lbs. each & $40 c$ & 4.40 \\
\hline egg & $21 / 4 \mathrm{lbs}$. each & $50 c$ & 5.50 \\
\hline
\end{tabular}

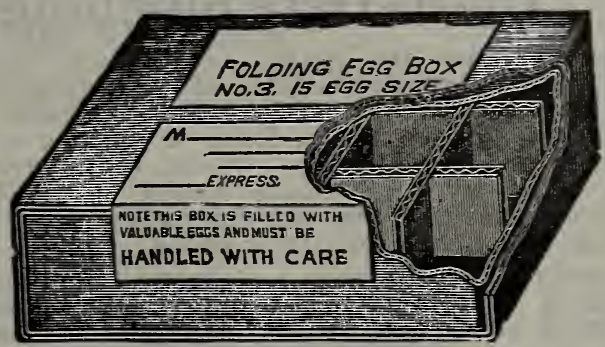

POSTAGE.-In ordering above egg or chick boxes by parcel-post be sure you add extra money for postage. Otherwise we will send by express or freight.

\section{Up-to-Date Baby Chick Boxes}

Well made, properly ventilated

These insure the safe arrival of your chicks

Made from the best grade of corrugated card board. Shipped in the flat, but quickly set un by anyone. The use of this box has made long distance express shipments of live baby chicks possible and safe.

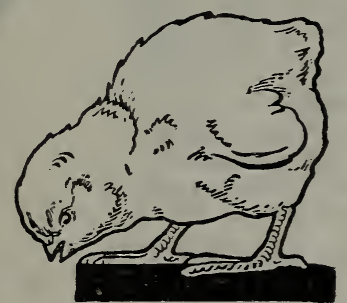

Doz.

Size Weight, Emopty Each

25 chick P. P. $11 / 4 \mathrm{lbs}$.

$30 \mathrm{c}$

$35 \mathrm{c}$

P. P. $21 / 4 \mathrm{lbs}$.

$45 c$

5.00

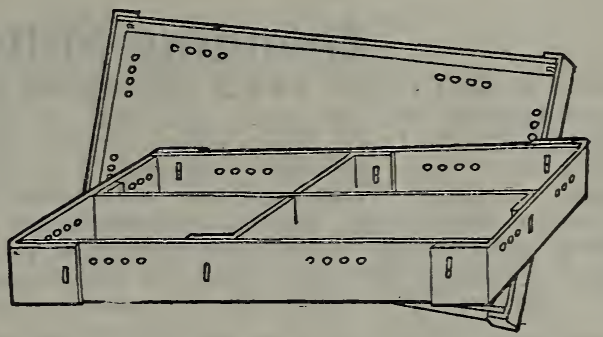

100-chick capacity, showing partitions

Don't wait until your chicks hatch to order $\$ 3.00$ your boxes. Order early and be sure of 4.00 stock when you want it.

Write for special prices per 1000 .

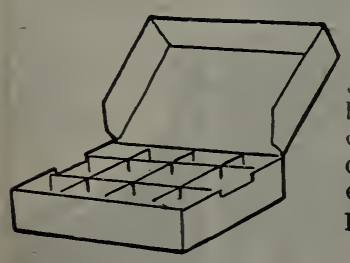

The Ideal

12 Egg Packer

\section{Ideal Egg Box}

Every poultry keeper who sells eggs should ...e these folding cardboard egg boxes to del.ver eggs in. They are folded flat, but the corners are locked, all ready to open up and drop the eggs in. No errors in counting, as each holds pust one dozen. Note our low prices for this year.

Price-Per doz. 20c (P. P. 13/4 lbs.); 100 for $\$ 1.10$ (P. P. 11 lbs.); 1000, $\$ 9.00$.

Extra fillers only, 10c doz.; 75c per 100.

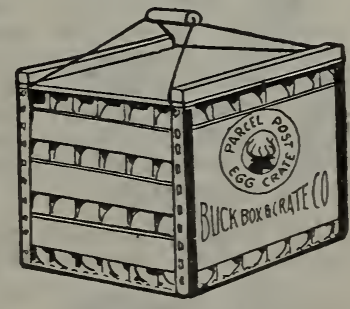

Buck 12 Doz.

Parcel Post

Egg Crate

\section{Buck 12-Dozen Egg Crate}

Made of wood, cardboard fillers. Very light, but strong; metal corners; holds 12 dozen eggs; lock wire bale, wooden handle. (P. P. weight 51/2 lbs., set up.)

HAVE YOU READ ABOUT OCULUM, PAGE 148? IT'S EASY TO FEED AND WONDERFUL IN RESULTS. MAKES HENS LAY. 


\section{Automatic Chick Greaser}

(See illustration)-Every chick its own doctor. It is the large lice which collect on the heads of young chicks which cause them to droop and die; and formerly the only way was to catch each chick and rub grease on its head; but this slow and tedious process is not necessary since the invention of the Automatic Chick Greaser. The wick around the upper part of the greaser is saturated with Conkey's Head Lice Ointment or with a mixture of twothirds lard and one-third kerosene (or black oil) and every chick which eats out of the pan will get its head thoroughly greased in a very few minutes. Can be moved from one pen to another.

NEW STYLE.-Mailing wt. 2 lbs., add postage. Price $\$ 1.25$

\section{Up-to-Date Shipping Coops}

These coops are really "up-to-date" and will give your customers that impression of you if you use them when shipping. Buyers who pay fancy prices for thoroughbred birds like to see them come in a nice coop-not some old cracker box or oil case. These coops are light but strong. The ends have the cleats nailed on. We ship in the flat to save charges, but it's an easy matter to nail them together, for each part is marked.

$\begin{array}{cccccc}\text { Number } & \text { Width } & \text { Length } & \text { Height } & \text { Wach } & \text { Doz. } \\ \text { NO. } 2 & 101 / 2 \mathrm{in} . & 18 \mathrm{ir} . & 24 \mathrm{in} . & 60 \mathrm{c} & \$ 6.60 \\ \text { NO. } 4 & 101 / 2 \mathrm{in} . & 24 \mathrm{in.} & 24 \mathrm{in} . & 70 \mathrm{c} & 7.75 \\ \text { NO. } 6 & 191 / 2 \mathrm{in} . & 24 \mathrm{in} . & 24 \mathrm{in.} & 85 \mathrm{c} & 9.25\end{array}$

For Parcel Post-No. 2 weight 10 lbs.; No. 4, 11 lbs.; No. 6, 17 Ibs.

Capacity.-No. 2 suitable for single birds or pair Mediterraneans. No. 4 suitable for Asiatic male, American or Mediterranean pair or small trio. No. 6 for a pen of five birds, any variety.

\section{Grinding Mills}

NO. 32 POULTRY FEED GRINDING MILL.-In this mill are embodied all the good features of other hand grinding mills to which have been added universal burrs or grinding plates that are quickly adjusted and locked for grinding coarse or fine. This machine will grind any kind of grain or seeds, dry bone, shells, crockery, etc.. for poultry feed. Has a 16-inch fly wheel and is light running; the capacity is not equalled by any other of the same size. Weight 40 lbs. Illustrated booklet on request. Price $\$ 7.50$

We have larger sizes in this mill both for hand and power. If interested, write for booklet and prices.

No. 32 Mill-You Need One

\section{Whitewashing and Whitewash}

The illustration here shows our No. 28 Whirlwind Sprayer in operation. No. 28 is made especially for whitewashing. See page 127 for price, etc.

NOW FOR THE WHITEWASH.-This year we are offering to our good customers a cold water combined whitewash paint and disinfectant, called Phenola. It comes in powder form and is mixed with either cold or hot water (full directions on each can). It is so convenient, and so good, that we are sure you will like it. You can either spray it or paint it on.

For use in poultry houses, cellars, stables, fences, walls, tree trunks, etc. See page 125 for prices.

DON'T OVERLOOK the valuable yet inexpensive books on Birds, Parrots, Dogs, Cats and Poultry, page 130.

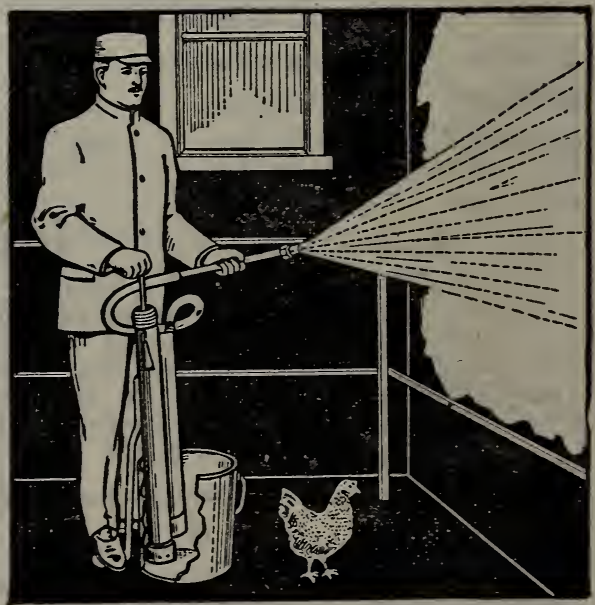

HAVE YOU TRIED "OCULUM" ON YOUR POULTRY? It surely is a wonderful preparation from what poultrymen say who have used it. Just think of DOUBLING THE EGG YIELD, and only 3 to 5 drops, in feed or water, per bird. See page 144. Pamphlet on request. 


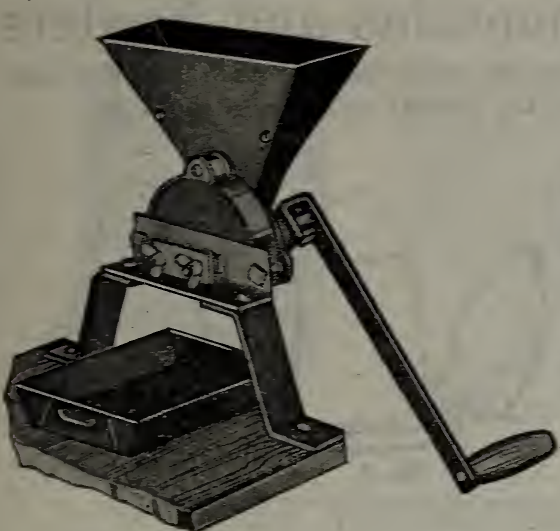

No. 9 Ohio

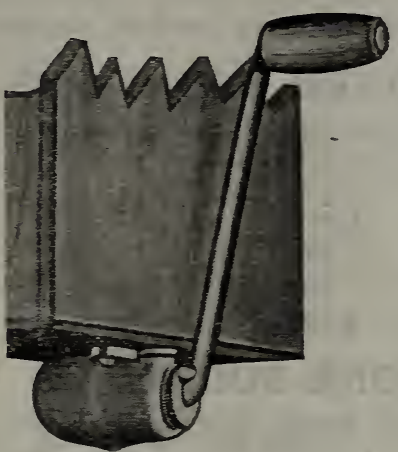

No. 24 Ohio

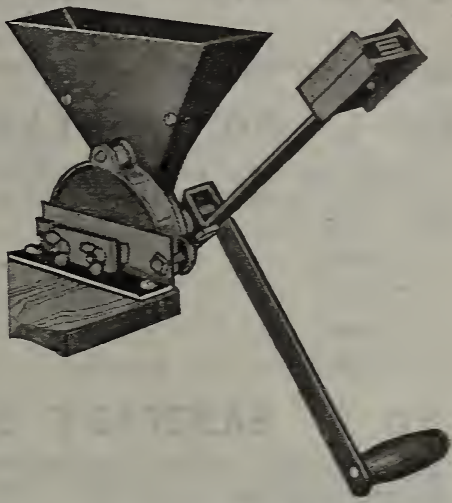

No. 2 Oh.o

\section{Ohio General Purpose Mills}

THE OHIO mills illustrated above are not very large in size, but the capacity is good and you will find them very useful, handy and convenient. They are made of steel plate, strong and durable and much lighter than cast.

NO. 9 OHIO. - Especially adapted for grinding grain, spices, coffee, herbs, etc. Can be set to grind fine or coarse. A handy mill for household use and also for the poultry raiser to grind or crack grain for baby chicks. Price as illustrated (weight 11 lbs.), \$4.75; with balancer weight, \$5.25.

NO. 1 OHIO.-Same as No. 2, without balance weight. Price $\$ 3.75$ (wgt 9 lbs.).
NO. 2 OHIO.-Same capacity as No. 9. No legs, bolts to table or bench. (Wgt. 12 lbs.) Price $\$ 4.25$.

OHIO NO. 24.-Fastens to under side of table-make a box hopper as large as you like. Excellent for cutting or cracking corn or wheat. Turns easy, works rapid. A child can do it. (Wgt. 2 ibs.) Only $\$ 1.50$.

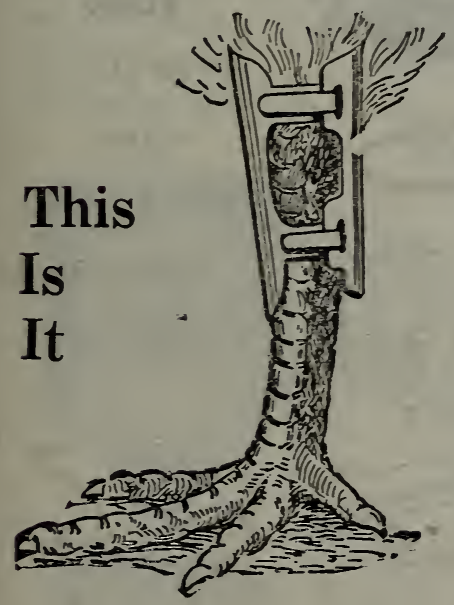

\section{Humane Anti-Hen-Setting Device}

(Patented March 13, 1917)

The only device ever invented that will stop a hen setting and cure her of broodiness in twenty-four hours, and do it without the slightest pain or suffering for the hen, and no wasted time or trouble for you.

Clasp on leg and let the hen run free for 24 hours, then remove.

\section{READ WHAT USERS SAY OF IT}

"I have investigated and examined your Anti-Setting Device for breaking up setting hens and can see nothing about your method that can be called cruel or that will cause physical pain. I think it the most humane way of treating a setting hen, and you have my consent to use it."-Fred J. Bartles, Humane Agent, Hornell, N. Y.

"I believe it to be the most practical and humane method of preventing hens from setting in use today. It does the trick so quickly and efficiently."

PRICE, $15 \mathrm{c}$ each; $\$ 1.25$ dozen, postpaid

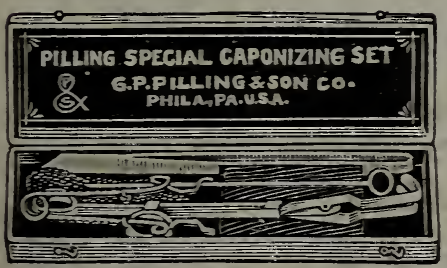

Caponizing Set

\section{Caponizing Tools}

Poultrymen can double their profits by Caponizing the young cockerels. The operattion is easily learned. The instructions are so full and explicit that any one, after a careful reading and a little practice, will be able to caponize. It is highly successful from every point of view. The demand for Capons far exceeds the supply, the price per pound being twice as much as for ordinary chicks.

The object of caponizing is to largely increase the weight of fowl, causing them, in many cases, to grow as large as turkeys and weighing from 10 to 15 pounds, and to make the meat a fine flavor, very juicy and tender. Caponize the males when they weigh about $1 \frac{112}{2}$ lbs. and sell them at 8 to 10 lbs. at a "fancy price." We offer good, practical outfits.

NEW PHILADELPHIA SET is $O$. $K$. and has many admirers. Price: cardboard box, $\$ 3.00$; wooden box, $\$ 3.25$.

THE CORNELL SET.-One of the new sets. Highly recommended. Price $\$ 5.00$. Fuls directions with each set.

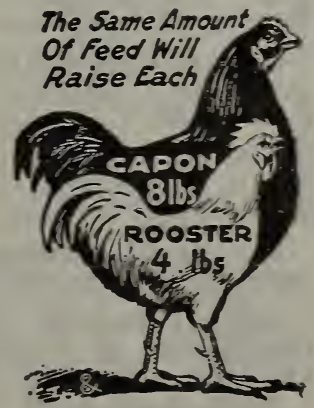




\section{Up-to-Date Sanitary Drinking Fountains and Feeders}

Increase your profits by saving the chicks. Start now by ordering sanitary, economical, up-to-date Fountains and Feeders. Note.-When wanted by parcel post, add postage.

NO. 1. NO. 2. STANDARD FOUNTAINS

Made in two parts, pressed out of heavy galvanized iron: will last for years. Easy to clean inside and out. (See cut.)

$\begin{array}{ccrr}\text { Capacity } & \text { P. P. Wgt. } & \text { Each } & \text { Doz. } \\ 1 \text { qt. } & 1 \text { lb. } & 40 \mathrm{c} & \$ 4.50 \\ 2 \text { qt. } & 11 / 2 \text { lb. } & 60 \mathrm{c} & 6.00 \\ 4 \text { qt. } & 2 \text { Ib. } & \$ 1.00 & 10.00\end{array}$

NO. 3. SANITARY STONE FOUNTAINS

An old and popular style that keeps the water cool; ses cut. (Not mailable.) Price, 1 qt. $30 \mathrm{c} ; 2$ qt. $40 \mathrm{c}$; 4 qt. $60 \mathrm{c} ; 8$ qt. $\$ 1.00$.

\section{NO. 4. STAR CHICK SERVER}

Very desirable style; made from 1 piece of non-rusting: metal; for chick feed or water. Any size. Mason jar fits it. Price (without jars), each 25c; doz. \$2.50, prepaid.

\section{NO. 5. OAKES CHICK SERVER}

This consists of a 6-inch scalloped pan and a collar to fit any size Mason jar. You fill the jar, screw on the collar, slip the pan in and turn it over. Simple, sanitary and perfect for small chicks. They can't get wet. Price (without jar), 25c each, $\$ 2.50$ per doz., prepaid.

\section{WALL FOUNTAINS}

Very desirable for adult fowls; hang up on the wall out of litter and dirt; made of heavy galvanized iron.

\section{NO. 7. CYPHER'S}

Very popular and satisfactory. Price, each, $1 / 2$ gal. (P. P. 2 lbs.) 70c; 1 gal. (P. P. 3 lbs.) 90c; 2 gal. (P. P. $31 / 2$ lbs.) $\$ 1.25$.

\section{NO. $7 \frac{1}{2}$. CHAMPION TELESCOPE}

Same general style as No. 7 , but the top pulls out. Easy to clean, best wall fountain made. Prices, $1 / 2 \mathrm{gal}$. $85 \mathrm{c} ; 1$ gal. $\$ 1.15 ; 2$ gal. $\$ 1.50$. (Mailing weights, $2 \frac{1}{4} \mathrm{lbs}$.. $31 / 2$ lbs. and 4 lbs. each.)

\section{GALVANIZED FEEDERS}

preventing waste. Sanitary, closed top self-feeders for

Made of galvanized iron; soon pay for themselves in granulated bone, beef scraps, grit, shells, charcoal, dry mash, etc. If these necessary foods are kept before your fowls they will eat just what their systems require for profitable results; in other words, properly balance their rations. Hang up out of the litter.

NO. 9 CHAMPION FEEDER. Two compartments, one holds 2 qts., the other 4 qts. (P. P. wgt. $3 \frac{1 / 2}{l b s}$.) Each $\$ 1.50$.

NO. $91 / 2$ CHAMPION FEEDER. The same shape as No. 9, with one large 9 qt. compartment, good for dry mash. (P. P. wgt. $3 \frac{1 / 4}{4}$ lbs.) Each \$1.75.

NO. 10 CHAMPION FEEDER. Has 3 compartments, each holding about 1 qt. (P. P. wgt. $2 \frac{1}{2}$ lbs.) Each \$1.25.

NO. 11 MOE'S, Extra strong and well made; the feed trough at bottom is round. 3 Section, 2 qts. each.
(P. P. wgt. 4 lbs.) Each $\$ 1.35$. 4 Sections (P. P. wgt. 5 ibs.), Each $\$ 1.75$.

\section{IMOE'S CHICK SERVER}

NO. 12. Practical and a great saver of feed. Chicks cannot get into it. For water or feed. Small (P. P. wgt. 2 lbs.), Each 25c; Doz. \$2.85; Large (P. P. wgt. 3 lbs.), Each 40c; Doz. $\$ 4.50$.
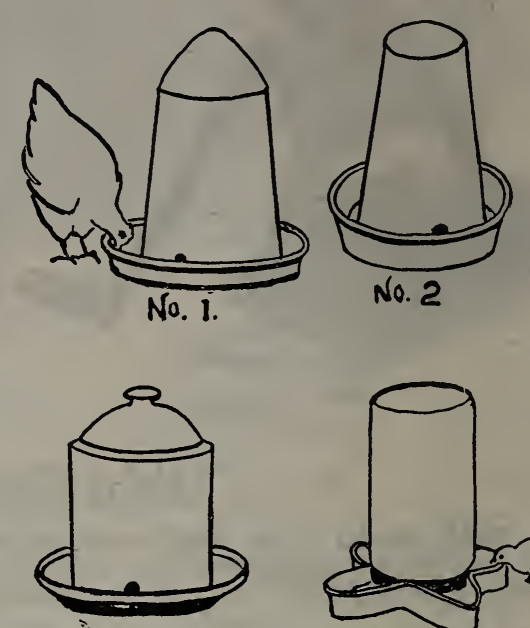

No. 3

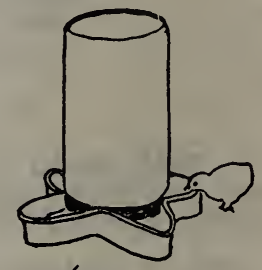

กิo. 4

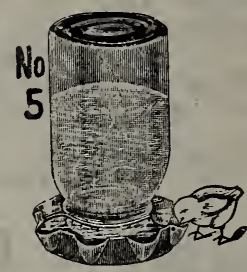

Use

Germo-

Tonic

in the

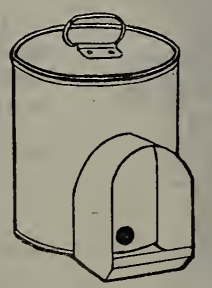

water.

See Insert,

Pages 1

and 161

№. 7

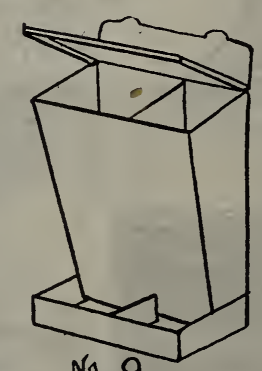

No. 9
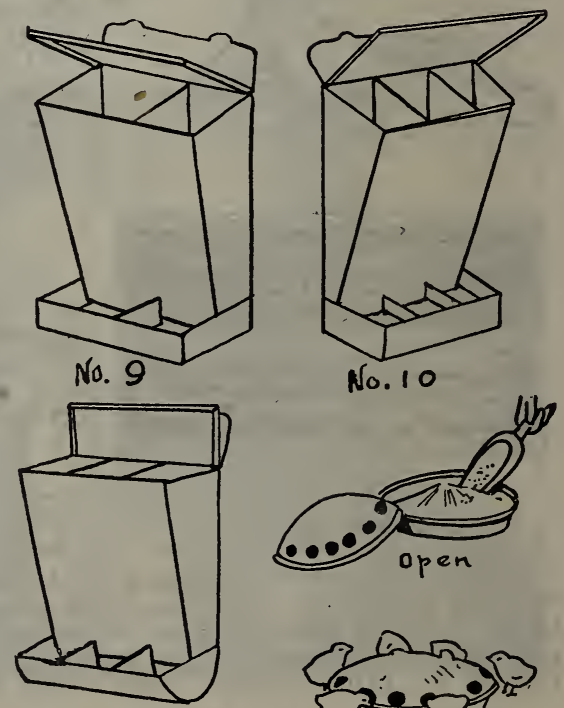

No. 11

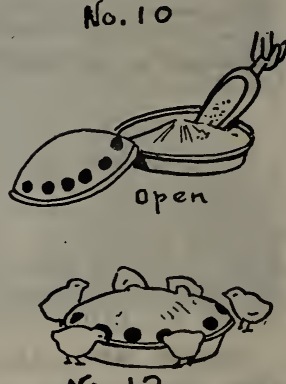

Don't forget to add postage if wanted by parcel post. 


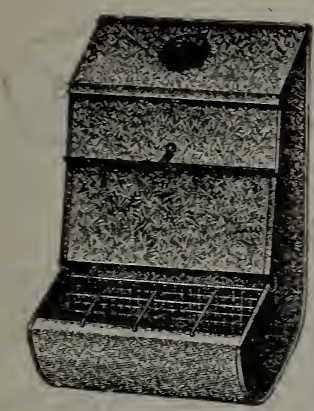

\section{DRY MASH HOPPER}

The curved bottom of the Hopper keeps the feed within easy reach of the birds The gradual enlaigement from the top to base prevents clogging. The wire grid and the wires running from the flange through the wire gird prevent any chance of the fowls throwing out or wasting the feed. The sloping cover prevents the bi ds from roosting on the Hopper, and when both covers are closed, it is rat and mouse proof. A trial will convince you that it is a Hopper of the greatest merit. Manufactured of heavy galvanized iron.

NO. 35. $8 \frac{1}{2}$ inches wide, capacity 12 qts. (Wgt. $4 \frac{11}{2}$ lbs.) Each $\$ 1.75$. NO. 36. 12 inches wide, (Wgi. $7 \frac{1}{2}$ lbs.) Capacity 18 qts. Each $\$ 2.35$. No. 37. 24 inches wide. (Wgt. 12 lbs.) Capacity 36 qts. Each $\$ 3.00$.

\section{POULTRY VEGETABLE RACK-RABBIT FEEDER}

Made from galvanized iron and wire. For feed, vegetable roots, beets, cabbage, kale, sprouted oats, etc. Use it in rabbit hutches to feed hay or grass. Big time and feed saver. Keeps the feed up out of the dirt and litter. NO. 44. (Wgt. 3 lbs.) Price, 85c each, 2 for $\$ 1.50$.

\section{SANITARY FOOD HOLDERS}

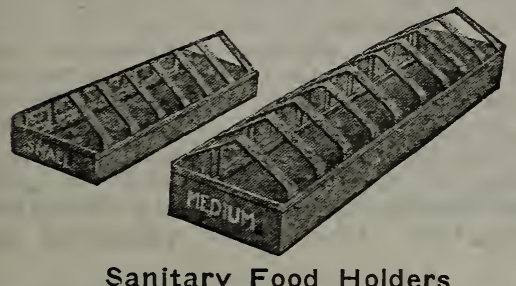

Sanitary Food Holders

For Poultry and Ducks of All Ages.-They are especially recommended for use in feeding mashes of any kind; steamed or dry alfalfa or spıouted grain. This protected receptacle saves 15 to 2. per cent in foodstuff. The top-guard that keeps the fowls out of the feed is removable from the pan, making them very easy to clean. There is nothing to get out of order. Made of heavy galvanized iron; safe, sani. tary, saving and serviceable.

No. 12 Chick, No. 18 Medium, No. 30 Extra Large, size $1 \times 31 / 4 \times 12$ inches (P. P. Weight $1 \frac{1}{4}$ Ibs.); Price, each....... $\$ 0.60$ size $13 / 4 \times 4 \times 18$ inches (P. P. Weight 2 lbs.); Price, each...... .85 size $3 \times 6 \times 30$ inches (P. P. Weight $4 \quad$ lbs.); Price, each....... 1.50

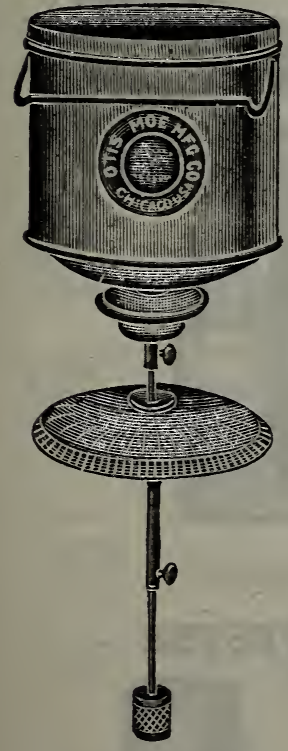

Kan't Klog Feeder

\section{"KAN'T KLOG" FEEDER AND EXERCISER}

One of the best combined feeders and exercisers. Cannot clog. No spring to get out of order. Swinging deflector scatters the grain all around, a little at a time, whenever the birds pick at the grain bait cup. Holds enough to be of real service. Can be set to feed little or much. Hang in the scratching pen with straw on the floor. With this feeder and a good water fountain you can leave your chickens for a day's outing and know that they are provided for.

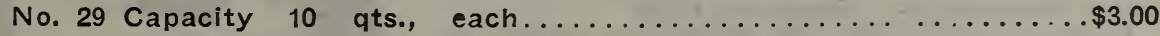

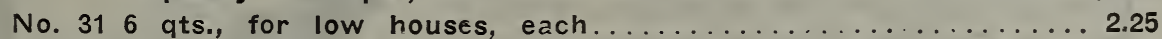

\section{OAKES HYDRO SAFETY LAMPS}

Made especially for incubators and brooders. Fill the water jacket full of cold water to keep the oil and burner cool and perfectly safe. Economical and satisfactory in every way. The best incubator and brooder lamp made.

No. $1-71 / 2$ in. high; $5 / 8$ in. wick (P. P. $\{1 / 2$

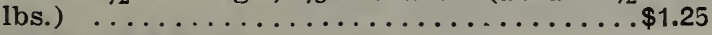

No. $2-\delta$ in. high; 1 in. wick (P. P. 2 lbs.) 1.75

No. 3-9 in. high; $1 \frac{1}{2}$ in. wick (P. P. 3

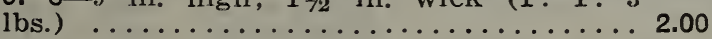

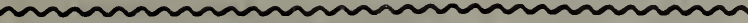

Millions of Baby Chicks Die Annually. White Diarrhoea kills them.

White Diarrhoea is a Germ disease. Science has proven this, and has located the microbe. This disease is not only prevented but eradicated by CHOLERINE. Read page 1.

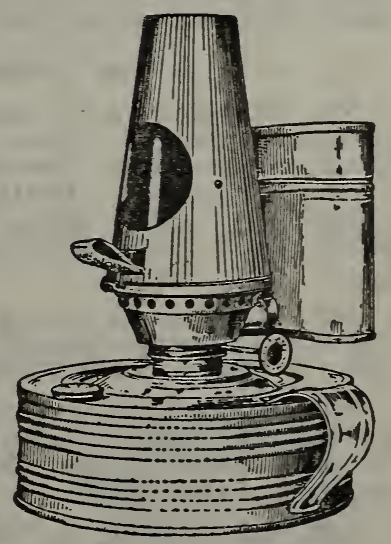

Oake's Safety Lamps

DAD'S ELECTRIC LANTERNS-Every poultry keeper needs one. It's always readyno danger of fire, makes a REAL LIGHT. See page 122. 


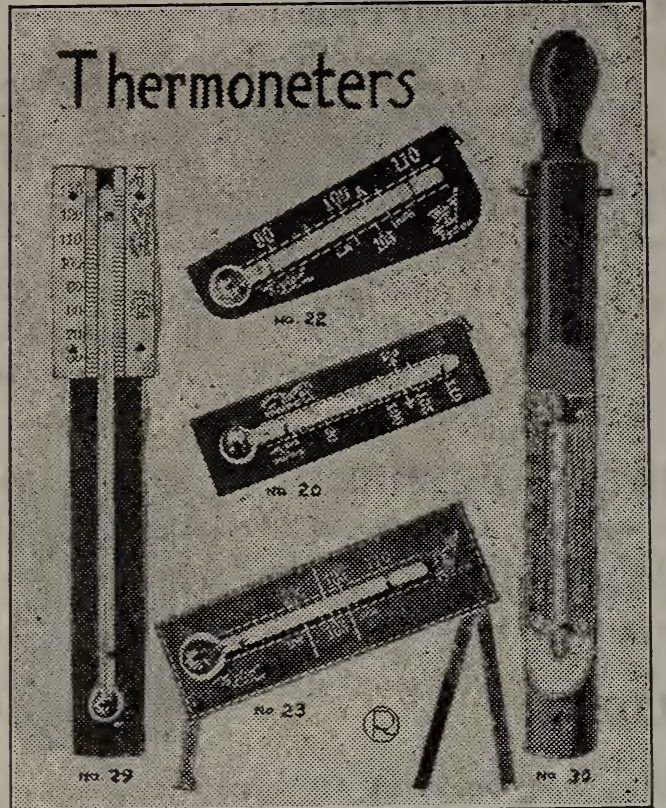

Without a reliable, accurate thermometer an incubator is practically worthless. Hundreds of hatches fail every year beciuse of inferior thermometers and large numbers of brooder chicks are destroyed for the same reason.

We sell the "Tyco's" tested, recognized as the most dependable.

\section{For Incubators}

TYCO'S CERTIFIED.-Same style as No. 22. Scale is etched on glass tube as well as metal back. "Certified correct," worth the price. Postpaid $\$ 1.50$.

NO. 22 "TYCO'S."-Very popular. Generally suspended on string or wire on level with eggs. Postpaid. $\$ 1.00$; wire hanger $10 \mathrm{c}$ extra.

NO. $221 / 2$ MODEL.-Same shape as No. 22 but not as high grade finish. Postpaid $75 \mathrm{c}$.

NO. 20.-'Tested, for incubators, used in Queen incubators. Postpaid \$1.25.

Buckeye Incubator Thermometer, \$1.25.

NO. 23 TYCO'S.-Similar to No. 20 , with folding legs, adjustable; to be set up in egg tray. Postpaid \$1.00; Model, same style, $75 \mathrm{c}$.

\section{For Brooders}

No. 29.-New style and convenient; temperature readable from above the hover. Used in Economy, Buckeye, and most all "hover" brooders. Postpaid, each \$1.25.

NO. 291/2.-Same style, Tyco's high grade. Black face, white figures, magnifying mercury. 8-in., $\$ 1.50$.

NO. 30.-See cut. Long round wood holder. Used in Cypher's Adaptable or Portable hovers. Postpaid, each $\$ 1.00$.

No. 5120.-For general use or brooder houses. Mercury. Scaled from 10 below zero to 120 above. Metal face, wood back. 8 inches. Price $\$ 1.50$.

NO. 2121.- Same as above. Scaled from 10 to 100 above. Spirit. Price \$1.25.

NO. 5410.-Black Japanned, 8-inch case. Scale range from 30 below to 120 above. For general use or brooder house. Price $\$ 1.25$,

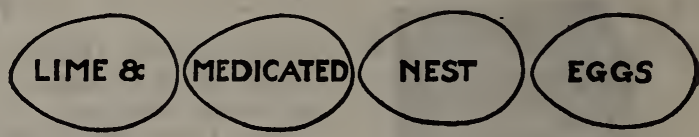

\section{NEST EGGS}

NEW MEDICATED.-Answers as a nest egg, also an insecticide. Helps to keep lice out of the nests and off the laying or setting hen. - Non-breakable.

Each 10c; 3 for 25c; 12 for 85c; (Wgt. 21/2 lbs. per doz.) Add postage.

LIME NEST EGG.-Better than China eggs; non-breakable. More natural.

Each 5c; 3 for 10c; 12 for 40c. (Wgt. 2 lbs. per doz.) Add postage.

\section{INCUBATOR HYGROIMETERS}

\author{
"Moisture Indicator"
}

Millions of chicks die in the shell every year, for the want of proper moisture conditions. The importance of a correct percentage of moisture during incubation has made the "Tyco's" Incubator Hygrometer as necessary as the "Tyco's" Incubator Thermometer. Neither takes the place of the other, but together they give the practical poultry raiser all the facts required for successfully regulating the heat and moisture of the incubator. Descriptive pamphlet on request.

Hygrometer, with full instructions, postpaid, \$2.00; with Tyco's "Certified" $\$ 1.25$ Incubator Thermometer; both postpaid $\$ 3.25$. Extra wicks, 15c each.

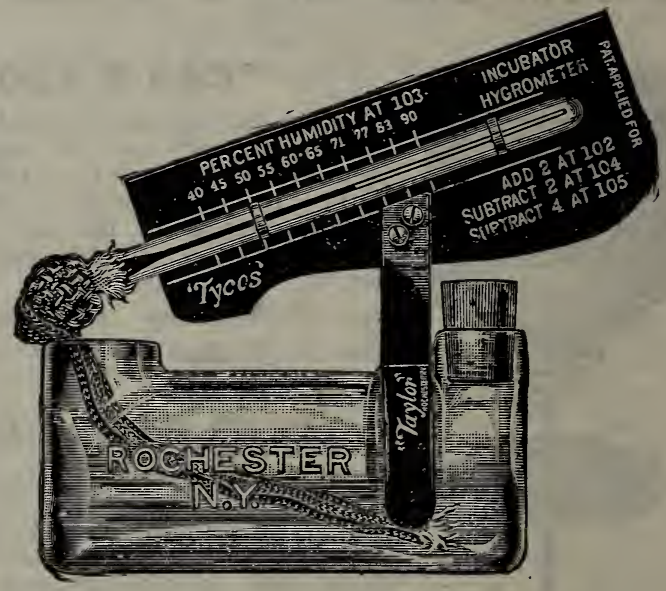

Tyco's Hygrometer

\section{X-RAY EGG TESTER}

Used to test fertility of eggs during first week of incubation. Use on an ordinary lamp (No. 2 burner), in a dark room. It will illuminate interior of egg so that you will know if the chick is alive. Also shows size of air-cell.

Price, postpaid, $60 \mathrm{c}$

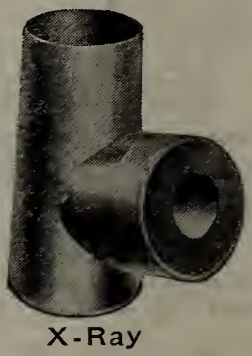

NOTE-W' -Weep in stock miscellaneous extra parts for Cypher's and Queen Incubators and Brooders. Ask for price of parts wanted. 


\section{Leg Bands for Poultry and Pigeons}

Keep a supply of Leg Bands on hand at all times; this is the only safe way to mark your different birds so you can tell certain stock or strains. Of course every bird must be marked with a band before it can be entered in a show.

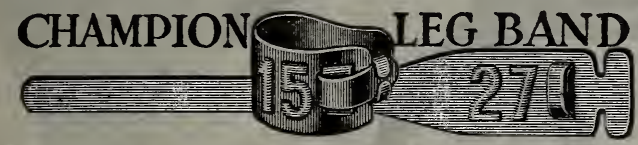

The most popular numbered band on the market. This band (see illustration above), is made in one piece and adjustable to fit any fowl. They will stay where you put them. Held by double lock. it is impossible for them to lose off. Made of aluminum with raised figures. Not made for baby chicks or pigeons.

DIRECTIONS. - Put small end through loop, draw through until it fits loosely on the leg, turn the end back, then bend the two lugs over the loose end as shown in cut. Cut off surplus with shears.
WHAT SIZE?-When you order, tell us size or what kind of birds you want them for and whether male or female. DON'T FORGET.

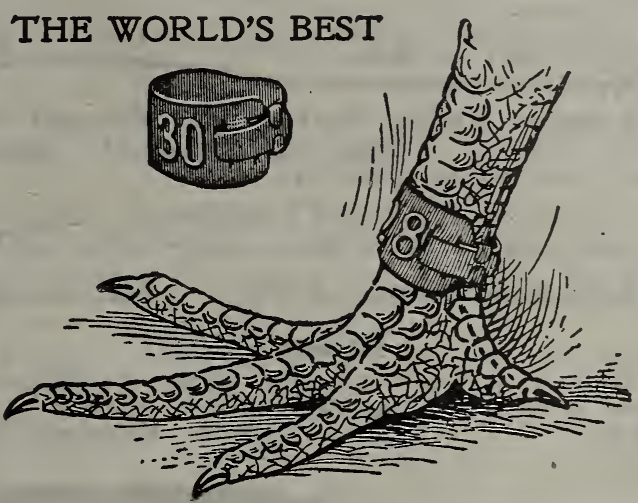

READ THIS.-This is our-mest popular band and we aim to have a large supply on hand at all times. We have them put up in packages numbered 1 to 12,13 to 25,26 to 50,50 to 100 , and boxes 101 to 200,201 to 300 . and in even hundreds up to 1000 . NOTE. - We do not break these packages. PRICES: 12 for 20c; 25 for $35 \mathrm{c} ; 50$ for $50 \mathrm{c} ; 100$ for $75 \mathrm{c} ; 500$ for $\$ 3.50$; 1000 for $\$ 6.25$.

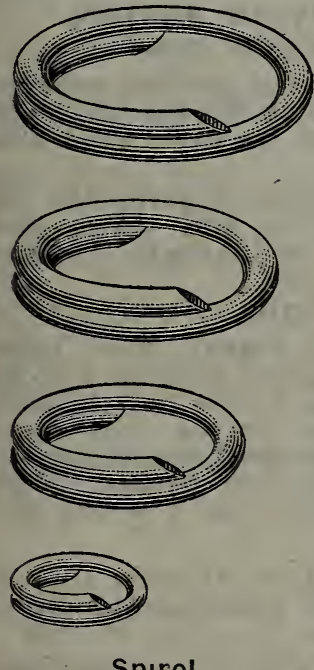

Spirol

\section{Colored Spirol-Celluloid Bands}

\section{(See illustration.)}

You have no ends to fasten together-made on the same principle as a key ring. Once put on they stay till taken off and do not chafe the leg. The ease with which these bands are used will be a revelation to the man who has used other style leg bands. And best of all they can be used again and again, without destroying in the least the utility of the band.

Durable, Practical, Economical. They provide instant identification without handling the birds. You can identify birds as far as you can distinguish colors, which will show you according to your markings, the early or late hatched pullets, the yearlings or 2 year olds, your different matings, and so on. Fine for baby chicks. Made in ten colors: Red, White, Pink, Amber, Light and Dark Blue, Black, Purple, Green and Garnet. They do not fade and are weather-proof.

ORDER BY NUMBER, AND STATE COLOR WANTED.

NO. 1, Baby Chicks; No. 2, Pigeons and Bantams or halfgrown chicks; NO. 3, Leghorns, all Mediterraneans and Spanish NO. 4, Rocks, Reds, and American classes; NO. 5, Asiatic classes and Ducks; No. 6, Asiatic Males, Turkeys and Geese. $100, \$ 1.00$

PRICES: Any Color or Size. -12 for 20 c; 25 for $35 c$; 50 for $60 c$; Very low prices for 1,000 . Write.

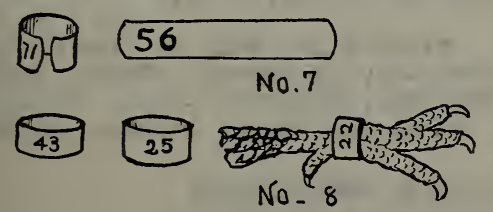

WIRE HEN NESTS

Wire nests are sanitary, there being no place for mites. They may be hung on the wall, and are easily taken down for cleaning. (Parcel Post weight 1 lb each.) Prices, 25c each, doz. \$2.50. Postage extra.
NO. 7. OPEN PIGEON OR CHICK BANDS. Prices postpaid, 12 for $15 \mathrm{c} ; 25$ for $30 \mathrm{c}$; 50 for $50 \mathrm{c}$; 100 for $75 \mathrm{c}$.

NO. 8. SEAMLESS PIGEON OR BABY CHICK BANDS. Prices, 12 for $35 c ; 25$ for $70 c ; 100$ for $\$ 2.00$. 


\section{POULTRY KILLING KNIVES}

You open the fowl's mouth and cut the juglar vein. Hang up by the feet, let them bleed, and pick dry while warm, without using hot water.

\section{Pilling's Nickeled, High Grade}

\section{(P) ANGULAR POULTRY KILLER S. PILLING-PHILA.}

Angular Killing Knife. Postpaid 65c By simply turning the wrist the juglar vein and spinal cord are cut.

FRENCH SGFE-EDEE KILLINE KNIFE \& 2 PILLING - PHILA.

Safe Edge Killing Knife. Postpaid 65c Robert's

This is a very popular style. Full size, good grip wood handle, highest quality steel blade. Postpaid 50c

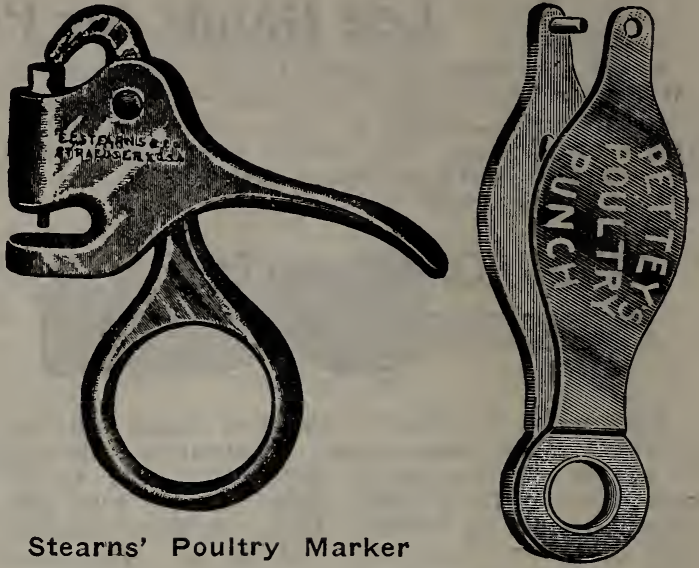

\section{POULTRY MARKERS}

Used for marking the web between the toes of baby chicks, if you wish to know different strains or stocks. Colored leg bands are now more popular.

Pettey's-(See illustration). Postpaid, 25c

Stearns-(See illustration). Postpaid, 35c

\section{OCULUIM LIQUID FOR POULTRY}

"OCULUM" is not a stimulant but is a SCIENTIFIC GERMICIDE. It destroys disease germs in the bowel and keeps fowls healthy.

\section{DIRECTIONS FOR FEEDING}

Use one drop of "OCULUM" a day to each grown fowl (or 10 drops to each pound of feed). A teaspoon holds 60 drops.

Mix the "OCULUM" with water (just enough to sprinkle), and sprinkle the feed with the mixture, stir it and cover it up and the "OCULUM" will penetrate the feed in thirty minutes. "OCULUM" mixes with feed wet or dry, whole or cracked grain. It mixes best with scratch feeds.

"OCULUM" may be successfully used in water, but 5 drops to the quart of water daily for 30 days as a tonic.

You can feed "OCULUM" treated feed with PERFECT SAFETY to any size fowl, from a day old chick up. Use "OCULUM" feed ONLY ONCE A DAY. all the fowls will eat Feed "OCULUM" DAILY for ONE MONTH and then stop for one month, and so cn.

PRICES: Trial size, $1 \mathrm{oz}$. (240 feeds), 15c; 50c bottles, 60c postpaid; $\$ 1.00$ bottles, $\$ 1.10$ postpaid; by Express, Pints, $\$ 2.00$; Quarts, $\$ 4.00$; Gal., $\$ 10.00$.

Extra Glass Syringes, $15 \mathrm{c}$.

\section{OCULUM OIL FOR STOCK}

STOCKMEN ARE DELIGHTED WITH ITS QUICK AND CERTAIN ACTION

AND REASONABLE COST

Sick hogs and sick sheep quickly relieved by its magic power. Sick horses and sick cattle made well again by its use. Feed bills reduced.

"Oculum Oil" is a scientific germicide for animals. Used in feed, it kills germs and worms in the organs of animals. Makes meat.

\section{DIRECTIONS}

For Health and Extra Flesh: Feed hogs, sheep, goats, and other small animals 3 drops "Oculum Oil" once a day in the feed to each $100 \mathrm{lbs}$ live weight; feed horses, cattle and otler large animals 5 drops once a day in the feed to each 100 lbs. live weight. Feed it 4 weeks at a time, then rest 4 weeks and so on.

For Sick Animals. Inject "Oculum Oil" in the anus, and also feed according to directions with each bottle.

We guarantee Oculum Oil to save feed and make more and better meat or money back. Full directions with each order.

PRICES: Trial size, 60c, or Half Pint $\$ 1.15$ postpaid; by Express, Pints $\$ 1.50$; Quarts, \$2.50; Gal., \$7.50.

SPECIAL SYRINGE FOR ANIMALS, 25c.

Ask for Pamphlets giving full information and testimonials

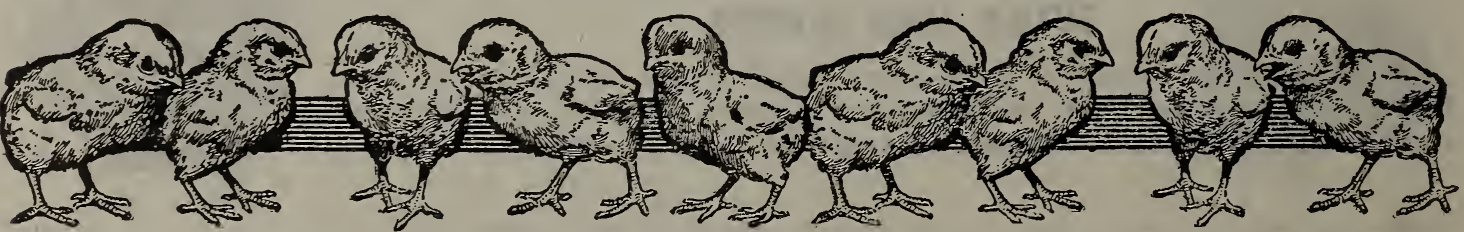

Baby 


\section{Routledge's "Highest Quality" Poultry Foods}

Don't invite disease and loss by using old pans, open dishes or wooden troughs. See page 141.

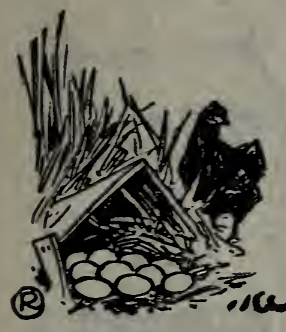

The poultryman who feeds the "Highest Quality" poultry foods, even though it is a little higher in price, makes more profit than he who is content with cheap mixtures or low grade grains because it costs less.

The demand for our poultry foods is enormous among the poultry raisers, for they have found out that we supply only highest quality foods. They also appreciate the fact that we give them wholesale prices in 5, 10 or 20-bag lots. We have no dealers to protect.

About Prices: All prices are subject to important market changes and

F. O. B. Portland. Write for prices at any time or order at following prices. If you send too much we will refund, if not enough we will cut the order down or bill you for balance due. Instruct us, please.

FISH MEAI_H. Q.

The grade we sell is the best obtainable, it contains nothing but pure fresh fish properly processed and will not taint the eggs. Fish Meal is rapidly taking the place of Beef Scraps, Beef and Meat Meal, Blood Meal, etc., as it contains more available animal protein.

Prices, 5 lbs. 40c; 10 lbs. 75c; 50 lbs. $\$ 3.00$; 100 lbs. $\$ 5.50 ; 500$ Ibs. @ \$5.40.

\section{BEEF SCRAPS}

Our "Highest Quality" beef scraps are rich in materials which make bone muscle and lean meat. They insure health, thrift and vigor, and satisfy the natural craving of the bird's system for flesh-food in some form. Rich in protein. Can be fed dry or with cooked rations. Don't waste any, feed in one section of Sanitary Feeder. See page 141.

Price, Ib. $10 \mathrm{c} ; 5 \mathrm{lbs}$. $50 \mathrm{c}$; $10 \mathrm{lbs} .75 \mathrm{c}$; $50 \mathrm{lbs}$. $\$ 3.50 ; 100$ lbs. $\$ 6.50$.

\section{GRANULATED BONE_"'SPECIAL",}

We offer only highest quality, white, pure and clean. Rich in phosphates, lime and protein. Should be kept before your chickens at all times. Feed in a Sanitary shell and Grit Box. (See page 141.)

Price, 5 lbs. 25c; 11 lbs. 50c; 100 lbs. $\$ 3.75$; 500 Ibs. @ $\$ 3.50$.

\section{POULTRY MUSTARD}

Ground fine.

1 lb. $25 \mathrm{c} ; 6$ lbs. $\$ 1.20$

\section{OYSTER SHELL, CRUSHED}

Best grade pure hard oyster shell, crushed and sifted. Supplies lime material for egg shells. Oyster shells should be within reach of your hens at all times.

Price, 6 lbs. 25c; 15 lbs. 50c; 100 lbs. \$2.50; 500 lbs. @ \$2.40.

\section{GRIT_Best Grade}

Every poultry raiser should keep a supply of this grit in each pen. Baby chicks and ducklings must have it. Made in three sizes, chick, pigeon or broiler and hen size. We always send hen size unless otherwise ordered.

Price, 5 lbs. 10c; 14 lbs. 25c; 100 lbs. \$1.50; 500 lbs.@ $\$ 1.40 ; 1,000$ lbs.@\$1.30.

\section{CLOVER OR ALFALFA MEAL}

The best substitute for green food for winter feeding; helps keep the egg basket full; mixed with the soft feed is good for large or small chicks; endorsed by leading experts.

Price, 1 lb. 10c; 10 Ibs. 50c; 100 lbs. \$2.75.

\section{CHARCOAL}

Our stock is prepared especially for poultry and of highest quality obtainable; a preventive of bowel trouble, sour crop and indigestion; a health preserver. State size wanted. A for mash, B for chicks, C for large chickens or hens.

Price, 1 lb. 10c; 3 lbs. 25c; 10 lbs. 75c; 50 lbs. $\$ 2.75$; 100 lbs. $\$ 5.00$.

POULTRY PEPPER

A good tonic and invigorator. Ground. Price, 1 lb. $40 \mathrm{c} ; 5$ lbs. $\$ 1.85$

\section{Conkey's Buttermilk Starting Food}

Buttermilk your baby chicks and make them grow like weeds.

Put vim and vigor into them when they most need it; help them throw off disease and withstand exposure.

Conkey's Buttermilk Starting Food provides buttermilk for the chicks in a dry, sanitary mash form. It makes a regular, uniform supply possible, and in addition to this it contains sweet, pure grains and just enough medication to start the organs working in a normal way. It is a nourishing, stamina building food that makes the youngsters husky and strong. It should be their very first food. Feed dry.

Prices, 5 lbs. 50 c; 12 lbs. $\$ 1.00 ; 50$ lbs. $\$ 3.75$; 100 lbs. $\$ 7.00$.

\section{Conkey's Buttermilk, Meat, Bone and Grain Mash}

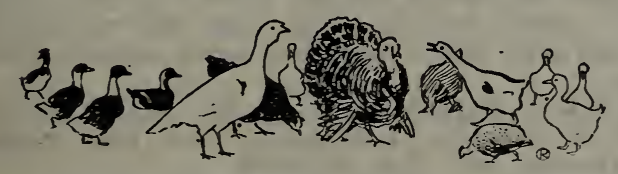

This new buttermilk mash for hens and grown poultry is prepared by the G. E. Conkey Co., who know what a real first-class buttermilk mash should contain. It certainly is a rich and profitable food in spite of the cost. We sold several carloads last season. It's made of nothing but pure sweet ground grains with plenty of meat, bone and butter. milk. It will get the eggs when nothing else will.

Prices: 5 lbs., 40c; 10 lbs., $75 \mathrm{c} ; 50$ lbs., $\$ 3.25$; 100 lbs., ' $\$ 6.25$. Write for quantity price. 


\section{FISHER'S PURE FOODS FOR POULTRY}

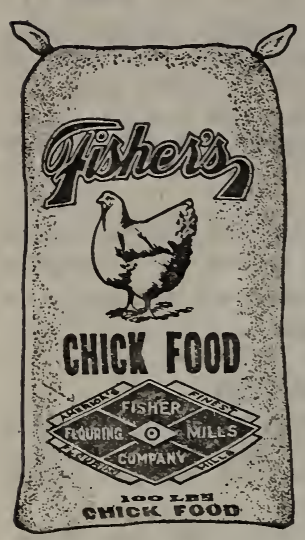

\section{FISHER'S CHICK STARTER}

The critical time in the life of a chick is the first few weeks. Until chicks are thirtysix hours old they should be given nothing but water and fine grits. Many play havoc with their broods by feeding them immediately. Avoid this fatal error. Fisher's Chick Starter contains food ingredients necessary to promote quick, rugged growth. You will find it a perfect food for the first few weeks. Make them scratch for it and keep "Buttermilk Chick Mash" Dry, in a feeder before them at all times.

Prices, 4 lbs. 25c; 8 lbs. $50 c$; 100 lbs. $\$ 5.00$; 500 lbs.@\$4.90; 1,000 lbs. @ $\$ 4.80$.

\section{FISHER'S CHICK FOOD}

This is a preparation of steel cut, pure, wholesome grains, carefully and scientifically combined. A month or two on this diet will kring remarkable 1 esults in the rounding out of the body and the development of a superb coat of feathers. Every element that goes into Fisher's Chick Food counts heavily in the building of the fowl. Feed Buttermilk Developing Mash with this.

Prices, 4 lbs. 25c; 8 lbs. 50c; 100 lbs. \$5.00; 500 Ibs.@\$4.90; 1,000 Ibs. @ \$4.80.

\section{FISHER'S DEVELOPING MASH}

There is no better known food ration for growing st, ong, sturdy and active chicks quickly, either for layers or for the show pen. It is a bone, tissue and feather producing ration of known merit. It should be fed after chicks are six or seven days old and kevt continually before them until they are fully matuied. (Feed it in a dry food hopper.) See pages 140-141.

Prices, 5 lbs. 25c; 10 lbs. 50c; 100 lbs. $\$ 4.10$; 500 lbs. @ $\$ 4.05 ; 1,000$ lbs. @ $\$ 3.95$

\section{FISHER'S GROWING FOOD}

This meets the wants of the growing chicks from the time they are eight to ten weeks of age until ready for scratch food. It contains the nutritive elements necessary for the rapid building of tissue and if fed Developing Mash will bring about the quickest possible development.

Prices, 4 lbs. 25c; 9 lbs. 50c; 100 lbs. $\$ 4.90$; 500 Ibs. $\$ 4.80 ; 1,000$ lbs. @ $\$ 4.70$.

\section{FISHER'S FATTENING MASH}

Prepared expressly to meet the wants of the fancier who lacks weight in his show birds or the grower desiring to quickly fatten and finish young or old stock for the market. It will quickly add weight to a mature or growing fowl.

Prices, 5 lbs. 25c; 10 lbs. 50 ; 100 lbs. \$4.15; 500 lbs.@\$4.05; 1,000 lbs. @ \$3.95.

\section{FISHER'S SCRATCH FOOD}

This is a perfectly balanced ration which, when fed with Fisher's Egg Producer for laying hens or Fisher's Developing Mash for maturing youngsters, contains all the food elements required to obtain the very best results known to scientific poultrymen. In its preparation only the purest and choicest grains are used. Experienced Poultrymen recognize it as the best scratch food the market supplies.

Prices, 4 lbs. 25c; 9 lbs. $50 c$; 100 lbs. $\$ 4.60$; 500 lbs. @ $\$ 4.50 ; 1,000$ lbs. @ $\$ 4.40$.

\section{FISHER'S EGG PRODUCER}

A mash mixture containing all the ingredients necessary to the matured laying hen; very rich in protein. It renders unnecessary the feeding of blood meal, beef scraps, etc. The rapidly increasing demand for Fisher's Egg Producer proves its real money-making value. Results will prove this the most economical mash on the market.

Prices, 5 lbs. 25c; 10 lbs. 50 ; 100 lbs. $\$ 4.20$; 500 lbs.@\$4.10; 1,000 lbs. @\$4.00.

BUTTERMILK.-Feed buttelmilk to your poultry. If you do not use the buttermilk mash, use "Fisher's Semi-Solid." See page 148 for full information.

\section{FISHER'S PIGEON FOOD}

In compounding a food for pigeons, the proper selection of various grains is of great importance, especially so during the breeding season and when squabs are to be marketed. The health of the birds and the weight of the squabs are dependent upon correct feeding.

Fisher's Pigeon Food is the most reliable and satisfactory mixture of the best grains obtainable for this purpose.

Prices, 4 lbs. 25c; 9 lbs. 50 ; 50 lbs. \$2.60; 100 lbs. $\$ 4.50$. Write for quantity price.

We make special prices direct to Poultry Raisers. 5 bags assorted foods at $500-1 b$. prlces; 50-1b. sacks 15c extra. Prices subject TO IMPORTANT MARKET CHANGES. WrIte for cuantity price when ready to buy. WE'LL SAVE YOU MONEY. 


\section{Fisher's Buttermilk Chick Starting Mash}

After 2 years of careful study, experimenting and testing the Fisher Flouring Mills Co. claim to have a Buttermilk Starting Food for balay chicks that is equal to any and better than most brands sold.

Claimed to contain less fiber and more protein and fat, Buttermilk Starting Food is without question the correct and most profitable and only feed for baby chicks for their first feed and for the first week. Feed it almost exclusively with a light scattering of fine grit and fine cut chick grain. Prices: Prices: 3 lbs. 25c; 10 lbs. 75c; 100 lbs. $\$ 5.00$. Write for low quantity price.

\section{Fisher's Buttermilk Developing Mash}

This is to follow the feeding of the Starting Mash. It is the best combination of ground grains and buttermilk in mash form known. It has all the food elements necessary to promote a natural, healthy growth. It meets every one of nature's demands, as it contains all the requisites for bone, tissue and feather building in the proper proportions, and best suited to the perfect development of growing birds.

Prices: 4 lbs. 25c; 9 lbs. 50c; 100 lbs. $\$ 4.50$; 500 lbs. @ \$4.40.

\section{Fisher's Buttermilk Mash}

This is for mature poultry and is a mash mixture containing the right elements in proper proportions for egg making and body maintenance. It provides the life and vigor promoting fat, keeps the layers in prime condition throughout the year, and balanced with Fisher's Scratch it completes a balanced body maintaining and egg-making nourishment. Keeps the layers up to maximum capacity the year round.

Buttermilk mash reaches the highest degree of palatability because buttermilk is proven one of the most important foodstuffs -whilst its composition is such that when used in combination with other foods it corrects their dietary deficiencies.

\section{Spratt's Poultry and Pheasant Foods}

A cooked food for Chickens, Pleasants and Turkeys. 3 sizes.

Spratt says: "Our experience of over 50 years in the poultry, game and dog-food business convinces us that a predigested cooked food, the basic ingredients of which is wheat and meat, solves the problem successfully." It promotes health, strength and vigor.

Spratt's Poultry Food is a cooked food and therefore easily digested. It should be mixed with sufficient (hot) water or milk to make it crumbly moist, not too dry, yet not sloppy. Generally fed in the morning and a grain food at night.

As a conditioner for show birds it has a great reputation among the Fanciers. It puts the birds in good "Condition," i. e., good health, right weight, good plumage and radiating energy and "pep." It's good policy to feed Spratt's Poultry Food all the year round if not as a steady diet as a change of foods. Oregon's largest pheasant farms feed it in great quantities.

This food, after being cooked and baked, is reground into 3 sizes:

No. 12-Pinhead size for baby chicks.

No. 5-Rice grain size, chicks over 3 weeks.

No. 3-Split pea size, adult birds.

In ordering be sure and state size wanted.

PRICES-1 lb. 15c; 5 lbs. 70c; 10 lbs. \$1.30; 50 lbs. $\$ 5.75 ; 100$ lbs. $\$ 10.50$. Write for quantity prices. Postage extra.
It contains a large amount of lactic acid which keeps the digestive tracts free and activates the gastric juices so important to normal digestion.

It creates appetite and is, in addition to its great feeding value, an excellent conditioner.

Its high per cent of protein-necessary in the making of the albumen of the egg-enables the hen to produce more eggs.

Its large percentage of sugar of milk produces energy. It is highly digestible and most economical.

Prices: 4 lbs. 25c; 9 lbs. 50c; 100 lbs. $\$ 4.50$; 500 lbs.@ $\$ 4.40 ; 1,000$ lbs.@ $\$ 4.30$.

\section{Fisher's Calf Meal}

Dairymen who sell whole milk must look for a milk substitute on which to raise their calves. Fisher's Calf Meal is a perfect substitute and is absolutely guaranteed if fed as directed.

Fisher's Calf Meal is a scientific product produced under perfect sanitary conditions and contains the proper proportions of oatmeal, cornmeal, soybean meal, linseed oil meal, milo maize meal, blood meal and a little salt.

Directions for Feeding: The calf should run with the cow for the first three days. It is very necessary that the calf gets all of the cow's first milk (colostrum). If you have plenty of skim milk or seperator milk, feed it to your calf until it is ten days' or two weeks' old. If you cannot do this, after the fourth day add cold water to two tablespoonfuls of Fisher's Calf Meal and stir into a thick paste free from lumps. Then add boiling water so that it will heat the gruel to 98 degrees, blood heat. Add two quarts of seperator, or skim milk, and feed three times a day at blood heat. Gradually increase the Calf Meal and decrease the seperator, or skim milk.

Prices: 25-lb. sacks, $\$ 2.00 ; 50-1 b$ sacks, $\$ 3.25 ; 100 \mathrm{lb}$. sacks, $\$ 6.00$.

\section{Directions for Feeding in Each Sack}

NOTE.-Some of the largest breeders and feeders in the Northwest who have tested Fisher's Calf Meal with other well-known brands, claim Fisher's is unequaled and more profitable because it costs less. Why pay "freight" from the East?

IMPORTANT NOTICE TO POULTRY KEEPER.-We want your trade direct-not the dealer's, therefore glve you strictly wholesale prices in 5, 10 and 20-bag lots. Ask for latest prices when ready to buy. Get your neighbor to order with you so as to secure the quantlty prices, the saving will pay the frelght charges in many cases. PRICES ON THIS PAGE SUBJECT TO IMPORTANT MARKET CHANGES. 


\section{Semi-Solid Buttermilk}

\section{THICK AS BUTTER-100\% DIGESTIBLE-WE RECOMMEND THIS PRODUCT}

Semi-Solid Buttermilk Is pure creamery buttermilk with the water eliminated.

All successful poultrymen recognize the value of buttermilk both as a food, tonic and conditioner for poultry, but the difficulties attended with getting fresh buttermilk make it a practical inıpossibility for the poultryman under average conditions. In the main these difficulties are excessive cost, inconvenience, trouble and expense of handling, and poor keeping qualities. Semi-Solid Buttermilk eliminates all of these difficulties and reduces the cost to a mere trifle.

The lactic acid contained in Semi-Solid Buttermilk is unsurpassed as an appetizer, tonic and conditioner.

Sem.-Scld Buttermilk, because of its high percentage of completely digestible protein and sugar of milk, large amount of mineral salts and stimulating lactic acid, constituting in full the lood value of buttermilk in a condensed form, is indispensible to rations in feeding for rap.d growth in chicks, producing eggs, and fattening poultry.

\section{For Poultry, All Kinds}

Feed them Semi-Solid Buttermilk, and eliminate the dreaded disease-white diarrhea. The lactic acid destroys bacterial growth, eliminates bowel trouble, and keeps you. chicks in a healthy growing condition. Successful poultrymen are feeding it to laying hens to produce more eggs and a higher percentage of fert.lity. Commercial poultry fatten.ng plants are feeding it to increase the appetite and qu.cken the gains in we ght. Butterm.lk fattened poultry have a flavor that is unexcelled.

Semi-Solid Buttermilk is guaranteed to contain nothing but the solids of pure creamery buttermilk. Onl the water is removed. It is pasteurized and sterilized, making it absolutely safe to feed. It will keep indefinitely in a cool place. After opening container keep water over surface or press thick paper down over it. Keep sides of barrel scraped clean. Leave the lid off; a wire screen is better.

DIRECTIONS FOR FEEDING.-Mix 1 lb. (1 pint) with 2 gallons of water. Let them urink it or mix in mash feeds. Try it, it's great.

PRICES: Semi-Solid is bought and sold by weight. For your convenience in ordering we $f$ gure average barrel we ght 450 lbs. Price $\$ 32.50$; one-quarter bbls., $\$ 12.50 ; 5$ gal. kegs, net, $\$ 6.00$. NOTE.-Remit at above prices. If weights are more or less we will refund or send b.li fo: the balance. Descriptive folder free.

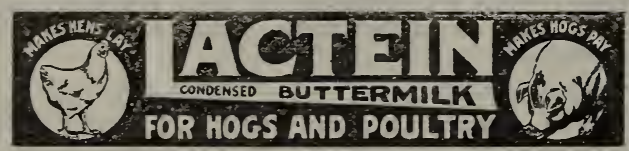

We have sold Lactein liquid buttermilk for several years. Descriptive booklet on request. Prices: Bbl. $\$ 31.50 ; 5$ gal. kegs $\$ 4.00$; gal. $\$ 1.25$.

\section{THOROUGHBRED POULTRY, AND EGGS}

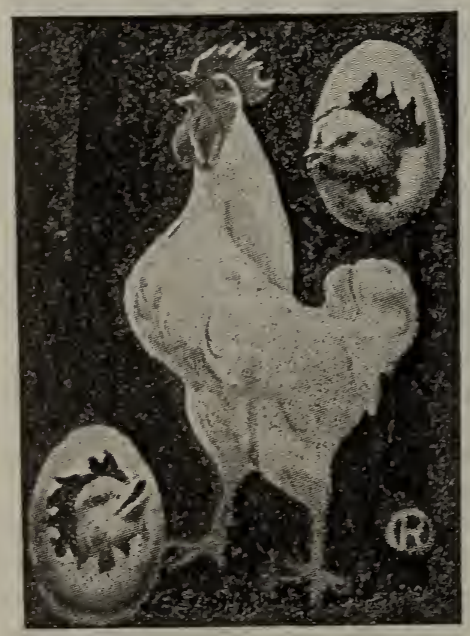

We are in a position to supply you with most any breed of poultry or eggs. We know good stock and those who keep it, and can probably save you money. Write for prices in quantity or for stock not listed below. Exhibition kirds come higher. Write.

NOTE.-Don't expect eggs or stock by return express or freight, for it takes several days, sometimes, to get them in from the farm. We guarantee safe delivery of eggs or birds to any express office.

\section{Prices of Stock and Eggs}

White, Buff or Brown Leghorns, White or Black Minorcas, White, Buff or Barred Piymouth Rocks, White or Silver Laced Wyandottes, Rhode Island Reds, Buff Orpingtons, Pekin or Indian Runner Ducks.

EGGS. $-\$ 3.50$ to $\$ 5.00$ per setting. MALES, $\$ 5.00$ to $\$ 7.50$ and $\$ 10.00$. FEMALES, $\$ 2.50$ to $\$ 3.00$ each.

BABY CHICKS.-Strong, healthy, guaranteed stock. White Leghorns, doz. $\$ 3.50 ; 100, \$ 25.00 ;$ Barred Rocks or Rhode Island Reds, doz. $\$ 4.00 ; 100, \$ 30.00$.

SPECIAL.-We are making special prices on the three leading breeds of eggs. Thest eggs are from a very select stock of heavy layers ar:d pen mated, which assures you a high fertility and a healthy chick. The breeding stock are fed special to prevent germs carrying in the esgs and affecting the life of baby chicks. It will pay you to use these eggs.

Barred. Rock or Rhode Island Red, per setting 15 eggs, $\$ 3.00$; per $100, \$ 15.00$. S. C. White Leghorn, 15 eggs, $\$ 2.50$; per $100, \$ 14.00$.

We can supply Mammoth Bronze or White Turkey Eggs from select stock at $50 \mathrm{c}$ each; 11 for $\$ 5.00$. Grey Toulouse or White Emden Geese eggs. 40c to $50 \mathrm{c}$ each.

We'll send you any priced stock you want. Remember, Quality makes the price. 


\section{CONKEY'S GUARANTEED POULTRY REMEDIES}

READ THIS. - We handle 2 to 3 carloads a year of these celebrated remedies which have built their reputation upon the scientific basis of one remedy for each disease.

A "Cure All" is not made by the Conkey Company. Each remedy is intended to serve one special purpose and serve it well. These goods are absolutely guaranteed, and we offer them to you on this basis. If they fail to satisfy you in any particular, your money will be re. funded to you cheerfully. Conkey's Descriptive Book free on request.

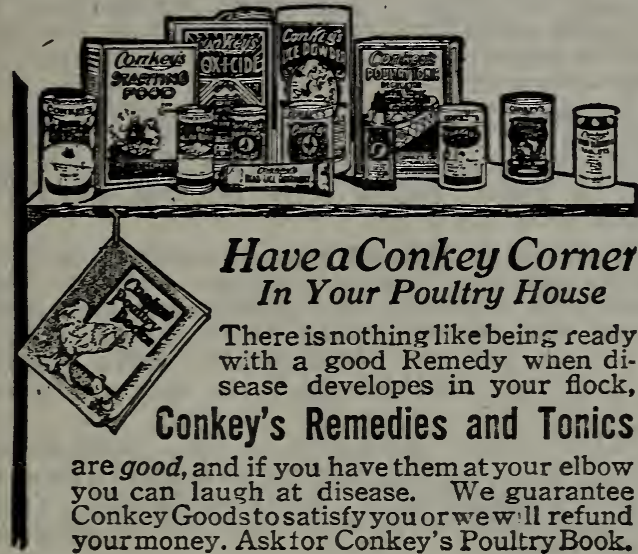

POSTAGE.-The following can be mailed safely but $A D D$ 5C EACH FOR POSTAGE and safe packing on the $30 \mathrm{c}$ packages and $10 \mathrm{c}$ extra on the 60c to $\$ 1.20$.

Roup Remedy (powder) $30 \mathrm{c}, 60 \mathrm{c}$ and $\$ 1.20$

Roup Pills, Special. $\quad 30 \mathrm{c}$ and $60 \mathrm{c}$

Canker Special Remedy. $60 \mathrm{c}$

Bronchitis Remedy. $60 \mathrm{c}$

Blackhead Remedy ................ .60

Cholera Remedy.

Gape Remedy. $\quad 30 \mathrm{c}$ and 60c

Lice Fix (Salve Form). $\quad 30 c$ and $60 c$

Limber Neck Remedy. $60 \mathrm{c}$

Scaly Leg Remedy. $30 \mathrm{c}$

Rheumatic Remedy. $60 \mathrm{c}$

Poultry Laxative. $30 \mathrm{c}$

Poultry Conditioner (General Tonic). 30c

$\begin{array}{ll}\text { Poultry Worm Remedy. } & 50 \mathrm{c} \\ \text { Poultry Flea Salve. } & 30 \mathrm{c}\end{array}$

Sulphur Candles.

$15 c ; 6$ for $80 c$

White Diarrhoea Remedy.-Save your baby chicks by putting it in their drinking water.

Price $30 c$ and $60 c$

For CONKEY'S BUTTERMILK START. ING FOOD for baby chicks and MASH for hens, see page 145 .
CONKEY'S NOXICIDE. - Absolutely unequaled as a non-poisonous deodorant and germ destroyer. Every pet stock fancier needs this. Dilute in water 1 to 20 or 1 to 50 according to directions and use as a spray or wash. Kills germs and prevents diseases. Kills fleas on dogs and lice on poultry or pet stock. Can also be used for cholera, roup, cankers, pip, flue, etc. Good for human or stock. Once used, always wanted. Prices: Pints, 50c; Quarts, 75c; $1 / 2$ Gal., \$1.25; 1 Gal., $\$ 2.00$.

NOTE.-We can send pints (P. P. wgt. 11/2 lbs), and quarts (P. P. wgt. 3 lbs.), by parcel post if you send postage at weights given and $10 \mathrm{c}$ extra for safe boxing.

CONKEY'S HEAD LICE OINTMENT.Save your little chicks from the ravages of the deadly head lice. Absolutely harmless to the little chicks. Put up in tubes. Eas to apply. Price $15 \mathrm{c}$ and $30 \mathrm{c}$; postage $5 \mathrm{c}$ extra.

CONKEY'S LICE POWDER.-It is positive death to lice, ticks, etc. Equally effective for lice on setting hens and young chicks. Gets them all. Cleans up the coop. Absolutely harmless to even the smallest chick. Easy to apply and does the business or your money back. Get a package today. Prices (not prepaid): 7-oz. pkg., 15c; 11/4lb., pkg., 30c; 31/2-lb., 60c; 14-lb., pail, $\$ 1.60$ $30-$ lb. pail, $\$ 3.00$. Note. - Weights given are wrapped; if wanted by parcel post add postage.

CONKEY'S LICE LIQUID.-A powerful liquid that will destroy the thousands of red mites that live in the cracks and crevices of the house and nests in the day and swarm the fowls' bodies at night. You can't reach them with a powder. Paint or spray the roosts, nests and walls. Prices: 1-qt. can. $60 \mathrm{c} ; 2$ qts., $20 \mathrm{c} ; 1$ gal., $\$ 1.50$; 5 gal., $\$ 7.00$.

CONKEY'S POULTRY TONIC.-It insures the maximum egg production both summer and winter. Guaranteed-to give results or money back. Prices (not postpaid): 2 lbs. 30c; 4 lbs. 60c; 14-Ib. pail, $\$ 1.60 ; 30-\mathrm{lb}$. pail, $\$ 3.00$. NOTE.-Add postage if wanted by mail. Weights given are wrapped.

\section{Conkey's Guaranteed Stock Remedies}

CONKEY'S 224-PAGE STOCK BOOK FREE.-It's full of the most practical information relative to the raising and keeping of livestock. Housing and feeding problems, diseaseshow to recognize them and how to treat them-are all explained. Every dairyman, every stockman, every farmer, should have this book. Get your copy. Free if you call at our store, or send $5 c$ in stamps to cover postage.

Stock Tonic.-Tones up their system, gives heat and strength; money well spent. For horses, cows, sheep and hogs. Prices (not prepaid): $11 / 2$ Ibs., 30c: 3 lbs., 60c: 7 ibs., $\$ 1.20 ; 12-1 \mathrm{~b}$. pails, $\$ 2.25$, and 2 ; $-1 \mathrm{~b}$ pails, \$3.75. Mailing weights given, add postage.

Worm Remedy.-Guaranteed. $60 \mathrm{c}$ postpaid.

Colic Remedy.-Just a few drops on the tongue; effective. $60 \mathrm{c}$; postpaid $70 \mathrm{c}$.

Healing Powder.-For gall sores, cuts or wounds; excellent. $30 \mathrm{c}$ or $35 \mathrm{c}$ postpaid.

Gall Salve. 20c: postage $10 \mathrm{c}$ extra.
Pain Lotion.-For swellings, etc. (P. P. 2 Ibs.) $60 \mathrm{c}$

Bag Ointment. $30 \mathrm{c}$ and $60 \mathrm{c}$; postage $10 \mathrm{c}$.

Dip and Disinfectant.-Best sheep and hog dip made. Quart, $75 \mathrm{c}$; $1 / 2$ gal. $\$ 1.25$; gal. $\$ 2.00 ; 5$ gals. $\$ 9.50$.

FLY KNOCKER.-Best fly spray made to keep flies off of horses or cows. Your money back if not satisfied. Qt., $75 \mathrm{c} ; 2$ qts, $\$ 1.25$; gal. $\$ 2.00 ; 5$ gals, $\$ 9.50$.

COW SPECIAL.-Every dairyman should keep this on hand; fully guaranteed. Prices: $60 \mathrm{c}$ can postpaid $70 \mathrm{c} ; \$ 1.20$ can 3 lbs. wrapped; add postage.

LIQUIDS BY PARCEL POST.-We can send by parcel post pint and quart cans of Lice Liqu'd, Nox cide, Sheep Dip and Fly Knocker, but it must be packed safely. We ask 15c extra hesides the postage to cover boxing cost. PLEASE REMEMBER. 


\section{SONG AND CAGE BIRDS}

We are the largest importers and dealers in Birds and Gold Fish in the Northwest. This department of our business has grown rapidly and we now carry large and complete stocks of cages, supplies and foods and all birds in their season.

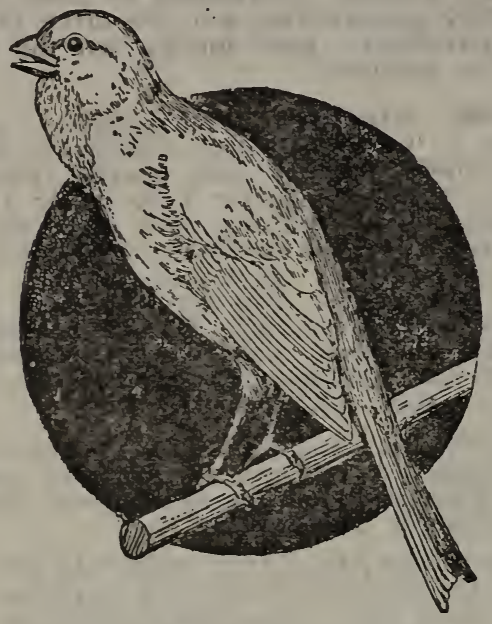

We Guarantee Our Singers

\section{CANARIFS}

Their cheery song is like sunshine to the soul; their bright plumage, active ways and cheerful dispositions make them great favorites. . For your convenience we have inclosed with glass two "Bird Parlors" on our first floor. You are welcome any time. Come in and see our birds and hear them sing.

ST. ANDREASBERG. World-renowned and the sweetest singers on earth. These birds have been given a musical training; their song is sweet and soft with many rare and pleasing notes, thrills, rolls, etc. Males, $\$ 20$ to $\$ 40.00 ;$ Females, $\$ 2.50$ to $\$ 3.50$.

HARTZ MOUNTAIN ROLLERS. Beautiful and incessant singers, always bright, active and cheerful. Some singers in this class are almost equal to the above, especially where they have had special training. These are our most popular sellers. Males, \$7.50; Extra Selected Singers, $\$ 10$ to $\$ 15.00$; Females, $\$ 1.50$ to $\$ 2.00$; Selected, $\$ 2.50$.

HARTZ MOUNTAIN SINGERS. The well-known ... nepular a mer:carb bred canary. Males, $\$ 5.00$; Selected Singers, $\$ 7.50$; Females, $\$ 1.00$; Selected $\$ 1.50$; Young Males, August and September only, not yet in song (no exchange), $\$ 3.50$ each.

Roslyn, Wash., July 23, 1919.

Routledge Seed \& Floral Co.

Kind Sirs: My St. Andreasbery came in the best of condition and we think him wonderful.

\section{Yours truly, MRS. C. M. DUNN.}

Amity, Ore., April 12, 1919.

Routledge Seed \& Floral Co.

Dear Sirs: I received the bird in firstclass shape and he is just lovely.

It went to singing in less than half an hour after I took it out of the box. My! how it does sing. Am well pleased with it. Yours truly, MRS. C. D. NAIRN, JR.

OTHER FAVORITE CAGE BIRDS.-We do not always have all of the following birds on hand, but can get them quickly on orders. For further information, write.

Japanese Robins ......... $\$ 5.00$

European Gold Finch......... 6.00

Chestnut Finch ............2.00

Zebra Finch ............ 7.00

Society and Strawberry Finch. 4.00

Pair $\$ 8.50$ 10.00 3.50 12.50

7.50

WHITE JAVA RICE BIRDS.-One of the handsomest of all aviary birds. A little larger in size than the average canary. Color pure white. Beak tinged with dark red toward the base. Each, $\$ 5.00$; pair, $\$ 8.50$.

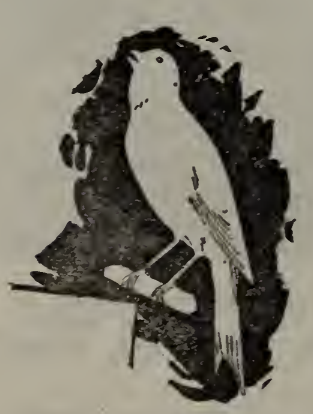

\section{CANARY BIRD SPECIALS}

\section{These Four Articles Have Merit, We Sell Gross After Gross}

BIRD MANNA.-A combination of seeds, herbs and roots that nature intended birds should have. Food and medicine combined. A tonic and conditioner. Comes in half-round cakes. Fastens on the cage wires. Per cake, 15c; postpaid 20c; 2 for $35 c$.

BIRD-O-LINE.-A preparation very similar to "Manna," except that it is $g_{1}$ anulated and dry and is fed in the seed cups, a little at a time. Per box, 20c; postpaid 25c; 2 for 40c.

CANARY HIGH BALLS.-Another article of above merits. Highly praised. Comes in ball form and hangs in the cage. "Mr. Bird" eats it as he needs it. Each, 15c; 2 for 25c; postpaid 20c; 2 for 35c.

SPRATT'S COD LIVER OIL NESTLING FOOD.-A food for young birds. A substitute for boiled eggs. An excellent food for old birds in the moulting season. Per pkg. 25c; postpald $30 \mathrm{c} ; 2$ for $50 \mathrm{c}$.

LIVING PRESENTS.-Did you ever stop and consider what a desirable Christmas or birthday present a beautiful CANARY makes.. They are so different, interesting and desir. able, SO CHEERFUL AND LOVABLE. 


\section{ROUTLEDGE SEED \& FLORAL CO.'S BIRD FOODS}

We are making a specialty of Bird Foods and Remedies and carry in stock the larg. est and only complete line in the Northwest. Our rapidly increasing trade shows that ine public appreciates the opportunity to get H. Q. "HIGHEST QUALITY" foods and remedies of "Merit" for their pets.

\section{Routledge Seed \& Floral Co.'s}

H. Q. IMPORTED BIRD SEED.-Our own special mixture for American, Hartz Mountain and St. Andreasberg Canaries; especial. ly prepared for the singers. Contains no hemp, but the correct proportions of highest quality recleaned Canary, Sweet Rape, small Golden Millet and a few other seeds to give health and "pep" to the singers.

It is no wonder that thousands of canaries die annually from the effects of common Bird Seeds bought from grocery and drug stores, which is so often old, musty, dirty, inferior seeds, incorrectly mixed.

Try a package of our H. Q. and note the difference and also the saving, even though it is a little higher in price.

"H. Q." sold only in sealed 1-lb. cartons (see illustration of our 1-1b. carton). Take no other.

Add postage if wanted by mail

H. Q. Hemp Seed.-Hemp is the large, round dark-grey seeds found in all cheap mixtures. It is very heating and fattening and should be fed sparingly and not to singers at all.

Price 20c. Ib.

H. Q. Canary.-Recent war conditions have made Sicily canary seed very scarce and higher than usually. $35 \mathrm{c} \mathrm{Ib.}$

H. Q. Millet.-Small golden soft shell. 20c Ib.

H. Q. Imported Sweet Rape.-Easily detected by the sweet taste. 25c Ib.

Note.-Beware of wild mustard, kale and turnip seeds sold as bird rape.

Lettuce seed.-For birds.

$25 \mathrm{c} \mathrm{Ib.}$

Bird Sand.-Silver, washed. $21 / 2-1$ b. cartons, $15 c$

"H. Q." Bird Gravel.-A new product becoming very popular with bird fanciers. 2-Ib. can $20 \mathrm{c}$

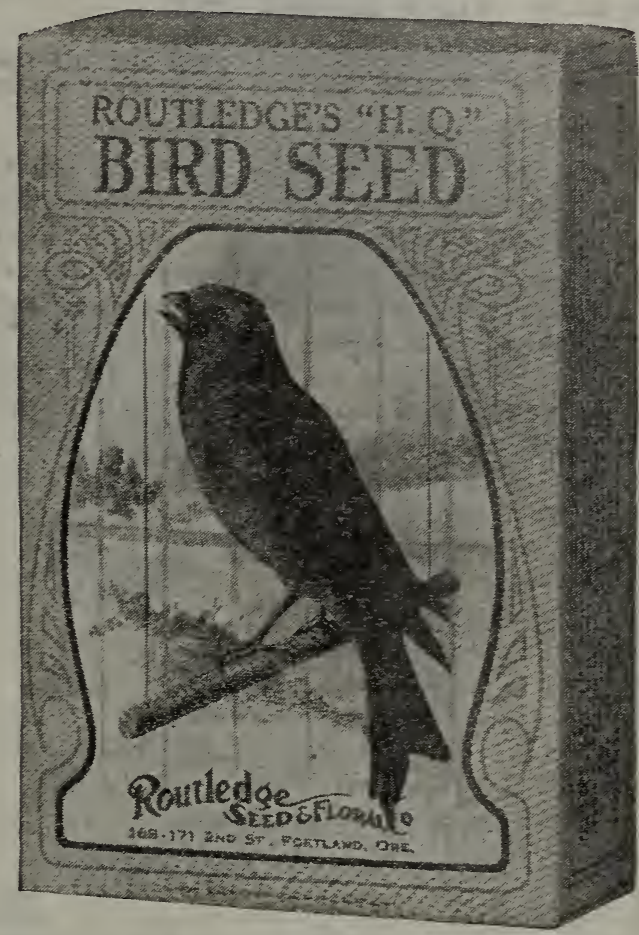

This is our H. Q. Bird Seed CartonHighest quality seed obtainable. (Green box, yellow bird.) Take no other.

Red Bird Gravel.-Preferred by many of our customers. Small pkg., 2 lbs., 20c.

Cuttle Bone, high grade, large size. Each $10 c$, or 2 for $15 c$, postpaid; with patent fas. teners or holders, $10 \mathrm{c}$ and $15 \mathrm{c}$, postpaid.

\section{Parrot Foods, Tonic, Etc.}

H. Q. Mixed Parrot Seeds.-This is our own mixture of clean, well cured sunflower, hemp, pumpkin and corn, properly mixed. Your "Polly" will like this. 25c lb.; 3 Ibs. for $70 \mathrm{c}$; postage extra.

H. Q. Sunflower, -We offer only large, plump, full meated seed properly cured and of the right age for health. Far superior to the average stock sold. 20c Ib.; 5 lbs. for $85 \mathrm{c}$; postage extra.

Parrot Corn.-Best quality for parrots. $15 \mathrm{c}$ lb.; 4 lbs. for $60 \mathrm{c}$; postage extra.

M. G. Parrot Spray.-Will cure Parrots of the habit of biting off their feathers. Per bottle $50 \mathrm{c}$; postpaid $65 \mathrm{c}$.

M. G. Mixed Parrot Seed.-Properly mixed for good health and plumage. Full and valuable directions on the care of Parrots on each box. Per carton 25c; postpaid 35c.

M. G. Prepared Corn, for Parrots.-To be given in addition to the seed. Per carton 20c; postpaid 25c.
M. G. Parrot Biscuit, for old and young, to keep them in good health and plumage. Per carton 25c; postpaid 35c.

Parrot Biscuits (P).-A high grade food. Per box $45 \mathrm{c}$; postpaid $55 \mathrm{c}$.

Parrot Tonic.-Unexcelled for young Parrots, cures catarrh, etc. Per bottle 25c; post. paid 35c. Spratt's 40c.

M. G. "Health Food" for Parrots, for health and fine feathers. Per carton 25c; postpaid $35 \mathrm{c}$.

Parrot Diarrhoea Cure (K).-A cure for diarrhoea or bloody flux. 40c; postpaid $50 \mathrm{c}$.

Parrot High Balls (K).-A breath and condition food. Each 25c; postpaid 30c.

Reliable Parrot Remedy (K).-For sickly parrots, loss of appetite, etc. 50c; postpaid $60 \mathrm{c}$.

Parrot Tablets.-For Polly when out of condition. Excellent. $30 \mathrm{c}$, postpaid $40 \mathrm{c}$

Pennakura (S).-Prevents external Parasites and feather-eating. 30c.

Canaradyne (S).-Use in drinking water for asthma or bronchitis. $30 c$. 


\section{Miscellaneous Bird Foods and Remedies}

We have used in our own Bird Stock Department the following remedies, all of which we can recommend. We buy them in one to five-gross lots and aim to have complete stock at all times.

To conserve space, we will designate the different stocks as follows: (G) for Max Geisler, (K) for Kaempfers, (P) for Philadelphia Bird Co.'s, (S) for Spratt's.

NOTE.-The following prices are all postpaid, $5 c$ less per package if called for. Prices subject to market changes.

SONG AND MOULTING FOODS

Always feed some of the following foods during moulting season and to restore the songs. Feed a "general tonic" when moult first starts, followed by a Song Restorer, which should bring your bird back into full song quickly.

size. $\quad 50 c$

Excelsior Song Restorer (K). $25 \mathrm{c}$

Drahota's Song Restorer (P). $30 \mathrm{c}$

Song Restorer (S).

Song and Moulting Foods (G). $30 \mathrm{c}$

Song Restorer (Spratt's). $30 \mathrm{c}$

The following are liquids:

Treatment A.-(Song Restorer) (G).

Treatment B.-(Digestive Trouble) (G).

For diarrhoea and bowel disorder. 35c

Treatment C.-(Cold Cure) (G). $35 \mathrm{c}$

Treatment D.-(General Tonic) (G). Use once a week in drinking water. 35c

General Tonics. - See 'Bird Specials," page 150.

Bird Tonic (S).

Bird Biscuit (G), for change of diet. $25 \mathrm{c}$

MOCKING BIRD FOODS.-An excellent and highly nutritious prepared food, made for Mocking Birds, Robins, Thrushes and all soft-billed birds. DEFIANCE (S), large cans, $75 \mathrm{c}$; RUHE'S, 1-lb. cans, 60c; GEISLER'S, $3 / 4$-lb., $50 \mathrm{c}$.

\section{MITE AND LICE POWDERS}

Watch out for lice on the birds and the little red mites that hide in the crevices of the cage or walk during the day and live on the birds at night. Your bird cannot be contented and happy with these pests.

Bird Lice Destroyer (S).-Put up in powder guns. $35 \mathrm{c}$.

H. Q. Mite Powder. 20c.

Mite Powders (P), large box, 40c.

H. Q. Insect Powders.-Very effective, 15c. Note.-We have small insect powder blowers at 25c each postpaid. You need one to apply powder effectively. (See page 128.)

H. Q. Bird Cage Wash.-A liquid to be diluted with water for disenfecting the cage and killing the mites. Full instructions on the label. $35 \mathrm{c}$, postpaid $40 \mathrm{c}$.

Asthma Tablets (K).

Price, Postpaid

Diarrhoea Tablets (K).

Constipation Tablets (K).

Bird Bitters (P), general tonic.

Vegetable Extra (G), general tonic. $35 \mathrm{c}$

Moulting Pepper (P), moulting season. $35 \mathrm{c}$

Nestling Food (P), for young birds. $35 \mathrm{c}$

Plumage Restorer (K), gives color. $30 \mathrm{c}$

Foot Ointment (K), for sore feet. $30 \mathrm{c}$

Bird Liniment $(\mathrm{K})$, for scaly legs. $30 \mathrm{c}$

Color Food, red or orange, gives feathers

better color. Fine for young birds or

after moulting. (S) $30 \mathrm{c}$; (P) $40 \mathrm{c}$.

Nesting Hair (P), for nests. $15 \mathrm{c}$

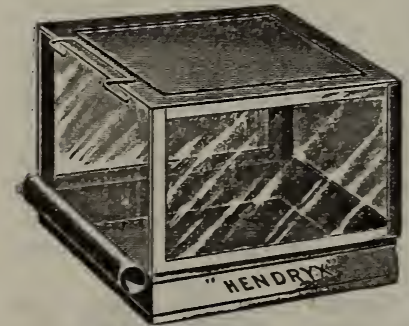

Glass Bath House

\section{Glass Bird Bath House}

Ideal in every way. Finished in white enamel and gold trimmed. The removable glass sides can be easily cleaned. To prepare the bath, fill the bottom with warm water, onen the eage door and hook bath house before it. "His Majesty" can go in and take his bath when he pleases and you lose no time standing around awaiting his pleasure. With this closed bath room the bird cannot scatter the water. (For bathing dishes, see page 155.)

Price $75 \mathrm{c}$; postpaid $80 \mathrm{c}$

\section{Valuable and Up-to-Date Books on Birds}

\section{BIRDS}

Canary Breeding and Training..........35c

Bird Culture, Spratt's ..............

Canary Birds. - A complete guide for their breeding, rearing and treatment; 100 pages. Postpaid ..............60
Parrots and Talking Birds.........40 c

Feathered Pets. -140 pages on breeding, care and food for Canaries, Finches, Parrots and all cage birds. Postpaid. 40c

American Bird Fancier. - New. Breeding and care of song and domestic birds.

120 pages ..................... 


\section{PARROTS}

We handle more young parrots than all other Northwestern dealers combined. The young parrots arrive during July and August, but we aim to have stock on hand at all times. Price of trained talkers on request. We offer hand raised, not the wild, trapped, unmanageable birds.

PANAMA PARROT.-The most popular parrot with our trade. Of quite large size, gentle disposition, easily taught and become great favorites. Deep green plumage. They often show a yellow spot on the back of the head. Young, 6 to 8 months old, each $\$ 20$ to $\$ 25.00$; extra select, \$35.00; Old Parrots. Trained Talkers, $\$ 35.00$ to $\$ 50.00$ and up.

CUBAN PARROT.-Medium size, green plumage, red tips on wings, light face, gentle, fine pets, good talkers. Note below.

MEXICAN RED-HEADED PARROTS. Medium size, trim and active, make fair talkers, gentle. Green plumage, bright red on head, blue in wing and tail.

NOTE.-Cubans and Mexican Parrots are cheaper in price than Panamas. They were not to be had last year, but may be obtainable this year. Write for prices.

B B OR DWARF PARROTS.-These cute little parrots make great pets. They are active, bright and wideawake. They are not much on the talk, but can be trained. Their dark green plumage is always smooth and pretty. Their gentle disposition and winning ways make them great favorites. Each, $\$ 5.00$ to $\$ 10.00$

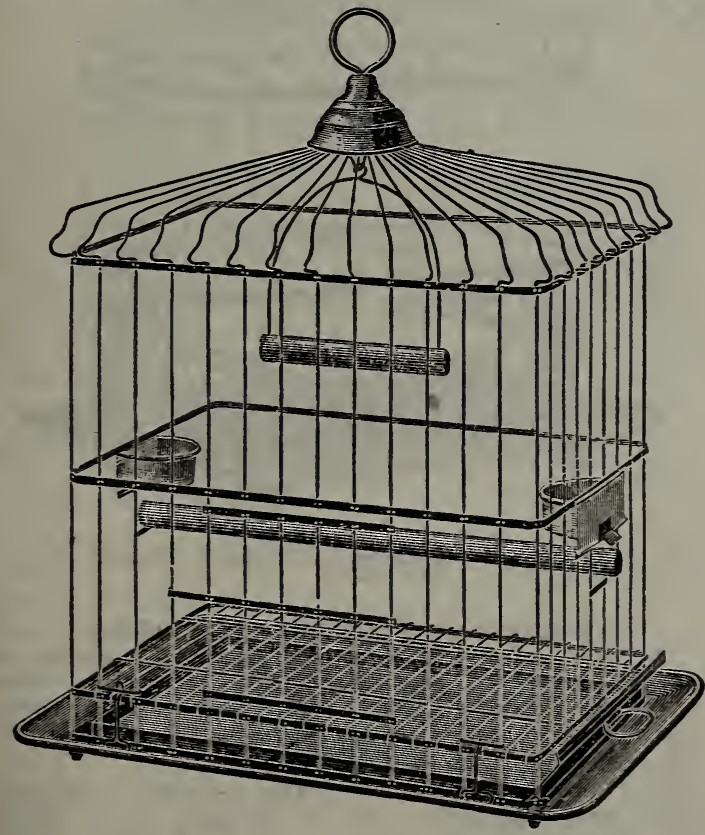

Moulding Base Nos. 101 to 103

FANCY SQUARE CAGES

Made of extra heavy tinned wire, zinc base, strong self-locking feed cups. They also have a slide cleaning pan on the bottom and wire grating to keep bird from getting down on the dirt.

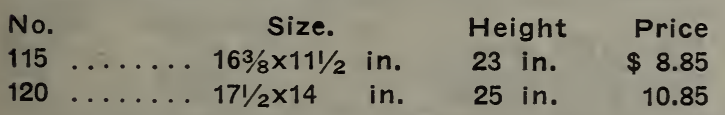

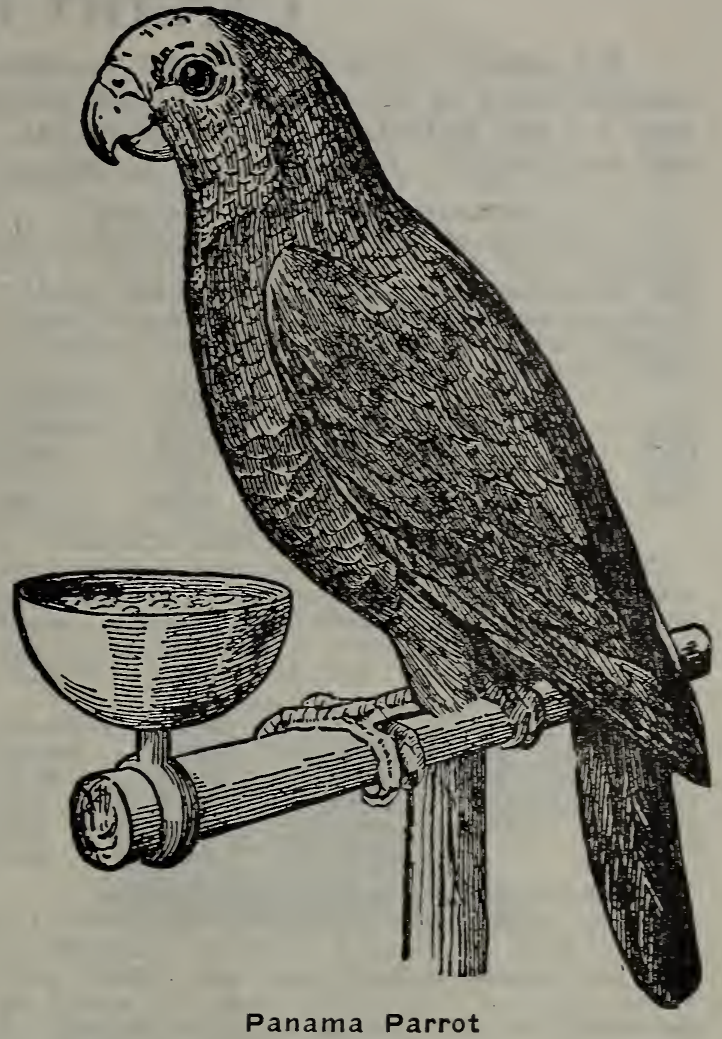

\section{Parrot Cages}

These are extra strong, large and roomy, well finished and of the latest and best designs of Parrot Cages on the market. Our Special Cage Catalog will show larger cuts of the three styles, extra cups, etc.

MOULDING BASE SQUARE CAGES

Made of extra heavy tinned wire, new style moulding base, with removable cleaning drawer, and also has wire grating to keep bird from getting down on dirt. Tinned iron, self-locking feed cups.

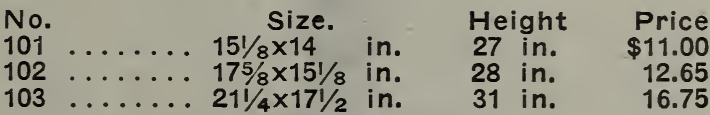

\section{ROUND PARROT CAGES}

These are very popular on account of the low prices. Our advice is to get the largest cage you can afford, as it gives "Polly" more room for exercise and less danger of spoiling the tail feathers. Heavy tinned wire, strong and well made; zinc bases, self-locking feed cups.

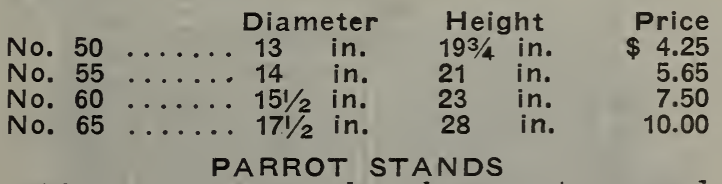

After your parrot has become tame and well trained, a parrot stand is very desirable. It gives more freedom and the bird greatly enjoys it, and can keep his plumage
in much better condition. Keep Polly chained when you leave.

No. 1.-Finished in black enamel. Complete with feed cups, tray and chain. Good heavy base, so it will not tip over. Tray adjustable to any height. Price $\$ 14.30$.

PARROT FOODS-You must remember that your parrot does not get all the foods nature intended it should have, therefore give "Poily", a treat by feeding our Health Food, Parrot Biscuits, Etc. See page 151. 


\section{CANARY BIRD CAGES}

We believe we carry the most complete line of plain and fancy cages on this coast. Limited space in this catalog will not permit us to illustrate all, but if further interested send for our SPECIAL CAGE CATALOG. We offer herewith some of our most popular and best sellers. Prices subject to change in metals.

\section{LA FAVORITE BRASS CAGES}

This is on $\theta$ of the new, late models; very popular and one of our best sellers. The full, graceful design at the top adds greatly to its general appearance. Handsome, bright finish, extra well made. (Wgt. packed 7 lbs.) See illustration.

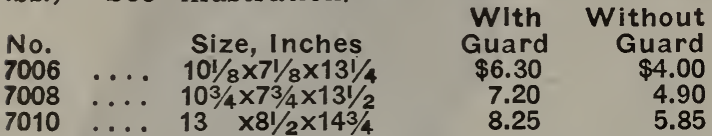

NIAGARA BRIGHT STEEL CAGES

These new metal cages are finished in bright steel and look real nice. Non-corrosive, neat, bright, well made cages, same style as La Favorite. See illustrations. Mighty good value for the price. (Weight packed 8 lbs.)

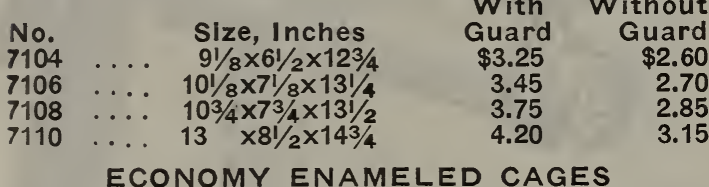

These cages are extra good value for the price. Well made and properly finished so that the enamel will not chip off. Color, pure white. For a low-priced cage, it would be impossible to find better value anywhere. A person often has use for a second cage for young birds or perhaps an extra one, and these are just the thing. See illustration. (Weight packed 7 to 10 lbs.)

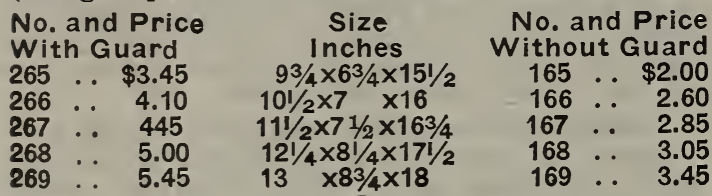

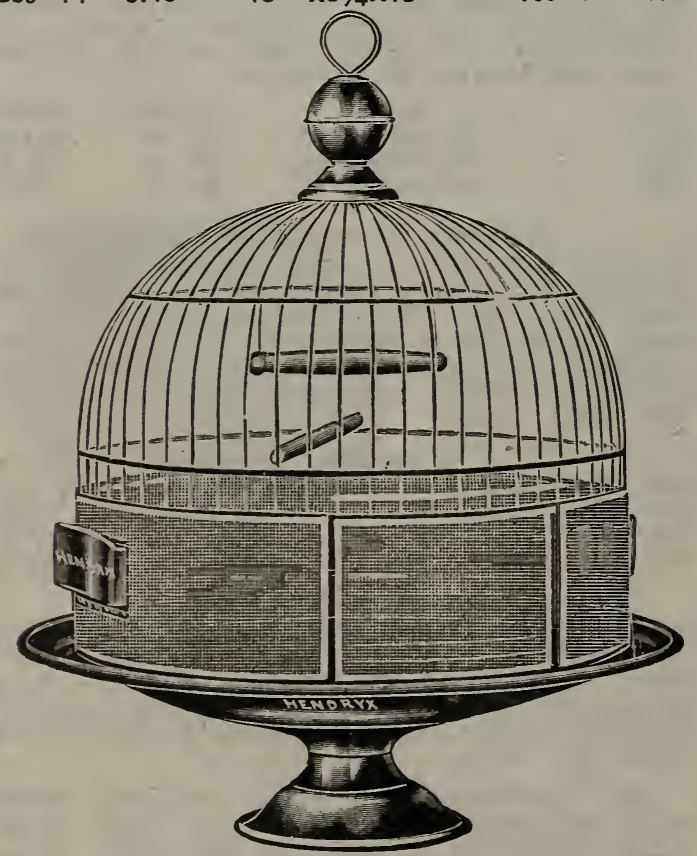

Imperial and Victoria Style

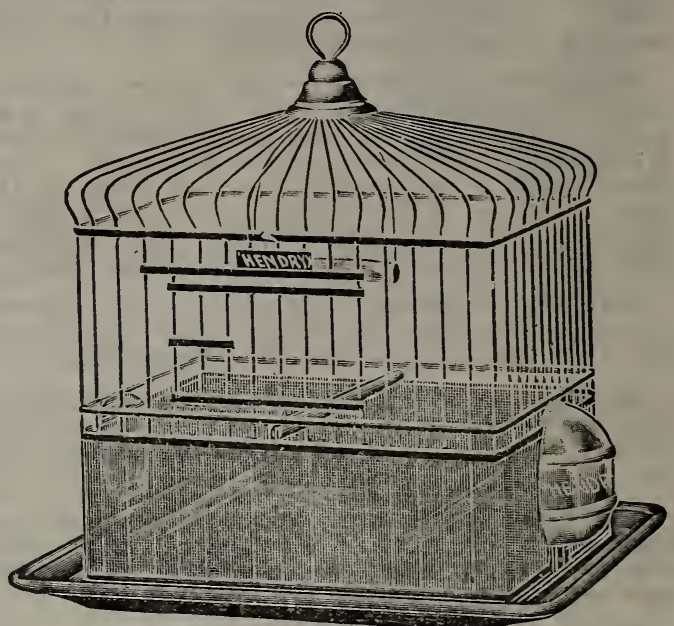

La Favorite, with Seed Guards

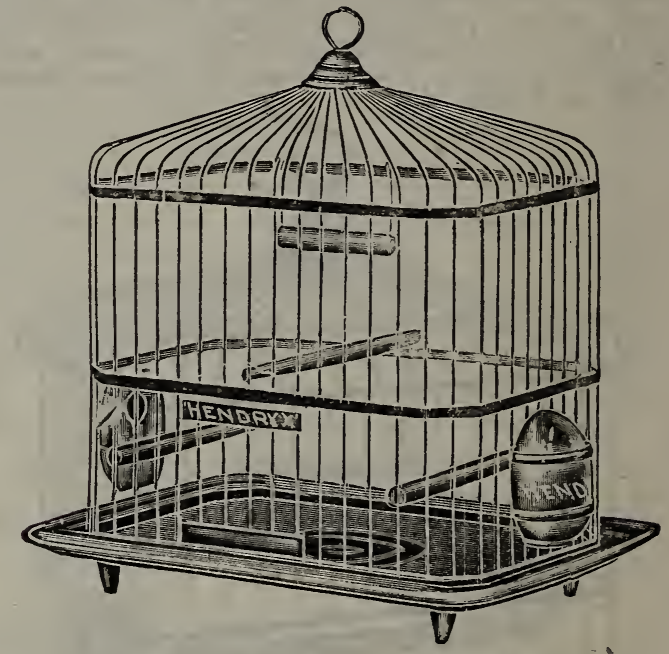

Economy Enamel, without Guard

\section{VICTORIA ENAMELED CAGES}

A new high-class white enameled cage of latest pattern and best quality. An ideal medium-priced cage. Neat in appearance, large and roomy. For a stand or a bracket. (Weight packed 8 to 10 lbs.)

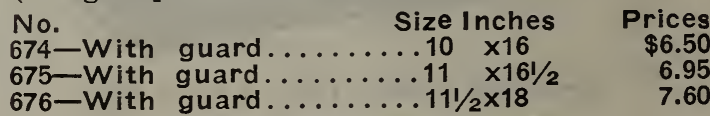

IMPERIAL BRASS CAGES

Well made, rigid and extra strong. Solid spun brass base, fitted with compact brass wire guards, making it a perfect, unusually clean and pretty cage, for stand or hanging bracket. (Weight packed 8 to 10 lbs.)

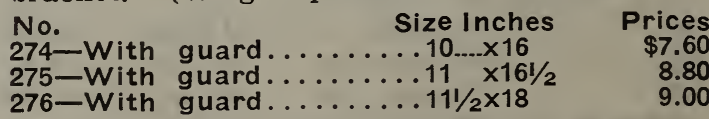

Note.-(P. P. wgt. 8 lbs.) means parcel post weight packed ready to mail, but all cages will be sent by express, which is safest. unless ordered by parcel post and extra money sent for postage in addition to $35 \mathrm{c}$ to cover cost of box and packing. 


\section{EXTRAS}

Bird Cups.-Open or half, egg shape, plain glass or opal. Each 15c; postpaid 20c. Breeding cage cups $20 \mathrm{c}$ each; $25 \mathrm{c}$ postpaid.

Bathing Dishes.-Opal or plain glass, 20c; postpaid $25 \mathrm{c}$.

Bird Nests.-Wire 20c; willow 25c.

Nesting Hair. $-15 \mathrm{c}$ pkg.; 2 for 25c postpaid.

Cage Suspension springs. - Single, light, 20c; heavy, 25c; Double, 40c; Single with adjustable chain, $30 \mathrm{c}$.

OUR CATALOG of Cages and Supplies illustrates these supplies.
BREEDING CAGES

All metal, enameled white, all complete.

No. 4 Single, for 1 pair $17 \times 9 \times 14$ in... $\$ 5.00$

No. 1 Double for 2 pairs $25 \times 12 \times 16$ in... 8.50

No. 2 Double $22 \times 11 \times 15$ in... 7.00

No. 3 Double $19 \times 10 \times 14$ in... 6.35

No. 113 Double $27 \times 10 \times 15$ in... 8.00

\section{ARM WALL BRACKETS}

Dandy, heavy nickle-plated wire. Swinging, 8 in. $30 \mathrm{c} ; 10$ in. $40 \mathrm{c} ; 12$ in. $50 \mathrm{c}$. Brass, swinging style, 8 in. $35 \mathrm{c} ; 10$ in. $50 \mathrm{c}$; 12 in. $60 \mathrm{c}$.

Acme.-Cast iron arm, fancy design, brass plated; 12 in. $\$ 1.00$.

\section{Cavies - Guinea Pigs}

Bright, active and harmless pets. They are in much demand and money can be made raising them. They come in combination colors of brown, white, yellow, black and tan,

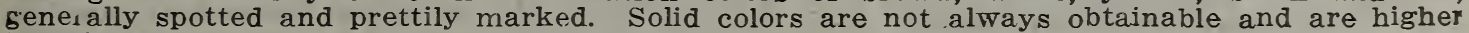
in price.

ENGLISH.-Smooth, short hair; hardy and bealthy. Young, Females $\$ 1.00$; Males 50c to $75 \mathrm{c}$; Old, Females $\$ 1.50$, Males $75 \mathrm{c}$ to $\$ 1.00$. A select breeding pair, $\$ 2.50$.

ANGORA.-Long, soft hair; 50c more than above.

Cavies, Care Books

Books
Management

$\$ 0.25$

Cavies. New book, nicely illustrated; complete ......................60

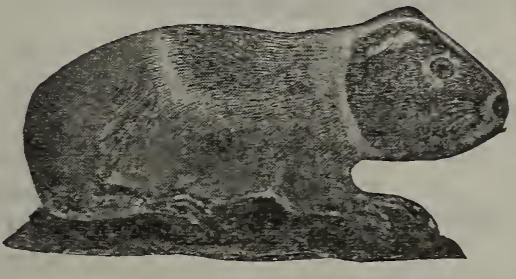

English Cavy (Guinea Pig)

\section{Rabbit Foods, Remedies, Supplies}

\section{Rabbit Foods and Remedies}

All tried and tested, of real merit. - Full directions on each package.

Slobber Remedy.-Sure cure.

Postpaid

Ear Remedy.-Sore ears.

Sore Hock Remedy.

Vent Remedy.-Very valuable.

Diarrhoea Remedy.

Snuffle Remedy.-Colds, etc.

Tonic-Condition Powder - Prevents disease, tones up the system and keeps stock healthy. 1 teaspoonful to $10 \mathrm{lbs}$. grain or mash. $65 \mathrm{c}$ pkg., postpaid $75 \mathrm{c}$.

Buck Tonic.-Keeps the males in vigorous, healthy condition. $\$ 1.00$ pkgs., postpaid $\$ 1.10$.

RABBIT BACTERIA.-Prevents and cures Snuffles. Ask for pamphlet, "The Truth About Snuffles."

Disinfectant.-Use "Germo"-harmless but effective. See pages 1-161.

\section{ROUTLEDGE RABBIT FEED}

This is a mixture of grains, rolled and ground, that should be fed in addition to alfalfa or clover hay and green vegetables and roots. Price, 5 lbs. 30c, 10 lbs. 50c, 2-bu. sack $\$ 3.50$.

\section{Ideal Feed and Water Dishes}

Made especially for rabbits, cavies and small pets. Cannot tip over, and the saving in feed soon pays for them. See illustration.

No. 2.-Earthenware, heavily glazed; the incurving top rim prevents the noseing out of feed. Will not tip over.

Prices: 6 -inch, 25c each, $\$ 2.50$ doz.; 8-inch $30 \mathrm{c}$ each, doz. $\$ 3.25$. If wanted by parcel post, add $8 \mathrm{c}$ each or $50 \mathrm{c}$ doz. for safe packing and postage at 2 lbs. each.
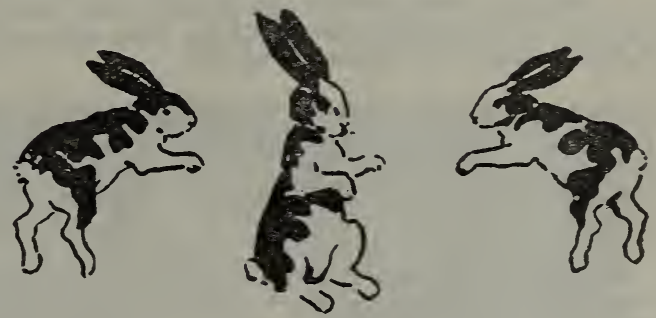

SANITARY SALT BLOCKS

These are pure salt, contain no medical preparations. Flat, square cakes with a nail hole in center. Nail to the wall or wire to hutch door. Rabbits should have salt before them and this is the ideal form. Prices, 10c each, $\$ 1.00$ doz. postpaid. Gross price on request.

\section{VEGETABLE AND HAY RACKS}

The vegetable rack illustrated on page 141 is ideal for rabbit hutches or runs. Keeps the feed out of the litter and saves money.
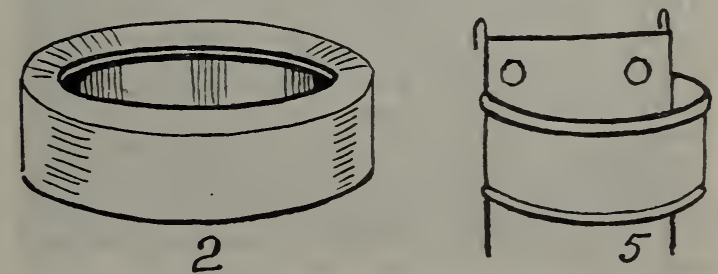

No. 5.-Heavy galvanized, half bowl shape, to hang on cage door or partition. Our new style, cannot drop or be knocked off. Each $30 \mathrm{c}$, doz. \$3.25. Mailing wgt. $1 \mathrm{lb}$. each. Postage extra. 


\section{RABBITS - BELGIAN HARES}

We keep in stock at our store about 20 pens of Rabbits of different breeds and can bring in on short notice most any stock wanted in this line.

Rabbit meat is now a staple and recognized product in the Portland markets and the demand is becoming greater and gieater. Rabbit meat is fine grained, tender, easily digested and equal in flavor and quality to chicken. France and Belgium have for years been producing and consuming millions of pounds of rabbit meat.

For cheapness of production, small amount of space, time and care required; the low cost of foods (especially on this coast where gieens and root crops are so plentiful), the rabbit industry will surely come into its own. Start now and make money.

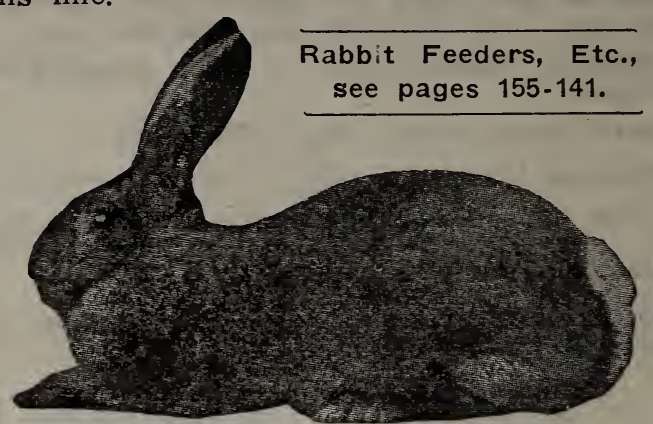

Flemish Giant Buck

Note.-By Young Stock, we mean from 2 to 3 months old; Breeding Stock, 6 months or uver; Fancy Stock, high-bred pedigree stock, bred for size, shape and color, for special bieeding or show purposes; Utility Stock, a pure- bred, good grade of healthy, vigorous stock for nieat and general purposes.

Young
PRICE LIST 3 Mos.
Bucks

WHITE ENGLISH $\ldots \ldots \ldots \ldots \ldots \ldots \ldots \ldots$

RUFUS RED BELGIANS......... Utility $1.50 \quad 2.00$

Fancy $2.50 \quad 3.50$

NEW ZEALAND REDS........... Utility 1.50

Fancy 2.50

FLEMISH GIANTS Utility 2.50

Fancy 3.50

HIMALAYANS ................Fancy 3.00

\begin{tabular}{ccr} 
& \multicolumn{2}{c}{ Breeders } \\
Does & B Mos. or Over \\
Bucks & Does \\
1.00 & $\$ 3.00$ & $\$ 4.00$ \\
2.00 & 5.00 & 6.50 \\
3.50 & 10.00 & 12.50 \\
2.00 & 5.00 & 6.50 \\
5.00 & 10.00 & 12.50 \\
3.00 & 7.50 & 10.00 \\
5.00 & 10.00 & 12.50 \\
4.00 & 7.50 & 10.00
\end{tabular}

Bred Does

6 Mos. or Over to Order $\$ 5.00$ \& up 7.50 \& up $15.00 \&$ up 7.50 \& up $15.00 \&$ up $12.50 \&$ up $15.00 \&$ up $12.50 \&$ up

English Lop-Ear stock limited; write. Weights given are mature stock.

Special Note.-The cheapest and quickest results can be obtained by the beginner by buying one or more Bred Does and an extra Buck, not related.. Utility Buck service, $75 \mathrm{c}$ to $\$ 1.50$; Pedigreed, $\$ 2.00$ to $\$ 5.00$.

HIMALAYANS. - Fur bearing. Very attractive; body generally all white, with black nose, ears, feet and tail. The fur is heavy, fine and of recognized value. Weight, 6 to $8 \mathrm{lbs}$.

FLEMISH GIANT-BELGIAN.-Very popular on account of their large size and quick growth, which makes them valuable for market. Color, light squirrel grey to solid black. Weight 10 to $12 \frac{1 / 2}{\mathrm{lbs}}$.

Friend, Ore., Feb. 15, 1919. Routledge Seed \& Floral Co.

Gentlemen: I have received my Rufus Red Belgian February 14th in good condition and am well satisfied with him. Yours very truly,

MRS. MARY ACKLEY.

WHITE ENGLISH.-Very popular pets with children as their white coats and pink eyes make them so attractive. Always in demànd as Easter Rabbits.

RUFUS RED BELGIANS. - I m p r ove d strain of the common Belgian Hare, Color, greyish red; coat fine and soft; weight, 8 to 9 lbs.

NEW ZEALAND REDS.-A hardy, sturdy strain very popular and much in demand; meat fine in quality and flavor. Color, red. Weight, 8 to 10 lbs.

Routledge Seed Co.

Imbler, Ore., May 4, 1919.

Dear Sir: Received pair of Flemish Giant rabbits all o. $k$. They were in fine shape and well matched; just the color we wanted. Thanks for same.

ALVIN WESTENSKOW.

\section{NEW BOOKS ON RABBITS}

Gibson's New Rabbit Book.-The latest and most complete information ever published about rabbits. Gibson is an international judge and secretary of the National Pet Stock Association. He has had twenty years' experience with all varieties. Over forty illustrations and full information on housing and hutches proper handling and selection; breeding, feeding, selling, shipping and exhibition. This book covers all breeds and gives tested receipts for cooking and serving as food; fur proposition, etc. 1918 4th edition, 200 pages, 5x7; well printed on white book paper. Price, paper cover, $\$ 1.00$; postpaid, $\$ 1.10$. Cloth cover, $\$ 1.60$.

Western Rabbit Book.-Complete rext book on the rabbit industry by C. A. Richey, Los Angeles, Cal. Well printed and nicely illustrated. Covers about the same subject as the above book but is not as complete in all departments. Very valuable for the beginner. Size $6 \times 9$ inches; 70 pages; paper cover Price, 50c; postpaid, 60c.

The Belgian Hare Guide.-Valuable, instructive book, devoted to the care, feeding, breeding, housing and diseases of the Belgian Hare, complete and up-to-date. One chapter on Flemish Giants. Good value for the price. Size $6 \times 9 ; 48$ pages; illustrated; paper cover. Price, 35c postpaid.

Save time, energy and money by reading these practical and up-to-date books. Did you ever stop to think that a few hours' reading now and then will give you valuable information that it has taken others years of labor and experience to obtain? 


\section{PUPPIES AND DOGS}

Buy your child a puppy and let them grow up together. Aside from the protection and companionship, educational experts advise that all children are better by having pets.

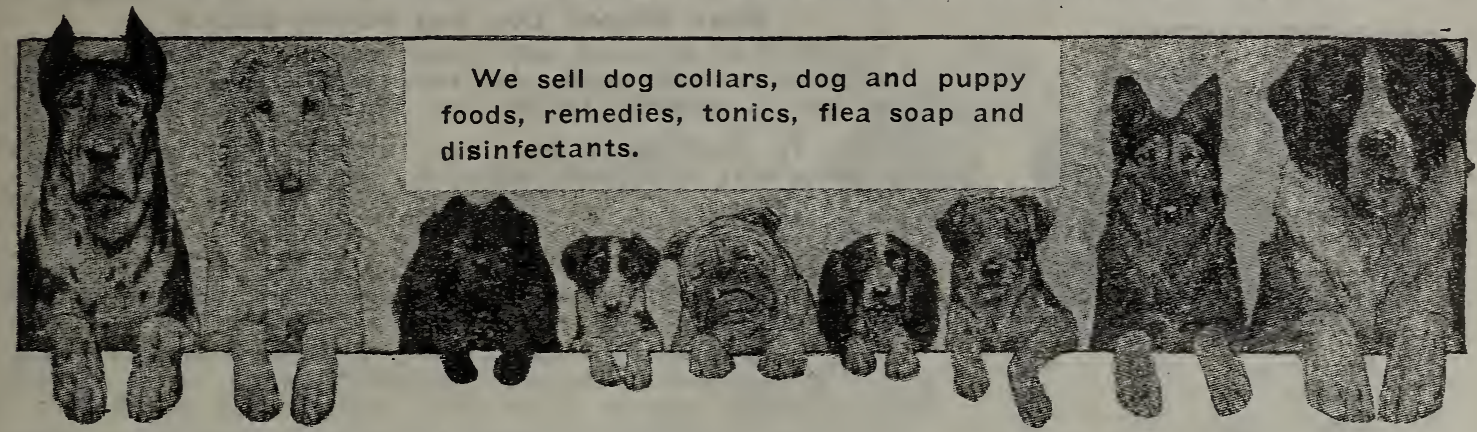

Mcst buyers prefer a pup so it can be raised and trained to suit, but occasionally someone wants a full-grown dog; we sell both. Our laıgest demand is for Fox or Irish Terriers, Toy, Boston and English Bulls, Airedales, Spitz, Cocker Spaniels and Scotch Collies, but we can also supply Setters, Pointers and most other breeds.

If out-of-town customers will write and tel! us what they want-breed, color and sex and what stock, fancy, pedigreed or just good, fairly pure strain, we are sure we can please you and give you extra good value. The prices on the different breeds and stock range from as low as $\$ 7.50$ to $\$ 50.00$ and up.

\section{BOOKS ON DOGS}

Amateur Dog Book. Training, care and treatment. 150 pages........... .60

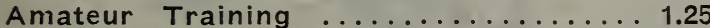

Airedale Terrior .................... 1.75

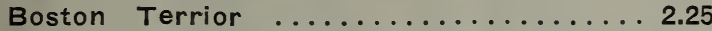

Common Sense Dog Doctor ............35 Dogs of All Nations. 130 pages; fully

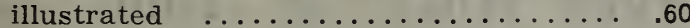

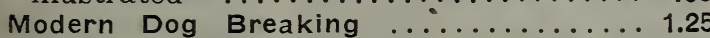

Perfect Fox Terrior ............... .60

Nehalem, Ore., February 1, 1919.

Dear Sirs: The pup arrived in fine condition and I am very well pleased with it. Yours very truly, MR. HENRY REUST.

\section{Persian Cats or Kittens}

These long, fluffy silky-haired pets are great favorites with the ladies, and with their bright intelligence, affectionate dispositions, cleanliness and beautiful appear. arice it is not to be wondered at. Aside from their value as pets there is good money in breeding and raising them, as they find quick sale. Most of the stock we offer is from pedigreed stock and eligible to registration. The popular colors are Orange, Silvers, Shaded Silvers,-Orange, Brown and Silver Tabbies,-White, Black, Blue and Tortoiseshell.

RANGE OF PRICES. - Young Kittens: Males, $\$ 10$ to $\$ 20$; Females, $\$ 7.50$ to $\$ 15$; Old, 6 months or over, prices on request.

\section{GOOD CAT BOOKS}

Cat Culture. Spratt's ...........\$0.15

Domesticated and Fancy Cats, by Jen-

nings. Covers all subjects.......... .55

\section{PEDIGREE BLANKS}

For Dogs, Cats and Rabbits

We offer breeders, what we believe to be the prettiest and most up-to-date, properly constructed pedigree blanks. These are $p_{i}$ inted in two colors and beautifully illustrated.

Prices.-State kind wanted, 10c each; 6 for $50 \mathrm{c} ; 12$ for $85 \mathrm{c}$.

Dufur, Oregon, April 8, 1918.

Routledge Seed \& Floral Co.,

Gentlemen: The little female Fox Terrier 1 bought of you in December is very fine and developing into an A-1 dog; thanks.

Sincerely yours,

M. M. BURTNER.

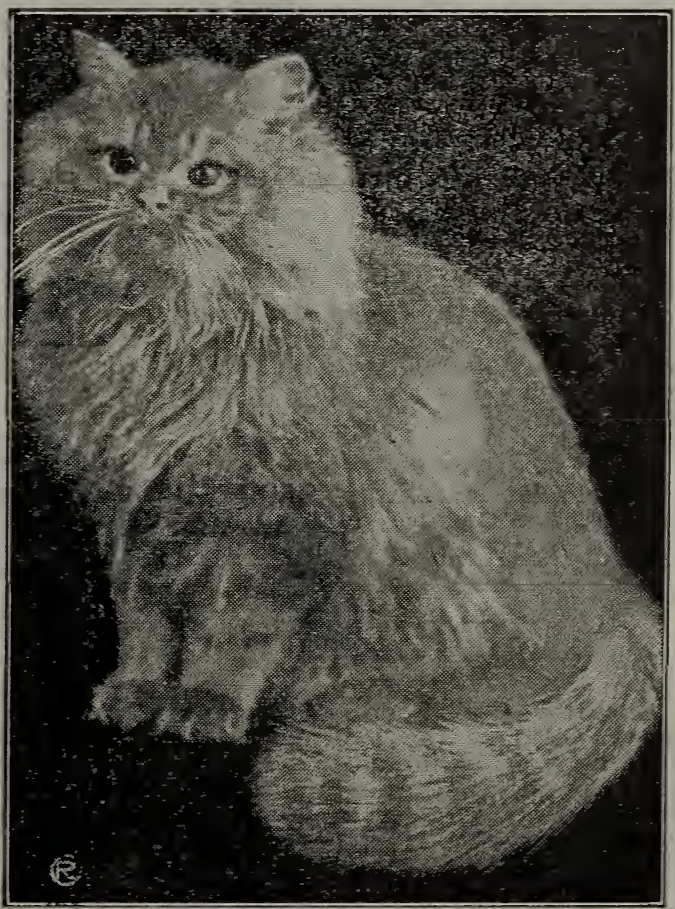

Silver-shaded Persian Cat

NOTE.-We would be very glad to hear from any reliable breeders of Dogs, when they have stock to sell. Give us full information in the first letter, BREED, WHAT: KIND OF STOCK, AGE, SEX and NET PRICE TO US. 


\section{MALTOID MILK-BONE DOG AND PUPPY FOOD}

\section{A FOOD THAT ALL DOGS LOVE. MADE ON A NEW PRINCIPLE.}

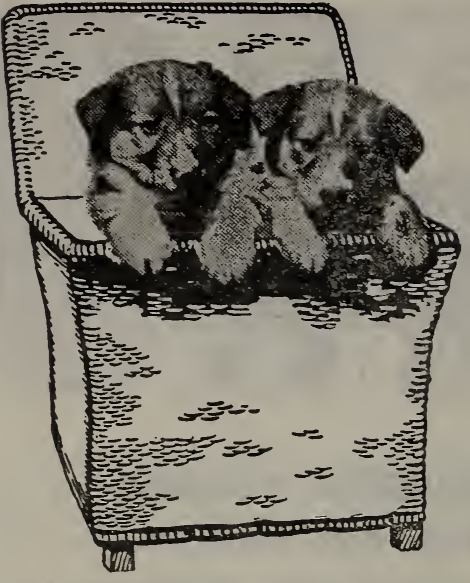

Remember, we sell Puppies of all kinds. Write for prices on the kind you want.

\section{Bone Shaped Dog and Puppy Biscuit}

The food of dogs not only must provide a certain amount of nourishment-it must also be pure, wholesome food. It must be not merely "filling" but appetizlng as well.

For, as everyone knows, food affects dogs in precisely the same way it affects humans. Food eaten with enjoyment is much more easily digested than food of unattractive flavor.

So, we make Maltoid Milk-Bone on the same principles of purity and good flavor as human food. Hence it ap. peals to the dog's senses of smell and taste.

And we guarantee that Maltoid. Milk-Bone contains only pure, wholesome foodstuffs, including good, clean meat, without sugar, spices or artificial flavoring of any kind.

Maltoid Milk-Bone is made to meet the particular physical needs of dogs; it is made to suit the peculiar digestive organism of dogs. Maltoid Milk-Bone not only provides the necessary energy-producing material, but it also supplies the materials for tissue repair.

If you want a happy, bright-eyed dog, full of life and ginger-whose skin is always healthy and coat always glossy, a dog with bright, clear eyes, sweet breath and regular habits, feed Maltoid Milk-Bone.

Prices.-Add postage if wanted by mail.

Milk-Bone Puppy Biscuit, 21/2 lb. pkgs., 45c.

Milk-Bone Dog Biscuit, $2 \frac{1}{2}$ lb. pkgs., $45 \mathrm{c}$.
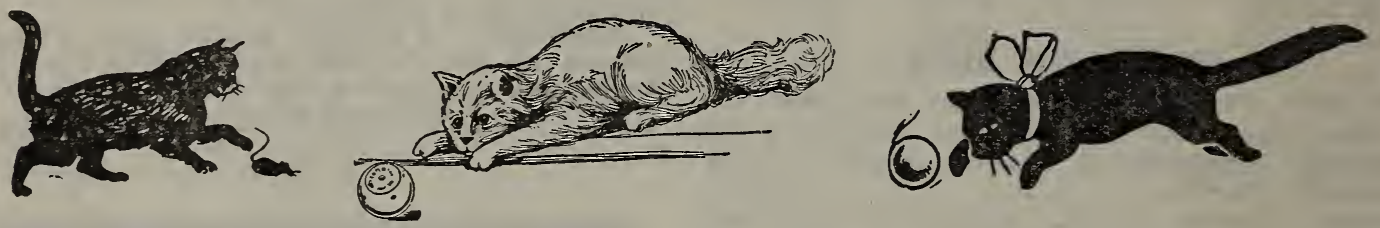

\section{Here You Are-Don't Forget "Kitty" or "Tom"}

Most every home has a cat and every cat should have a plaything. Catnip Mice and Catnip Balls are just the thing, make the cats playful, healthy and wide awake-they love the smell of catnip and crave it; a little occasionally to keep in good health is almost necessary.

\section{CATNIP MICE}

Made of cloth, same size, shape and color of a real mouse, and stuffed with dried catnip leaves. Kitty will play for hours with this mouse and then should be given a little catnip. Price, 15c; postpaid, 20c.

SPECIAL. - 1 Catnip Ball, 1 Catnip Mouse and 1 pkg. Catnip, postpaid, for $50 \mathrm{c}$.

\section{CATNIP BALLS}

These are hollow wooden $11 / 2$-inch red balls, filled with catnip. It's great sport for the cat to roll them around. A wonderful toy for cats. Price, 15c; postpaid, 20c.

\section{CATNIP LEAVES}

Catnip leaves, properly cured and dried. Always keep a package on hand to treat Kitty with. Price, $15 \mathrm{c}$; postpaid, 20c.

\section{SPRATT'S CAT FOOD AND REMEDIES}

Spratt's Cat Food.-A complete food for cats. Used at the leading catteries throughout the world and daily becoming more popular among the fancy. Small pkg. (P. P. 1 lb.), 25c; large pkg. (P. P. $23 / 4$ lbs.), price $45 c$. Add postage.

The above is also prepared with PasteurIzed Milk, excellent for kittens and invalid cats, or prepared with Fish to be used as a change of diet, especially during the summer months. Prices same as the regular Cat Food above.

Vermifuge Capsules for Cats. Postpaid 50c Distemper Tablets for Cats. Postpaid 75c Tonic and Condition Tablets for cats. Postpaid 50c.
Malted Kitten Food.-Use tablespoonful to pint of hot water; very valuable and inex. pensive. Can, $45 \mathrm{c}$; postpaid $50 \mathrm{c}$.

CAT COMBS. - We sell Spratt's nickled cat combs. No. 8, $\$ 1.25$; No. $0, \$ 1.35$; No. 7 , Double, $\$ 1.50 ; 6 \mathrm{~A}, \$ 1.75$.

CAT BOOKS.-Cat Culture, Spratt's, 15c; Domestic and Fancy Cats, by Jennings, cover's all subjects, 55c postpaid.

NOTE.-Cat owners are feeding Fibo, Pepsinated Meal, Midget, Puppy and Cod Liver Oil Biscuits with the greatest success. 


\section{Spratt's Dog, Puppy and Cat Foods, Remedies, Etc.}

Known and used the world over. None better. We have hundreds of customers and now buv in caıload lots. Prices subject to market changes. Spratt's descriptive Dog Book and Catalog free.

\section{Spratt's Dog Foods}

NOTE.-Carton wgts. are wrapped for mailing. ADD POSTAGE on all sizes if wanted by parcel post.

SPRATT'S DOG CAKES.-A properly balañced meat, grain meal and vegetable compound that will not spoil with age. Known and recommended the world over as a com. plete and constant food for dogs. Most owners of dogs rely on scraps from the table as "dog feed." This is all right as far as it goes, but to be on the safe side and for vacation trips, etc., always keep a supply of Dog Cakes on hand.

Prices: (Whole) $2 \frac{1}{2}-1 \mathrm{~b}$. cartons, 45c; $5-1 b$. bags, $80 \mathrm{c}$; $10-\mathrm{lb}$. bags, $\$ 1.50 ; 25-1 \mathrm{~b}$. bags, $\$ 3.25 ; 50$-lb. bags, $\$ 6.35 ; 100-1$ b. bags, $\$ 12.60$. (Packed in boxes $1 / 2 \mathrm{c}$ lb. extra.)

DOG CAKES (Kibbled.)-Nut size.-21/2-1b. carton, 45c; 5-1b. bags, 80c; 10-1b. bags, $\$ 1.50 ; 25-1 \mathrm{~b}$. bags, $\$ 3.25 ; 50-1 \mathrm{~b}$. bags, $\$ 6.35$; 100-1b. bags, $\$ 12.60$.

COD-LIVER OIL BISCUITS are invaluable for old or delicate dogs or those recovering from sickness. Dogs eat them without coaxing.

Prices: 21/2-lb, cartons, 45c; 5 -lb bags, 90c; 10 -lb. bags, $\$ 1.75 ; 25-1$ b. bags, $\$ 3.45 ; 50-1 \mathrm{~b}$. bags, $\$ 6.85$; $100-1 \mathrm{~b}$. bags, $\$ 13.60$. (Packed in boxes $1 / 2$ c lb. extra.)

FIBO, for Puppies or Growing Dogs.-For shy feeders or those recovering from sickness, or as a change of food at any time for all dogs. Small nut size.

Prices: 21/2-lb. cartons, 45c; 5-lb. bags, \$1.05; 10-lb. bags, \$2.05; 25-lb. bags, \$4.20; $50-1 b$. bags, $\$ 8.30 ; 100-1 b$. bags, $\$ 16.50$.

"MIDGET" CHARCOAL BISCUIT. - TO correct all bowel troubles, weak digestion, fetid breath, etc. All dogs should have at least once a week, and preferably at regular intervals, a meal of these excellent cakes. $2 \frac{1}{2}-1 \mathrm{~b}$. cartons, $45 \mathrm{c}$.

BULLDOG AND TERRIER MEAL.-A conditioner. Makes bone and muscle. 21/2lb. cartons, $45 \mathrm{c}$.

\section{Spratt's Puppy Foods}

A perfect and whole rood lur puppies of all breeds. Puppies should be started on these biscuits when about one month old, and they should be continued until such time as their teeth become sound and strong, usually when they are about six months old.

PUPPY BISCUIT.-21/2-lb. cartons, 45c; 5 -lb. bags, $85 \mathrm{c}$; $10-1 \mathrm{~b}$. bags, $\$ 1.60 ; 25-1 \mathrm{~b}$. bags, $\$ 3.40$; 50 -lb. bags, $\$ 6.70$; $100-$ lb. bags, $\$ 13.25$. (Packed in boxes $1 / 2 \mathrm{c}$ lb. extra.)

PLAIN PUPPY MEAL.-The standard weaning food. This Meal should be used before, during and after the weaning period to insure large, vigorous and healthy puppies. Also an invaluable food for dogs of any age out of condition. $2 \frac{1}{2}-1 \mathrm{~b}$. cartons, 45c.

PEPSINATED PUPPY MEAL for delicate puppies. To be used in place of our Plain Puppy Meal for puppies of weak digestion. Contains the requisite proportion of pepsin to render it an easily assimilated food for "bad doers." 11/2-lb. cans. 50c.

SPRATT'S DOG CULTURE-New edition,

, 48 pages, contains valuable information on the care, management, breeding, rearing and feeding. Also tells all about Spratt's Food,
Remedies and Supplies. FREE UPON REQUEST.

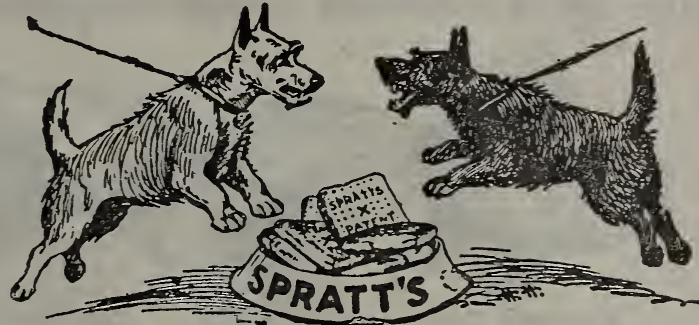

ORPHAN PUPPY FOOD.-Substitute for Natural Milk. For use when mother is dead or deficient in milk. Puppies should be fed on this food until weaning time. $1 \frac{1 / 2-1 b}{}$. can, 60c.

BONE MEAL FOR PUPPIES.-The strong frame builder. Specially prepared in a state to most readily supply the constituents needed to assist in building up a strong frame and preventing rickets, large joints, etc. 3-lb. tin can, 40c.

MIDGET BISCUITS.-A small biscuit of superior quality, containing a lesser percentage of meat fibrine than the ordinary cake. About 30 to the pound. Excellent for puppostage extra.

"S P R A T T'S" MOLLICODDLES (MilkWheat-Meat).-For dainty feeders, puppies, for toys. These biscuits satisf $v$ the jaded palate, restore the failing appetite and AT THE SAME TIME provide a sound and wholesome food. $2 \frac{1}{4}-\mathrm{lb}$. carton, $45 \mathrm{c}$.

\section{Spratt's Remedies and Medicines}

DOG SOAP (White).-Kills lice and fleas, prevents skin diseases and leaves the coat smooth and glossy, contains no tar, nicely perfumed. Per cake, 25c; postpaid, 30c.

Antiseptic Soap (Black). - For cut $\mathbf{s}$, wounds, ulcers, etc., disinfectant and germicide. Cake 50c.

Chronic Skin Disease Tablets. Postpaid 50c. Alternative Cooling Tablets.-For heated blood, etc. Postpaid 50c.

Digestive Tablets.-For severe cases of indigestion. Postpaid 50c.

Diarrhoea Tablets.-To relieve diarrhoea, Postpaid 50c.

Distemper Tablets.-For toy dogs and puppies. Postpaid 75c.

Ear Canker Ointment.-Postpaid 50c.

Eye Lotion (tablet form).-Postpaid 50c.

Eczema Remedy.-Postpaid 50c.

Hair Stimulant and Restorer.-Postpaid 50c.

Purgative Tablets.-Perfectly safe and effective. Postpaid 50c.

Tonic and Condition Tablets.-For toy dogs and puppies. Postpaid 50c.

Worm Capsules.-An excellent remedy for Round, Maw and Tape Worms. Postpaid $50 c$.

Worm Capsules for Puppies.-May be given with perfect safety. For dogs, for puppies. Postpaid 50c.

Vermifuge Capsules.-For toy dogs and puppies. Postpaid 50c.

Mange Remedy.-Pints 50c; prepaid $65 \mathrm{c}$

DOG WASH.-Disinfectant and deodorizer Read about Conkey's Noxicide, page 149 


\section{GOLDFISH, GLOBES, FOOD, ETC.}

We are the largest retail and wholesale dealers in Fancy Gold Fish in the Northwest, of ten having a thousand or more on display in our large aquarium at our store.

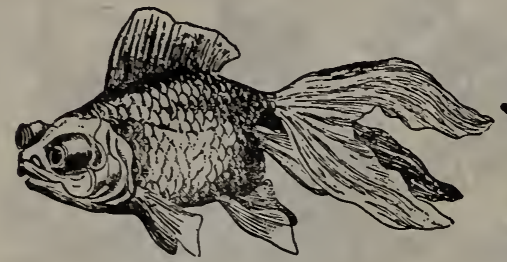

Chinese Telescope

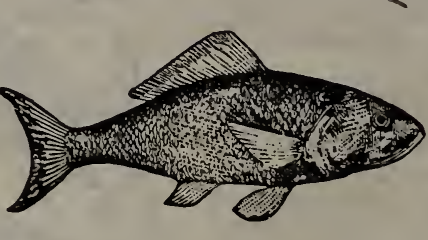

Common Gold Fish

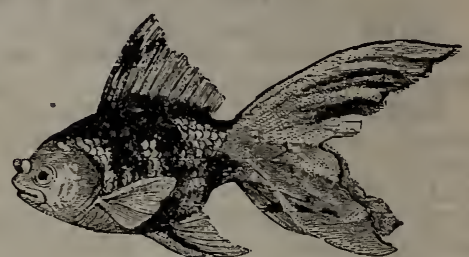

Japanese Fan-tail

An aquarium is a beautiful ornament. It suits everywhere-parlor, library, dining and sitting-room, and may indeed be introduced in apartments of the sick. The bright, active Gold Fish are very interesting, a perpetual source of amusement for both old and young folks. Children are always delighted with them.

CARE OF GOLD FISH.-The care of Gold Fish is very simple and little trouble. The water in the aquaria must be changed from one to six times a week, depending on the size of the globe, the number of fish and the temperature. When the fish come to surface and gasp for air, they should be given fresh water.

FEEDING.-The only safe diet is our prepared Fish-Food, fed daily and only what they will eat up quickly. Bread or cracker crumbs should never be fed. More fish die from over-feeding than from any other cause. Keep the aquariums out of the direct hot sunlight and in a cool place.

\section{PRICE LIST OF FISH}

COMMON GOLD FISH (see cut).-Very hardy and lively. Each, very small, 25c; small, 35c; medium, 50c; medium large, 60c; large, 3 to 4 inches, $75 \mathrm{c}$; extra large, $\$ 1.00$; extra large breeders, $\$ 2.00$ to $\$ 3.00$; fancy tri-colored, 50c to $\$ 1.50$ and up.

COMMON SILVER FISH.-Same as above, except they are silvery white. Each, medium, 25c; large, 50c to $75 \mathrm{c}$ and up to $\$ 1.50$.

JAPANESE FAN-TAIL (see cut). The most popular fancy fish. The fins and tail are of a delicate lace-like appearance, very showy and attractive. Price, golden, small, 35c; medium, $50 \mathrm{c}$; large, $75 \mathrm{c}$ to $\$ 1.00$ and up to $\$ 3.00$; tri-colored, golden-red, pearly-white and black, showing two or all three colors, $75 \mathrm{c}$ to

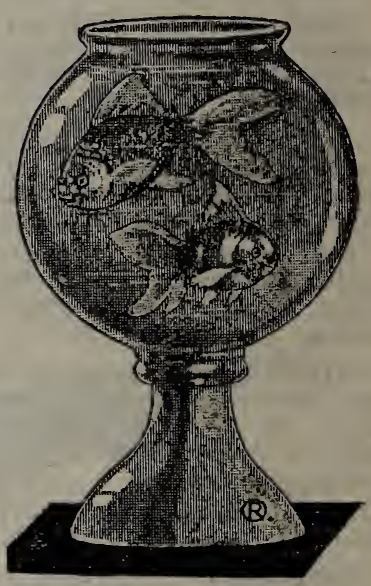

Standard Globe $\$ 1.50$ each.

COMET.-Very fancy; the most graceful of all. Similar to the Japanese Fan-tail, but the fins and tail are much longer and delicate. The tail is often longer than the fish. Price each, 50c, 60c, $75 c, \$ 1.00$ and $\$ 1.50$.

CHINESE TELESCOPE (see cut).-Curious and attractive on account of the large, elongated eyes, having the appearance of a telescope. Flowing double tails. Very rare. Price each, $75 c$ to $\$ 1.00$.

TADPOLES.-Desirable as scavengers for the aquaria. They consume the decaying matter and help keep the water pure. Price each, $15 \mathrm{c}$.

\section{FISH FOOD}

Best rice wafer, large box, enough food for four fish for six months. 25c, postpaid. Directions for feeding and care on each box.

\section{SPRATT'S FISH FOOD}

A baked food that is reground to pin head size. Fish are very fond of it. Per can, 15c; postpaid, 20 c.

\section{AQUARIA PLANT OR FISH MOSS}

This water plant improves the appearance of the aquaria or globe and helps purify the water, also keeps the water fresh longer. Price per bunch, 25c, postpaid. Cannot supply in July or August.
NOTE.-ALL SHIPMENTS (outside of the city) must go by express. A charge of 25c is made to cover cost of Shipping Bucket, holding from two to eight fish. Gold Fish can be shipped safely overland hundreds of miles. They cannot be sent by mail.

\section{FISH GLOBES}

Cannot Be Mailed

The stock we offer is highest grade blown glass, not moulded, and superior to the average stock sold. This style can be set on the table or sideboard, or suspended by brass chains; the most popular and best seller. Each, pint, 60c; quart, 90c; $1 / 2$ gal. $\$ 1.25$; $3 / 4$ gal. \$1.40; 1 gal., \$1.50; $11 / 2$ gal., \$1.75; 2 gal., $\$ 2.25 ; 21 / 2$ gal., $\$ 2.75 ; 3$ gal. $\$ 3.25 ; 31 / 2$ gal. $\$ 3.60$.

\section{FOOTED FISH GLOBES}

\section{Cannot be Sent By Mail}

Each, 1 gal., $\$ 3.00 ; 11 / 2$ gal., $\$ 4.00 ; 2$ gal., $\$ 4.50 ; 3$ gal., $\$ 6.00$.

\section{AQUARIA CASTLES}

As ornaments to set in the globes. Prices, $50 \mathrm{c}$ and up to $\$ 1.50$ each.

BOOK.- "The Aquaria and Care of Fish"; paper cover; $35 \mathrm{c}$, postpaid. 


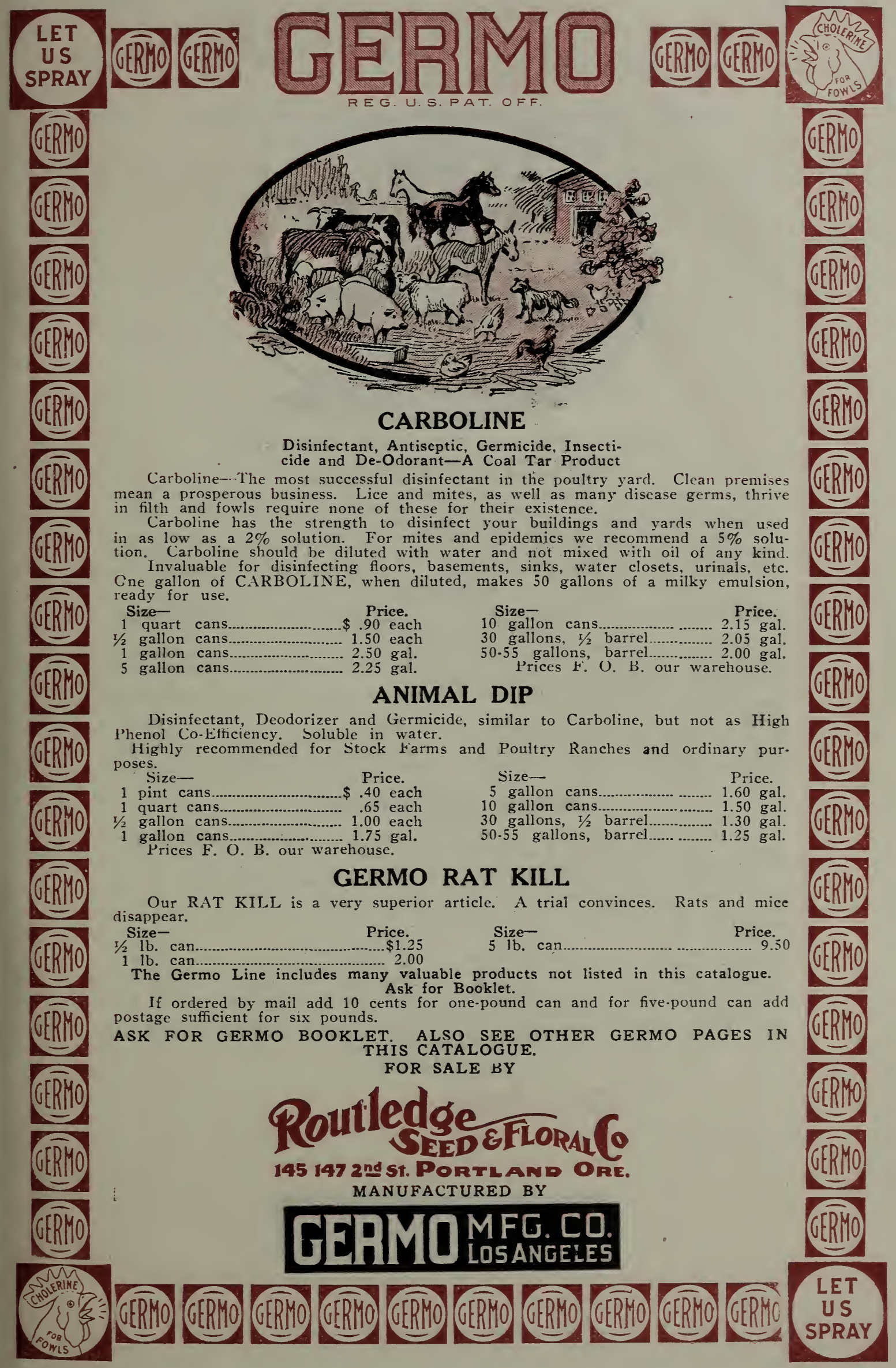




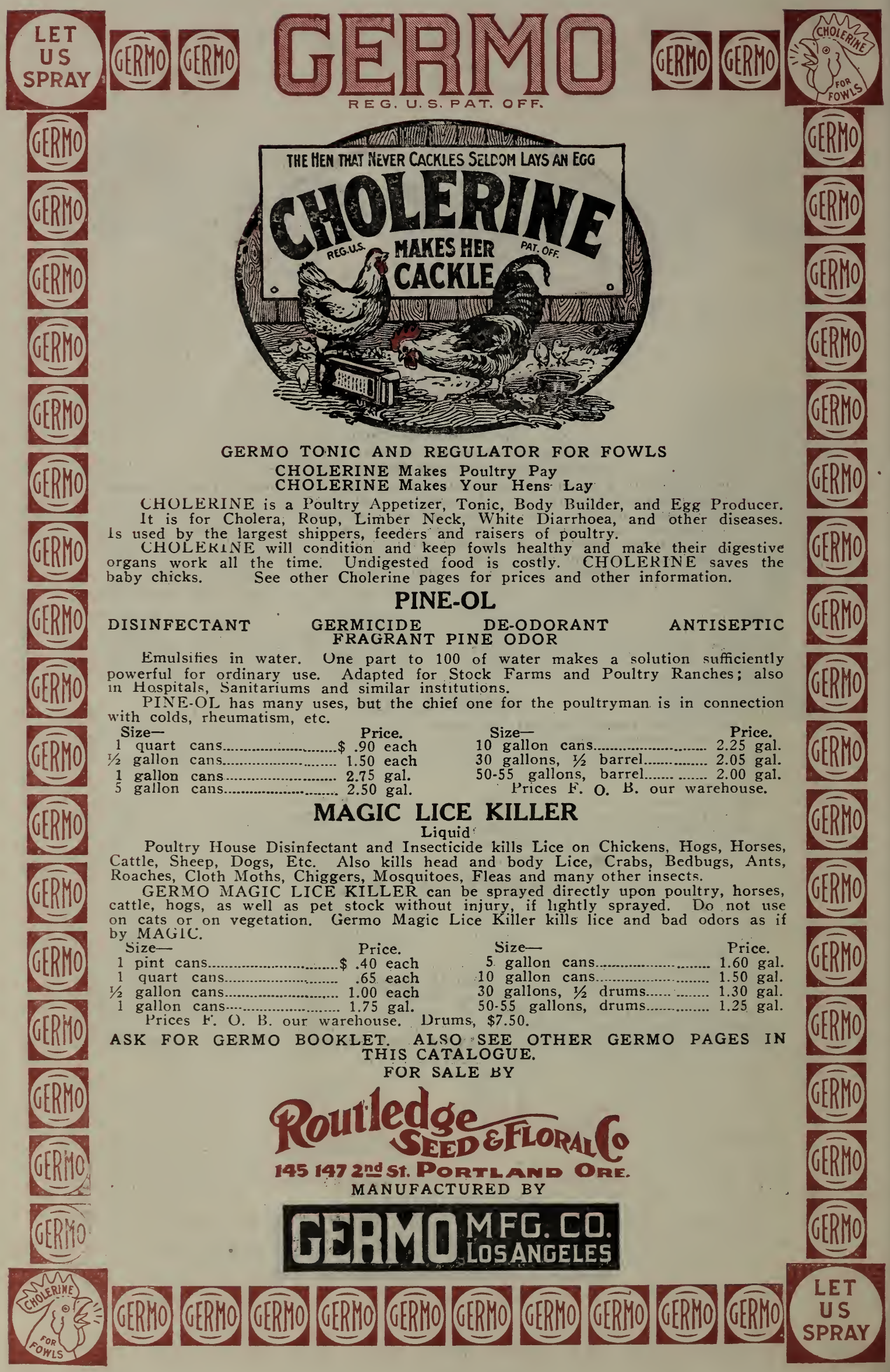




\section{Order Sheet \\ 1920

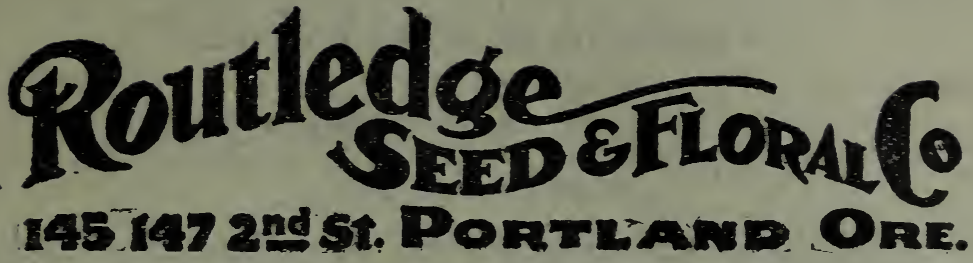

In filling this order we will use the greatest care to have it true to name, and will replace any that may prove untrue. But no sale by us carries a warranty of quality, express or implied, and for any error we shall not be liable for more than the purchase price. Every purchase from us is made on these terms. ROUTLEDGE SEED \& FLORAL CO.

NATE

DO NOT USE THESE SPACES

POST OFFICE

R. F. D. NO.

No.

STATION

(If different from P. O.)

COUNTY STATE

DATE. AMIOUNT ENCLOSED, \$

FORWARD BI

State if wanted by Mail, Express, Freight or Steamer. (Read Note on bottom of this page.)

Card Made

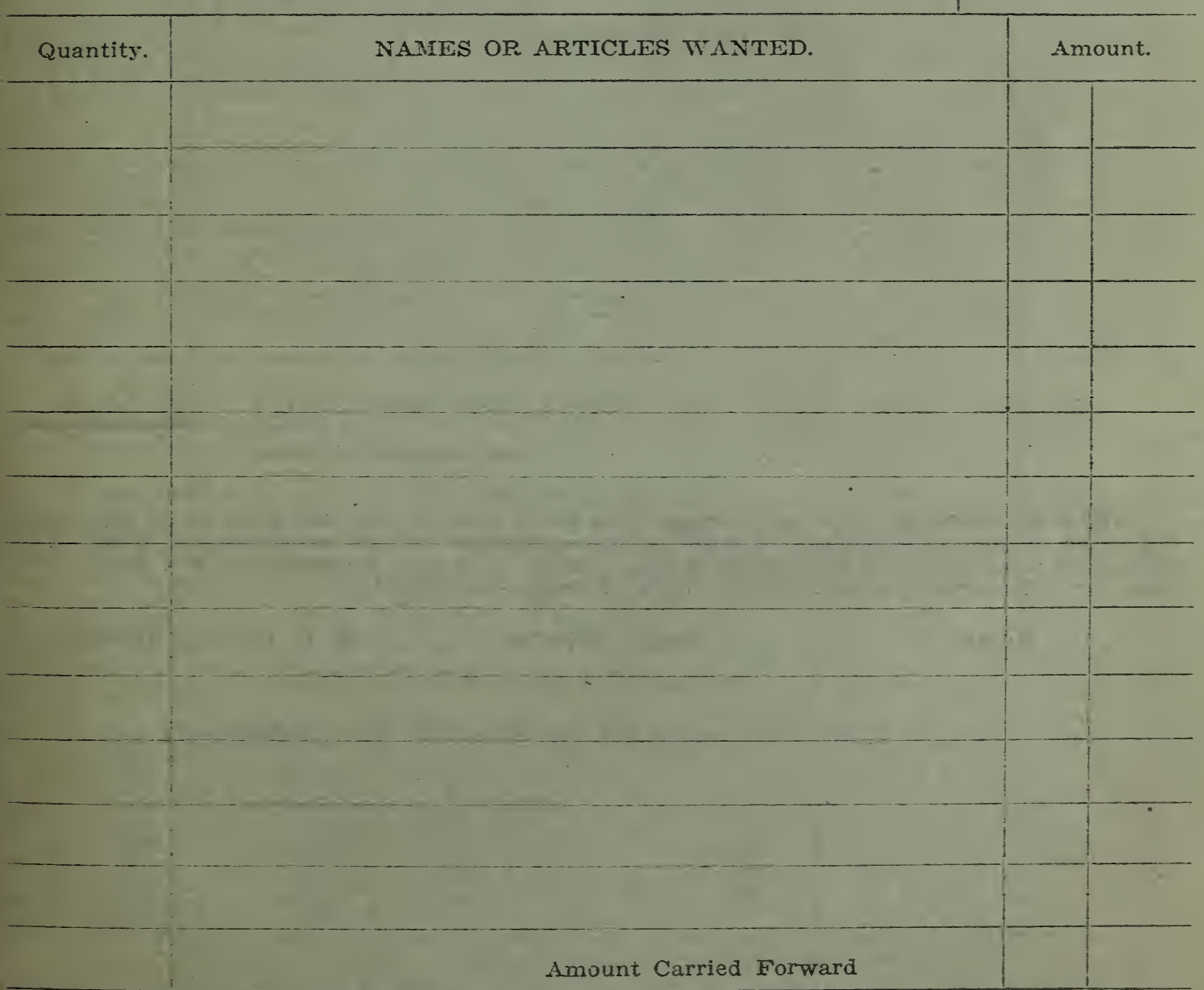

NOTE. - Before you send this order read carefully what we have to say about parcel post and transportation charges on inside front cover and on page 1. 


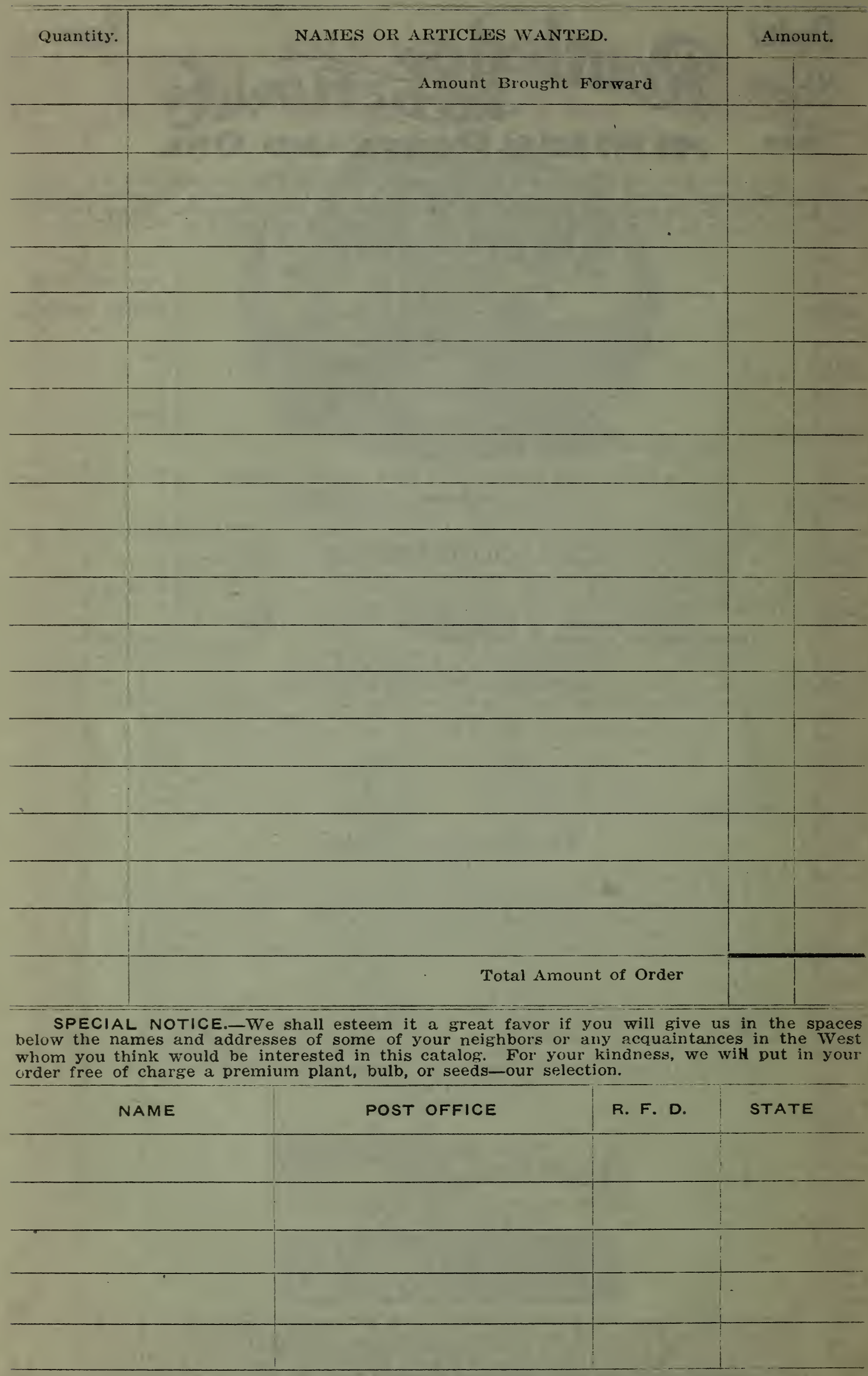

NOTE.-Before you send this order read, carefully what we have to say about parcel post and transportation charges on inside front cover and on page 1. 


\section{REFERENCE TABLES}

Quantity of Seeds to produce a given number of plants or to sow an acre We have carefully revised and lowered the following amounts so that you will NOT PLANT TOO MUCH and thereby WASTE seed while they are HIGH AND SCARCE.

\section{Vegetable Seeds}

\section{Per Acre}

Asparagus - 1 oz. to 200 plants. Beans, Dwarf-1 lb. to $125 \mathrm{ft}$ drill. Pole-1 lb. to $150 \mathrm{ft}$. drill........

Pole-1 lb. to 200 hill.........

Field-1 lb. to $200 \mathrm{ft}$. drill.

Lima-1 lb. to 75 hills.

Beet, Table-1 oz. to $60 \mathrm{ft}$. drill

Mangel-1 oz. to $75 \mathrm{ft}$. drill.

Broccoli-1 oz. to 3,000 plants.

Brussels Sprouts-1 oz. to $3,000 \mathrm{P}$.

Cabbage-1 oz. to 3,000 plants.

Carrot-1 oz. to $150 \mathrm{ft}$. drill.

Cauliflower-1 oz. to 4,000 plants.

Celery -1 oz. to 5,000 plants.

Chicory-1 oz. to $100 \mathrm{ft}$. drill.

Corn, Sweet-1 lb. to $150 \mathrm{ft}$. drill.

Sweet-1 lb. to 160 hills.

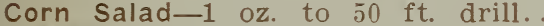

Cress-1 oz. to $40 \mathrm{ft}$. drill........ 1 lb.

Cucumber -1 oz. to 50 hills........ 2 lbs.

Egg Plant-1 oz. to 3,000 plants.. 4 ozs.

Endive -1 oz. to $300 \mathrm{ft}$ drill...... 4 id $4 \mathrm{lbs}$.

$\begin{array}{ccccc}\text { Kale, Table }-1 \text { oz. to } 3,000 \text { plants.. } & 1 & \text { lb. } \\ \text { Stock }-1 \text { oz. to } 300 \text { ft. drill..... } & 2 & \text { lbs }\end{array}$ oz. drill.... 2 lbs.

Lettuce to $100 \mathrm{ft}$ drill......... 3 lbs.

200 ft. drill........ 3 lbs.

TTater-1 oz. to 35 hills......... 2 lbs.

Okra-1 oz. to $100 \mathrm{ft}$. drill......... 5 lbs.

Onion seed-1 oz. to $200 \mathrm{ft}$. drill.. $3 \mathrm{lbs}$.

For Sets- ….............. 50 lbs.

Onion sets-1 ib. to $35 \mathrm{ft}$ drill.....2 $200 \mathrm{lbs}$.

oz. to $300 \mathrm{ft}$. drill.... 3 lbs.

Parsley -1 oz. to 350 ft. drill.... 2 lbs.

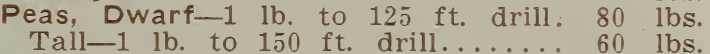

Pepper-1 oz. to 2,000 plants..... 4 ozs.

Potatoes …..................

Pumpkin-1 oz. to 35 hills....... 3 lbs.

Radish-1 oz. to $100 \mathrm{ft}$. drill...... 10 lbs.

Rutabaga-1 oz. to $250 \mathrm{ft}$. drill.... z lbs.

Salsify -1 oz. to $100 \mathrm{ft}$. drill...... $8 \mathrm{lbs}$.

Spinach -1 oz. to $100 \mathrm{ft}$. drill...... 10 lbs.

Squash, Summer-1 oz. to 50 hills.. 2 lbs.

Winter -1 oz. to 35 hills........ 3 lbs.

Tomatoes $-1 \mathrm{oz}$. to 3,000 plants.... 3 ozs.

Tobacco-1 oz. to 4,000 plants.

Turnips-1 oz. to $250 \mathrm{ft}$. drill.

\section{Field, Farm, Grass and Clover Seeds}

Quantity

per Acre

Alfalfa 12 to $25 \mathrm{lbs}$.

Artichokes 400 to $600 \mathrm{lbs}$

Barley-(drills 75 lbs.) ...broadcast $100 \mathrm{lbs}$ Buckwheat-(drills 30 lbs). broadcast 50 lbs.

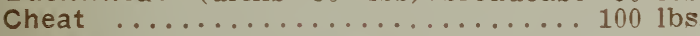

Clover-Alsyke and White....6 to $10 \mathrm{lbs}$. White for lawn...... lb. to $25 \mathrm{ft}$. square Crimson ............... 10 to $15 \mathrm{lbs}$ Red $\ldots \ldots \ldots \ldots \ldots \ldots \ldots .6$ to 15 lbs.

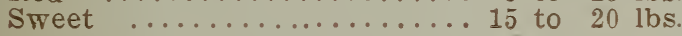

Corn, Field-Hills

For Fodder, drills ............... $50 \mathrm{lbs}$

Grass, Kentucky Blue-Pasture.20 to 30 lbs. Kentucky Blue-for Lawns.1 lb. to $15 \mathrm{ft}$. sq ILixed Lawn ........... $1 \mathrm{lb}$. to $15 \mathrm{ft}$. sq. Red Top-Common …...25 to $30 \mathrm{lbs}$ Red Top-Hulled, Solid Seed.10 to $15 \mathrm{lbs}$.

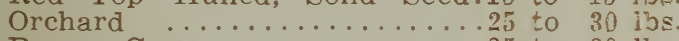

Brome Grass ...........25 to $30 \mathrm{lbs}$
Pye Grass-for Pasture.

Rye Grass-for Lawn

Sudan-drills

Kaffir Corn-drills

Millet-for Seed

For Hay

Oats-for Seed

For Hay

d-100 lbs. or $80 \mathrm{lbs}$. with 35 lbs. Oats Rye-for Grain ............. 80 to 100 lbs. For Hay

Speltz or Emmer ............ $80 \mathrm{lbs}$

Sugar Cane .............. 10 to $12 \mathrm{lbs}$

sunflower ..................... 5 to $7 \mathrm{lbs}$

Timothy .............. 12 to $15 \mathrm{lbs}$

$\checkmark$ tches -85 ibs. or 60 lbs. with 40 lbs. Grain Vetch, Hairy or Sand........... 30 lbs.

Wheat ............. 80 to $100 \mathrm{lbs}$

\section{Suitable Distance for Planting Trees and Plants} Note.-In planting in the home garden for hand cultivation you can set plants or trees
closer.

Apples, Standard .........20 to 30 feet Apples, Dwarf ................ 10 to 12 feet Pears, Standard .... ....... 18 to 20 feet Pears, Dwarf ............ 10 feet Peaches and Apricots .......... 16 to 18 feet Cherries, Sweet ............20 to 25 feet Cherries, Sour ............ 16 to 20 feet Plums and Prunes........... 16 to 20 feet Quinces ................... 10 to 12 feet Grapes

\section{Number of Trees or Plants On An Acre}

1 by 2 feet

21,780

by 3 -feet.......... 14,520

3 by 5 feet................

3 by 6 feet........... $2,42,420$

by 2 feet........... 14,520

by 3 feet......... 9.680

by 3 feet.............. 7,260

by 4 feet

5,445

4 by

4 by 6 feet...... 1,815

6 by 8 feet............. 907

6 by 6 feet............. 1,210

10 by 10 feet.......... 430

Currants

Raspberries

es $\ldots \ldots \ldots \ldots \ldots \ldots$ by 6 feet

Other Blogans, etc. 6 by 8 feet

Strawberries, in Hills............ $1 \frac{1}{2}$ by $2 \frac{1}{2}$ feet

Iatted Rows.... $2 \frac{1}{2}$ by 4 feet

Asparagus, in Beds ........... 1 by $1 \frac{1}{2}$ feet

Asparagus, in Field ............... 1 by 4 feet

$\begin{array}{llll}1 & \text { by } & 4 & \text { feet } \\ 2 & \text { by } & 4 & \text { feet }\end{array}$

RULE.-Multiply the distance in feet between the rows by the distance the nlants are apart in the rows, and the product will be the number of square feet, for each plant or hill, which, divided into the number of square feet in an acre $(43,560)$, will give the number of plants to the acre. 


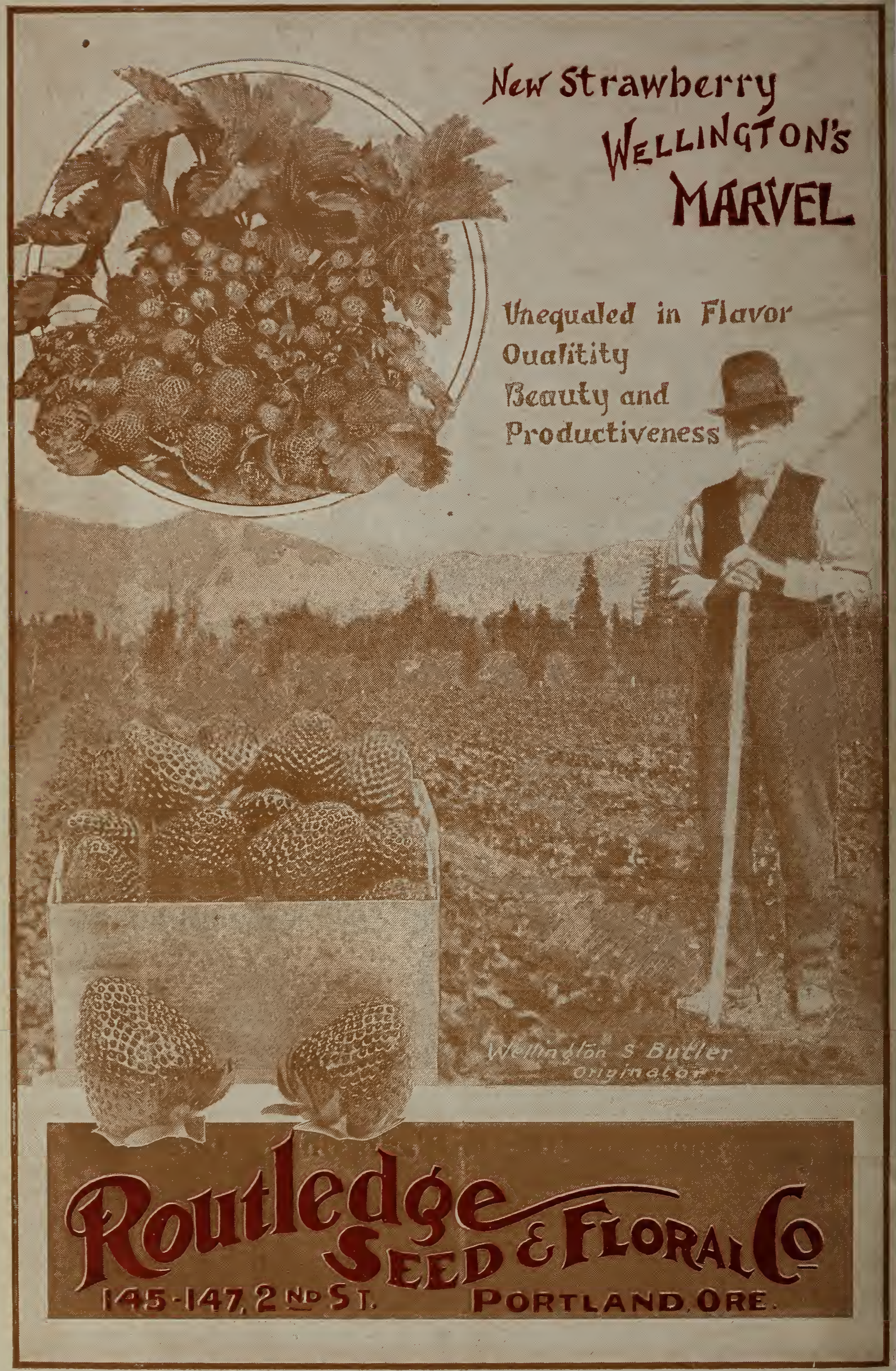

